\title{
Complexe medisch-technische zorg : ontwikkeling, implementatie en evaluatie van infuusbehandeling thuis
}

Citation for published version (APA):

Smeets, P. M. J. H. (1999). Complexe medisch-technische zorg : ontwikkeling, implementatie en evaluatie van infuusbehandeling thuis. [Doctoral Thesis, Maastricht University]. Universiteit Maastricht. https://doi.org/10.26481/dis.19990702ps

Document status and date:

Published: 01/01/1999

DOI:

10.26481/dis.19990702ps

Document Version:

Publisher's PDF, also known as Version of record

\section{Please check the document version of this publication:}

- A submitted manuscript is the version of the article upon submission and before peer-review. There can be important differences between the submitted version and the official published version of record. People interested in the research are advised to contact the author for the final version of the publication, or visit the DOI to the publisher's website.

- The final author version and the galley proof are versions of the publication after peer review.

- The final published version features the final layout of the paper including the volume, issue and page numbers.

Link to publication

\footnotetext{
General rights rights.

- You may freely distribute the URL identifying the publication in the public portal. please follow below link for the End User Agreement:

www.umlib.nl/taverne-license

Take down policy

If you believe that this document breaches copyright please contact us at:

repository@maastrichtuniversity.nl

providing details and we will investigate your claim.
}

Copyright and moral rights for the publications made accessible in the public portal are retained by the authors and/or other copyright owners and it is a condition of accessing publications that users recognise and abide by the legal requirements associated with these

- Users may download and print one copy of any publication from the public portal for the purpose of private study or research.

- You may not further distribute the material or use it for any profit-making activity or commercial gain

If the publication is distributed under the terms of Article $25 f a$ of the Dutch Copyright Act, indicated by the "Taverne" license above, 


\section{Complexe medisch-technische zorg}

Ontwikkeling, implementatie en evaluatie van infuusbehandeling thuis

ter verkrijging van de graad van doctor aan de Universiteit Maastricht, op gezag van de Rector Magnificus, Prof. Dr. A.C. Nieuwenhuijzen Kruseman volgens het besluit van het College van Decanen, in het openbaar te verdedigen op vrijdag 2 juli 1999 om 16.00 uur door 


\section{Promotores :}

Prof. dr. H.F.J.M. Crebolder

Prof. dr. P. Pop

\section{Co-promotores : \\ Dr. G.H.M.I. Beusmans \\ Dr. R.A.G. Winkens}

Beoordelingscommissie :

Prof. dr. H. Huijer Abu-Saad (voorzitter)

Dr. J. Carpay, azM

Prof. dr. H. Philipsen

Prof. dr. E. Schadé (Universiteit van Amsterdam)

Prof. dr. C. Spreeuwenberg

Smeets, Patricius Martinus Johannes Henri. Complexe medisch-technische zorg. Ontwikkeling, implementatie en evaluatie van infuusbehandeling thuis.

Maastricht: Unigraphic; 1999. Nederlandse hoofdtekst en bijlagen. Engelse samenvatting. ISBN 90-5681-062-6

Trefwoorden: technologie, thuiszorgtechnologie, infusie, thuiszorg, zorgmodel, Orem, innovatie, implementatie, terminale zorg, huisartsgeneeskunde, eerstelijns zorg, transmuraal, integrale zorg, kwaliteit van leven, kwaliteit van zorg, kosten. Subject headings: Technology, Home Care, Home Care Services, Care Model, Orem, Infusion Therapy at Home, Home Intravenous Antibiotic Therapy, Innovation, Implementation, Terminal Care, Primary Care, Shared Care, Integrated Care, Quality of Life, Quality of Care, Costs.

Lay-out / logo: Patrick Smeets

Omslag: Guus van Rooy

Summary: Bob Wilkinson

Druk: Unigraphic Maastricht

Het onderzoek gepubliceerd in dit proefschrift is uitgevoerd binnen het Research Institute for Extramural and Transmural Health Care (ExTra), dat deel uitmaakt van the Netherlands School of Primary Care Research (CaRe), in 1995 erkend door de Koninklijke Nederlandse Academie van Wetenschappen (KNAW).

Het onderzoek was mogelijk door subsidie uit het Stimuleringsfonds Thuiszorgtechnologie van het Ministerie van Welzijn, Volksgezondheid en Cultuur. 


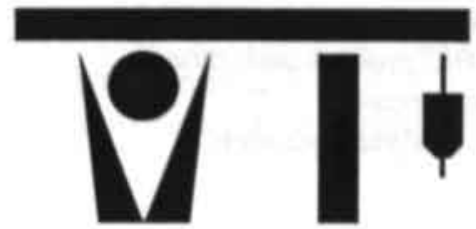

Het projectlogo is uitgegaan van het logo van de thuiszorg (twee verticale balken die een horizontale dragen). Eén pijler is vervangen door een zelfzorgende mens (patient, naaste of zorgverlener) en er is een infuuszak toegevoegd. De resterende T, de thuiszorgtechnologie, vormt een balans waaromheen mens en techniek evenwicht zoeken.

Opgedragen aan allen die het vermogen tot zelfzorg bevorderen, in het bijzonder mijn ouders en familie 


\section{Inhoudsopgave}

\section{DEEL I: INLEIDING EN METHODEN}

1 Achtergrond, probleemstelling en opbouw

1.1 Achtergrond

1.2 Probleem-, doel- en hoofdvraagstellingen

1.3 Opbouw proefschrift

2 Methoden

2.1 Inleiding

2.2 Modellen

2.3 Methode van inventarisatie-onderzoek

2.4 Methode van innovatie(proces)-onderzoek

2.5 Methode van effectonderzoek

2.6 Dataverzameling en analysemethoden

2.7 Samenvatting

\section{DEEL II: INVENTARISATIE EN MODELONTWIKKELING}

3 Literatuurverkenning complexe medisch-technische zorg thuis

3.1 Inleiding

3.2 Ervaringen met toepassing van medische technologie thuis

3.3 Implementatie van technologie in de thuiszorg

3.4 Conclusies

4 Kaders bij complexe medisch-technische zorg: de zorgverleningstheorie van Orem

4.1 Inleiding

4.2 Theoretische zorgkaders

4.3 Feitelijke zorgkaders

4.4 Conclusies

5 Enquête naar taken en verantwoordelijkheden bij infuusbehandeling

5.1 Inleiding

5.2 Methode

5.3 Resultaten

$5.4 \quad$ Beschouwing

5.5 Conclusies

6 Model voor complexe medisch-technische zorg

6.1 Inleiding

6.2 Zorginhoud bij complexe medisch-technische zorg

6.3 Zorgproces bij complexe medisch-technische zorg

6.4 Zorgorganisatie bij complexe medisch-technische zorg

6.5 Conclusies 
7 Selectie van doelgroepen en patiënten

7.1 Doel van selectiecriteria (fase 1)

7.2 Analyse van selectiecriteria (fase 2)

Perspectief op selectiecriteria (fase 3 )

Concept bij selectiecriteria (fase 4) 86

Verspreiding en toepassing van selectiecriteria (fase 5+6)

Evaluatie van selectiecriteria (fase 7)

\section{Organisatie van zorg}

8.1 Doel van organisatie van zorg (fase 1) 101

8.2 Analyse, perspectief en concept bij organisatie van zorg (fase 2-4) 101

8.3 Verspreiding van organisatie van zorg (fase 5) 103

8.4 Toepassing en evaluatie van organisatie van zorg (fase 6+7) 106

8.5 Conclusies

\section{Informatievoorziening}

9.1 Doel van informatievoorziening (fase 1)

9.2 Analyse van informatievoorziening (fase 2)

9.3 Perspectief en concept bij informatievoorziening (fase 3+4)

9.4 Verspreiding en toepassing van informatievoorziening (fase 5+6)

9.5 Evaluatie van informatievoorziening (fase 7)

9.6 Conclusies

10 Scholing

10.1 Doel van scholing (fase 1)

10.2 Analyse van scholingsbehoefte (fase 2) 129

10.3 Perspectief op scholing (fase 3) 131

10.4 Concept bij scholing (fase 4) 132

10.5 Verspreiding en toepassing van scholing (fase 5+6) 132

$\begin{array}{lll}10.6 & \text { Evaluatie van scholing (fase 7) } & 133\end{array}$

$\begin{array}{lll}10.7 & \text { Conclusies } & 138\end{array}$

\section{Financiering en technologie}

11.1 Doel van keuzen in financiering en technologie (fase 1)

11.2 Analyse van keuzen in financiering en technologie (fase 2) 141

11.3 Perspectief en concept bij financiering en technologie (fase 3+4) 142

11.4 Verspreiding en toepassing van financiering en technologie (fase 5+6) 143

11.5 Evaluatie van financiering en technologie (fase 7) 144

11.6 Conclusies

12 Keuze en toepassing thuiszorgtechnologie: de infuusbehandelingen

12.1 Doel van de behandelingen (fase 1)

12.2 Analyse, perspectief en concept bij de behandelingen (fase 2-4)

12.3 Verspreiding, toepassing en evaluatie van de behandelingen (fase 5-7) 150

12.4 Conclusies 


\section{Zorgsituatie en kwaliteit van leven}

$\begin{array}{ll}13.1 \text { Inleiding } & 179\end{array}$

13.2 Theorie zorgsituatie en kwaliteit van leven 179

13.3 Doel- en vraagstellingen 183

13.4 Model voor borging en meting zorgsituatie en kwaliteit van leven 184

$\begin{array}{lll}13.5 & \text { Resultaten } & 190\end{array}$

13.6 Beschouwing 206

$\begin{array}{llr}13.7 & \text { Conclusies } & 209\end{array}$

14 Zorg: kwaliteit, tevredenheid en doelmatigheid

$\begin{array}{ll}14.1 & \text { Inleiding }\end{array}$

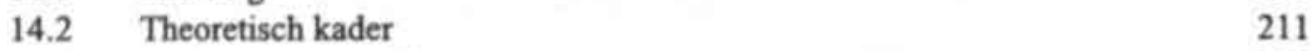

14.3 Doel- en vraagstellingen 215

14.4 Overkoepelend aspectmodel voor borging en meting kwaliteit van zorg 216

14.5 Resultaten 222

$\begin{array}{lll}14.6 & \text { Beschouwing } & 234\end{array}$

$\begin{array}{lll}14.7 & \text { Conclusies } & 236\end{array}$

15 Kosten voor de gezondheidszorg, patiënt en maatschappij

15.1 Inleiding 239

15.2 Theorie bij studies naar kosten van gezondheidszorg 239

15.3 Vraagstelling, indicatoren en operationalisatie 239

15.4 Resultaten 242

15.5 Beschouwing 246

$\begin{array}{llr}15.6 & \text { Conclusies } & 247\end{array}$

DEEL V: BESCHOUWING EN SAMENVATTING

16 Slotbeschouwing en aanbevelingen

16.1 Inleiding 249

$\begin{array}{lll}16.2 & \text { Ontwikkeling zorginnovatie } & 249\end{array}$

16.3 Proefimplementatie en procesevaluatie zorginnovatie 253

$\begin{array}{lll}16.4 & \text { Effectevaluatie zorginnovatie } & 257\end{array}$

$\begin{array}{ll}\text { 16.5 Eindconclusie } & 260\end{array}$

16.6 Aanbevelingen voor de gezondheidszorg, onderzoek en onderwijs 263

17 Samenvatting 265

17 Summary 275

$\begin{array}{ll}\text { Dankwoord } & 285\end{array}$

$\begin{array}{ll}\text { Curriculum Vitae } & 289\end{array}$

$\begin{array}{ll}\text { Afkortingen (abbreviations) } & 291\end{array}$ 


\section{Bijlagen (addenda)}

1.1 Achtergrond project

1.2 Medical Technology Assessment / Technolgy Assessment in Health Care

$2.1 \quad$ Het netwerk van het project Infuusbehandeling Thuis

2.2 Overzicht onderzoeksmethoden

4.1 Het gezondheidskundig metaparadigma

4.2 Noten bij hoofdstuk 4

6.1 Definities

7.1 Selectielijst doelgroepen

7.2 Toepassing selectiecriteria doelgroepen

Enquête thuisbehandeling met cytostatica

7.4 Toepassing selectiecriteria individuele patiēnten

8.1 Kenmerken Stichting Groene Kruis Heuvelland

8.2 Kenmerken academisch ziekenhuis Maastricht

Structuur werkoverleg

8.4 Zorgdossier Thuiszorg

8.5 Verdeling van het aantal problemen

9.1 Chronologisch overzicht verspreide informatie

Informatie-enquête

10.1 Oordeel van huisartsen over de ontvangen scholing 330

10.2 Oordeel van TMVs over de ontvangen scholing 331

$\begin{array}{lll}11.1 & \text { Prijzen van pompsystemen } & 332\end{array}$

11.2 Bijdrage aan zorgverlening vanuit project 333

11.3 Kostenraming morfine- en mannitolbehandeling 333

11.4 Berekening effect van technologiekeuze 334

11.5 Berekening effecten technologie- en financieringskeuzen 335

11.6 Resultatenrekeningen van het azM en de SGKH 336

12.1 Aanpassingen op het Wijk Administratie Systeem 337

12.2 Subcutane infusie van morfine 339

$\begin{array}{ll}12.3 & \text { Parenterale infusie van mannitol } \\ 12.45\end{array}$

$\begin{array}{lll}12.4 & \text { Intraveneuze infusie van antibiotica } & 349\end{array}$

12.5 Centraalveneuze infusie van hartmiddelen 355

13.1 Dimensiescores Sickness Impact Profile (68 items) 360

13.2 Itemscores Caregiver Strain Index 361

13.3 SIP-68 items ter vervanging van ADL/HDL items in STG methodiek 362

13.4 Beroepen patiënt en naaste verzorger 363

13.5 Verklarende variantie in oordelen over de kwaliteit van leven 363

14.1 Antwoordmogelijkheden Client Satisfaction Questionnaire 364

14.2 Berekening kosten verblijfsdag academisch ziekenhuis Maastricht 364

14.3 Verklarende variantie in oordelen over de kwaliteit van zorg 365

14.4 Gevoeligheidsanalyse besparingen 366

15.1 Salarisberekening Transmuraal infuusverpleegkundigen (TMVs) 367

15.2 Berekening afvalkosten 367

15.3 Gevoeligheidsanalyse kosten van de gezondheidszorg 368

15.4 Inspanningen van naaste verzorgers in tijd 370

$\begin{array}{lll}\text { 15.5 Gevoeligheidsanalyse rentabiliteit } & 371\end{array}$ 



\section{Achtergrond, probleemstelling en opbouw}

\subsection{Achtergrond}

De gezondheidszorg verandert voortdurend. Deze veranderingen maken deel uit van de ontwikkelingen in de samenleving die aangeduid worden met de term modernisering., Belangrijkste elementen hierin zijn: toename van op wetenschap gebaseerde kennis; technologisering; uiteenvallen van beroepsmatige gedragingen in afzonderlijke functies, taken en verrichtingen (specialisatie en functionele differentiatie); ordening van verbijzonderde gedragingen in nieuwe structuren als beroepen, instellingen en organisaties (arbeidsdeling en structurele differentiatie); beheersing van deze differentiaties middels bureaucratisering; tegelijkertijd toenemende verzelfstandiging én interdependentie; schaalvergroting, snelle informatiespreiding en internationalisering; interactie met de leefwereld vanuit deze systemen.' Onder andere de Stuurgroep Toekomstscenario's Gezondheidszorg (STG) geeft een helder overzicht van uitingen van deze veranderingen ten tijde van het project. ${ }^{3}$ Patiēnten en hun belangenorganisaties emanciperen. ${ }^{3.7}$ In de beleving van veel patiënten en hun naasten is de thuissituatie de meest geëigende plaats om perioden van ziekte door te brengen. ${ }^{3}$ De grenzen tussen ziekenhuiszorg en thuiszorg als ook tussen de specialistische en huisartsgeneeskundige zorg vervagen. ${ }^{8}$ Binnen de verpleegkundige discipline wordt gediscussieerd over functie-inhoud en takverdeling en de vereiste deskundigheid. Ziekte wordt ook door professionals steeds meer gezien en geaccepteerd als een integraal en onlosmakelijk onderdeel van het menselijk bestaan. Daarom is er meer belangstelling voor zorg thuis. Een en ander wordt gestimuleerd door het streven naar een meer doelmatige gezondheidszorg en doordat zorgaanbieders en verzekeraars door de terugtredende overheid steeds meer autonomie krijgen bij het bepalen van de inhoud en de vormgeving van de gezondheidszorg. Er moet dus als het ware een nieuwe balans gezocht worden tussen de functionele (haalbaarheid, effectiviteit, efficiëntie) en de substantiěle (betekenisvolheid, welzijn, solidariteit) rationaliteit. Eerstgenoemde rationele ontwikkelingen en de leefwereld van de patiënt interacteren en beïnvloeden elkaar.' Zolang het streven naar meer doelmatige zorg parallel loopt met dat om patiënten zolang mogelijk in staat te stellen thuis te verblijven, is deze ontwikkeling zowel patiëntvriendelijk als doelmatig. Genoemde veranderingen in de gezondheidszorg leiden onder andere tot een meer technisch georiënteerde zorg in de eerstelijn. ${ }^{10}$ Een continue en integrale zorgverlening aan de patiënt in diens eigen omgeving is daarbij van belang. Het transmuraal concept is een reactie op deze veranderingen. " Binnen dit concept worden de zorgbehoeften van patiënten los van de belangen van disciplines en organisaties gedefinieerd. Vervolgens worden de voor de gewenste zorgverlening benodigde kennis en vaardigheden vastgesteld. 
Ten slotte worden de professies en organisaties benoemd die de zorg het best kunnen verlenen. In het transmuraal concept staat de afstemming van het zorgaanbod op de zorgbehoefte centraal. Het beoogt de sterke kanten van thuis- én ziekenhuiszorg te combineren. Inspelend op de diverse veranderingen heeft het toenmalige Ministerie van Welzijn, Volksgezondheid en Cultuur (WVC) het Stimuleringsprogramma Thuiszorgtechnologie ingesteld. ${ }^{12}$ De verplaatsing van toepassing van technologie van het ziekenhuis naar de thuissituatie is één van de centrale thema's. Hierbij ligt het accent op het definiëren van (para)medische voorwaarden waaronder toepassing van technologie in de thuiszorg op grotere schaal mogelijk is. Uitgangspunten zijn: acceptatie van de technologie, bevordering van deskundigheid en voorlichting, definiëring van logistieke voorwaarden en de ontwikkeling van protocollen en richtlijnen. Binnen dit programma heeft het onderzoeksproject Infuusbehandeling Thuis vanuit de Universiteit Maastricht (UM) de voorwaarden voor de verplaatsing van infuusbehandelingen naar de thuissituatie bestudeerd (bijlage 1.1). De te ontwikkelen zorg is opgevat als een zorginnovatie. ${ }^{13,14}$ Dit type onderzoek is te rekenen tot het terrein van Medical Technology Assessment. ${ }^{15-17}$ Het project is uitgevoerd in de Zuid-Limburgse regio 'Heuvelland'. De zorguitvoering is gefinancierd door de zorgverzekeraars, het academisch ziekenhuis Maastricht (azM) en de Stichting Groene Kruis Heuvelland (SGKH). Het Ministerie financierde de evaluatie.

In deze studie staat de zorgverlening met technische hulpmiddelen aan de patiënt in diens eigen omgeving centraal. Schema 1.1 geeft de (f)actoren en interacties in dit materięle onderzoeksveld weer. ${ }^{18}$ De primaire leefeenheid is de patiënt en zijn huisgenoten.

Sehema 1.1 Het onderzoeksterrein.

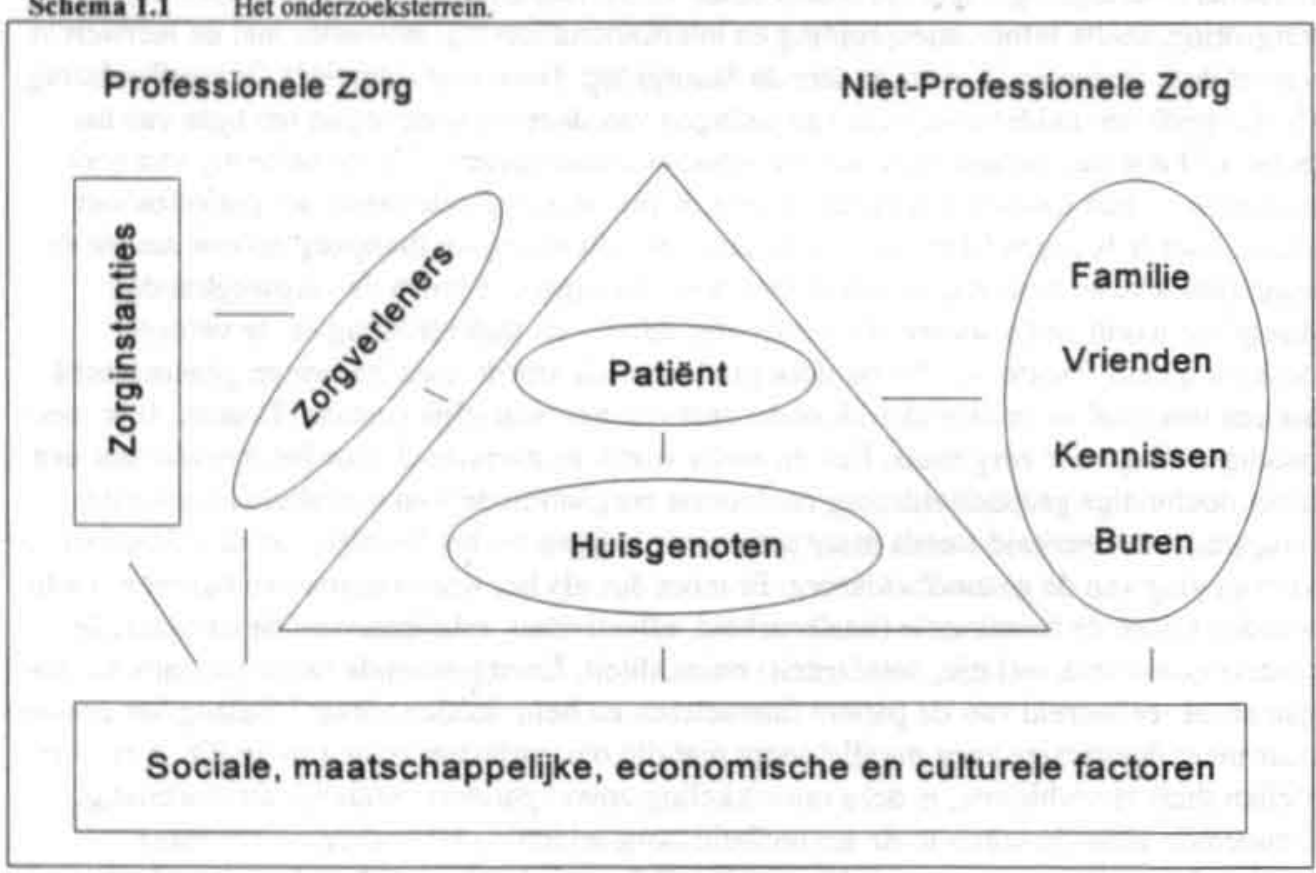

Door maatschappelijke ontwikkelingen treden bij de patient en diens omgeving, de zorgverleners en de gezondheidszorg continu veranderingen op. Onderzoeken als deze ondergaan soortgelijke invloeden en veranderen zelf de te bestuderen werkelijkheid door 
ontwikkeling en invoering van nieuwe zorgvormen. Interactie tussen de uitvoering en de evaluatie van de zorg is hierdoor vrijwel onvermijdbaar. Voor de kwaliteit van de zorg kan $z o ' n$ interactie door tussentijdse bijsturing positief uitwerken. Tegelijkertijd wordt puur experimentele wetenschappelijke toetsing hierdoor gehinderd $(\$ 2.5){ }^{19}$

\subsection{Probleem-, doel- en hoofdvraagstellingen}

\subsubsection{Probleemsteuling}

Enerzijds bestonden er in 1992 aanwijzingen dat medische technologie op een kwalitatief verantwoorde wijze en tegen maatschappelijk aanvaardbare kosten ingepast zou kunnen worden in het zorgaanbod in de thuissituatie, anderzijds leek dit nog nauwelijks in de reguliere zorg ingebed. ${ }^{4,8,20-22}$ Bij patiënten, hun naasten, zorgverleners en hun organisaties zijn belemmeringen gesignaleerd. In termen van het oorspronkelijke onderzoeksvoorstel: "Patiënten en hun naasten hebben onvoldoende kennis van de mogelijkheden tot thuiszorgtechhnologie. Ook ontbreken gegevens over hun eventuele acceptatie van technologie in de thuissituatie. Bij de zorgverleners ontbreekt kennis over de in aanmerking komende ziektebeelden, type en aantallen patiënten aan wie technologie in de thuiszorg ten goede kan komen. Tevens zijn veel zorgverleners van mening dat deze technologie alleen intramuraal optimaal gebruikt kan worden. Bij de toepassing van zorgtechnologie thuis ontbreken vaak de kennis en vaardigheden. Meestal is er voor deze extra zorgfuncties ook een te geringe capaciteit bij de zorgverleners. Op organisatorisch gebied bestaat veelal onvoldoende samenwerking tussen thuiszorg en ziekenhuis. Soms ontbreekt een continu bereikbaar meldpunt voor thuiszorg of is de beschikbaarheid van kruiswerk en huisarts ontoereikend. Ook kunnen protocollen en richtlijnen voor het gebruik van thuiszorgtechnologie ontbreken. Vaak is de beschik- en bereikbaarheid van technische hulpmiddelen ontoereikend. Tot slot kunnen de benodigde organisatie en financiering ontbreken", ${ }^{22}$

\subsubsection{DOELSTELLINGEN}

Vanuit bovenstaande probleemstelling is de algemene doelstelling van dit onderzoek: Het ontwikkelen van een kader waarmee complexe medisch-technische zorg (CMTZ) thuis bij patiënten en naasten, zorgverleners en organisaties geïntroduceerd kan worden.

Deze algemene doelstelling valt uiteen in drie deeldoelstellingen:

1. Ontwikkelen: het formuleren van voorwaarden waaronder CMTZ thuis toegepast kan worden.

2. Implementeren: het als een innovatie op proef implementeren van CMTZ thuis, in casu infuusbehandeling thuis (IT).

3. Evalueren: het evalueren van kwaliteit van leven, kwaliteit van en tevredenheid met zorg en de kosten van CMTZ thuis.

Vanwege het exploratieve karakter betreft het een exemplarisch beschrijvend en geen toetsend of vergelijkend onderzoek. Kwaliteit van leven is gedefinieerd als "de subjectieve beoordeling van het leven in haar geheel ten tijde van de zorg"; kwaliteit van zorg als "de zorginhoudelijk, bedrijfskundig en dienstverlenend optimale verhouding tussen de individuele op zelfzorgbehoeften gebaseerde zorgvraag van de patient en de aangeboden gestandaardiseerde zorg"; tevredenheid met zorg als "de algemene evaluatie van de zorg of het algemene gevoel van wel- of onbehagen daarbij"; en kosten als "de kosten van zorgverlening binnen de gezondheidszorg en de materiële en personele kosten voor patiënten en hun naasten". De definities worden in de desbetreffende hoofdstukken nader toegelicht. 
De interactie tussen wetenschap, technologie en maatschappij is op verschillende wijzen te bestuderen. ${ }^{23,24}$ In dit onderzoek is gekozen voor klassiek Medical Technology Assessment (MTA) of Technology Assessment in Health Care (bijlage 1.2). ${ }^{15}$ Op klassiek MTA is kritiek mogelijk. ${ }^{25}$ Soms wordt daarom 'Constructief' Technology Assessment (CTA) onderzoek gebruikt. ${ }^{24,25}$ In Nederland bestaan van MTA eerder lange omschrijvingen, dan sluitende definities getuige titels als "Medische Technology Assessment en gezondheidsbeleid" of de term "Technologisch Aspectenonderzoek" door gezaghebbende bronnen. ${ }^{26,27}$ Hier is assessment opgevat als beoordelen en medical of health care als gezondheidszorg. In afwijking van de definitie volgens de Raad voor Gezondheidsonderzoek (RGO) omvat MTA in deze studie naast het beoordelen van gezondheidszorgtechnologie vanwege de interactie ook de systemen waarin deze wordt verleend. ${ }^{16}$ De essentie van Technology Assessment is: "het streven om (oorspronkelijk: van) alle mogelijke aspecten die van belang zijn bij invoering van nieuwe of gebruik van bestaande technologie in hun samenhang af te kunnen wegen, en aldus de mogelijkheid te scheppen de richting van de technologische ontwikkeling onderdeel te maken van expliciete besluitvorming". ${ }^{16}$ Volgens onderzoekers en beleidsmakers in Nederland worden bij MTA combinaties van de in schema 1.2 genoemde kennisgebieden toegepast. ${ }^{16.26}$

Schema 1.2 Onderdelen binnen MTA volgens "RGO"16 en volgens "MTA en gezondheidsbeleid". $\%$

\begin{tabular}{ll} 
RGO & MTA en gezondheidsbeleid \\
& Epidemiologie en demografie \\
Implicaties voor de kwaliteit (inhoud) van de zorg & Medische biologische kennis \\
& Medische effectiviteit \\
Maatschappelijke implicaties & Sociale aspecten \\
Organisatorische implicaties & Organisatorische aspecten \\
Ethische en juridische implicaties & Juridische en ethische aspecten \\
Economische en financiele implicaties & Financien en kosten \\
\hline
\end{tabular}

Binnen deze studie zijn keuzes gemaakt. Epidemiologische en demografische aspecten zijn bestudeerd om de potentiële omvang van te behandelen patiëntengroepen in te schatten. De medisch biologische kennis en medische effectiviteit zijn niet onderzocht. Grotendeels waren deze reeds bekend. Onderzoek naar de werkzaamheid of effectiviteit vereist andere omstandigheden en gaat normaal aan de introductie van technologie vooraf. ${ }^{27}$ Analoog aan het Stimuleringsprogramma Thuiszorgtechnologie was het doel van onze studie toepassing van in het ziekenhuis gebruikte technologie in de thuiszorg. Bij de ontwikkeling van nieuwe zorg blijken de kwaliteit van zorg en de organisatorische en de sociaalmaatschappelijke gevolgen onderling vaak sterk verbonden. Er zijn accenten gelegd. Bij de kwaliteit van zorg staat het door de diverse zorgverleners geleverde produkt 'infuusbehandeling thuis' centraal. Bij de organisatie staan invloeden op de ziekenhuis- en thuiszorgorganisaties, die medische, verpleegkundige en farmaceutische zorg leveren, centraal. Sociaal-maatschappelijke gevolgen beperken zich tot patiënten en hun naasten. MTA-onderzoek omvat vaak juridische en ethische aspecten. Juridische consequenties zijn vanwege de veranderingen in de medische en verpleegkundige beroepsuitoefening bestudeerd. Ethische aspecten zijn niet gericht bestudeerd. Wel worden eventuele ethische vraagstukken gesignaleerd. Kosten en financiěle en economische gevolgen lijken erg op elkaar, maar vaak ontbreekt de relatie tussen kostprijs en financiering. Ook in Nederland is de financiering van de gezondheidszorg ondoorzichtig en nog vooral gericht op het in 
stand houden van de organisaties die een bepaald type zorg verlenen (budgetfinanciering). Financiering en maatschappelijke kosten zijn beide bestudeerd.

Op basis van de doelstellingen en bovenstaande keuzes met betrekking tot het MTA onderzoek zijn hoofdvraagstellingen en aandachtspunten geformuleerd.

De hoofdvraagstellingen luidden:

I) Wat is er bij de start van het project bekend over de ontwikkeling, invoering, toepassing en evaluatie van innovaties op het gebied van CMTZ thuis?

II) Op welke wijze kan zo'n innovatie ontwikkeld, geintroduceerd en toegepast worden en wat zijn ervaringen daarbij?

III) Hoe kunnen kwaliteit van leven, kwaliteit van en tevredenheid met zorg en kosten bij de introductie en toepassing van zo'n innovatie gemeten worden en wat zijn ervaringen daarbij?

Hoofdvraagstelling I was gericht op alle aandachtspunten. Hoofdvraagstellingen II en III zijn uitgewerkt in respectievelijk de aandachtspunten 1-5 en 6-9:

1) Benoemen van potentięle doelgroepen, omschrijven van individuele selectiekenmerken en inschatten van aantallen patiěnten.

2) Organisatorisch en logistiek vormgeven van de zorgverlening en het protocolleren en afstemmen daarvan.

3) Informeren en scholen van patiěnten, hun naasten en zorgverleners.

4) Vormgeven van de financiering.

5) Kiezen en toepassen van een zorgtechnologie thuis.

6) Kenmerken van patiënten, hun naasten en zorgverleners.

7) Kwalificatie van het leven van patiënten en hun naasten.

8) Kwalificatie van de zorg in termen van kwaliteit, tevredenheid en doelmatigheid.

9) Kosten voor gezondheidszorg en patiëntsysteem in maatschappelijk perspectief.

Binnen het zorgproces interacteert een min of meer gestandaardiseerd zorgaanbod (1-5) met op basis van aandoeningen en kenmerken individuele zorgvragen van patiënten (6) en is via kwalificatie van de leefsituatie (7), zorg (8) en kosten (9) te bestuderen (schema 1.3).

Schema 1.3 Samenhang aandachtspunten.

Vernieuwingsproces:

Keuze doelgroepen en omschrijven criteria (1)

Afstemming, protocollering en organisatie zorg (2)

Informeren/Scholen (3)

Financiering (4)

Keuze en toepassing zorgtechnologie thuis (5)

1

Gestandaardiseerd zorgaanbod

in interactie met

Kenmerken patient en naaste (6):

Demografisch

Lichamelijk

Psychisch

Sociaal

Aandoeningen en behandelingen

1

\begin{tabular}{|ccc|}
\hline & in interactie met & Individuele zorgvraag \\
Daadwerkelijk tot stand gekomen zorgverieningssituatic & \\
\hline$!$ & $\downarrow$ & \\
Kwalificatie zorg (8) & Kwalificatie kosten (9) & Kwalificatie leven (7) \\
\hline
\end{tabular}

Legenda: ... =de zorgverleningssituatie zelf is niet rechtstreeks bestudeerd, 1-9=aandachtspunten. 


\section{DEEL I: INLEIDING EN METHODEN}

Hoofdstuk 1 introduceert het project Infuusbehandeling Thuis tegen de achtergrond van de modernisering en de daaruit voortvloeiende technologisering en transmuralisering. Hoofdstuk 2 geeft een overzicht van de gebruikte methoden en leidt het bij deze innovatie gehanteerde inventarisatie-, implementatie- en effectonderzoek in.

\section{DEEL II: INVENTARISATIE EN MODELONTWIKKELING}

Hier wordt getracht continuîteit in zorgbehoefte en aanbod te bewerkstelligen door vanuit zowel het gezichtspunt van substantiele als van functionele rationaliteit een zorgconcept te ontwikkelen. Vanuit het perspectief van de patiënt en diens naaste wordt daarvoor binnen het gezondheidskundig metaparadigma inhoud gegeven aan het concept zelfzorg in relatie tot de -vanuit kennistoename en technologisering voortvloeiende- specialisatie, arbeidsverdeling en functionele en structurele differentiatie binnen de professionele zorgverlening. Hoofdstuk 3 beschrijft een literatuurinventarisatie van de ervaringen met CMTZ thuis. In hoofdstuk 4 worden de kaders bij deze soort zorg, waaronder de zorgverleningstheorie van Orem uitgewerkt. Hoofdstuk 5 beschrijft een landelijke enquête onder verpleegkundigen en artsen over de taken en verantwoordelijkheden bij infuusbehandeling. Dit hoofdstuk geeft inzicht in hoe kaders beleefd worden en een toespitsing op IT. Hoofdstuk 6 ten slotte introduceert op grond van het inventarisatie-onderzoek een zorgmodel voor CMTZ.

\section{DEEL III: PROCESBESCHRIJVING EN PROCESEVALUATIE INNOVATIE}

Dit deel heeft vooral betrekking op coördinatie van zorg vanuit bovengenoemde aspecten van functionele rationaliteit met accent op de bijbehorende toename in interdependentie, informatie, schaalgrootte en bureaucratisering. De keuze van doelgroepen en omschrijving van individuele criteria wordt in hoofdstuk 7 besproken. De vormgeving van de zorgverlening in de praktijk op basis van het transmuraal zorgmodel volgt in hoofdstuk 8 . De informatievoorziening, de scholing en de combinatie van technologie en financiering blijken hierbij essentieel en worden in de hoofdstukken 9 tot en met 11 uitgewerkt. Hoofdstuk 12 beschrijft de toegepaste behandelingen met aandacht voor de thuiszorgtechnologie en ervaringen hiermee.

\section{DEEL IV: EFFECT-EVALUATIE}

In dit deel wordt expliciet stilgestaan op de -vaak niet onderkende- interactie tussen de substantiële rationaliteit zoals die tot uiting komt in expressieve waarden als sociale steun, tevredenheid en welzijn (kwaliteit van leven) en de functionele rationaliteit (organisatie en kosten). Het kruispunt van beide rationaliteiten komt met name tot uiting bij kwaliteit van, tevredenheid over en doelmatigheid van zorg. Hoofdstuk 13 beschrijft de leefsituatie en de evaluatie van de kwaliteit van leven van de patiẻnt en diens naaste. De zorgkwaliteit, tevredenheid en doelmatigheid komen in hoofdstuk 14 aan bod. De kosten van infuusbehandeling thuis voor de gezondheidszorg en het patièntsysteem volgen in hoofdstuk 15 .

\section{DEEL V: BESCHOUWING EN SAMENVATTING}

Hoofdstuk 16 geeft een algemene beschouwing over en enige aanbevelingen ten aanzien van technologisering en transmuralisering bij infuusbehandeling thuis tegen de achtergrond van de substantiěle en rationele functionaliteit. Een Nederlandse en Engelse samenvatting volgen in hoofdstuk 17 . 
Een aantal begrippen wordt, nadat ze de eerste keer genoemd zijn, verder afgekort. Deze afkortingen staan nogmaals vermeld achter in het boek. 


\section{Methoden}

\section{$2.1 \quad$ Inleiding}

Vanuit de moderniseringsgedachte is gezocht naar een passende combinatie uit de vele modellen over vormgeving van onderzoek naar de invoering van medische technologie en naar veranderingen in de gezondheidszorg en in het algemeen. Nadat dieper ingegaan wordt op het inventarisatie-, proces- en effectonderzoek, beschrijft dit hoofdstuk kort de dataverzameling en analysemethoden en vat de onderzoeksmethoden globaal samen.

\subsection{Modellen}

Voor de bestudering van de relatie tussen gezondheidszorg en medische technologie zijn, afhankelijk van de te onderzoeken aspecten, diverse modellen beschikbaar. Vanuit een vooral technische benadering duidt het instituut voor Toegepast Natuurwetenschappelijk Onderzoek (TNO) het geheel van de bij de introductie van medische technologie in de thuiszorg te ontplooien activiteiten aan met de term 'vervolgonderzoek'. Hierbij staat niet de ontwikkeling, maar de toepassing van de technologie centraal (schema 2.1). ${ }^{28}$

Schema 2.1 Introductie van medische technologie in de thuiszorg volgens TNO. ${ }^{2 x}$

A) Algemene voorbereiding: conceptrichtlijnen, laboratoriumtest, afspraken/taken

B1) Voorbereiding praktijk: organisatie, financiên, behandelprotocol

C1) Praktijkexperiment

D) Analyse en evaluatie

E) Rapportage: praktijkuitvoering, effectiviteit, veiligheid, kwaliteit van leven, kosten

F) Richtlijnen: opstellen, validatie, verspreiden

Vanuit een meer sociologische benadering kan introductie van medische technologie in de thuiszorg ook opgevat worden als 'invoering van een verandering' of 'innovatie'. ${ }^{13,14} \mathrm{Bij}$ visies op innovatie is 'verandering' ook het belangrijkste gemeenschappelijke kenmerk. Innovaties hebben tenminste drie hoofdfasen. ${ }^{20.31}$ De periode voorafgaand aan het besluit een verandering of vernieuwing (inclusief ontwikkeling) in te voeren is de innovatiefase (fase I). De activiteiten om de innovatie toe te passen behoren tot het implementatieproces (fase II). Tot slot volgt de rejectie of continuering van de implementatie (fase III). Verdere detaillering kan op meerdere wijzen plaatsvinden. ${ }^{13,14}$ Analoog aan Barnhoorn en Walda is innovatie in deze studie opgevat als: "een op elkaar afgestemd geheel van doelstellingen, 
middelen en materialen, een onderliggende theorie en een ideologische rechtvaardiging, dat bedoeld is om aspecten van de zorg te veranderen en door het uitvoerend niveau binnen de zorg als nieuw wordt ervaren". ${ }^{13}$ In het innovatieproces worden verschillende elkaar chronologisch opvolgende activiteiten met de mogelijkheid tot terugkoppeling onderscheiden (schema 2.2). Een te ontwikkelen innovatief idee dient doorlopend getoetst en mogelijk bijgesteld te worden. De analyse van de vernieuwingssituatie geeft inzicht in de doelgroep, vernieuwing, invoerende organisatie en omgeving. Het ontwikkelen van een innovatieperspectief dient om in te schatten onder welke omstandigheden de betrokkenen gewoonlijk leren en veranderingen doorvoeren. Vanuit de tot dan verzamelde gegevens wordt een bruikbaar innovatieprogramma of -concept opgesteld en verspreid. De doelgroep is hierbij op diverse wijzen te betrekken. De verspreidingsfase is de cruciale schakel naar daadwerkelijke toepassing. In de ontwikkelings- en/of implementatiefase wordt de innovatie daadwerkelijk toegepast. Met de evaluatie van processen en effecten wordt de innovatie aan de vooraf geformuleerde doelstellingen getoetst.

Schema 2.2 De activiteiten in het innovatiemodel volgens Barnhoorn en Walda."

1. Ontwikkelen van een innovatief idee

2. Analyseren van de vernieuwingssituatie

3. Ontwikkelen van een innovatieperspectief

4. Ontwikkelen van een innovatieprogramma of -concept of het benaderen van de doeigroep

5. Verspreiden van de innovatie of het concept of dit samen met de doelgroep opstellen

6. Ontwikkelen en /of implementeren van de innovatie

7. Evalueren van het proces en het effect

Doelstelling van deze studie is de exploratie van de mogelijkheden tot IT bezien vanuit de functionele én substantiele rationaliteit. Daartoe is IT dan ook geleidelijk ingevoerd en tussentijds bijgesteld op basis van een combinatie van het TNO-model (A-F), de hoofdfasen bij innovaties (I-III) en het model van Barnhoorn en Walda (1-7) (schema 2.3).

Schema 2.3 Het innovatiemodel bij het project Infuusbehandeling Thuis.

\begin{tabular}{|c|c|c|}
\hline & 1. Ontwikkeling innovatie (TNO: $A, B$ ) & Fase \\
\hline 1. & Ontwikkelen van een innovatief idee & I \\
\hline 2. & Analyseren van de vernieuwingssituatie & $I+P$ \\
\hline 3. & Ontwikkelen van een innovatieperspectief & P \\
\hline 4. & Ontwikkelen van een innovatieprogramma of -concept of het benaderen van de doelgroep & $\mathbf{P}$ \\
\hline 5. & $\begin{array}{l}\text { II. Proefimplementatie en evaluatie innovatie (TNO: C,D,E) } \\
\text { Verspreiden van de innovatic of concept of dit samen met de doelgroep opstellen }\end{array}$ & $\mathbf{P}$ \\
\hline 6. & Ontwikkelen en/of implementeren van de innovatic & $\mathbf{P}$ \\
\hline $7 \mathrm{a}$ & Evaluatie-onderzock van het proces & $\mathbf{P}$ \\
\hline $7 b$ & Evaluatie-onderzoek van het effect & $\mathrm{E}$ \\
\hline 8. & $\begin{array}{l}\text { III. Contimuering/Rejectie innovatie (TNO: } F) \\
\text { Aanbieden van een geevalueerd innovatieprodukt }\end{array}$ & \\
\hline
\end{tabular}

Legenda: $\mathrm{I}=$ =inventarisatic bij ontwikkeling, $\mathrm{P}$-procesbeschrijving/evaluatie bij implementatie, $\mathrm{E}=$ =ffectevaluatic.

Het TNO-model is breed toepasbaar en scheidt praktijk en evaluatie. Ook in deze studie wordt dit onderscheid gemaakt, maar afgeweken van het TNO-model omdat naast een effectevaluatie en procesbeschrijving ook een procesevaluatie is opgenomen. De door Barnhoorn en Walda vanuit innovatietheorieên ontwikkelde, procesgerichte benadering is 
ruim inzetbaar. Het aanbieden van een geĕvalueerd innovatieprodukt is als een achtste fase op te vatten. De gebruikte onderzoeksmethoden zijn zowel inventariserend als proces- en effectgericht. Inventarisatie-onderzoek kan binnen het TNO-model aangemerkt worden als algemene voorbereiding, binnen het innovatiemodel als het ontwikkelen van een innovatief idee en het analyseren van de vernieuwingssituatie. Innovatie(proces)-onderzoek kan zich in het TNO-model uitstrekken van voorbereiding op de praktijk tot en met de rapportage, in het innovatiemodel van het analyseren van de vernieuwingssituatie tot en met de procesevaluatie. Effectonderzoek beslaat binnen het TNO-model de voorbereiding van de evaluatie tot en met de rapportage, binnen het innovatiemodel maakt zij deel uit van de proefimplementatie. Gedeeltelijke controle door de onderzoekers via standaardisering en protocollering is nodig om het model te kunnen ontwikkelen en reproduceren. Het onderzoek heeft daardoor zowel beschrijvende als quasi-experimentele kenmerken. ${ }^{32,33} \mathrm{De}$ evaluatie omvat kwantitatieve en kwalitatieve elementen. ${ }^{34}$

\subsection{Methode van inventarisatie-onderzoek}

Hoofdvraagstelling I vereist inventarisatie-onderzoek omtrent de ontwikkeling, invoering, toepassing en evaluatie van innovaties op het terrein van thuiszorgtechnologie. Bij MTAonderzoek kunnen nieuwe gegevens verzameld of oude opnieuw geraadpleegd worden. ${ }^{26}$ Heronderzoek van bekende gegevens of het gebruik van opinies van deskundigen, noemt men 'synthese-onderzoek' ${ }^{15}$ Methoden hierbij zijn: (meta)analyse van literatuur en meningsonderzoek bij de doelgroep via enquêtes, interviews en groepsmethoden zoals Delphi-onderzoek en consensusbijeenkomsten. Inventarisatie-onderzoek beslaat binnen het gekozen innovatiemodel de fasen 1 en 2 (schema 2.3). Analyse van de gesignaleerde behoeften en problemen beoogt de relevantie van het innovatief idee in te schatten. ${ }^{14}$ Daarnaast dient dit onderzoek als fundament voor verder onderzoek en zorgontwikkeling. Om inzicht te krijgen in de beschikbare kennis over IT is de in hoofdstuk 3 weergegeven literatuurinventarisatie gedaan naar de ervaringen met toepassing van technologie thuis. Daarnaast is vanuit de CTA gedachte met sleutelfiguren gesproken en aan netwerken deelgenomen of werden deze mee opgebouwd. ${ }^{24,25}$ Op deze wijze is kennis uitgewisseld binnen het netwerk dat het project omgaf, bestaande uit medisch en verpleegkundig specialisten van het azM en de SGKH, wetenschappers van de UM en leden van de begeleidingscommissie (bijlage 1.1 en 2.1) ${ }^{24}$ Doel hiervan was om continu ideeën te kunnen ontwikkelen en toetsen. Deze continue 'zoektocht' kan verwoord worden als 'research by walking around' en is niet uitgebreid gedocumenteerd. Bijlage 2.1 geeft een indicatieve opsomming van personen, organisaties en kennisprodukten die de vormgeving van het onderzoek en/of de zorgverlening beïnvloed hebben. ${ }^{24,35,36}$ Door op een dergelijke wijze op zoek te gaan naar de 'ideale' zorgverlening is 'bias' onontkoombaar. Vrijwel alle organisaties die binnen de gezondheidszorg zorg verlenen, deze bestuderen of hierover adviseren gedragen zich in meerdere of mindere mate als (markt)partijen met eigen belangen. Men observeert elkaar en sluit bijvoorbeeld strategische allianties of verbreekt deze. Precieze gevolgen van deze opstelling zijn moeilijk te geven. Door zoveel mogelijk partijen te benaderen is gepoogd het 'netto-effect' van deze 'bias' te beperken. Vanuit de literatuurinventarisatie en de contacten bleek tot nu toe vooral de functionele rationaliteit bestudeerd te zijn. Ons inziens leek verdere verdieping van de bredere kaders bij CMTZ thuis en de taak- en verantwoordelijkheidsverdeling bij IT gewenst.

De eerste verdieping vanuit de substantiële rationaliteit betreft fundamentele vragen over uitgangspunten in medische en verpleegkundige zorgverlening bij CMTZ. Het Kwaliteits- 
Instituut voor Toegepaste ThuisZorgvernieuwing (KITTZ) geeft door haar benadering enig inzicht in dit aspect. ${ }^{37}, 38$ Centraal staat de afstemming van zorg op de objectieve en subjectieve behoeften van de patiênt, de continuilteit van zorg. Daarom zijn in hoofdstuk 4 vanuit substantięle en functionele rationaliteit enkele kaders bij CMTZ thuis bestudeerd, zoals maatschappelijke aspecten, wet, financiering en bestaande zorgvormen.

Een tweede verdieping -tegen de achtergrond van specialisatie en functionele differentiatie alsmede arbeidsdeling en structurele differentiatie- betreft een zodanige taak-, verantwoordelijkheids- en bevoegdheidsverdeling en afstemming bij infuusbehandeling (thuis) dat de coördinatie van zorg ge(waar)borgd is. Uit de literatuurinventarisatie en de contacten komt een veelheid aan werkwijzen en organisatievormen naar voren. Toch geven zij slechts een globaal inzicht in wat werkelijk op de werkvloer gebeurt. Verslagen als van het Verdun Hospital-in-the-Home program, dat ook de praktische uitvoering gedetailleerd beschrijft, zijn zeldzaam. ${ }^{39}$ Ter inventarisatie van de Nederlandse situatie en vanwege de externe validiteit beschrijft hoofdstuk 5 de mening van huisartsen, specialisten, wijk- en ziekenhuisverpleegkundigen over de bestaande en de gewenste verdeling van taken, verantwoordelijkheden en bevoegdheden bij infuusbehandeling. ${ }^{15}$ Dit om het risico te beperken dat de te ontwikkelen innovatie niet relevant is voor de doelgroep of in een onacceptabele vorm wordt aangeboden. ${ }^{13,14}$ Een andere reden betreft de juridische invalshoek. Meestal is dit onderzoek kwalitatief. In deze studie dient de enquête om de mening van de beroepsbeoefenaars kwantitatief te kunnen relateren aan de invoering van de nieuwe wetgeving betreffende de beroepsuitoefening. Over deze overgangssituatie was toen al op diverse maatschappelijke niveau's een tiental jaren gediscussieerd. ${ }^{40-44}$ Op basis van alle verzamelde informatie wordt ten slotte in hoofdstuk 6 een algemeen zorgmodel voor CMTZ (thuis) uitgewerkt.

\subsection{Methode van innovatie(proces)-onderzoek}

Hoofdvraagstelling II betreft de introductie en toepassing van IT als voorbeeld van thuiszorgtechnologie. Hoofdvraagstelling III omvat ook het evalueren van de kwaliteit van zorg. Deze hoofdvraagstellingen worden gelet op de coördinatie van zorg uitgewerkt in de vorm van een procesbeschrijving en evaluatie in de hoofdstukken 7 tot en met 12. Eerst wordt vanuit de vernieuwingssituatie het innovatie-onderzoek toegespitst. Daarna worden een vernieuwingsperspectief en invoeringsstrategie gekozen en het werkplan toegelicht. Innovatie-onderzoek beslaat binnen het gekozen innovatiemodel fase 2 tot en met $7 \mathrm{a}$ (schema 2.3). Bij veranderingsprocessen in de thuiszorg onderscheiden Barnhoorn en Walda zeven kernactiviteiten. ${ }^{13}$ De vernieuwingssituatie is te verkennen door de doelgroep te portretteren, de vernieuwing te beoordelen, de veranderaar te positioneren en de context te bestuderen. De vernieuwing is te implementeren door het ontwikkelen van een visie op vernieuwing, het ontwerpen van een implementatiestrategie en het sturen van het invoeringsproces. Afhankelijk van de visie van waaruit de kernactiviteiten vorm worden gegeven, zijn een technologisch, een machts-, een evolutie- en een cultureel-politiek innovatieperspectief te onderscheiden. Ook zijn er verschillende invoeringsstrategieën.

\subsubsection{DE VERNIEUWINGSSITUATIE}

Bij een innovatie als IT zijn de context, vernieuwing, doelgroep en veranderaar ("agent of change") te beschrijven in termen van structuur, cultuur en beïnvloedingswijze (schema 2.4). ${ }^{13} \mathrm{Bij}$ de context blijken twee zaken van belang. In de gezondheidszorg leiden de structuur en complexe wet- en regelgeving tot de tweedeling klinische en thuiszorg. 
Kenmerken context

\section{Structuur}

-Nederlandse gezondheidszorg -onderzoek betaald uit stimuleringssubsidie overheid ${ }^{12}$ -andere betrokkenen: inspectie Volksgezondheid, particuliere zorgverleners en farmaceutische industrie, onderzoekers van thuiszorgtechnologie

Kenmerken vernieuwing

Structuur

-technologie tevens in dienst van bevorderen autonomie patient - geen nieuwe organisaties nodig -veranderingen in organisaties, met name uitbreiding takenpakket thuisverpleging -verpleegkundigen voor medischtechnisch handelen aangesteld -gelijke of betere kwaliteit van zorg tegen acceptabele kosten

\section{Kenmerken doelgroepen}

Structuur

Klinische zorg:

-hièrarchische organisatie -vooral cure

\section{Thuiszorg:}

-segmentale organisatie

-cure en care

Kenmerken veranderaar

\section{Structuur}

-deelnemende organisaties en belangenvereniging huisartsen zijn verenigd in stuurgroep -de dagelijkse uitvoering vindt plaats door projectgroep

\section{Cultuur}

-Westers normen- en waardenpatroon -regulering van gezondheidszorg middels 0.2 . wetgeving -omgeving en inzichten sterk aan verandering onderhevig -meer ruimte voor concurrentic in de gezondheidszorg

\section{Cultuur}

-sterk veranderde kennis- en vaardigheidseisen voor huisartsen en wijkverpleging -hoge eisen aan communicatie en samenwerking tussen klinische en thuiszorg -nieuwe zorgvorm geen gemeengoed en vereist overtuigingskracht
Beīnvloedingswijze

-diverse belanghebbenden oefenen invloed uit via belangenorganisaties en adviesorganen die tezamen een 'maatschappelijk middenveld' met grote invloed op onder andere de wet-en regelgeving vormen 45,5

\section{Beinnvloedingswijze}

-vereist overeenstemming tussen special ist en huisarts over vorm en inhoud van de behandeling - afweging van verlies en winst van kwaliteit van leven door de thuisbehandeling -nieuwe zorgvorm dient voordelen te hebben voor patienten, zorgverleners en zorgverzekeraars

\section{Cultuur}

Klinische zorg: -professionele autonomie binnen door team geleverde zorg -actieve attitude gericht op behandeling ter genezing

Thuiszorg: -professionele autonomie bij individueel geleverde zorg -actieve of terughoudende attitude bij genezing, verzorging of begeleiding

\section{Beĭnvloedingswijze}

Klinische zorg: -sterk bureaucratisch en geinstitutionaliseerd machtsblok

\section{Thuiszorg:}

-huisartsen en thuisverpleging werken onafhankelijk van elkaar -in- en extern heeft de thuiszorg minder invloed dan de kliniek

\section{Cultuur}

-informatieverstrekking naar en vertegenwoordiging van achterban

-kritische discussie over zorgontwikkeling met als uitgangspunt belang patient

\section{Beïnvloedingswijze} -de projectgroep is autonoom in zorgontwikkeling en uitvoering, maar legt verantwoording af aan de stuurgroep

Ook noopt de kostenontwikkeling tot bezuinigingen die vaak egaal over diverse sectoren verdeeld worden. Beiden belemmeren de verschuiving van klinische naar thuiszorg. De vernieuwing infuusbehandeling betekent voor de thuiszorg uitbreiding van het zorgarsenaal en mogelijkheid tot verdere professionalisering. Anderzijds nemen ook de zorgaanspraken direct (infuusbehandeling zelf) en indirect (overige zorg bij infuuspatiênten) toe. In de regel staan daar voor de wijkverpleging geen, en voor huisartsen slechts bij particuliere patiënten extra inkomsten tegenover. Thuisbehandeling biedt ziekenhuizen 
mogelijkheden tot samenwerking met de thuiszorg. Substitutie van zorg kan leiden tot een hogere patiëntendoorstroom met effecten op onder andere de werkdruk, de gemiddelde kosten per behandeling en het bedbezettingspercentage.

Buiten het patielntsysteem bestaan de doelgroepen uit hulpverleners in de klinische en de thuiszorg. De specialistische versus generalistische zorgverlening vereist een verschillende organisatie en werkwijze. Er is dan ook niet één homogene doelgroep. De samenwerking bij en vormgeving van thuisbehandeling kan hierdoor noch door één centrale besluitvormer opgelegd worden, noch volledig vanuit de doelgroep zelf ontstaan.

De veranderaar, het project Infuusbehandeling Thuis, werd door de Vakgroep Huisartsgeneeskunde van de UM, het Transmuraal \& Diagnostisch Centrum (TDC) van het azM en de SGKH, binnen een samenwerkingsverband uitgevoerd. Zij hebben aandacht voor zorg op het grensvlak van de generalistische en specialistische zorg. ${ }^{4-51} \mathrm{De}$ thuisbehandeling is aangeboden in de vorm van een onderzoek met vrijwillige deelname van patiēnten en zorgverleners. Beìnvloeding is dan vooral mogelijk door motivatie, het aanreiken van kennis en vaardigheden, alsmede financiering. Slechts in continue samenspraak en met gezamenlijke verantwoordelijkheid is een voor elke doelgroep aanvaardbare zorgvorm te ontwikkelen.

Deze kenmerken sturen de keuzen van vernieuwingsperspectief en invoeringsstrategie.

\subsubsection{HET VERNIEUWINGSPERSPECTIEF}

Ten aanzien van een innovatie zijn verschillende perspectieven te onderscheiden. ${ }^{13}$

Bij het technologisch perspectief is de vernieuwing meestal zo goed en aantrekkelijk dat de doelgroep deze zonder twijfel invoert. Om infuusbehandeling succesvol vanuit dit perspectief te kunnen bestuderen zou het een kleine, exact omschreven en algemeen geaccepteerde innovatie moeten zijn, die op uitvoerend niveau geen discussie kan geven over doelstellingen en de inzet van middelen. Het feit dat dit onderzoek voortkomt uit een stimuleringsprogramma, wijst erop dat dit perspectief hier niet goed toepasbaar is.

Het machtsperspectief gaat er vanuit dat besluitvormers van de doelgroep(en) overtuigd zijn van de noodzaak en de innovatie van bovenaf opleggen. Dit perspectief is eigenlijk alleen toepasbaar bij bestudering van hiërarchische organisaties of als een vernieuwing gemakkelijk toepasbaar is en een breed draagvlak heeft. De ervaring heeft geleerd dat, gezien de toenemende decentralisatie van de maatschappij en de gezondheidszorg, een centralistische aanpak minder geschikt is voor innovaties in de eerste lijn.

Het evolutieperspectief gaat er vanuit dat de doelgroep zelf, gegeven ruime kaders, de richting van de vernieuwing bepaalt en het leervermogen vergroot teneinde te kunnen reageren op een werkomgeving die steeds nieuwe en onvoorspelbare problemen oplevert. Gezien de voor infuusbehandeling benodigde kennis en vaardigheden, de noodzakelijke investeringen in mensen en middelen en de technische en organisatorische complexiteit, is niet te verwachten dat deze vanuit de doelgroep zelf ingevoerd wordt.

In het cultureel-politiek perspectief komt een innovatie tot stand door continue interactie tussen de doelgroep en de veranderaars. Bovendien is bij dit perspectief de doelgroep mede verantwoordelijk voor de vormgeving van de vernieuwing. Het betreft hier vaak de invoering van een veranderde werkwijze met vaste en variabele aspecten die alleen is te bewerkstelligen door beĭnvloeding van kennis, gedrag en motivatie (via onderhandeling). Omdat blijkens de inventarisatie in de vernieuwingssituatie bij IT (\$2.4.1) veel aspecten van belang zijn, de behandeling op veel manieren is vorm te geven en zich beweegt op de grensvlakken van klinische zorg en thuiszorg en van de medische en verpleegkundige 
professie, plus hetgeen hiervoor bij de perspectieven opgemerkt is, lijkt het cultureelpolitiek perspectief (schema 2.5) het meest geschikt om deze innovatie in te voeren en te bestuderen. IT in de regio 'Heuvelland' is dan ook op basis van een, vanuit dit perspectief ontwikkeld, transmuraal zorgmodel ingevoerd. ${ }^{13,14,52}$

Schema 2.5 De zeven innovatiefasen in cultureel-politiek perspectief. ${ }^{13}$

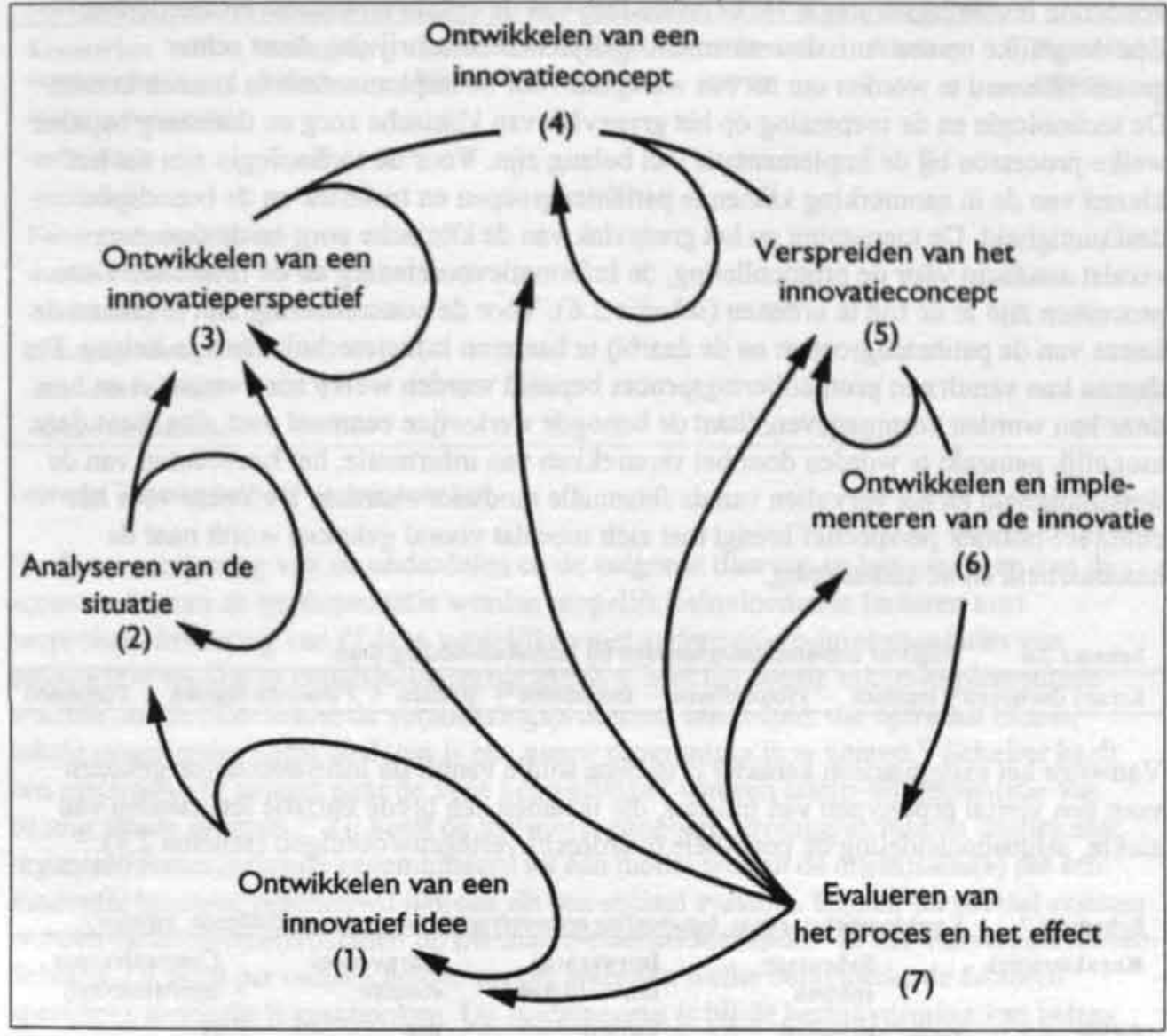

\subsubsection{DE INVOERINGSSTRATEGIE}

Gerelateerd aan de veranderingssituatie en het gekozen perspectief kunnen verschillende invoeringsstrategieën gebruikt worden. Bekend zijn vooral de "empirisch rationele", "normatief heropvoedende" en "macht" strategieën. ${ }^{13}$ Het technologisch perspectief gaat meestal uit van een rationeel overwegingsproces gebaseerd op cognities en inzichten. Het evolutie- en het cultureel-politiek perspectief hanteren normatief heropvoedende strategieën, gebaseerd op het normatieve waardensysteem van de betrokkenen. De machtsstrategieën gaan uit van geïnstitutionaliseerde macht. Vanwege de keuze voor het cultureel-politiek perspectief is bij de invoering van de IT vooral de normatief heropvoedende strategie gebruikt. ${ }^{13,14,52}$ Omdat de infuusbehandeling sterk gestoeld is op technologie en de betrokken partijen niet altijd overeenstemming bereiken, spelen soms ook empirisch rationele en machtsstrategieën een rol. 


\subsubsection{HET WERKPLAN}

Vanuit de innovatietheorie definiêren wij de invoering van IT als: de invoering van een op technologie geënte vernieuwing in de gezondheidszorg, die plaats heeft op het grensvlak van de klinische zorg en de thuiszorg en aangeboden wordt in de vorm van een door de overheid gesubsidieerd onderzoek, dat vanuit het cultureel-politiek perspectief gericht is op haalbaarheid en afstemming en gebruik maakt van een overwegend normatief heropvoedende invoeringsstrategie via beïnvloeding van de opinie en kennisvermeerdering. ${ }^{13}$ Een dergelijke op een 'mission statement' gelijkende omschrijving dient echter geconcretiseerd te worden om tot een werkplan voor de implementatie te kunnen komen. De technologie en de toepassing op het grensvlak van klinische zorg en thuiszorg bepalen welke processen bij de implementatie van belang zijn. Voor de technologie zijn dat het kiezen van de in aanmerking komende patientengroepen en techniek en de benodigde deskundigheid. De toepassing op het grensvlak van de klinische zorg en de thuiszorg vereist aandacht voor de protocollering, de informatievoorziening en de financiën. Deze processen zijn in de tijd te ordenen (schema 2.6). Voor de concretisering zijn allereerst de keuze van de patiëntengroepen en de daarbij te hanteren infusietechnieken van belang. Pas daarna kan vanuit een protocolleringsproces bepaald worden welke zorg vereist is en hoe deze kan worden vormgegeven. Staat de beoogde werkwijze eenmaal vast, dan dient deze mogelijk gemaakt te worden door het verstrekken van informatie, het bevorderen van de deskundigheid en het vervullen van de financiële randvoorwaarden. De keuze voor het cultureel-politiek perspectief brengt met zich mee dat vooral gekeken wordt naar de haalbaarheid en de afstemming.

Schema $2.6 \quad$ Volgorde implementatieprocessen bij infuusbehandeling thuis.

Kiezen doelgroep + technick - Protocolleren - Informeren + Scholen + Financien regelen - Toepassen

Vanwege het exemplarisch karakter is in deze studie vanuit de infusietechniek gekozen voor een viertal prototypen van infusies, die tezamen een brede variatie ten aanzien van ziekte, infuusbehandeling en potentielle overdracht vertegenwoordigen (schema 2.7).

Schema 2.7 Karakteristieken ziekte, behandeling en overdracht tijdens de verschillende infusies.

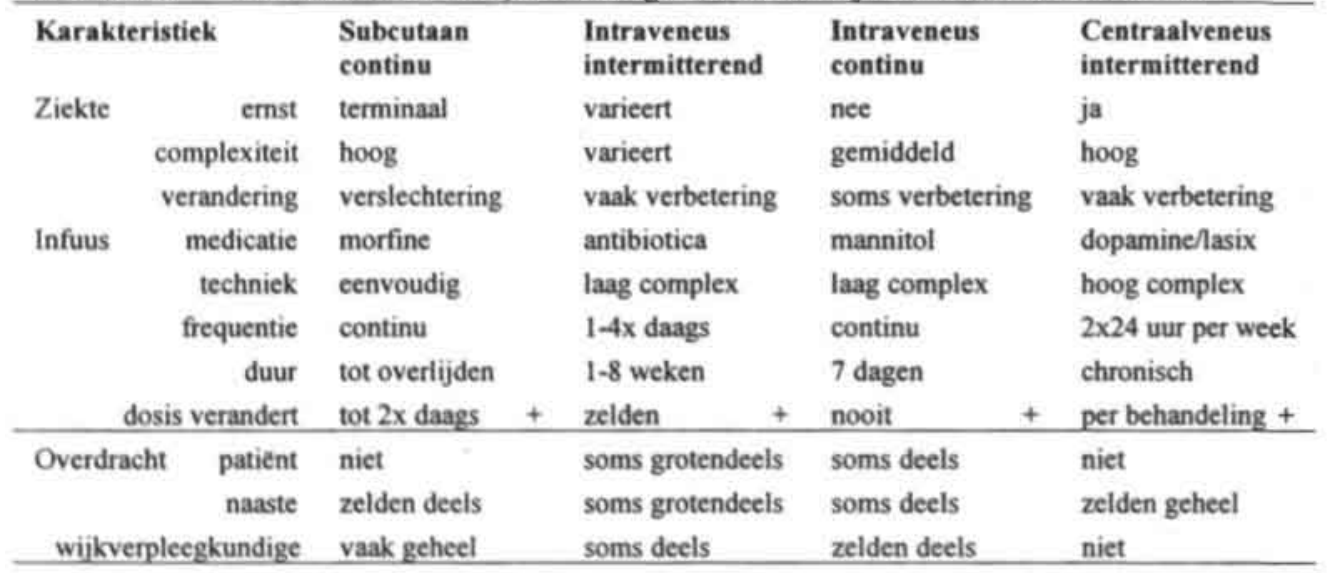

Bij de gehanteerde normatief heropvoedende invoeringsstrategie staan beĭnvloeding van de kennis en de opinie centraal (schema 2.8). Bij de processen die meer gerelateerd zijn aan 
de technologie van de innovatie (doelgroep, techniek, scholing), ligt het accent op het inschatten van de haalbaarheid en kennisbeïnvloeding. Bij de processen die meer gerelateerd zijn aan het grensvlak waarop de innovatie plaatsvindt (protocolleren, informeren, financieren), ligt het accent op de afstemming en het belnvloeden van de opinie. Elders is implementatie op vergelijkbare wijze onder te verdelen. ${ }^{53}$

Schema 2.8 Accenten bij de concrete implementaticprocessen vanuit de innovatiedefinitic.

\begin{tabular}{|c|c|c|c|c|c|c|}
\hline $\begin{array}{l}\text { Kenmerken } \\
\text { vernieuwing }\end{array}$ & $\begin{array}{l}\text { Doeigroep } \\
\text { kiezen }\end{array}$ & $\begin{array}{l}\text { Techniek } \\
\text { kiezen }\end{array}$ & $\begin{array}{l}\text { Protocol- } \\
\text { leren zorg }\end{array}$ & $\begin{array}{l}\text { Informatie } \\
\text { geven }\end{array}$ & Scholen & $\begin{array}{l}\text { Financiěn } \\
\text { regelen }\end{array}$ \\
\hline \multicolumn{7}{|l|}{ Vernieuningssituatie } \\
\hline -technologie & $\mathrm{x}$ & $\mathrm{x}$ & . & . & $\mathrm{x}$ & . \\
\hline -grensvlak & . & . & $\mathrm{x}$ & $\mathrm{x}$ & . & $\mathrm{x}$ \\
\hline \multicolumn{7}{|c|}{ Vernieuwingsperspectief } \\
\hline -haalbaarheid & $\mathrm{x}$ & $\mathrm{x}$ & . & . & $\mathrm{x}$ & 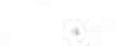 \\
\hline -afstemming & . & . & $\mathrm{x}$ & $\mathrm{x}$ & . & $\mathrm{x}$ \\
\hline \multicolumn{7}{|l|}{ Invoeringsstrategie } \\
\hline -kennis bevorderen & $\mathrm{x}$ & $\mathrm{x}$ & . & . & $\mathrm{x}$ & $\therefore$ \\
\hline -opinic veranderen & . & . & $\mathrm{x}$ & $\mathrm{x}$ & . & $\mathrm{x}$ \\
\hline
\end{tabular}

Legenda: $X=$ =nderdeel waar de nadruk op ligt.

$\mathrm{Na}$ de concretisering van de onderdelen en de volgorde daarvan en het aangeven van de accenten binnen de implementatie worden mogelijk beìnvloedende factoren kort besproken. Invoering van IT is te vergelijken met andere micro-implementaties van innovatieve sociale of behandelingsprogramma's. Met het begrip micro-implementatie worden ook in deze studie de veranderingsprocessen aangeduid, die optreden binnen lokale organisaties nadat besloten is een nieuw programma in te voeren. ${ }^{52}$ Scheirer heeft een meta-analyse gedaan naar de voor het welslagen van een micro-implementatie van belang zijnde factoren. ${ }^{30} \mathrm{Zij}$ heeft de zes meest gangbare stromingen binnen studies naar organisatieveranderingen gecombineerd tot één model waarin de organisatie(s) die een innovatie invoeren beschouwd worden als een sociaal systeem. Binnen dit sociaal systeem worden factoren onderscheiden op het macro-, het middenkader- en het individuele niveau. Schema 2.9 geeft per onderscheiden proces weer aan welke beïnvloedende factoren specifieke aandacht is geschonken. Op macroniveau is bij de besluitvorming van belang hoe, waarom en door wie de beslissing tot innovatie is genomen. De invoering van de innovatie dient congruent te zijn met de controleprocedures -centraal hetzij decentraalbinnen de organisatie. Voldoende mensen en middelen dienen vrijgemaakt te worden om de innovatie te kunnen toepassen en begeleiden. Tot slot is de invloed van de omgeving van belang. Ook het middenkader kan het welslagen van een innovatie beïnvloeden. Daarbij is van belang of de innovatie binnen de organisatie en de standaardprocedures past of dat deze voldoende op elkaar afgestemd worden. Ook speelt een rol of de hoofden het beleid van de directie in woord en daad steunen, of er voldoende communicatie is om de innovatie toe te lichten (top-down) of moeilijkheden snel op te sporen (bottom up) en of de innovatie verenigbaar is met de heersende groepsnormen en waarden. Op het individuele niveau ten slotte, spelen gedragsvaardigheden, materie̋le beloningen en morele steun een rol. Ook bij andere innovaties in de gezondheidszorg worden deze factoren onderkend..$^{54.56}$ Scheirer's studie toont aan dat kwantitatieve en kwalitatieve bestudering van deze 


\begin{tabular}{|c|c|c|c|c|c|c|}
\hline $\begin{array}{l}\text { Niveau en factor naar } \\
\text { Seheirer }{ }^{20}\end{array}$ & $\begin{array}{l}\text { Doelgroep } \\
\text { kiezen }\end{array}$ & $\begin{array}{l}\text { Techniek } \\
\text { kiezen }\end{array}$ & $\begin{array}{l}\text { Protocol- } \\
\text { leren zorg }\end{array}$ & $\begin{array}{l}\text { Informatie } \\
\text { geven }\end{array}$ & Scholen & $\begin{array}{l}\text { Financièn } \\
\text { regelen }\end{array}$ \\
\hline \multicolumn{7}{|l|}{ Macro } \\
\hline -besluitvorming & $\mathrm{x}$ & $x$ & & $\mathrm{x}$ & & \\
\hline -controleprocessen & $\mathrm{x}$ & $\mathrm{x}$ & $\mathrm{x}$ & & & \\
\hline $\begin{array}{l}\text {-allocatie mensen en } \\
\text { middelen }\end{array}$ & $\mathrm{x}$ & $\mathrm{x}$ & $\mathrm{x}$ & & & $\mathrm{x}$ \\
\hline -relatie omgeving & $\mathrm{x}$ & $\mathrm{X}$ & $\mathrm{x}$ & $\mathrm{x}$ & & \\
\hline \multicolumn{7}{|l|}{ Middenkader } \\
\hline -attitude hoofden & & & & $\mathrm{x}$ & & \\
\hline -dagelijkse routine & & & $\mathrm{x}$ & & $\mathrm{x}$ & \\
\hline -pasvorm innovatic & & & $\mathrm{x}$ & & & \\
\hline -communicatiepatroon & & & $\mathrm{x}$ & $\mathrm{x}$ & $\mathrm{x}$ & \\
\hline -groepsnormen & & & $\mathrm{x}$ & $\mathrm{x}$ & $x$ & \\
\hline \multicolumn{7}{|l|}{ Individueel } \\
\hline $\begin{array}{l}\text {-kennis en kunde, } \\
\text { attitude, communicatic }\end{array}$ & & & $\mathrm{x}$ & & $\mathrm{x}$ & \\
\hline -materiele beloning & & & & & & $\mathrm{x}$ \\
\hline -morele steun & & & & $\mathrm{x}$ & $\mathrm{x}$ & \\
\hline
\end{tabular}

Legenda: X-specifieke andacht voor beinvloedende factoren bij een implementatieproces.

elementen in hun complexe samenhang een onderzoek op zich vormt. ${ }^{30}$ In de komende hoofdstukken zullen de door haar onderscheiden factoren dan ook vooral als conceptue:! kader gebruikt worden bij de procesbeschrijving.

\subsection{Methode van effectonderzoek}

Bij de evaluatie van gezondheidszorg komen menselijkheid, technologie en middelen samen. ${ }^{57}$ Onderzoek naar medische technologie, zorgvernieuwing en kwaliteitsverbetering betreft dan ook vaak kwaliteit van leven $(\mathrm{KvL})$, tevredenheid met en kwaliteit van zorg (KvZ) en kosten. ${ }^{53,58}$ De derde hoofdvraagstelling richt zich op het kruispunt van substantiële (KvL, tevredenheid) en functionele ( $\mathrm{KvZ}$, kosten) rationaliteit.

$\mathrm{KvL}$ onderzoek is halverwege de zeventiger jaren ontstaan. ${ }^{59,60}$ Door toename van het aantal chronische zieken, explosieve groei van de diagnostische en behandelmogelijkheden en inzicht in de gevaren van overbehandeling, was het levensbehoud in jaren niet langer het enige criterium bij behandeling. Optimale zorg was niet langer gelijk aan maximale zorg. ${ }^{61}$ Men ging op zoek naar andere waarden waaraan criteria ontleend konden worden. Onderkend werd dat in de gezondheidszorg bij het nemen van beslissingen op het gebied van de individuele patiëntenzorg, bij onderzoek of bij beleid de verbetering of instandhouding van $\mathrm{KvL}$ van de patiënt een belangrijke rol dient te spelen. ${ }^{61}$ Temeer daar de financierbaarheid van de gezondheidszorg tot keuzes ging dwingen.

Daarnaast is vooral in het laatste decennium het kwaliteitsdenken in de bedrijfsvoering steeds explicieter geworden. ${ }^{62}$ De kern van dit principe is dat men de continue en integrale zorg voor de kwaliteit en een efficiënte bedrijfsvoering tracht te incorporeren in de eigen bedrijfscultuur door bij voortduring te streven naar een optimale afstemming van materiēle, immateriēle en persoonlijke schakels in het organisatieproces. ${ }^{63}$ Binnen de gezondheidszorg werd deze impuls gegeven door het plan 'Dekker'. ${ }^{4}$ Hierin wordt de 
koppeling gelegd tussen kostenbeheersing, grotere marktgerichtheid en integrale kwaliteitszorg. De overheid zou dienen terug te treden en aan beroepsbeoefenaren en tot dan 'externe partijen' (financiers en gebruikers) werd een belangrijke rol toebedeeld bij de beīnvloeding van kwaliteit. ${ }^{65} \mathrm{KvL}$ ging daarbij steeds meer deel uitmaken van de (bestudering van) $\mathrm{KvZ}$ en zorgvernieuwing. ${ }^{53} \mathrm{Zo}$ omschrijft de Kwaliteitswet Zorginstellingen in artikel 2 verantwoorde zorg als "zorg van goed niveau, die in ieder geval doeltreffend, doelmatig en patiëntgericht wordt verleend en die afgestemd is op de reęle behoefte van de patiënt". ${ }^{66}$ De gezondheidstoestand van patiënten kan een indicatie geven over de KvZ bij zorgvernieuwingen. Zo noemen Schrijvers en van Londen bij onderzoek naar doeltreffendheid enerzijds (medisch)-biologische variabelen, psychisch welbevinden, functionele gezondheidstoestand, maatschappelijk functioneren en anderzijds tevredenheid met de zorg, veiligheid en $\mathrm{KvL}^{53}$

Naast de inventarisatie van de mogelijkheden voor een zorgmodel en de beschrijving van de praktijk, zijn in de hoofdstukken 13 tot en met 15 dan ook voornoemde effecten geëvalueerd. Gezien het exemplarisch karakter van dit onderzoek is in het algemeen gestreefd naar bruikbaarheid voor diverse belangengroepen en toepasbaarheid bij bestudering van andere CMTZ. Het effectonderzoek beslaat binnen het gekozen innovatiemodel fase $7 \mathrm{~b}$ (schema 2.3). Effectevaluatie heeft tot doel te onderzoeken of de beoogde doelen worden gehaald. ${ }^{14}$

Van de onderzochte infusies (tabel 12.1) is een viertal ziekte-behandelcombinaties als 'prototypen' uitgebreid vervolgd: morfine subcutaan, antibiotica en mannitol intraveneus, en hartmiddelen (dopamine en lasix=furosemide) centraalveneus (schema 2.1). Binnen het zorgmodel is voorzien in zorg afgestemd op de objectieve en subjectieve behoeften van het patiëntsysteem: de patiënt en diens naaste verzorger(s). Omdat met name vanwege de financiële en maatschappelijke kaders adequate zorg en geen maximale zorg is verleend, dienden parameters voor $\mathrm{KvL}, \mathrm{KvZ}$ en kosten geanalyseerd te worden. Ten eerste om de behandelde patiënten en de verleende zorg in een referentiekader te plaatsen. Ten tweede om de spreiding binnen en tussen patiëntengroepen en behandelingen te bestuderen. Ten derde om na te gaan of de vanuit de theorie bekende en in ander onderzoek aangetroffen samenhangen tussen variabelen ook in dit onderzoek aangetroffen zouden worden.

In eerste instantie is gestreefd naar evaluatie middels controlegroepen bestaande uit in het ziekenhuis behandelde patiënten. Dit bleek om meerdere redenen niet haalbaar. De belangrijkste reden is dat door de experimentele ontwikkeling en daaraan inherente tussentijdse bijstelling het te evalueren object zelf continu aan verandering onderhevig was. Daarnaast bleken de binnen de projectperiode in de regio 'Heuvelland' voor IT in aanmerking komende patiëntengroepen niet voldoende groot om, bij -al dan niet gerandomiseerde- vergelijking, voor de deelpopulaties verantwoorde uitspraken te kunnen doen over verschillen en/of overeenkomsten. In het geval van de terminale patiënten waren er bovendien ethische bezwaren om hen rondom de stervensfase met een vragenlijst of interview te belasten. Ook waren er ethische bezwaren om deze patiënten in het kader van randomisatie in het ziekenhuis te (gaan) behandelen (grootste groep) indien het hun laatste wens was om thuis te sterven of om hen thuis te (gaan) behandelen indien zij in het ziekenhuis wilden overlijden (nog afgezien van het vervoer). In mindere mate golden deze bezwaren ook voor de randomisatie bij patiënten met chronisch hartfalen. Overigens was ook bij opheffing van de ethische bezwaren de kans groot, dat patiënten en zorgverleners 
geen toestemming zouden geven om door randomisatie de plaats van de behandeling te laten bepalen. Ten tijde van het onderzoek bestonden er bovendien grote capaciteitsproblemen in het dagcentrum, waardoor er voor de patiënten met infusie van mannitol of hartmiddelen vrijwel geen plaats was. Daar ook de verpleegafdelingen met capaciteitsproblemen worstelden kon daar niet op teruggevallen worden. Samengevat vervielen door al deze praktische en/of ethische bezwaren de mogelijkheden om een prospectieve studie experimenteel of quasi-experimenteel met een concurrente controlegroep in de eigen omgeving voldoende betrouwbaar uit te voeren binnen de looptijd van het project. Een vergelijking met een controlegroep van buiten de regio bleek om praktische (infusie van mannitol en hartmiddelen vinden ook in ziekenhuizen nog steeds slechts op kleine schaal voor de indicaties zoals in deze studie plaats, de met antibiotica-infusen behandelde patiënten zijn vanwege de uiteenlopende onderliggende aandoeningen moeilijk te matchen) en organisatorische (te weinig tijd en financiering om samenwerking op te zetten met andere ziekenhuizen) redenen niet te realiseren. De korte duur van het gehele onderzoek maakte een pre-postvergelijking onmogelijk. Tot slot werden de in deze studie prospectief gebruikte vragenlijsten bij retrospectieve toepassing om te vergelijken met eerder in het ziekenhuis behandelde patiënten niet voldoende valide en/of betrouwbaar geacht.

\subsection{Dataverzameling en analysemethoden}

\subsubsection{DATAVERZAMELING}

Omdat het ten dele een tevredenheidsonderzoek betreft, zijn de uitvoering en evaluatie van zorg strikt gescheiden. De respondenten is medegedeeld dat de resultaten vertrouwelijk behandeld en anoniem verwerkt worden. Schriftelijke of mondelinge bevraging van de patiënt of een ander hebben ieder hun voor- en nadelen wat betreft volledigheid, waardering, betrouwbaarheid, antwoordtendenties, sociale wenselijkheid en haalbaarheid. ${ }^{67,68}$ Planning van interviews met zorgverleners in de thuiszorg is moeilijk vanwege hun werkzaamheden en hun mobiliteit. De Haes vond in haar onderzoek onder patie̋nten dat een schriftelijke beantwoording van vragen betrouwbaardere resultaten oplevert dan een interview. ${ }^{59}$ In deze studie is gekozen voor een gestructureerde schriftelijke vragenlijst die ook bij een interview te gebruiken is. De data zijn voornamelijk verzameld via door het onderzoeksbureau verstuurde vragenlijsten (met gefrankeerde antwoordenveloppe). Deze zijn direct na afloop van de zorg verzonden. Voor vragen en/of opmerkingen over de vragenlijst konden de respondenten contact opnemen met het onderzoeksbureau. ${ }^{69}$ Was de vragenlijst na één maand niet geretourneerd, dan werd een herinnering gestuurd. Reageerde men ook hier niet op, dan werd telefonisch contact opgenomen om alsnog om medewerking te vragen of de reden van de non-respons te achterhalen. ${ }^{69}$ Als patiěnten of naasten zich niet in staat voelden om de vragenlijst in te vullen nam een onafhankelijke professionele enquêteur van het Medisch en Maatschappelijk Informatie Centrum (MEMIC) op basis van de vragenlijst een interview af. ${ }^{69}$ De meningen van terminale patiënten ontbreken door de evaluatie na afloop van de behandeling. Bij deze patiènten is de naaste, meestal de partner, na vier tot zes weken benaderd voor een interview (tijdstip in verband met rouwverwerking en emoties die naar boven kunnen komen). In een enkel geval gaf de naaste de voorkeur aan toezending van de vragenlijst. De huisartsen en de verpleegkundigen of hun maatschap of werkgever ontvingen $f 50$,- per ingevulde vragenlijst om het produktiviteitsverlies te compenseren. 


\subsection{2}

Bij de analyses zijn vooral frequentieverdelingen in aantallen en percentages of gemiddelden en standaarddeviaties gebruikt. Soms is het bereik gegeven. Bijvoorbeeld om de minimale en maximale morfinedosering te kunnen aangeven of om bij vragen over tevredenheid eventuele sociale wenselijkheid op het spoor te komen. Omdat het ordinale variabelen betrof, is de Spearman rang correlatie ( $\rho$; tweezijdig getoetst) gebruikt om de overeenstemming tussen verschillende groepen respondenten en verschillende variabelen te meten. ${ }^{70,71}$ Bij correlaties dient een punt als decimaal scheidingsteken. In alle andere gevallen dient de komma als decimaal scheidingsteken en de punt als scheidingsteken voor duizendtallen. Vanwege de geringe grootte van vrijwel volledige datasets, zijn de bij KvL vermoede verbanden niet verder onderzocht middels regressie-analyse $(\$ 13.4 .4)$. Een enkele maal is Cohen's kappa gebruikt om de overeenstemming na correctie voor toevalsbevindingen te bepalen. Als indicatie voor de interne consistentie is de Cronbach's $\alpha$ gebruikt. De statistische bewerkingen zijn gedaan met SPSS versies 5.0 en 7.5.

\subsection{Samenvatting}

Schema 2.10 vat globaal de gehanteerde onderzoeksmethoden in relatie tot de projectstructuur samen. Een verdere uitwerking van de onderzoeksmethoden volgt in de betreffende hoofdstukken (globaal overzicht bijlage 2.2). In termen van de innovatietheorie beschrijft deze studie aldus het geẽvalueerde innovatieprodukt 'infuusbehandeling thuis' en kan gezien worden als één van de bronnen waarop beslissingen over continuering/rejectie van deze innovatie genomen kunnen worden.

Schema 2.10 Het project Infuusbehandeling Thuis (IT).

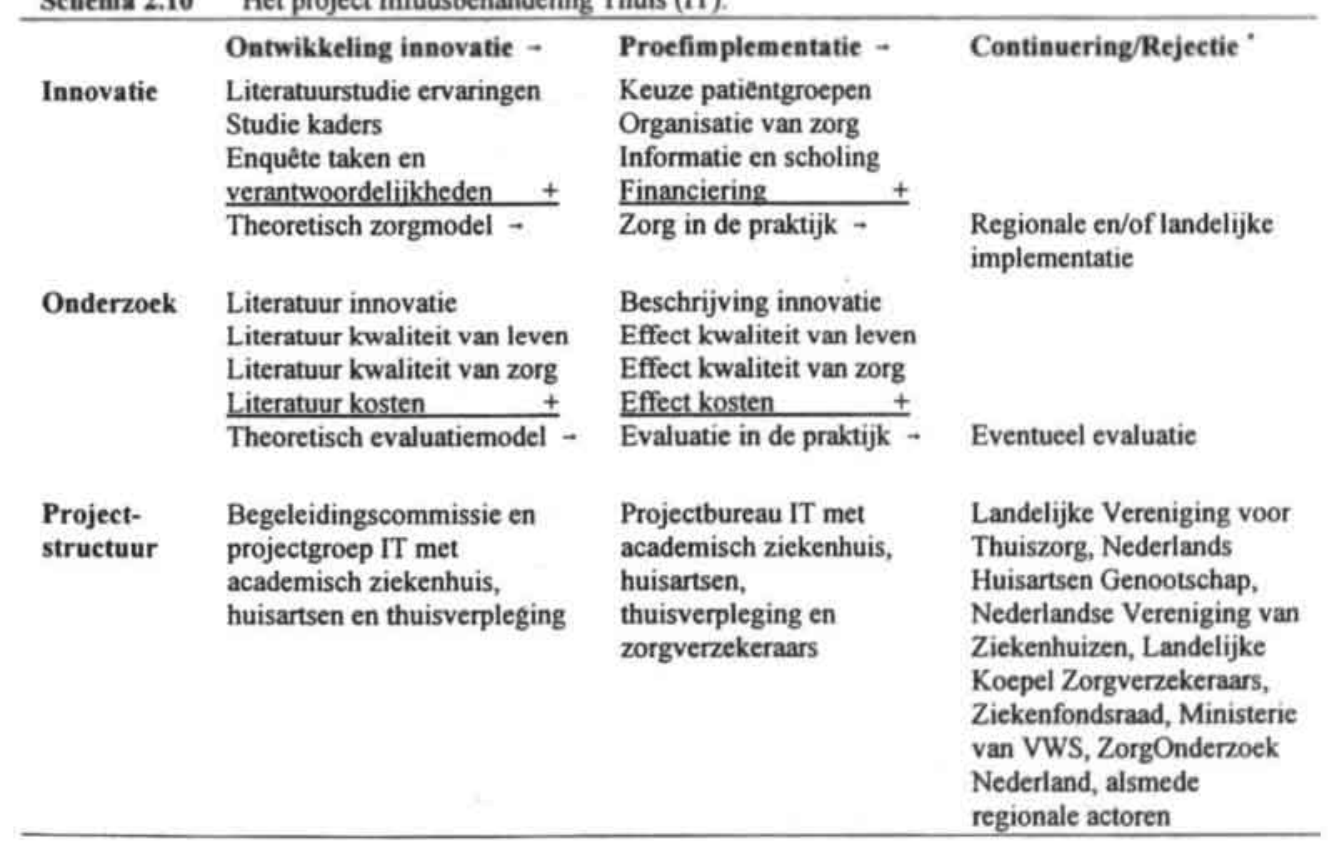

Legenda:" Verdere regionale of landelijke implementatie en/of evaluatie behoort niet tot deze studic. 


\section{Literatuurverkenning complexe medisch- technische zorg thuis}

\subsection{Inleiding}

Gegeven de technologisering en transmurale ontwikkelingen is vanuit hoofdvraagstelling I geìnventariseerd wat bij de start van deze studie over de introductie en evaluatie van medische technologie in de thuiszorg bekend was. Daartoe zijn het Medisch Contact, Nederlands Tijdschrift voor Geneeskunde en Maatschappelijke GezondheidsZorg systematisch doorgenomen (1988-1992). Daarnaast zijn referenties vervolgd (sneeuwbalmethode). Vanwege het accent op de nationale context is een eerste zoekstrategie tot deze tijdschriften beperkt. Voor een breder perspectief is recentere en voor de deelonderwerpen relevante (internationale) literatuur per hoofdstuk verwerkt. Eerst volgt een overzicht van projecten over toepassing van thuiszorgtechnologie. Vervolgens staat de diffusie van medische technologie in de thuiszorg centraal. Tot slot volgen enige algemene conclusies.

\subsection{Ervaringen met toepassing van medische technologie thuis}

De ervaring met medisch-technologische thuiszorgprojecten in Nederland, de Verenigde Staten (VS) en Canada wordt hierna aan de hand van een aantal concrete projecten beschreven. De wijze waarop men thuiszorg definieert, is op de keuze van invloed.

\subsubsection{DEFINITIES}

Volgens van Beekum is thuiszorg niet revolutionair en zou eerder "het verzorgen en behandelen van zieken in ziekenhuizen en verpleeghuizen als een verschijnsel van de laatste driekwart eeuw moeten worden gezien". ${ }^{4}$ Wel nieuw is de toepassing van hoogwaardige medische technologie thuis. Het huidige overheidsbeleid stimuleert thuiszorg. ${ }^{72}$ De dubbele vergrijzing, toenemende emancipatie en medisch-technische ontwikkelingen waardoor aandoeningen vaker en succesvoller kunnen worden behandeld, leiden tot een toename van de vraag naar gezondheidszorg. ${ }^{3,4}$ De resulterende capaciteitsuitbreiding en kostenstijging hoopt men met substitutie van ziekenhuis- en verpleeghuiszorg door thuiszorg te kunnen beperken. ${ }^{4}$

In Nederland dienen nog de nodige obstakels te worden overwonnen, alvorens technologie in de thuiszorg een alledaagse aangelegenheid kan worden. Volgens de Stuurgroep Toekomstscenario's Gezondheidszorg (STG) kan technologie slechts dan een substantiële bijdrage leveren aan thuiszorg wanneer deze is ingebed in een zorgsysteem. ${ }^{73}$ In Nederland is de thuiszorg vooralsnog incrementeel gegroeid in plaats van systematisch gepland en

Een eerdere versie van dit hoofdstuk is gepubliceerd in Medisch Contact 1993;48(29/30):905-7 en $1993 ; 48(31 / 32): 944-6$. 
georganiseerd. De vele bij de thuiszorg betrokken organisaties en beroepsbeoefenaren hebben ieder hun eigen achtergronden en prioriteiten. Ook bestaan er verschillende, soms overlappende adherentiegebieden. De communicatie en de coōrdinatie tussen de verschillende zorgaanbieders is vaak te beperkt, vooral wanneer de zorg 'grensoverschrijdend' is. Het antwoord op de vraag, hoe deze thuiszorg te coördineren, zal de toekomst ervan bepalen. ${ }^{3}$ Het voormalige ministerie van Welzijn Volksgezondheid en Cultuur (WVC) leek te anticiperen op het verdwijnen van de geëchelonneerde gezondheidszorg, of zoals Goudriaan en Wennink stelden: "Het lijkt erop dat de door de overheid gesteunde en gefinancierde experimenten expliciet ten doel hebben alternatieve zorgorganisaties te onderzoeken". ${ }^{14} \mathrm{Er}$ worden uiteenlopende betekenissen toegekend aan termen als 'thuiszorg' en 'thuiszorgtechnologie'. Dit heeft mogelijk mede te maken met 'de verborgen agenda'. ${ }^{75-77}$ Spreeuwenberg constateert: "Thuiszorg is een terrein waarop particuliere verpleegbureaus, verzekeraars, het kruiswerk, de gezinsverzorging, ziekenhuizen en verpleeghuizen en organisaties van huisartsen staan te dringen om hun plaats te veroveren" ${ }^{76}$ Wij volgen de Nationale Raad voor de Volksgezondheid in haar definitie: "Thuiszorg is het geheel van verzorging, verpleging, behandeling en begeleiding van de hulpvrager in de thuissituatie, dat verricht wordt met behulp van zelfzorg, naastenzorg, vrijwilligerswerk en/of (aanvullende) professionele zorg en dat er specifiek op gericht is de hulpvrager in staat te stellen zich te handhaven in de thuissituatie". ${ }^{78}$ Ten aanzien van 'thuiszorgtechnologie' worden eveneens veel verschillende definities gehanteerd. Hier wordt de indeling van het rapport Anticipating and Assessing Health Care Technology gevolgd, waarin technologie in hardware en software wordt onverdeeld. ${ }^{3}$ Software bestaat uit menselijke vaardigheden, hardware uit aangepaste klinisch-medische technologie zoals beademingsapparatuur, technologie gericht op functionele beperkingen zoals het hoog-laag bed en informatie-technologie zoals alarmeringssystemen.

\subsubsection{THUISZORGPROJECTEN}

In Nederland zijn diverse, deels experimentele thuiszorgprojecten gestart. ${ }^{79}$ Een opsomming geven van Duijn en Baggerman. ${ }^{80,81} \mathrm{Er}$ zal niet worden ingegaan op reeds langer bestaande programma's, als thuisdialyse, het gebruik van bloedglucosemonitoren en subcutane insuline-infusors. ${ }^{81}$ Exemplarisch waren de Experimenten Thuisverpleging van de Ziekenfondsraad, die in 1987 van start gingen met als doel "meer inzicht te verkrijgen in de mogelijkheden, de beperkingen en de randvoorwaarden voor inbouw van (vormen) van thuisverpleging in het regulier gefinancierde verstrekkingenpakket" ${ }^{82}$ Het betrof hoofdzakelijk (terminale) kankerpatiënten en het accent lag niet op de toepassing van technologie thuis. ${ }^{\mathrm{s}}$ Een tussentijdse evaluatie leidde tot de subsidieregeling voor intensieve thuiszorg in heel Nederland in mei 1990. Drie projecten die sterk bij het project Infuusbehandeling Thuis aansluiten worden nader toegelicht. Tabel 3.1 vermeldt enkele andere projecten die aspecten van medische technologie en thuiszorg combineren. Het eerste project betreft 'Thuiszorgtechnologie 2000', een ontwikkelingsprogramma van het Provinciale Groningse Groene Kruis (PGGK), later opgegaan in het KwaliteitsInstituut voor Toegepaste ThuiszorgZorgvernieuwing (KITTZ), ${ }^{\text {st }}$ Het door WVC gesteunde project is in 1989 gestart met als doelstelling: "door het toepassen en verder ontwikkelen van technologie de zelfredzaamheid van mensen te bevorderen en de mogelijkheden van behandeling en verpleging in de thuissituatie te vergroten". ${ }^{84}$ Het programma vormt een 'paraplu' waaronder deelprojecten worden ontwikkeld en uitgevoerd. Het Groene Kruis stelt haar infrastructuur beschikbaar. Het programma omvat negen hoofdonderdelen: 
Regio plus betrokken instellingen

Stadskanaal/Noord-Nederland 45 -

Refaja ziekenhuis, Provinciale

Kruisvereniging, Kruisverenigingen

Oost-Gelderland ${ }^{\text {sis }}$

Integraal Kankercentrum Oost,

regionale ziekenhuizen

Nijmegen " wo

Canisius-Wilhelmina ziekenhuis

\section{Brunssum ${ }^{\text {1/.4 }}$}

Stichting SAmenwerkingsverband eerste en tweede lijn voor REgionale geZOndheidszorg (SAREZO)

Utrecht en Tilburg ${ }^{\text {s }}$

Academisch Ziekenhuis Utrecht, Elisabeth- en Mariaziekenhuis

Amsterdam *

Academisch Medisch Centrum

Amsterdam $^{97}$

Academisch Medisch Centrum

\section{Midden Twente *}

Streekziekenhuis Midden Twente

Kruiswerk Midden- en Noord-Oost

Twente

\section{Heuvelland $*$}

Stichting Thuiszorg Zuid-Limburg, Groene Kruis Heuvelland, Stichting Maatschappelijke Dienstverlening Zuid-Limburg, Regionale Huisartsen Vereniging Maastricht e.o.

Rotterdam 100

Sophia Kinderziekenhuis

Behandeling

Uitvoering door

Aantal

patie̋nten

Epidurale
pijnbestrijding bij
kankerpatienten

Start door ziekenhuis

200

dan overdracht naar (1 jaar)

kankerpatienten

thuiszorg

\begin{tabular}{ll}
$\begin{array}{l}\text { Spinale pijnbestrijding } \\
\text { bij kankerpatienten }\end{array}$ & $\begin{array}{l}\text { Huisarts, facilitair } \\
\text { bedrijf en apotheker } \\
\text { i.s.m. ziekenhuis }\end{array}$ \\
\hline $\begin{array}{l}\text { Sondevoeding en } \\
\text { parenterale toediening } \\
\text { van chemotherapie, }\end{array}$ & $\begin{array}{l}\text { Verpleegkundig } \\
\text { specialisten oncologic } \\
\text { vantibiotica en vamengevoegde }\end{array}$ \\
bij kankerpatienten & $\begin{array}{l}\text { (poli)kliniek en } \\
\text { dagbehandeling }\end{array}$ \\
\hline
\end{tabular}

36

(1 jaar)

$57.7 \mathrm{GBD}$

$40-45$

(5 maanden)

$\mathrm{k}$ en

Peridurale pijnbestrij-

ding en ambulante

cytostaticabehandeling

Gespecialiseerde

12-15

ziekenhuis- en

(1 jaar)

bij kankerpatiênten

wijkverpleegkundigen

i.s.m. facilitair bedrijf

\begin{tabular}{lll}
$\begin{array}{l}\text { Monitoring van } \\
\text { risicovolle } \\
\text { zwangerschappen thuis }\end{array}$ & $\begin{array}{l}\text { Verloskundigen en } \\
\text { maatschappelijk } \\
\text { werkenden }\end{array}$ & $\begin{array}{l}2.100 \\
\text { (planning } \\
\text { voor 3 jaar) }\end{array}$ \\
\hline $\begin{array}{l}\text { Vergelijking van } \\
\text { poliklinische en } \\
\text { ambulante } \\
\text { cytostaticabchandeling }\end{array}$ & $\begin{array}{l}\text { Voor projectduur door } \\
\text { twee basisartsen en een } \\
\text { evaluatiedeskundige }\end{array}$ & $\begin{array}{l}50+50 \\
\text { (planning } \\
\text { voor 3 jaar) }\end{array}$ \\
\hline
\end{tabular}

Parenterale thuisvoeding Patiēnt of verzorger, 14

begeleiding van

werkgroep metabolisme

(5 jaar)

Interne Geneeskunde

Diabetes, CARA,
reuma, stoma- en
wondverzorging en
oncologie (deels in
voorbereiding)

Aanvullende thuiszorg aan terminale patienten
Gespecialiseerde

transmurale

verpleegkundigen in

dienst van ziekenhuis én

kruiswerk

Samenwerkingsverband van kruiswerk en

gezinszorg
300

(1 jaar, opstartfase)
119

(1 jaar)

$10,8 \mathrm{GBD}$
Verschillende

(be)handelingen
Ouders wordt via stappenplannen de medisch-technische verzorging van hun kinderen aangeleerd
Enige

honderden

(geen registratic)

Legenda: i.s.m.=in samenwerking met, $0=$ projectduur, $\mathrm{GBD}=\mathrm{Gemiddelde}$ behandeiduur per patient in dagen. 
infuusbehandeling thuis; medische diagnostiek en bewaking op afstand; longaandoemgen in de thuissituatie; thuiszorg bij CF-patiennten; tractiebehandeling thuis; wondbehandiing thuis; gebruikservaring materialen thuis; wonen op maat; kwaliteit en thuiszorg.

Een kernaspect vormt de ontwikkeling van thuiszorgprogramma's, die worden omscreven als gesystematiseerde beschrijvingen van het zorgproces rond specifieke patiëntencategorieën. ${ }^{101}$ Aan bod komen onder meer infrastructuur, materialen, financiering er taakverdeling. Deze programma's, die na de testperiode landelijk beschikbaar komer beschouwt men als een belangrijk instrument om thuiszorg voor nieuwe categorieën patiênten in te voeren. ${ }^{102}$ Het project maakt gebruik van de communicatiecentrale (vor 24 uurs bereikbaarheid) en het bemiddelingspunt van het Groene Kruis. ${ }^{101}$ In het Skillslo worden wijkverpleegkundigen, huisartsen en patiënten (wanneer die handelingen zel uitvoeren) geĭnstrueerd door een verpleegkundige. ${ }^{101,}{ }^{103}$ Het KITTZ vervult een centale, coordinerende rol en geeft een periodiek uit over de ontwikkelingen.

Het project 'Van ziekenhuiszorg naar thuiszorg' in Gorinchem startte in 1992 met susidie van WVC. Het werd geĭnitieerd en begeleid door de Stichting Medische Technologiin Maastricht. ${ }^{104,105}$ Dit door derden te evalueren substitutie-experiment duurde één jaar Zes technologieën werden thuis toegepast: chemotherapie, oximetrie, zwangerschapsmonitoring, ambulante bloeddrukmeting, hoog/laag bed plus tractie en cardiobeeper. Uitgangspunten waren het opdoen van praktische ervaring met technologie thuis en et beschikbaar stellen daarvan. Voor iedere patiententeep is een protocol volgens vas: stramien opgesteld bevattende (contra-)indicaties voor patiëntdeelname, bevoegdheen en verantwoordelijkheden van de diverse hulpverleners, opleidingsvereisten, logistieke aspecten en een behandel-stappenplan. Dit beschrijtt welke taken, door wie en wanner dienen te worden uitgevoerd. Met het oog op een kosten-baten analyse werd de

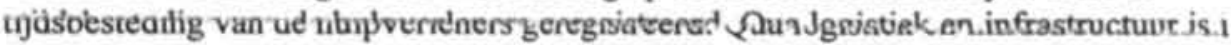
eerste instantie gekozen voor het werkgebied van één kruisvereniging. Er was geen centraal meldpunt of coördinator en per technologie wisselen de betrokken hulpverleners. De specialist stelde de indicatie en bezocht de patiênt thuis. Wijkverpleegkundigen voerden technische handelingen uit (de eerste paar maal onder toezicht van een arts). In eerste instantie leverde de ziekenhuisapotheek de medicatie, op termijn namen de officinale apotheken dit over. De technische dienst van het ziekenhuis onderhield de apparatuur. Het Gorinchemse model benaderde 'hospital in the home'-programma's, die in de VS en Canada courant zijn.

Als derde het project 'Infuus Thuis' te Amsterdam. ${ }^{106-108}$ Het werd in opdracht van intramurale en thuiszorginstellingen door het Innovatieproject opgezet, eveneens met financiële ondersteuning van WVC. 'Infuus Thuis' kwam voort uit de dagbehandeling van AIDS-patiënten met een cytomegalie-infectie. De vrijwel dagelijkse toediening van medicamenten per infuus in het ziekenhuis belastte de patiênt sterk. De implantatie van een Port-A-Cath@ infuussysteem maakte de behandeling thuis door de patiènt zelf of een naaste mogelijk. Omdat de thuiszorg en het ziekenhuis het wenselijk achtten dat de huisarts en de wijkverpleging de patient thuis konden ondersteunen en zo nodig diens zelfzorgactiviteiten moesten kunnen overnemen, zijn in het protocol de hoofdlijnen opgenomen van afspraken over: taakverdeling, overdracht, communicatie en coördinatie tussen AIDS-afdelingen van ziekenhuizen, de Stichting Amsterdams Kruiswerk (SAK), de Amsterdamse Huisartsenvereniging en de Stichting Farmaceutische Thuiszorg Amsterdam (SFTA). Het protocol bevatte ook instructies voor de thuisbehandeling. Voor het project zijn drie part-time verpleegkundigen in dienst genomen; deze coördineerden de zorg en 
konden alle basiseenheden van de wijkverpleging en huisarts praktijken inschakelen. Het SAK verzorgde een centraal meldpunt. De medicamenten en infuusbenodigdheden werden aan huis geleverd door officinale apotheken via de SFTA. De belangrijkste conclusies in de evaluatie van 'Infuus Thuis' waren: Het werken met gespecialiseerde verpleegkundigen is succesvol. Pogingen om de wijkverpleging 'on the job' te trainen lukken wel, maar zijn ondoelmatig en belastend voor de patiënt. De huisarts speelt bij de toepassing van het infuus een geringe rol. Officinale apotheken zijn goed in staat binnen twee dagen de benodigde materialen te leveren. Het centrale meldpunt SAK blijkt over het geheel genomen goed te functioneren, maar een goede bereikbaarheid van gespecialiseerde verpleegkundigen buiten kantooruren verdient extra aandacht. De ziekenhuizen hebben grote problemen met de extra inspanningen die het protocol met zich meebrengt. ${ }^{107}$ In de VS en Canada is er een enorme markt voor thuiszorg(technologie). De kosten voor medische zorg zijn erg hoog en de overheid reguleert en bevordert de thuiszorg relatief weinig. Er zijn meerdere typen organisaties die verschillende soorten thuiszorg leveren. ${ }^{109}$ De groei speelt zich dan ook vooral af in de particuliere sector. ${ }^{110}$ Honderden bedrijven zijn actief en er bestaan zelfs gespecialiseerde tijdschriften. Vanwege de grote verschillen in de gezondheidszorg tussen Nederland en Noord-Amerika, vooral ten aanzien van de structuur en financiering, is de relevantie van ervaringen met thuiszorg in die landen voor het project Infuusbehandeling Thuis in het algemeen beperkt. Een van de uitzonderingen vanwege de uitgebreide praktijkbeschrijving vormt een Canadees project: het 'Verdun Hospital-in-the-Home Program' ${ }^{39}$ Dit programma werd opgezet om het grote beddentekort op te lossen in het Centre Hospitalier de Verdun, een academisch ziekenhuis van 400 bedden in een dichtbevolkt deel van Montreal. In 1986 werd begonnen met IT. Tot en met 1988 werden 451 patiënten behandeld, voornamelijk met antibiotica ( 255 patiënten). Een centrale functie vervullen de ziekenhuisverpleegkundigen die de zorg uitvoeren en de patiënt en diens naasten begeleiden. De patiënt wordt dagelijks bezocht door een arts; de hoofdbehandelaar ziet de patiënt meestal poliklinisch. Voor spoedgevallen zijn er speciale afspraken met de ambulancedienst. Diensten van andere hulpverleners zoals fysiotherapeuten, diëtisten en maatschappelijk werkenden, worden zo nodig ingehuurd. Het project wordt zeer positief beoordeeld, zowel door patienten en hun familie als door de verpleging en ziekenhuisartsen.

\section{3}

Implementatie van technologie in de thuiszorg

Naar aanleiding van de hiervoor beschreven ervaringen, kunnen enige algemene voorwaarden voor de diffusie van medische technologie in de thuiszorg geformuleerd worden die bij de implementatie van infuusbehandeling in de thuissituatie van belang zijn. Het is wenselijk inzicht te krijgen in (criteria ten aanzien van) de:

* keuze van doelgroepen, individuele patiënten, toepassingsgebieden en technologiëen,

* activiteiten van zorgverleners: protocollering, organisatie en logistiek,

* technische hulpmiddelen, en

* voorlichting voor patiënten, hun naasten en professionele zorgverleners.

\subsubsection{Keuze doelgroepen, patiënten, toepassingsgebieden en technologiëen}

Bij de toepassing van medische technologie thuis in Nederland is relatief veel ervaring opgedaan bij kankerpatiënten, vooral ten aanzien van pijnbestrijding. Op dit vlak bestaat ook reeds samenwerking en scholing. ${ }^{85}$ Sinds 1 april 1991 is de verstrekking "van draagbare, uitwendige infusiepompen ter behandeling van pijn die niet op andere wijze 
adequaat bestreden kan worden" geregeld via de AWBZ." De betrokken groep patiênten is groot, neemt vanwege de vergrijzing in omvang toe en verblijft vaak langdurig in het ziekenhuis. ${ }^{112}$ Volgens Kraaipoel (Landelijk Overlegorgaan van de Integrale Kankercentra) zijn de mogelijkheden van 'intramurale thuiszorg' het grootst bij de zorg voor kankerpatielnten, omdat rondom hen al een infrastructuur bestaat. ${ }^{13}$ Van der Linden ziet de kankercentra vanuit deze visie dan ook als een: "platform voor de thuiszorg en ziekenhuisorganisaties die afspraken gaan maken over de organisatie en taakverdeling voor thuiszorg ten behoeve van patienten met kanker en voor mensen met chronische ziekten". ${ }^{114}$ Kinderen met bepaalde aandoeningen vormen eveneens een potentielle doelgroep. Langdurige ziekenhuisopnames zijn nadelig voor hun ontwikkeling. Daarnaast wordt het gezinsleven verstoord, zeker wanneer er meer kinderen zijn. Er is een toename te verwachten in de behandeling van kinderen thuis, omdat te vroeg geborenen en kinderen met ernstige afwijkingen steeds betere overlevingskansen hebben. ${ }^{110}$ Als behandelingsmogelijkheden worden genoemd: sondevoeding bij (premature) stabiele neonaten, fototherapie bij icterische neonaten, parenterale antibioticatoediening bij cystic fibrosis en infusie van cytostatica bij oncologiepatiëntjes. $28,24,104,110,115-117$

Ten aanzien van de individuele patient gelden algemene voorwaarden voor (medische) thuiszorg. Belangrijk zijn in dit kader een adequaat begripsvermogen, emotionele en psychische stabiliteit, elementair inzicht in de aandoening en de behandeling daarvan, voldoende motivatie en verantwoordelijkheidsgevoel, toereikende huisvesting (ergonomisch en hygiënisch) en adequate 'naastenzorg'.

Een veel voorkomend toepassingsgebied van infusen in de thuiszorg betreft de toediening van antibiotica bij een breed scala aan aandoeningen. Potentieel is het aantal patiënten voor Nederland-mogelijk bescheiden- op 1.000 per jaar geschat. ${ }^{28}$ In de thuisbehandeling kunnen vele soorten antibiotica parenteraal toegediend worden. ${ }^{118-122}$ Hetzelfde geldt voor antimycotica bij diepe schimmelinfecties en antivirale middelen. ${ }^{106,118}$ Deze worden met name toegepast bij AIDS-patiënten, maar ook bij anderen die immuun-gecompromitteerd zijn. ${ }^{106}$ De toediening van immunoglobuline bij primaire antilichaam-deficiëntie syndromen, idiopathische trombocytopenische purpura en andere auto-immuunziekten vindt op kleine schaal plaats. ${ }^{123-125}$ Op grotere schaal toepasbaar is ook de thuisbehandeling met cytostatica (potentieel voor Nederland -mogelijk bescheiden- geschat op 1000-5000 patiennten per jaar) ${ }^{28}$ Chemotherapie thuis zou met minder misselijkheid en braken gepaard gaan dan in het ziekenhuis. ${ }^{86}$ Analgetica bij kankerpatiënten worden naast oraal voornamelijk epiduraal, spinaal en subcutaan toegediend. $85,87,88,91-93$ Enkele andere toepassingsgebieden zijn geringer van omvang. Voor (totale) parenterale voeding worden onder meer als indicaties Morbus Crohn, diverticulitis, colitis ulcerosa, short bowel-syndroom en peri-operatieve patiënten genoemd. ${ }^{28} \mathrm{Bij}$ oncologische patiënten is een aantal problemen bij de thuisbehandeling met parenterale voeding naar voren gebracht. ${ }^{97}$ Dobutamine en dopamine worden op kleine schaal bij patiënten met ernstige chronische decompensatio cordis (NYHA III//V) parenteraal toegediend. ${ }^{126-129}$ Deze patiënten worden vaak langdurig in het ziekenhuis opgenomen voor uitsluitend palliatieve therapie. Intraveneuze toediening van heparine bij de behandeling van thrombose komt mogelijk in aanmerking voor substitutie. ${ }^{28}$ Men verwachtte in 1993 dat intermitterend subcutaan toe te dienen heparine continue parenterale toediening op termijn in ieder geval ten dele zou verdringen. Een definitieve keuze voor één van beide therapieên kon bij de start van het project echter nog niet worden gemaakt. ${ }^{130-135}$

In Noord-Amerika vormen (par)enterale voeding en intraveneuze toediening van 
antibiotica en chemotherapeutica verreweg de grootste en meest winstgevende markt voor de -veelal particuliere- thuiszorgbedrijven. ${ }^{110}$ Ook voor de toekomst wordt daar de grootste groei in de medische thuiszorg verwacht, gevolgd door parenterale en enterale voeding.

Bij het kiezen van technologieën is de TNO-studie van Haerkens en van Beekum over het stellen van prioriteiten voor de introductie van medische apparatuur in de thuiszorg waardevol. ${ }^{28}$ Als uitgangspunt hanteerden zij de inventarisatielijst van het Nederlands Ziekenhuisinstituut. Uitgesloten werd apparatuur die weinig of geen extra substitutie meer op kon leveren, apparatuur waarvan de toepassing wellicht snel achterhaald zou zijn door nieuwe ontwikkelingen, apparatuur waarvan de toepassing nog in experimentele fase verkeerde en apparatuur waarvoor al richtlijnen waren of werden opgesteld. Zij bevalen aan de implementatiemogelijkheden te onderzoeken van: parenterale toediening van antimicrobiële middelen, analgetica en cytostatica, hoog-laag bedden voor de behandeling van patiënten met heup- en knieprothesen, apparatuur voor de bewaking van bedrusthoudende zwangeren, tractie-apparatuur voor femurfracturen en het care-bed. Deze aanbevelingen zijn geëffectueerd in diverse reeds genoemde projecten. Wel zinvol, maar minder pregnant werden geacht: enterale voeding, parenterale voeding, tractie-apparatuur voor patiëntjes met congenitale heupdysplasie en fototherapie voor icterus neonatorum.

\subsubsection{Activiteiten zorgverleners, protocollering, organisatie, logistiek}

Bij de ontwikkeling van medische thuiszorg lijkt het zinnig niet uit te gaan van de aanspraken die de verschillende beroepsbeoefenaren en organisaties in de thuiszorg maken op hun rol in het thuiszorgscript. Het is van het grootste belang thuiszorg zodanig te ontwikkelen dat ze (ook op de lange termijn) de grootste kans van slagen heeft. ${ }^{136}$ Protocollering kan hierbij een doel maar evenzeer een middel zijn om te komen tot standaardisatie en afstemming tussen thuiszorg en ziekenhuiszorg en zo te voorkomen dat er een caleidoscopisch aanbod van formulieren, procedures en zorgaanbieders ontstaat. ${ }^{137}$ Wel dient er voor te worden gewaakt dat de professionele autonomie van de beroepsbeoefenaar wordt behouden. ${ }^{138}$ Op deze wijze kan tevens een optimale kosten-baten verhouding of de hiervan afgeleide prijs-kwaliteit verhouding voor de bij de thuiszorg betrokken partijen, zowel afzonderlijk als in samenhang binnen de maatschappelijke context, worden nagestreefd.

Zoals reeds gesteld, kan technologie slechts dan een substantiële bijdrage leveren aan thuiszorg wanneer zij is ingebed in een zorgsysteem. ${ }^{73}$ Het grootste struikelblok voor introductie van medische thuiszorg in Nederland lijkt het gebrek aan duidelijke organisatie te zijn. ${ }^{4}$ De patiënt en naaste verzorgers dienen na vertrek uit het ziekenhuis het gevoel te hebben dat de patiënt, hoewel niet meer fysiek in het ziekenhuis verblijvend, toch eenzelfde kwaliteit van zorg ontvangt. ${ }^{85}$ Veiligheid en continuitteit van zorg dienen bij de overgang van ziekenhuis naar thuis centraal te staan. Een centrale, continue bereikbaarheid (24 uur) is dan ook een absolute voorwaarde voor een thuiszorgproject. ${ }^{107}$ Een centraal bemiddelingspunt is van grote waarde. ${ }^{99}$ Meestal is dit ondergebracht bij de thuiszorg. Opgemerkt dient te worden dat transmurale samenwerking wordt vergemakkelijkt naarmate het bemiddelingspunt een meer autonome positie heeft. ${ }^{102}$

Onder meer door de Landelijke Huisartsen Vereniging wordt bij thuiszorg een centrale rol toebedacht aan de huisarts, zijnde de meest geschikte om te fungeren als spil tussen patiënt, familie, wijkverpleging, apotheek en ziekenhuis. ${ }^{138}$ Binnen de meeste Nederlandse thuiszorgprojecten wordt deze rol evenwel bekleed door het kruiswerk. ${ }^{84,}{ }^{107}$ De huisarts heeft wel een belangrijke stem in de beoordeling van de geschiktheid van patiënt en 
naasten voor medische thuiszorg en is onmisbaar wanneer er thuis medisch-technische handelingen plaatsvinden. De rol van de specialisten varieert. Bij de indicatiestelling en verplaatsing van medische technologie naar de thuissituatie dienen zij, als deskundigen bij uitstek, betrokken te worden. In de VS blijven ook bij behandeling thuis de specialisten verantwoordelijk. In Nederland zou, gelet op de structuur en traditie van de gezondheidszorg, de huisarts die verantwoordelijkheid waar mogelijk dienen over te nemen.

In Canada en de VS bezoeken ziekenhuisverpleegkundigen de patiênten thuis. ${ }^{39}$ Ofschoon dit praktisch is (vereist geen samenwerking en/of afstemming) en de continulteit van zorg kan worden gewaarborgd, is dit model onaantrekkelijk vanwege de positie van de thuiszorg in Nederland. In het merendeel van de Nederlandse thuiszorgprojecten doen -afhankelijk van de toegepaste technologie- al dan niet speciaal getrainde (wijk)verpleegkundigen het praktische werk thuis. ${ }^{92,139}$ In Gorinchem worden hiervoor gemengde teams ingezet. ${ }^{140}$ In Midden-Twente besloten ziekenhuis en kruiswerk de aansluiting tussen ziekenhuis en thuiszorg te optimaliseren door (gespecialiseerde) transmuraal opererende verpleegkundigen aan te stellen met een duale basis in het ziekenhuis en het kruiswerk. ${ }^{98}$ $\mathrm{Er}$ is veel voor te zeggen het traditionele verschil tussen ziekenhuis- en wijkverpleegkundige op te heffen ten behoeve van thuiszorgpatiennten. Het valt dan ook te overwegen per regio enkele transmurale verpleegkundigen zorg te laten dragen voor de begeleiding en de uitvoering van infuusbehandelingen thuis. Het medisch-technisch handelen in de thuissituatie kan juridische knelpunten opleveren. ${ }^{140} \mathrm{Om}$ de noodzaak van een uitvoeringsverzoek te vermijden wordt aanbevolen, (groepen) patiënten te kiezen die voldoende geschoold en in staat zijn om zelf (of met behulp van naasten) het infuus te hanteren. ${ }^{92}$ Wat betreft de logistiek is het voor ziekenhuisapotheken wettelijk verboden extramuraal te leveren. Praktisch komt dit echter wel voor en wordt dan vooral gezien als een service aan de officinale collega's; secundair is dit ook een bron van extrabudgettaire inkomsten. ${ }^{85}$ Voor de bereiding is de ziekenhuisapotheek namelijk veelal beter toegerust dan de officinale apotheek. ${ }^{81}$ Ook het plotselinge ontslag van patiënten uit het ziekenhuis kan de officinale apotheek voor logistieke problemen stellen, vooral buiten de gewone werkuren. ${ }^{85}$ Buiten de factor 'tijd' kunnen de voor medicatie en toebehoren benodigde investeringen nopen tot concentratie. ${ }^{91}$ Vaak verzorgt de ziekenhuisapotheek daarom de levering thuis (zeker in het begin; overdracht aan de officinale apotheken kan later volgen). ${ }^{81}$

\subsubsection{Technische hulpmiddelen}

Op grond van vele studies is gebleken, dat gewone infuuszakken gecombineerd met een perifere infuusnaald bij tijdelijke parenterale toediening te prefereren zijn. Bij chronische toediening doet het Porth-A-Cath® systeem steeds meer opgang en bij continue toediening wordt vaak gebruik gemaakt van draagbare infuuspompjes. ${ }^{81.92,119,120,126,141-145}$ Het succesvol invoeren van thuiszorgtechnologie hangt in belangrijke mate af van de gebruiksvriendelijkheid. ${ }^{146}$ In het algemeen dient medische technologie voor thuisgebruik ergonomisch aangepast te worden, dient de signaal-ruisverhouding bij alarmering te worden geoptimaliseerd en moet verkeerde en/of niet-geautoriseerde bediening worden uitgesloten. ${ }^{147}$ Een eenvoudige, beknopte doch volledige handleiding in de eigen taal is van essentieel belang. ${ }^{148}$

\subsubsection{VOORLICHTING VOOR PATIENT, NAASTE EN PROFESSIONELE ZORGVERLENERS}

Bij voorlichting aan (potentiěle) patiênten en naasten dient de impact van het introduceren van technologie in de thuiszorg niet te worden onderschat. Een infuus wordt nog vaak als 
een 'levenslijn' gezien en niet als een alternatieve toedieningsweg voor medicijnen, vocht en nutriënten. Blijkens een enquête ten tijde van de start van deze studie vindt meer dan de helft van de artsen en meer dan driekwart van de verpleegkundigen de ontwikkelingen op medisch-technologisch gebied een bedreiging voor de 'alledaagse zorg' voor chronisch zieken en gehandicapten. ${ }^{2}$ Introductie van technologie in de thuiszorg vereist een goede voorlichting, die ook gericht dient te zijn op de attitude van allen betrokken bij of werkzaam in de gezondheidszorg.

\subsection{Conclusies}

Het aantal publikaties over concrete ervaringen met toepassing van hoogwaardige medische technologie thuis in Nederland was tijdens deze inventarisatie nog relatief gering. Het betrof veelal eerste rapportages en slechts een enkele eindevaluatie. Geen enkel project leverde een volledige blauwdruk voor een medisch thuiszorgproject. Een aantal bevorderende factoren wordt echter vaak genoemd. Belangrijk is, dat de patiënt en diens naasten het gevoel hebben dat bij het vertrek uit het ziekenhuis naar huis de zorg en veiligheid worden gecontinueerd. Dit kan worden bewerkstelligd door de combinatie van transmuraal werkende verpleegkundigen en een efficiënt 24-uurs meldpunt. Voorlichting en scholing van zorgverleners, alsook voorlichting en instructie van de patiënt en naasten, zijn onmisbaar. Thuiszorg dient te worden aangeboden als een samenhangend geheel. Standaardisatie en afstemming tussen thuiszorg en ziekenhuiszorg kunnen voorkomen dat er een caleidoscopisch aanbod van formulieren, procedures en zorgaanbieders onstaat. Tevens kan zo optimalisatie van de kosten en baten voor de bij de thuiszorg betrokken partijen nagestreefd worden. Opvallend is dat de invloed van technologisering op de leefwereld van de patiënt nauwelijks geproblematiseerd wordt. 


\section{Kaders bij complexe medisch-technische zorg: de zorgverleningstheorie van Orem}

\subsection{Inleiding}

Vanuit hoofdvraagstelling II over de introductie van de innovatie en aandachtspunt 2 over de protocollering en afstemming daarvan, zijn de theoretische en de feitelijke kaders van CMTZ bestudeerd. De theoretische kaders om het zorgproces te kunnen schematiseren, de feitelijke om de werkelijkheid genuanceerd te kunnen weergeven (schema 1.1).

\subsection{Theoretische zorgkaders}

De beroepsuitoefening bij CMTZ omvat complexe medisch-technische en bijkomende medische en verpleegkundige handelingen en heeft vaak een sterke empirische basis met kenmerken van een ambacht of kunst. Theoretische zorgkaders kunnen een toetsbare basis voor professionele zorgverlening vormen.

\subsubsection{VAN METAPARADIGMA TOT ZORGVERLENINGSTHEORIE}

Wat ligt ten grondslag aan beroepsuitoefening in en vormgeving van de gezondheidszorg? Evers geeft een overzicht van theorieën en principes van de verpleegkunde en de diverse niveaus van theorieontwikkeling. ${ }^{149}$ In navolging van Fawcett wordt hier een hiërarchische structuur van de verpleegkundige -en in dit onderzoek ook medische- kennisontwikkeling aangehouden. ${ }^{150}$ Daarbij wordt uitgegaan van een metaparadigma, dat onder te verdelen is in diverse paradigmata, die weer uit diverse theorieën kunnen bestaan. Een metaparadigma heeft betrekking op de filosofische en methodologische vragen bij de theorieontwikkeling. Paradigmata, ook wel conceptuele (begrippen)kaders of raamwerken genoemd, geven pretheoretische bases voor theorieontwikkeling. ${ }^{150} \mathrm{Zij}$ zijn "a set of concepts and the propositions that integrate them into a meaningful configuration". Een paradigma is dus een verzameling van abstracte multi-dimensionele begrippen. De daaruit voortvloeiende theorieën, proberen veel directere, meer gepreciseerde en gespecificeerde verbanden te leggen met de observeerbare werkelijkheid.

Binnen dit onderzoek is uitgegaan van het gezondheidskundig metaparadigma waarin de medische en/of verplegende activiteiten in de context van gezondheid plaatsvinden in relatie met de patiënt en zijn omgeving (bijlage 4.1)..$^{151}$ Dit metaparadigma is via diverse conceptuele kaders concreter te benaderen. Veranderingen in de gezondheidszorg kunnen bijvoorbeeld met innovatietheorieën beschreven worden. Een als paradigma te hanteren concept is de driedeling in zelfzorg, mantelzorg en professionele zorg van Hattinga Verschure. ${ }^{152} \mathrm{Bij}$ zelfzorg voorziet het individu zelf in diens eigen behoefte aan zorg. Bij mantelzorg wordt zorg verleend binnen een kleine groep waarvan de leden met elkaar in 
relatie staan. Deze zorgverlening geschiedt op basis van emotionele banden en veelal ook op basis van (bereidheid tot) wederkerigheid. Professionele zorg beperkt zich wat betreft functie, kenmerken, machtspositie en systeem vaak tot één soort, beroepsmatig verleende zorg. ${ }^{153-156}$ Hierbij zijn de rollen van zorgverlener en ontvanger niet uitwisselbaar.

De medische en verplegende activiteiten van zorgverleners in de gezondheidszorg kunnen met diverse zorgverleningstheoriežn worden beschreven. Een theorie is hier opgevat als een verzameling van samenhangende begrippen, definities en proposities die activiteiten beschrijven, verklaren en voorspellen. ${ }^{149}$ Uitgaande van het gekozen gezondheidskundig metaparadigma en het zorgconcept van Hattinga Verschure dient de hieraan gerelateerde theorie voor zorgverlening dan ook de medische en verplegende activiteiten, die plaats hebben in de context van gezondheid in relatie met de patiënt en diens omgeving, met gebruikmaking van de onderverdeling in zelfzorg, mantelzorg en professionele zorg concreet te kunnen beschrijven, verklaren en voorspellen.

De huisartsgeneeskunde heeft zich in de afgelopen decennia binnen de geneeskunde in Nederland tot een aan de specialismen gelijkwaardige professie ontwikkeld. ${ }^{157}$ Toch is voor CMTZ op (huisarts)geneeskundig gebied geen passende theorie aangetroffen. Het lijkt of nog weinig theorievorming aangaande de vormgeving van de beroepsuitoefening binnen de (huisarts)geneeskunde heeft plaatsgevonden. Ook Touw-Otten constateert dit in haar studie naar 145 huisartsgeneeskundige proefschriften (periode 1945-1979): "Het wetenschappelijk onderzoek in de huisartsgeneeskunde is gericht op toepassing". ${ }^{158}$ Geen van deze studies heeft de theorie van de beroepsuitoefening zelf tot onderwerp (toelichting noot 1 bijlage 4.2). Een vergelijkbare meta-analyse van dissertaties in de Nederlandse huisartsgeneeskunde van na 1979 ontbreekt. De KNAW rapportage uit 1991 geeft aan dat diverse universitaire huisartsinstituten normen en waarden/nut bestuderen. ${ }^{159}$ Uit geen van de omschrijvingen blijkt dat de theorievorming van de beroepsuitoefening daar deel van uit maakt. Aan huisartsgeneeskundige leerboeken en het beroepsprofiel kunnen wel essentiële kenmerken van de inhoud van de beroepsuitoefening ontleend worden. ${ }^{160-162} \mathrm{Zo}$ heeft de World Health Organisation (WHO) ruime definities voor het beroep van huisarts opgesteld (noot 2). ${ }^{161}$ Dergelijke definities omschrijven de inhoud van de beroepsuitoefening op paradigma niveau, maar gaven tot voor kort geen aanwijzingen over de vormgeving. ${ }^{163}$ In de verpleegkunde is theorievorming al lang onderwerp van onderzoek..$^{149,150,164-166} \mathrm{Als}$ basis voor een te ontwikkelen zorgmodel bij CMTZ thuis, dat primair uitgaat van substantiële rationaliteit, is gekozen voor een breed gedragen zorgverleningstheorie uit de verpleegkunde, de (praktijk)theorie van Orem. Deze Amerikaanse verpleegkundige (geboren 1914) heeft deze theorie gedurende een aantal decennia (1949-1988) in dialoog met studenten en staf van verpleegkunde opleidingen, werkers in de gezondheidszorg en adviserende en beleidsvormende organen zoals de Nursing Development Conference Group (1968-1973) steeds verder ontwikkeld. ${ }^{165}$ De theorie gaat uit van compensatie van en educatie bij zelfzorgtekorten. Orem biedt daarvoor zowel een conceptueel kader, een algemene overkoepelende theorie voor verpleging, als drie nader uitgewerkte onderling verbonden theorieên op het gebied van zelfzorg, zelfzorgtekorten en verpleging. ${ }^{164}$ Omdat geneeskunde en verpleegkunde als praktijkdisciplines nauw verwant zijn en handelingen van beide disciplines bij CMTZ een continuüm vormen, kan de theorie ons inziens verbreed worden tot één zorgverleningstheorie voor medisch én verpleegkundig handelen. ${ }^{149}, 136,164$ Dat de STG in haar studies over toekomstig zorggebruik aan termen als zelfredzaamheid en te onderscheiden tekorten een belangrijke rol toekent, illustreert dat het denken over gezondheidszorg in termen van zelfzorgtekorten breder ingang vindt. ${ }^{3}$ 
Volgens Orem doen mensen aan zelfzorg, dat zij definieert als aangeleerd en doelbewust gedrag van mensen om in leven te blijven, om hun gezondheid en welbevinden te bewaren en om bij te dragen aan hun integraal functioneren en ontwikkeling. Dit gedrag is zowel gericht op de eigen zelfzorgbehoeften als op die van hen afhankelijken (zie §6.3.1). Degenen die deze niet-professionele zorg aan de patiēnt verlenen, duiden wij in navolging van Philipsen aan met naasten, de zorg die zij leveren met naastenzorg. ${ }^{167}$ Voldoen aan zelfzorgbehoeften is het concrete doel dat nagestreefd wordt ter realisering van gezondheid en welbevinden. Aansluitend op de leefwereld van de patiěnt onderscheidt Orem:

A. Algemene of universele zelfzorgbehoeften: deze gelden voor alle mensen in alle levensfasen zoals behoefte aan lucht, water of voedsel. Voorbeelden van CMTZ: zuurstoftoediening bij duiken, infusie van voeding bij wielrenners.

B. Zelfzorgbehoeften in het kader van ontwikkelingsprocessen welke verband houden met de ontwikkelingsfasen van de mens zoals zelfzorgbehoeften in relatie met geboorte, puberteit, zwangerschap, ouderdom of terminale fase. Voorbeelden van CMTZ: cardiotocografische bewaking bij problemen in de zwangerschap, infusie van morfine bij pijnbestrijding in de terminale levensfase.

C. Zelfzorgbehoeften naar aanleiding van gezondheidsverstoringen, waaronder structurele en functionele stoornissen en de gevolgen van medisch diagnostische en therapeutische maatregelen. Voorbeelden van CMTZ: dialyse bij nierfalen, zuurstoftoediening bij spierziekten, plasmaferese bij intoxicatie, infusie van voeding bij short bowel syndroom, infusie van antibiotica bij infectie.

Het zelfzorgvermogen definieert Orem als de aangeleerde eigenschap om aan zelfzorg te doen. Het zelfzorgvermogen kan verschillen per individu en is afhankelijk van factoren als gezondheid, leeftijd, opleiding, cognitief functioneren en cultuur. Het zelfzorgvermogen heeft een drielagige opbouw:

A. Een algemeen vermogen om doelgericht acties te kunnen ondernemen vormt de basis. Bijvoorbeeld voldoende algemene fysiologische (zoals waarneming, motoriek) alsook psychologische (zoals geheugen, redeneren) capaciteiten.

B. Daarenboven dient iemand te beschikken over het vermogen om de voornoemde algemene vermogens te gebruiken om zelfzorg te realiseren. Daarbij worden tien vermogenscomponenten onderscheiden: aandacht hebben en waakzaam zijn, kennis verwerven, redeneren, motiveren, prioriteren, integreren, besluiten nemen, gecontroleerd gebruik van energie, lichaamscontrole en een repertoire van vaardigheden. Van elk van de vermogenscomponenten kan de ontwikkeling, de mate van operationeel zijn en de mate van adequaat zijn worden omschreven.

C. Tot slot het vermogen om specifieke zelfzorgactiviteiten te kunnen realiseren. Dit wordt onderscheiden in het vermogen om de noodzaak van een zelfzorgactiviteit te beoordelen, om daarover een besluit te nemen en om deze uit te voeren.

De mate waarin iemand de drie lagen kan aanspreken, bepaalt het daadwerkelijk tot stand gekomen en voor anderen waarneembare zelfzorggedrag. Ons inziens kan bij CMTZ het zelfzorgvermogen van de patiënt en diens naaste(n) volgens bovenstaande indeling geanalyseerd en benut worden.

Orem spreekt van een zelfzorgtekort als het zelfzorgvermogen ontoereikend is om in de zelfzorgbehoeften te voorzien. Een zelfzorgtekort wordt veroorzaakt doordat er eisen aan de betreffende persoon en diens naaste(n) worden gesteld welke diens kennis en/of vaardigheden te boven gaan. Zelfzorgtekorten kunnen door patiënt en zorgverlener 
gediagnosticeerd worden naar aard en oorzaak. Vervolgens kunnen de patie̋nt en de zorgverlener afspraken maken over de te realiseren doelen en daarvan afgeleide mediscie en/of verpleegkundige interventies. Deze dienen regelmatig geěvalueerd te worden. De afspraken worden vastgelegd in een zorgverleningsplan en na elke evaluatie geactualiseerd. Bij het begin van een aandoening waarvoor patiênten $\mathrm{CMTZ}$ behoeven, zullen zij vrijwel nooit voldoende zelfzorgvermogen hebben voor alle extra daaruit voortvloeiende zelfzorgbehoeften en zullen zelfzorgtekorten optreden. Alle handelingen alsook de daarvoor vereiste kennis en vaardigheden kunnen bezien worden in termen van zelfzorg. Daarbij hoeft het geen verschil te maken of het beroepsmatige zorg door artsen en verpleegkundigen of zorg door naasten betreft. Van belang is dat de patiênt in zijn zelfzorg kan worden bijgestaan doordat een derde ter aanvulling een deel van die zelfzcrg overneemt. In dit onderzoek wordt alle zorg tot de realisering van zelfzorg gerekend. De zorgverlener beschikt over zes zorgverleningsmethoden die ondersteunend educatief, gedeeltelijk compenserend en/of geheel compenserend kunnen zijn: handelen in naam van of doen voor een ander; (be)geleiden; fysieke ondersteuning geven; psychologische ondersteuning geven; een omgeving creëren, die persoonlijke ontwikkeling bevordert; instructie, onderwijs en educatie. De keuze hangt af van de mate waarin de patiënt en/of diens naaste(n) de zelfzorgbehoeften van de patiênt kunnen realiseren. De activiteiten van de zorgverlener zouden complementair daaraan moeten zijn.

Zelfzorg wordt volgens Orem verleend binnen sociale, interpersonele en technologische kaders. Het sociale kader is voorwaarden scheppend voor de interpersonele en technologische kaders en het interpersonele vervolgens voor het technologische. In de westerse wereld wordt het sociaal-maatschappelijk kader tussen patiënt en zorgverlener grotendeels bepaald door de wetgeving, financiering, organisatie en werkverdeling ten aanzien van het gezondheidszorgsysteem. Het interpersonele kader omvat onder andere de percepties, communicatie en wederzijdse beïnvloeding van de patiënt en de zorgverlener. In het westen is dit kader geëvolueerd vanuit de traditie van christelijke naastenliefde naar een professionele hulpverlening die gedefinieerd wordt in termen van samenwerking tussen autonome patiënten en zorgverleners. Het zorgtechnologische kader betreft de visie van waaruit daadwerkelijk zorg wordt verleend. Volgens Orem is zorgverlening geîndiceerd bij feitelijke of dreigende zelfzorgtekorten van de patient, die de patient en/of diens naaste(n) niet kunnen oplossen.

In hoeverre de verpleegkundige zorgverleningstheorie van Orem, gezien de gemeenschappelijke kaders $(\$ 4.2 .1, \S 4.3, \S 5.1)$, naar medische of zelfs alle zorgverlening in de gezondheidszorg is te verbreden, moet blijken. Bij gebrek aan een uitgewerkte medische zorgverleningstheorie, biedt zij in ieder geval een uitgangspunt. Wel lijkt zij beter toegerust om in algemene termen de inhoud ('wat') van de interactie tussen patiēnt en zorgverleners te beschrijven dan dat deze reeds concreet uitgewerkt kan worden ('hoe'). ${ }^{166}$ Hier was dit geen belemmering, omdat bij de modelontwikkeling behoefte was aan een algemeen kader. Alvorens een bepaald soort CMTZ verder kan worden uitgewerkt, dienen de specifieke vereisten nader geĩnventariseerd te worden (zie voor infuusbehandeling in hoofdstuk 5).

\subsection{Feitelijke zorgkaders}

Naast eventuele theoretische zorgkaders beinnvloeden feitelijke sociale, maatschappelijke, economische en culturele factoren het zorgproces bij CMTZ. Zij vormen grotendeels de basis voor en tegelijkertijd de begrenzing van de zorgverlening. Met de indeling in een sociaal-maatschappelijk, interpersoneel en zorgtechnologisch kader wordt zoveel mogelijk 
aangesloten bij de zorgverleningstheorie van Orem. Vanwege het oriënterend karakter volgt hier een algemeen overzicht.

\subsubsection{HET SOCIAAL-MAATSCHAPPEUIJKE KADER}

De structuur, cultuur en ontwikkelingen van de voorzieningen in het algemeen en in de gezondheidszorg bepalen grotendeels het sociaal-maatschappelijk kader van CMTZ. Structureel bepalen de opvattingen over het doel en de inrichting van de staat de soort voorzieningen en de wijze waarop deze geacht worden hun doel te bereiken. ${ }^{168}$ Voor de inhoud is vooral van belang op welke gebieden de staat haar inwoners als burger of als consument beschouwt. Bij voorzieningen van algemeen nut (meritgoederen of diensten) heeft de staat een grotere verantwoordelijkheid ten opzichte van haar burgers dan bij consumptiegoederen of diensten. ${ }^{169}$ Naast een klassiek grondrecht als vrijheid van meningsuiting kan ook gezondheidszorg als sociaal grondrecht wettelijk vastgelegd worden. Volgens Coase is overheidsbemoeienis slechts verantwoord indien een taak niet aan particuliere organisaties kan worden overgelaten..$^{170} \mathrm{Bij}$ de vormgeving is vooral van belang op welke gebieden een staat een centraal geleide of een vrije markteconomie nastreeft. ${ }^{171}$ Nederland heeft een kleine overheid en een grote collectieve sector beide gericht op centrale overeenstemming. ${ }^{47}$

Ook culturele factoren beïnvloeden de feitelijke inhoud van en toegang tot voorzieningen. De verzorgingsstaat is de meest invloedrijke naoorlogse culturele factor in West-Europa (toelichting noot 3 ). ${ }^{172}$ Sectoralisering van de samenleving (differentiëring) en culturele verscheidenheid van opvattingen (pluralisme) maken de maatschappij complexer en individueler (toelichting noot 4 ). ${ }^{173},{ }^{174}$ Voorzieningen zijn via als anoniem beleefde instanties beschikbaar voor elke individuele burger die daar aanspraak op kan maken, daar 'recht op heeft'. In de kluwen van voorzieningen en financieringswijzen, hebben burgers en overheden geleerd te kiezen én rechten en plichten tegen elkaar af te wegen -te 'calculeren'- om maatschappelijk te kunnen functioneren (functionele rationaliteit). De belangrijkste ontwikkelingen in Nederland die als uitvloeisel kunnen worden gezien van de modernisering met invloed op voornoemde structuur en cultuur tijdens de start van deze studie waren de uitbreiding van het (deels oneigenlijke) gebruik van voorzieningen vanwege demografische en economische ontwikkelingen. Door de gewijzigde concurrentieverhoudingen (toelichting noot 5) groeiden de kosten van voorzieningen relatief sterk en was de financiering via premies en belastingen op loonkosten internationaal onhoudbaar geworden. Of en hoe de staat hierop invloed kan uitoefenen stond ter discussie. ${ }^{47,175}$ In Nieuw-Zeeland bleek een radicale afschaffing van voorzieningen geen afdoende oplossing te zijn. ${ }^{174} \mathrm{De}$ ontwikkelingen ten aanzien van de ziektewet, de wet op arbeidsongeschiktheid, de nabestaandenwet, de bijstandswet, het ontslagrecht en de immigratie tonen aan dat het succes van het veel geroemde Nederlandse poldermodel deels wel degelijk toe te schrijven is aan beperking van vooral onterechte, maar ook terechte aanspraken op de voorzieningen.

De voorziening gezondheidszorg heeft daarnaast een aantal eigen kenmerken. Structureel verschillen staten wat betreft voorzieningen, maar toezicht op de (volks)gezondheid behoort vrijwel altijd tot de kerntaken (toelichting noot 6). In het "functionele systeem" van Heydelberg bepaalt de verhouding tussen het voorkómen van ziekte (preventie), het behandelen van ziekte (curatie/palliatie) en de zorg voor zieken (care) de inhoud van de gezondheidszorg. ${ }^{176}$ Ook de vormgeving varieert. De Verenigde Staten gaan evenals in hun 
gehele economie uit van de vrije markt. Toch is er ook daar centrale interventie getuigede Health Maintenance Organisations en programma's voor wie niet op de vrije markt tereht kan, zoals Medicaid voor armen en Medicare voor ouderen..$^{17}$ In China en voormalige Oostbloklanden is de gezondheidszorg evenals de economie centraal geleid. ${ }^{178} \mathrm{De}$ leder van de Europese Unie zijn wat betreft hun gezondheidszorg nog autonoom. Wel kan de regelgeving omtrent goederen en diensten invloed hebben. ${ }^{177}$ In de Europese Unie is voornamelijk sprake van een centrale leiding. Diverse zelfstandige partijen zonder winstoogmerk leveren gezondheidszorg, maar de staat heeft grote invloed op de wettelike en financielle kaders. ${ }^{179}$ Groot-Brittanniê combineerde tot voor kort als enige een vrije markteconomie met een staatsgezondheidszorg, de National Health Service. ${ }^{180} \mathrm{De}$ Verenigde Staten en Groot-Brittannië tonen aan dat volledig vrije markt of collectieve benaderingen van de gezondheidszorg niet hoeven te leiden tot een evenwichtige opbotw van basis-naar hooggespecialiseerde gezondheidszorg met brede formele én materiële toegankelijkheid tegen acceptabele kosten. ${ }^{13-183}$ Nederland volgt het Europese model. $\mathrm{C}_{\mathrm{e}}$ inspanningsverplichting van de staat inzake de bevordering van gezondheidszorg is in n $_{n}$ sociaal grondrecht (art. 22) vastgelegd en gelijke toegang is gewaarborgd (art. 1). ${ }^{184} \mathrm{De}$ gezondheidszorg is gedifferentieerd: de verdeling in algemene en specialistische zorg bepaalt de vormgeving. ${ }^{13,}$, 185 De gezondheidszorg is daartoe ingedeeld in drie echelons, wordt grotendeels door partijen zonder winstoogmerk uitgevoerd en centraal gestuurd $\mathrm{r}_{\mathrm{et}}$ financie̋le en wettelijke regelingen (toelichting noot 7). Deze structurering heeft geleid $b t$ een sterk rond de diverse voorzieningen ingerichte gezondheidszorg. De scheiding tuss ${ }_{h}$ generalistische en specialistische zorg is daarbij uitgegroeid tot een tweedeling waarbij door de organisatie- en financieringswijze het contrast tussen de behandelmogelijkhede alsook de benodigde kennis- en vaardigheidsgebieden (te) groot is geworden. ${ }^{78,186,187}$ De voorziening gezondheidszorg wordt cultureel bepaald door de verdeling van taken, verantwoordelijkheden en bevoegdheden tussen de patiënt, de niet-professionele en de professionele zorgverleners. Door de niet functiegerichte opbouw en de 'professionele hulpverleningscultuur' behartigen met name beroepsgroepen en organisaties de belangen (toelichting noot 8). ${ }^{45-47}$ Dit introduceert een 'resistance to change', waarbij de belangen van de patiěnt lang niet altijd centraal staan vanwege de vrees voor de uitkomst van het nieuwe evenwicht in termen van competentie, omvang, invloed en financiering. ${ }^{13}, 78$ Ook in de Nederlandse gezondheidszorg zijn de belangrijkste ontwikkelingen van de afgelopen jaren de kostenstijging en herstructurering (structureel) en de patiëntenemancipatie (cultureel). ${ }^{170}$ De herstructurering ontstond in wisselwerking met de onbetaalbaarheid van (de groei van) de gezondheidszorg (toelichting noot 9) ${ }^{185,}$, 188,189 Vanaf de nota "Grenzen van de zorg" is het overheidsbeleid met wisselend succes meer gericht op efficiency en marktwerking. ${ }^{16,64,190,191}$ Afgewogen zou moeten worden of zorg vanuit oogpunt van deelname aan de samenleving noodzakelijk is, de werkzaamheid ervan is aangetoond, deze doelmatig geleverd wordt én of zij voor eigen rekening en verantwoordelijkheid kan blijven. ${ }^{192}$ De overheid wil haar directe invloed op de gezondheidszorg verminderen en kaderwetten vervangen gedetailleerde regelgeving. Ook de macht van het maatschappelijk middenveld lijkt tanende. ${ }^{A}$ Door een veranderde gezondheidsbeleving, de toename van de behandelmogelijkheden en de dubbele vergrijzing is de belangstelling voor gezondheid in de maatschappelijke discussie en de media groot. ${ }^{173}$ Daardoor krijgen de patiënt en diens omgeving meer kennis over aandoeningen en behandelmogelijkheden en verandert de perceptie van gezondheidszorg. Hierdoor emancipeert de patiënt tot cliënt (en in de toekomst mogelijk consument) en evolueert de hulpvraag tot zorgvraag. 
Hoewel de kostenstijging in de Nederlandse gezondheidszorg zowel ten opzichte van eerdere schattingen als mondiaal meevalt, is ook vanuit een politieke keuze de noodzaak tot doelmatigheidsverhoging of bezuiniging voor de gezondheidszorg een vaststaand gegeven en voor CMTZ thuis één van de belangrijkste ontstaansredenen. ${ }^{190,}{ }^{193}$ De grootste doelmatigheidswinst is haalbaar bij die produktiemiddelen (personeel en materieel) die het grootste deel van de kosten van het eindprodukt vormen. ${ }^{194}$ In de gezondheidszorg is dit op de diverse 'werkvloeren' met haar professionele beroepsbeoefenaars. ${ }^{190}$ Vanuit macroeconomisch en maatschappelijk perspectief lijkt het niet aanwenden (van een deel) van een behandeling thuis verspilling. ${ }^{171}$ Naast 'hotelkosten' en -bij groeiende consumptie- hoge investeringen voor klinische capaciteitsuitbreiding, lopen de reguliere huisvestingskosten van de patiënt door. Ook lijken de salariskosten van 24-uurs zorg in een zorginstelling hoger dan die van zorg door de patiēnt of diens omgeving zelf plus een professionele 'on-demand' beschikbaarheid met 24-uurs bereikbaarheid.

\subsubsection{HET INTERPERSONELE KADER}

Professionele verantwoordelijkheid en autonomie van handelen bepalen grotendeels het interpersoneel kader tussen zorgverleners en patiěnten en naasten. ${ }^{190,195-197}$

Freidson omschreef de professionele autonomie van artsen als het zelf mogen bepalen van de precieze inhoud en uitvoering van hun werkzaamheden vanuit een wettelijk erkende en concurrentie uitsluitende positie op basis van een eigen opleiding en beroepscode. ${ }^{189}$ Juist deze relatieve machtspositie legt hen een grote verantwoordelijkheid op ten opzichte van de patiënten die zich tot hen wenden. De beroepsgroep, instellingen en wettelijke regelingen bepalen de omvang en de reikwijdte van de autonomie van de individuele arts en soms ook de behandelmogelijkheden voor de individuele patiënt. ${ }^{8,190}$ Voor de patiënt is van belang dat bij afwegingen in de zorg de beroepsgroep zélf kiest voor verlenging van de ziektevrije levensduur en bevordering van de kwaliteit van leven. ${ }^{198}$

Van oudsher staat de verpleegkundige beroepsuitoefening in dienst van patiënt en naaste. De erkenning van verpleegkunde als professie staat nog ter discussie, doch in wezen bezit zij reeds alle -ook academische- kenmerken. ${ }^{199,}{ }^{200}$ In de geneeskunde is als kern van professie geaccepteerd "a prolonged specialized training in a body of abstract knowledge, and a collectivity or service orientation". ${ }^{190}$ Analoog handelen verpleegkundigen in hun eigen beroepsuitoefening professioneel en dragen eigen verantwoordelijkheid vanuit een wettelijk erkende positie op basis van een opleiding. $\mathrm{Zij}$ handelen niet autonoom indien zij medische behandeling zoals CMTZ deels van artsen overnemen. Dit vereist afbakening. ${ }^{201}$ Ook heeft het medisch en verpleegkundig handelen in Nederland een wettelijke en deels strafrechtelijke grondslag. De taken en verantwoordelijkheden van de professionele beroepsbeoefenaars waren tot voor kort enkel gebaseerd op de Wet op de Uitoefening van de Geneeskunst (WUG). ${ }^{202}$ Ten tijde van deze studie werd de wet op de Beroepen in de Individuele Gezondheidszorg (BIG) gefaseerd ingevoerd $(\S 5.1){ }^{203}$

Daarnaast wordt het medisch en verpleegkundig handelen op basis van samenwerking tussen autonome patiënten en zorgverleners gezien als contractuele hulpverlening met privaatrechterlijke waarborgen. De Kwaliteitswet Zorginstellingen vereist verantwoorde zorg, dat wil zeggen: van goed niveau, doeltreffend, doelmatig en patiëntgericht. ${ }^{204} \mathrm{De}$ Wet op de Geneeskundige Behandelingsovereenkomst (WGBO) omkleedt de relatie en daaruit voortvloeiende rechten en plichten van de patiënt en diens zorgverlener. ${ }^{205,206}$ Een 'goede hulpverlener' handelt in overeenstemming met de professionele standaarden en licht de patiënt voor. ${ }^{204,207-209}$ Ook dienen zorgverleners vanuit WGBO en de Wet op de Registratie 
van Persoonsgegevens behoorlijk en zorgvuldig met persoonsgegevens om te gaan. 204,216 De BIG (art. 40) verklaart wettelijk verankerde waarborgen expliciet van toepassing op ie individuele gezondheidszorg. ${ }^{203}$ Tot slot waarborgt de Wet Klachtrecht Cliēnten Zorgsector de mogelijkheid tot klagen. ${ }^{211}$ Naast deze regelingen, die het gedrag van hulpverleners en organisaties naar de patiěnten toe bepalen, streeft de overheid ook naar grotere betrokkenheid van de patiënten bij de vormgeving van de gezondheidszorg zelf, zoals inspraak bij regionaal gezondheidszorgbeleid. ${ }^{212}$

Het interpersonele kader van de medische en verpleegkundige beroepsuitoefening is in Nederland daarnaast omschreven in takenpakketten, met daarin de verantwoordelijkheden en de vereiste kennis en vaardigheden. Met het oog op CMTZ thuis, is wat betreft de medici vooral naar de huisarts gekeken. Volgens het basistakenpakket van de Landelijke Huisartsen Vereniging is de huisarts vanuit diens functie in de gezondheidszorg gericht op het, vanuit medische invalshoek, helpen van mensen bij het maken van keuzen -en bij de realisering daarvan- ter bevordering of instandhouding van hun welbevinden en optimaa lichamelijk, geestelijk en sociaal functioneren in hun eigen leefsituatie. ${ }^{162}$ De huisarts verleent daartoe samen met anderen persoonlijke, integrale en continue zorg. ${ }^{213,214} \mathrm{De}$ huisarts functioneert in de thuiszorg als algemeen medisch deskundige en behandelt patielnten zo mogelijk zelf binnen hun eigen leefmilieu (toelichting noot 2 ). ${ }^{161,215}$ De Nationale Raad voor de Volksgezondheid (NRV) baseert haar definitie van beroepsmatis verplegen op die van de American Nursing Association uit 1980: "diagnosis and treatment of human responses to actual or potential health problems". De NRV definitie luidt: "Beroepsmatig verplegen is het herkennen, analyseren, alsmede advies en bijstand verlenen ten aanzien van feitelijke of dreigende gevolgen van lichamelijke en/of geestelijike ziektęnrocessen. handicaps, ontwikkelingsstoornissen en hun behandeling vor de fundamentele levensverrichtingen van het individu. Verpleegkundig handelen houdt tevens in het zodanig beĭnvloeden van mensen, dat menselijke vermogens worden benut met het oog op het in stand houden en bevorderen van gezondheid". ${ }^{216}$ Het primaire aandachtsgebied van verpleegkundigen betreft problemen met de zelfzorg als gevolg van ziekte en behandeling. Verstoringen van de gezondheid zelf en behandeling daarvan behoren primair tot de taak van de arts. Voor zover verpleegkundigen in de thuissituatie werkzaam zijn, is het merendeel van de kenmerken van generalistische zorgverlening, zoals die bij de huisarts beschreven zijn, evenzeer van toepassing.

De relaties tussen patiënt/burger, zorgverlener/zorgverzekeraar en overheid zijn bij uit publieke middelen gefinancierde gezondheidszorg en zeker bij CMTZ thuis complex. Ondanks de driehoeksverhouding lopen de meeste contacten via zorgverleners, ook waar het eigenlijk een relatie tussen de burger en overheid betreft. (Ogenschijnlijk) treedt de overheid terug via kaderwetten waarin zij concurrentie op kwaliteit en service voorstaat. ${ }^{47}$ In het algemeen leidt individualiteit tot een streven naar autonomie, zelfontplooiing en competitie. ${ }^{173}$ Mede hierdoor zou in een geèmancipeerde relatie tussen patiënt/cliënt en hulp/zorgverlener primair uitgegaan kunnen worden van individuele behoeften en zou het individu bij de invulling van de zorg een grotere rol kunnen spelen. ${ }^{198,}{ }^{217}$ Het aanbieden van zorg thuis waar de patiēnt autonoom is of het creëren van een 'thuis' in zorginstellingen, illustreert de te nemen drempel. Ook het rapport van de STG gaat nog niet uit van zelfzorgbehoeften, maar van de bij de patiēnt geconstateerde tekorten. ${ }^{218}$

Bij noodzaak tot keuzen en ter preventie van overconsumptie, kan het solidariteitsprincipe gehanteerd worden door zorg op noodzaak te beoordelen en zoveel mogelijk slechts die 
zorg te verlenen waarin patiēnten en hun omgeving niet zelf kunnen voorzien. 192, 217 Bij afweging van individualiteit en solidariteit verdienen ook de nadelen van zorg thuis aandacht. De consumptie van gezondheidszorg is meestal niet bewust: de patiênt en diens omgeving zijn van nature niet vrij. ${ }^{173,190}$ Aandoeningen zullen de autonomie en zelfontplooiing overwegend bedreigen. Niet iedereen wil of kan, naast het ondergaan en/of verwerken van een aandoening en/of de gevolgen daarvan, actief participeren in de behandeling (grenzen aan autonomie en zelfontplooiing). Zelfs niet iedereen wil of kan daar zelfstandig een afgewogen oordeel over vormen (grenzen aan emancipatie). CMTZ thuis plaatst het totale ziekteproces centraal in het clięntsysteem, kan dit belasten of zelfs geheel gaan overheersen (belemmering van autonomie en zelfontplooiing naasten). Zorg in instellingen en zorg thuis blijven dan ook onvergelijkbaar, zolang thuis niet ook alle benodigde zorg door professionele zorgverleners geleverd kan worden. ${ }^{217}$ Ook de relatie tussen verstrekkers en gebruikers van voorzieningen wordt niet per definitie gelijkwaardiger. De verschuiving van een verzorgings- naar een zelfstandigheidsideaal is ambivalent. ${ }^{219}$ Enerzijds biedt zij ruimte voor een gelijkwaardigere communicatie tussen zorgverleners en ontvangers en voor zorgrelaties met een meer intrinsieke betekenis voor zorgverleners. Anderzijds dreigt deze ruimte te verkleinen en grotendeels te verdwijnen, omdat de verschuiving vaak in het teken staat van doelmatigheid en organisatie, maar vooral omdat de zelfstandigheid op individualiserende wijze dreigt te worden ingevuld. Patiënten/clięnten veranderen dan in zorgconsumenten die instrumentele en strategische verhoudingen aangaan met zorgverleners, in plaats van communicatieve relaties met een intrinsieke betekenis. ${ }^{219}$ Hierdoor kan de substantiële rationaliteit in gedrang komen.

\subsubsection{HET ZORGTECHNOLOGISCHE KADER}

Evenals de gehele gezondheidszorg wordt het zorgtechnologisch kader bepaald door de paradox van de maximaliserende individuele aanspraak en het minimaliserende collectieve aanbod. Tegelijkertijd moet zorg meer toegespitst worden op de behoeften van de patiënt én moeten minder zorgonderdelen binnen het standaardpakket aangeboden worden. De verschuiving van verzorgings- naar zelfstandigheidsideaal is met drie ontwikkelingen te kenschetsen: van communicatieve naar strategische relaties, van alledaagse zorg door naasten naar specialistische zorg door professionals en van ziekenhuiszorg naar transmurale zorg. ${ }^{219}$ Technologie wordt daarbij ingezet om thuis gezondheidszorg te kunnen verlenen en de zelfredzaamheid te verhogen. ${ }^{220}$ Doelen van gezondheidszorg zijn: deelname aan de gemeenschap te bevorderen, de ziektevrije levensduur te verlengen en de kwaliteit van leven te bevorderen; thuiszorg is met name gericht op handhaving in de thuissituatie. ${ }^{78,198,217}$ Analoog daaraan kan CMTZ thuis tot doel hebben de verblijfsduur in de thuissituatie te verlengen en de kwaliteit van leven temidden van de primaire leefgemeenschap te bevorderen. Uit de ervaringen blijkt CMTZ thuis -mits ingebed in een zorgsysteem- mogelijk. Gezien de taken en verantwoordelijkheden lijken beroepsbeoefenaars daarbij een lichte voorkeur te hebben voor vormgeving vanuit de thuiszorg. Omdat (volks)gezondheid van algemeen belang blijft en marktwerking door de prijsinelasticiteit van het produkt gezondheidszorg (onvrijwillige afname) en transactiekosten (zoals advertenties) macro-economisch niet goedkoper hoeft te zijn (zie ontwikkelingen met betrekking tot de thuiszorg), is handhaving van een goeddeels niet op winst gericht karakter nog steeds verdedigbaar. ${ }^{170,190}$ Vanwege de veranderingskosten, ter voorkoming van nadelige effecten op de bestaande zorginfrastructuur, vanwege de machtsverhoudingen en de voorkeur voor regionaal vormgegeven gezondheidszorg ligt samenwerking tussen 
bestaande, regionale zorgvoorzieningen voor de hand. ${ }^{45,46,170,187}$ Voor kwaliteit, service en doelmatigheid in de gezondheidszorg is namelijk niet het aanbieden door marktpartijen, maar het aanbieden volgens marktprincipes van belang. Dit streven hoeft dan ook niet strijdig te zijn met het streven het algemeen welzijn te bevorderen middels een goed uitgeruste en gemakkelijk toegankelijke gezondheidszorg waarvan de kosten vanuit een solidariteitsgedachte gelijk verdeeld worden. ${ }^{185}$ Zelfs het indelingsprincipe volgens echelons hoeft niet verlaten te worden. ${ }^{221}$ Wel dient de gezondheidszorg op een substantieel én functioneel rationele wijze te worden heringericht. ${ }^{173}$

Een volledig uitgewerkt zorgtechnologisch kader voor CMTZ dat aan bovenstaande eisen tegemoet kan komen, ontbrak bij aanvang van deze studie. Daarom is uitgegaan van het zorgtechnologische kader volgens Orem, voor de visie van waaruit zorg wordt verleend en voor de inhoudsbepaling en de vormgeving daarvan. ${ }^{164}$ In $1993 \mathrm{kwam}$ voor de huisarts een praktische handleiding voor thuiszorgtechnologie beschikbaar. ${ }^{222}$

De inhoud van de zorg volgt bij Orem uit de zelfzorgbehoeften (schema 6.2). ${ }^{164}$ Om te bepalen of een zelfzorgbehoefte een zelfzorgtekort oplevert, is van belang of een patiënt die zelfzorgbehoefte zelf kan onderkennen, zelf over voorzieningen daarvoor kan beslissen en zelf de zorg kan uitvoeren. Bij CMTZ zullen de aandoening(en) en/of de behandeling vrijwel altijd zelfzorgtekorten met zich meebrengen. ${ }^{n}$ Ook kunnen algemene zelfzorgtekorten en zelfzorgtekorten bij ontwikkelingsprocessen beïnvloed worden of ontstaan. ${ }^{164}$ Vanuit hun basisopleiding en praktijkervaring konden zorgverleners in de thuissituatie de afgelopen jaren niet altijd adequaat inspelen op de zelfzorgtekorten bij CMTZ. ${ }^{72,76}$ Voor de vormgeving van de zorg zijn vooral de indeling van het zorgproces en de zorgmethoden van belang. De indelingen van het zorgproces volgens Orem en de, in de praktijk vaak gehanteerde, kernachtiger indeling volgens McFarland en McFarlane komen grotendeels overeen (schema 4.1). ${ }^{164,223}$ Beiden vatten het zorgproces op als een spiraalvormige gebeurtenis, waarbij per winding de verschillende stappen doorlopen worden.

Schema 4.1 Indeling van het zorgproces volgens Orem en McFarland en McFarlane. 149,22

\section{Orem}

1. De initiele en de voortdurende bepaling van de reden waarom een patient medische en/of verpleegkundige zorg ontvangt.

2. Het ontwikkelen van cen systeem van zorgverlening dat effectief bijdraagt aan het bereiken van de gezondheidsdoelen van de patient middels therapeutische zelfzorg en het bereiken van zelfzorgdoelen door de patient en diens naaste(n). Planning van zorgverlening volgens dit systeem, omvat specificaties van de rollen, de middelen, de coordinatic en de tijd, de plaats en de frequentie van het uitvoeren van de activiteiten door de zorgverleners, de patient en de naaste(n).

3. Het begin, de uitvoering en de controle van de ondersteunende activiteiten om:

a. te compenseren voor de beperkingen in de zelfzorg van de patient om te verzekeren dat therapeutische zelfzorg wordt verleend en om het voor de patient mogelijk te maken om diens gedrag aan de bestaande beperkingen aan te passen;

b. waar mogelijk zelfzorgtekorten van de patient en/of de naaste(n) te overwinnen teneinde tegemoet te komen aan de toekomstige therapeutische zelfzorgvereisten op korte of lange termijn; c. de zelfzorgvermogens van de patient in stand te houden en te beschermen ter voorkoming van nieuwe zelfzorgtekorten.

\section{McFarland en McFarlane}

1. Anamnese en diagnosestelling.

2. Doelbepaling, interventiebepaling en interventieplanning.

3. Uitvoering van de interventies.

4. Evaluatie. 
De eerste twee stappen worden in de verpleegkundige praktijk vaak samengenomen en aangeduid met indicatiestelling. In de medische praktijk is dit door de verregaande specialisatie minder goed mogelijk.

De zes zorgverleningsmethoden volgens Orem zijn hier geoperationaliseerd in vier voor patiënten, naasten en zorgverleners meer herkenbare soorten (schema 4.2). ${ }^{18}, 164,196,197$

Schema 4.2 Soorten zorgverlening volgens Orem en dit onderzoek. ${ }^{104}$

\section{Orem}

Handelen in naam van of doen voor een ander Fysiek ondersteunen

Educatic en training

Informeren en adviseren

Een omgeving creèren, die persoonlijke ontwikkeling bevordert

Psychologisch ondersteunen

\section{Model in deze studie}

Directe zorguitvoering

Informeren

Opmerken veranderingen en aanpassen zorg

Psychosociale begeleiding

Het overnemen van CMTZ, eventuele fysieke ondersteuning en het instrueren van de patiënt zijn gebundeld tot directe zorguitvoering. Omdat situaties met CMTZ snel kunnen veranderen en dan bijna altijd aanpassing van de zorg is benodigd, is het creëren van een omgeving die persoonlijke ontwikkeling bevordert hierdoor vervangen ${ }^{56} \mathrm{Het}$ 'monitoren' van de omgeving is behouden, de aandacht is echter niet zozeer gericht op persoonlijke ontwikkeling alswel op het creëren van een acceptabele verhouding tussen draaglast en draagkracht en op de kwaliteit van leven van de patiënt en diens directe omgeving. De directe zorguitvoering vormt de kern van het zorgproces en is vooral gericht op de behandeling. De andere drie soorten zorgverlening zijn daarbij benodigde klantgerichte activiteiten. ${ }^{224}$ Samen vormen zij de hoofdonderdelen van professionele CMTZ.

\subsection{Conclusies}

Vanuit het gezondheidskundig metaparadigma, de concepten zelfzorg, mantelzorg en professionele zorg van Hattinga Verschure en de zorgverleningstheorie van Orem, kan een theoretische basis gelegd worden voor zorgverlening in de gezondheidszorg -zoals CMTZdie recht doet aan zowel de substantiële als de functionele rationaliteit. De theorie van Orem biedt een praktisch kader voor de analyse en beschrijving van de zorgverlening bij CMTZ aangezien alle vereiste medische en verpleegkundige activiteiten opgevat kunnen worden in termen van bij de patiënt en/of diens naaste(n) optredende en/of dreigende zelfzorgtekorten. Hoewel de medische en verpleegkundige beroepsbeoefenaars hun handelen meestal niet op de theorie van Orem baseren, heeft de wijze waarop zij momenteel in het algemeen zorg verlenen duidelijke overeenkomsten daarmee. Ook bij CMTZ thuis kan aldus gehele of gedeeltelijke compensatie van en educatie bij zelfzorgtekorten met als uitgangspunt het zo optimaal mogelijk benutten van het zelfzorgvermogen van de patiënt en/of diens naaste(n) centraal staan.

Het blijkt mogelijk ook de feitelijke kaders bij CMTZ inherent aan de westerse leefomgeving en de Nederlandse gezondheidszorg met de theorie van Orem te beschrijven. Naast de technische mogelijkheden bepalen de kosten én de relatie tussen patiënten, zorgverleners, verzekeraars en de overheid de huidige veranderingen in de gezondheidszorg en dus ook bij CMTZ thuis. Hun ordening is zowel te baseren op de verhoudingen tussen individualiteit en solidariteit als op die tussen overheid en marktpartijen. ${ }^{225}$ 


\section{Enquête naar taken en verantwoordelijkheden bij infuusbehandeling *}

\subsection{Inleiding}

Uit de literatuurinventarisatie blijkt dat met verschillende werkwijzen en organisatievormen de verdeling van taken en verantwoordelijkheden bij medisch-technisch handelen varieert. Deze zijn daarom vanuit de hoofdvraagstellingen I en II en aandachtspunt 2 bestudeerd. Infuusbehandeling omvat medisch- en verpleegtechnische handelingen. Verpleegtechnische handelingen worden tot het verpleegkundig beroeps-domein gerekend. ${ }^{216}$ Medisch-technische handelingen zijn: "Handelingen op het gebied van de geneeskunde die door de arts al dan niet aan de verpleegkundige gedelegeerd kunnen worden" ${ }^{226}$ Met de toename van de mogelijkheden van de gezondheidszorg zijn ook de medisch-technische handelingen toegenomen. Hierbij werken artsen en verpleeg-kundigen vaak samen. Er zijn diverse verdelingen van taken en verantwoordelijkheden mogelijk. In de loop der jaren hebben verpleegkundigen steeds meer taken overgenomen, die naar de letter van de wet alleen artsen mogen uitvoeren omdat ze onder de uitoefening van de geneeskunst vallen. Deze discongruentie tussen wet en praktijk is al jaren onderwerp van wetenschappelijke en maatschappelijke discussie..$^{40-44,227,228}$ Consensus ontbreekt vooralsnog, hoewel de uitkomsten van dit debat wel direct van invloed zijn op de individuele en gezamenlijke beroepsuitoefening en als zodanig op de inrichting van de gezondheidszorg. Zo ook bij infuusbehandeling (thuis). Daartoe is in 1993 via een enquête geïnventariseerd hoe theorie en praktijk van specialisatie en functionele differentiatie alsmede arbeidsdeling en structurele differentiatie zich verhouden:

-Wat is de huidige en gewenste verdeling van taken, verantwoordelijkheden en bevoegdheden tussen artsen en verpleegkundigen bij infuusbehandeling (thuis)? -Hoe verhoudt zich bovenstaande tot de Wet Uitoefening Geneeskunst (WUG) ${ }^{202}$, de wet Beroepen in de Individuele Gezondheidszorg (BIG $)^{203}$ en hun maatschappelijke vertaling? Voor zover handelingen bij infuusbehandeling gerekend kunnen worden tot de voorbehouden handelingen is getracht de toestand vóór de invoering van de BIG te beschrijven (onder de WUG). Ook is de beroepsbeoefenaars los van elk wettelijk kader gevraagd naar hun wensen. Beide aspecten maken een evaluatie voorafgaande aan de invoering van de BIG mogelijk. Daarnaast zijn aan infuusbehandeling (thuis) gerelateerde niet voorbehouden, al dan niet medisch-technische, handelingen bestudeerd. Het "Rapport Staatscommissie Medische Beroepsuitoefening" luidde in 1973 de verandering van WUG naar BIG in. ${ }^{229}$ Volgens van der Mijn was van eerste aanzetten

\footnotetext{
- Een samenvatting van dit hoofdstuk is gepubliceerd in Medisch Contact 1997;52(10):324-6.
} 
zelfs al sprake in 1961 en daarvoor in $1917 !^{227}$ In de WUG uit 1865 werd zowel de geneeskundige en verloskundige beroepsuitoefening als de daarbij behorende titelbescherming vastgelegd. Alleen artsen zijn daarin gerechtigd de geneeskunst (het beroepsmatig verlenen van genees-, heel- of verloskundige raad of bijstand) uit te oefenen (art.1): de bescherming van de beroepsuitoefening. Ook zijn alleen zij gerechtigd aan te kondigen dat zij de geneeskunst uitoefenen of een titel te voeren die hen als zodanig aanwijst (art.3): de beroepstitelbescherming. Later is dit enigermate genuanceerd middels de jurisprudentie die bekend staat als de 'verlengde-armconstructie'. Deze gaf artsen de mogelijkheid onder voorwaarden medisch-technische handelingen aan verpleegkundigen te delegeren. Deze voorwaarden, voortkomend uit jurisprudentie, literatuur en adviezen van adviesorganen, verwoordt de Geneeskundige Hoofdinspectie als volgt (zij vormen ook de voorloper voor delegatie via de BIG): ${ }^{230}$

"1. De arts neemt de beslissingen omtrent diagnose, therapie en indicatie.

2. De arts behoort toezicht te houden op de wijze van uitvoering, althans zich ervan te verzekeren dat de uitvoering zorgvuldig zal plaatsvinden; tevens dient de arts beschikbaar te zijn voor eventueel overleg en voor daadwerkelijke bijstand bij eventuele complicaties. Onder beschikbaar wordt niet per definitie verstaan het lijfelijk aanwezig zijn in de situatie, maar wel het bereikbaar zijn voor advies en zo nodig voor verder medisch handelen.

3. De arts wijst de verpleegkundige op eventuele bijverschijnselen en complicaties en geeft aan hoe dan te handelen.

4. De arts draagt slechts handelingen op, c.q. vertrouwt slechts die handelingen toe welke de verpleegkundige krachtens opleiding en ervaring beheerst. ${ }^{216}$ De verpleegkundige moet een opdracht weigeren indien hij/zij de bekwaamheid daartoe mist. De opdrachten dienen schriftelijk te worden vastgelegd.

5. De arts en verpleegkundige stellen en houden elkaar op de hoogte opdat elk van beiden hun respectievelijke verantwoordelijkheden kan waarmaken."

De BIG rekent tot individuele gezondheidszorg handelingen op het gebied van de geneeskunst én alle andere handelingen -waaronder onderzoeken en raad geven- die rechtsreeks betrekking hebben op een persoon en ertoe strekken diens gezondheid te bevorderen of te bewaken (art.1 lid 1). De geneeskunst betreft alle verrichtingen -waaronder onderzoeken en raad geven- die rechtsreeks betrekking hebben op een persoon en ertoe strekken hem van een ziekte te genezen of voor het ontstaan daarvan te behoeden of zijn gezondheidstoestand te beoordelen, dan wel verloskundige bijstand te verlenen (art.1 lid 2). De BIG beschrijft het deskundigheidsgebied van de arts als: "het verrichten van handelingen op het gebied van de geneeskunst" (art.19 lid 1). Het deskundigheidsgebied van de verpleegkundige bestrijkt: "a. het verrichten van handelingen op het gebied van observatie, begeleiding, verpleging en verzorging; $b$. het ingevolge opdracht van een beroepsbeoefenaar op het gebied van de individuele gezondheidszorg verrichten van handelingen in aansluiting op diens diagnostische en therapeutische werkzaamheden" (art.33 lid a en b). De verpleegkundige kan dus op twee manieren bij CMTZ betrokken worden. Ten eerste bij de observatie, begeleiding en verpleging van de patiënt. Ten tweede door het ingevolge opdracht uitvoeren van handelingen, waaronder medisch-technische. In de BIG wordt het aantal beroepen met beroepstitelbescherming (art. $3 \mathrm{t} / \mathrm{m} \mathrm{17}$ ) sterk uitgebreid, de bescherming van de beroepsuitoefening (art.35 $t / \mathrm{m}$ 39) beperkt én worden beide begrippen ontkoppeld. Eenieder, die aan de beroepsvereisten voldoet, is gerechtigd een beschermde titel op het gebied van de individuele gezondheidszorg te dragen. 
De bescherming van de beroepsuitoefening is beperkt tot de 'voorbehouden handelingen'. Deze handelingen dienen, als zij buiten noodzaak én beroepsmatig uitgevoerd worden, aan drie criteria te voldoen. Bij uitvoering door ondeskundigen moeten ze een aanmerkelijk gevaar opleveren voor gezondheid en leven van patiënten. Ook dienen ondeskundigen in de gelegenheid te zijn deze praktisch uit te voeren en dienen ze duidelijk afgrensbaar te zijn. De verschillende voorbehouden handelingen en de delegatie daarvan is in de BIG expliciet beschreven en staat in de maatschappelijke en wetenschappelijke discussie centraal (art.35 t/m 39). ${ }^{231}$ In artikel 36 en 37 staat om welke handelingen het gaat, wie uit hoofde van zijn titel uitvoeringsbevoegd is en hoe wijzigingen aangebracht kunnen worden. Artsen, zijn bevoegd tot het doen van heelkundige handelingen (art. 36 lid 1), catheterisaties (lid 4), en het geven van injecties (lid 5). Dit alleen voor zover zij redelijkerwijs mogen aannemen dat zij bij het uitvoeren over de vereiste bekwaamheid beschikken (lid 14). Wijzigingen kunnen worden aangebracht door Algemene Maatregelen van Bestuur (art.37). De artikelen 35, 38 en 39 beschrijven het delegeren van voorbehouden handelingen (aan bijvoorbeeld verpleegkundigen). Artikel 38 is de wettelijke vertaling van de 'verlengde-arm-constructie'. In artikel 39 effent de wetgever de weg voor een nog zelfstandiger uitvoering van gedelegeerde voorbehouden handelingen. ${ }^{232}$

\subsection{Methode}

Binnen deze exploratieve studie is ernaar gestreefd 100 artsen (huisartsen en specialisten) en 100 verpleegkundigen (wijk- en ziekenhuisverpleegkundigen) schriftelijk te enquêteren over hun ervaringen met infuusbehandeling in de huidige én de gewenste situatie. Om de gewenste situatie zo waardenvrij mogelijk weer te geven is expliciet gevraagd deze los van eventuele belemmeringen voortvloeiend uit de huidige of toekomstige wet- en/of regelgeving te beschrijven. Schema 5.1 geeft globaal aan welke aspecten zijn opgenomen. De enquête bevat overwegend vragen met vaste antwoordmogelijkheden. ${ }^{67}$

Schema 5.1 Aspecten enquête.

\section{Kenmerken respondenten}

Primair proces

Zorguitvoering

-algemeen (A-D)

-specifiek (E-H)

\section{Randvoorwaarden}

Bevoegdheid en bekwaamheid

Continuiteit van zorgverlening

-taakverdeling

-overdracht

-overleg

Voorzieningen

-personeel

-matericel

De artsen zijn aselect benaderd via het "Geneeskundig Adresboek Nederland'. ${ }^{233} \mathrm{Om}$ landelijke spreiding te bewerkstelligen, is bij de verzending per provincie gecorrigeerd naar inwoneraantal. ${ }^{234,235}$ Alleen specialismen, waarbij regelmatig infuusbehandelingen voorkomen, zijn geselecteerd. " Gezien de benaderingswijze, een landelijke, schriftelijke enquête (plus reminder) zonder vergoeding, is vooraf rekening gehouden met een relatief lage respons (één op zes). ${ }^{236,}{ }^{237} \mathrm{Er}$ is gestreefd naar de mening van 100 artsen. Vanuit de verwachte respons en een beroepsomvang van 83 specialisten en 42 huisartsen per 100.000 inwoners zijn 600 vragenlijsten verstuurd, 389 naar specialisten en 211 naar huisartsen. ${ }^{235}$ 
Door het ontbreken van een centraal adressenbestand van verpleegkundigen waren er bij de betreffende steekproef twee benaderingsmogelijkheden: via instellingen of via vakbonden. Beiden geven selectiebias, maar de benadering via instellingen vergt meer organisatorische inspanningen. De AbvaKabo, de CFO en NU '91 zijn benaderd. De AbvaKabo, met de meeste verpleegkundigen en verzorgenden onder haar leden (ongeveer 45.000 ), was bereid een geanonimiseerde, aselecte steekproef van haar adressenbestand te leveren. $\mathrm{Zij}$ vroeg de leden in de steekproef of die bezwaar tegen deelname hadden. Bij geen bezwaar verzond zij de vragenlijsten met een begeleidend schrijven van de onderzoekers en haarzelf. Verpleegkundigen en verzorgenden waren niet apart geregistreerd. De AbvaKaBo verwachtte dat zij in gelijke mate in het adressenbestand en dus de steekproef voorkwamen. Vanwege het streven naar 100 bruikbare enquêtes van verpleegkundigen zijn daarom, bij een verwachte respons van één op zes, 1200 enquêtes verzonden aan verpleegkundigen en verzorgenden. ${ }^{237}$

Vanwege het inventariserend karakter zijn alleen frequentieverdelingen opgenomen.

\subsection{Resultaten}

\subsubsection{KENMERKEN RESPONDENTEN}

De lage respons is uitgebreid geanalyseerd (bijlage 5.1). De voornaamste resultaten worden kort weergegeven. De 64 responderende huisartsen (32\%) komen qua landelijke spreiding, geslacht, leeftijd en praktijkvorm overeen met de beroepsgroep. De 52 responderende specialisten (14\%) komen qua landelijke spreiding en onderlinge verhoudingen tussen de diverse specialismen overeen met de beroepsgroep. De 87 responderende wijkverpleegkundigen ( $26 \%$ ) komen qua landelijke spreiding, geslacht, leeftijd, dienstverband en praktijkvorm overeen met de beroepsgroep. Bij de 112 responderende ziekenhuisverpleegkundigen (18\%) ontbreken referentiekaders.

\subsubsection{HUIDIGE EN GEWENSTE PRAKTIJK}

Op de volgende paginas geven tabellen 5.1 en 5.3 de resultaten van de enquête betreffende de huidige en tabellen 5.2 en 5.4 betreffende de gewenste verdeling van algemene en specifieke taken bij infuusbehandeling (thuis) weer. Bij de huidige situatie geven enerzijds specialisten, huisartsen en wijkverpleegkundigen die ervaring hebben met IT en anderzijds specialisten en ziekenhuisverpleegkundigen die alleen ervaring hebben met infuusbehandeling in het ziekenhuis, aan of volgens hen de diverse beroepsgroepen een bepaalde taak vervullen. Bij de gewenste situatie is weergegeven of men taken medisch, verpleegkundig of gezamenlijk van aard vindt. Laatstgenoemde antwoordmogelijkheid is toegevoegd om overlappende taakgebieden in kaart te brengen.

\subsubsection{Algemene en specifieke zorguitvoering}

$\mathrm{Bij}$ de algemene zorguitvoering worden vier clusters onderscheiden: indicatiestelling (A), informeren/instrueren (B), bewaken/beoordelen effect (C) en coördinatie (D). Ook bij de specifieke zorguitvoering worden vier clusters onderscheiden: inbrengen infuusnaald (E), medicatietoediening $(F)$, bediening infuussysteem $(G)$ en verwijderen infuusnaald $(H)$.

Binnen het proces van indicatiestelling, te verdelen in signaleren, beslissen en bepalen van de behandeling (cluster A), lijkt een rol weggelegd voor verpleegkundigen bij het signaleren van de noodzaak tot behandeling. Artsen en verpleegkundigen verschillen echter duidelijk van inzicht met betrekking tot het beslissen omtrent de noodzaak tot behandeling. 
De artsen vinden dat dit -evenals in de huidige situatie- een medische taak moet blijven, de verpleegkundigen wensen dat dit tot hun beider taak gerekend gaat worden. Het bepalen van de inhoud van de behandeling wordt door allen tot de medische taak gerekend. Naarmate meer achtergrondkennis vereist is, wordt een taak medischer geacht.

Bij het informeren en instrueren over de behandeling (cluster B) liggen de rollen anders. Informeren vindt men een gezamenlijke of een medische taak (artsen), instrueren een gezamenlijke of een verpleegkundige taak. Naarmate meer praktische kennis en vaardigheden vereist zijn, wordt een taak verpleegkundiger geacht. In de huidige situatie informeren vooral de artsen en in het ziekenhuis ook de ziekenhuisverpleegkundigen. In het ziekenhuis instrueren ook nu vooral de ziekenhuisverpleegkundigen, thuis noemen de respondenten vooral hun eigen beroepsgroep maar ook alle andere.

Bij het bewaken en beoordelen van het effect van de behandeling $(C)$ treden vergelijkbare verschillen op als bij het signaleren en beslissen omtrent de noodzaak tot behandeling. Artsen vinden het bewaken even vaak hun beider of een medische taak, verpleegkundigen rekenen dit vooral tot hun beider taak. Het verschil is echter zowel bij artsen als verpleegkundigen minder uitgesproken zoals afgeleid kan worden uit de kleinere verschillen tussen bewaken en beoordelen van het effect in de huidige situatie.

Binnen de coördinatie (cluster D) valt vooral de gezamenlijkheid op. Het fungeren als aanspreekpunt ziet men als beider of als verpleegkundige taak. De coördinatie rekent men tot beider taak of tot de taak van de eigen beroepsgroep. Dit komt overeen met hetgeen men aangeeft bij de huidige situatie.

Het inbrengen van de infuusnaald (cluster E) wordt door degenen in wiens werkomgeving deze taak vaker voorkomt (ziekenhuis) minder als een strikt medische taak gezien. Verpleegkundigen zien het inbrengen meer als een medische tak dan artsen. De meeste ziekenhuisverpleegkundigen zien het inbrengen als een medische taak, terwijl ze in de huidige situatie toch in meerderheid zelf infuusnaalden inbrengen. Het assisteren bij het inbrengen van een infuus rekent $20 \%$ van de artsen tot beider taak. Dit komt wel overeen met hetgeen men aangeeft over de huidige situatie thuis, niet met die in het ziekenhuis.

De medicatietoediening (cluster F) komt deels overeen met hetgeen men over de huidige praktijk aangeeft. De eerste toediening vindt men in het algemeen een medische taak, de vervolgtoediening beider of een verpleegkundige taak. Toch geven verpleegkundigen -vooral in het ziekenhuis- aan vaak medicatie voor de eerste keer toe te dienen. Anderzijds melden huisartsen thuis vervolgtoedieningen te geven.

Bij de bediening van het infuussysteem (cluster $\mathrm{G}$ ) treedt een gradatie op. Bij het instellen van het infuus wordt de arts nog genoemd. Het controleren van de systemen en het verwisselen van de infuuszakken zien allen als een verpleegkundige taak. Toch geeft men aan dat buiten het ziekenhuis nu nog vaak artsen daarbij betrokken zijn.

Het verwijderen van de infuusnaald (cluster $\mathrm{H}$ ) ziet men vooral als een verpleegkundige en in mindere mate als beider taak. Degenen in wiens werkomgeving het vaker voorkomt (ziekenhuis) ziet het meer als een verpleegkundige taak. 


\begin{tabular}{|c|c|c|c|c|c|c|}
\hline \multicolumn{2}{|l|}{ Huidige situatie } & \multicolumn{3}{|c|}{ Thuis } & \multicolumn{2}{|c|}{ In het ziekenhuis } \\
\hline \multicolumn{2}{|c|}{ Vraag plus antwoordmogelijkheden } & SP & HA & wv & SP & ZHV \\
\hline \multirow{5}{*}{$\begin{array}{l}\text { Signaleren of infuusbehandeling } \\
\text { nodig is (A). } \\
N: 7-14-42 / 34-105\end{array}$} & SP & 100 & 50 & 86 & 97 & 93 \\
\hline & HA & 29 & 64 & 43 & 9 & 1 \\
\hline & ZHV & 0 & 0 & 5 & 41 & 65 \\
\hline & wV & 0 & 7 & 17 & 0 & 0 \\
\hline & TMV & 0 & 0 & 2 & 0 & 0 \\
\hline \multirow{5}{*}{$\begin{array}{l}\text { Beslissen dat infuusbehandeling } \\
\text { nodig is (A). } \\
N: 7-14-42 / 34-105\end{array}$} & SP & 100 & 64 & 90 & 100 & 100 \\
\hline & HA & 29 & 71 & 45 & 0 & 0 \\
\hline & ZHV & 0 & 0 & 0 & 3 & 13 \\
\hline & wv & 0 & 7 & 2 & 0 & 0 \\
\hline & TMV & 0 & 0 & 2 & 0 & 0 \\
\hline \multirow{5}{*}{$\begin{array}{l}\text { Bepalen medicatie plus aard, } \\
\text { volume en inloopsnelheid van de } \\
\text { infuusvlocistof (A). } \\
\mathrm{N}: 7-14-42 / 34-105\end{array}$} & SP & 100 & 71 & 90 & 100 & 98 \\
\hline & $\mathrm{HA}$ & 14 & 64 & 57 & $3^{*}$ & 0 \\
\hline & $\mathrm{ZHV}$ & 0 & 0 & 0 & 6 & 10 \\
\hline & wV & 0 & 7 & 10 & 0 & 0 \\
\hline & TMV & 0 & 0 & 2 & 0 & 0 \\
\hline \multirow{5}{*}{$\begin{array}{l}\text { Patient informeren over de } \\
\text { mogelijkheden van de } \\
\text { infuusbehandeling (B). } \\
\text { N:7-14-41/34-105 }\end{array}$} & SP & 86 & 57 & 80 & 97 & 78 \\
\hline & HA & 29 & 86 & 41 & 9 & 3 \\
\hline & $\mathrm{ZHV}$ & 14 & 7 & 22 & 41 & 72 \\
\hline & wV & 14 & 14 & 17 & 3 & 1 \\
\hline & TMV & 14 & 7 & 5 & 3 & 2 \\
\hline \multirow{5}{*}{$\begin{array}{l}\text { Patient instrueren over de } \\
\text { infuusbehandeling (B). } \\
\mathrm{N}: 7-14-42 / 34-103\end{array}$} & SP & 86 & 50 & 36 & 41 & 22 \\
\hline & $\mathrm{HA}$ & 29 & 64 & 40 & $3^{*}$ & 0 \\
\hline & ZHV & 43 & 21 & 43 & 91 & 95 \\
\hline & wv & 14 & 36 & 69 & $3^{\circ}$ & $1^{\circ}$ \\
\hline & TMV & 43 & 14 & 5 & $3^{*}$ & $1^{\circ}$ \\
\hline \multirow{5}{*}{$\begin{array}{l}\text { Bewaken van het effect van de } \\
\text { infuusbehandeling }(C) \text {. } \\
N: 7-14-42 / 33-105\end{array}$} & SP & 57 & 29 & 26 & 76 & 52 \\
\hline & HA & 57 & 93 & 83 & $3^{*}$ & $1^{\circ}$ \\
\hline & ZHV & 14 & 7 & 14 & 73 & 91 \\
\hline & wV & 43 & 36 & 81 & 0 & $1^{\circ}$ \\
\hline & TMV & 0 & 0 & 5 & $3^{*}$ & $3^{\circ}$ \\
\hline \multirow{5}{*}{$\begin{array}{l}\text { Beoordeien van het effect van de } \\
\text { infuusbehandeling }(C) \text {. } \\
\mathrm{N}: 7-14-42 / 33-105\end{array}$} & SP & 71 & 29 & 48 & 97 & 96 \\
\hline & HA & 57 & 86 & 86 & $3^{\circ}$ & $2^{\circ}$ \\
\hline & ZHV & 14 & 0 & 2 & 27 & 41 \\
\hline & wV & 43 & 29 & 31 & 0 & 0 \\
\hline & TMV & 0 & 7 & 2 & $3^{\circ}$ & $1^{\circ}$ \\
\hline \multirow{5}{*}{$\begin{array}{l}\text { De coordinatie van de directe } \\
\text { patientenzorg - degene die deze } \\
\text { taak het meest op zich neemt (D). } \\
\mathrm{N}: 7-14-42 / 31-104 \text { plus } \\
\mathrm{N}: 7-13-40 / 30-99\end{array}$} & SP & $86-57$ & $43-39$ & $33-15$ & $90-70$ & $71-23$ \\
\hline & HA & $43-43$ & $93-46$ & $69-20$ & $3^{*}-0$ & $4^{*}-1$ \\
\hline & $\mathrm{ZHV}$ & $29-0$ & $7-8$ & $12-0$ & $65-27$ & $90-76$ \\
\hline & wV & $29-0$ & $43-8$ & $83-60$ & $0-0$ & $4^{*}-0$ \\
\hline & TMV & $0-0$ & $7-0$ & 7.5 & $3^{*}-3^{*}$ & $3 \div 0$ \\
\hline
\end{tabular}

Legenda: SP=specialist, $\mathrm{HA}=$ huisarts, $\mathrm{ZHV}=$-ziekenhuisverpleegkundige, $\mathrm{WV}=$-wijkverpleegkundige, $\mathrm{TMV}$-transmuraal werkend infuusverpleegkundige, $(\mathrm{X})=$ cluster, $\mathrm{N}: \mathrm{a}-\mathrm{b}-\mathrm{c} / \mathrm{d}-\mathrm{e}-\mathrm{-respondenten} \mathrm{met} \mathrm{extramurale}$ ervaring/aantal respondenten met alleen intramurale ervaring op het gebied van infuusbehandeling" =gezien de lokatic is hier a priori $0 \%$ verwacht omdat deze zorgverieners niet in het zickenhuis werken. Doordat meerdere altematieven mogelijk zijn, is er geen totaalpercentage. 


\begin{tabular}{|c|c|c|c|c|c|c|}
\hline \multicolumn{2}{|c|}{ Vraag plus antwoordmogelijkbeden } & SP & HA & ZHV & wV & тот \\
\hline \multirow{3}{*}{$\begin{array}{l}\text { Signaleren of infuusbehandeling } \\
\text { nodig is (A). } \\
\text { N:51-64-108-86-309 }\end{array}$} & Verpl & 4 & 0 & 4 & 1 & 2 \\
\hline & Medisch & 43 & 55 & 14 & 22 & 29 \\
\hline & Beide & 53 & 45 & 82 & 77 & 68 \\
\hline \multirow{3}{*}{$\begin{array}{l}\text { Beslissen dat infuusbehandeling } \\
\text { nodig is (A). } \\
\mathrm{N}: 51-64-109-86-310\end{array}$} & Verpl & 0 & 0 & 5 & 0 & 2 \\
\hline & Medisch & 77 & 77 & 33 & 44 & 52 \\
\hline & Beide & 24 & 23 & 62 & 56 & 46 \\
\hline \multirow{3}{*}{$\begin{array}{l}\text { Bepalen medicatie plus aard, } \\
\text { volume en inloopsnelheid van de } \\
\text { infuusvloeistof (A). } \\
\mathrm{N}: 51-64-111-86-312\end{array}$} & Verpl & 0 & 0 & 1 & 0 & 0 \\
\hline & Medisch & 96 & 84 & 84 & 91 & 88 \\
\hline & Beide & 4 & 16 & 15 & 9 & 12 \\
\hline \multirow{3}{*}{$\begin{array}{l}\text { Patiênt informeren over de } \\
\text { mogelijkheden van de } \\
\text { infuusbehandeling (B). } \\
\text { N:51-64-109-86-310 }\end{array}$} & Verpl & 4 & 2 & 11 & 7 & 7 \\
\hline & Medisch & 39 & 47 & 16 & 19 & 27 \\
\hline & Beide & 57 & 52 & 73 & 74 & 67 \\
\hline \multirow{3}{*}{$\begin{array}{l}\text { Patient instrueren over de } \\
\text { infuusbehandeling (B). } \\
\mathrm{N}: 51-64-110-87-312\end{array}$} & Verpl & 29 & 42 & 44 & 31 & 38 \\
\hline & Medisch & 6 & 6 & 3 & 3 & 4 \\
\hline & Beide & 65 & 52 & 54 & 66 & 58 \\
\hline \multirow{3}{*}{$\begin{array}{l}\text { Bewaken van het effect van de } \\
\text { infuusbehandeling }(C) \text {. } \\
\text { N:50-64-110-86-310 }\end{array}$} & Verpl & 4 & 3 & 10 & 2 & 6 \\
\hline & Medisch & 42 & 55 & 15 & 14 & 27 \\
\hline & Beide & 54 & 42 & 76 & 84 & 67 \\
\hline \multirow{3}{*}{$\begin{array}{l}\text { Fungeren als aanspreekpunt voor } \\
\text { patient en mantelzorg (D). } \\
\text { N:50-64-110-86-310 }\end{array}$} & Verpl & 26 & 19 & 37 & 22 & 27 \\
\hline & Medisch & 14 & 14 & 5 & 2 & 7 \\
\hline & Beide & 60 & 67 & 58 & 76 & 65 \\
\hline \multirow{3}{*}{$\begin{array}{l}\text { De coordinatie van de directe } \\
\text { patientenzorg (D). } \\
\text { N:51-64-111-87-313 }\end{array}$} & Verpl & 10 & 9 & 41 & 38 & 28 \\
\hline & Medisch & 39 & 27 & 5 & 3 & 14 \\
\hline & Beide & 51 & 64 & 55 & 59 & 57 \\
\hline
\end{tabular}

Legenda: $\mathrm{SP}=$ specialist, $\mathrm{HA}=$ huisarts, $\mathrm{ZHV}=$-ziekenhuisverpleegkundige, $\mathrm{WV}=$ wijkverpleegkundige, $(\mathrm{X})=$ cluster, $\mathrm{N}$ :a-b-c-d-e=aantal respondenten per kolom, Verpl=verpleegkundig. Door afronden is het totaalpercentage soms geen $100 \%$.

\subsubsection{Bevoegd- en bekwaamheid}

Tabel 5.5 geeft de huidige en de gewenste bevoegdheid en bekwaamheid bij medischtechnisch handelen weer. Iedere beroepsgroep beoordeelt de eigen én andere beroepsgroepen. Bij de huidige situatie zijn de antwoorden van respondenten met ervaring met IT en met ervaring beperkt tot het ziekenhuis apart weergegeven. Bevoegdheid is gedefinieerd als: "de wettelijke erkenning tot het mogen verrichten van die handeling" en deskundigheidsgebied als: "het kennisgebied dat door opleiding behoort tot een beroepsgroep". Bij de huidige bevoegdheid en bekwaamheid valt op dat de artsen niet de verwachte $100 \%$ scoren. Betreft dit bij de thuisbehandeling een enkeling, vanuit het ziekenhuis acht men met name de huisarts niet bevoegd. Bij de verpleegkundigen valt juist op dat zij door een deel van de respondenten wel bevoegd geacht worden. Artsen achten verpleegkundigen in een hoger percentage bevoegd dan de verpleegkundigen zelf. Ook scoren verpleegkundigen het ziekenhuis bijna altijd hoger dan die in de wijk. De TMV neemt een tussenpositie in. Of een verpleegkundige met bekwaamheidsverklaring en uitvoeringsverzoek van een arts bevoegd is tot het uitvoeren van alle medisch-technische handelingen 


\begin{tabular}{|c|c|c|c|c|c|c|}
\hline \multicolumn{2}{|l|}{ Huidige situatie } & \multicolumn{3}{|c|}{ Thuis } & \multicolumn{2}{|c|}{ In het ziekenhuis } \\
\hline \multicolumn{2}{|c|}{ Vraag plus antwoordmogelijkheden } & SP & HA & wv & SP & ZHV \\
\hline \multirow{5}{*}{$\begin{array}{l}\text { Inbrengen van de infuusnaald }(E) \text {. } \\
N: 7-14-42 / 34-105\end{array}$} & SP & 100 & 50 & 74 & 85 & 77 \\
\hline & HA & 0 & 71 & 52 & $3^{*}$ & 0 \\
\hline & $\mathrm{ZHV}$ & 0 & 7 & 10 & 38 & 53 \\
\hline & wv & 0 & 7 & 7 & 0 & 0 \\
\hline & TMV & 0 & 21 & 2 & 0 & $1^{*}$ \\
\hline \multirow{5}{*}{$\begin{array}{l}\text { Assisteren bij het inbrengen van } \\
\text { de infuusnaald (E). } \\
\mathrm{N}: 7-13-41 / 33-102\end{array}$} & SP & 14 & 8 & 10 & 3 & 5 \\
\hline & HA & 29 & 31 & 12 & 0 & $1^{*}$ \\
\hline & ZHV & 57 & 31 & 61 & 100 & 100 \\
\hline & wV & 29 & 62 & 51 & $1^{\circ}$ & $1^{*}$ \\
\hline & TMV & 0 & 15 & 12 & 0 & $1^{\circ}$ \\
\hline \multirow{5}{*}{$\begin{array}{l}\text { Eerste toediening medicatie }(\mathrm{F}) \text {. } \\
\mathrm{N}: 7-13-40 / 34-105\end{array}$} & SP & 71 & 46 & 50 & 44 & 37 \\
\hline & HA & 29 & 62 & 68 & 0 & 0 \\
\hline & $\mathrm{ZHV}$ & 29 & 8 & 18 & 76 & 90 \\
\hline & wv & 14 & 0 & 13 & $3^{\circ}$ & 0 \\
\hline & TMV & 0 & 8 & 3 & $3^{\circ}$ & $1^{*}$ \\
\hline \multirow{5}{*}{$\begin{array}{l}\text { Vervolgtoediening medicatic (F). } \\
\text { N:7-13-38/34-105 }\end{array}$} & SP & 14 & 23 & 8 & 12 & 6 \\
\hline & $\mathrm{HA}$ & 57 & 69 & 53 & 0 & 0 \\
\hline & $\mathrm{ZHV}$ & 43 & 8 & 18 & 97 & 98 \\
\hline & wV & 43 & 54 & 66 & $6^{\circ}$ & $2^{*}$ \\
\hline & TMV & 0 & 15 & 5 & $3^{\circ}$ & $2^{*}$ \\
\hline \multirow{5}{*}{$\begin{array}{l}\text { Instellen druppelsnelheid }(G) \text {, } \\
N: 7-14-42 / 34-105\end{array}$} & SP & 57 & 21 & 24 & 21 & 10 \\
\hline & HA & 29 & 71 & 24 & 0 & 0 \\
\hline & $\mathrm{ZHV}$ & 43 & 14 & 29 & 88 & 96 \\
\hline & wV & 0 & 57 & 62 & $6^{\circ}$ & $1^{\circ}$ \\
\hline & TMV & 14 & 14 & 7 & $3^{\circ}$ & $1^{*}$ \\
\hline \multirow{5}{*}{$\begin{array}{l}\text { Controleren van het infuus- } \\
\text { systeem, de inloopsnelheid en de } \\
\text { insteekopening (G). } \\
\mathrm{N}: 7-14-42 / 34-105\end{array}$} & SP & 14 & 14 & 2 & 18 & 1 \\
\hline & $\mathrm{HA}$ & 57 & 86 & 24 & $3^{*}$ & 0 \\
\hline & $\mathrm{ZHV}$ & 43 & 7 & 19 & 97 & 100 \\
\hline & wV & 71 & 71 & 93 & $6^{\circ}$ & $1^{\circ}$ \\
\hline & TMV & 0 & 14 & 7 & $3^{\circ}$ & $2^{\circ}$ \\
\hline \multirow{5}{*}{$\begin{array}{l}\text { Verwisselen infuuszak- en } \\
\text { systeem, zonder verwijdering van } \\
\text { de infuusnaald (G). } \\
\mathrm{N}: 7-13-42 / 34-105\end{array}$} & SP & 14 & 8 & 2 & 0 & 2 \\
\hline & HA & 57 & 62 & 17 & 0 & 0 \\
\hline & ZHV & 43 & 8 & 21 & 100 & 100 \\
\hline & wV & 57 & 85 & 93 & $6^{\circ}$ & $1^{*}$ \\
\hline & TMV & 0 & 15 & 7 & $3^{\circ}$ & $3^{\circ}$ \\
\hline \multirow{5}{*}{$\begin{array}{l}\text { Verwijderen van de infuusnaald } \\
\text { (H). } \\
\mathrm{N}: 7-14-41 / 34-105\end{array}$} & SP & 28 & 7 & 12 & 3 & 2 \\
\hline & HA & 57 & 86 & 49 & 0 & 0 \\
\hline & $\mathrm{ZHV}$ & 43 & 7 & 20 & 100 & 100 \\
\hline & wV & 57 & 64 & 71 & $6^{\circ}$ & $1^{*}$ \\
\hline & TMV & 0 & 14 & 2 & $3^{\circ}$ & $3^{\circ}$ \\
\hline
\end{tabular}

Legenda: $\mathrm{SP}=$-specialist, $\mathrm{HA}=$ huisarts, $\mathrm{ZHV}=$ ziekenhuisverpleegkundige, $\mathrm{WV}=$ wijkverpleegkundige, $\mathrm{TMV}$-transmuraal werkend infuusverpleegkundige, $(\mathrm{X})=\mathrm{cluster,} \mathrm{N}: \mathrm{a}-\mathrm{b}-\mathrm{c} / \mathrm{d}-\mathrm{e}=-\mathrm{respondenten} \mathrm{met} \mathrm{extramurale}$ ervaring/aantal respondenten met alleen intramurale ervaring op het gebied van infuusbehandeling, "=vanwege de lokatie is hier a priori $0 \%$ verwacht omdat deze zorgverleners niet in het ziekenhuis werken. Doordat meerder alternatieven mogelijk zijn, is er geen totaalpercentage. 
Vraag plus antwoordmogelijkheden

Inbrengen van de infuusnaald (E).

N:51-64-111-86-312

Assisteren bij het inbrengen van de infuusnaald (E).

N:51-63-110-85-309

Eerste toediening medicatic (F).

$\mathrm{N}: 51-64-110-86-311$

Vervolgtoediening medicatie (F).

N:51-64-111-86-312

Instellen druppelsnelheid (G).

N:51-64-111-86-312

Controleren van het infuus-

systeem, de inloopsnelheid en de insteekopening $(\mathrm{G})$.

N:51-64-110-86-311

Verwisselen infuuszak- en systeem, zonder verwijdering van de infuusnaald (G).

N:51-64-110-86-311

Verwijderen van de infuusnaald (H).

$\mathrm{N}: 51-64-110-86-311$

\begin{tabular}{l|ccccc} 
Verpl & SP & HA & ZHV & WV & TOT \\
Medisch & 10 & 2 & 6 & 0 & 4 \\
Beide & 33 & 58 & 54 & 88 & 61 \\
Verpl & 57 & 41 & 40 & 12 & 35 \\
\cline { 2 - 6 } Medisch & 80 & 73 & 80 & 77 & 78 \\
Beide & 0 & 0 & 0 & 1 & 0 \\
Verpl & 20 & 27 & 20 & 22 & 22 \\
\cline { 2 - 6 } Medisch & 14 & 3 & 7 & 0 & 6 \\
Beide & 55 & 64 & 50 & 86 & 64 \\
Verpl & 31 & 33 & 43 & 14 & 31 \\
\cline { 2 - 6 } Medisch & 53 & 48 & 45 & 19 & 40 \\
Beide & 2 & 3 & 5 & 14 & 7 \\
Verpl & 45 & 48 & 50 & 67 & 54 \\
\cline { 2 - 6 } Medisch & 57 & 33 & 67 & 34 & 49 \\
Beide & 20 & 20 & 12 & 13 & 15 \\
Verpl & 24 & 47 & 22 & 54 & 36 \\
\cline { 2 - 6 } Medisch & 57 & 61 & 87 & 65 & 71 \\
Beide & 0 & 0 & 0 & 0 & 0 \\
Verpl & 43 & 39 & 13 & 35 & 29 \\
\cline { 2 - 6 } Medisch & 86 & 84 & 88 & 73 & 83 \\
Beide & 0 & 0 & 0 & 2 & 1 \\
Verpl & 14 & 16 & 12 & 24 & 16 \\
\cline { 2 - 6 } Medisch & 78 & 61 & 87 & 52 & 71 \\
Beide & 2 & 3 & 1 & 9 & 4 \\
\hline & 20 & 36 & 12 & 38 & 25 \\
\hline & & & & & \\
\hline
\end{tabular}

Legenda: $\mathrm{SP}=$ specialist, $\mathrm{HA}=$ huisarts, $\mathrm{ZHV=ziekenhuisverpleegkundige,} \mathrm{WV}=$ wijkverpleegkundige, $(\mathrm{X})=$ cluster, $\mathrm{N}: \mathrm{a}-\mathrm{b}-\mathrm{c}-\mathrm{d}-\mathrm{e}=\mathrm{aantal}$ respondenten per kolom, Verpl=verpleegkundig. Door afronden is het totaalpercentage soms geen $100 \%$.

blijkt onduidelijk. Dat dit niet zo is, is bij lang niet iedereen bekend. Alle respondenten vinden in de gewenste situatie IT meer tot het kennis- en vaardigheidsgebied van de huisarts en de wijkverpleegkundige behoren dan tot dat van de specialist en de ziekenhuisverpleegkundige. Hierbij zou de huisarts zowel de kennis als de vaardigheid moeten hebben en de wijkverpleegkundige in ieder geval de vaardigheid. Ziekenhuisverpleegkundigen gaan minder van het primaat van de huisarts uit en rekenen het vaardigheidsgebied zelfs meer tot dat van de wijkverpleegkundigen. Vooruitlopend op de BIG, is ook gevraagd of verpleegkundigen bevoegdheid tot het uitvoeren van medisch-technische handelingen moeten krijgen. Bij huisartsen, specialisten en ziekenhuisverpleegkundigen lijken de cijfers voor bevoegdheid te corresponderen met de vaardigheid, terwijl de deskundigheid consequent lager scoort. Bij wijkverpleegkundigen lijkt de bevoegdheid te corresponderen met de deskundigheid. In de BIG lijken deskundigheid en vaardigheid minimale voorwaarden om voorbehouden handelingen functioneel zelfstandig -al dan niet 'uitvoeringsbevoegd'- te mogen uitvoeren (art.39). ${ }^{232,238}$ 
Huidige situatie bij infuusbehandeling

Vraag plus antwoordmogelijkheden

Huidige bevoegdheid/wettelijke SP

erkenning tot verrichten alle N:7-14-42/34-105

Huidige bevoegdheid/wettelijke
erkenning verpleegkundige met
bekwaamheidverklaring en
uitvoeringsverzoek arts.
$\mathrm{N}: 7-14-42 / 34-103$
medisch-technische handelingen.

Thuis

In het ziekenhuis

SP
HA
ZHV
WV
TMV
Ja
Nee

Gewenste situatie bij infuusbehandeling thuis

\begin{tabular}{|c|}
\hline SP \\
\hline 100 \\
\hline 100 \\
\hline 43 \\
\hline 29 \\
\hline 14 \\
\hline 71 \\
\hline 29 \\
\hline 0 \\
\hline
\end{tabular}

(1)

SP ZHV

\begin{tabular}{ll|ll}
93 & 98 & 100 & 97
\end{tabular}

$93 \quad 98$

$21 \quad 12$

74

\begin{tabular}{l|l}
12 & 29
\end{tabular}

\begin{tabular}{ll|l}
36 & 10 & 15
\end{tabular}

95

$36 \quad 21$

41

33

57

$\begin{array}{l:l}71 & 47\end{array}$

$47 \quad 56$

12

Alle medisch-technische
handelingen bij
infuusbehandeling thuis behoren
tot het deskundigheidsgebied.
$\mathrm{N}: 49-64-111-85-309$
Alle medisch-technische
handelingen bij
infuusbehandeling thuis behoren
tot het vaardigheidsgebied.
$\mathrm{N}: 50-63-110-86-309$
Bevoegdheid/wettelijke
erkenning tot verrichten van alle
medisch-technische handelingen
door verpleegkundigen.
$\mathrm{N}: 50-63-110-84-307$

\section{Vraag plus antwoordmogelijkheden}

Alle medisch-technische

handelingen bij

infuusbehandeling thuis behoren

tot het deskundigheidsgebied.

N:49-64-111-85-309

Alle medisch-technische

handelingen bij

infuusbehandeling thuis behoren tot het vaardigheidsgebied.

N:50-63-110-86-309

SP

HA

ZHV

WV

TMV

SP

HA

ZHV

WV

TMV

Ja

HA

ZHV

WV

TOT

$\begin{array}{lllll}78 & 56 & 51 & 53 & 57\end{array}$

80

83

67

88

49

$56-52$

41

$49 \quad 56$

$42 \quad 24$

36

$62 \quad 46 \quad 22$

86

$84 \quad 63$

30

77

$\begin{array}{lll}84 & 63 & 85\end{array}$

24

$\begin{array}{lllll}38 & 29 & 25 & 13 & 24 \\ 62 & 65 & 75 & 55 & 65\end{array}$

a

Nee

$54 \quad 73 \quad 55$

53

64

70

70

34

59

36

30

31

67

41

Legenda: SP=specialist, $\mathrm{HA}=$ huisarts, ZHV=ziekenhuisverpleegkundige, WV=wijkverpleegkundige, $\mathrm{TMV}=$ transmuraal werkend infuusverpleegkundige, $\mathrm{N}: \mathrm{a}-\mathrm{b}-\mathrm{c} / \mathrm{d}-\mathrm{e}=\mathrm{respondenten} \mathrm{met} \mathrm{extramurale} \mathrm{ervaring/aantal}$ respondenten met alleen intramurale ervaring op het gebied van infuusbehandeling, $\mathrm{N}: \mathrm{a}-\mathrm{b}-\mathrm{c}-\mathrm{d}-\mathrm{e}=\mathrm{aantal}$ respondenten per kolom, ? =weet niet of geen mening. Door afronden of doordat meerdere alternatieven mogelijk zijn, is het totaalpercentage soms geen $100 \%$.

\subsubsection{Continuĭteit van zorgverlening}

Tabel 5.6 geeft de huidige en gewenste taakverdeling en continuiteit van zorgverlening weer. De huidige taakverdeling bij IT blijkt in tegenstelling tot het ziekenhuis meestal niet (geheel) duidelijk, terwijl de mate waarin deze schriftelijk is vastgelegd weinig verschilt. Een meerderheid wenst dan ook de verantwoordelijkheden en taken vast te leggen in strikte richtlijnen. Ook een 24-uurs bereikbaarheid bij problemen acht men noodzakelijk. Tabel 5.7 beschrijft de huidige en gewenste overdracht. Overdracht is omschreven als: "het geven van informatie aan een ander over patiëntenzorg (eenzijdig)". In de huidige situatie draagt men in meer dan de helft van de gevallen niet elke keer nadat er directe patiëntenzorg is geweest over. Deze overdracht komt zowel op eigen initiatief als volgens richtlijnen tot stand. Het accent ligt hierbij buiten het ziekenhuis wat meer op het eigen initiatief en binnen het ziekenhuis wat meer op richtlijnen. De overdracht geschiedt zowel 
Huidige situatie bij infuusbehandeling

\begin{tabular}{l|ccc|cc} 
& \multicolumn{3}{c}{ Thuis } & \multicolumn{3}{c}{ In het ziekenhuis } \\
n & SP & HA & WV & SP & ZHV \\
Ja & 43 & 50 & 20 & 97 & 40 \\
Deels & 29 & 36 & 46 & 0 & 41 \\
Nec & 29 & 14 & 34 & 3 & 20 \\
\cline { 2 - 7 } Ja & 14 & 15 & 21 & 24 & 18 \\
Deels & 14 & 31 & 43 & 38 & 38 \\
Nee & 71 & 54 & 36 & 38 & 45
\end{tabular}

Vraag plus antwoordmogelijkheden

Huidige taakverdeling tussen de $\mathrm{Ja}$ beroepsbeoefenaars is duidelijk. $\mathrm{N}: 7-14-41 / 30-101$

Huidige taakverdeling tussen de beroepsbeoefenaars is schriftelijk vastgelegd.

$\mathrm{N}: 7-13-42 / 29-96$

Nee

Gewenste sinuatie bij infuusbehandeling thuis

Vraag plus antwoordmogelijkheden

Het is een voorwaarde strikte richtlijnen vast te stellen over taken en verantwoordelijkheden. N:49-64-111-87-311

Meest geschikte beroepsbeoefenaar voor zorginhoudelijke ondersteuning.

N:41-57-89-78-265

Taken

Beide

Verant

SP

HA

24-uurs bereikbaarheid bij problemen is een noodzakelijke voorwaarde.

$\mathrm{N}: 50-63-111-87-311$

Meest geschikte beroepsbeoefenaar voor 24-uurs beschikbaarheid.

N:41-50-92-78-261

\begin{tabular}{l|ccccc} 
& SP & HA & ZHV & WV & TOT \\
Taken & 4 & 0 & 1 & 0 & 1 \\
Beide & 94 & 95 & 89 & 93 & 92 \\
Verant. & 2 & 5 & 10 & 7 & 7 \\
\cline { 2 - 6 } SP & 17 & 4 & 3 & 6 & 10 \\
HA & 37 & 19 & 26 & 21 & 25 \\
ZHV & 2 & 0 & 8 & 9 & 6 \\
WV & 20 & 18 & 22 & 23 & 21 \\
TMV & 24 & 60 & 40 & 41 & 39 \\
\cline { 2 - 6 }++ & 72 & 71 & 87 & 79 & 79 \\
+ & 24 & 25 & 14 & 21 & 20 \\
+ +- & 0 & 3 & 0 & 0 & 1 \\
- & 4 & 0 & 0 & 0 & 1 \\
- & 0 & 0 & 0 & 0 & 0 \\
\hline SP & 2 & 0 & 2 & 1 & 2 \\
HA & 39 & 58 & 35 & 73 & 51 \\
ZHV & 0 & 0 & 0 & 0 & 0 \\
WV & 39 & 18 & 37 & 23 & 30 \\
TMV & 20 & 24 & 26 & 3 & 18 \\
\hline
\end{tabular}

Legenda: $\mathrm{SP}=$-specialist, $\mathrm{HA}=$ huisarts, $\mathrm{ZHV}=$ ziekenhuisverpleegkundige, $\mathrm{WV}=$ wijkverpleegkundige,

$\mathrm{TMV}=$ transmuraal werkend infuusverpleegkundige, $\mathrm{N}: \mathrm{a}-\mathrm{b}-\mathrm{c} / \mathrm{d}-\mathrm{e}=$-respondenten met extramurale ervaring/aantal respondenten met alleen intramurale ervaring op het gebied van infuusbehandeling, $\mathrm{N}: \mathrm{a}-\mathrm{b}-\mathrm{c}-\mathrm{d}-\mathrm{e}=\mathrm{aantal}$ respondenten per kolom, Verant =verantwoordelijkheden, $++=$ zeer mee eens, $+=$ mee eens, $+/=$ =noch mee eens noch mee oneens, - =mee oneens, - =zeer mee oneens. Door afronden of doordat meerdere alternatieven mogelijk zijn, is het totaalpercentage soms geen $100 \%$.

mondeling als schriftelijk. In het algemeen is men tevreden met de overdracht van andere beroepsbeoefenaars of voldoet deze. Artsen zijn tevredener dan verpleegkundigen. In de toekomst vindt men het niet nodig om na elke directe patiëntenzorg over te dragen. De overdracht kan zowel op eigen initiatief als volgens richtlijnen tot stand komen. Het accent verschuift hierbij zowel binnen als buiten het ziekenhuis van eigen initiatief naar richtlijnen. De gewenste overdracht geschiedt zowel mondeling als schriftelijk. Voornamelijk schriftelijk door de huisarts, de wijk- en de ziekenhuisverpleegkundige en voornamelijk mondeling door de specialist.

Tabel 5.8 geeft het huidige en gewenste overleg weer. Overleg is omschreven als: "het 
uitwisselen van informatie met een ander over patiëntenzorg (tweezijdig)". In de huidige situatie voldoet de overlegfrequentie meestal. Soms vinden met name verpleegkundigen deze te laag. Bij infuusbehandeling buiten het ziekenhuis overlegt men voornamelijk op eigen initiatief of via initiatief en richtlijnen. Binnen het ziekenhuis overlegt men zowel op eigen initiatief als volgens richtlijnen of voornamelijk volgens richtlijnen. De verdeling bij

Tabel 5.7 Huidige en gewenste overdrachtsituatic in percenten.

\begin{tabular}{|c|c|c|c|c|c|c|}
\hline \multirow{2}{*}{\multicolumn{2}{|c|}{$\begin{array}{l}\text { Huidige situatie bij infuusbehandeling } \\
\text { Vraag plus antwoordmogelijkheden }\end{array}$}} & \multicolumn{3}{|c|}{ Thuis } & \multicolumn{2}{|c|}{ In het ziekenhuis } \\
\hline & & SP & HA & WV & SP & ZHV \\
\hline \multirow{2}{*}{$\begin{array}{l}\text { Overdracht na elke keer dat } \\
\text { directe patientenzorg is vericend. } \\
N: 7-14-41 / 31-90\end{array}$} & Ja & 29 & 43 & 44 & 42 & 28 \\
\hline & Nee & 71 & 57 & 56 & 58 & 72 \\
\hline \multirow{5}{*}{$\begin{array}{l}\text { Manier waarop overdracht tot } \\
\text { stand komt (initiatief/richtlijn) } \\
N: 7-13-41 / 31-88\end{array}$} & All. ini & 14 & 15 & 12 & 3 & 10 \\
\hline & $V m$ ini & 29 & 31 & 39 & 3 & 25 \\
\hline & Beide & 29 & 46 & 24 & 77 & 49 \\
\hline & Vrn. ric & 29 & 8 & 22 & 13 & 10 \\
\hline & All. ric & 0 & 0 & 2 & 3 & 6 \\
\hline \multirow{5}{*}{$\begin{array}{l}\text { Vorm van de overdracht. } \\
N: 7-14-41 / 31-89\end{array}$} & All. sch & 0 & 0 & 0 & 3 & 1 \\
\hline & Vm. sch & 29 & 14 & 24 & 3 & 12 \\
\hline & Beide & 0 & 64 & 54 & 71 & 55 \\
\hline & Vm. mo & 57 & 21 & 22 & 13 & 25 \\
\hline & All. mo & 14 & 0 & 0 & 10 & 7 \\
\hline \multirow{5}{*}{$\begin{array}{l}\text { Oordeel over overdracht met } \\
\text { andere beroepsbeoefenaars. } \\
N: 7-14-40 / 31-89\end{array}$} & $\mathrm{Z}$ goed & 0 & 0 & 0 & 7 & 0 \\
\hline & Goed & 57 & 36 & 15 & 74 & 30 \\
\hline & Voldoet & 29 & 57 & 68 & 16 & 62 \\
\hline & Slecht & 14 & 7 & 18 & 3 & 9 \\
\hline & Z slecht & 0 & 0 & 0 & 0 & 0 \\
\hline \multicolumn{7}{|c|}{ Gewenste situatie bij infuusbehandeling thuis } \\
\hline \multicolumn{2}{|c|}{ Vraag plus antwoordmogelijkheden } & SP & HA & ZHV & WV & TOT \\
\hline \multirow{2}{*}{$\begin{array}{l}\text { Overdracht is gewenst elke keer } \\
\text { nadat patientenzorg verleend is. } \\
\mathrm{N}: 48-64-99-79-290\end{array}$} & Ja & 31 & 31 & 31 & 41 & 34 \\
\hline & Nee & 69 & 69 & 69 & 60 & 66 \\
\hline \multirow{5}{*}{$\begin{array}{l}\text { Gewenste manier waarop } \\
\text { overdracht tot stand komt } \\
\text { (initiaticf/richtlijn). } \\
\mathrm{N}: 47-64-99-79-289\end{array}$} & All. ini & 0 & 8 & 1 & 0 & 2 \\
\hline & Vm. ini & 6 & 9 & 4 & 4 & 6 \\
\hline & Beide & 70 & 61 & 82 & 80 & 75 \\
\hline & Vm. ric & 17 & 16 & 10 & 13 & 13 \\
\hline & All. ric & 6 & 6 & 3 & 4 & 5 \\
\hline \multirow{5}{*}{$\begin{array}{l}\text { Gewenste vorm van de } \\
\text { overdracht. } \\
\text { N:47-64-99-79-289 }\end{array}$} & All. sch & 9 & 6 & 2 & 3 & 4 \\
\hline & Vm. sch & 9 & 39 & 21 & 35 & 27 \\
\hline & Beide & 66 & 44 & 73 & 60 & 62 \\
\hline & Vm. mo & 15 & 11 & 4 & 3 & 7 \\
\hline & All. mo & 2 & 0 & 0 & 0 & 0 \\
\hline
\end{tabular}

Legenda: SP=specialist, $\mathrm{HA}=$ huisarts, $\mathrm{ZHV}=$ zickenhuisverpleegkundige, $\mathrm{WV}=$ wijkverpleegkundige, $\mathrm{N}: \mathrm{a}-\mathrm{b}-\mathrm{c} / \mathrm{d}-\mathrm{e}-\mathrm{aantal}$ respondenten met extramurale ervaring/aantal respondenten met alleen intramurale ervaring op het gebied van infuusbehandeling, $\mathrm{N}: \mathrm{a}-\mathrm{b}-\mathrm{c}-\mathrm{d}-\mathrm{e}=\mathrm{aantal}$ respondenten per kolom, all.=alleen, vm.=voomamelijk ini-initiatief, ric-richtlijn, sch=schriftelijk, mommondeling, z=zeer. Door afronden of doordat meerdere alternatieven mogelijk zijn, is het totaalpercentage soms geen $100 \%$. 
overleg en overdracht is hetzelfde. Het overleg geschiedt zowel mondeling als schriftelijk of voornamelijk mondeling. Evenals bij de overdracht is men in het algemeen tevreden over het overleg of vindt dit voldoende. Verpleegkundigen zijn ook hierbij minder tevreden dan artsen. In de toekomst wil men dat het overleg zowel op eigen initiatief als volgens richtlijnen tot stand komt. Het accent verschuift ook hierbij zowel binnen als buiten het ziekenhuis van initiatief naar richtlijnen. Het gewenste overleg geschiedt zowel mondeling als schriftelijk of voornamelijk mondeling.

Tabel 5.8 Huidige en gewenste overlegsituatie in percenten.

\section{Huidige situatie bij infiusbehandeling}

Vraag plus antwoordmogelijkheden

Oordecl over overlegfrequentic met andere beroepsbeoefenaars.

N: $7-14-42 / 33-102$

Manier waarop overleg tot stand komt (initiatief/richtlijn).

$\mathrm{N}: 7 \cdot 14-40 / 31-90$

Vorm van het overleg.

N:7-14-41/31-92

Oordeel over overleg met andere beroepsbeoefenaars.

N:7-13-41/31-91

\section{.}

Te laag

Voldoet

Te hoog

All. ini

Vm. ini

Beide

Vm. ric

All. ric

All sch

Vm. sch

Beide

Vm. mo

All. mo

$\mathrm{Z}$ goed

Goed

Voldoet

Slecht

Z slecht

Gewenste situatie bij infunsbehandeling thuis

Vraag plus antwoordmogelijkheden

Gewenste manier waarop overieg tot stand komt

(initiatief/richtlijn).

N:48-64-97-79-288

Gewenste vorm van het overleg.

N:48-64-97-79-288

\begin{tabular}{l|ccccc} 
All. ini & SP & HA & ZHV & WV & TOT \\
Vm. ini & 4 & 9 & 1 & 0 & 3 \\
Beide & 10 & 17 & 3 & 4 & 8 \\
Vm. ric & 71 & 56 & 81 & 89 & 76 \\
All. ric & 13 & 16 & 10 & 6 & 11 \\
All. sch & 2 & 2 & 4 & 1 & 2 \\
\cline { 2 - 6 } Vm. sch & 0 & 0 & 1 & 0 & 0 \\
Beide & 6 & 5 & 6 & 8 & 6 \\
Vm. mo & 25 & 56 & 78 & 75 & 70 \\
All. mo & 8 & 3 & 13 & 15 & 21 \\
\end{tabular}

Legenda: $\mathrm{SP}=$ specialist, $\mathrm{HA}=$ huisarts, $\mathrm{ZHV=ziekenhuisverpleegkundige,} \mathrm{WV=wijkverpleegkundige,}$

$\mathrm{N}: \mathrm{a}-\mathrm{b}-\mathrm{c} / \mathrm{d}-\mathrm{e}=\mathrm{aantal}$ respondenten met extramurale ervaring/aantal respondenten met alleen intramurale ervaring op het gebied van infuusbehandeling, $\mathrm{N}: \mathrm{a}-\mathrm{b}-\mathrm{c}-\mathrm{d}-\mathrm{e}=\mathrm{aantal}$ respondenten per kolom, all. $=$ alleen, $\mathrm{vm}=$ =voomamelijk ini=initiatief, ric=richtlijn, sch=schriftelijk, mo=mondeling, $z=z e e r$. Door afronden of doordat meerdere alternatieven mogelijk zijn, is het totaalpercentage soms geen $100 \%$. 


\subsubsection{Enkele personele en materiële randvoorwaarden}

Tabel 5.9 geeft enkele huidige en gewenste personele randvoorwaarden voor infuusbehandeling weer. De verschillende beroepsbeoefenaars vinden de huidige werkdruk (zeer) hoog of gemiddeld, maar zien toch toekomst voor IT. Of hiervoor personeelsuitbreiding binnen de eigen beroepsgroep noodzakelijk is, daarover zijn de meningen bij de artsen verdeeld. De meeste verpleegkundigen vinden uitbreiding gewenst. Scholing en training vinden alle respondenten noodzakelijke voorwaarden voor IT. De persoonlijke behoefte varieert: de meeste specialisten hebben hieraan geen behoefte, van de ziekenhuisverpleegkundigen heeft ongeveer de helft en van de huisartsen en wijkverpleegkundigen heeft het merendeel behoefte aan scholing en training.

Tabel 5.10 geeft tot slot enkele huidige en gewenste materiële randvoorwaarden voor infuusbehandeling weer. De materiaalvoorziening in de thuissituatie geschiedt door

Tabel 5.9 Huidige en gewenste personele voorzieningen in percenten.

\begin{tabular}{|c|c|c|c|c|c|c|}
\hline \multirow{2}{*}{\multicolumn{2}{|c|}{$\begin{array}{l}\text { Huidige situatie bij infuusbehandeling } \\
\text { Vraag plus antwoordmogelijkheden }\end{array}$}} & \multicolumn{3}{|c|}{ Thuis } & \multicolumn{2}{|c|}{ In het ziekenhuis } \\
\hline & & SP & HA & wv & SP & ZHV \\
\hline \multirow{5}{*}{$\begin{array}{l}\text { Ervaring van huidige werkdruk. } \\
\text { N:7-14-41/33-104 }\end{array}$} & Z Hoog & 29 & 14 & 5 & 12 & 6 \\
\hline & Hoog & 57 & 36 & 49 & 49 & 51 \\
\hline & Gemidd. & 14 & 50 & 39 & 39 & 40 \\
\hline & Laag & 0 & 0 & 5 & 0 & 3 \\
\hline & Z Laag & 0 & 0 & 2 & 0 & 0 \\
\hline \multicolumn{7}{|c|}{ Gewenste situatie bij infuusbehandeling thuis } \\
\hline \multicolumn{2}{|c|}{ Vraag plus antwoordmogelijkheden } & SP & HA & ZHV & WV & TOT \\
\hline \multirow{5}{*}{$\begin{array}{l}\text { Gezien huidige werkdruk heeft } \\
\text { infuusbehandeling thuis geen } \\
\text { toekomst. } \\
\text { N:49-63-107-85-304 }\end{array}$} & + & 4 & 5 & 2 & 5 & 4 \\
\hline & + & 6 & 11 & 9 & 7 & 9 \\
\hline & +1 & 29 & 38 & 22 & 18 & 25 \\
\hline & $\cdot$ & 45 & 38 & 42 & 49 & 44 \\
\hline & - & 16 & 8 & 24 & 21 & 19 \\
\hline \multirow{5}{*}{$\begin{array}{l}\text { Uitbreiding personeel binnen } \\
\text { eigen beroepsgroep is } \\
\text { noodzakelijke voorwaarde voor } \\
\text { infuusbehandeling thuis. } \\
\mathrm{N}: 49-63-104-86-302\end{array}$} & + & 6 & 11 & 21 & 14 & 15 \\
\hline & + & 27 & 25 & 39 & 41 & 34 \\
\hline & +1 & 29 & 29 & 16 & 27 & 24 \\
\hline & - & 22 & 32 & 17 & 14 & 20 \\
\hline & - & 16 & 3 & 7 & 5 & 7 \\
\hline \multirow{5}{*}{$\begin{array}{l}\text { Scholing en training zijn } \\
\text { noodzakelijke voorwaarden voor } \\
\text { infuusbehandeling thuis. } \\
\mathrm{N}: 50-64-110-87-311\end{array}$} & + & 70 & 48 & 76 & 69 & 68 \\
\hline & + & 30 & 39 & 21 & 29 & 28 \\
\hline & +1. & 0 & 5 & 2 & 0 & 2 \\
\hline & - & 0 & 8 & 1 & 2 & 3 \\
\hline & - & 0 & 0 & 0 & 0 & 0 \\
\hline \multirow{2}{*}{$\begin{array}{l}\text { Persoonlijke behoefte aan } \\
\text { scholing en training. } \\
\text { N:46-64-107-87-304 }\end{array}$} & Ja & 20 & 75 & 55 & 81 & 61 \\
\hline & Nee & 80 & 25 & 45 & 20 & 39 \\
\hline
\end{tabular}

Legenda: SP-specialist, HA=huisarts, ZHV=ziekenhuisverpleegkundige, WV=wijkverpleegkundige, $\mathrm{N}: \mathrm{a}-\mathrm{b}$-c/d-e-aantal respondenten met extramurale ervaring/aantal respondenten met alleen intramurale ervaring op het gebied van infuusbehandeling, $\mathrm{N}: \mathrm{a}-\mathrm{b}-\mathrm{c}-\mathrm{d}-\mathrm{e}=\mathrm{eantal}$ respondenten per kolom, $\mathrm{z}=\mathrm{zeer}$, gemidd $=$ gemiddeld, ++ -zeer mee eens, + -mee eens, $+1-$-noch mee eens noch mee oneens, - =mee oneens, - - zeer mee oneens. Door afronden of doordat meerdere alternatieven mogelijk zijn, is het totaalpercentage soms geen $100 \%$. 
verschillende organisaties en levert in de thuissituatie nogal eens problemen op. Eenieder pleit ervoor de materiaalvoorziening in de toekomst vooral door de openbare apotheker in samenspraak met de kruisvereniging te laten geschieden.

Tabel 5.10 Huidige en gewenste materiele voorzieningen in percenten

\begin{tabular}{|c|c|c|c|c|c|c|}
\hline \multirow{2}{*}{\multicolumn{2}{|c|}{$\begin{array}{l}\text { Huidige situatie bij infiasbehandeling } \\
\text { Vraag plus antwoordmogelijkheden }\end{array}$}} & \multicolumn{3}{|c|}{ Thuis } & \multicolumn{2}{|c|}{ In het ziekenhuis } \\
\hline & & SP & HA & $\mathbf{W V}$ & SP & ZHV \\
\hline \multirow{4}{*}{$\begin{array}{l}\text { Leverancier van materialen voor } \\
\text { infuusbehandeling. } \\
N: 7-14-42 / 33-101\end{array}$} & Zks apo & 100 & 43 & 24 & 97 & 92 \\
\hline & Op. apo & 43 & 100 & 86 & 3 & 6 \\
\hline & Kruisv. & 0 & 14 & 19 & 0 & 0 \\
\hline & Fac. bed & 43 & 14 & 14 & 0 & 19 \\
\hline \multirow{5}{*}{$\begin{array}{l}\text { Levert de materiaalvoorziening } \\
\text { problemen op. } \\
\text { N:7-14-41/33-101 }\end{array}$} & Altijd & 0 & 7 & 0 & 0 & 0 \\
\hline & Meestal & 0 & 14 & 12 & 0 & 0 \\
\hline & Soms & 43 & 21 & 71 & 9 & 19 \\
\hline & Zelden & 29 & 50 & 15 & 36 & 45 \\
\hline & Nooit & 29 & 7 & 2 & 55 & 37 \\
\hline \multicolumn{7}{|c|}{ Gewenste situatie bij infuusbehandeling thuis } \\
\hline \multicolumn{2}{|c|}{ Vraag plus antwoordmogelijkheden } & SP & HA & ZHV & wV & TOT \\
\hline \multirow{4}{*}{$\begin{array}{l}\text { Voorkeursleverancier bij } \\
\text { infuusbehandeling thuis. } \\
\text { N:47-60-109-85-301 }\end{array}$} & Zhs. apo & 30 & 28 & 6 & 11 & 15 \\
\hline & Op. apo & 72 & 63 & 72 & 81 & 73 \\
\hline & Kruisv. & 23 & 23 & 37 & 16 & 26 \\
\hline & Fac. bed & 11 & 17 & 13 & 14 & 14 \\
\hline
\end{tabular}

Legenda: $\mathrm{SP}=$ specialist, $\mathrm{HA}=$ huisarts, $\mathrm{ZHV}=$ ziekenhuisverpleegkundige, $\mathrm{WV}=$ wijkverpleegkundige, $\mathrm{N}: \mathrm{a}-\mathrm{b}-\mathrm{c} / \mathrm{d}-\mathrm{e}=\mathrm{aantal}$ respondenten met extramurale ervaring/aantal respondenten met alleen intramurale ervaring op het gebied van infuusbehandeling, $\mathrm{N}: \mathrm{a}-\mathrm{b}-\mathrm{c}-\mathrm{d}-\mathrm{e}=\mathrm{aantal}$ respondenten per kolom, zks=ziekenhuis, apo=apotheek, op=openbare, kruisv.=kruisvereniging, fac. bed=facilitair bedrijf. Door afronden of doordat meerdere alternatieven mogelijk zijn, is het totaalpercentage soms geen $100 \%$.

\subsubsection{RELATIE MET REGELGEVING}

Schema 5.2 vat samen hoe de interpretatie van wetten en hun maatschappelijke vertaling zich verhouden tot de huidige en gewenste praktijk volgens de geënquêteerden. Per kolom is aangegeven of een handeling tot de medische, de verpleegkundige of beider taak te rekenen is of was. Kolom één zet de handelingen af tegen de WUG. Kolom twee geeft de maatschappelijke vertaling anno 1991 via het standpunt van de Geneeskundige Hoofdinspectie. Dit standpunt is onder meer gebaseerd op de 'verlengde-armconstructie' en dient voor toepassing gecombineerd te worden met het Verpleegkundig Beroepsprofiel van de Nationale Raad voor de Volksgezondheid. ${ }^{216,230}$ Kolommen drie en vier geven de huidige praktijk van de geënquêteerden weer. Het gaat hierbij niet zozeer om het absolute afkappunt (50\%), maar veeleer over de verdeling tussen de disciplines (het totaal kon meer dan $100 \%$ zijn). Kolom vijf zet de handelingen af tegen de BIG. Omdat de BIG zich niet duidelijk uitspreekt over het informeren van de patiënt, wordt daarvoor verwezen naar de Wet op de Geneeskundige Behandelingsovereenkomst. ${ }^{239,}{ }^{240}$ Kolom zes biedt een eerste maatschappelijke vertaling anno 1995 via het "Advies Voorbehouden Handelingen" van de Raad BIG (en dient wederom gecombineerd te worden met het Verpleegkundig Beroepsprofiel). ${ }^{232}$ De Raad BIG adviseert als kamer van de Nationale Raad voor de Volksgezondheid zelfstandig aan de minister van VWS. ${ }^{241}$ Wel wordt gestreefd naar 


\section{Activiteit}

Signaleren of infuusbehandeling nodig is (A).

Beslissen dat infuusbehandeling nodig is (A).

Bepalen medicatie plus aard, volume en inloopsnelheid van de infuusvloeistof (A).

Patient informeren over de behandelmogelijkheden (B).

Patient instrueren over de infuusbehandeling (B).

Bewaken van het effect van de infuusbehandeling $(C)$.

Beoordelen van het effect van de infuusbehandeling (C).

De coordinatie van de directe patientenzorg (D).

Inbrengen van de infuusnaald (E)

Assisteren bij het inbrengen van de infuusnaald (E).

Eerste toediening medicatie (F).

Vervolgtoediening medicatie (F).

Instellen druppelsnelheid $(G)$.

Controleren infusie en

insteekopening $(\mathrm{G})$.

Verwisselen infuuszak - en systeem

(G).

\section{Huidige praktijk (anno 1993)}

Gewenste praktijk

\begin{tabular}{|c|c|c|c|c|c|c|c|}
\hline WUG & Vert1 & arts & vp & BIG+ & Vert2 & arts & vp \\
\hline$M$ & M & $\mathrm{M}^{*}$ & $\mathrm{~B}^{\circ}$ & M & M & $\mathrm{B}^{\circ}$ & $B^{\circ}$ \\
\hline M & $M$ & $\mathrm{M}^{*}$ & $M^{*}$ & M & M & $M^{\prime}$ & B $^{*}$ \\
\hline$M$ & M & $\mathrm{M}^{*}$ & $\mathrm{M}^{*}$ & M & M & $M^{*}$ & $M^{*}$ \\
\hline$?$ & B & $M^{*}$ & $\mathrm{~B}^{\circ}$ & $? / \mathrm{M}$ & B & $\mathrm{B}^{\circ}$ & $\mathrm{B}^{*}$ \\
\hline$?$ & B & $\mathrm{B}^{\circ}$ & $\mathrm{B}^{\circ}$ & $?$ & B & $\mathrm{B}^{*}$ & $\mathrm{~B}^{*}$ \\
\hline M & M & $\mathrm{B}^{\circ}$ & $\mathrm{B}^{\circ}$ & B & B & $\mathrm{B}^{\circ}$ & $\mathrm{B}^{\circ}$ \\
\hline$M$ & $\mathrm{M}$ & $\mathrm{M}^{*}$ & $\mathrm{M}^{\circ}$ & M & M & nvt & nvt \\
\hline$?$ & B & $\mathrm{M}^{*}$ & $v^{*}$ & B & B & $\mathrm{B}^{\circ}$ & $\mathrm{B}^{*}$ \\
\hline M & M & $M^{*}$ & $\mathrm{~B}^{\circ}$ & M & B & $\mathrm{M}^{*}$ & $M^{*}$ \\
\hline$?$ & B & $v^{*}$ & $v^{*}$ & B & B & $v^{\prime}$ & $v^{\prime}$ \\
\hline M & B & B & $\mathrm{B}^{*}$ & B & M & $\mathrm{M}^{*}$ & $M^{*}$ \\
\hline M & B & $v^{0}$ & $v^{\circ}$ & B & B & $v^{*}$ & $\mathrm{~B}^{*}$ \\
\hline$?$ & B & $\mathrm{B}^{\circ}$ & $v^{*}$ & B & B & $\mathrm{B}^{\circ}$ & $\mathrm{B}^{\circ}$ \\
\hline$?$ & B & $\mathrm{B}^{\circ}$ & $v^{\circ}$ & B & B & $v^{*}$ & $v^{\prime}$ \\
\hline$?$ & B & $\mathrm{B}^{\circ}$ & $\mathrm{v}^{\circ}$ & B & B & $v^{*}$ & $v^{*}$ \\
\hline M & $\mathrm{M}$ & $\mathrm{B}^{\circ}$ & $\mathrm{B}^{\circ}$ & B & B & $\mathrm{V}^{*}$ & $\mathrm{~V}^{*}$ \\
\hline
\end{tabular}

Verwijderen van de infuusnaald $(H)$.

Legenda: WUG=Wet Uitoefening Geneeskunst, Vertl=brief Geneeskundige Hoofdinspectie+Verpleegkundig Beroepsprofiel, BIG+-regeling inzake Beroepen in de Individuele Gezondheidszorg plus Wet Geneeskundige Behandelovereenkomst, Vert2=advies BIG raad over voorbehouden handelingen+Verpleegkundig Beroepsprofiel, vp=-verpleegkundige. $(X)$-cluster algemene:A-D en specifieke: $E-H, M=$ medisch, $B=b e i d e$, $\mathrm{V}$-verpleegkundig. ?=geen oordeel mogelijk, nvt-niet van toepassing,"=duidelijk boven $50 \%$ voor de ene disciplines en duidelijk onder de $50 \%$ voor de andere of beide indien gespreid, ${ }^{-}=$vanwege verdeeldheid respondenten (vaak thuis- versus ziekenhuiszorg) definitieve keuze door onderzoeker op grond van alle gegevens, " =gemiddeld 50 tot $70 \%$ vindt dit, "=gemiddeld $70 \%$ of meer vindt dit. Cursief-voorbehouden handelingen.

eenheid van opvattingen met de Nationale Raad voor de Volksgezondheid. Kolom zeven en acht eindigen met de door de geěnquêteerden gewenste situatie. Hierbij zijn afkappunten bij een gemiddelde overeenstemming van $50 \%$ en $70 \%$ gehanteerd.

\subsection{Beschourwing}

\subsubsection{METHODE}

De in de inleiding genoemde vraagstellingen zijn op diverse wijzen te onderzoeken. ${ }^{13}$ In de jarenlange discussie die de totstandkoming van de BIG begeleid heeft, zijn reeds vele 'deskundigen' aan het woord gekomen. Hier ligt de nadruk op de mening van de werkers 
in het veld. Om steekproeven voor dit type wetenschappelijk onderzoek in de toekomst te vergemakkelijken, is het wenselijk dat de registers voor beroepsgroepen waarin de BIG voorziet, daarvoor op enigerlei wijze toegankelijk worden.

\subsubsection{RESPONS}

Een lage respons kan tot selectie en vertekening leiden. De respons is, conform de inschatting vooraf, laag. Dit kan liggen aan een zekere kritische houding en waardering ten opzichte van medische technologie in vergelijking met alledaagse zorg onder artsen en verpleegkundigen, maar ook aan het geringe aantal respondenten met ervaring met IT, en aan de omvang van de enquête en het ontbreken van een beloning. ${ }^{242}$ Met name artsen geven 'enquêtemoeheid' aan. De respons onder huisartsen (32\%) is vergelijkbaar met de respons van bijvoorbeeld de Medisch Contact enquête naar "Huisartsen en medische informatie in de media". ${ }^{243}$ De respons onder wijkverpleegkundigen (26\%) is vergelijkbaar met die van een eerdere enquête over medisch-technisch handelen onder wijkverpleegkundigen in $1985(27 \%){ }^{237}$ Op grond van deze aantallen lijkt er in deze studie geen bijzondere vertekening op te treden in vergelijking met andere onderzoeken. De respons van zorgverleners werkzaam buiten het ziekenhuis is hoger. Waarschijnlijk hangt dit samen met het accent op de IT. Gezien dit accent hoeft deze positieve selectie geen vertekening te geven. In deze studie varieert de ervaring met infuusbehandeling in het algemeen en met IT. Welke ervaring de bestudeerde beroepsgroepen landelijk hebben, is onbekend. De respondenten kunnen meer dan gemiddelde ervaring hebben met infuusbehandeling of meer dan gemiddeld met vakinhoudelijke ontwikkelingen bezig zijn. Gezien het inventariserende doel van de enquête behoeft dit geen belemmering te zijn voor de validiteit van de uitkomsten bij de gewenste situatie. Bij de huidige situatie kan er overrepresentatie zijn van ervaring met IT.

Ten behoeve van een basaal inzicht in de representativiteit van de steekproef zijn de respondenten globaal vergeleken met hun gehele beroepsgroep. De responderende huisartsen, specialisten en wijkverpleegkundigen vormen allen ongeveer $1 \%$ van hun beroepsgroep en komen wat betreft de vergeleken kenmerken overeen met hun beroepsgroep. Bij de ziekenhuisverpleegkundigen is dit bij gebrek aan referentiekaders moeilijk aan te geven. $\mathrm{Zij}$ benaderen ongeveer $2 \%$ (promille) van de in algemene, academische en categorale ziekenhuizen werkende beroepsgroep.

\subsubsection{HUIDIGE EN GEWENSTE PRAKTIJK}

In deze studie is expliciet gekozen voor de Nederlandse situatie. In de Verenigde Staten, Canada en het Verenigd Koninkrijk brengt de verplaatsing van medisch(-technisch) handelen naar verpleegkundigen ook discussie over de taak- en verantwoordelijkheidsverdeling met zich mee, maar zijn de omstandigheden anders. ${ }^{244}$

$\mathrm{Bij}$ de gewenste situatie voor algemene en specifieke zorguitvoering is gevraagd of een bepaalde handeling tot de medische, verpleegkundige of beider taak gerekend wordt. $\mathrm{Bij}$ de eventuele vormgeving van IT kan van dit onderscheid worden uitgegaan ${ }^{245} \mathrm{Er}$ is geen directe koppeling gelegd tussen taken en functies, omdat dit het risico met zich meebrengt dat de antwoorden tevens afhangen van de mate waarin men een dergelijke functionaris als ondersteunend dan wel concurrerend beschouwt (bijvoorbeeld wijkverpleegkundige en TMV) ${ }^{246}$ Een aantal verschillen in antwoorden tussen artsen en wijkverpleegkundigen kan hierdoor overigens wel worden verklaard. Ook de ervaring met infusen speelt een belangrijke rol. Ziekenhuisverpleegkundigen vinden taken bij infusie vaak verpleegkundiger van 
aard, wijkverpleegkundigen dezelfde taken meer medisch. Soms worden bij de huidige behandeling in het ziekenhuis ook huisartsen, wijkverpleegkundigen en TMVs genoemd. Dit duidt waarschijnlijk op invulfouten, maar kan ook duiden op samenwerking tussen zorgverleners binnen en buiten het ziekenhuis.

De indicatiestelling acht men een medische taak. Verpleegkundigen wensen de mogelijkheid om te signaleren en mee te beslissen. Het informeren ten aanzien van de behandeling beschouwt men beider taak, het instrueren meer een verpleegkundige. Bij de zorguitvoering valt de gezamenlijkheid op. Alleen het bewaken van de behandeling ziet men als een medische taak. Het inbrengen van een infuusnaald vindt men in hoofdzaak medisch. Ook een vakbond als de CFO rekende dit in 1992 niet tot het takenpakket van de A-,B-, Z-, MGZ- of HBO-V verpleegkundige. ${ }^{207}$ Artsen en ziekenhuisprofessionals rekenen het meer tot beider taak. De assistentie bij het inbrengen evenals de verdere bediening van het infuus en het verwijderen van de infuusnaald vindt iedereen een verpleegkundige taak. Laatstgenoemde taken rekenden wijkverpleegkundigen in een enquête over dit onderwerp in 1985 ook tot de verpleegkundige taak. ${ }^{27}$ (Deze enquête is als referentiekader genomen, omdat die dezelfde onderwerpen behandelt en de hier besproken materie zich slechts langzaam ontwikkelt en aldus een wat verder weggelegen referentiepunt rechtvaardigt.) De eerste toediening van medicatie vindt eenieder een medische taak, vervolgtoedieningen beider taak. In 1985 vonden wijkverpleegkundigen dit vooral een medische taak.

Allen vinden dat IT meer tot het kennis- en vaardigheidsgebied van de huisarts en de wijkverpleegkundige behoort dan tot dat van specialist en ziekenhuisverpleegkundige. De mate waarin beroepsgroepen bevoegd worden geacht komt grotendeels overeen met de mate waarin dit tot hun bekwaamheidsgebied gerekend wordt. In 1985 wensten wijkverpleegkundigen vooral een wettelijke vastlegging van de bevoegdheid. ${ }^{237}$ De gewenste en de huidige taakverdeling in de thuissituatie geven aan dat IT nog in ontwikkeling is en er nog veel ad hoc en op persoonlijk initiatief gebeurt. Er is meer behoefte aan duidelijkheid omtrent de taken en verantwoordelijkheden alsmede vastlegging in richtlijnen. Dit is niet veranderd ten opzichte van $1985 .{ }^{277}$ Ook van den Boomen pleit hiervoor. ${ }^{248}$ Een 24-uurs bereikbaarheid, een adequate ondersteuning in de specifieke zorgverlening, overdracht en overleg zijn daarbij noodzakelijk. Te verwachten is dat de thuissituatie dan meer kenmerken gaat vertonen van de huidige ziekenhuissituatie bij infusie.

Over de vormgeving van IT verschillen de diverse beroepsgroepen -evenals bijvoorbeeld bij spinale pijnbestrijding- op onderdelen. ${ }^{246}$ In grote lijnen lijken zij voor de toekomst eerder voor vormgeving vanuit de thuiszorg dan vanuit het ziekenhuis te kiezen, hoewel in de huidige praktijk infuusbehandelingen zowel vanuit het ziekenhuis als vanuit de thuiszorg gerealiseerd worden. Scholing en training vinden huisartsen en wijkverpleegkundigen daarbij noodzakelijk. Een beeld dat overeenkomt met 1985 en 1995. ${ }^{237,248}$

Eenieder signaleert een hoge werkdruk en wijkverpleegkundigen pleiten voor uitbreiding van personeel bij IT. Dit in tegenstelling tot 1985 waarin een deel van wijkverpleegkundigen nog aangaf dat medisch-technische handelingen binnen de basiszorg gebracht zouden kunnen worden. ${ }^{237}$ In 1991 zijn de hoge werkdruk en de wens tot personeelsuitbreiding echter al aangegeven. ${ }^{242} \mathrm{Bij}$ levering van de materialen verdient samenwerking tussen de openbare apotheker en de kruisvereniging de voorkeur.

\subsubsection{RELATIE MET REGELGEVING}

Bij vergelijking van wet, maatschappelijke vertaling en praktijk komen bij enkele handelingen verschillen naar voren. Signaleren van de noodzaak tot infuusbehandeling is 
een medische taak, hoewel het veld hierin ook een rol voor de verpleegkundige ziet weggelegd. De BIG geeft evenals de WUG geen duidelijkheid omtrent het informeren en instrueren van de patiênt. Het veld rekent dit tot beider taak. Het inbrengen van de infuusnaald is als voorbehouden handeling in principe overdraagbaar, hoewel het veld dit tot de taak van de arts rekent. Mogelijk kunnen deze verschillen nogmaals nader bezien worden. Het advies van de Raad BIG brengt de ruimte die de BIG biedt voor de eerste toediening van medicatie door verpleegkundigen in overeenstemming met de gewenste situatie: namelijk dat dit een niet overdraagbare voorbehouden handeling is.

Praktijk en wetgeving inzake infuusbehandeling lijken bij vergelijking tussen de BIG en de door de beroepsbeoefenaars gewenste situatie beter op elkaar afgestemd dan tussen de WUG en de huidige situatie. Bij vergelijking van de maatschappelijke vertalingen in de vorm van het advies van de Geneeskundige Hoofdinspectie over de WUG en het advies "Voorbehouden Handelingen" van de Raad BIG over de BIG met de huidige en gewenste situatie, is dit verschil aanmerkelijk kleiner. Als zodanig kan de BIG beschouwd worden als de wettelijke vastlegging van de reeds bestaande maatschappelijke vertaling van de WUG die -in de vorm van arresten en adviezen betreffende de 'verlengde-armconstructie'al in de regelgeving was opgenomen. Een conclusie die Spreeuwenberg deelt. ${ }^{249}$ De BIG en haar maatschappelijke vertaling bieden echter nog steeds ruime interpretatiemogelijkheden. ${ }^{248}$ Helaas is in het huidige onderzoek niet gevraagd of men moeite had met de interpretatie van de wetgeving. In 1985 bleek dit een probleem. ${ }^{27}$ Nadere precisering van al dan niet voorbehouden handelingen per onderdeel van de infuusbehandeling lijkt hoe dan ook gewenst. Het advies "Voorbehouden Handelingen" biedt een aanzet daartoe, maar geeft slechts ten dele antwoord op de in de praktijk gerezen onduidelijkheden en aanleiding tot verdere discussie, zoals over artikel $39 . .^{238,250-253}$ De voorwaarden voor en consequenties van medisch-technisch handelen door verpleegkundigen dienen daarom nader uitgewerkt te worden. ${ }^{254} \mathrm{Het}$ is zaak alle geledingen daarbij te betrekken, eenieder te informeren en voor de invoering aan te sluiten bij de actuele mogelijkheden van het veld.

\section{$5.5 \quad$ Conclusies}

Nederlandse huisartsen, specialisten, wijk- en ziekenhuisverpleegkundigen hebben in een enquête hun oordeel gegeven over medisch- en verpleegtechnische handelingen bij infusie. Een centrale rol bij vormgeving vanuit de thuiszorg is weggelegd voor de huisarts en -vanwege de vereiste specialisatie en functionele differentiatie- een apart opgeleide TMV. $\mathrm{Bij}$ de laatste gaat de voorkeur -vanwege de arbeidsverdeling en structurele differentiatieuit naar een bij de thuiszorg werkende verpleegkundige, die deskundig en bekwaam is op het gebied van het medisch-technisch handelen bij infusies. Het lijkt aan te bevelen om de beroepsmatige gedragingen bij een complexe zorg als IT, vanwege de vereiste kennis, kunde en continuîteit van zorgverlening te ordenen naar beroepen, instellingen en organisaties. Bijvoorbeeld in een transmuraal zorgmodel waarbij zorgverleners na afdoende scholing, op geprotocolleerde wijze, 24 uur per dag samenwerken.

Bij vergelijking van de WUG en de BIG, hun maatschappelijke vertaling en de dagelijkse praktijk, lijkt de BIG meer aan te sluiten op de praktijk dan de WUG. Worden tevens hun maatschappelijke vertalingen bezien, dan zijn de onderlinge verschillen kleiner. Als zodanig kan de BIG beschouwd worden als de wettelijke vastlegging van de bestaande maatschappelijke vertaling van de WUG die ook al ten dele in de regelgeving was opgenomen. Bij de huidige stand van zaken blijft binnen de BIG verschil van interpretatie mogelijk. Bij voorbehouden handelingen, zoals bij infusie, is nadere precisering gewenst. 


\section{Model voor complexe medisch-technische zorg}

\subsection{Inleiding}

In Nederland vindt CMTZ vooralsnog overwegend klinisch plaats. Thuisbehandeling biedt de patiënt uitbreiding van de mogelijke behandellokaties. In de kliniek dient de technologie voornamelijk voor toepassing van diagnostiek en therapie. Bij thuisbehandeling dient bij de toepassing daarvan ook expliciet rekening gehouden te worden met substantiêle waarden als de autonomie en zelfredzaamheid van de patiênt in diens omgeving. Zorgverleners en organisaties lijken nog onvoldoende toegerust voor deze nieuwe vormen van zorgverlening in de thuissituatie. Aanbod, inhoud en structuur van de zorgverlening dienen daarom geĭnnoveerd te worden. De zorgverleningstheorie van Orem gaat uit van het zelfzorgvermogen van de patiënten en/of hun naasten en baseert zorgverlening op gehele of gedeeltelijke compensatie van en educatie bij zelfzorgtekorten. ${ }^{164,165}$ Deze uitgangspunten maken een functiegerichte zorgbenadering mogelijk. ${ }^{78}$

Vanuit hoofdvraagstelling II over de vormgeving van zorg en aandachtspunt 2 over de protocollering en afstemming daarvan, beschrijft dit hoofdstuk op basis van de voorgaande inventarisaties en de literatuur een patiëntgericht algemeen zorgmodel voor CMTZ thuis (definities bijlage 6.1). Analyse van de sociale, interpersonele en technologische kaders levert enkele uitgangspunten op. Vanuit ervaringen en theoretische zorgkaders bij CMTZ alsook taken en verantwoordelijkheden bij IT, wordt de inhoud van de zorg omschreven in zelfzorgbehoeften en nagegaan welke (niet-)professionele zorgverleners zelfzorgtekorten kunnen opheffen. Daarna worden het zorgproces met een aantal voorwaarden bij CMTZ en enkele implicaties voor de zorgorganisatie omschreven. Dit algemene zorgmodel voor CMTZ wordt in hoofdstuk 8 voor IT in de regio 'Heuvelland' concreter uitgewerkt.

\subsection{Zorginhoud bij complexe medisch-technische zorg}

Om bij CMTZ substantieel en functioneel rationeel in de zelfzorgbehoeften tengevolge van aandoening en behandeling te voorzien, zijn kennis en vaardigheden vereist (schema 6.1). Ook kunnen algemene zelfzorgtekorten en zelfzorgtekorten bij ontwikkelingsprocessen ontstaan of beïnvloed worden. Hoewel deze beiden het welslagen van CMTZ kunnen beïnvloeden, worden ze hier niet gedetailleerd uitgewerkt. In theorie zouden de patiënt en of diens naaste volledig in de zelfzorgbehoeften bij CMTZ kunnen voorzien, in werkelijkheid vrijwel nooit. Bij de individuele patiënt is immers zelden de soort aandoening en het eerste tijdstip van optreden te voorspellen. Hierdoor is de benodigde voorbereiding niet mogelijk. Bij de meeste aandoeningen hebben de patiënt en diens naaste onvoldoende kennis van hun 'objectieve' gezondheidstoestand en behandelingsalternatieven. ${ }^{190}$ 
1) Signaleren en controleren van symptomen

- Algemene kennis over symptomen en aandoeningen (b.v. media, opleiding, e.d.).

- Vaardigheid om symptomen te kunnen signaleren, eventueel te meten en te controleren.

- Algemene kennis en vaardigheid om vanuit symptomen de juiste actie te ondernemen.

- Specifieke kennis en vaardigheid om op grond van symptomen en eventueel aanvullend onderzoek een waarschijnlijkheidsdiagnose te kunnen stellen.

2) Informatie over waarschijnlijkheidsdiagnose, symptomen en behandelmogelijkheden

- Specifieke kennis over de meest waarschijnlijke aandoening, de daar aan toe te schrijven of te verwachten symptomen en de behandelmogelijkheden.

- Vaardigheid om deze specifieke kennis te kunnen vertalen naar de individuele situatic.

3) Keuze voor een behandelplan *

- Kennis en vaardigheid om, indien men geinformeerd is over de waarschijnlijkheidsdiagnose, symptomen en behandelmogelijkheden, een behandelplan te kunnen kiezen dat bij de individuele situatie past.

4) Uitvoeren van een complexe medisch-technische handeling

- Beschikken over medicatie en materialen.

- Kennis van de achtergrond, doel, inhoud en mogelijke complicaties van de handeling".

- Vaardigheid om de behandeling uit te voeren, complicaties te signaleren en gerichte actie te ondernemen.

- Vaardigheid om de effecten van de behandeling te evalueren.

5) Veranderen zelfbeeld (zo nodig)

- Kennis om de implicaties van de aandoening en/of behandelplan voor het zelfbeeld te onderkennen.

- Vaardigheid om veranderingen in het zelfbecld door aandoening en/of behandelplan te verwerken.

6) Veranderen leefstijl (zo nodig)

- Kennis om de implicaties van de aandoening en/of behandelplan voor de leefstijl te onderkennen.

- Vaardigheid om veranderingen in de leefstijl door aandoening en/of behandelplan door te voeren.

7) Signaleren en controleren van effecten van het behandelplan

- Kennis en vaardigheid om fysische en/of psychologische effectparameters te beoordelen.

- Kennis en vaardigheid om de gevolgen van aandoening en behandeling op de individuele leefsituatie te beoordelen.

Legenda: "=bijvoorbeeld infuusbehandeling thuis of peritoneaal dialyse.

Een tekortschietend zelfzorgvermogen op deze gebieden vereist professionele ondersteuning. Vanwege de benodigde kennis en vaardigheden, kunnen patiënten en/of hun naasten en zorgverleners meestal slechts tezamen in de totale zelfzorgbehoefte bij CMTZ voorzien.

\subsection{Zorgproces bij complexe medisch-technische zorg}

\subsubsection{ACTOREN, INDELING EN ZORGVERLENINGSMETHODEN}

Bij het zorgproces interacteren het meer substantieel geaarde patiëntsysteem en de meer functioneel geaarde professionele zorgverlening (schema 6.2).

Het patiëntsysteem bestaat uit de patiēnt en diens naaste(n). Van oudsher helpen naasten bij het opheffen van zelfzorgtekorten. Steenvoorden en Goudriaan geven een goed overzicht van het denken over mantelzorg in Nederland. ${ }^{255}$ Mantelzorg is een van de pijlers waarop de zorg thuis rust. Ze kan verleend worden door naasten vanuit de primaire leefgemeenschap, door uitwonende familie, door buren, kennissen en vrijwilligers. In aard, duur en/of intensiteit verschilt mantelzorg door naasten vaak van die door de andere groepen. Patiënten en naasten dienen als één samenhangend patiëntsysteem te worden beschouwd. ${ }^{256}$ De zorg door de andere niet-professionele zorgverleners is vaak minder blijvend en verzorgend. ${ }^{25} \mathrm{Zij}$ vormen een mantel om de patiěnt én de naasten. Zorg door vrijwilligers is in opkomst en betreft oppas/thuishulp en begeleiding. ${ }^{258-260}$ Ook CMTZ thuis lijkt niet mogelijk zonder inzicht van en participatie door de patiēnt en naasten. ${ }^{112,261}$ 


\section{Zelfzorgbehoefte ${ }^{10,164}$}

A) Tengevolge van aandoening en behandeling :

Signaleren en controleren van symptomen

Informatie over symptomen, waarschijnlijkheidsdiagnose en behandelmogelijkheden

Keuze voor een behandelplan

Uitvoeren van complexe medisch-technische behandeling

Veranderen van zelfbeeld en leefstijl

Signaleren en controleren van effecten van het behandelplan B) Algemeen":

Opname lucht, vocht en voedsel

Lichaamshygiene en uitscheiding

Balans tussen rust en activiteit

Voorkomen gezondheidsrisico's en ongevallen

Balans tussen alleen zijn en sociale interactic

Sociaal functioneren in groepsverband

C) Tengevolge van ontwikkelingsprocessen :

Overgang tussen levensfasen in de normale levensloop

Verwerking van belangrijke levensgebeurtenissen

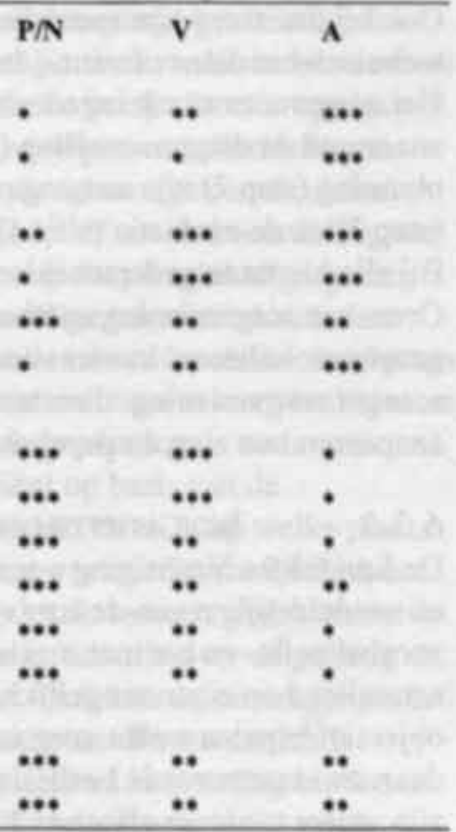

Legenda: $\mathrm{P} / \mathrm{N}=$ patient en/of naaste, $\mathrm{V}=$ verpleegkundige, $\mathrm{A}=$ arts, $\cdots * * *$ vervult een zelfzorgbehoefte doorgaans "beperkt "* gedeeltelijk of "**:volledig,"=Maslow rekent in zijn "Needs hierarchy" tot de behoeften van de mens: fysiologische behoeften, een basaal gevoel van veiligheid, liefde ontvangen, liefde geven, respect, zelfrespect en zelfrealisering. ${ }^{215}$

Nieuw is dat zij ook actief kunnen deelnemen aan het opheffen van zelfzorgtekorten bij CMTZ. Door hun betrokkenheid bij medisch-technische handelingen zetten zij de stap naar die van (mede)behandelaar. Dit stelt eisen aan het waarnemings-, inschattings-, verwerkings- en leervermogen. ${ }^{262}$ De aandacht voor gezondheid en de technische mogelijkheden (van de geneeskunde) in de media zal zeker een bijdrage leveren aan hetgeen leken hierover zelf reeds weten dan wel bij uitleg door zorgverleners kunnen begrijpen en aanleren. ${ }^{243,263}$ Ook de professionele zorgverlening verandert. De individualiteit en de veranderde gezondheidsbeleving nopen tot een verschuiving van een probleemnaar een doelgeoriënteerde werkwijze, zoals die van Orem. ${ }^{256}$ De van aard veranderende deelname door het patiëntsysteem aan de zorg vergt van de professionals een andere benadering. ${ }^{264}$ Met name de zeggenschap van het patiëntsysteem verdient aandacht. ${ }^{112}$ Tevens verschuift de zorg interdisciplinair. ${ }^{199}$ Voorheen behartigden artsen de 'cure' en verpleegkundigen de 'care'. Momenteel vervullen verpleegkundigen ook veel cure activiteiten en besteden de artsen ook explicieter aandacht aan care-aspecten. ${ }^{265}$ Huisartsen rekenen dit ook tot hun taak. ${ }^{162}$ De veranderde zorgverlening vereist een samenhangend zorgbeleid. ${ }^{112}$ Post riep de thuis en in het ziekenhuis werkzame professionals al in 1988 op zich in hun werkwijze te hergroeperen in medische, verpleegkundige en sociale ordes. ${ }^{188}$ Schadé onderscheidt medische, verpleegkundige, verzorgende en ondersteunende functies in het zorgproces. ${ }^{266}$ Uitgangspunt is complementariteit in gelijkwaardigheid. ${ }^{188,217,256}$ Specialisten en huisartsen dienen erop gericht te zijn de kennis en vaardigheden van anderen te benutten wanneer het beantwoorden van de zorgvraag tevens andere deskundigheid vereist. ${ }^{205}$ Samen met andere zorgverleners kunnen zij zo gezamenlijk kwalitatief 
goede zorg met een 24-uurs bereikbaarheid en beschikbaarheid waarborgen. ${ }^{112,217,267,268}$ Ook bij thuiszorg zijn specialisatie, arbeidsdeling en beleidsinstrumentaria voor medischtechnisch handelen onvermijdelijk. ${ }^{254}$

Het zorgproces wordt ingedeeld volgens McFarland en McFarlane (schema 4.1). De anamnese en diagnosestelling (stap 1) en doelbepaling, interventiebepaling en interventieplanning (stap 2) zijn samengevoegd tot 'indicatiestelling'. De uitvoering van interventies (stap 3) en de evaluatie (stap 4) zijn gebundeld tot 'zorguitvoering en evaluatie'. . $^{\text {s }}$

$\mathrm{Bij}$ alle hierna te onderscheiden stappen in het zorgproces staan de zorgverleners volgens Orem zes zorgverleningsmethoden ter beschikking. Deze zijn in het hier gebruikte model geoperationaliseerd in vier -voor patiënten, naasten en zorgverleners meer herkenbaresoorten zorgverlening: directe zorguitvoering, informeren, opmerken van veranderingen en aanpassen van zorg én psychosociale begeleiding (schema 4.2). ${ }^{\text {is }}$

\subsubsection{INDICATIESTELUING}

De Landelijke Vereniging voor Thuiszorg definieert indicatiestelling als: "het verkennen en verduidelijken van de zorgvraag van het patiěntsysteem -het inventariseren van de zorgbehoefte- en het met inachtneming van bepaalde criteria (noodzakelijkheidsprincipe, aanvullend op eigen mogelijkheden, ontbreken deskundigheid, preventie/bijsturen) objectief bepalen welke zorg naar inhoud, omvang en kwaliteit nodig is, zodat op grond daarvan verantwoorde beslissingen omtrent de inzet en financiering van zorg mogelijk zijn; zulks mede ter effectuering van wettelijke zorgaanspraken". ${ }^{269}$ De indicatiestelling koppelt de individueel uiteenlopende en collectief toenemende zorgbehoeften aan de beschikbare soorten en omvang van de zorgverlening. Tijdens de anamnese (inclusief vraagverheldering) en diagnosestelling inventariseert de zorgverlener de actuele en/of potentiële zelfzorgtekorten in het lichamelijk, psychisch, huishoudelijk en sociaal functioneren van het patiëntsysteem en analyseert deze naar aard en oorzaak (objectieve en subjectieve zelfzorgbehoeften en tekorten). Op basis hiervan wordt samen met het patiëntsysteem doelen geformuleerd, prioriteiten gesteld en de benodigde interventies afgesproken en vastgelegd in een zorgplan (objectieve en subjectieve professionele zorgbehoefte). De indicatiesteller geeft tegelijkertijd én de patiënt én de organisatie een advies over de benodigde zorginzet en houdt daarbij rekening met de inhoud, frequentie en duur van de zorg en de benodigde deskundigheid van de zorgverlener. ${ }^{269}$ Tot slot worden er afspraken gemaakt voor de verdere zorgverlening. De indicatiesteller kan tijdens de intake een checklist, documentatie- en voorlichtingsmateriaal gebruiken.

Bij CMTZ wordt tijdens de indicatiestelling informatie verzameld over: ${ }^{270}$

* De risico's van de aandoening zelf, van de daarvoor benodigde CMTZ alsook van eventuele andere aandoeningen en behandelingen.

- De actuele en de te verwachten zelfzorgtekorten van het patiēntsysteem tengevolge van de aandoening en/of de behandeling daarvan, waarbij tevens eventuele algemene en/of aan ontwikkelingsprocessen gerelateerde zelfzorgtekorten worden meegenomen. Aandachtspunten voor haalbaarheid van CMTZ op het niveau van het patiěntsysteem zijn:

draagkracht van het systeem in relatie tot de thuisbehandeling; waarnemings-, inschattings-, verwerkings- en leervermogen van het systeem in relatie tot de benodigde informatie en instructie; leefbaarheid en werkbaarheid in en veiligheid van de thuissituatie.

- De haalbaarheid van CMTZ op het niveau van de professionele zorgverlening: deskundigheid, vaardigheid, bevoegdheid, continulteit, bereikbaarheid, materialen/hulpmiddelen. - De financiering van produkten en diensten. ${ }^{271}$ 
De indicatiestelling kan op diverse manieren bevorderd worden. Een arts kan het nut van een bepaald soort CMTZ in relatie tot de (ervaren) gezondheidstoestand het best inschatten. ${ }^{190} \mathrm{Bij}$ de vraag of behandeling thuis mogelijk is dient het oordeel van de huisarts zwaar te wegen vanwege zijn kennis van de gezins- en woonsituatie én in zijn functie van 'poortwachter'. ${ }^{162} \mathrm{Bij}$ het beoordelen van de implicaties van aandoeningen en behandelingen voor de totale zelfzorgbehoeften van de patiênt dient de verpleegkundige een sleutelrol te vervullen vanwege haar kennis en vaardigheden op dit gebied. ${ }^{216}$ Voor de beoordeling van de mogelijkheden van verpleging in de thuissituatie lijkt de wijkverpleegkundige gezien haar specifieke kennis de aangewezen persoon. ${ }^{272}$ Een deskundige ten aanzien van de betreffende medisch-technische handeling kan de consequenties van de techniek inschatten voor het patiëntsysteem en de zorgverlener(s). Bij gebrek aan kennis over aandoeningen en therapieën valt de patiënt meestal terug op het oordeel van de professionals voor wat betreft soort en inhoud van de behandeling. Wel kan de patiênt op basis van de voorlichting kiezen om een behandeling al dan niet te ondergaan en zo ja op welke plaats. Vanwege de complexiteit en de tijdsdruk kan ook aanmelding via een Centraal Meldpunt (CM) bevorderend werken. Bij deskundige bemensing en gebruik van een gestructureerde aanmeldingsprocedure kan reeds een deel van de benodigde informatie over de patiënt, de beoogde behandeling en de zorgverleners verkregen worden. Ook kan de aanvrager reeds bij aanmelding worden medegedeeld of aan de meest essentięle randvoorwaarden is voldaan. Het $\mathrm{CM}$ kan tevens informatie verstrekken, secretariěle ondersteuning bieden en bij spoedeisende behandelingen materialen bestellen. Een CM kan de wachttijd tussen aanmelding en start van de zorg bekorten.

Het verdient aanbeveling om de totaal benodigde zorg bij CMTZ in een multidisciplinair zorgprogramma te omschrijven. ${ }^{273}$ Dit geschiedt het best in samenspraak met alle betrokkenen, maar met een uniforme aanpak en coördinatie vanuit één persoon. ${ }^{56}$ Een zorgprogramma moet recht doen aan de principes van continulteit, communicatie, complementariteit en coördinatie. ${ }^{266}$ Een goed gedocumenteerd zorgprogramma is het belangrijkste handvat bij de voorbereiding op de daadwerkelijke uitvoering van de CMTZ. Het vormt het uitgangspunt voor het in stelling brengen van de benodigde mensen en materialen. Bij het in overeenstemming brengen van de zorgbehoeften van de patiënt met de beschikbare soorten zorgverlening kan een modulaire opzet uitkomst bieden. ${ }^{274}$ Daarbij kunnen leveranciers van medicatie, hulpmiddelen en apparatuur vanuit hun deskundigheid ondersteunen. Het voorbereidingsproces verdient voortdurende bewaking. Dit voorkomt een poging tot opstarten zonder de benodigde materialen of professionele zorgverleners. Contacten met het patiëntsysteem in deze fase kunnen spanning wegnemen of alsnog een te hoog ingeschatte draagkracht opsporen. Een zorgprogramma wordt bij voorkeur in een zorgschrift, logboek of zorgplan vastgelegd..$^{273,275}$ Een zorgplan omvat tenminste..$^{267,276}$ * Persoons-, adres- en bereikbaarheidsgegevens van de patiënt, alle betrokken en/of te consulteren (niet)professionele zorgverleners en de eventuele zorgcoördinator.

* Datum van opstellen én van evaluatie van het zorgplan.

* Een schematische omschrijving van de taken die voornoemde personen vervullen om tegemoet te komen aan: $a$. de zelfzorgbehoefte van de patiënt; $b$. optimale bevordering van de zelfredzaamheid van de patiënt; $c$. ondersteuning van de naaste(n).

* Een rapportagesectie voor vastlegging van de toestand van de patiënt en het verloop van de door voornoemde personen verleende zorg (toegevoegd).

* Een communicatie- of mededelingensectie voor onderlinge communicatie en gerichte vragen van niet spoedeisend karakter. 
Deze elementen zijn terug te vinden in diverse zorgplannen. ${ }^{27-280} \mathrm{Bij}$ CMTZ is het aan te bevelen deze aan te vullen met:

* Protocollen ter ondersteuning bij en instructie van de uitvoering van complexe medischtechnische handelingen.

* Bij de CMTZ benodigde standaardformulieren, zoals een uitvoeringsverzoek en de handelingen-rapportagelijst.

Voor diverse thuiszorgtechnologieln zijn protocollen ontwikkeld. ${ }^{92,281-283}$ Ook bestaan diverse voorbeelden van combinaties van zorgplannen en protocollen. ${ }^{2 \mathrm{~S}, \text {, 2ss }} \mathrm{Het}$ zorgplan (eventueel gecombineerd met een protocol) is geen monodisciplinair dossier, maar een multidisciplinaire status, die voorafgaand aan de zorg met het patiêntsysteem doorgenomen wordt. ${ }^{204,}, 276$

Ten slotte kan het instellen van een zorgbemiddelaar, zorgcoördinator of zorgplanner de indicatiestelling en zorguitvoering bevorderen. ${ }^{204,} 267$ De benaming zorgcoördinator doet het meest recht aan de taakinhoud en de relatief neutrale positie. De zorgcoördinator dient kennis en vaardigheden te bezitten om: een complexe zorgsituatie in te schatten, een adequaat zorgprogramma op en bij te stellen, zorgdoelstellingen te formuleren en deze via de inzet van (niet-)professionele zorgverleners en hulpmiddelen te realiseren. ${ }^{267,273}$ Belangrijke vaardigheden betreffen communicatie en onderhandeling. Belangrijke attitudekenmerken zijn openheid, respect voor (keuzen van) de patiěnt en diens omgeving, empathie, integriteit en geduld. Gevoel voor andermans professionele autonomie is in de functie van zorgcoördinator onmisbaar, omdat bij het instellen hiervan andere zorgverleners een deel van hun autonomie overdragen. De betrokkenen bepalen per situatie in overleg wie de zorg coördineert. Meestal zal dat -gezien de kennis en vaardigheden- in de thuiszorg de wijkverpleegkundige of huisarts zijn en in het ziekenhuis een specialist of ziekenhuisverpleegkundige. ${ }^{44,107}$ Een juiste indicatiestelling en het hanteren van een zorgprogramma, zorgdossier en zorgcoördinatie bevorderen een goede start van de zorgverlening. Door een gezamenlijk optreden en contact met de patiënt kunnen betrokkenheid en samenwerking tot uiting worden gebracht.

\subsubsection{ZORGUITVOERING EN EVALUATIE}

In de directe zorguitvoering dienen de, tijdens de intake door het patiëntsysteem en de indicatiesteller gezamenlijk geformuleerde, doelstellingen gerealiseerd te worden. De zorguitvoering richt zich daarbij op de beľnvloedbare factoren van de geĭnventariseerde zelfzorgtekorten en vindt in multidisciplinaire samenwerking plaats. De zorguitvoering wordt vastgelegd in het zorgdossier, periodiek geëvalueerd en zo nodig bijgesteld door de zorgcoördinator in overleg met het patiëntsysteem en de andere betrokkenen. In de evaluatie komen zowel het proces -de zorguitvoering zelf- als de beoogde effecten -het bereiken van de doelen- aan bod. De evaluatiegegevens worden eveneens vastgelegd in het zorgdossier. Bij het bereiken van de doelstellingen wordt de zorgverlening beěindigd.

Deskundigheid, continutteit, flexibiliteit en samenwerking zijn voorwaarden voor CMTZ. Uitgaande van het zelfzorgconcept van Orem kan, bij de uitvoering van de complexe medisch-technische handelingen, theoretisch iedere gewenste taakverdeling overeengekomen worden, zolang de desbetreffende zorgverlener op het moment van uitvoering maar de benodigde kennis en vaardigheden bezit. Dit uitgangspunt wordt in de praktijk gestuurd door drie elkaar opvolgende tweedelingen in taakverdeling die wel eens in de verkeerde volgorde geplaatst worden. Ten eerste dient het handelen van professionele 
zorgverleners gestuurd te worden vanuit het bezit van kennis en vaardigheden, dat van leken wordt gestuurd vanuit het ontbreken daarvan. De patiěnt en diens naaste zullen dus bijna altijd professioneel ondersteund moeten worden. Hetzelfde dient te gebeuren bij professionele zorgverleners ten aanzien van gebieden waarop zij 'relatieve' leken zijn. Bij complexe medisch-technische handelingen wordt de relatieve incompetentie van professionele zorgverleners vooral veroorzaakt door de cumulatieve invloed van differentiatie en technologie waardoor zij niet voor alle taken in de gezondheidszorg inzetbaar zijn. De oorzaak van deze incompatibiliteit is gelegen in verschillen in kennis en kunde en niet in de werkplek. ${ }^{286,287}$ Ten tweede is er de verdeling in een medische en verpleegkundige professie, met elk een eigen taak- en daarbij behorend kennis-, vaardigheids- en bevoegdheidsgebied. De CMTZ dient daartoe onderverdeeld te worden in medisch- en verpleegtechnische handelingen. ${ }^{157,202,203}$ De meeste medisch-technische handelingen mag de verpleegkundige (tot nu toe) niet autonoom uitvoeren. Ten derde verschilt de situatic in een instelling en thuis. De benodigde technische kennis en vaardigheid bij CMTZ kunnen hetzelfde zijn. Wel verschillen de gevolgen van de behandeling op het dagelijks leven van de patiënt en diens naasten. Bij behandelingen in instellingen wordt het dagelijks leven in zijn geheel tijdelijk 'onderbroken'. ${ }^{2 s}$ Dit vereist kennis en vaardigheden om de patiënt zich 'thuis' te laten voelen in deze bijzondere situatie. Bij thuisbehandeling belemmeren de aandoening én behandeling direct het dagelijks leven van patiënten en hun naasten. Dit vereist specifieke kennis en vaardigheden van zorgverlening thuis.

De CMTZ kan dus bij voldoende kennis en vaardigheden door zowel specialisten, huisartsen, ziekenhuis- als wijkverpleegkundigen worden uitgevoerd. De verpleegkundige mag daarbij medisch-technische handelingen in opdracht uitvoeren. Daar waar kennis, vaardigheden, diagnostische- of behandelmogelijkheden van de uitvoerende zorg te kort schieten, dient ondersteuning gezocht te worden bij een instelling waar personeel met de benodigde kennis en vaardigheid aanwezig is. ${ }^{217}$ Telefonische consultatie, klinische presentatie of opname, of thuisbezoek door een expert zijn enkele mogelijkheden. Bij CMTZ is continuîteit in diverse opzichten van belang. Ten eerste de herkenbare voortzetting van de zorgverlening indien daar een opname in een instelling aan vooraf ging. Ten tweede de continuitteit in de tijd, in werkwijze en zoveel mogelijk in persoon gedurende de zorgverlening. Deze verplichting is wettelijk verankerd (BIG art. 40 lid f). ${ }^{289}$ Vanwege de afwezigheid van professionele zorgverleners is een continue bereik- en beschikbaarheid nodig ter eventuele ondersteuning van het patiëntsysteem en bij calamiteiten. Professionele zorgverleners moeten als het ware achter de drempel klaar staan. Een 24-uurs bereikbaarheid en beschikbaarheid kan bij CMTZ thuis noodzakelijk zijn. Bij noodgevallen kan teruggevallen worden op de noodhulpdiensten. Bij medische problemen kan gebruik gemaakt worden van de huisarts. Is er een ander probleem of kan het niet door het patiëntsysteem ingeschat worden, dan waarborgt 'trechtering' via een $\mathrm{CM}$, verpleegkundige, huisarts en specialist dat het probleem op het meest doelmatige kennis- en vaardigheidsniveau wordt opgelost. Ten derde de continuitteit in het leven van het patiëntsysteem tegen de achtergrond van levensloop en levensstijl. ${ }^{290}$

Flexibiliteit en continuilteit lijken strijdige begrippen. Continuïteit wordt vooral geassocieerd met stabiliteit. Bij CMTZ kunnen echter altijd veranderingen optreden die snelle aanpassing van de zorg behoeven. Tijdens de zorgverlening dienen daarom de voortgang doorlopend en de doorgang periodiek geëvalueerd te worden. Personen en materialen dienen flexibel ingezet te kunnen worden. 
Gezien het voorgaande is bij instellingen die CMTZ thuis leveren samenwerking onontbeerlijk om $7 \times 24$ uurs deskundigheid, continuiteit en flexibiliteit te kunnen bieden. Enkele organisatorische implicaties hiervan volgen in \$6.4.

$\mathrm{Na}$ afloop van de directe zorguitvoering worden medicatie, hulpmiddelen en apparatuur geretourneerd, wordt gerapporteerd aan relevante zorgverleners, worden patiëntgegevens gearchiveerd en vindt declaratie naar patiènt of zorgverzekeraar plaats. ${ }^{204}$ Het is van belang de inzet van mensen en middelen die deze fase van het zorgproces vergt te onderkennen.

\section{Schema 6.3 vat de belangrijkste onderdelen van het professionele zorgproces bij CMTZ} samen (nadere concretisering voor infuusbehandeling thuis in schema 8.3).

\section{Sehema 6.3 Professioneel zorgproces bij complexe medisch-technische zorg.}

Indicatiestelling*

\section{Stap}

Indiceren

medisch

Aanmelden

Indiceren verpleegkundig

en overig

Voorbereiden

Zorguitvoering en evaluatie ${ }^{\text {" }}$

Stap

Starten en continueren

\section{Inhoud}

Inhoud -aandoening en soort behandeling

-gestructureerd bij centraal meldpunt ${ }^{2}$

-vormgeving behandeling, gevolgen voor leefsituatie en haalbaarheid

-overige benodigde zorg

technische mogelijkheden behandeling en/of apparatuur

-zorgprogramma opstellen en vastleggen in zorgdossier, aanstellen coordinator -aanleveren benodigde materialen

-realiseren wettelijke en financiele randvoorwaarden

-zorguitvoering op basis van deskundigheid, taakafspraken en bevoegdheidsregelingen -24-uurs bereikbaar- en beschikbaarheid -mogelijkheid om op een hoger deskundigheidsniveau terug te vallen

Herindiceren en evalueren

Afwikkelen -proces én effecten van zorguitvoering -bewaken van continutteit en flexibiliteit -archiveren en declareren -informeren relevante zorgverieners

\section{Betrokken professionele zorgverleners -instellingsarts ' en/of huisarts}

-door/in opdracht van huisarts en/of instellingsarts

$-\mathrm{EV}+\mathrm{MV}$ ' en eventueel intaker van wijkverpleging ${ }^{4}$ of zorginstelling -intaker gezinsverzorging ${ }^{4}$, fysiotherapic, ergotherapie, enzovoorts. -deskundigen op specifiek technische onderdelen van de behandeling

$-\mathrm{EV}+\mathrm{MV}$ met huisarts en/of instellingsarts en/of andere zorgverleners $-\mathrm{EV}+\mathrm{MV}$ met centraal meldpunt ${ }^{2}$, apotheek en/of uitleendienst instelling en/of facilitair bedrijf

$-\mathrm{EV}+\mathrm{MV}$ met centraal meldpunt ${ }^{2} \mathrm{en}$ eventueel huisarts en/of instellingsarts

\section{Betrokken professionele zorgverleners $-E V+M V$ en verpleegkundigen en artsen en/of andere zorgverleners -facilitair apotheek en/of uitleendienst instelling en/of facilitair bedrijf -specialisten en deskundigen op specifiek technische onderdelen van de behandeling \\ -artsen en EV+MV \\ $-E V+M V$ en verpleegkundigen en artsen plus organisaties}

Legenda: $=$ McFarland en McFarlane: anamnese en diagnosestelling plus doelbepaling, interventiebepaling en interventieplanning, " $=\mathrm{McF}$ arland en McFarlane: uitvoering van interventies plus evaluatic, ${ }^{\prime}=$ bijvoorbeeld een specialist of een verpleeghuis- of een revalidatiearts, ${ }^{2}=$ afhankelijk van de organisatie kunnen meldpunt en andere diensten ondersteunen, $=$ EV:eerst verantwoordelijke verpleegkundige belast met coordinatie over de complexe en eventueel andere zorg MV:verpleegkundige met complexe medisch-technische zorg als specialisatic; beide functies kunnen tegelijkertijd uitgevoerd worden, "-tegenwoordig indiceren centrale intakers vaak voor deze en andere thuiszorg gezamenlijk. 


\section{4}

Zorgorganisatie bij complexe medisch-technische zorg

In de voorgaande paragrafen zijn de inhoud, het zorgproces zelf en de daarbij betrokken zorgverleners aan bod gekomen. In deze paragraaf volgen tot slot enige kenmerken van de organisatie. Omdat deze CMTZ kenmerken heeft van buiten de instellingen geboden generalistische én van binnen de instellingen geboden specialistische zorg, kan deze tot de transmurale zorg gerekend worden. ${ }^{11,291}$ Zowel vanuit de verpleegkundige als de medische discipline zijn op het transmurale vlak diverse, vaak gelijksoortige initiatieven ontwikkeld, die opgevat kunnen worden als uitingen van functionele en structurele differentiatie. Het betreft zorg voor bepaalde patienntencategorieèn, die specifieke deskundigheid en meestal betrokkenheid van meerdere disciplines vraagt (schema 6.4). ${ }^{105,287,292-297}$

\section{Schema 6.4 Vormen van transmurale zorg.}

\section{Protocollering:}

Uniformering en afstemming van de zorg voor een bepaalde patientencategorie thuis en/of in een instelling staan centraal en worden in zorgprotocollen beschreven. ${ }^{26-302}$

\section{Het transmuraal spreekuur, waaronder de buurtpoli:}

-Huisartsen en specialisten houden gezamenlijk spreekuur (tot nu toe alleen in de huisartspraktijk). ${ }^{2 k}$, an

-Gespecialiseerde ziekenhuis- of wijkverpleegkundigen houden een spreekuur in de huisartspraktijk, het

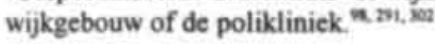

\section{Transfer-casu quo liaison-verpleegkundige:}

Een gespecialiseerd verpleegkundige draagt zorg voor een tijdige en goed geregelde overdracht van een patient tussen instellingen onderling of van en naar de thuiszorg. ${ }^{303.306}$

\section{4. "Ziekenhuis verplaatste zorg" onder regie van het ziekenhuis:}

Specialisten of gespecialiseerde ziekenhuisverpleegkundigen bieden -al dan niet in samenwerking met anderen- thuiszorg voor bepaalde patiêntencategorieenn. ${ }^{105,307,30 \mathrm{~s}}$

Een sluitende indeling voor deze initiatieven is vanwege de verschillende definities van transmurale zorg moeilijk te geven. ${ }^{187}$ Voor CMTZ thuis lijken met name 1,3 en 4 van belang. Transmurale zorgverlening beperkt zich nog vaak tot verpleegkundige zorg. Een voorheen veel gehanteerde definitie van Brasker omschrijft transmurale zorg dan ook als: "vormen van verpleegkundige zorgverlening waarbij obstakels tussen thuiszorg en klinische zorg die een adequaat, efficiënt en continu zorgverleningsproces in de weg staan worden opgeruimd". ${ }^{309}$ Deze definitie wordt vanwege de gerichtheid op het zorgproces en de verpleegkundige als te beperkt ervaren.

Wij gaan bij dit zorgmodel voor CMTZ thuis sinds 1992 uit van de volgende definitie voor transitionele (tot dusverre in Nederland transmuraal genoemde) zorg: zorg aan patiënten en hun omgeving op basis van hun behoefte aan gezondheidszorg die generalistische en specialistische kennis en vaardigheden vereist, die door zorgverleners uit de thuiszorg en klinische zorg gezamenlijk wordt aangeboden op basis van afspraken over de inhoud, het proces en de organisatie van zorg. Ook in dit transmurale concept staat de afstemming tussen zorgvraag en zorgaanbod centraal, doch het uitgangspunt verschilt van dat in andere definities. Conform de theorie van Orem wordt het zorgaanbod afgestemd op de behoeften van de patiënt en diens omgeving. Karakteristiek voor transmurale zorg is dat deze generalistische en specialistische kenmerken heeft en eisen stelt. Het gezamenlijk aanbieden is hiervan meer het gevolg dan de oorzaak. In zoverre is de benaming transmuraal wat ongelukkig en zou transitioneel -ook internationaal- minder moeilijkheden opleveren. Dit begrip verwijst op het niveau van de patiënt én van de zorg zowel naar de mengvorm, de tussenvorm van deze soort zorg, als het overgangskarakter en ontwikkelingskader waarin die vaak geboden wordt. Het belang van afspraken om de 
afstemming en de continuitteit van zorg tussen instellingen onderling en met de thuiszorg te optimaliseren, wordt onderkend. Zorginhoudelijke afspraken zijn nodig om te kunnen definiëren welke zorg in welke vorm aangeboden wordt. De procedurele afspraken betreffen het traject dat de patient aflegt en de wijze waarop de zorg georganiseerd is. Dat wil zeggen welke disciplines de zorg op welke tijden en lokaties aanbieden. De gezamenlijk aangeboden zorg hoeft niet gezamenlijk uitgevoerd te worden. In structurele afspraken worden de voorwaarden scheppende zaken geregeld, zoals de financiering van de zorg, bij wie zorgverleners in dienst zijn, enzovoorts. Deze verschillende soorten afspraken geven tegelijkertijd de meest voorkomende spanningsgebieden weer. Elke zorgverlener dient daarbij binnen de toebedeelde zorgverlenersrol de behoeften van de patiênt en de mogelijkheden van de organisatie in evenwicht te brengen.

CMTZ thuis past ook binnen de definitie van Nationale Raad voor de Volksgezondheid en het College voor Ziekenhuisvoorzieningen in het advies "Transmurale somatisch zorg": "Transmurale zorg omvat vormen van zorg die, toegesneden op de behoefte van de patiênt, verleend worden op basis van afspraken over samenwerking, afstemming en regie tussen generalistisch en specialistische zorgverleners, waarbij sprake is van een gemeenschappelijk gedragen verantwoordelijkheid met expliciete deelverantwoordelijkheden". ${ }^{187}$ Deze definitie is echter abstracter en de vormgeving vanuit de beroepsgroepen en organisaties staat centraal. Ook is er geen aandacht voor structurele factoren.

\subsection{Conclusies}

Bij CMTZ thuis kunnen vanwege de zelfzorgbehoeften dusdanige kennis en vaardigheden benodigd zijn, dat patiënten en hun naasten daarin niet alleen, doch slechts gezamenlijk met verpleegkundigen en artsen op een substantieel en functioneel rationele wijze kunnen voorzien.

Het zorgproces kan vanwege de vereiste deskundigheid en samenwerking, continuitteit en flexibiliteit, bereikbaarheid en beschikbaarheid én het kostenaspect, worden vormgegeven door een team van specifiek deskundige verpleegkundigen die echelon overstijgend werkzaam zijn in een 24-uurs dienst. Zij dienen daarin nauw samen te werken met huis- en instellingsartsen, apothekers, technici en eventuele andere zorgverleners vanwege de flexibiliteit en de mogelijkheid om op specifieke deskundigheid terug te kunnen vallen. Een transmurale zorgorganisatie biedt de mogelijkheid om CMTZ thuis vorm te geven. 
ZORGMODEL 


\section{Selectie van doelgroepen en patiënten}

\subsection{Doel van selectiecriteria (fase 1)}

De zorginnovatie is gestart met aandachtspunt 1 binnen hoofdvraagstelling 1 betreffende de potentiěle doelgroepen, individuele criteria ter selectie van patiënten en schatting van de aantallen patiënten. Voorafgaand aan het project zijn binnen het azM potentiěle patiëntengroepen geldentificeerd. Er bleken geen uniforme selectiecriteria voorhanden. Daarom zijn deze naar analogie van de innovatiemethodiek (schema 2.5) bestudeerd.

\subsection{Analyse van selectiecriteria (fase 2)}

Bij het opstellen van selectiecriteria is geput uit binnen- en buitenlandse ervaringen met CMTZ. Deze zorg maakt nogal eens deel uit van frequente en langdurige behandelingen bij chronische patiënten. Bij CMTZ thuis zijn selectiecriteria op twee niveau's te onderscheiden: ten aanzien van patiëntengroepen en ten aanzien van individuele patiënten. Bij patiëntengroepen lijken van belang: voorkomen, duur en ernst van de aandoening; ernst en complexiteit van de (co)morbiditeit en de daarbij benodigde diagnostiek en/of behandeling; inhoud, frequentie, duur, bijwerkingen en acute complicaties van de behandeling en daarbij behorende controles; technologische en organisatorische complexiteit van de behandeling; zelfzorgvermogen. Bij de individuele patiënt lijken van belang: een adequaat begripsvermogen; emotionele en psychische stabiliteit; elementair inzicht in de aandoening en behandeling; voldoende verantwoordelijkheidsgevoel; toereikende huisvesting (ergonomisch en hygiënisch); genoeg ondersteuning door naaste verzorger(s).

\subsection{Perspectief op selectiecriteria (fase 3)}

Ziekenhuisopname geschiedt in de regel ten behoeve van specialistische behandeling. Hoog gekwalificeerd en gespecialiseerd personeel en complexe technologie staan de specialist 24 uur per dag terzijde en er is een korte responstijd op veranderingen. Deze uit de functie en schaalgrootte van het ziekenhuis voortvloeiende infrastructurele voordelen kunnen thuis niet geëvenaard worden. De mogelijkheden tot uitgebreide diagnostiek, behandeling, verzorging en bewaking alsook een korte responstijd vervallen of zijn slechts in beperkte mate of tegen hoge kosten te realiseren. Bij CMTZ thuis, staan de aanpassing van behandeling en techniek ten behoeve van de toepassing thuis op de voorgrond. Uitgangspunt bij het opstellen van de selectiecriteria was dan ook om de patiënt en/of diens naaste verzorger(s) zoveel mogelijk zorg zelf te (kunnen) laten uitvoeren. De inzet van professionele zorg zou zoveel mogelijk geschieden vanuit de thuiszorg met ondersteuning door het ziekenhuis. Het project heeft zich niet beperkt tot chronische 
patiënten, waarvoor momenteel in de gezondheidszorg veel aandacht bestaat. Technisch gezien zijn ook kortdurende of eenmalige behandelingen thuis mogelijk, maar overige behandelingsvereisten bepalen de haalbaarheid.

\subsection{Concept bij selectiecriteria (fase 4)}

Op basis van literatuurstudie en binnen de projectgroep aanwezige kennis, zijn vanuit de aandachtspunten (schema 1.3; worden tussen haakjes vermeld) selectiecriteria voor CMTZ thuis opgesteld voor doelgroepen (schema 7.1) en individuele patiënten (schema 7.2).

\subsubsection{SELECTIECRITERIA VOOR DOELGROEPEN}

Bij de doelgroepen (schema 7.1 hier kort toegelicht, volledige lijst bijlage 7.1) zijn de in aanmerking komende patiěnten (1) en kenmerken van hen en hun naasten (6) onderzocht. De ernst van de pathologie is ingeschat aan de hand van de complexiteit (comorbiditeit), de noodzaak tot stringente behandeling of hospitalisatie, complicaties en interventiemogelijkheden en de prognose van plotseling overlijden. Van de behandeling zijn inhoud, frequentie, duur, toedieningstijdstippen, bijwerkingen, complicaties en effecten van foutief handelen geinventariseerd. Om het zelfzorgend vermogen te bepalen is nagegaan in welke

Schema 7.1 Criteria ter selectie van doelgroepen voor complexe medisch-technische zorg thuis.

\begin{tabular}{|c|c|}
\hline Onderwerp & Items \\
\hline \multicolumn{2}{|c|}{ Keuze doelgroepen en omschrijving criteria $(1,6)$ plus inschatting effecten op levenskwaliteit en kosten $(7,9)$} \\
\hline Pathologie & $\begin{array}{l}\text { ernst en complexiteit (co)morbiditeit; prognose overlijden; prognose acute } \\
\text { complicaties; behandelmogelijkheden acute complicaties; hospitalisatie }\end{array}$ \\
\hline Behandeling + Effecten & $\begin{array}{l}\text { behandeling; frequentie; duur, toedieningstijdstippen; bijwerkingen en } \\
\text { complicaties; effecten foutief handelen }\end{array}$ \\
\hline Patient + Naaste verzorger(s) & leeftijdscategorie; woonsituatie; leefsituatic \\
\hline Maatschappelijke relevantie & $\begin{array}{l}\text { incidentie en prevalentie; landelijk en regionaal aantal behandelingen; } \\
\text { beinvloeding kwaliteit van leven; beìnvloeding levensverwachting; effecten } \\
\text { op kosten; publieke opinie; overall maatschappelijke relevantie }\end{array}$ \\
\hline Evaluecrbaarheid & $\begin{array}{l}\text { resultaten eerder onderzoek; wetenschappelijke relevantie onderzoek; } \\
\text { randomisatie mogelijkheid; belasting onderzoek; behoefte, belasting en } \\
\text { financiering aanvullend gewenst onderzoek }\end{array}$ \\
\hline
\end{tabular}

Technische voorzieningen en hulpmiddelen (5)

Technische voorzieningen complexiteit techniek; behoefte monitoring; behoefte overige technologie

Hulpmiddelen verplecghulpmiddelen; aanpassingen in de woning

Protocollering van de zorgverlening (2)

Behandeling

intensiteit behandeling: deskundigheidsniveau patient en naaste verzorger(s); medisch en verpleegkundig deskundigheidsniveau; indicatie gezinsverzorging, fysiotherapie en/of psychosociale begeleiding

Logistick instroom patiênten; medicatie en overige benodigdheden; medische en verpleegkundige overdracht; medische en verpleegkundige bereikbaarheid

Organisatic organisatorische complexiteit; taakverdeling

Samenwerking kliniek motivatie; werkdruk; instructie; overdracht

Informatievoorziening en deskundigheidsbevordering (3)

Informatievoorziening informatiebehoefte

Deskundigheidsbevordering

scholingsbehoefte

Financiering ( $\$$ )

Financiering

financiering thuisbehandeling; vergoeding huisarts en specialist 
leeftijdscategorie, woonsituatie (zelfstandig of institutioneel) en leefsituatie (gezinsfase, activiteitenpatroon) de meeste patiënten en hun naaste verzorger(s) zich bevinden. De maatschappelijke relevantie is gedefinieerd in termen van de incidentie en prevalentie van de aandoening, het potentieel aan landelijke en regionale behandelingen en de te verwachten publieke opinie. Op grond van deze factoren heeft de projectgroep de 'overall' relevantie ingeschat. Omdat het hier tevens een onderzoeksproject betrof is ook gekeken naar de wetenschappelijke relevantie. Daarom zijn ten aanzien van de evaluatie de vorm en resultaten van eerder onderzoek, de relevantie ervan voor de diverse beroepsgroepen, de mogelijkheid tot randomisatie, de behoefte aan en belasting van aanvullend onderzoek in kaart gebracht. Deze zijn bij zorgvernieuwingsprojecten zonder onderzoeksdoelstelling niet van belang. Op het gebied van de technische voorzieningen en hulpmiddelen (5) zijn bezien de technologische complexiteit, de behoefte aan monitoring en de eventuele noodzaak van toepassing van overige technologie, verpleeghulpmiddelen of aanpassingen

Schema 7.2 Selectiecriteria voor individuele patienten bij complexe medisch-technische zorg thuis.

Patientgebonden medische factoren $(1,6)$

- Afhankelijk van soort behandeling: goede reactic patiènt op behandeling in ziekenhuis alvorens voortzetting thuis;

- Geen (andere) pathologie die onderzoek of behandeling in ziekenhuis vereist;

- Geen (andere) pathologie of functiebeperking die de voor thuisbehandeling vereiste zelfredzaamheid -met name waarneming, mobiliteit en communicatic- ernstig belemmert,

- Geen middelenmisbruik.

Patientgebonden persoonlijke factoren $(1.6)$

- Intelligentie: mogelijkheid om kennis van en inzicht in ziekte, behandeling en techniek te verwerven;

- Psychische draagkracht: vermogen om eventuele stress van de thuisbehandeling te hanteren;

* Motivatie: ondersteunt keuze thuisbehandeling;

- Verantwoordelijkheidsgevoel: acceptatie van medeverantwoordelijkheid voor de zorg voor zichzelf.

Omgevingsfactoren $(1,6)$

* Woonsituatie geêigend (te maken);

- Hygiéne gewaarborgd;

- Telefoon of vergelijkbare communicatievoorziening;

* Betrokken naaste verzorgers:

-fysieke en psychische draagkracht;

-basale kennis van en inzicht in ziekte, behandeling en techniek;

-motivatie en verantwoordelijkheidsgevoel;

-tijdens behandeling aanwezig indien professionele zorgverleners afwezig, of vergelijkbare alarmvoorziening;

- Zo nodig huishoudelijke hulp door naaste of gezinsverzorgende.

Zorginhoudelijke factoren $(2,3,5)$

* Toedieningssysteem, dosering en toedieningssnelheid veilig en geprotocolleerd (bij infusie);

- Duur, frequentic en zorginhoud afhankelijk van soort behandeling enerzijds en individuele situatie van patient en naaste verzorgers anderzijds;

- Uitvoering medisch-technische handelingen door arts of door verpleegkundige onder diens verantwoordelijkheid of door naaste verzorger of patient;

- Deskundige (kennis), bekwame (praktische vaardigheid) en bevoegde (wettelijk geregeld) verpleging en verzorging.

Organisatorische factoren (2)

- Indicatiestelling voor thuisbehandeling vastgelegd: medisch, persoonlijk, omgeving, zorginhoudelijk, organisatorisch en financieel;

- Gezamenlijk zorgprogramma met verdeling van taken en verantwoordelijkheden vastgelegd in een zorgplan. Bij voorkeur een zorgcoðrdinator.

Financiële factoren (4)

- Financiering van produkten en diensten geregeld. 
in de woning. Voor de organisatie van de zorgverlening (2) is de uitgebreidheid en complexiteit van de behandeling onderzocht. Daartoe is gekeken naar de voorspelbaarheid van de instroom, de benodigde medicatie en infuusbenodigdheden, de medische en verpleegkundige overdracht, de benodigde medische en verpleegkundige bereikbaarheid en de interdisciplinaire taakverdeling. Vanwege het streven naar samenwerking met en ondersteuning vanuit het ziekenhuis zijn de motivatie, de werkdruk, de mogelijkheden tot instructie van patiënten en hun naaste verzorger(s) en de mogelijkheden tot overdracht onderzocht. Verder zijn de belastbaarheid van patiēnten en hun naaste verzorger(s) en de indicatie voor gezinsverzorging, fysiotherapie of psychosociale begeleiding bekeken. Op basis van de intensiteit van de behandeling en het vereiste deskundigheidsniveau is getracht een indruk te verkrijgen van de informatie- en scholingsbehoefte (3) van de patiënten, hun naaste(n) en zorgverleners. De financiering (4) is onderzocht op basis van de te verwachten inzet van mensen en middelen. Binnen de maatschappelijke relevantie zijn ook de mogelijke effecten op de kwaliteit en de duur van het leven (7) en de kosten van thuisbehandeling (9) ten opzichte van hun ziekenhuisalternatief (dagbehandeling of opname) globaal geînventariseerd. De kwaliteit van zorg is niet vooraf onderzocht (8).

\subsubsection{SELECTIECRITERIA VOOR INDIVIDUELE PATIENTEN}

Vanuit de aandachtspunten zijn tevens zes clusters van selectiecriteria voor individuele patiënten geformuleerd uiteenlopend van patiëntgebonden medische tot financiēle factoren (schema 7.2). Daarnaast zijn drie exclusiecriteria geformuleerd. Ten eerste aandoeningsen behandelspecifieke criteria $(\$ 12.3)$. Ook het wonen buiten de regio 'Heuvelland' (bijlage 1.1) was een exclusiecriterium. Buiten de onderzoeksregio werd zo mogelijk ondersteuning gegeven bij de realisatie van de thuisbehandeling. Tot slot was er sprake van exclusie indien de zorgverzekeraar (een deel van) de kosten niet wilde vergoeden.

\section{5}

\section{Verspreiding en toepassing van selectiecriteria (fase $5+6$ )}

\subsubsection{VERSPREIDING EN TOEPASSING VAN SELECTIECRITERIA VOOR DOELGROEPEN}

Uit de inventarisatie onder specialisten van het azM voorafgaand aan het project kwamen als doelgroepen naar voren: patiënten die behandeld werden met cytostatica, pijnbestrijding, voeding, dopamine (hartfalen) of heparine (trombose) ${ }^{310}$ Uit de literatuur kwamen als doelgroepen naar voren patiēnten in aanmerking komend voor epidurale en peridurale pijnbestrijding en parenterale toediening van chemotherapie, antibiotica, antimycotica, virostatica, immunoglobulines, bloedtransfusies, heparine, dopamine en voeding. Diverse potentielle doelgroepen binnen het azM zijn op basis van de opgestelde criteria gescreend. Daartoe zijn de selectievragen (bijlage 7.1) in interviews aan de betreffende medische en de verpleegkundige disciplines voorgelegd. Waar relevant zijn ook andere paramedische disciplines geînterviewd. Aan de hand van deze tweede inventarisatie is in de projectgroep gekozen voor doelgroepen waarvoor concrete voorstellen uitgewerkt zouden worden en de volgorde waarin. Een en ander is met de betrokkenen besproken. Bijlage 7.2 vat de resultaten in tabelvorm samen of verwijst naar uitgebreidere bespreking elders. Hieronder volgt per doelgroep een toelichting. $\mathrm{Bij}$ de omrekening van de regionale naar de landelijke cijfers of omgekeerd wordt altijd gebruikt gemaakt van de verhouding tussen het aantal inwoners van de onderzoeksregio (208.623) en het aantal inwoners van Nederland (15.341.553) tijdens de studie. ${ }^{311}$ Dit wordt aangeduid met omrekening gevolgd door het uitgangsgetal. 


\subsubsection{Morfinomimetica bij terminale patiênten}

Terminale zorg thuis neemt in omvang toe nu men er weer naar streeft de laatste levensfase zo veel mogelijk in de eigen vertrouwde omgeving temidden van familie en vrienden door te brengen. ${ }^{5,6,312}$ Terminale zorg (thuis) omvat onder andere pijnbestrijding. ${ }^{313}$ De meeste terminale patiënten die pijnstilling behoeven, hebben kanker. Pijn (71\%) komt bij hen na gewichtsverlies (77\%) het meest frequent voor. ${ }^{314} \mathrm{Bij}$ ongeveer $90 \%$ van de patiënten kan de pijn medicamenteus verlicht worden. ${ }^{315}$ Uit onderzoek van Dorrepaal kwam naar voren dat bij ongeveer de helft van de kankerpatiènten de pijnbestrijding tekort schiet. ${ }^{316}$ In deze studie zijn de mogelijkheden tot infusie van morfinomimetica bestudeerd $(\$ 12.3 .1)$.

In Nederland is de incidentie van kanker 60.000 per jaar en de prevalentie $0,7 \%( \pm 20-25$ per huisartspraktijk). ${ }^{317.319}$ Van de 130.000 mensen die er per jaar overlijden, sterven er ongeveer 35.000 aan kwaadaardige nieuwvormingen. ${ }^{314}$ Van de kankerpatiënten overlijdt volgens Wagenaar c.s. $45 \%$ thuis, $35 \%$ in het ziekenhuis, $10 \%$ in een verpleegtehuis en $10 \%$ elders. ${ }^{6}$ Volgens Everveen overleden in 1994 daarentegen maar zo'n 8.000 kankerpatiěnten thuis $( \pm 25 \%) .{ }^{320}$ Uitgaande van 8.000 thuis overlijdende kankerpatiènten waarvan $70 \%$ pijn heeft die in $90 \%$ medicamenteus behandeld kan worden en bij $50 \%$ in de terminale fase tekort schiet, zouden maximaal zo'n 2.500 patiěnten voor parenterale pijnbestrijding met morfinomimetica in aanmerking kunnen komen $(8.000 \times 0,7 \times 0,9 \times 0,5)$. Indien thuis evenals in het ziekenhuis adequate pijnstilling mogelijk is, valt te verwachten dat meer patiënten thuis willen sterven. Ook door demografische ontwikkelingen zal het aantal patiënten dat thuis sterft toenemen. ${ }^{112,321}$ Indien de helft van de kankerpatiënten thuis sterft, komen van hen per jaar maximaal zo'n 5.500 voor parenterale pijnbestrijding in aanmerking $(0,5 \times 35.000 \times 0,7 \times 0,9 \times 0,5) .{ }^{321}$ Meyler noemt een aantal van 2.500 patiënten waarbij parenterale infusietechnieken geïndiceerd zijn voor een afdoende pijnbestrijding in de terminale fase. ${ }^{315}$ De stichting Ziekenhuis Verplaatste Zorg rekent op vier- tot achtduizend patiënten voor pijnbestrijding. ${ }^{322}$

In de DGD regio 'Zuidelijk Zuid-Limburg' met 182.215 inwoners overleden er in 1991 234,9 per 100.000 aan kwaadaardige nieuwvormingen. ${ }^{31,}{ }^{323}$ De projectregio 'Heuvelland' omvat ook de gemeenten Gulpen, Vaals en Wittem (26.408 inwoners), waardoor het verwachte aantal ongeveer 500 bedraagt, ongeveer gelijk aan de 476 geschat via landelijke cijfers (omrekening: 35.000 ). In de projectregio (66 huisartspraktijken) overlijden per praktijk jaarlijks zeven à acht mensen aan kanker, waarvan ongeveer de helft thuis of in een verzorgingshuis. ${ }^{324}$ Per jaar zal per praktijk bij 1,2 patiënt ( \pm 75 in totaal) een indicatie bestaan voor morfine-infusie (patiënt $\mathrm{x}$ thuis $\mathrm{x}$ pijn $\mathrm{x}$ tekortschieten $=7,5 \times 0,45 \times 0,7 \times 0,5$ ).

\subsubsection{Mannitol bij sympathische reflexdystrofie}

In Nederland is mannitolinfusie bij sympathische reflexdystrofie (SRD) één van de gangbare behandelingsvormen. ${ }^{325,}{ }^{326}$ In het onderhavige onderzoek zijn de mogelijkheden tot infusie thuis nader bestudeerd $(\$ 12.3 .2)$.

Ten aanzien van de epidemiologie van SRD zijn nog geen prospectieve studies gedaan. De lichter verlopende gevallen van SRD worden lang niet altijd gepresenteerd of herkend. Het is dan ook niet bekend hoeveel patiënten met SRD er onder de Nederlandse bevolking zijn. De gerapporteerde incidentie van SRD bedraagt $1-2 \%$ na fracturen, $2-5 \%$ na een perifeer zenuwletsel en $7-35 \%$ na een Collesfractuur. ${ }^{327-330}$ Goris c.s. schatten de incidentie van SRD in Nederland op 7.500 patiënten per jaar. ${ }^{331}$ Door de groeiende aandacht voor SRD, zal de diagnose vaker gesteld worden. ${ }^{332,333}$

Bij aanvang van het project was het landelijk behandelpotentieel voor mannitolinfusie bij 
SRD patiênten slechts bij benadering te schatten. In 1991 zijn 367 patiënten (437 maal hoofd- en nevendiagnose) met SRD (ICD-9 code 733.7) gedurende 5.292 dagen

(gemiddeld 14) in het ziekenhuis behandeld en in 1993659 patiënten ( 774 maal hoofd-en nevendiagnose) gedurende 8.536 dagen (gemiddeld 13). ${ }^{334}$ Ook was in 1993 bij 2.261 dagbehandelingen SRD de hoofddiagnose. ${ }^{326,335}$

Vanwege de bovenregionale functie hebben in het azM jaarlijks zo'n 120 behandelingen plaats (afdeling en dagcentrum). ${ }^{326}$ Dit betreft vrijwel uitsluitend mannitolinfusie.

Regionaal zouden in de regio 'Heuvelland' volgens de incidentiecijfers van Goris, per jaar zo'n 102 nieuwe gevallen van SRD optreden (omrekening: 7.500). ${ }^{336}$ Uitgaande van de behandelcijfers zouden regionaal per jaar vanuit de kliniek maximaal (alle opgenomen patiënten ontvangen mannitolinfusie) negen patiěnten (omrekening: 659) voor 11 behandelingen (omrekening: 774) in aanmerking komen plus een onbekend aantal patiênten van de 31 dagbehandelingen (omrekening: 2.261). Hoewel voornoemde cijfers niet eenduidig zijn, kon geschat worden dat er in de regio 'Heuvelland' (66 huisartspraktijken) jaarlijks maximaal tussen 40 à 100 thuisbehandelingen met mannitolinfusie bij SRD patienten zouden kunnen plaatsvinden. ${ }^{324}$ Ongeveer één behandeling per huisartspraktijk per jaar.

\subsubsection{Antibiotica}

De indicaties voor intraveneuze behandeling met antibiotica veranderen door de ontwikkeling van nieuwe soorten antibiotica, het beschikbaar komen van orale vormen van voorheen alleen parenteraal toe te dienen antibiotica en veranderingen in resistentiepatronen. Er zijn geen grote doelgroepen te identificeren. ${ }^{377}$ In dit onderzoek zijn de mogelijkheden tot infusie van antibiotica thuis nader bestudeerd $(\$ 12.3 .3)$.

Een duidelijk af te grenzen doelgroep bleken de patiēnten met Cystic Fibrosis (CF). Binnen de doelgroep kinderen leken alleen kinderen met CF qua omvang en frequentie van de behandelingen ( \pm 15 deels referentiepatienten per jaar) in aanmerking te komen voor de ontwikkeling van een thuisbehandeling. ${ }^{338,}{ }^{339}$ De gemiddelde levensverwachting van $\mathrm{CF}$ patiěnten zal rond 2.000 zo'n 40 jaar zijn. In Europa schommelt de incidentie van CF tussen 1:2.000 en 1:2.600, in Nederland rond de 1:3.600 levend geborenen. ${ }^{340.341}$ Landelijk zijn er zo'n 1.000 CF-patiënten bekend. ${ }^{341} \mathrm{Al}$ in 1984 bleek in het buitenland thuisbehandeling in vergelijking met ziekenhuisbehandeling door CF patiënten geprefereerd te worden en geen verschillen in herinfectie of verbetering in geforceerd expiratoir éen-secondevolume op te leveren. ${ }^{362}$ Ook in Nederland waren voorwaarden voor thuisbehandeling geformuleerd. ${ }^{117,343}$ In Nederland blijkt antibiotica-infusie bij CF-patiënten goed mogelijk en treden er wat betreft gemiddelde veranderingen in vitale capaciteit, geforceerd expiratoir één-secondevolume, en de verandering in lichaamsgewicht voor en na een behandeling géén verschillen op bij dezelfde patiënten die eerst in het ziekenhuis en later thuis behandeld zijn. ${ }^{341}$ Thuisbehandeling met continue in plaats van intermitterende toediening van ceftazidim bij Pseudomonas aeruginosa blijkt de klinische toestand en de kwaliteit van leven statistisch significant te verbeteren. ${ }^{344}$

Landelijk werd het aantal voor intraveneuze thuisbehandeling in aanmerking komende patie̋nten op zo'n 40 en het aantal behandelweken op zo'n 500 per jaar geschat. ${ }^{343} \mathrm{Bij}$ nadere analyse bleken er in de onderzoeksregio maar vier potentięle patiënten te wonen. ${ }^{339}$ De behandeling bestond in het azM veelal uit een breedspectrum B-lactam antibioticum viermaal daags en eventueel een aminoglycoside één tot tweemaal daags. ${ }^{340}$ Vanuit het Wilhelmina Kinderziekenhuis en het KITTZ waren specifieke thuiszorgprogramma's voor $\mathrm{CF}$ in ontwikkeling. ${ }^{345-34}$ In overleg met de afdeling kindergeneeskunde is daarom besloten 
geen apart thuiszorgprogramma voor CF-patiěnten te ontwikkelen, maar hen net als andere antibioticabehandelingen ad hoc in te plannen $(\$ 12.3 .3)$. Het project verzorgde de technische en administratieve afhandeling bij IT, het CF-team en professionele zorgverleners in de thuiszorg de overige multi-disciplinaire behandeling. ${ }^{303}$

\subsubsection{Xanthinederivaten en corticosteroìden bij COPD}

Op grond van de omvang van de patientenpopulaties en de ernst van de aandoeningen is er in eerste instantie voor gekozen om de mogelijkheden tot thuisbehandeling bij Chronic Obstructive Pulmonary Disease (COPD) en niet bij astma te onderzoeken. ${ }^{349}$ Van astma en COPD samen wordt de incidentie op $11 \%$ per jaar en de prevalentie op $80 \%$ geschat. ${ }^{350,351}$ Bij COPD in de huisartspraktijk wordt de incidentie op 2-3\% per jaar en de prevalentie op $12-19 \%$ geraamd. ${ }^{352}$ Landelijk is in 1993 bij 55.776 opnames COPD ( $\approx$ ICD codes 490-492,496) 22.253 maal als hoofd-en 33.523 maal als nevendiagnose opgegeven (stijging van $12 \%$ ten opzichte van 1990 ). ${ }^{334,}, 353$ Er wordt een prevalentiestijging van $23 \%$ tussen 1990 en 2005 verwacht en een afname van onderdiagnostiek van $50 \%$ tot $25 \%$. ${ }^{350}$ In de projectregio zal de toename vanwege de hogere gemiddelde leeftijd nog hoger zijn. Met de vakgroep longziekten zijn de mogelijkheden voor intraveneuze toediening van xanthinederivaten en corticosteroìden thuis onderzocht. ${ }^{344}$ Hierbij bleek dat de indicatiestelling voor orale versus parenterale versus respiratoire behandeling van COPD met corticosteroiden en xantinederivaten ter discussie stond. Het toedienen van een stootdosis aminofylline op de eerste hulp werkte bijvoorbeeld contraproductief. ${ }^{355}$ Tevens leken patiěnten selectiever opgenomen te kunnen worden op geleide van peakflowmeting. ${ }^{356}$ Tijdens de concretisering van het protocol heeft de vakgroep longziekten dan ook haar behandelingsbeleid herzien. De voor IT in aanmerking komende COPD-patiënten, vielen grotendeels samen met de patiënten die geen opname meer zouden behoeven. Het was te voorzien dat het ontwikkelen en evalueren van deze vorm van thuiszorg, achterhaald zou worden door deze nieuwe therapeutische inzichten. Een deel van de COPD-patiënten zal ook in de toekomst parenterale behandeling behoeven. Hun klinische toestand is echter doorgaans dermate instabiel dat, gelet op de eisen wat betreft klinische monitoring, snelle therapie-aanpassing en intensieve betrokkenheid van fysiotherapie en diëtetiek, thuisbehandeling onverantwoord is. ${ }^{357}$

\subsubsection{Heparine bij diep veneuze trombose}

De incidentie van diep veneuze trombose bedraagt $1-2 \%$ per jaar. ${ }^{358}$ Tijdens de inventarisatie was bij de behandeling de waarde van heparinetoediening gedurende vijf dagen aangetoond. ${ }^{359,360}$ Incidenteel waren patiënten thuis behandeld met continue intraveneuze infusie. ${ }^{361-363}$ Aantallen van voor thuisbehandeling in aanmerking komende patiënten met een diep veneuze trombose van het been waren moeilijk in te schatten (ICD codering 453 en 453.8 niet consequent toegepast). Ook zouden nogal wat patiënten niet voor thuisbehandeling in aanmerking komen vanwege andere daaraan ten grondslag liggende pathologie. Ook bleek het instellen op de juiste heparinedosering individueel bepaald en zou tussentijds bewaakt (laboratoriumbepalingen) en op grond daarvan regelmatig bijgesteld dienen te worden. Zo'n kwart van de patiënten zou voor thuisbehandeling in aanmerking komen. ${ }^{337}$ Ten slotte leken de eerste behandelingen met laag moleculair heparine (tweemaal daagse subcutane injectie zonder laboratoriumbewaking) in plaats van met standaard heparine hoopgevend. ${ }^{135,358}$ In overleg met de werkgroep hematologie is daarom besloten deze intraveneuze thuisbehandeling niet te ontwikkelen. ${ }^{337}$ 


\subsubsection{Hartmiddelen: dopamine en lasix (furosemide) bij chronisch hartfalen}

De incidentie en prevalentie van en het ziekenhuisgebruik vanwege hartfalen stijgen in Nederland gestaag. ${ }^{364}$ De prevalentie van hartfalen in het Registratienet Huisartspraktijken is $6,75 \%{ }^{365}$ In Nederland worden per jaar ongeveer 25.600 patienten met hartfalen (ICD 428 ) opgenomen met een gemiddelde verpleegduur van 15,3 dagen. Hiervan overlijden er jaarlijks ongeveer $4.000 .^{334}$ De vijfjaars overleving van alle patiênten met hartfalen is $50 \%$ of minder, voor patiënten met NYHA III is de éénjaars overleving $60-65 \%$ en bij NYHA IV zelfs minder dan $50 \%{ }^{364}$ In deze studie gaat het binnen de groep patięnten met hartfalen om patienten met chronische decompensatio cordis. ${ }^{366,}{ }^{367}$ Deze worden vaak langdurig in het ziekenhuis opgenomen voor uitsluitend palliatieve therapie. Aanvankelijk ging het behandelend specialisme uit van 3.000 tot 4.000 patiënten in Nederland..$^{368}$ In dit onderzoek zijn de mogelijkheden tot infusie van hartmiddelen nader bestudeerd $(\$ 12.3 .4)$. In het azM is in het dagcentrum en de short-stay afdeling plaats voor maximaal tien patienten (x2 behandelingen per week x 52 weken=maximaal 1.040 zonder uitval). In 1993 werden hiervan 720 behandelingen gerealiseerd (overlijden, vakantie, implantatie centraalveneuze poort, ziekenhuisopname) ${ }^{369}$ Schattingen over potentiële aantallen patiënten waren moeilijk te geven.

\subsubsection{Virostatica bij cytomegalle-retinitis}

In Nederland zijn in diverse regio's virostatica via een centraalveneuze poort toegediend. ${ }^{106,107,370,371}$ Het betreft met name ganciclovir en foscavir bij AIDS-patiênten. Gezien de toxiciteit dient men met deze middelen om te gaan als met cytostatica. ${ }^{372}$ Voor bepaling van het landelijk potentieel zijn van belang de incidentie van AIDS (4.288 in 15 jaar $=286$ per jaar, afgerond 300 ) in combinatie met de overleving (één jaar $47 \%$, twee jaar $24 \%$ ) of de geschatte prevalentie $( \pm 1.500){ }^{373-375}$ Daarnaast spelen een rol percentages patiënten die zo wie zo niet doorverwezen willen worden naar de specialist ( $2 / 29 \approx 7 \%$ ), die een CMV-infectie hebben (onbekend), die niet met antiretrovirale middelen behandeld willen worden $(4 / 29 \approx 14 \%)$, die na instelling in het ziekenhuis verder parenterale behandeling behoeven (onbekend), die thuisbehandeling verkiezen (onbekend) en die hiervoor in aanmerking komen (onbekend) ${ }^{375}$ Stelt men elk onbekend percentage op $75 \%$, dan resulteert dit per jaar op maximaal tussen de $150(300 x\{1+1 / 2+1 / 4+.\}$. x93\%x75\%x86\%x75\%x75\%x75\%) en de $375(1.500 \times 93 \% x 75 \% x 86 \% x 75 \% \times 75 \% x 75 \%$ ) patienten die langdurig virostatica voor CMV-retinitis behoeven (bij de start van het project alleen parenteraal mogelijk). Het grootste deel van de patiënten woont in de Randstad. ${ }^{376}$ De samenstelling van de regionale patiěntenpopulatie (percentage besmetting via onveilig spuitgedrag hoger dan landelijk) verkleint bovendien de mogelijkheden tot thuisbehandeling. ${ }^{37,378}$ Daarom is, gezien het geringe aantal regionaal te verwachten behandelingen en de expertise elders, in overleg met het AIDS-team gekeken of een algemeen voor centraalveneuze infusie thuis te ontwikkelen protocol ook aangepast kon worden voor toediening van virostatica. Gezien de vergelijkbaarheid van de infusietechniek en de geringe incidentie wordt deze behandeling niet uitgebreid besproken.

\subsubsection{Cytostaticatoediening bij kankerpatiēnten}

Behandeling met cytostatica thuis in plaats van in het ziekenhuis kan een betere kwaliteit van leven geven. ${ }^{379}$ Ook in Nederland is thuisbehandeling niet nieuw. ${ }^{380,}, 381$ Sommige initiatieven zijn niet verder uitgewerkt of kenden een lagere dan verwachte instroom. ${ }^{92}$ Een zusterproject uit Amsterdam was gericht op chemotherapie met fluorouracil thuis. ${ }^{382}$ Een 
zusterproject uit Utrecht was eveneens gericht op kankerpatiènten en hierbinnen ontving het merendeel van de patienten een continue cytostaticabehandeling thuis. ${ }^{3 \mathrm{~s}}$ Omdat onze studie later startte, bleek uit overleg al snel dat die daarom in innovatief opzicht mogelijk minder meerwaarde zou bieden ten aanzien van cytostaticabehandelingen. ${ }^{3 \mathrm{H}}$

Vanuit het azM werd bovendien al een aantal patiěnten via de afdeling en het dagcentrum thuis behandeld. ${ }^{385} \mathrm{Zij}$ werden in het azM aan- en afgekoppeld. De interne geneeskunde garandeerde een 24-uurs bereikbaarheid en bij tussentijdse problemen kwamen de patiënten terug naar het azM. De patiënten en zorgverleners waren tevreden met deze constructie en er bestond vanuit de kliniek geen behoefte aan participatie in onze studie. ${ }^{36}$ Om met het oog op toekomstige ontwikkelingen enig inzicht te verkrijgen in de mening van de patiênt, is een dwarsdoorsnede van de patiêntenpopulatie, die in het dagcentrum cytostatica ontving, geënquêteerd (bijlage 7.3). Vrouwen en hoger opgeleiden lijken iets minder geneigd om thuis behandeld te willen worden. De mate waarin de individuele patiënt voor thuisbehandeling zou kiezen lijkt overeen te komen met een 'objectieve' inschatting van de mate waarin aan de (rand)voorwaarden voor thuisbehandeling kan worden voldaan. Er zijn drie groepen patiënten te onderscheiden: de grootste $(53 \%)$ wil thuisbehandeling en is hiervoor ook geschikt; de kleinste ( $9 \%)$ twijfelt, maar is wel geschikt; een derde (38\%) wil geen thuisbehandeling en is hiervoor veelal ongeschikt. Daarom zouden van de 205 patiēnten (gegevens 1994) die cytostaticabehandeling in het dagcentrum ontvingen, maximaal 127 (62\%) thuisbehandeling kunnen krijgen. In $23 \%$ ontvingen patiênten tevens een bloedtransfusie, hetgeen thuis moeilijker is. Dit vermindert het potentiêle aantal patiènten tot ongeveer 100 . Volgens de literatuur wordt fluorouracil het vaakst thuis gegeven. Een kwart van de patiënten ontving alleen fluorouracil. Van de 100 patiënten zouden er ongeveer 25 voor deze behandeling in aanmerking komen.

\subsubsection{Parenterale voeding}

De indicaties tot parenterale voeding verschillen per land. In Nederland zijn de mogelijkheden tot enterale voeding in ziekenhuis en thuis de laatste jaren door de verdere ontwikkeling van dieetpreparaten, sondevoeding en de PEG-catheter toegenomen ${ }^{387-389} \mathrm{De}$ voornaamste indicatie voor parenterale voeding binnen de interne geneeskunde lijkt nog steeds het onvermogen om de aangeboden hoeveelheid voedsel te verwerken, of door ziekte van het maag-darmkanaal of doordat het benodigde aanbod van voedsel in vergelijking tot de verwerkingscapaciteit te groot is. ${ }^{390,}{ }^{391}$ Binnen de heelkunde kan er een indicatie bestaan bij de (dreigend) ondervoede patiënten in de pre- of postoperatieve fase ${ }^{392}$ De discussie over indicaties bij oncologische patiënten duurt voort, maar zij lijken beperkt tot incidentele patiënten met pre-operatieve voeding of met peritonitis carcinomatosa. ${ }^{391,393,394}$ Ook in de pediatrie is parenterale voeding, zij het in andere samenstelling, mogelijk. ${ }^{395,} 396$ Thuisbehandeling van volwassenen en oudere kinderen is mogelijk via een Scribner of een Cimino shunt of een centraalveneuze poort. ${ }^{391,397-399}$ De mogelijkheden tot thuisbehandeling lijken beperkt tot patiënten met bovengenoemde 'interne' indicaties in een stabiele fase. ${ }^{400}$ In Nederland zijn dit zo'n 40 à 50 patiënten die voor een groot deel vanuit Nijmegen en Amsterdam behandeld worden. ${ }^{391}$ Omdat zij vaak de rest van hun leven van parenterale voeding afhankelijk zijn, is thuisbehandeling door professionele zorgverleners mogelijk maar niet gewenst. ${ }^{391,401}$ De patiënt zelf of diens naaste worden geïnstrueerd om de behandeling zelf uit te voeren. ${ }^{402} \mathrm{Gezien}$ de geringe incidentie is in overleg met het voedingsteam alleen onderzocht of de te ontwikkelen algemene protocollen ook geschikt gemaakt konden worden voor toediening van voeding. 


\subsubsection{Verspreiding en toepassing van individuele selectiecriteria}

$\mathrm{Na}$ bepaling van de doelgroepen en de individuele selectiecriteria, zijn deze kenbaar gemaakt aan de huisartsen, de betrokken specialisten en de verpleegafdelingen in het ziekenhuis, de medewerkers van het $\mathrm{CM}$ en de intakers van het Groene Kruis (\$9.4). Het $\mathrm{CM}$ gebruikte de instroomvoorwaarden voor een eerste selectie bij de aanmelding, de TMVs bij de verdere indicatiestelling (\$8.4.3). In de hierna volgende evaluatie wordt de patienteninstroom besproken. Verder is vanuit het oogpunt dat de zorg breed toegankelijk moet zijn de leefsituatie van het patiêntsysteem beschreven (H:13). Per toegepaste behandeling wordt aandacht besteed aan de specifieke exclusiecriteria (H:12).

\subsection{Evaluatie van selectiecriteria (fase 7)}

De toepassing van de criteria is geěvalueerd via het gebruik ervan in de praktijk. Bij de criteria voor doelgroepen ligt de nadruk op de aantallen ingestroomde patiënten, bij de individuele selectiecriteria op die criteria die thuisbehandeling verhinderden. Voor omrekeningen tussen regionale en landelijke cijfers wordt wederom de in $\$ 7.5$ genoemde verhouding gebruikt." ${ }^{31}$ Omdat het uitgangsgetal meestal in de buurt staat, wordt dit niet meer tussen haakjes vermeld. Tot slot wordt de respons van de ingestroomde patiënten, hun naasten en zorgverleners besproken.

\subsubsection{KeUze VAN DOELGRoEPEN}

Infusie van morfine en antibiotica was vanaf september 1993 mogelijk, die van mannitol vanaf januari 1994 van hartmiddelen vanaf mei 1994 (figuur 7.1). Het wegwerken van een wachtlijst voor mannitolinfusie via de thuisbehandeling veroorzaakt voorjaar 1994 een piek (overzicht van eerste en vervolgbehandelingen in figuur 8.1).

\section{Figuur 7.1 Prevalentie van soorten infuusbehandelingen.}

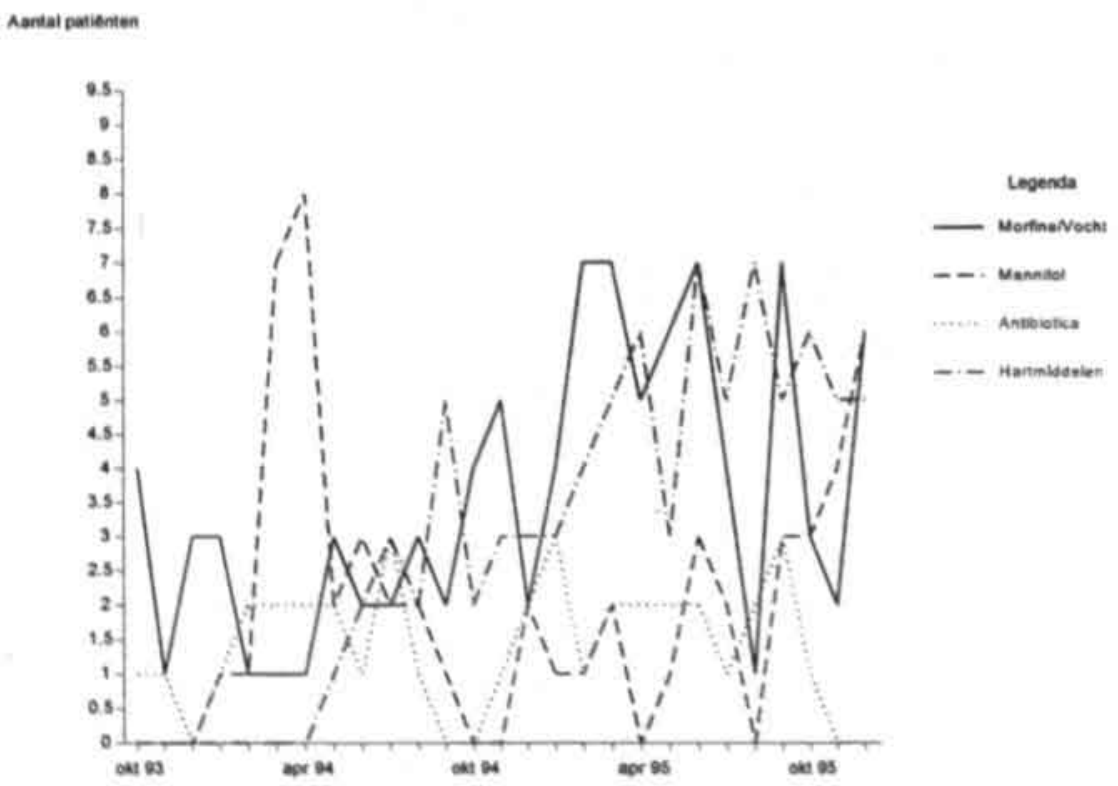


In het algemeen was de instroom kleiner dan verwacht. Oorzaken lijken evenals in het Gorinchemse project: een te optimistische inschatting van de omvang van de doelgroep door de geraadpleegde specialismen, te weinig alertheid in het ziekenhuis op potentiele patiēnten -temeer daar de instroom zich maar beperkt uitbreidde buiten de bij de ontwikkeling betrokken afdelingen en specialisten- en te weinig informatie $(\mathrm{H:12}){ }^{105}$ De schattingen ten aanzien van de morfine-infusie waren aan de hoge kant. Tussen 8 oktober 1993 en 1 januari 1996 zijn 61 patiênten 62 maal behandeld $(\$ 12.3 .1)$. Per jaar $(: 263 / 4 \times 12)$ betreft dit ongeveer 27 behandelingen bij evenveel patiěnten. Mogelijk hangt deze lage instroom samen met een te hoge schatting van het aantal gevallen waarin de pijnbestrijding tekort schiet (studie Dorrepaal uit 1989). ${ }^{316}$ Ook zijn enkele patiēnten buiten het onderzoek om behandeld. Tot slot zijn in de laatste jaren de inzichten omtrent euthanasie veranderd. De introductie van de fentanylpleister aan het eind van het project maakte een deel van de morfine-infusies overbodig.

De schattingen bij de mannitolinfusie lijken redelijk accuraat. In 1993 hebben 49 SRD-patiēnten ( 38 dagcentrum, 11 afdeling) afkomstig uit de regio 'Heuvelland' 63 maal (51 dagcentrum, 12 afdeling) mannitol gekregen. ${ }^{403}$ Tussen 21 januari 1994 en 2 januari 1996 zijn in dezelfde regio 28 patiënten (per jaar geteld 34 verschillende patiënten) 46 maal thuis behandeld $(\$ 12.3 .2)$. Per jaar betreft dit regionaal 18 patiěnten $\left(34: 231 / 2 \times 12=17 \frac{1}{2}\right)$ en 24 behandelingen $(46: 231 / 2 \times 12=23 \% / 4)$. Hetgeen jaarlijks landelijk 1.746 thuisbehandelingen bij 1.290 patiênten zou kunnen inhouden. Het jaarlijks landelijk equivalent van de in totaal 338 infusiedagen thuis (tabel B12.3.2) zou dan op ongeveer 12.800 komen en overtreft het aantal van de minimaal 10.797 verpleegdagen (ICD 733.7 klinisch of dagbehandeling in 1993). ${ }^{334}$ De groei van SRD als ontslagdiagnose duidt landelijk gezien op onderdiagnostiek. ${ }^{334,}{ }^{335}$ In de regio 'Heuvelland' zijn in 1994 en 1995 47 patiënten in totaal 56 maal opgenomen voor mannitolinfusie (tabel B12.3.2). ${ }^{404}$ Omgerekend vertegenwoordigen deze landelijk jaarlijks 1.727 patiënten met 2.059 ziekenhuisbehandelingen. Samen leveren ziekenhuis- en thuisbehandeling een totaal landelijk potentieel op van ongeveer 3.000 patiënten, 3.800 behandelingen en 23.000 infusiedagen per jaar (935 regionale infusiedagen 1993-1995 tabel B12.3.2).

De protocolontwikkeling ten aanzien van de IT van COPD patiënten heeft een katalyserende werking gehad op het debat over de uitgangspunten bij deze behandeling. De aangekondigde vervangende behandeling omvat eveneens medische technologie, verneveling middels jetstream of ultrasoon geluid, die zorgvuldige toepassing vereist. ${ }^{405-407}$ De ervaringen met emfyseempatiënten leren dat binnen geïntegreerde zorgprogramma's thuis veel mogelijk is. ${ }^{408}$

Ten aanzien van de antibiotica-infusies in het algemeen zijn vooraf geen schattingen gedaan. In de periode tussen 27 oktober 1993 en 1 januari 1996 zijn 15 patiënten 22 maal behandeld (waaronder één patiënt met CF achtmaal)(§12.3.3). Per jaar betreft dit regionaal ongeveer zeven patiënten $\left(15: 261 / 4 \times 12 \approx 6^{3} / 4\right)$. Landelijk zou dit jaarlijks uitkomen op ongeveer 500 patiënten. Omdat er voor antibiotica niet gericht doelgroepen benoemd en specialismen benaderd zijn, zijn deze cijfers waarschijnlijk aan de lage kant.

Met betrekking tot intraveneuze behandeling met heparine bij de behandeling van diep veneuze trombose ondersteunen recente meta-analyses en gerandomiseerde studies over de vergelijking met subcutaan toegediend laagmoleculair heparine het besluit om af te zien van intraveneuze thuisbehandeling met standaard heparine. ${ }^{409-414}$

Ten aanzien van de infusie van hartmiddelen zijn moeilijk schattingen te geven. In de periode tussen 26 mei 1994 en 10 januari 1996 zijn negen patiënten 30 perioden (van 
maximaal twee maanden) behandeld. Per jaar betreft dit ongeveer zes patiënten

$\left(9: 19 \% / x_{12}\right)$ en 19 behandelingen $\left(30: 19 \frac{1}{1} \times 12\right)$ van maximaal twee maanden. Ten tijde van het project zijn de infusies via het dagcentrum en de afdelingen gewoon doorgegaan (tabel B12.5.3). ${ }^{415}$ De regionale cijfers ( $697+905 / 2$ infusiedagen en $25 / 2$ patiēnten) zouden landelijk resulteren in zo'n 59.000 infusiedagen bij zo'n 900 patiěnten.

Betreffende infusie van virostatica blijkt dat door een goede preventie de incidentie van AIDS in Nederland lijkt af te nemen en er steeds effectievere therapieschema's ontwikkeld worden. ${ }^{37}$ Door het beschikbaar komen van een orale toedieningsvorm van ganciclovir in 1996 en cidofovir dat slechts eenmaal per 14 dagen parenteraal hoeft te worden toegediend, zal het aantal patienten, dat na klinische instelling parenterale thuisbehandeling behoeft, zeker kleiner worden. ${ }^{416,417}$ Binnen het project is slechts één patiënt behandeld. Belemmeringen voor de instroom vormden de beperking tot de onderzoeksregio, het bestaande protocol en ander wetenschappelijk onderzoek bij deze patiëntengroep. ${ }^{370}$ Bij cytostaticatoediening bij kankerpatiënten kunnen de opvattingen over de taakverdeling tussen specialisten, ziekenhuisverpleegkundigen huisartsen en wijkverpleegkundigen verschillen. ${ }^{418}$ Een belemmering was dat de TMVs en de huisartsen op het gebied van de oncologie niet dezelfde deskundigheid zouden kunnen bieden als specialisten en oncologieverpleegkundigen en de bestaande continulteit van zorg verstoord zou worden. ${ }^{419}$ Anderzijds zijn ook bij dit soort thuisbehandeling de vereisten voor professionals uit de thuiszorg te definiëren en hadden de TMVs reeds voldoende deskundigheid betreffende infusie. ${ }^{420}$ Ook kan vanuit de thuiszorg gemakkelijker tegemoet gekomen worden aan de andere behoeften van thuis- of in dagbehandeling behandelde kankerpatiënten. ${ }^{421}$ Temeer daar het SGKH op het gebied van de oncologie een verpleegkundig specialist en gedifferentieerd werkend wijkverpleegkundigen in dienst heeft. ${ }^{245,422}$ De mogelijkheden tot (een variant op) verdergaande samenwerking tussen ziekenhuis en thuiszorg à la Enschede lijken dus ook in de regio Heuvelland aanwezig. ${ }^{98}$ De thuiszorg voor patiënten met kanker ontwikkelt zich regionaal mogelijk dan ook anders dan voorzien door de Gezondheidsraad. ${ }^{112}$ Het ontwikkelen van thuiszorgprogramma's op dit gebied blijft echter zelfs voor 'routiniers' lastig. ${ }^{423}$

$\mathrm{Na}$ het gereedkomen van het behandelprotocol voor parenterale voeding, is er geen patiënt meer aangemeld die na beoordeling van het voedingsteam hiervoor in aanmerking kwam. Wel is één oncologische patiënt met verslechterende toestand aangemeld en één andere vanuit een ander ziekenhuis buiten het project om thuis behandeld.

\subsubsection{INDIVIDUELE SELECTIECRITERIA}

Tussen 8 oktober 1993 en 31 december 1995 zijn 155 patiěnten aangemeld. Hiervan kwamen vanwege de volgende redenen 19 patiênten niet (meer) voor thuisbehandeling binnen het project in aanmerking. Buiten de onderzoeksregio (tabel 8.1) vielen patiěnten met CF (drie), hartfalen (twee), cytomegalieretinitis (twee), antibiotica (één) en één patiênt die een infuuspomp behoefde. Driemaal kwam er een verzoek tot bloedtransfusie thuis. Omdat de toediening hiervan organisatorisch complex is (kruisproeven, gekoeld transport) en continue bewaking behoeft (infusiereacties), is -in tegenstelling tot elders- ervoor gekozen deze behandeling niet thuis maar in het dagcentrum te blijven aanbieden. Bij twee patiěnten die parenterale voeding behoefden, was er ten tijde van de aanmelding nog geen protocol voorhanden. Een patient had subcutane injecties nodig, hetgeen binnen de reguliere wijkzorg mogelijk was. Bij twee patiènten voorzag de familie uiteindelijk zelf in de gehele zorg ( $\sigma^{*} 19 \mathrm{jr}$. infusie morfine, 
$\$ 79 \mathrm{jr}$. infusie vocht), van één patiēnt verbeterde de situatie ( $\sigma^{*} 67 \mathrm{jr}$. infusie morfine) en één patiênt overleed kort na aanmelding voordat de zorg opgestart kon worden ( $\& 77 \mathrm{jr}$. infusie morfine). Dit laatste kwam ook in het Utrechtse thuiszorgtechnologie project (in $6 \%$ voor. ${ }^{3 \mathrm{~s}}$

Bij de resterende 136 aanmeldingen zijn de individuele selectiecriteria onderzocht. Bij 14 patiënten $(10 \%)$, waarvan er tien ( $71 \%$ van de uitvallers) aangemeld waren voor infusie van hartmiddelen, kon niet aan alle voorwaarden worden voldaan (bijlage 7.4). Bij acht patiënten ( $57 \%$ van de uitvallers) was er zowel een medische als een persoonlijke patiëntgebonden reden, bij zeven $(50 \%)$ voldeed de omgeving niet en bij drie $(21 \%)$ was er een zorginhoudelijke belemmering. Bij het Gorinchemse thuiszorgtechnologie project was de uitval bij de screening ongeveer even groot $(8 \%)$, met als voornaamste reden het ontbreken van voldoende mantelzorg. ${ }^{24}$ In het algemeen is de CMTZ thuis bij hantering van de hier gehanteerde in- en exclusiecriteria breed toegankelijk. Bij patiênten die infusie van hartmiddelen behoeven, komt maar de helft voor thuisbehandeling in aanmerking. Met name het ontbreken van de vereiste steun van naasten en slechthorendheid (alarmering pomp) scoren hoog. Dit laatste lijkt vooral samen te hangen met de hoge leeftijd. Uit onderzoek van Knook blijkt bijvoorbeeld dat $54 \%$ van de 85 -plussers gehoorstoornissen heeft, $47 \%$ een verminderd gezichtsvermogen en $43 \%$ een cognitieve beperking. ${ }^{42 s}$ Over niet aangemelde patienten zijn weinig gegevens beschikbaar. Het is dus zeer wel mogelijk dat zorgverleners bepaalde patiēnten niet aangemeld hebben omdat ze uit de kennis over de patiënt, uit de verspreide informatie of uit eerdere ervaringen konden bevroeden dat deze niet voor thuisbehandeling in aanmerking zouden komen.

\subsubsection{RESPONS}

Van de 155 aangemelde patiënten kwamen 19 patiënten niet (meer) voor behandeling in aanmerking en voldeden 14 niet aan de voorwaarden (\$7.6.2). Bij de resterende 122 patiënten zijn 123 eerste (één patiënt ontving mannitol eerst intra- en later centraalveneus) en 50 vervolgbehandelingen gestart. Het verloop van de behandeling en de kosten van de gezondheidszorg zijn bij alle 173 behandelingen bekend. De kwaliteit van leven en van zorg en de kosten voor de patiënten en naasten zijn na elke eerste behandeling gemeten via vragenlijsten. Bij drie patiënten is de behandeling om medisch-technische redenen vrij snel gestaakt (\$12.3), waardoor 119 patiënten resteerden voor evaluatie door de zorgverleners. Van de 68 terminale patiënten overleden er 64 tijdens de behandeling. Het betrof 60 patiënten met infusie van morfine en eventueel andere medicatie en vier met vochtinfusie. Drie antibiotica-infusies en één virostatica-infusie waren mogelijk ondanks het feit dat een naaste verzorger ontbrak en bij één infusie van hartmiddelen was geen naaste beschikbaar (infusie in verpleeghuis).

De non-respons bij de patiënten, naasten, verpleegkundigen en huisartsen heeft diverse redenen (tabel 7.3). Bij patiënten en naaste verzorgers zijn dat vooral overlijden, hoge leeftijd, ziekte, een korte behandeling of het tekortschieten van het begripsvermogen. Soms waren naasten van overleden patiënten verhuisd of konden een interview psychisch niet aan. Volgens de interviewers stond dit laatste los van de ervaringen met de IT. Bij huisartsen komt de non-respons vooral voort uit onbekendheid met de patiëntsituatie (patiënt niet of slechts eenmalig bezocht tijdens behandeling). Omdat de vragenlijsten soms niet volledig zijn ingevuld, kan de uiteindelijke respons op een bepaalde vraag of gedeelte van de vragenlijst afwijken van de aantallen uit onderstaande tabel. Vaak is daarom bij de resultaten het precieze aantal respondenten vermeld. 


\begin{tabular}{l|cccccc} 
Potentile respons & \multicolumn{7}{c}{ Non-respons } \\
& Morfine & Mannitol & Antibiotica & Hartmiddelen & Overig & Totaar $^{*}$ \\
P: $-127 / 15 / 9 / 4 / 55$ & - & $2(7)^{*}$ & 0 & $1(11)$ & 0 & $3(6)$ \\
N: $60 / 27 / 12 / 9 / 7 / 115$ & $5(8)$ & $3(11)$ & 0 & 0 & $2(29)$ & $10(9)$ \\
V: $60 / 27 / 15 / 9 / 8 / 119$ & $2(3)$ & 0 & 0 & $1(11)$ & $1(13)$ & $4(3)$ \\
A: $60 / 27 / 15 / 9 / 8 / 119$ & $6(10)$ & $3(11)$ & 0 & $2(22)$ & $4(50)$ & $15(13)$ \\
\hline
\end{tabular}

Legenda: P=patient, $\mathrm{N}$-naaste verzorger, $\mathrm{V}$-verpleegkundige, $\mathrm{A}=$ huisarts, "-maximaal aantal mogelijke respondenten per behandeling $\mathrm{en}$ in het totaal, morfine'=morfine met eventuele parenterale comedicatic, "-inclusief de medicatiegroepen vocht, anti-epileptica, virostatica en overigen,"=aantal (percentage).

\subsection{Conclusies}

Bij de introductie van CMTZ thuis zoals IT dient bij de keuze van de behandelingen ten eerste rekening gehouden te worden met behandeltechnische ontwikkelingen als nieuwe medicamenten en toedieningswijzen.

Ten tweede vergt een dergelijke keuze een genuanceerde afweging op maatschappelijke niveau van effecten op de kwaliteit van leven per patiënt(systeem), de kwaliteit van zorg en de kosten. Daarbij is een inschatting van de omvang per soort behandeling op jaarbasis van belang. Zelfs indien een redelijk betrouwbare schatting mogelijk is, beweegt zich de verhouding tussen deze schattingen en de daadwerkelijke instroom grofweg tussen de 2:1 en de 4:1. Ook in de thuiszorg is een zekere schaalgrootte vereist om de expertise van de medewerkers te waarborgen. Vanuit een inschatting van de omvang kan dan ook per behandeling gekozen worden voor uitvoering door gespecialiseerde artsen en verpleegkundigen of door de reguliere professionals in de thuiszorg. Ten slotte is ook CMTZ individuele gezondheidszorg die per patiënt(systeem) een inschatting van de haalbaarheid vergt. Ook hiervoor zijn praktisch toepasbare selectiecriteria vereist. 


\section{Organisatie van zorg ${ }^{*}$}

\subsection{Doel van organisatie van zorg (fase 1)}

De bij de diverse infuusbehandelingen thuis $(\$ 12.3)$ benodigde specifieke deskundigheden, materialen en continunteit van zorg vergen discipline- en organisatie-overstijgende intensieve samenwerking om IT te realiseren. Vanwege de vereiste sturing is organisatie van de zorgveriening onontkoombaar (\$2.4). Aandachtspunt 2 binnen hoofdvraagstelling II betreft dan ook de zorgveriening alsmede de organisatorische en logistieke protocollering. Protocollering en afstemming van zorg zijn beschouwd als instrumenten voor kwaliteitsborging en reproduceerbaarheid van handelen. ${ }^{201,27}$ Ook zijn ze aangewend in een streven naar efficiêntie. De protocollering is gericht op invoering van nieuwe activiteiten en standaardisatie van het uitvoeringsproces: zowel van individueel uit te voeren handelingen als van onderlinge afstemming van werkzaamheden. Tevens vormen protocollen en zorgafspraken de basis voor de in de volgende hoofdstukken beschreven informatievoorziening, scholing en afspraken over de financiering. Het hoofdstuk volgt de zeven innovatiefasen (schema 2.5). ${ }^{13}$ Omdat hoofdstuk 6 reeds een blauwdruk geeft voor CMTZ, worden de fasen 2 tot 4 toegespitst op IT hier kort samengevat.

\section{2 \\ Analyse, perspectief en concept bij organisatie van zorg (fase 2-4)}

Infuusbehandeling thuis, het via de bloedbaan toedienen van medicatie en/of vocht en/of voeding in de thuissituatie, is op te vatten als CMTZ. Door de toepassing van generalistische en specialistische kennis en vaardigheden is zij transmurale zorg, welke op basis van zorginhoudelijke, procedurele én structurele afspraken door zorgverleners uit de klinische en de thuiszorg gezamenlijk wordt aangeboden.

Dutrée pleit voor een kleinschalig ingerichte zorgverlening op de werkvloer, geboden vanuit brede, bestaande netwerken en gebaseerd op afspraken tussen specialisten, huisartsen, ziekenhuis- of wijkverpleegkundigen en gezinsverzorgenden. ${ }^{56}$ Enerzijds is door de complexe organisatorische vereisten -zeker in de experimentele opzet of aanloopfase- een beperking van het aantal betrokken patiënten, zorgverleners en organisaties gewenst $(\S 12.2) \cdot{ }^{138}$ Anderzijds is een voldoende grote populatie vereist, gezien de lage incidentiecijfers van voor IT in aanmerking komende ziektebeelden $(\$ 7.5) .{ }^{426} \mathrm{Het}$ azM heeft vanwege haar academische functie een groot, maar ook diffuus adherentiegebied. Het adherentiegebied van de regionaal werkende SGKH, de regio 'Heuvelland', voldeed aan voornoemde eisen om IT doelmatig en geïntegreerd te kunnen aanbieden. ${ }^{187}$

\footnotetext{
"Een bewerking van dit hoofdstuk is gepubliceerd in: Handboek Thuiszorg 1999; HAT 34/51-84 G6.4 1-34.
} 
Deze regio (bijlage 1.1) beslaat $295 \mathrm{~km}^{2}$ en heeft 208.623 inwoners. ${ }^{311}$ In deze regio vervult het azM als enig ziekenhuis tevens een streekfunctie. Bijlagen 8.1 en 8.2 geven enige structuur- en produktiekenmerken en bijlage 11.6 enkele financiële. In de regio werken 98 huisartsen in 66 praktijken in 14 huisartsgroepen en bestaat een traditie naar onderzoek op het grensvlak van generalistische en specialistische zorg. ${ }^{49-51,286,427-430}$ In het professioneel zorgproces bij infuusbehandeling (schema 6.3) ligt het accent op specifieke deskundigheid, continuiteit van zorg en intensieve samenwerking tussen de verschillende disciplines en organisaties. Bij het welslagen van CMTZ thuis kan een gespecialiseerd (wijk)verpleegkundige een belangrijke rol spelen. ${ }^{107,431}$ Omdat de uitkomsten van de enquête over de te onderscheiden medische en verpleegkundige deeltaken en de mogelijke rol voor een gespecialiseerd werkende infuusverpleegkundige dit bevestigden (\$5.3.2.2), is binnen het project gekozen voor het creëren van een dergelijke functie in de vorm van de TMV. Haar taken betroffen de indicatiestelling voor verpleegkundige en overige niet medische zorg (inclusief eventuele overdracht van ziekenhuis naar thuiszorg) voor en de verzorging van patienten met IT (schema 8.1).

Sehema 8.1 Taken van de TMV bij infuusbehandeling thuis.

- intake bij patient en naaste(n)

- overdracht van ziekenhuis naar thuiszorg en vice versa

* zorgdragen voor materialen voor infuusbehandeling en verpleging thuis

- verpleegkundige interventies waaronder medisch-technische handelingen bij infusen

- voorlichting, advisering en begeleiding patient, naaste(n) en professionele zorgverleners

- instructie en/of training patient, naaste(n) en zorgverleners en eventuele overdracht van infuuszorg

- 24-uurs bereikbaarheid en beschikbaarheid inclusief patientenoverdracht

- discipline- en organisatic-overstijgend overleg en afstemming met professionele zorgverleners

- zo nodig coordinatie van de totale professionele en niet-professionele zorgveriening

- periodieke evaluatic en eventuele bijstelling van zorg

- verslaglegging van activiteiten en afspraken

De TMVs waarborgden een 24-uurs bereik- en beschikbaarheid. Daarnaast hadden zij taken op het gebied van scholing van collega zorgverleners en rapportage ten behoeve van innovatie en onderzoek. De taken van de TMV zijn enigszins vergelijkbaar met die van een gedifferentieerd werkend wijkverpleegkundige bij de SGKH ${ }^{432}$ Deze taken dienden als basis voor de aan kandidaten te stellen functie-eisen (schema 8.2). Ook waren zij verplicht een aanvullende scholing met goed gevolg af te ronden (\$10.5.2). Er werd geworven onder thuiszorg- en ziekenhuisverpleegkundigen. Een combinatie van beide

Schema 8.2 Functie-eisen / Profiel van de TMV bij infuusbehandeling thuis.

* gediplomeerd A en/of wijkverpleegkundige

- meerdere jaren ervaring als (wijk)verpleegkundige

- patientenbelang als uitgangspunt nemen

- centraal stellen van de zelfzorg door patiènten, naasten en vrijwilligers

- affiniteit met medisch-technisch handelen als onderdeel van het totale verpleegproces

- goede communicatieve vaardigheden

- didactische kwaliteiten

- technische vaardigheden en improvisatievermogen

- adequaat en kordaat kunnen optreden in acute situaties

- vaardigheden met betrekking tot discipline- en organisatic-overstijgende samenwerking

- bekendheid met de thuiszorg en de sociale kaart in het werkgebied

- bereidheid in onregelmatige diensten te werken

- affiniteit met onderzoek en zorginnovatic 
disciplines kan zowel voor de zorginhoud als voor het draagvlak meerwaarde hebben. Er is een team van zes verpleegkundigen (vier part-timers, twee invallers) aangesteld, ongeveer gelijkelijk afkomstig van de SGKH en van het azM. Bij beide organisaties bestond voorkeur voor aanstelling van de TMVs bij de SGKH. Redenen waren: het accent op de zorgverlening thuis, de ervaring met het uitvoeren van medisch-technisch handelingen in samenspraak met en onder verantwoordelijkheid van de huisarts, de aansluiting met de overige benodigde verpleging en verzorging thuis, en de arbeidsvoorwaardenstructuur. De TMVs werkten binnen de juridische kaders voor medisch-technisch handelen door verpleegkundigen voortvloeiend uit de WUG en de BIG. ${ }^{202},{ }^{201}$ Hierover bestonden tussen de SGKH en de huisartsen in de regio werkafspraken, die ook bekend waren in het azM. ${ }^{93}$ De zorgverleningstheorie van Orem biedt een kader voor de zorguitvoering bij IT (\$4.2.2). De zelfzorgbehoeften bij infuusbehandeling voortvloeiend uit aandoening en behandeling zijn af te leiden van die bij CMTZ (schema 6.1). Bij het voorzien in de zelfzorgbehoeften wordt waar mogelijk gebruik gemaakt van de aanwezige en/of nog aan te leren kennis en vaardigheden van patienten en hun omgeving (schema 6.2). Na instructic en educatie kunnen zij soms zelf in een aantal zelfzorgbehoeften bij IT voorzien.

Gebaseerd op schema 6.3 geeft schema 8.3 het zorgproces (A) en medische en verpleegkundige deeltaken (B) die daarbij volgens het wettelijk kader en de beroepsprofielen zijn te onderscheiden. ${ }^{66} 160-162,203,216$ De 'verpleegkundige' deeltaken mogen veelal ook door artsen uitgevoerd worden, het omgekeerde is niet het geval.

\subsection{Verspreiding van organisatie van zorg (fase 5)}

Het concept voor IT is aanvankelijk op twee niveau's verspreid. $\mathrm{Bij}$ de start is een begeleidingscommissie ingesteld met vertegenwoordigers van de belangrijkste betrokken partijen (bijlage 1.1). Zij had tot taak om de voortgang van het project wat betreft zorgorganisatie en onderzoek te bewaken, een draagvlak in de regio te bewerkstelligen en relevante ontwikkelingen te signaleren. De commissie vergaderde tweemaal per jaar en heeft onder andere de discussienota "Het transmuraal verpleegkundig model", basis voor het zorgmodel, vastgesteld. ${ }^{291}$

De projectgroep heeft samen met protocolgroepen zorgprotocollen ontwikkeld. ${ }^{137,434-436} \mathrm{Op}$ basis van de behoeften van de patiënt zijn zorginhoud en zorgorganisatie onderscheiden. De zorginhoud is ontwikkeld in nauwe samenwerking met diverse specialisten, huisartsen, apothekers, hygiënisten en verpleegkundigen, de zorgorganisatie met het management van diverse organisaties (bijlage 2.1).

Bij de concrete invulling van het zorgmodel kwamen (oude) belangentegenstellingen naar voren. Vanuit het cultureel-politiek perspectief waren er zowel binnen de protocolgroepen als binnen de begeleidingscommissie discrepanties tussen instemming met 'de visie' en bereidheid tot daadwerkelijke bijdrage. Bij de protocolgroepen was vooral de academische setting met haar eigen onderzoeksbelangen hieraan debet.

Onenigheden over de vormgeving en de financiering bij de zorgverlening leidden tot ernstige stagnatie. Hoewel de zorguitvoering na een jaar onderhandelen startte, bleef de financiering en daarmee de zorgverlening problematisch. De begeleidingscommissie (directieniveau) bleek niet in staat om deze impasse te doorbreken. Na drie maanden is de zorguitvoering tijdelijk stilgelegd en het Samenwerkingsverband Transmurale Zorg (STZ) opgericht. ${ }^{55}$ Hierin zijn door ter zake verantwoordelijken (hoofden van dienst) van betrokken partijen bindende afspraken gemaakt over de zorgverlening en financiering in een sfeer van gezamenlijke verantwoordelijkheid en oog voor win-win situaties. ${ }^{47,438}$ 


\begin{tabular}{|c|c|}
\hline Fase & Inhoud \\
\hline $\begin{array}{l}\text { Indiceren } \\
\text { medisch (1) }\end{array}$ & -aandoening en soort infuusbehandeling \\
\hline Aanmelden ( 1 ) & -gestructureerd bij centraal meldpunt \\
\hline \multirow{2}{*}{$\begin{array}{l}\text { Indiceren } \\
\text { verpleegkundig } \\
\text { en overig } \\
\text { (1) }\end{array}$} & $\begin{array}{l}\text {-vormgeving infuusbehandeling, gevolgen } \\
\text { voor leefsituatie en haalbaarheid } \\
\text {-overige benodigde zorg }\end{array}$ \\
\hline & $\begin{array}{l}\text { technische mogelijkheden } \\
\text { infuusbehandeling en/of apparatuur }\end{array}$ \\
\hline
\end{tabular}

Voorbereiden

(2)

Starten en continueren

(3)

\section{-zorgprogramma opstellen en vastleggen} in zorgplan, aanstellen coordinator -aanleveren benodigde medicatie, infuusbenodigdheden en verpleeghulpmiddelen -realiseren wettelijke en financiele randvoorwaarden

-zorguitvoering op basis van
deskundigheid, taakafspraken en
bevoegdheidsregelingen
-24-uurs bereikbaar- en beschikbaarheid
-mogelijkheid om op een hoger
deskundigheidsniveau terug te vallen

Herindiceren en evalueren (3/4)

Stoppen en afwikkelen (4) -proces én effecten van zorguitvoering -bewaken van continutteit en flexibiliteit

-informeren relevante zorgverleners -archiveren en declareren
Betrokken professionele zorgverleners

-specialist en/of huisarts

-door/in opdracht van huisarts of specialist transmuraal verpleegkundige (TMV) en eventueel intaker wijkverpleging -intaker gezinsverzorging, nachtzorg. fysiotherapie -deskundigen: apparatuur, apotheker, microbioloog, ziekenhuishygienist -TMV met huisarts en/of specialist en/of andere zorgverleners

-TMV met centraal meldpunt", apotheek en/of uitleendienst Groene Kruis en/of facilitair bedrijf

-TMV met centraal meldpunt" en eventueel huisarts en/of specialist -huisarts en TMV/wijkverpleegkundige en/of andere zorgverleners -apotheek en/of uitleendienst Groene Kruis en/of instrumentele dienst ziekenhuis en/of facilitair bedrijf

-zorgverieners in het ziekenhuis en deskundigen op specifiek technische onderdelen van de behandeling

-huisarts en/of specialist en TMV

-TMV/wijkverpleegkundige en huisarts en/of specialist plus organisaties

Legenda: ${ }^{14}=\mathrm{McF}$ arland en McFarlane I:anamnese en diagnosestelling 2:doelbepaling, interventiebepaling en interventieplanning 3:uitvoering van interventies 4 evaluatie,"-is binnen het project geindiceerd door de TMV, "=afhankelijk van de organisatie kunnen meldpunt en daarbij betrokken diensten ondersteunen.

Later is de STZ uitgebreid en met andere overlegvormen opgegaan in de huidige Stuurgroep Transmurale Zorg.

Verdere verspreiding van het concept op de werkvloer heeft plaatsgevonden door diverse publikaties, intensieve persoonlijke contacten door de projectcoördinatoren met sleutelfiguren op de werkvloer en door de daadwerkelijke zorguitvoering door en betrokkenheid van de aangestelde infuusverpleegkundigen (bijlage 2.1). Schema 8.4 vat de bij de verspreiding van de innovatie te onderscheiden organisatieniveau's, organen en instrumenten samen. Na het onderzoek is IT als reguliere zorgvoorziening voortgezet. ${ }^{49}$

Schema 8.4 De verspreiding van het transmuraal concept bij infuusbehandeling thuis

\begin{tabular}{lll}
\hline Organisatieniveau & Orgaan & Toepasbare instrumenten \\
Directie & Begeleidingscommissic & Discussienota \\
Hoofden van dienst & Samenwerkingsverband Transmurale Zorg & Zorgafspraken en begroting \\
Professionals & Protocolgroepen & Protocollen \\
\hline
\end{tabular}




$\begin{array}{ll}\text { Fase } & \text { Medisch } \\ \text { Indiceren } & \text {-signaleren en beslissen over de noodraak } \\ \text { (1) } & \text { tot infuusbehandeling } \\ & \text {-bepalen medicatie en dosering en aard, } \\ & \text { volume en inloopsnelheid infuusvlocistof }\end{array}$

Voorbereiden

(2)

Starten

(3)

Continueren

(3)

Herindiceren en evalueren (3/4)

Stoppen

(3/4)

Afwikkelen (4) -bijdrage leveren aan zorgprogramma, kiezen/aanwijzen/aanstellen coordinator -uitschrijven uitvoeringsverzoek medischtechnisch handelen

-realiseren financiele randvoorwaarden

-informeren/instrueren patiênt en naaste(n) -inbrengen perifere infuusnaald lege artis ${ }^{2}$ -eerste toediening medicatic -verslaglegging

-informeren/instrueren patient en naaste(n) -observatie algemene toestand patient -observeren draagkracht/last patientsituatie -inbrengen perifere infuusnaald lege artis ${ }^{2}$ -24-uurs bereikbaar- en beschikbaarheid -verslaglegging
Verpleegkundig
-participatie in signaleren van de noodzaak tot infuusbehandeling -vormgeving infuusbehandeling, gevolgen voor leefsituatie en haalbasheid -overige benodigde zorg -technische mogelijkheden van infuusbehandeling en/of apparatuur

-zorgprogramma opstellen en vastleggen in zorgplan, aanstellen coordinator -verkrijgen uitvoeringsverzock medischtechnisch handelen

-realiseren financièle randvoorwaarden -bewaken aanleveren benodigde materialen -informeren/instrucren patient en naaste(n) \#assisteren bij inbrengen perifeer infuus \#instellen druppelsnelheid \#verslaglegging en aparte medischtechnisch handelen (MTH) rapportage

-informeren/instrueren patient en naaste(n) -observeren algemene toestand patient -aandacht voor ADL-beperking -observeren draagkracht/last patientsituatie Wlichamelijk hygienische zorg

\#bewaken aseptisch werken \#vervolgtoediening medicatic \#instellen druppelsnelheid \#controle infuussysteem en inloopsnelheid \#verwisselen infuuszak en -systeem \#flushen lijn en plaatsen heparine slot \#controle en verzorging insteekopening \#verwijderen van de infuusnaald \#assisteren bij inbrengen perifeer infuus -24-uurs bereikbaar-en beschikbaarheid \#verslaglegging en aparte MTH rapportage -informeren/instrueren patiènt en naaste(n) -bewaken effect van infuusbehandeling -observeren algemene toestand patiênt -observeren draagkracht/last patientsituatic -bewaken continulteit en flexibiliteit -verslaglegging

-informeren/instrueren patient en naaste(n) \#verwijderen van de infuusnaald \#verslaglegging en aparte MTH rapportage -informeren relevante zorgverleners -archiveren en declareren

Vervolg legenda: \#=zelfzorgtaken die patienten en/of naasten eventueel (gedeeltelijk) zelf kunnen uitvoeren, ${ }^{1}=$ in overleg met apotheker of andere medicus, ${ }^{2}-$ zowel medici als verpleegkundigen kunnen een subcutane infuusnaald inbrengen, een centraalveneuze poort aanprikken of een infuus aan- of afkoppelen bij een centraalveneuze catheter. 


\subsection{Toepassing en evaluatie van organisatie van zorg (fase $6+7$ )}

Het zorgproces is geěvalueerd op grond van de onderscheiden medische en verpleegkundige taken (schema 8.3). Omwille van een kort overzicht worden na de methode eerst enkele organisatorische kenmerken van de zorg besproken: instroom, zorg- en infusieduur. Daarna volgen gedetailleerde beschrijvingen van de onderdelen van het zorgproces. Deze worden, vanwege de leesbaarheid, direct gevolgd door hun evaluaties. Deze evaluaties omvatten zowel de resultaten (grotendeels in tabelvorm) als hun beschouwing. Bij de indicatiestelling is expliciet aandacht besteed aan de communicatie en organisatie van infuusbehandeling, bij de zorguitvoering is ook gekeken naar het gebruik van het protocol. Enkele voor het gehele zorgproces van belang zijnde factoren zijn overkoepelend geêvalueerd. Hierbij is aandacht besteed aan het gebruik van het zorgdossier. Tot slot is gekeken naar de verdeling van problemen in relatie tot de verschillende soorten IT.

\subsubsection{Methoden BI] de eValuatie Van het zorgproces}

De instroom, de zorg- en de infusieduur zijn geregistreerd. Bij de evaluatie van de organisatie van de zorg zijn vragenlijsten en notulenonderzoek gebruikt.

De meest betrokken zorgverleners, de wijkverpleegkundige of TMV en de huisarts, hebben het model beoordeeld met behulp van stellingen (vijf- of vierpuntsschaal) (borging en operationalisatie \$14.4). Zij hebben onder andere geoordeeld over de communicatie en organisatie, de duidelijkheid en het gebruik van protocollen en het zorgdossier. Het totaal van deze stellingen als een schaal beschouwend, is de Cronbach's $\alpha$ als maat voor de interne consistentie voor de verpleegkundigen $0,86(n=115)$, voor de artsen $0,81(n=102)$. Deze hoge interne consistentie wordt niet veroorzaakt doordat op verschillende manieren naar hetzelfde concept is gevraagd. Dit blijkt uit de navolgende inter-item correlaties van de zorgverleners. Inclusief de toevalsovereenstemming zoals uitgedrukt in de Spearman rang correlatie zijn deze bij de verpleegkundige gemiddeld $0.22(-0.18$ tot 0.74$)$ en bij de arts gemiddeld $0.16(-0.34$ tot 0.69$)$. Ook verschillen verpleegkundigen en artsen onderling van mening bij individuele items $(-0.25 \leq \rho \leq 0.25)$, hoewel dit veelal niet significant is. In de notulen van het wekelijkse, gestructureerde TMV-overleg werd elke patiënt besproken per fase van diens zorgproces (bijlage 8.3). De notulen zijn per casus gescoord op knelpunten met behulp van een checklist. Deze is gebaseerd op de onderscheiden medische en verpleegkundige taken (schema 8.3) en kwaliteitsaspecten volgens de Nationale Raad voor de Volksgezondheid, de Raad voor Gezondheidsonderzoek en de Nederlandse organisatie voor Wetenschappelijk Onderzoek (schema 14.2). ${ }^{40-442}$ Niet alle aspecten zijn getoetst, omdat sommige bij IT niet van toepassing zijn of niet via notulenonderzoek te achterhalen zijn. De taken zijn allen getoetst. Kanttekening vooraf hierbij is dat de verslaglegging weliswaar gestructureerd was naar het zorgproces, maar niet specifiek naar al deze aspecten. Omdat perfecte zorgverlening vermoedelijk niet bestaat, worden alleen die aspecten en taken waarbij in $5 \%$ of meer van de gevallen knelpunten zijn gerapporteerd, verder toegelicht.

Bij het interpreteren van de resultaten van de stellingen en het notulenonderzoek is ook gebruik gemaakt van de ervaringen van de projectcoördinatoren.

\subsubsection{ORGANISATORISCHE ZORGKENMERKEN: INSTROOM, ZORG- EN INFUSIEDUUR}

De doelgroep bestond uit patiênten met een indicatie voor IT wonend in het werkgebied van de SGKH en onder behandeling bij het azM of de huisarts. Het instroomverschil tussen de west- en de oostkant van de onderzoeksregio is verklaarbaar (tabel 8.1). In de westkant en het midden draineren de patiěnten op het azM, meer oostwaarts overwegend 
West en midden:

Maastricht (5)

Meerssen (8)

Valkenburg (12)

Eysden (12)

Margraten (11)

Oost:

Gulpen (16)

Vaals (27)

Wittem (19)

\section{Patiènten N}

83

14

9

7

4

2

2

1
Patiēnten \%

68

12

7

6

3

24

25

Legenda: " =gemiddelde afstand in kilometers tot het academisch ziekenhuis Maastricht.

op het toenmalige De Weverziekenhuis (nu Atrium geheten) te Heerlen. Van de 98 huisartsen heeft $58 \%$, van de 66 praktijken $76 \%$ en van de 14 huisartsengroepen $100 \%$ én of meerdere patienten met IT gehad. De maximale behandelduur is om administratieve redenen beperkt tot acht weken. $\mathrm{Bij}$ langer durende behandelingen en vervolgbehandelingen ging daarna een nieuwe episode in. De instroom van de diverse soorten infusies is redelijk grillig (figuur 7.1), maar lijkt zich in zijn totaliteit in de tijd te stabiliseren (figuur 8.1). De piek begin 1994 markeert het wegwerken van een wachtlijst voor mannitolinfusie.

Figuur 8.1 Aantal eerste- en vervolgbehandelingen in de tijd.

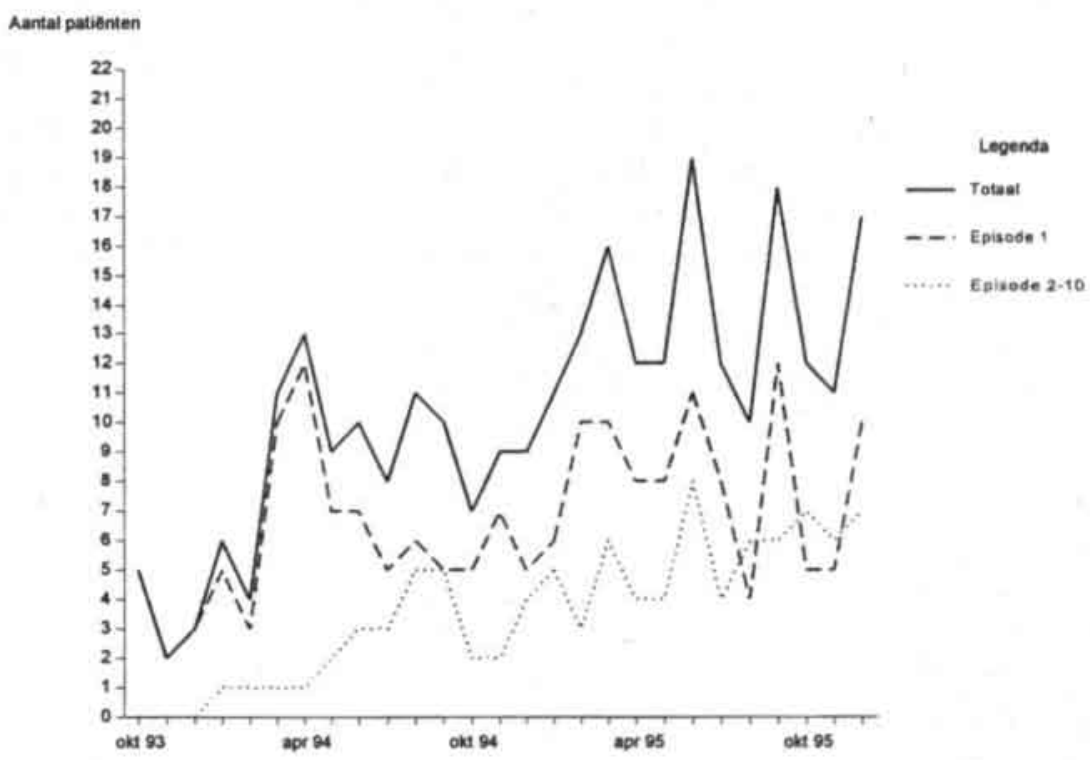

Maand

Vanwege de voorbereiding en afwikkeling beperken de werkzaamheden bij IT zich niet tot die dagen waarop infusie plaats heeft. Daarom is de zorgperiode langer dan de infusieduur. 
Tabel 8.2 geeft een overzicht van de duur van de 123 eerste behandelingen (122 patiēnten: één patiênt ontving mannitol eerst intra- en later centraalveneus). Bij patiēnten met hartmiddelen, benadert de behandelduur de administratief beperkte periode van acht weken (met daarin 32 infusiedagen). Door foutieve administratie is de maximale behandelduur bij de morfinebehandeling eenmaal overschreden.

Tabel 8.2 Zorgperiode in dagen ${ }^{\circ}$ en aantal dagen infusie ${ }^{*}$ naar medicatiegroep (eerste behandeling).

\begin{tabular}{|c|c|c|c|c|c|c|c|c|c|}
\hline \multicolumn{2}{|c|}{ Morfine ${ }^{*}$} & \multicolumn{2}{|c|}{ Mannitol } & \multicolumn{2}{|c|}{ Antibiotica } & \multicolumn{2}{|c|}{ Hartmiddeien } & \multicolumn{2}{|c|}{ Totaal * } \\
\hline Zorg & Infusie & Zorg & Infusie & Zorg & Infusie & Zorg & Infusie & Zorg & Infusie \\
\hline $12,4^{\prime}$ & 11,2 & 13,4 & 7,0 & 22,9 & 20,7 & 54,2 & 26,9 & 17,7 & 13,0 \\
\hline $15,2^{2}$ & 13,6 & 5,3 & 1,5 & 14,3 & 14,2 & 17,5 & 8,8 & 17,6 & 13,0 \\
\hline $1.71^{\prime}$ & $1-69$ & $5-26$ & $3-8$ & $10-61$ & 7.57 & $18-74$ & $6-32$ & $1-74$ & $1-69$ \\
\hline
\end{tabular}

Legenda: "-vanaf de intake tot en met de uitschrijving, "=aantal dagen waarop infusie, morfine"=morfine met eventuele parenterale comedicatie,"-inclusief de medicatiegroepen vocht, anti-epileptica, virostatica en overigen, '=gemiddelde, ${ }^{2}=$ standaarddeviatic, ${ }^{3}=$ bereik. Patienten met eerste behandeling: 60/28/15/9/122.

\subsubsection{ORganisatie EN EVALUATIE VAN INDICEREN, AANMELDEN EN VOORBEREIDEN}

\subsubsection{Organisatie van indiceren, aanmelden en voorbereiden}

De indicatiestelling is onderverdeeld in 'medische' en 'verpleegkundige en overige' indicatiestelling. De huisarts indiceert medisch voor patiēnten vanuit de thuiszorg, waaronder ook bejaarden- en verzorgingstehuizen en meldt deze aan. Bijvoorbeeld bij subcutane infusie van morfine. De specialist indiceert patiěnten instromend vanuit de kliniek, zoals bij intraveneuze antibioticabehandeling bij infecties, of de polikliniek, zoals bij mannitolinfusie. Deze patiënten worden na overleg tussen de medisch specialist en de huisarts, eventueel door of in ieder geval onder verantwoordelijkheid van de huisarts aangemeld. Zo kan de huisarts vanuit diens ervaring met de patiënten en zijn naaste(n) een eerste inschatting maken van de mogelijkheden tot thuiszorg. De verantwoordelijkheid van de huisarts is expliciet benoemd, omdat deze in de thuissituatie hoofdbehandelaar van de patiënt is en -al dan niet in overleg met de specialist- het medisch beleid bepaalt. De huisarts hoeft niet altijd de gehele daadwerkelijke aanmelding bij het $\mathrm{CM}$ te doen. $\mathrm{Na}$ overleg kan dit onder zijn verantwoordelijkheid door de specialist, de wijk- of de ziekenhuisverpleegkundige gebeuren, waarna de huisarts de aanmelding kort bevestigt. Degene die de patiěnt aanmeldt, dient over alle relevante gegevens te beschikken.

Het verwerken van de aanmelding en de eerste toetsing van de zorgvraag geschiedt conform een standaardprocedure door de verpleegkundige van het $\mathrm{CM}$ van het Groene Kruis ( 24 uur per dag bereikbaar). De zorgvraag, relevante medische informatie waaronder het betreffende infuusbeleid, een eerste inschatting van de zelfzorgbehoefte, alsmede gegevens over de patiënt, de aanvrager en reeds betrokken zorgverleners worden geregistreerd. Het meldpunt verstrekt informatie over de instroomcriteria bij IT (\$7.6) en de vervolgprocedure hierbij. Het meldpunt geeft de zorgvraag en de betreffende informatie door aan de dienstdoende TMV. Deze brengt vervolgens een intakebezoek bij de patiënt en diens naasten om met hen de bij IT bestaande en te verwachten zelfzorgtekorten te inventariseren en analyseren. Schema 8.5 geeft de onderdelen van de intake weer toegespitst op IT. De zelfzorgtekorten worden vertaald in termen van benodigde mantel- 


\section{- geven van voorlichting}

- bepalen wens en motivatie van patient en naasten

- analyseren actuele en potentiele zelfzorgtekorten patientsysteem

- inventariseren mogelijke bijdrage van patient en naasten aan infuusbehandeling, verpleging en huishouding

- inschatten benodigde instructie en training van patiènt en naasten

- inschakelen van professionele en niet-professionele zorgverleners

- overleg met zorgverleners over fasering, aard, frequentie en taakverdeling

- inventariseren benodigde infuusmaterialen en verpleeghulpmiddelen

- plannen datum en tijdstip van de start van de infuusbehandeling thuis

- aanleggen zorgdossier

en professionele thuiszorg. De intake gebeurt op de afdeling van het ziekenhuis of thuis. Op de afdeling wordt deze gepland in overleg met de afdelings- en de transferverpleegkundige. Met de transferverpleegkundige zijn samenwerkingsafspraken gemaakt. Ook met de Stichting Thuiszorg bestonden afspraken over intake voor de gezinszorg door de TMV. Dit liep vooruit op een gezamenlijke indicatiestelling zoals door het Regionaal Indicatie Orgaan. De TMV is derhalve vrijwel vanaf het begin betrokken bij de voorbereiding en kan tijdig de procedures voor de zorgverlening thuis starten. Naar aanleiding van de informatie uit de intake wordt een zorgprogramma opgesteld. In overleg met de apotheker en medisch microbioloog kunnen medicatie- en infusieschema's aangepast worden aan de mogelijkheden in de thuiszorg. Er worden afspraken gemaakt met de patient, naasten, de huisarts en andere betrokken zorgverleners over wie, wanneer, welke zorg uitvoert of materialen levert, wie de zorgcoördinator is en wanneer de zorg voor het eerst geěvalueerd wordt. De afspraken worden beschreven in een individueel zorgprogramma in het daartoe ontwikkeld Zorgdossier Thuiszorg (bijlage 8.4). Het zorgdossier blijft bij de patiënt en kan door alle relevante betrokkenen gelezen en ingevuld worden, opdat de zorgverlening onderling kan worden afgestemd en geëvalueerd. Met name de contacten met de apothekers en andere facilitaire diensten en bedrijven zijn in dit stadium van belang. Bij subcutane infusie van morfine is het relatief eenvoudige pakket van infuusbenodigdheden via de perifere apothekers geleverd. Voor de overige behandelingen heeft het project als 'facilitair bedrijf' geopereerd. De medicatie is betrokken via de ziekenhuisapotheek (op naam van de patiënt), de infuusmaterialen via het magazijn of via de afdeling inkoop (project als virtuele afdeling). De infuuspompen (IVAC 591@) zijn via de instrumentele dienst van het azM betrokken en de infuusstandaarden en verpleeghulpmiddelen via de uitleendienst van de SGKH. Deze werkwijze is intensief, maar betekent wel dat alle benodigde materialen binnen aanvaardbare tijd geleverd kunnen worden (op werkdagen binnen 24 uur). Bij de infusie van hartmiddelen zijn de draagbare infuuspompen (CADD IQ) door de zorgverzekeraar aan de patiënt ter beschikking gesteld. Als richtperiode tussen aanmelding en zorgverlening is twee werkdagen aangehouden. De periode kan korter (pijnbestrijding 6 uur) of langer zijn (SRD en hartfalen twee weken). Patiënten voor een mannitolinfusie worden vanuit het specialistenspreekuur rechtstreeks doorgestuurd naar de afsprakenbalie van het dagcentrum en twee weken later ingepland op vooraf daarvoor 'gereserveerde' plaatsen (maximaal twee per week). De langere duur bij hartfalen komt door de uitgebreide intakeprocedure vanwege de in principe levenslange therapie en het aantal procedures dat in gang gezet moet worden: prikdienst, toestemming van verzekeraar, pompen aanschaffen bij facilitair bedrijf na machtiging van de verzekeraar. 


\subsubsection{Evaluatie van indiceren, aanmelden en voorbereiden}

Ter evaluatie zijn in tabel 8.3 de resultaten uit de vragenlijsten over communicatie en organisatie weergegeven. De telefonische bereikbaarheid van het $\mathrm{CM}$ is in het algemeen vrij goed. Tussen $17.00 \mathrm{u}$ en $19.00 \mathrm{u}$ traden in verband met overdrachten aan de avondzorg in combinatie met de eenpersoonsbezetting buiten kantooruren de meeste problemen op. Omdat de belasting van het meldpunt almaar toenam, is de bereikbaarheid op een gegeven moment problematisch geworden. Daarop is een tweede nummer voor het $\mathrm{CM}$ ingesteld. Tijdens de ingebruikname bleek de bereikbaarheid onvoldoende. Gedurende twee weken is toen teruggevallen op de bewakingsdienst van het azM voor het laten oproepen van de TMVs.

Vanwege de complexiteit van de zorg is vooraf reeds veel informatie over het project en bijvoorbeeld de aanmeldingsprocedures verspreid (bijlagen 9.1+9.2). Bij de aanmelding en het vervolgtraject blijkt de TMV een cruciale rol te spelen bij de informatie-uitwisseling. Het op tijd regelen van de medicatie en infuus-benodigdheden en de daarvoor benodigde recepten en machtigingen is vaak een race tegen de klok, maar lukt -vanwege de gekozen procedures- meestal. Eventuele bij de aanmelding bestaande verwarring over de eindverantwoordelijkheid, verdwijnt bij het opstellen van een zorgprogramma. Bij de voorbereiding zijn afspraken gemaakt over het beleid bij calamiteiten.

Over het geheel genomen is men tevreden met de totale organisatie van IT. Om te kijken in hoeverre het feit dat de TMV het merendeel van de organisatie op zich neemt weerspiegeld wordt in het eindoordeel, is de correlatie tussen het rapportcijfer voor de zorgverleners (§14.3) en dat voor de organisatie (stelling 9) bepaald. Deze correlatie is, zowel bij de verpleegkundigen als bij de huisartsen het hoogst voor de TMV (\$14.5.3).

Tabel 8.3 Communicatic en organisatic van infuusbehandeling thuis.

\begin{tabular}{|c|c|c|}
\hline Stelling * & Verpleegkundige & Huisarts \\
\hline 1. Het centraal meldpunt is telefonisch goed bereikbaar. & $3,9 / 0,6 / 1-5^{\circ}$ & $4,1 / 0,7 / 2-5$ \\
\hline $\begin{array}{l}\text { 2. Over de infuuszorg bestaat een goede informatic } \\
\text { uitwisseling tussen eerste en tweede lijn. }\end{array}$ & $3,5 / 0,7 / 1-5$ & $3,5 / 0,8 / 1-5$ \\
\hline $\begin{array}{l}\text { 3. De transmuraal infuusverpleegkundige verbetert de } \\
\text { communicatic tussen eerste en tweede lijn. }\end{array}$ & $3,7 / 0,6 / 2-5$ & $3,5 / 0,8 / 1-5$ \\
\hline $\begin{array}{l}\text { 4. Het is moeilijk om de medicatie en de } \\
\text { infuusbenodigdheden op het juiste moment bij de } \\
\text { patient thuis te krijgen." }\end{array}$ & $3,8 / 0,8 / 1-5$ & $3,8 / 0,9 / 1-5$ \\
\hline 5. Het is duidelijk wie de eerst verantwoordelijke is. & $4,1 / 0,6 / 2-5$ & $3,9 / 0,8 / 1-5$ \\
\hline $\begin{array}{l}\text { 6. Als zich bij de patient thuis een noodsituatie mocht } \\
\text { voordoen dan is er snel een oplossing voorhanden. }\end{array}$ & $3,9 / 0,5 / 2-5$ & $3,9 / 0,7 / 2-5$ \\
\hline $\begin{array}{l}\text { 7. Bij een onhoudbare thuissituatie is noodopvang of } \\
\text { spoedopname mogelijk. }\end{array}$ & $3,7 / 0,6 / 1-5$ & $3,7 / 0,7 / 2-5$ \\
\hline $\begin{array}{l}\text { 8. Het coordinatiebureau 'Infuusbehandeling Thuis' } \\
\text { reageert adequaat op vragen of problemen. }\end{array}$ & $4,0 / 0,6 / 2-5$ & $4,1 / 0,7 / 2-5$ \\
\hline $\begin{array}{l}\text { 9. Geef een rapporteijfer voor de organisatie van de } \\
\text { infuuszorg thuis. }\end{array}$ & $8,0 / 0,8 / 6-10$ & $8,2 / 0,8 / 6-10$ \\
\hline
\end{tabular}

Legenda: "mvijfpuntsschaal 1:zeer mee oneens 2:mee oneens 3:niet mee eens en niet mee oneens 4 :mee eens 5 ;zeer mee eens, "-rapportcijfer 0-10, " =gemiddelde, standaarddeviatie, bereik" $=$ deze negatieve stelling is ter vergelijking omgecodeend, ook hier drukt een hoog getal dus meer tevredenheid uit. Respondenten verpleegkundige: $115-116$ huisarts: 102-106. 
De evaluatie via het notulenonderzoek levert de volgende aandachtspunten bij aanmelden, indiceren en voorbereiden van IT op (tabel 8.4). Bij 'ontbrekende informatie' beeft meestal de specialist de huisarts niet op de hoogte gebracht. Eenmaal is daardoor een mannitolbehandeling twee weken uitgesteld. Ook heeft het $\mathrm{CM}$ de aanmeldingsformulieren niet altijd volledig ingevuld of zijn invalkrachten niet altijd voldoende op de hoogte van de procedures. Indien de aanmelding 'niet conform procedure' geschiedt, is dit vooral omdat de kliniek bij het projectbureau in het azM heeft aangemeld, veelal uit onbekendheid met de procedures ( $\$ 9.5)$. Ook hier blijken specialisten huisartsen niet voldoende te betrekken bij het medisch beleid na ontslag. ${ }^{40}$ In een aantal gevallen heeft een specialist de huisarts wel op de hoogte gesteld van de voorgenomen mannitolbehandeling, maar meldt de huisarts de patiènt vervolgens niet aan. Bij het 'bepalen van medicatie en toediening' blijkt de kliniek onvoldoende op de hoogte van de mogelijkheden om subcutaan morfine en/of vocht toe te dienen en zoekt men alternatieven in de vorm van intraveneuze, centraalveneuze of epidurale toediening of zelfs combinaties daarvan. Soms zijn hierbij wrijvingen opgetreden omdat specialisten niet 'verwachten' dat de thuiszorg in de palliatieve fase een ander beleid voert ten aanzien van pijnbestrijding en vochttoediening. Het 'uitschrijven van het uitvoeringsverzoek' is voor huisartsen een probleem. Vaak vergeet de huisarts dit, tekent te laat of is 'wars van bureaucratie'. Ook bij het 'aanleveren van de benodigde materialen' treden problemen op. Meestal heeft de perifere apotheek of de apotheekhoudende huisarts daarbij de materialen niet in voorraad, of levert niet volledig of verkeerd uit. Soms levert het SGKH een hoog-laag bed niet op tijd of levert een verkeerde infuusstandaard, of blijkt de uitlevering via het project onvolledig.

Tabel 8.4 Problemen bij het aanmelden, indiceren en voorbereiden in percenten van behandelingen.

\begin{tabular}{|c|c|c|c|c|}
\hline Zorgtaak & $\begin{array}{c}\mathrm{SC} \\
\mathrm{N}=59\end{array}$ & 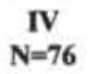 & $\underset{\mathrm{N}=38}{\mathrm{CV}}$ & $\begin{array}{l}\text { Totaal } \\
N=173\end{array}$ \\
\hline Ontbrekende informatie & 7 & 10 & 5 & 8 \\
\hline Late aanmelding & 2 & 4 & 0 & 2 \\
\hline Niet conform procedure & 2 & 18 & 13 & 12 \\
\hline Signaleren en beslissen over noodzaak behandeling & 2 & 0 & 3 & 1 \\
\hline Bepalen medicatie en toediening / indicatiestelling (3) & 9 & 17 & 8 & 12 \\
\hline Participeren in noodzaak tot behandeling & 2 & 3 & 0 & 2 \\
\hline Bijdrage zorgprogramma, keuze zorgcoordinator & 0 & 0 & 3 & 1 \\
\hline Uitschrijven uitvoeringsverzoek MTH & 3 & 7 & 3 & 5 \\
\hline Bewaken aanleveren materialen & 12 & 4 & 5 & 7 \\
\hline
\end{tabular}

Legenda: $\mathrm{SC}=$ subcutane infusie, IV=intraveneuze infusie, $C V=$ centraalveneuze infusie, $(3)=R G O$-aspect nummer 3 (schema 14.2).

\subsubsection{ORGANISATIE EN EVALUATIE VAN STARTEN, CONTINUEREN EN STOPPEN}

\subsubsection{Organisatie van starten, continueren en stoppen}

Bij de start van IT is de TMV altijd aanwezig. Het inbrengen van een intraveneus infuus of het de eerste maal toedienen van medicatie, vereist aanwezigheid van de huisarts. Het continueren van zorgverlening -de uitvoering- heeft tot doel: het tegemoet komen aan de zelfzorgtekorten zoals die tijdens de intake door de patiënt, diens naaste(n), de medisch behandelaar en de TMV zijn vastgesteld. De professionele zorguitvoering bestaat veelal uit een intensieve samenwerking tussen de huisarts, specialist, TMV, wijkverpleegkundige 
en apotheek. De medische en verpleegkundige handelingen bij IT vormen de basis voor de handelingslijsten, de zorgactiviteiten voor de multidisciplinaire protocollen waarin deze zijn opgenomen (schema 8.3). Ook zijn hieraan de criteria ontleend ten aanzien van voor een adequate uitvoering vereiste kennis en vaardigheden $(\$ 10.2-\S 10.4)$. Instructie aan patiënten, naasten en andere zorgverleners is gebaseerd op deze specifieke kennis en vaardigheden en wordt meestal verzorgd door de TMV.

De huisarts en de specialist bepalen in onderling overleg het diagnostisch en therapeutisch beleid, dat thuis onder eindverantwoordelijkheid van de huisarts uitgevoerd wordt. De specialist kan de huisarts bij de zorguitvoering ondersteunen of een deel ervan overnemen. Vooral zeer specialistische zorg (bijvoorbeeld infusie hartmiddelen) vereist nauwe samenwerking tussen de specialist en de huisarts. De huisarts kan met een specialist, een ziekenhuis- of perifere apotheker overleggen over de medicatie. De apotheker verschaft regelmatig informatie over de beschikbaarheid, farmacokinetiek, bijwerkingen en interacties van de toegediende medicamenten. De TMV en/of wijkverpleegkundige verrichten taken op het gebied van de observatie, verzorging, verpleging en begeleiding alsmede medisch-technische handelingen. Dit laatste in opdracht van de huisarts en in aansluiting op diens diagnostische en therapeutische werkzaamheden. In de praktijk biedt de TMV de verpleegkundige, aan IT gerelateerde zorg. Tevens verleent de TMV in beperkte mate reguliere wijkzorg en kan, indien nodig, de functie van zorgcoördinator op zich nemen. Wanneer de patiënt en/of diens naaste(n) en/of wijkverpleegkundigen kunnen participeren in de infuuszorg ontvangen zij van de TMV de daarvoor benodigde instructie en training. De TMV hanteert daarbij het betreffende protocol. Alle betrokken professionele en niet professionele zorgverleners leggen hun aandeel in de zorg vast in het zorgdossier.

De uitvoering van IT vereist binnen dit model samenwerking tussen de TMVs en andere (niet) professionele verplegenden en verzorgenden. Bij de taakverdeling zijn van belang:

- Competentie: de deskundigheid en vaardigheid van bij infuusbehandeling betrokken of te betrekken professionals (gezinsverzorgenden, wijkziekenverzorgenden en (gedifferentieerd) wijkverpleegkundigen) en niet-professionals (patiënt, naasten).

* Doelmatigheid: de totale behoefte aan verpleging en verzorging bij de patiènt en/of naasten vóór, tijdens en na de IT qua inhoud, uitvoering, frequentie en variatie.

* Continulteit van zorg: indien de patiënt en/of naasten vóór de infuusaanvraag reeds zorg van (gedifferentieerd) wijkverpleegkundigen ontvangen of deze zorg na de infuusbehandeling nodig is.

$\mathrm{Bij}$ het opstarten van de IT vindt op grond van deze uitgangspunten een heroriêntatie op de zorg plaats. Conform de zorgverleningsvisie van Orem worden de patiënt en/of naaste zoveel mogelijk betrokken bij de uitvoering van de zorg. Voor gezinsverzorgenden is een beknopte taakomschrijving gemaakt en zij zijn casusgericht geînformeerd. Voor wijkziekenverzorgenden is eveneens een taakomschrijving gemaakt. Ten aanzien van wijkverpleegkundigen zijn op basis van bovenstaande uitgangspunten onderstaande drie samenwerkingsvormen onderscheiden:

1. De TMVs voeren de verpleegkundige IT uit. Ook bieden zij zo nodig reguliere wijkzorg (beperkt tot $1 / 2$ uur per bezoek) en coördineren eventueel de zorg. Bij meer behoefte aan reguliere wijkzorg wordt de wijk ingeschakeld. Afhankelijk van competentie, doelmatigheid en continuilteit worden vervolgens afspraken gemaakt zoals beschreven onder 2 en 3 . Wordt het infuus gestaakt en behoeft de patiënt nog reguliere wijkzorg, dan wordt deze overgedragen aan de wijkverpleging. Deze 
constructie is meestal gehanteerd bij intra- en centraalveneuze infusie.

2. De TMVs instrueren één of meer wijkverpleegkundigen uit een wijkteam en trainen hen om de infuuszorg in een bepaalde situatie gedeeltelijk over te nemen. De TMVs zijn als inhoudsdeskundige aanspreekbaar voor de infuuszorg en participeren in de totale zorg. De wijkverpleegkundigen zijn verantwoordelijk voor de reguliere wijkzorg en participeren in de infuuszorg. In gezamenlijkheid leveren zij de totale verpleegkundige zorg. De zorgcoördinatie ligt veelal bij een wijkverpleegkundige. De TMVs en de wijkverpleegkundigen maken afspraken over vaste dagen en/of tijdstippen van verzorging. Bij afwezigheid van de geìnstrueerde wijkverpleegkundigen nemen de TMVs hun taken bij het infuus weer over. De TMVs blijven 24 uur per dag als achterwacht bereikbaar. Deze constructie is veelvuldig gehanteerd bij subcutane infusie van morfine of vocht en langer durende intraveneuze infusie.

3. De TMVs instrueren één of meer wijkverpleegkundigen uit een wijkteam en trainen hen om de infuuszorg in een bepaalde situatie volledig over te nemen. De TMVs participeren daarna niet meer in de infuuszorg, maar behouden wel de 24-uurs achterwachtfunctie. Deze constructie is enkele malen gehanteerd bij terminale patiēnten met subcutane infusie van morfine en vocht.

Periodiek wordt de behandeling geĕvalueerd en eventueel geherindiceerd. Dit gebeurt in nauw overleg met de eindverantwoordelijke huisarts en andere betrokken zorgverleners. Samen met de patient en diens naaste(n) wordt bezien of de in de intake dan wel voorgaande evaluaties gesignaleerde behoeften aan thuiszorg zowel wat betreft inhoud als uitvoering nog overeenstemmen met de geboden zorg. De uitkomst van deze evaluatie en daaruit voortvloeiende afspraken worden wederom vastgelegd in het zorgdossier.

De huisarts en/of specialist nemen de beslissing tot het stoppen van de behandeling. De afwikkeling van de zorg gebeurt deels door de diverse zorgverleners afzonderlijk en voor het overige door de TMV. Na afsluiting van de zorg worden relevante gegevens uit het zorgdossier verwerkt en wordt het zorgdossier conform de wettelijke voorschriften gearchiveerd door de SGKH. De resterende materialen worden door de patiënt, naasten, TMV, apotheek of de SGKH terugbezorgd en/of opgehaald. De financiële afhandeling geschiedt grotendeels via het project en incidenteel rechtstreeks naar de zorgverzekeraar.

\subsubsection{Evaluatie van starten, continueren en stoppen}

Uit de evaluatie via de vragenlijst blijkt dat vanwege het uitgebreide voorbereidingstraject de start van de IT meestal goed verloopt. De zorg is grotendeels op basis van protocollen uitgevoerd. In het algemeen zijn de protocollen vrij positief beoordeeld: "overzichtelijk, maar ook omslachtig" (tabel 8.5). De verpleegkundigen zijn iets positiever dan de artsen. Toch blijft ondanks de scholing en instructie vaak ondersteuning door andere zorgverleners nodig. Ook blijken de in de protocollen opgenomen handelingslijsten niet altijd als instructie bij de uitvoering van de infuuszorg gebruikt te worden. Het is bekend dat protocollen in het dagelijks handelen niet altijd naar de letter maar veeleer vanuit de daaruit voortvloeiende inzichten worden gebruikt. ${ }^{444,445}$ Schaamte om aan de patiënt te tonen dat men een protocol nodig heeft, gebrek aan tijd om het protocol door te nemen of volgens protocol te werken en een algemene afkeer tegen 'papier en bureaucratie' zijn de voornaamste beperkingen bij het daadwerkelijk gebruiken van protocollen. 


\section{Stelling}

Oordeel over het protocol

1. De indeling van het protocol is overzichtelijk.

2. Het protocol geeft voldoende aan welke middelen nodig zijn voor het verrichten van de handelingen

3. Het protocol geeft duidelijk aan hoe de medicatic en de infuusbenodigdheden verkregen kunnen worden.

4. In het protocol staan de te verrichten handelingen duidelijk omschreven.

5. In combinatie met de scholing of instructie biedt het protocol voldoende basis om handelingen zelfstandig te verrichten.

6. Ondanks de scholing of instructic heb ik regelmatig ondersteuning nodig van andere zorgverleners."

7. Het protocol blijkt in de praktijk goed uitvoerbaar
Verpleegkundige

Huisarts

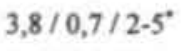

$3,6 / 0,8 / 1-5$

$4,0 / 0,5 / 3-5$

$3,9 / 0,5 / 2-5$

$3,8 / 0,6 / 2-5$

$3,7 / 0,6 / 2-5$

$4,0 / 0,4 / 3-5$

$3,9 / 0,5 / 3-5$

$4,0 / 0,5 / 2-5$

$3,8 / 0,5 / 2-5$

$3,4 / 1,0 / 1.5$

$3,2 / 1,1 / 1-5$

$4,0 / 0.5 / 2-5$

$3.8 / 0.5 / 2-5$

Welke functie heeft het protocol in de praktijk gekregen? -

8. Instructic voor uitvoering van de infuuszorg.

$2,8 / 0,8 / 1-4$

Legenda: "-vijfpuntsschaal I:zeer mee oneens 2:mee oneens 3:niet mee eens en niet mee oneens 4:mee eens $5: z e e r$ mee eens, ${ }^{-}$-vierpuntsschaal 1 :nee, beslist niet 2:nee, niet echt 3:ja, in het algemeen wel 4:ja, zeker, "-gemiddelde, standaarddeviatie, bereik, "=deze negatieve stelling is ter vergelijking omgecodeerd, ook hier drukt een hoog getal dus tevredenheid uit. Respondenten verpleegkundige: 115-116 huisarts: 102-106.

Uit het notulenonderzoek naar de zorguitvoering kwam een aantal problemen naar voren (tabel 8.6). Bij het 'informeren en instrueren van de patiënt door de arts' heeft in de meeste gevallen de specialist de patiënt onvolledig voorgelicht of de IT te rooskleurig voorgesteld. Opvallend is dat bij de infusie van hartmiddelen de patiënt en naaste zich vaak niet aan de instructie houden (zie ook attitude bij tabel 8.8). Soms lijkt de instructie door de TMV onvoldoende geweest. In een aantal gevallen lukt het de huisarts niet 'vervolg infuusnaalden in te brengen' ( $\$ 10.6 .5)$. Soms geeft vervolgens ook het aanprikken op de EHBO problemen, met name bij chronische patiēnten met mannitolinfusie. Soms durft de huisarts het niet aan, wellicht door het ontbreken van scholing (\$10.5.1). Bij het 'aankoppelen, instellen en controleren van de infusie' treden de meeste problemen op door hetzij technische gebreken hetzij het niet volgens protocol werken door zowel patiënten en naasten als verpleegkundigen en huisartsen $(\S 12.3)$. Bij intraveneuze infusie kan het infuus bij de 'insteekopening' gaan lekken. Bij problemen bij het 'bewaken en eventueel wijzigen van de behandeling' bij subcutane infusie handelt de huisarts vaak niet volgens het pijnbestrijdingsprotocol. Voor patiênten, hun naasten en collega zorgverleners is het 'pijnbestrijdingsbeleid' niet altijd duidelijk.

Ook als 'tijdens het zorgproces opnieuw materialen' nodig zijn, treden in het traject van voorraadcontrole, bestelling en uitlevering problemen op. Omdat de specialistische zorg bij patięnten met infusie van hartmiddelen frequent een $7 \times 24$ uurs continuiteit vereist, zijn de eigen huisarts en specialist wel eens niet bereikbaar. De 'verslaglegging' blijkt bij zowel artsen als verpleegkundigen niet altijd volledig of duidelijk.

\subsubsection{EVAluATIE VAN OVERKOEPElENDE KWALITEITSASPECTEN}

Naast de gedetailleerde beschrijving en evaluatie van het zorgproces, zijn algemene aspecten ten aanzien van de organisatie van zorgverlening, zoals veiligheid en continuitteit, 


\begin{tabular}{|c|c|c|c|c|}
\hline Zorgtaak & $\underset{N=59}{S C}$ & $\underset{N=76}{N}$ & $\underset{\mathrm{N}=38}{\mathrm{CV}}$ & $\begin{array}{l}\text { Totaal } \\
\mathrm{N}=173\end{array}$ \\
\hline Informeren en instrueren patient (arts) & 2 & 4 & 5 & 4 \\
\hline Informeren en instrueren patient (verpleegkundige) & $2+0^{2}$ & $1+1^{2}$ & $3+8^{2}$ & $2+2^{2}$ \\
\hline Observeren algemene toestand patient (arts) & 2 & 1 & 0 & 1 \\
\hline Observeren draagkracht/draaglast (verpleegkundige) & 0 & 0 & 3 & 1 \\
\hline Lichamelijke hygienische zorg & 2 & 3 & 0 & 3 \\
\hline Inbrengen eerste infuusnaald intraveneus (arts) & • & 3 & • & • \\
\hline Inbrengen volgende infuusnaald intraveneus (arts) & • & 22 & $\bullet$ & • \\
\hline $\begin{array}{l}\text { Aankoppelen infuus, instellen druppelsnelheid/pomp, } \\
\text { controle infuus en inloopsnelheid }\end{array}$ & $4+4^{3}$ & $1+17^{\prime}$ & $13+32^{3}$ & $4+16$ \\
\hline Verwisselen infuuszak en systeem & 3 & 0 & 0 & 1 \\
\hline Eerste toediening medicatic & 0 & 4 & 3 & 2 \\
\hline Controle en verzorging insteekopening & 2 & 5 & 0 & 3 \\
\hline $\begin{array}{l}\text { Bewaken en beoordelen effect infuusbehandeling plus } \\
\text { bijstellen medicatie en infuusvloeistof }\end{array}$ & 17 & 0 & 0 & 6 \\
\hline Aanleveren benodigde materialen & $3+2$ s & $3+7$ & $5+8$ & $4+5$ \\
\hline Continuiteit en flexibiliteit & 0 & 0 & 3 & 1 \\
\hline 24-uurs bereik/beschikbaarheid (arts)(16) & 0 & 0 & 5 & 1 \\
\hline 24 -uurs bereik/beschikbaarheid (verpleegkundige) $(16)^{6}$ & 3 & 1 & 3 & 2 \\
\hline Verslaglegging (arts) & 2 & 0 & 11 & 3 \\
\hline Verslaglegging (verpleegkundige) & 2 & 0 & 11 & 3 \\
\hline
\end{tabular}

Legenda: $\mathrm{SC}=$ subcutane infusie, IV=intraveneuze infusie, $\mathrm{CV}=$ centraalveneuze infusie, "-niet van toepassing, (16) $=R G O$-aspect nummer $16,^{\prime}=$ ontsteking niet in schema $(\$ 12.3), x+y^{2}=x$ :verpleegkundige $y$ :patient/naaste, $\mathrm{x}+\mathrm{y}^{3}=\mathrm{x}$ :verpleegkundige $\mathrm{y}$ :anderen, $\mathrm{x}+\mathrm{y}^{4}=\mathrm{x}$ :verpleegkundige $\mathrm{y}$ :technische fouten, $\mathrm{x}+\mathrm{y}^{5}=\mathrm{x}$ :verpleegkundige of naaste verzorger $y$ :apotheek, ${ }^{6}=$ centraal meldpunt en/of collega wijkverpleegkundige (TMV is altijd op te seinen).

onderscheiden. Deze worden hier nader uitgewerkt. Het zorgdossier is in alle fasen van het zorgproces van belang als communicatiemiddel en ter bevordering van de afstemming.

Uit de vragenlijsten blijkt dat men over het zorgdossier zelf redelijk positief is (tabel 8.7). Het zorgdossier draagt zeker bij aan de communicatie. De verpleegkundigen en huisartsen gebruiken het zorgdossier verschillend. Huisartsen geven in mindere mate dan de verpleegkundigen aan het zorgdossier voor verslaglegging gebruikt te hebben. Het oordeel over de documentatie van de andere discipline lijkt dit te weerspiegelen. Ook patiënten en naasten hebben in de verslaglegging geparticipeerd (observatie tijdens dossieronderzoek).

Ook het notulenonderzoek levert een aantal problemen bij algemene kwaliteitsaspecten op (tabel 8.8). Niet alle algemene aspecten (schema 14.2) zijn bestudeerd, omdat sommige bij IT niet van toepassing zijn of niet via notulenonderzoek te achterhalen zijn. De algemene items 'doeltreffendheid (1)', 'belasting patiënt en naaste (25)' en patiëntensatisfactie (17)' zijn wel bestudeerd, maar de uitkomsten hiervan bleken te onbetrouwbaar. Wel komen zij in de effectevaluatie aan de orde (H:14). De items 'indicatiestelling' en 'bereikbaarheid' zijn reeds aan de orde geweest. Bij de items 'veiligheid', 'attitude/verantwoordelijkheidsgevoel', 'zorgvuldigheid', 'bereidheid tot verantwoording', 'bereidheid tot coöperatie' komt het er in het overgrote deel op neer dat de patiënt en/of naaste door een beperkt 


\section{Stelling}

Oordeel over het zorgdossier"

1. Het is duidelijk op welke wijze de formulieren van het logboek ingevuld dienen te worden.

2. $\mathrm{Er}$ is voldoende schrijfruimte in het logboek.

3. De andere disciplines hebben hun bijdrage aan de behandeling voldoende gedocumenteerd in het logboek.
Verpleegkundige

$3,7 / 0,8 / 1-5^{*}$

$4,1 / 0,4 / 2-5$

$3,4 / 0,8 / 2-5$
Huisarts

$3,6 / 0,7 / 1-5$

$3,9 / 0,7 / 1-5$

$3,8 / 0,6 / 2-5$

Welke functie(s) heeft het zorgdossier in de prakijk gekregen? -

4. Communicatie tussen zorgverleners

5. Informatieverstrekking aan patient en of naaste verzorger.

6. Verslaglegging van eigen handelen.
$3,2 / 0,7 / 1-4$

$3,0 / 0,7 / 1-4$

$3,6 / 0,6 / 1-4$
$2,9 / 0,8 / 1-4$

$2,7 / 0,8 / 1-4$

$2,8 / 0,9 / 1-4$

Legenda: "-vijfpuntsschal 1:zeer mee oneens 2 mee oneens 3:niet mee eens en niet mee oneens 4:mee cens 5:zeer mee eens, - Jvierpuntsschaal 1:nee, beslist niet 2:nee, niet echt 3:ja, in het algemeen wel 4 ja, zeker, "-gemiddelde, standaarddeviatie, bereik. Respondenten verpleegkundige: 115-116 huisarts: 102-106.

ziekte- en behandelinzicht de veiligheid tijdens de behandeling in gevaar brengen of zich willens en wetens niet aan gemaakte afspraken houden. Dit gedrag komt vooral voor bij chronische patienten en hun naasten. Zij willen vanuit hun ervaringsdeskundigheid mede bepalen hoe zij behandeld worden. De wens om de behandeling aan te passen aan de eigen leefwijze (bijvoorbeeid uitstapjes buiten de projectregio tijdens infusie) is te verkfaren uit het feit dat de thuisbehandeling de autonomie beperkt. Vooral thuis wordt de beknelling van een chronische behandeling voelbaar. Dagen die men bij behandeling in het ziekenhuis ' $k w i j t$ ' is, wil men thuis toch zo optimaal mogelijk benutten. De wens tot behandeling in de avonduren bij infusie van hartmiddelen kon helaas niet gehonoreerd worden. $\mathrm{Zij}$ zou in de duurdere avonduren de inzet van een extra apotheker(sassistente), van meerdere TMVs

Tabel 8.8 Problemen bij algemene RGO/NWO kwaliteitsaspecten in percenten van behandelingen.

\begin{tabular}{lcccc}
\hline Kwaliteitsaspect & $\mathbf{S C}$ & $\mathbf{I V}$ & $\mathbf{C V}$ & Totaal \\
Veiligheid (5) & $\mathbf{N = 5 9}$ & $\mathbf{N = 7 6}$ & $\begin{array}{c}\mathbf{N = 3 8} \\
\mathbf{N = 1 7 3}\end{array}$ \\
Hygiene (21) & 0 & $1+5^{2}$ & $3+11$ & $1+5$ \\
Deskundigheid: kennis en kunde (2) & 0 & $0+4$ & 3 & $1+2$ \\
Attitude (7)/ verantwoordelijkheidsgevoel (11)' & 0 & $0+3$ & 0 & $0+2$ \\
Zorgvuldigheid (6) & 0 & $0+4$ & $3+32$ & $1+9$ \\
Bereidheid tot verantwoording (11) & 0 & $0+1$ & $0+5$ & $0+2$ \\
Bereidheid tot cooperatic (10) & 0 & $0+3$ & $0+5$ & $0+2$ \\
Continuiteit (12) & 0 & 0 & $0+13$ & $0+3$ \\
Integrale zorg / afstemming (15) & 2 & 1 & 3 & 2 \\
Financiele toegankelijkheid (18) & 10 & 0 & 0 & 4 \\
Gelijk recht op zorg (31) & 0 & 3 & 3 & 2 \\
\hline
\end{tabular}

Legenda: $\mathrm{SC}$-subcutane infusic, IV=intraveneuze infusie, $\mathrm{CV}=$ centraalveneuze infusie, ${ }^{2}=\mathrm{RGO}$ nummer (schema 14.2), $x+y^{2}-x$ :zorgverleners $y$ :patientsysteem, de patient en nasste verzorgers, ${ }^{\prime}=$ bij de zorgverleners wordt alleen verwezen naar de attitude; omdat het patientsysteem medebehandelaar wordt zijn ook bij hen beide items geevalueerd zij zijn echter moeilijk te scheiden en daarom samengenomen,"=betreft bij het patientsysteem de aanspreekbaarheid achteraf, "-vanwege het accent op de relationele kant is "bereidheid tot" toegevoegd. 
op hetzelfde tijdstip en meer bereikbaarheid van de specialist vereisen. De mogelijkheid tot meer 'maatwerk' in plaats van 'confectie' had wellicht ook een aantal problemen met betrekking tot de coōperatie van het patiēntsysteem kunnen voorkomen. Het is niet altijd mogelijk om zorg op maat aan te bieden en deze tevens verantwoord (met name veilig) en doelmatig te houden. In zoverre heeft ook patiěntenparticipatie zijn 'prijs' en is 'volledige zorg op maat' maatschappelijk onbetaalbaar. Bij de 'integrale zorg en afstemming' treden er soms problemen op tussen de TMV en de huisarts, maar met name tussen de TMV en de wijkverpleegkundige bij subcutane infusie van morfine. Bij andere infusies wordt de TMV als inhoudsdeskundige gezien en geaccepteerd. Bij subcutane infusie van morfine is de wijkverpleegkundige vaak al langer bij de patiēntsituatie betrokken, is de infusietechniek op zich eenvoudig en wordt deze vaak (groten)deels aan wijkverpleegkundigen overgedragen. Participatie door de TMV wordt hier soms als bedreigend ervaren. Het wordt de TMV in zo'n situatie niet in dank afgenomen als zij vanuit haar rol als procesbewaker de wijkverpleegkundige aanspreekt op fouten. Bij 'gelijk recht op zorg' blijkt dat de infusie van hartmiddelen ook in het ziekenhuis niet altijd mogelijk is (capaciteits- en deskundigheidsprobleem).

De casusbesprekingen tijdens het werkoverleg van de TMVs zijn ook gehanteerd als instrument voor interne kwaliteitsbewaking. Bij subcutane, intraveneuze, centraalveneuze infusie en in totaal hebben ze in respectievelijk $64 \%, 45 \%, 58 \%$ en $55 \%$ van de behandelingen bijgedragen aan het aanscherpen van afspraken, protocollen en procedures.

\subsection{6 \\ EVALUATIE VAN DE PROBLEMENVERDELING PER SOORT INFUUSBEHANDEUING}

In de notulen is per behandeling bij 93 aspecten (combinatie schema's 8.3 en 14.2) gezocht naar eventuele problemen. Bij ongeveer de helft (46) treden geen problemen op. De problemen zijn aan de hand van het zorgproces reeds in detail besproken. Tot slot is in algemenere zin gekeken naar de verdeling van de problemen in relatie tot de soort infuusbehandeling. Voor zover bekend is nooit eerder op deze wijze het zorgproces bij IT bestudeerd. De bespreking beperkt zich daardoor tot de resultaten van deze studie. Figuur 8.2 geeft aan bij hoeveel percent van de verschillende soorten infusie problemen optreden. Naarmate een behandeling complexer is, treden ogenschijnlijk meer problemen op (zie ook bijlage 8.5 en verderop). Het gemiddeld aantal problemen per behandeling is voor subcutane, perifeer intraveneuze en centraalveneuze infusie, en in totaal dan ook respectievelijk $1,1,1,9,2,4$ en 1,7 . In relatie tot de vele aspecten (93) die per behandeling fout konden gaan, valt dit alleszins mee. In de totale groep van infusies lijkt het aantal problemen dat optreedt sterk samen te hangen met de zorgduur. Indien de 'administratieve' vervolgbehandelingen (behandelduur maximaal acht weken) bij de eerste behandelingen worden opgeteld, neemt het totaal aantal behandelingen af van 173 naar 148 . Indien men aanneemt dat gedurende het gehele zorgproces fouten kunnen optreden, zou men tussen het aantal infusiedagen en het aantal problemen een hoge correlatie verwachten. De Pearson's correlatie is dan ook hoog $(r=0.79 n=148 p<0,001)$. Omdat het zorgproces zich ook uitstrekt buiten de dagen dat infusie wordt gegeven, is ook de correlatie tussen het aantal zorgdagen en het aantal problemen berekend. Hier lijkt het verband nog iets sterker $(r=0.83 n=148 \mathrm{p}<0,001)$. Beide correlaties ('helling' kleiner dan één) weerspiegelen dat in de opstartfase van een behandeling relatief meer problemen kunnen optreden. Het gemiddeld aantal problemen per dag is voor subcutane, perifeer intraveneuze en centraalveneuze infusie, en in totaal respectievelijk $0,10,0,16,0,09$ en 0,12 (bijlage 8.5 ). Hieruit blijkt dat per dag niet minder problemen optreden naarmate een 
Percentage van behandelingen

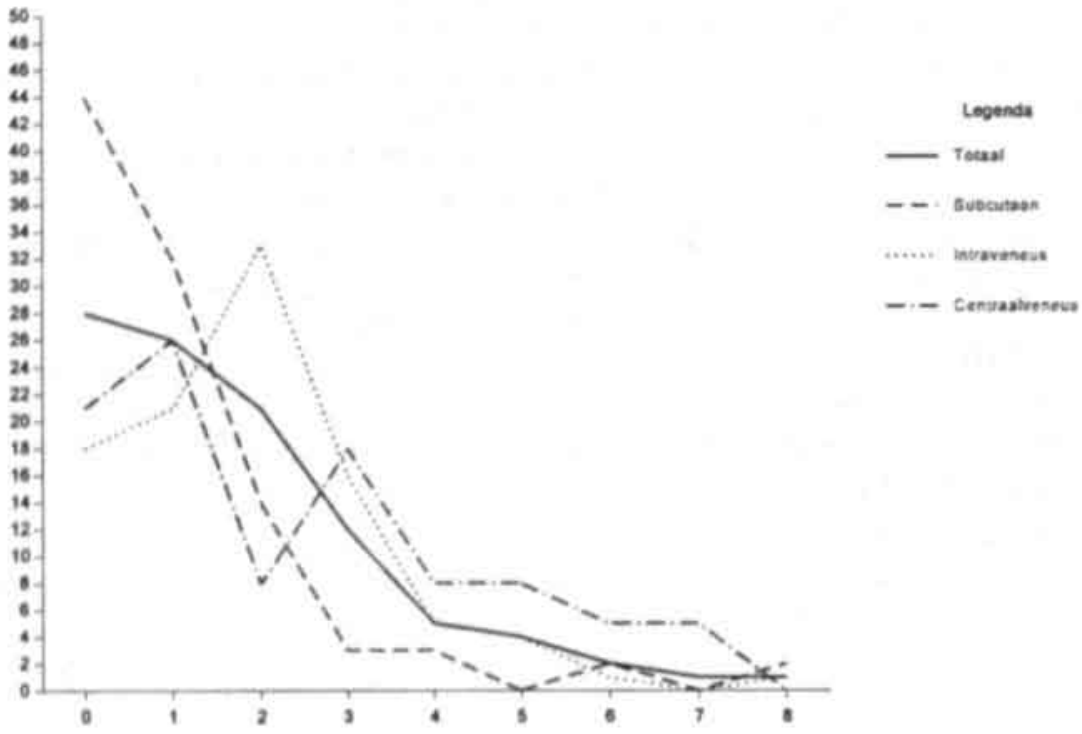

Aantat prociemen

Figuur 8.3 Bijdrage per probleemklasse aan het totaal aantal problemen (\%).

Percentage van het totaal anntal problemen per klasse

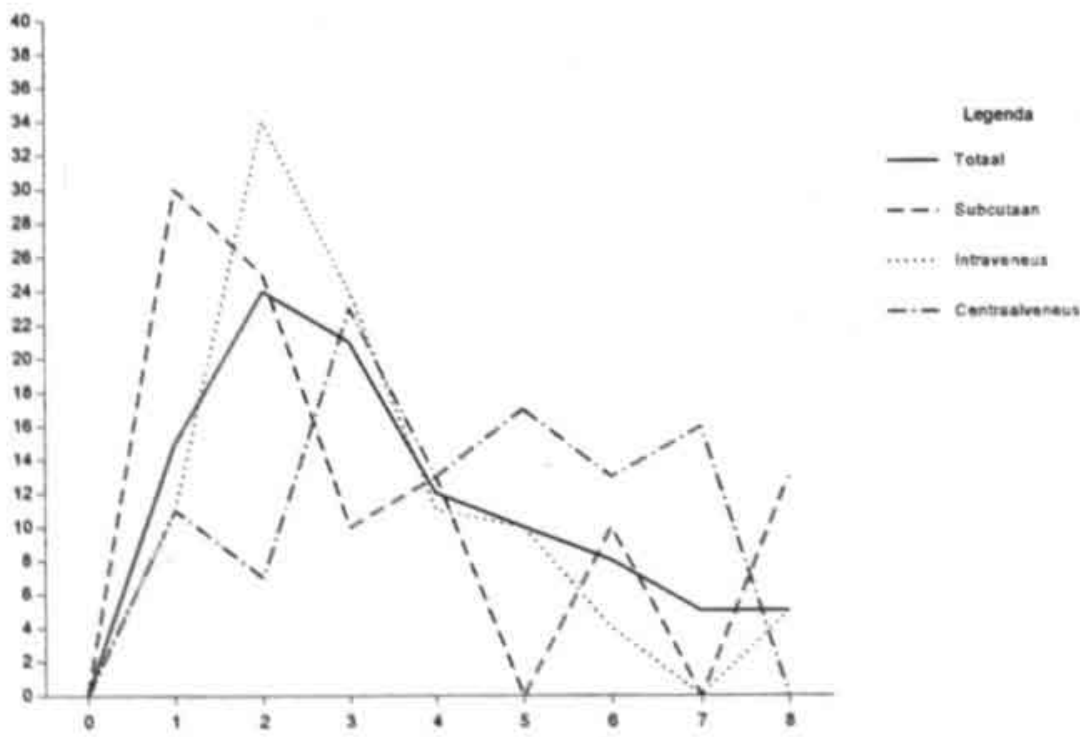

Asntal problemen per behandeleng 
behandeling als geheel gemiddeld langer duurt (tabel 8.2). Ook treden niet meer problemen op naarmate een behandeling complexer is. Wel zijn de perifeer intraveneuze, subcutane en centraalveneuze infusies in deze volgorde toenemend strakker geprotocolleerd en zijn voor een groter deel door de TMVs uitgevoerd. Dit lijkt het aantal problemen te doen afnemen.

Ter preventie van deze problemen in de toekomst is voorts van belang of deze clusteren bij bepaalde soorten infusie of bepaalde patienten. De verdeling van het aantal fouten per infusie ten opzichte van het totaal $(300)$ geeft een vertekening vanwege de verschillende aantallen van de diverse soorten infusies (bijlage 8.5). Daarom drukt figuur 8.3 in percenten uit in hoeverre een bepaalde klasse van problemen (behandelingen gegroepeerd naar aantal fouten) bijdraagt aan het totaal aantal problemen per soort infusie. Bij subcutane en intraveneuze infusie treden per behandeling meestal maar eén of twee fouten op en zijn de fouten verdeeld over een groter aantal behandelingen dan bij de centraalveneuze infusie. Bij de laatstgenoemde zijn de problemen dan ook gerichter te identificeren. Eerder bleek reeds dat de problemen bij centraalveneuze infusie met name bij een aantal patiënten met infusie van hartmiddelen voorkomen (\$8.4.5), waarschijnlijk vanwege het chronisch karakter van de behandeling.

\subsection{Conclusies}

Het ontwikkelde model voor CMTZ (thuis) lijkt concreet toepasbaar bij IT. Voor het creëren van de noodzakelijke randvoorwaarden dienen ter zake verantwoordelijken van de betrokken partijen bindende afspraken te maken omtrent de zorgverlening en financiering. Een slagvaardig werkend $\mathrm{CM}$ faciliteert zowel de aanmelding als de zorguitvoering. Multidisciplinaire protocollering en verslaglegging kunnen dienen als hulpmiddel voor standaardisering en kwaliteitsborging. In het integrale zorgproces kunnen in teamverband werkende TMVs een spilfunctie vervullen. Deze functie kan zeer wel in de thuiszorg geïntegreerd worden. Ook in de aansturing van een dergelijk gespecialiseerd team en de coördinatie en bewaking van de zorgorganisatie dient voorzien te zijn. Een structurele werkbespreking is daarbij als instrument voor continue kwaliteitsverbetering te gebruiken.

Ondanks dat er problemen in de zorgverlening optreden, zijn deze niet ernstig en/of omvangrijk. Het patiëntsysteem is overwegend tevreden. Enerzijds lijkt het zorgmodel een aantal problemen te kunnen absorberen, waardoor het patiëntsysteem deze niet ervaart. Anderzijds kon het patiëntsysteem in deze studie met problemen omgaan, waardoor deze geaccepteerd werden. Tot slot is het patiëntsysteem ook in deze studie positief in zijn oordeel. Vanuit het zorgmodel is geprotocolleerde zorg meestal op maat te leveren. Evenals in de overige gezondheidszorg conflicteert echter met name bij chronisch zieken de door hen gewenste zorg op maat soms met het leveren van doelmatige zorg. Al met al lijkt het alleszins verantwoord om IT onder de beschreven condities uit te voeren. 


\section{Informatievoorziening}

\subsection{Doel van informatievoorziening (fase 1)}

Bij een zorginnovatie zoals IT veranderen zowel de zorgprocedures als de verhoudingen tussen patiênten, zorgverleners, zorgorganisaties en financiers. Informatievoorziening biedt houvast in de nieuwe situatie. Dit eerste deel van aandachtspunt 3 binnen hoofdvraagstelling II wordt aan de hand van de innovatiecyclus (schema 2.5 ) besproken. De informatievoorziening heeft twee doelen: naamsbekendheid om het project in de regionale gezondheidszorg te plaatsen en het draagvlak onder zorgverleners, zorgorganisaties en financiers te vergroten en om aanvragen uit het veld te genereren; daarnaast het bieden van informatie om de uitvoering van de patiëntenzorg soepel te laten verlopen..$^{18}$ Alleen de bekendheid van het project onder artsen van het azM is expliciet geëvalueerd. Het informeren van de patiënt en naaste(n) tijdens de behandeling is inherent aan het zorgproces en wordt in dit hoofdstuk niet verder uitgewerkt. ${ }^{239,240}$ Hiervoor wordt verwezen naar de hoofdstukken 4, 6, 8 en 14 .

\subsection{Analyse van informatievoorziening (fase 2)}

De informatie is onder te verdelen in algemene over het project en specifieke over de behandelingen. Vóór de start van de behandeling hebben de patiënt en naaste behoefte aan algemene informatie (waarop zij bij onderzoek ook toestemming tot deelname kunnen baseren). ${ }^{446}$ Huisartsen, specialisten, ziekenhuis- en, wijkverpleegkundigen, en TMVs behoeven vooraf informatie over de indicatiestelling en aanmeldingsprocedure. Tijdens de behandeling hebben patiënten, naasten en zorgverleners behoefte aan informatie over de procedures en de precieze uitvoering. Zorgorganisaties en financiers hebben informatie nodig betreffende de organisatie en de benodigde menskracht en middelen.

\subsection{Perspectief en concept bij informatievoorziening (fase 3+4)}

Het zorgmodel naar Orem en voorgaande analyse leveren de volgende doelgroepen op: patiënt en naasten, verpleegkundigen, artsen, andere zorgverleners, zorgorganisaties en financiers. ${ }^{13} \mathrm{De}$ informatiebehoefte is verdeeld in algemene informatie over het project en specifieke informatie voor, tijdens en ter afsluiting van de diverse behandelingen. Het projectbureau heeft de informatievoorziening verzorgd en sloot zoveel mogelijk aan bij de regionale informatiecultuur en structuren. Hierbij is samengewerkt met het Bureau Ondersteuning Huisartsen Heuvelland (BOHH), het TDC en de afdeling voorlichting van het azM. Om het project als 'eigen' te presenteren en betrokkenheid te genereren, is per organisatie informatie verstrekt via de bestaande informatiebulletins. Omdat de 
medewerking van huisartsen cruciaal is en zij niet allen bij voorbaat overtuigd leken van de haalbaarheid, is hen tevens periodiek een nieuwsbrief vanuit het project toegezonden.

\subsection{Verspreiding en toepassing van informatievoorziening (fase 5+6)}

$\mathrm{Er}$ is algemene informatie over het project en specifieke informatie over behandelingen verstrekt. Bij het eerste ligt het accent op beĭnvloeding van de opinie, bij het tweede op kennistoename (schema 2.8). Bijlage 9.1 geeft een chronologisch overzicht van de verspreide informatie. Buiten de regio zijn Nederlandse en Belgische thuiszorgorganisaties en andere belangstellenden geīnformeerd. Dit betreft vooral informatie over de werkwijze.

\subsubsection{ALGEMENE INFORMATIE OVER HET PROJECT}

Om de eigen identiteit van het project te benadrukken is bij alle informatie en correspondentie altijd het projectlogo gehanteerd; ter herkenning tevens de logo's van het TDC en de UM. Belangrijke informatie is in groen, de 'huiskleur' van het project, uitgevoerd. Ook de materiaalkoffers van de TMVs waren groen en met "Infuuszorg Thuis" bedrukt. Er was een algemene folder voor zorgverleners, zorgorganisaties en financiers (bijlage 9.2).

De huisartsen in de regio Heuvelland zijn op diverse momenten geĭnformeerd:

1. bij de start tijdens een symposium over samenwerking tussen eerste en tweede lijn;

2. tijdens het project via hun eigen "Nieuwsbrief" én via nieuwsbrieven van het project. In deze nieuwsbrieven zijn de start, belangrijke veranderingen en nieuwe behandelingen aangekondigd en protocollen samengevat. Alle medewerkers van de SGKH zijn ingelicht via hun instellingsblad "Informatief". De middenkaderfunctionarissen zijn geĭnformeerd via de bestaande overlegsituaties. Ook hebben zij de voor de wijkverpleging relevante informatie en afspraken ontvangen, zoals de nota "Het Transmuraal Verpleegkundig Model", de registratie-afspraken en samenvattingen van de notulen van het wekelijkse TMV-overleg. De clustermanagers informeerden de wijkverpleegkundigen; de TMVs informeerden wijkverpleegkundigen over individuele infuuspatiënten. De vertegenwoordiger in de begeleidingscommissie informeerde de gezinsverzorgenden van de Stichting Thuiszorg Zuid-Limburg. Samen met de verpleegkundig projectcoördinator zijn de taken van gezinsverzorgenden omschreven en toegelicht. Alle medewerkers van het azM zijn geǐnformeerd via hun instellingsblad "Traject" en via het Stafbureau Zorgmanagement. Via het Stafbureau zijn contacten gelegd met het medisch en verpleegkundig management. De projectcoördinatoren hebben specialismen en afdelingen met voor IT relevante groepen patiënten bezocht.

Chirurgen, internisten, kinderartsen, longartsen, neurologen en orthopaeden zijn bij de protocolontwikkeling betrokken. Periodiek zijn zij bericht via de Stafraad. In juni 1994 hebben ze nogmaals een projectfolder (bijlage 9.2) met begeleidend schrijven ontvangen. Het verpleegkundig management is periodiek geĭnformeerd, bijvoorbeeld via de nota "Het Transmuraal Verpleegkundig Model", en heeft op haar beurt de verpleegkundigen geînformeerd. Per etage zijn bovendien de verpleegkundige unitleiders geînformeerd. Alle relevante zorgorganisaties in de regio 'Heuvelland' waren op het hoogste bestuurlijk niveau vertegenwoordigd in de begeleidingscommissie. Deze diende ook om informatie uit te wisselen en vergaderde tweemaal per jaar. Collega's en hun organisaties uit andere regio's zijn naar aanleiding van hun behoefte ad hoc van informatie voorzien.

Vanaf het begin is de grootste regionale zorgverzekeraar, de VGZ, via de begeleidingscommissie bij het project betrokken. De VGZ is per patiēntengroep geĭnformeerd. Andere verzekeraars zijn per verzekerde benaderd. 


\subsubsection{SPECIFIEKE INFORMATIE PER BEHANDEUING}

Binnen het project is gestreefd naar een ruime informatievoorziening voorafgaand aan de behandeling. Dit om zoveel mogelijk te voorkomen dat patiēnten en zorgverleners door gebrek aan informatie met verkeerde verwachtingen aan thuisbehandeling begonnen. $\mathrm{Bij}$ standaardbehandelingen ontvingen de huisartsen informatiepakketten, met een brief van de specialist en een samenvatting van de behandeling. Ook bevatte dit pakket formulieren ter goedkeuring (intentieverklaring) en uitvoering (uitvoeringsverzoek medisch technisch handelen) van de IT. Bij andere behandelingen zijn huisartsen individueel geīnformeerd. Patiënten en hun naasten zijn geľnformeerd op het moment dat de patiënt voor thuisbehandeling in aanmerking kwam. De behandelaar lichtte de patiěnt en/of naaste in over de diagnose en de thuisbehandeling. Hiervoor was per doelgroep algemene informatie op schrift voor de patiēnt en naasten beschikbaar. Voordat de patiënt of naaste toestemming verleende voor IT, is deze informatie met hen doorgenomen en ontvingen zij een informed consent formulier. Ook zijn in het azM patiēntenfolders beschikbaar, waaronder éen over wetenschappelijk onderzoek. Desgewenst informeerde de TMV patiënten en naasten uitgebreid bij de intake. Ook bij de verdere behandeling speelde de TMV een belangrijke rol in de totale informatie-uitwisseling rondom de patiënt. De instroom van patiënten in het project geschiedde door aanmelding of akkoordverklaring door de huisarts. Indien specialisten een thuisbehandeling geindiceerd achtten, overlegden zij met de huisarts. Bij aanmelding volgde nogmaals informatic over de procedures en het onderzoekskader. Het $\mathrm{CM}$ van de SGKH diende als aanmeldings- en communicatiecentrum. De medewerkers daarvan zijn uitvoerig geïnformeerd over de doelstelling en procedures van het project. De handleiding bij de instructie is periodiek aangepast. Ook ten behoeve van afstemming met de Transferverpleegkundige is informatie uitgewisseld.

Voor informatieoverdracht tijdens de behandeling is analoog aan de medische en verpleegkundige status in het ziekenhuis een logboek ontwikkeld met specifieke gegevens over de behandeling en algemene gegevens van de patiënt en diens (niet-)professionele zorgverleners. ${ }^{27,447}$ Per behandeling zijn achtergrondinformatie en gestandaardiseerde handelingslijsten tot protocollen gebundeld. Bij de ontwikkeling zijn bestaande protocollen van het azM, de Nationale Kruisvereniging, de Landelijke Huisartsenvereniging en het Integraal Kankercentrum Limburg gebruikt. ${ }^{448,}{ }^{449}$ Voor patiënten en naasten zijn de behandeling en de voornaamste aandachtspunten beschreven. Ook zijn specialistische zorgverleners, contactadressen en/of patiëntenverenigingen opgenomen.

$\mathrm{Bij}$ de aanmelding waren patiënten, naaste verzorgers en zorgverleners reeds geïnformeerd over de afsluiting van de behandeling en de daarop volgende onderzoeksvragen. De TMV herhaalde deze informatie nogmaals bij het afsluiten en evalueren van de zorg.

\subsection{Evaluatie van informatievoorziening (fase 7)}

\subsubsection{INLEIDING}

De per individuele behandeling verstrekte informatie is elders geëvalueerd $(H: 8,14)$. Vanwege de introductie van een nieuwe zorgvorm op het grensvlak van de klinische en thuiszorg is algemene en deels opiniegerichte informatie verspreid. Dit soort informatie is divers en derhalve moeilijk te evalueren. Het effect van de algemeen verspreide informatie -en met name de mailing van juni 1994 aan azM-artsen- is in november 1994 geëvalueerd. Over de andere aspecten kan een indruk worden verkregen via de evaluatie aan het eind van elke behandeling en mededelingen aan het projectbureau $(\mathrm{H}: 8,14)$. 


\subsubsection{Vraagstellingen en methode enquête}

Ondanks de voorlichtende activiteiten bestond de indruk dat het project nog onvoldoende bekend was en het aantal verwijzingen mogelijk uit te breiden zou zijn. De vraag rees in hoeverre verschillende aspecten van het project bekend waren bij de artsen in het azM. In november 1994 (één jaar na de start van de patiënteninstroom) zijn zij schriftelijk geěnquêteerd (bijlage 9.3). ${ }^{226,450}$ De vraagstellingen luidden:

a) Is het project voldoende bekend?

b) Is men op de hoogte van de aanmeldings- en uitvoeringsprocedures, en beĭnvloedt dit de instroom?

c) Is men op de hoogte van de behandelingsmogelijkheden in het project?

d) Zijn alle infuusbehandelingen die thuis mogelijk zijn in het project opgenomen?

e) Heeft men opmerkingen en/of suggesties voor verbetering van het project?

f) Bestaat er behoefte aan meer informatie over het project?

Het specialisme psychiatrie is uitgezonderd, omdat hiervan geen patiënten zijn behandeld (H:7). Omdat de respons na drie weken voldeed, is geen herinnering verstuurd.

\subsubsection{Resultaten enquête}

Gemiddeld bedroeg de respons $63 \%$ (224 van 355 aangeschreven artsen). Bijlage 9.4 geeft de respons per specialisme en functie absoluut en percentueel weer. Specialisten en assistentgeneeskundigen in opleiding vormen de grootste groep. De respons van de specialismen die de meeste patiênten voor IT verwijzen (heelkunde, interne geneeskunde, kindergeneeskunde, longziekten, neurologie en orthopedie) varieert van $60 \%$ tot $88 \%$, die van specialismen met weinig mogelijkheden tot infuusbehandeling (thuis) is lager.

Onder respondenten was de gemiddelde naamsbekendheid $82 \%$ (182 van 223). Bijlage 9.4 geeft dit per specialisme en functie absoluut en percentueel weer. De naamsbekendheid onder specialismen die de meeste patienten naar het project verwijzen (zie onder respons) varieert van $80 \%$ tot $96 \%$. Specialismen bij wie de naamsbekendheid minder groot is, leveren over het algemeen geen patiënten aan het project. De verdeling van de naamsbekendheid over de functies lijkt overeen te komen met de duur van de dienstverbanden. De naamsbekendheid onder specialisten, assistenten in opleiding en assistenten niet in opleiding is respectievelijk $86 \%, 77 \%$ en $71 \%$.

Om de kennis van aanmeldings- en uitvoeringsprocedures te achterhalen, is gevraagd of men van de werkwijze op de hoogte is en door wie en waar patiênten kunnen worden aangemeld (tabel 9.1). Het stroomdiagram begint met een vraag over de naamsbekendheid. Deze vraag hebben 223 (wordt als $100 \%$ beschouwd) van de 224 respondenten beantwoord. Daarvan hebben $182(82 \%)$ van het project gehoord. Van deze 182 zeggen 50 $(22 \%)$ te weten, hoe het project in de praktijk werkt. Van deze 50 weten $29(13 \%)$ wie patiênten kunnen aanmelden en $26(12 \%)$ waar. Uiteindelijk zijn er maar $21(9 \%)$ volledig op de hoogte. Ten slotte is de behoefte aan aanvullende informatie weergegeven. Om na te gaan of ervaring met het project de kennis van de werkwijze van het project beìnvloedt, is gevraagd of men patienten heeft laten instromen (tabel 9.2). Van de 62 respondenten geven $25(40 \%)$ aan eigen patiënten te hebben laten instromen. De samenhang tussen het zelf hebben laten instromen en het op de hoogte zijn door wie en waar patiěnten kunnen worden aangemeld is voor de 22 respondenten die beide vragen beantwoord hebben vergeleken met de andere respondenten. De bekendheid met de 


\begin{tabular}{|c|c|c|c|c|c|c|c|c|}
\hline Naam beken & & $\begin{array}{l}\text { Werkwijze } \\
\text { bekend? }\end{array}$ & & $\begin{array}{l}\text { Wie kan } \\
\text { aanmelden ? }\end{array}$ & & $\begin{array}{l}\text { Waar kan men } \\
\text { aanmelden? }\end{array}$ & $\begin{array}{l}\text { Wil men } \\
\text { info? }\end{array}$ & $\begin{array}{l}\% \text { van } \\
\text { totaal }\end{array}$ \\
\hline 182 wel $(-8)$ & - & 50 wel $(-3)$ & 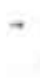 & 29 wel & $\rightarrow$ & $\begin{array}{l}21 \text { wel } \\
4\end{array}$ & $\begin{array}{l}4 \text { wel } \\
17 \text { nict }\end{array}$ & 2 \\
\hline 1 & & 1 & & 1 & & 8 nict & $\begin{array}{l}1 \text { wel } \\
7 \text { niet }\end{array}$ & $\frac{1}{3}$ \\
\hline 1 & & 4 & & 18 niet $(-1)$ & $\rightarrow$ & $\begin{array}{l}5 \text { wel } \\
1\end{array}$ & $\begin{array}{l}2 \text { wel } \\
3 \text { niet }\end{array}$ & $\begin{array}{l}1 \\
1\end{array}$ \\
\hline 1 & & I & & & & 12 niet & $\begin{array}{l}4 \text { wel } \\
8 \text { niet }\end{array}$ & $\begin{array}{l}2 \\
4\end{array}$ \\
\hline 1 & & 124 niet $(-2)$ & - & & - & 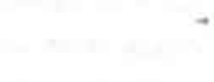 & $\begin{array}{l}73 \text { wel } \\
49 \text { niet }\end{array}$ & $\begin{array}{l}32 \\
23\end{array}$ \\
\hline 41 niet & $\rightarrow$ & & - & & - & $\rightarrow$ & $\begin{array}{l}21 \text { wel } \\
20 \text { niet }\end{array}$ & $\begin{array}{l}9 \\
9\end{array}$ \\
\hline
\end{tabular}

Legenda: 0 -aantal respondenten die de volgende vraag niet hebben beantwoord.

procedures blijkt niet groter indien reeds eigen patiênten in het project zijn opgenomen.

Tabel 9.2 Bekendheid met aanmeldingsprocedure ( $\mathrm{n}=-62)$.

\begin{tabular}{|c|c|c|c|c|}
\hline & Wel waar & Niet waar & $\begin{array}{l}\text { Respondenten met } \\
\text { patient in project }\end{array}$ & Alle respondenten \\
\hline Wel bij wie & 10 & 4 & $64 \%$ & $62 \%$ \\
\hline Niet bij wie & 1 & 7 & $36 \%$ & $38 \%$ \\
\hline $\begin{array}{l}\text { Respondenten met } \\
\text { patient in project }\end{array}$ & $50 \%$ & $50 \%$ & & \\
\hline Alle respondenten & $57 \%$ & $44 \%$ & & \\
\hline
\end{tabular}

Verder is gevraagd welke behandelingen tot nu toe via het project mogelijk zijn en of nog andere infuusbehandelingen gewenst worden (tabel 9.3). Bij 165 respondenten zijn deze

Tabel 9.3 Mogelijkheid en wenselijkheid van infuusbehandelingen.

\begin{tabular}{|c|c|c|c|c|}
\hline \multirow[t]{2}{*}{ Soort infusie } & \multicolumn{2}{|c|}{ Nu mogelijk $(n=59)$} & \multicolumn{2}{|c|}{ Wenselijk $(n=57)$} \\
\hline & Absoluut & $\%$ & Absoluut & $\%$ \\
\hline Antibiotica & 46 & 74 & 2 & 3 \\
\hline Morfine & 37 & 60 & 0 & 0 \\
\hline Dopamine / lasix & 30 & 48 & 0 & 0 \\
\hline Mannitol & 27 & 44 & 0 & 0 \\
\hline Cytostatica * & 21 & 34 & 0 & 0 \\
\hline Virostatica ${ }^{\circ}$ & 1 & 2 & 0 & 0 \\
\hline Vocht & 2 & 3 & 4 & 7 \\
\hline Anti-epileptica ${ }^{*}$ & 2 & 3 & 0 & 0 \\
\hline Voeding ${ }^{\times}$ & 4 & 7 & 8 & 14 \\
\hline Bloed(produkten) ${ }^{x}$ & 0 & 0 & 4 & 7 \\
\hline Heparine ${ }^{x}$ & 0 & 0 & 3 & 5 \\
\hline
\end{tabular}

Legenda: "=incidentele behandeling, "=behandeling niet mogelijk via het project. 
vragen niet gesteld omdat zij vanwege de onbekendheid met de naam (41) of de werkwijze (124) van het project direct doorverwezen zijn naar de laatste vraag (tabel 9.1+bijlage 9.3). De respondenten die van het project gehoord hebben, zijn redelijk op de hoogte van de meest voorkomende infuusbehandelingen die via het project mogelijk zijn. Van infuusbehandelingen die niet via het project mogelijk zijn, worden die van voeding, bloed (produkten) en heparine wenselijk geacht.

Tot slot is gevraagd of en zo ja waarover behoefte aan informatie bestond. Van de respondenten heeft $50 \%$ (111 van 224) geen behoefte aan extra informatie (tabel 9.1). Van de overige respondenten wil $66 \%$ algemene informatie (bijlage 9.4 ).

Omdat de vragen weinig ruimte lieten voor een eigen mening, is aan het eind van de enquête gevraagd naar opmerkingen en/of suggesties. De volgende opmerkingen zijn allen éénmaal gemaakt: een duidelijk formulier aan de patiënt meegeven met de medicatie en de dosering, betere bereikbaarheid in avonduren en nacht, meer bekendheid aan het project geven, uitbreiding van de regio, training voor parenterale voeding dient intensief te zijn.

\subsubsection{Beschouwing enquête}

De respons van $63 \%$ lijkt voor een enquête als de onderhavige voldoende. De naamsbekendheid van het project onder alle aangeschreven potentiēle verwijzers in het azM bedraagt een half jaar na een algemene mailing over het project tenminste $51 \%$ (182 van $355)$, onder de respondenten is deze $81 \%$. (182 van 223 ).

Slechts een minderheid (9\%) van de respondenten is volledig bekend met de werkwijze van het project. Dit komt niet door onervarenheid met het project. Artsen die al eens een patiênt voor het project aangemeld hebben, zijn niet beter op de hoogte. Het is de vraag of het voor patiënteninstroom noodzakelijk is dat de verwijzend arts weet hoe de aanmelding in zijn werk gaat. Wellicht volstaat het te streven naar naamsbekendheid en een positieve houding ten opzichte van de nieuwe behandeling, zodat potentiële verwijzers bij een geschikte patiënt aan de thuisbehandeling denken. De daadwerkelijke aanmelding kan daarna ook met hulp van anderen (collegae, verpleegkundigen) tot stand komen.

De vraag over de bekendheid met de diverse soorten infuusbehandelingen (c) kan mogelijk verschillend gelinterpreteerd zijn. De toevoeging "volgens u" kan de respondent doen denken dat het hier gaat om soorten infusen die hijzelf geschikt vindt. Een andere kanttekening is dat, vanwege de instructies in de vragenlijst, alleen de respondenten die aangeven op de hoogte te zijn van de naam en werkwijze deze vraag hebben beantwoord. Hierdoor resteert slechts een kleine groep. Het ware beter geweest ook hen die niet op de hoogte waren van de werkwijze van het project, hun mening over infuusbehandelingen te laten geven. Van de met het project bekende verwijzers, weet ongeveer de helft welke van de in omvang belangrijkste infuusbehandelingen via het project gegeven kunnen worden. Een klein deel wenst parenterale voeding in het project op te nemen, een nog kleiner deel infusie van bloed(produkten) en heparine. De belangrijkste groepen blijken reeds in het project opgenomen te zijn.

Het aantal op- en aanmerkingen is klein. Wel bestaat duidelijk behoefte aan meer informatie. Deze is gelijk verdeeld over respondenten die de naam of de werkwijze van het project al dan niet kennen. $\mathrm{Er}$ is vooral vraag naar algemene informatie alsook informatie over de mogelijke soorten infusen en de relevantie voor het eigen vakgebied.

De vraagstellingen zijn met behulp van de enquête in voldoende mate beantwoord. De uitkomsten zijn gebruikt om in maart 1995 een schrijven te doen uitgaan met de voornaamste resultaten van de enquête en beknopte informatie over het doel en het 
werkgebied van het project alsook de aanmeldingsprocedure en de kaders voor IT. Ook zijn van de tot dan toe in het project ingestroomde patiênten de diagnoses en therapieên vermeld en per specialisme de relevante categorieên geneesmiddelen.

\subsubsection{Globale eVAluatie Van De informatievoorziening}

De indruk bestaat dat het project ook bij de huisartsen voldoende naamsbekendheid had. Ondanks het ruime aanbod aan informatie traden echter ook bij hen, met name bij de aanmelding en indicatiestelling problemen op. Waarschijnlijk vanwege een tekort aan parate kennis over de procedures, zoals aangetoond bij de artsen in het azM. Gedegen en herhaalde informatievoorziening lijkt dus essentieel. Een probleem hierbij vormt de veelheid aan informatie die huisartsen ontvangen vanwege hun centrale plaats in de gezondheidszorg. In de regio 'Heuvelland' dragen de aanwezigheid van een universiteit en een academisch ziekenhuis daartoe bij.

De informatievoorziening lijkt te hebben bijgedragen aan het streven om het project regionaal naamsbekendheid te geven en aanvragen uit het veld te genereren. De beeldvorming is echter niet specifiek geêvalueerd. De reacties op deze studie in publikaties en bij voordrachten waren over het algemeen positief (bijlage 2.1). Anderzijds waren er ook zorgverleners die niet wisten wat het project precies inhield of dit associeerden met 'ingewikkeld' en 'veel formulieren en procedures'.

Het draagvlak is niet gemeten, maar er zijn geen huisartsen geweest die bij een vraag vanuit het ziekenhuis weigerden aan thuisbehandeling mee te werken. Ook waren er vanuit de enquête geen aanwijzingen (bijvoorbeeld opmerkingen) voor een gering draagvlak onder azM-artsen. Anderzijds zijn mogelijk potentiële patiënten niet aangemeld. Toen in december 1993 adequate uitvoering van het project zonder inspanning van de diverse betrokken zorgorganisaties en financiers onmogelijk bleek, was er bij hen voldoende draagvlak om een bijdrage te leveren $(\$ 8.3){ }^{451}$

\section{$9.6 \quad$ Conclusies}

Geconcludeerd kan worden dat het project onder de voornaamste verwijzers, de azMartsen, een goede naamsbekendheid had en dit geen reden voor de geringe instroom was. De indruk bestaat dat het project ook bij de huisartsen voldoende naamsbekendheid had. Ook het draagvlak voor het project bij de zorgverleners, zorgorganisaties en financiers leek voldoende. 


\section{Scholing}

\subsection{Doel van scholing (fase 1)}

Een zorginnovatie zoals IT is alleen dan kwalitatief verantwoord, als het benodigde medisch-technisch handelen adequaat uitgevoerd wordt. ${ }^{56,217}$ Het tweede deel van aandachtspunt 3 binnen hoofdvraagstelling II betreft dan ook de scholing van patiënten, hun naaste verzorgers en zorgverleners. Uitgangspunt is een zoveel mogelijk zelfvoorzienend zorgsysteem naar Orem waarin patiënten en hun naaste verzorgers centraal staan (schema 1.1). Omvat het zorgaanbod ook instructie, dan kunnen zij de behandeling (deels) overnemen, mits zij daartoe in staat en gemotiveerd zijn. ${ }^{42}$ Scholing stelt de huisarts en de TMV in staat om in onderlinge samenwerking de daarop volgende zorgschil te vormen en de zelfzorgtekorten van het patiëntsysteem op te vangen. Naast het bewerkstelligen van voldoende kennis, vaardigheden en uniformering in de handelwijze bij alle betrokkenen, is scholing ook een instrument voor draagvlakvergroting onder zorgverleners, zorgorganisaties en financiers. De scholing wordt aan de hand van de innovatiecyclus (schema 2.5 ) besproken en is op diverse momenten geëvalueerd.

\subsection{Analyse van scholingsbehoefte (fase 2)}

$\mathrm{Bij}$ patiënten en naasten is de scholingsbehoefte niet geanalyseerd, omdat bij hen geen voorkennis en vaardigheden voorondersteld is. $\mathrm{Bij}$ de professionele zorgverleners is het kennis- en vaardigheidsniveau zo precies mogelijk bepaald omdat scholing vooral zin heeft als ingegaan wordt op de leemtes die professionals zelf ervaren en als aangegeven kan worden welke voordelen scholing oplevert. ${ }^{453} \mathrm{Te}$ weinig scholing leidt bij toepassing in de praktijk tot frustratie, teveel scholing komt bevoogdend over.

\subsubsection{INVENTARISATIE VAN DE SCHOLINGSBEHOEFTE VAN DE HUISARTSEN}

Ook in andere regio's hebben huisartsen zich geschoold in medisch-technische hulpmiddelen bij thuiszorg. ${ }^{454} \mathrm{De}$ scholingsbehoefte van de huisartsen in de regio 'Heuvelland' is op drie enquêtes gebaseerd. Voorafgaand aan het project hebben huisartsen in juni 1992 in een schriftelijke enquête van het Bureau Ondersteuning Huisartsen Heuvelland (BOHH) van de Regionale Huisartsen Vereniging aangegeven nageschoold te willen worden in medisch-technisch handelen, waaronder infuusbehandeling. ${ }^{455}$ De respons onder de 91 aangeschreven huisartsen was $81 \%$ (74). Hiervan wenste $38 \%$ scholing in infusie en $45 \%$ scholing in hypodermoclyse (subcutane infusie van vocht, ook toepasbaar bij behandeling met morfine).

Aansluitend op de BOHH-enquête heeft het project in mei 1993 (reminder juli 1993) de 96 
toen in de projectregio 'Heuvelland' praktiserende huisartsen schriftelijk geẻnquêteerd of en op welk niveau ze scholing wensten in subcutane en intraveneuze infusie en infusie via een centraal veneuze poort (Port-A-Cath(). Er zijn drie deskundigheidsniveau's onderscheiden. Het laagste niveau, "kennis hebben van", is omschreven als: "de theoretische kennis hebben over de indicatiestelling en in staat zijn enkele complicaties te herkennen en observaties te plegen". Bijvoorbeeld: herkennen dat een infuus subcutaan loopt. Het middelste niveau, "uitvoeren", omvat kennis van het laagste niveau plus de bekwaamheid om een behandeling volgens vooraf opgesteld protocol of behandelplan uit te voeren. De specialist voert wijzigingen in het behandelplan door. Bijvoorbeeld: het aanhangen van infuuszakken met vooraf opgegeven hoeveelheden medicijn en dosisaanpassing na eventuele ruggespraak met de specialist. Het hoogste deskundigheidsniveau, "zelfstandig indiceren en uitvoeren", omvat kennis van beide andere niveau's plus voldoende bekwaamheid om zelfstandig de indicatie te stellen en zelfstandig het behandelplan te wijzigen. Bijvoorbeeld: volledig zelfstandig de indicatie voor subcutane infusie met morfine stellen en deze behandeling uitvoeren. Centraalveneuze poorten worden op indicatie van een specialist tijdens een operatie geplaatst. Huisartsen konden daardoor niet het hoogste niveau kiezen. De respons was $68 \%$. De meeste respondenten wensten scholing in een of meerdere soorten infusie, $74 \%$ op alle drie de gebieden (tabel 10.1 ).

Tabel 10.1 De behoefte en het gewenste niveau van scholing van huisartsen (\%).

\begin{tabular}{lccc}
\hline Vraag & Subcutaan & Intraveneus & Centraalveneus \\
Schoingsbehoefte & 94 & 94 & 72 \\
Laag niveau & 5 & 13 & 41 \\
Middel niveau & 15 & 23 & 59 \\
Hoog niveau & 80 & 64 & nvt \\
\hline
\end{tabular}

Legenda: nvt-niet van toepassing. Respondenten: wenselijkheid scholing:65/65/65; niveau scholing:61/61/51.

Ook de landelijke enquête over de taakverdeling tussen artsen en verpleegkundigen bij infuusbehandeling bevatte een vraag over scholing (§5.3.2.4). De respons onder de 96 huisartsen in de projectregio was bij deze enquête $50 \%$. Met de stelling "Scholing en training zijn noodzakelijke voorwaarden voor infuusbehandeling in de thuissituatie" was $94 \%$ het gedeeltelijk of volledig eens. Op de vraag "Vindt $U$ dat $U$ aanvullende scholing en training zou moeten krijgen, alvorens $\mathrm{U}$ infuusbehandeling in de thuissituatie zal kunnen toepassen?" antwoordde $86 \%$ "Ja". Ook had $38 \%$ (meestal eenmalig) ervaring met IT. Dit betrof subcutane infusie bij pijn en uitdroging, intraveneuze infusie bij multiple sclerose en chemotherapie. Indien vooral huisartsen met affiniteit en/of ervaring respondeerden en de non-responders $(50 \%)$ geen ervaring hadden, had in de regio minimaal $\pm 20 \%$ ervaring met IT.

De behoefte aan scholing in de regionale enquête (voor de drie infuussoorten gemiddeld $89 \%$ tabel 10.1 ) en de landelijke enquête $(86 \%)$ komen goed overeen. Deze percentages zijn beduidend hoger dan in de BOHH-enquête van 1992. Wellicht omdat deze meerdere medisch-technische handelingen bevatte. Ook kan de thuisbehandeling door de start van het project actueler zijn geworden. Voorts heeft het Integraal Kankercentrum Limburg eind 1992 een protocol voor subcutane pijnbestrijding bij terminale patiênten verspreid. Ook lijkt de confrontatie met infuusbehandeling in een praktijksituatie de behoefte aan scholing op te roepen. Zo is op verzoek een Balint-groep geünstrueerd. ${ }^{456}$ 
In bovengenoemde landelijke enquête werden ook 58 wijkverpleegkundigen van de SGKH gevraagd naar hun scholingsbehoefte. De respons was $45 \%$ (26). Met de stelling "Scholing en training zijn noodzakelijke voorwaarden voor infuusbehandeling in de thuissituatie" was $96 \%$ het gedeeltelijk of volledig eens. Op de vraag "Vindt $U$ dat $U$ aanvullende scholing en training zou moeten krijgen, alvorens $\mathrm{U}$ infuusbehandeling in de thuissituatic zal kunnen toepassen?" antwoordde $96 \%$ "Ja". Van de respondenten had $27 \%$ ervaring met IT. Dit betrof subcutane en intraveneuze infusie bij pijn en uitdroging en epidurale infusie. Omdat alle wijkverpleegkundigen in de regio aangeschreven zijn, had -bij een respons van $45 \%$ - minimaal $\pm 12 \%$ van hen ervaring met infuusbehandeling.

Als TMVs zijn wijk- (MGZ of HBO-V) en ziekenhuisverpleegkundigen (in service opleiding A of $\mathrm{HBO}-\mathrm{V}$ ) aangesteld. De kennis en vaardigheden van deze opleidingen zijn bekend verondersteld. Ook is uitgegaan van het deskundigheidsniveau van wijkverpleegkundigen (reeds nageschoold in subcutane infusie) bij de SGKH. ${ }^{141}$

\subsection{Perspectief op scholing (fase 3)}

Om protocolontwikkeling, te hanteren technieken en scholing optimaal op elkaar te kunnen afstemmen is de scholing vanuit het project mee ontwikkeld. Nagegaan is welke kennis, vaardigheden en attitude (vooral gericht op samenwerking) nodig zijn en wie op welke wijze scholing kon organiseren. ${ }^{457}$ Het overleg met de scholingsorganisaties is gebruikt om de eigen wensen en verwachtingen te verhelderen. ${ }^{47} \mathrm{Er}$ is voor gezorgd dat de voor de scholing ontwikkelde handelingslijsten ook geschikt zijn voor instructie aan patiënten en naasten. Vanuit de analyse is aangenomen dat verpleegkundigen en huisartsen evenals elders -vanuit hun opleiding en ervaring- onvoldoende (parate) kennis en vaardigheden kunnen hebben voor medisch-technische handelingen bij IT. ${ }^{107,201}$ In de taakomschrijving, het functieprofiel en de scholing van de TMVs is rekening gehouden met instructie van patiënten en andere al dan niet professionele zorgverleners. ${ }^{100}$ Het samenwerkingsmodel tussen huisarts en TMV impliceert dat de scholing van de TMV vanwege de vereiste inhoudsdeskundigheid en organisatorische en voorlichtende taken anders van aard en een stuk intensiever is. ${ }^{291}$ De cursus van de TMV dient bruikbaar te zijn bij de 'differentiatie' infuusverpleegkundige. ${ }^{245}$ Samenwerking met de volgende instituten is onderzocht: \# Binnen de vakgroep Huisartsgeneeskunde van de UM liep een onderzoek naar de toetsing van technische vaardigheden in de huisartsgeneeskunde. Hiervoor is een aantal vaardigheidscursussen ontwikkeld, waaronder "Infuustoepassingen voor de huisarts". 458, 459 De cursus gaf mogelijkheden tot het toetsen van vaardigheden, maar is gericht op de huisarts en beperkt zich tot perifere infusie. Het ontbreken van trainingsfaciliteiten en het zelf moeten organiseren van de cursus bij deze optie zouden het project onevenredig belast hebben. Ook was de continuîteit onvoldoende te waarborgen.

\# Het Skillslab van de UM is opgericht om vaardigheidsonderwijs in medisch-technische handelingen voor de thuiszorg te verzorgen.$^{40}$ Dat een Skillslab daartoe goed geëigend kan zijn bewijst het Skillslab Groningen. ${ }^{103}$ Ook het Maastrichtse Skillslab heeft ruime ervaring op het gebied van ontwikkeling en organisatie van onderwijs voor medische studenten en uitstekende trainingsfaciliteiten. Gezien het zorgmodel opperde het Skillslab een gezamenlijke scholing van huisartsen en verpleegkundigen. Als onderdeel van de universiteit had het Skillslab echter beperkte mogelijkheden om voor derden scholingen te realiseren. Daarom is in goed onderling overleg besloten deze optie niet verder uit te werken. Mogelijk verandert de rol van het Skillslab te Maastricht in de toekomst. ${ }^{103,461}$ 
\# De Dienst Opleidingen van het azM (DO-azM) verzorgde de in-service opleiding A en contractonderwijs en had ervaring in het onderwijzen van medisch-technisch handelen aan wijkverpleegkundigen. De DO-azM heeft goede faciliteiten en kan bemiddelen bij stages in het ziekenhuis. $\mathrm{Zij}$ heeft een aanzet gegeven tot een intensieve en uitgebreide scholing voor de TMVs. Voor de huisartsen kost deze intensieve scholing teveel tijd en geld.

Daarom is bij hen van deze optie afgezien.

\# De Werkgroep Deskundigheidsbevordering Huisartsen (WDH) van de Regionale Huisartsenvereniging Heuvelland heeft jarenlange ervaring met nascholing van huisartsen en zorgverzekeraars vergoeden het geaccrediteerde onderwijs gedeeltelijk. ${ }^{462} \mathrm{Naar}$ aanleiding van de BOHH-enquête waren alreeds nascholingsavonden over medisch-technisch handelen, waaronder infuusbehandeling, gepland. Eén van die avonden is aan IT gewijd.

\subsection{Concept bij scholing (fase 4)}

De projectcoördinatoren en de DO-azM hebben de cursus voor de TMVs ontwikkeld. ${ }^{463}$ Voor de DO-azM is gekozen vanwege de ervaring met onderwijs in medisch-technisch handelen, de beschikbare mensen en middelen en de bereidheid om de cursus mee vorm te geven. Daarbij zijn ziekenhuishygiënisten en specialistisch verpleegkundigen uit het azM geraadpleegd. Gezien de prijs-kwaliteit verhouding, de accenten binnen de organisaties en de benodigde samenwerking, is bij de huisartsen gekozen voor een gezamenlijke scholing door de WDH, de DO-azM en het project. ${ }^{464}$ Voor de lezingen is samengewerkt met de WDH en azM specialisten. Het praktijkgedeelte is gebaseerd op de uitgebreide en intensieve scholing van de TMVs. Schema 10.1 vat de basiselementen van beide scholingen samen. In navolging van Ooms wordt niet van na- of bijscholing maar van scholing gesproken. ${ }^{465}$

Schema 10.1 Basiselementen scholing huisarts en TMV 253 , «os

\begin{tabular}{lcc}
\hline Basiselement & Huisarts & TMV \\
Opfrissen basiskennis & + & $+/-$ \\
Verwerven nieuwe kennis & $+/-$ & + \\
Vaardigheidstraining & + & + \\
Attitudeverbetering & - & $+/-$ \\
\hline
\end{tabular}

\section{5}

Verspreiding en toepassing van scholing (fase 5+6)

\subsubsection{SCHOLING VAN DE HUISARTSEN}

Vanwege de omvang van de lesgroepen en om vakanties, diensten en dergelijke op te vangen, zijn in oktober 1993 en februari 1994 scholingsavonden voor de regionale huisartsen georganiseerd. De keuze voor scholing in één avond ( 3 uur plus een $1 / 2$ uur pauze) beperkte het aantal onderwerpen. Doel van de scholing was de huisarts toe te rusten met de minimumkennis, vaardigheden en attitude voor IT. De scholing bestond uit lezingen over pijnbestrijding, samenwerking bij infuusbehandeling en vaardigheidstrainingen op onderdelen van de infuusbehandeling (schema 10.2). ${ }^{464}$ De Dienst Opleidingen onderwees de medisch-technische handelingen via de handelingslijsten uit de protocollen. De TMVs waren aanwezig voor assistentie en ter kennismaking. Bij de eerste scholingsavond waren $30(60 \%)$ van de 50 aangemelde huisartsen aanwezig, bij de tweede negen $(56 \%)$ van de 16 . In totaal hebben $39(41 \%)$ van de 96 regionale huisartsen deelgenomen. Per avond kost dit ongeveer $f 1.700$. De huisartsen betaalden $f 50$ (het ziekenfonds vergoedde $61 \%$ via WDH accreditatie). 
Lezingen (3x15 minuten)

- Het project 'Infuusbehandeling Thuis'

- Pijnbestrijding in de thuissituatic

- Ins en outs van infuusbehandeling

Workshop 1 (45 minuten): vaardigheidstraining inbrengen perifeer infuus

- Een infuuscanule inbrengen bij een fantoom

- Aansluiten van een toedieningssysteem aan een infuuscanule

- Afplakken van de infuuscanule

- Verzorging van de insteekopening

- Verwijderen van een infuuscanule

- Interventies bij onvoldoende functioneren van het infuus

Workshop 2 (20 minuten): vaardigheidstraining infusie

- Een toedieningssysteem vullen volgens de handelingenlijst

- Het gebruik van drie-weg kranen

- Centraal veneuze poort aanprikken

Workshop 3 (20 minuten): rekenen en pompsystemen

- Berekening van het infuusvolume en de toedienings/druppelsnelheid

- Werking elastomeerpomp

- Werking perfusoren en volumegestuurde pompen

\subsubsection{SCHOLNG VAN DE TMVS}

De DO-azM heeft de TMVs geschoold. ${ }^{43}$ De scholing is gebaseerd op het model van Clinical Teaching. Daarbij zijn de theoriecomponent, de theoriecomponent van de vaardig. heden, de vaardigheidscomponent en de praktijkcomponent integraal op elkaar afgestemd. Bij de onderwijsbijeenkomsten is gebruik gemaakt van de interactieve onderwijsmogelijkheden van een kleine groep. De scholing bestaat uit zeven modules van elk vier uur (schema 10.3). Voorafgaand aan elke bijeenkomst wordt het studiepakket zelfstandig doorgenomen (drie uur). De medisch-technische handelingen zijn aan de hand van in de protocollen opgenomen handelingslijsten onderwezen. De vaardigheden zijn getoetst met op de handelingslijsten gebaseerde observatiescoringslijsten. ${ }^{467}$ De scholing kost $f 900$ cursusgeld plus $28 \mathrm{x} \pm f 30=f 840$ uurloon per TMV. Tevens hebben de projectcoördinatoren de TMVs uitgebreid geïnstrueerd (drie halve dagen) over:

* Achtergronden en doelstellingen van het project.

* Reguliere aanmeldings- en andere procedures bij thuiszorg in de regio Heuvelland.

* Afwijkende aanmeldings- en andere procedures ten behoeve van het project.

* Logboek en registratieformulieren.

* Rol en attitude van de TMVs binnen het project.

Exclusief het uurloon van de projectcoördinatoren kost dit $12 x \pm f 30=f 360$ per TMV.

\section{6}

\section{Evaluatie van scholing (fase 7)}

\subsubsection{MetHODEN}

De scholing is op twee manieren geëvalueerd. De deelnemers is gevraagd naar hun mening over de scholing (proces). Ook is gekeken in hoeverre de aangeboden kennis en kunde in de praktijk van de IT aanwezig waren (effect). Bij huisartsen en TMVs is daartoe in de vragenlijst na elke behandeling gevraagd of zij zich voldoende toegerust achtten voor de praktijk (methode $\$ 8.4 .1+\$ 14.4 .1$; resultaten $\mathrm{H}: 8,12,14$ ). Bij de huisartsen is tevens bijgehouden in hoeverre zij het inbrengen van een perifere infuuscanule beheersten. 
Module 1: consequenties medisch-technisch handelen door verpleegkundigen (theorie)

- Het Verpleegkundig Beroepsprofiel

- De Wet Beroepen in de Individuele Gezondheidszorg

- Raamovereenkomst medisch-technisch handelen in de regio Heuvelland

- Medisch-technisch handelen door een verpleegkundige

- Medisch-technisch handelen door een TMV in de thuissituatie aan de hand van casus

Module 2: subeutane/perifere infusie in de thuissituatie (theorie en vaardigheden)

- Het berekenen van oplossingen en druppelsnelheid

- Het toevoegen van medicatic aan infusievloeistof

- Het opbouwen van een infuustoedieningssysteem

- Aansluiten/verwisselen van zakken/kolven infusievloeistof

- Inbrengen van een subcutane infuuscanule en assisteren bij het inbrengen van een perifere infuuscanule

- Verzorging van de insteekopening van een subcutane/perifere infuuscanule

- Verwijderen van een subcutane/perifere infuuscanule

Module 3: centraal veneuze poort en catheter in de thuissituatie (theorie en vaardigheden)

- De werking van de centraal veneuze poort (Port-a-cathø) of catheter

- Voorzorgsmaatregelen in verband met centraalveneuze infusic

- Het aan-en afkoppeien van een infuustoedieningssysteem bij de centraal veneuze poort of catheter

- Het verzorgen van de insteekopening van een centraal veneuze poort of catheter

- Het aanbrengen en verwijderen van een Hobnernaald bij een centraal veneuze poort

Module 4: pompen en hulpmiddelen bij infusie (theoric en vaardigheden)

- De werking van infuuspompen, perfusoren en elastomeerpompen

- Probleemidentificatie en -oplossing

- Soorten infuusvloeistoffen, samenstelling, werkwijze en observatie tijdens de toediening

- Het medicijn verwijzingssysteem in de thuissituatie en de rol van de TMV hierin

Module 5: instructie geven (theorie en vaardigheden)

- Het verzorgen van vaardigheidsonderwijs

- Stappen in een onderwijssituatic

- Doelen formuleren

- Didactische werkvormen

- Het gebruik van leermiddelen

- Organisatorische aspecten en de invloed op de onderwijssituatie

- Het maken van een lesopzet en het uitvoeren van een mini-les

Modules 6.1 en 6.2: stage bij patiēnt thuis en in het dagcentrum van het azM (vaardigheden)

- Berekenen van oplossingen en druppelsnelheden

- Verzamelen en klaarzetten materiaal voor een infusie

- Aansluiten/verwisselen van zakken/kolven infusievloeistof

- Inbrengen van een subcutane infuuscanule en assisteren bij het inbrengen van een perifere infuuscanule

- Het aanbrengen en verwijderen van een Hobnernaald bij een centraal veneuze poort

- Beoordelen van de insteekopeningen

Toetsing (theoric en vaardigheden)

- Doorlopende toetsing van vaardigheden tijdens de lessen in het skillslab van de Dienst Opleidingen

- Afsluitende toetsing van de theorie met $40 \mathrm{ja} / \mathrm{nee}$ vragen

- Afsluitende toetsing van de vaardigheden in de praktijk tijdens de stage in het dageentrum

\subsubsection{OORDEEL VAN DE HUISARTSEN OVER DE ONTVANGEN SCHOLING}

Doel van de scholing is om de huisartsen voor subcutane en intraveneuze infusie het hoogste onderscheiden deskundigheidsniveau te laten bereiken. Voor centraalveneuze infusie wordt het laagste niveau voldoende geacht. De scholingsdoelstelling is vanuit het project geslaagd geacht, indien $50 \%$ of meer van de deelnemende huisartsen tenminste de bovengenoemde deskundigheidsniveau's bereikt. De huisartsen zelf is gevraagd hun eigen deskundigheidsniveau in te schatten. Tijdens de scholing is bij de 39 deelnemende huisartsen vooraf een enquête afgenomen over het reeds aanwezige deskundigheidsniveau 
en het niveau dat men wenste te behalen. Aan het eind van de scholing is het aanwezige deskundigheidsniveau nogmaals nagevraagd. Van 25 huisartsen (64\%) zijn beide vragenlijsten voor verwerking geschikt. Tabel 10.2 geeft aan welk deskundigheidsniveau de huisartsen volgens henzelf voor en na de scholing hebben en welk niveau zij wensen te bereiken. Het gemiddelde niveau is op een schaal van 1,0 tot 3,0 uitgedrukt.

Tabel 10.2 Deskundigheidsniveau van huisartsen op verschillende tijdstippen (\%).

\begin{tabular}{lccc|ccc|ccc}
\hline Deskundigheidsaiveaut & \multicolumn{3}{c}{ Subcutaan \% } & \multicolumn{3}{c}{ Intraveneus \% } & \multicolumn{3}{c}{ Centraalveneus \% } \\
& Voor & Wens & Na & Voor & Wens & Na & Voor & Wens & Na \\
Laag (waarde 1) & 80 & 4 & 16 & 68 & 8 & 4 & 100 & 32 & 28 \\
Middel (waarde 2) & 8 & 8 & 16 & 28 & 40 & 56 & 0 & 40 & 64 \\
Hoog (waarde 3) & 12 & 88 & 68 & 4 & 52 & 40 & 0 & 28 & 8 \\
Gemiddeld (1-3) & 1,3 & 2,8 & 2,5 & 1,4 & 2,4 & 2,4 & 1 & 2 & 1,8 \\
\hline
\end{tabular}

Legenda: Respondenten: 25.

Vervolgens is de toename in deskundigheidsniveau's gemeten en in hoeverre de scholing aan de individuele wensen van de huisartsen heeft voldaan (bijlage 10.1). De gewenste scholingsniveau's van aan de scholing deelnemende huisartsen zijn hoger dan die van alle huisartsen (tabel 10.1). De scholing over subcutane en centraalveneuze infusie heeft aan de wensen van de huisartsen en die van het project voldaan. Bij de intraveneuze infusie is met $40 \%$ op het hoogste niveau de projectdoelstelling (streven $50 \%$ ) niet gehaald. Het gemiddeld behaalde niveau komt wel dicht in de buurt van wat de huisartsen zelf wensen. Van alle deelnemende huisartsen heeft gemiddeld $20 \%$ geen profijt van de scholing (bijlage 10.1). Zij vinden het tempo te hoog. 'Overall' leren de huisartsen in $24 \%$ minder dan gewenst, in $64 \%$ evenveel en in $12 \%$ meer (bijlage 10.1). De verwachtingen voor de scholing liggen bij de subcutane infusie hoger, bij de centraalveneuze infusie lager.

Het streven (tabel 10.3) bij intraveneuze infusie was om $50 \%$ of meer van de huisartsen bij

Tabel 10.3 Het door huisartsen op onderdelen bereikte deskundigheidsniveau (\%).

\begin{tabular}{|c|c|c|c|c|c|}
\hline Specifiek onderdeel & Laag & Midden & Hoog & $\begin{array}{l}\text { Streef } \\
\text { niveau }\end{array}$ & $\begin{array}{l}\text { Niveau } \\
\text { bereikt }\end{array}$ \\
\hline $\begin{array}{l}\text { Berekening van de vereiste inloop-en } \\
\text { druppelsnelheid }\end{array}$ & 58 & 31 & 12 & hoog & - \\
\hline Infuustoedieningssysteem opbouwen & 15 & 54 & 31 & hoog & - \\
\hline Perifere infuuscanule inbrengen & 4 & 46 & 50 & hoog & + \\
\hline $\begin{array}{l}\text { Aansluiten toedieningssysteem op perifere } \\
\text { infuuscanule }\end{array}$ & 4 & 46 & 50 & hoog & + \\
\hline Het gebruik van drie-weg kranen & 15 & 50 & 35 & hoog & $\cdot$ \\
\hline Verzorgen van de insteekopening & 8 & 46 & 46 & hoog & $\cdot$ \\
\hline Perifere infuuscanule verwijderen & 4 & 35 & 62 & hoog & + \\
\hline $\begin{array}{l}\text { Interventiemogelijkheden bij onvoldoende } \\
\text { functioneren infuus }\end{array}$ & 19 & 35 & 46 & hoog & $\cdot$ \\
\hline Centraalveneuze poort aanprikken & 4 & 62 & 35 & laag & + \\
\hline De elastomeerpomp & 58 & 27 & 15 & laag & + \\
\hline Perfusoren en volumegestuurde pompen & 77 & 15 & 8 & laag & + \\
\hline
\end{tabular}

Legenda: $+/=$ =het hoogste niveau is bij $50 \%$ of meer al dan niet gehaald. Respondenten: 26 . 
de acht essentieel geachte onderdelen het hoogste niveau te laten behalen (tabel 10.3). Slechts bij drie onderdelen is de doelstelling gehaald. De resultaten weerspiegelen dat informatie over het aanprikken van de centraalveneuze poort en pompsystemen slechts ter kennisname is aangeboden.

\subsubsection{OORDEEL VAN DE TMVS OVER DE ONTVANGEN SCHOLING}

De scholing van de eerste zes TMVs is door vijf (83\%) van hen na afloop schriftelijk geèvalueerd. Elke scholingsmodule is beoordeeld op de cursusinhoud, de docent en de lesorganisatie (bijlage 10.2). De waardering voor de inhoud van de modules varieert omgerekend van 6,9 tot 8,4 , die voor de docenten van 5,7 tot 9,0 en die voor de lesorganisatie van 6,3 tot 8,6 . De meeste modules zijn door de deelnemers als goed beoordeeld. Het onderdeel 'Perifere Infusie' is lager beoordeeld. Bij navraag blijkt dit grotendeels terug te voeren op de docent. Het 'overall eindoordeel' van de cursisten is gemiddeld 8,0 (bereik: $7,5-10)$. Het uit de afzonderlijke modules berekende 'overall eindoordeel' is gemiddeld 7,9 (bereik: 7,2-8,4) en stemt hiermee goed overeen.

\subsubsection{OORDEEL VAN HUISARTSEN EN TMVS OVER HET NUT VAN DE SCHOLING}

Naast het oordeel over de scholing zelf, is de zorgverleners ook in de evaluatie aan het eind van elke behandeling gevraagd naar het nut van het gehanteerde protocol en de scholing (tabel 10.4). Over de duidelijkheid van het protocol, de combinatie van protocol en scholing en de praktische uitvoerbaarheid is men redelijk positief. In de praktijk bestaat echter ook na scholing nog behoefte aan ondersteuning door andere zorgverleners.

Tabel 10.4 Oordelen huisartsen en verpleegkundigen combinatie scholing en ondersteunend protocol.

\begin{tabular}{|c|c|c|}
\hline Stelling ${ }^{\bullet}$ & Verpleegkundige & Arts \\
\hline $\begin{array}{l}\text { In het protocol staan de te verrichten handelingen } \\
\text { duidelijk omschreven. }\end{array}$ & $4,0 / 0,4 / 3-5$ & $3,9 / 0,5 / 3-5$ \\
\hline $\begin{array}{l}\text { In combinatie met de scholing of instructie biedt het } \\
\text { protocol voldoende basis om handelingen zelfstandig te } \\
\text { verrichten. }\end{array}$ & $4,0 / 0,5 / 2-5$ & $3,8 / 0,5 / 2-5$ \\
\hline Het protocol blijkt in de praktijk goed uitvoerbaar. & $4,0 / 0,5 / 2-5$ & $3,8 / 0,5 / 2-5$ \\
\hline $\begin{array}{l}\text { Ondanks de scholing of instructie heb ik regelmatig } \\
\text { ondersteuning nodig van andere zorgverieners." }\end{array}$ & $3,4 / 1,0 / 1-5$ & $3,2 / 1,1 / 1-5$ \\
\hline
\end{tabular}

Legenda: $=$ vijfpuntsschaal $1: z e e r$ mee oneens 2 mee oneens 3 :niet mee eens en niet mee oneens 4:mee eens $5: z e e r$ mee eens, " =gemiddelde, standaarddeviatic, bereik" $"=$ deze stelling is ter vergelijking omgecodeerd, ook hier drukt een hoog getal dus tevredenheid uit. Respondenten verpleegkundig: 109-116, arts:102-105.

\subsubsection{VAARDIGHEID BI] HET INBRENGEN VAN DE PERIFERE INFUUSCANULE}

Een andere graadmeter voor het effect van de scholing bij de huisarts is de vaardigheid betreffende het inbrengen van perifeer intraveneuze infusen. Deze parameter is via de notulen van het werkoverleg en de zorgdossiers vervolgd. Het inbrengen bleek in 13\% (32/164) van zowel de eerste als van vervolgbehandelingen thuis mogelijk (tabel 10.5). De meeste patiènten met een intraveneuze behandeling startten echter in het ziekenhuis. Daarom is het rešler te kijken naar het aantal tijdens de behandeling ingebrachte infuuscanules. Deze blijken in 25\% (22/88) door de huisarts te zijn ingebracht. Dat toch veel infusen tijdens de behandelingen in het ziekenhuis ingebracht zijn, wordt veroorzaakt door enkele patiěnten bij wie het inbrengen van de infuuscanule moeilijk is. Hetzelfde doet 
zich voor bij de vervolgbehandelingen (hoe vaker behandeld hoe groter de kans op moeilijkheden bij het aanprikken). Ook in het ziekenhuis moeten dan vaak meerdere pogingen ondernomen worden om een infuuscanule in te brengen. Wellicht representeren de in de eerste behandeling tijdens de behandeling ingebrachte infuuscanules dan ook het beste het technisch vaardigheidsniveau van de huisartsen. Deze blijken in $43 \%(20 / 46$ tabel 10.5) door huisartsen ingebracht te zijn. In een aantal gevallen brengen huisartsen geen nieuwe infuuscanule in omdat zij de vereiste kennis en vaardigheid ontberen. Hetzij omdat zij de scholing niet hebben bijgewoond, hetzij omdat zij vanwege de geringe toepassing de vaardigheid niet op peil hebben kunnen houden.

Tabel 10.5 Plaats van thuis $\mathrm{en}$ in het ziekenhuis ingebrachte perifeer intraveneuze infusen.

\begin{tabular}{lcc|cccc}
\hline Plaats & \multicolumn{2}{c}{ Behandeling 1 } & \multicolumn{2}{c}{ Behandeling 2-10 } & \multicolumn{2}{c}{ Totaal } \\
& Start & Tijdens & Start & Tijdeas & Start & Tijdeas \\
Polivafdeling & 16 & 1 & 6 & 13 & 22 & 14 \\
Dagcentrum & 29 & - & 14 & - & 29 & - \\
EHBO & 1 & 25 & 0 & 27 & 15 & 52 \\
Thuis & 7 & 20 & 3 & 2 & 10 & 22 \\
Totaal & 53 & 46 & 23 & 42 & 76 & 88 \\
\hline
\end{tabular}

Legenda: *-niet van toepassing: vervolgnaalden werden op een van de andere lokaties ingebracht.

\subsubsection{VAARDIGHEDEN TMVS}

De scholing van de TMVs lijkt voldoende voor de meeste praktijksituaties (tabel 10.4). Tekortkomingen betreffen vooral materiaalgebruik en infectiepreventie. Hierover zijn bij de start van het project geen bindende richtlijnen opgesteld. Eerst moest er een vertaling gemaakt worden van de kliniek naar de thuissituatie. Ook blijkt er soms een discrepantie tussen de officiële protocollen en de dagelijkse praktijk in de kliniek. De instructie aan het begin van het project blijkt noodzakelijk. In het wekelijks werkoverleg is veelvuldig tijd besteed aan de protocollen en werkafspraken. Continue instructie -tezamen met de terugkoppeling van hoe één en ander in de praktijk werkt- blijkt nodig.

\subsubsection{BESCHOUWING}

De scholing had tot doel om door kennis, vaardigheid en uniformering in de handelwijze thuisbehandeling mogelijk te maken. Ook is draagvlakvergroting beoogd.

Een meerderheid van de regionale huisartsen had bij diverse inventarisaties behoefte aan scholing betreffende subcutane, intraveneuze en centraalveneuze infusie. Van de 96 regionale huisartsen heeft $41 \%$ aan de scholing deelgenomen. Dit is een gebruikelijk opkomstpercentage voor scholing onder WDH auspiciën. ${ }^{462}$ Op grond van hun reacties leken de huisartsen de combinatie van kennis- en vaardigheidsonderwijs te waarderen. ${ }^{468}$ Wel gaven ze aan dat het tempo hoog lag. De scholing lijkt overigens grotendeels te voldoen aan hetgeen onder postacademisch onderwijs geneeskunde wordt verstaan. ${ }^{469} \mathrm{Er}$ komt een duidelijk scholingseffect naar voren. De effectmaat bestaat echter uit het subjectieve, door de deelnemers aan de scholing over zichzelf gegeven, oordeel. Dit oordeel is meestal hoger, maar correleert wel met objectief gemeten scholingseffecten. ${ }^{470}$ De idealistische scholingsdoelstellingen van het project zijn slechts gedeeltelijk bereikt. Het is -ook gezien de ervaringen met de scholing van de TMVs- niet realistisch te verwachten dat huisartsen zich in slechts enkele uren de vereiste kennis en vaardigheden volledig eigen kunnen maken. Het is dan ook aan te bevelen om -uit het oogpunt van 
continue scholing- aan het infuusbeleid en het inbrengen van infusen in de huisartsopleiding expliciet aandacht te schenken.

De scholing blijkt aanvullende ondersteuning bij een concrete patiënt niet overbodig te maken (H:8). Een afnemend scholingseffect is ook bekend van andere weinig frequent toegepaste medisch-technische handelingen. ${ }^{47}$ Wanneer huisartsen de infuuszorg in de regio 'Heuvelland' in de praktijk brengen, worden zij ondersteund door de TMVs, die een veel uitgebreidere training hebben gehad en ook geschoold zijn in het geven van instructies. Over de scholing die zij hebben ontvangen zijn de TMVs (zeer) tevreden. Men waardeert met name de wisselwerking tussen theorie en praktijk, de mogelijkheden om vaardigheden te oefenen, en het uitwisselen van ervaringen. Wel vinden ook zij dat in de scholing veel in korte tijd aan bod komt ('stoomcursus'). De TMVs instrueren de patiënten, hun naasten en de in de zorg participerende wijkverpleegkundigen (die vooraf geen extra scholing hebben ontvangen). Bij instructie volgens een uniforme handelwijze kunnen patiênten en naasten in de thuisbehandeling participeren. Wordt dit nagelaten, dan treedt verwarring op, geven patiënt en/of naaste verzorger(s) aan zich duidelijk minder op hun gemak te voelen en kan hun leerproces vertraagd worden (H:8,14). Dit is ook het geval bij andere toepassingen van thuiszorgtechnologie. ${ }^{42}$ De actieve rol van de TMVs in de continue deskundigheidsbevordering is analoog aan die van het verpleegkundig instructieteam bij het Kruiswerk Amsterdam. ${ }^{47}$ Toch blijft, ondanks de scholing van huisartsen en van en door TMVs, bij sommige patiënten specialistische aanvullende ondersteuning vanuit het ziekenhuis of het Groene Kruis nodig. Ook blijft, zelfs bij uitgebreide protocollen en daarop afgestelde scholing zoals in het onderhavige project, inter individuele variatie bij medisch-technische handelen bestaan.

In hoeverre de scholing heeft bijgedragen aan de draagvlakvergroting onder zorgverleners, zorgorganisaties en financiers is niet vervolgd. Uit de reacties op, tijdens en naar aanleiding van de scholingsactiviteiten lijkt scholing deze functie wel te vervullen.

\subsection{Conclusies}

In Nederland bestaat een veelheid aan locoregionale handelwijzen en protocollen. Bij de uitvoering van complexe medisch-technische handelingen thuis naar het model van Orem is het essentieel dat consequent éénzelfde handelwijze toegepast wordt. Een voor patiěnten, naasten, verpleegkundigen en artsen op elkaar afgestemde scholing is hiervoor een vereiste. 


\section{Financiering en technologie}

\subsection{Doel van keuzen in financiering en technologie (fase 1)}

De financiering van de Nederlandse gezondheidszorg is wettelijk gereguleerd onder andere middels de Wet Tarieven Gezondheidszorg. De totale (overheids)uitgaven voor gezondheidszorg en de verdeling daarvan worden bovendien jaarlijks (van overheidswege) vastgesteld in het Jaaroverzicht Zorg (voorheen Financieel Overzicht Zorg). De tarieven van diverse behandelingen worden van overheidswege vastgesteld in het Centraal Orgaan Tarieven Gezondheidszorg. Tijdens de projectperiode is de Intensieve Thuiszorg (ITZ) regeling van kracht geweest. ${ }^{64}$ Deze regeling voorzag in extra financiering voor intensieve verpleging en verzorging thuis ter voorkoming of uitstel van, of overbrugging tot aan ziekenhuis- of verpleeghuisopname. Omdat voor IT geen centrale tarieven zijn vastgesteld, betreft aandachtspunt 4 uit hoofdvraagstelling II de vormgeving van de financiering. ${ }^{475}$ Hierbij zijn via de innovatiecyclus (schema 2.5 ) de invloed van de keuze van de financieringsvorm en technologie bestudeerd.

\subsection{Analyse van keuzen in financiering en technologie (fase 2)}

Vanaf de projectaanvraag is de interactie tussen financiering en technologie onderkend. Er werd uitgegaan van ongeveer 200 patiënten en 1.775 infusiedagen (bijlage 11.1).

Binnen het project was voor betaling van de wijkverpleegkundigen en de huisartsen $f 200.000$ en voor scholing $f 24.000$ begroot. De kosten van één training voor één patiënt via een facilitair bedrijf werden geschat op $f 262,50$ (drie in ziekenhuis en één thuis; totaal drie uur à $f 87,50$ per uur) ${ }^{476} \mathrm{Bij} 200$ patiënten $(200 \times f 262,50=f 52.500)$ zou per infusiedag ongeveer $f 97$ ( $f 224.000-f 52.500 / 1.775)$ resteren voor de bekostiging van de huisarts en de wijkverpleegkundige. Dit kwam overeen met maximaal \pm 2 huisartsconsult of $11 / 4$ uur wijkverpleegkundige zorg per infusiedag. De tarieven voor visites van de huisarts bedroegen bij ziekenfondspatiënten via ITZ $f 34,25$, later $f 34,50$ en bij particulieren $f 51$, later $f 52,50$ (buiten kantooruren beide dubbel tarief). Het wijkverpleegkundig uurtarief was $f 55$ tot $f 65$, exclusief overhead (richttarief inclusief overhead $f 81,25$ ). 226

Het ministerie van Welzijn Volksgezondheid en Cultuur (nu Volksgezondheid Welzijn en Sport) sloot bekostiging van infusie-apparatuur, medicatie en infuusvloeistoffen vanuit de projectfinanciering uit. Daarvoor is financiering gezocht binnen de ITZ (totaal maximaal $f 200$ per dag). De kosten van de infuussystemen en toebehoren (cassettepomp exclusief medicatie) betrokken via een facilitair bedrijf werden op $f 90$ per dag geraamd (bijlage 11.1). ${ }^{476}$ Dit bedrag was scherp gecalculeerd. De elastomeer- en de veerpomp bleken niet veel goedkoper (bijlage 11.1). Implanteerbare pompsystemen zijn vanwege hun 
beperkingen (langdurige toediening één soort medicatie, 'break even' ten opzichte van andere systemen pas na 12 weken) niet vergeleken. ${ }^{47}$ Per dag zou derhalve ongeveer $f 110$ $(f 200-f 90)$ resteren voor medicatie en infuusvloeistoffen. Overschrijding hiervan zou het azM dienen te bekostigen aangezien de zorgverzekeraar VGZ een bijdrage van het azM wenste (via het toenmalige geneesmiddelen vergoedingssysteem). ${ }^{478,479}$

Per infusiedag was aldus in totaal $\pm f 325$ gulden beschikbaar $(f 224.000 / 1.775+f 200)$, plus een eventuele bijdrage van het azM. Op grond van de volgende overwegingen leek het desondanks niet opportuun om op basis van de oorspronkelijke financieringsafspraken infuusbehandelingen thuis aan te gaan bieden:

- Deze financieringsvorm zou patiēnten ongelijke toegang tot zorg bieden. Alleen patiënten die na een korte training in staat waren de infuusbehandeling grotendeels zelf uit te voeren zouden in aanmerking komen (er was slechts financiering voor $1 \frac{1}{2}$ à 2 uur professionele hulp per dag).

- Deze financieringsvorm zou IT voor veel terminale patiēnten slechts toegankelijk maken, indien zij zelf een financièle bijdrage zouden leveren. Bij veel terminale patienten werd namelijk reeds ITZ-zorg ingezet, vaak al tot het maximum van $f 200$ per dag.

- De projectgelden zouden binnen deze financieringsvorm niet louter als 'stimuleringssubsidie' worden ingezet, maar voor vergoeding van zorgverlening.

* De VGZ wilde dat het azM de eventuele meerkosten voor medicatie en infuusvloeistoffen voor haar rekening nam omdat thuisbehandeling verpleegdagen zou besparen. Het azM daarentegen wees op haar academische functie en de druk op de bedden. Bij thuisbehandeling zouden in de hierdoor vrijkomende bedden andere patiěnten van de wachtlijst opgenomen worden.

* Er was in feite sprake van een open-eind-financiering en het was onduidelijk welke partij daarvoor de eindverantwoordelijkheid zou moeten nemen. Noch de vakgroep Huisartsgeneeskunde (verantwoordelijk voor project), noch het azM, noch de SGKH, noch de VGZ konden of wilden die verantwoordelijkheid nemen.

\subsection{Perspectief en concept bij financiering en technologie (fase $3+4$ )}

Op grond van bovenstaande is het financieringsconcept herzien. Er is vanuit gegaan dat de financiering zoveel mogelijk marktconform is, hetgeen betekent dat goederen en diensten tegen reelle prijzen geleverd en volgens gangbare principes gefinancierd worden: ${ }^{480}$

* Zorgverleners en organisaties kunnen onder normale financiële omstandigheden werken (loon naar werken, maar ook verplicht kwalitatief goede zorg te verlenen).

* De projectgelden worden niet voor zorgverlening ingezet. De projectgelden (scholing, investeringen) moeten 'leverage' (hefboomwerking) hebben.

* Omdat hun budget al gelabeld is, committeren zorgorganisaties zich alleen tot te overziene bijdragen.

* Het project financiert enkele vaste zorgkosten ('risico' lage instroom).

- Zorgverzekeraars dragen per patiënt de variabele zorgkosten ('risico' hoge instroom).

Ter operationalisatie van deze uitgangspunten zijn de kosten voor IT binnen het project onderscheiden in wetenschappelijk onderzoek, investering en zorgverlening. Alleen de kosten betreffende investering en zorgverlening worden verder besproken. Deze kosten zijn onderscheiden in vaste en variabele componenten. 


\section{4}

Verspreiding en toepassing van financiering en technologie (fase $5+6$ )

Op basis van voornoemde uitgangspunten was het mogelijk een financiēle basis te creëren binnen het Samenwerkingsverband Transmurale Zorg (\$8.3). De vaste materiêle investeringen zijn op $f 10.000$ begroot, de vaste personele kosten voor twee jaar op ongeveer $f 90.000$ voor scholing/basisaanstelling TMVs en $f 96.800$ voor zorgcoördinatie (bijlage 11.2). Het project (IT) zou ongeveer $f 1.000$ per patiënt betalen. De variabele kosten waren vooraf grotendeels onbekend. De SGKH nam de TMVs in dienst en stelde ze op uurbasis voor de prijs van $f 55$ beschikbaar aan het project. Voorts nam de SGKH de debiteuren/crediteuren administratie voor haar rekening ( $f 52,50$ per patiěnt) en stelde haar $\mathrm{CM}$ gratis ter beschikking ( $200 \times f 55)$. Het azM vergoedde een deel van de kosten van infuusmaterialen $(f 22.000)$ en de afvalverwerking $(f 5.000)$. Het TDC financierde de kosten $(f 30.000)$ om het project als business unit te kunnen laten opereren. De overige variabele zorgkosten zouden bij de zorgverzekeraars (verz) worden gedeclareerd. Tabel 11.I geeft weer dat onzekerheden over kosten bleven bestaan, maar dat de oorspronkelijke risico's voor het project en het azM gereduceerd werden. Voor de zorgverzekeraars leken de risico's het grootst, maar zij gaven meestal op grond van een individuele offerte per patiênt goedkeuring. Omdat een formele financieringsgrondslag ontbrak, gebeurde dit hetzij op basis van de ITZ-regeling hetzij uit coulance. De VGZ gaf daarnaast op voorhand een financieringsgarantie af voor 50 patiěnten met morfine-infusie à raison van $f 1.300$ en 50 met mannitolinfusie à $f 2.075$, totaal $f 168.750$ (bijlage 11.3 ). ${ }^{451}$

Door vertragingen in het ontwikkelen van de zorgverlening diende de projectduur verlengd te worden. Bij de tussenrapportage in mei 1994 is daartoe bij WVC met goed gevolg een verzoek tot budgetneutrale verlenging gedaan (bijlage 11.2). De nieuwe begroting gaf slechts beperkte afdekking van financiële risico's in de zorgverlening ( $f 15.000)$.

Tabel 11.1 Begrote kosten volgens oorspronkelijk voorziene en gekozen financiering (guldens).

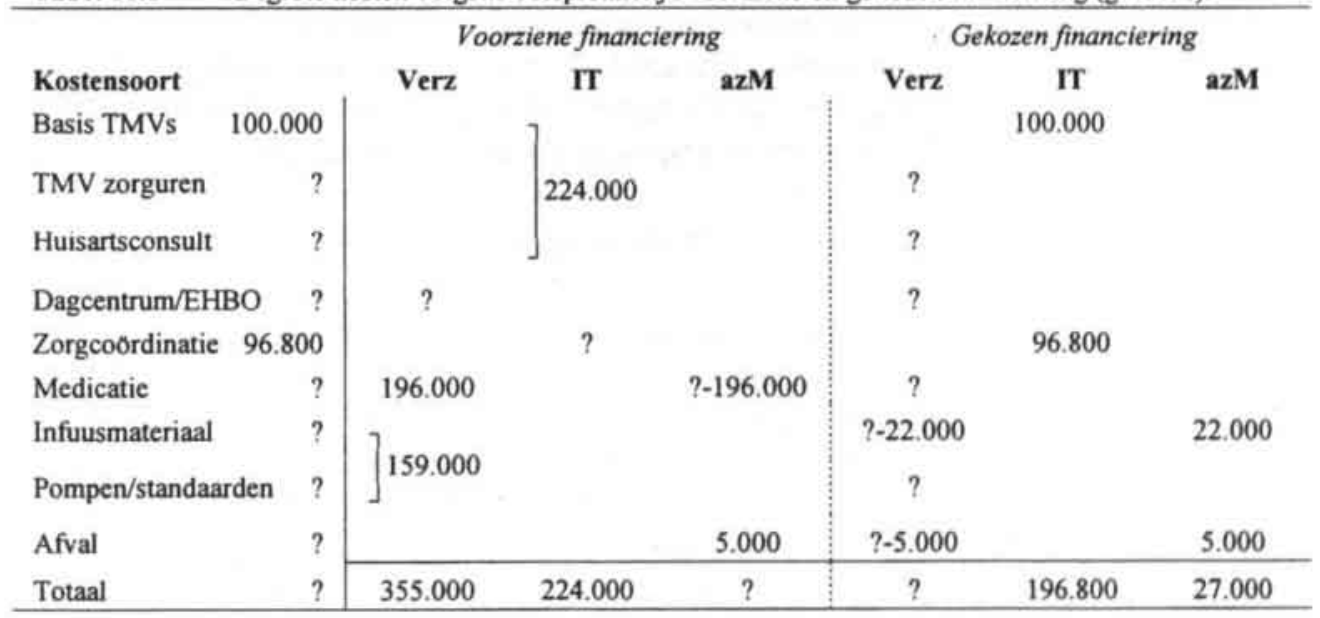

Legenda: Verz-zorgverzekeraars, ?=een bij de start van het project onbekend bedrag, ?-x=een bedrag dat resteert als een andere partner een vast bedrag bijdraagt, $\mid=$ éen bedrag voor meerdere begrotingsposten tezamen. 


\subsection{Evaluatie van financiering en technologie (fase 7)}

\subsubsection{METHODE BESTUDERING VAN FINANCIERINGS- EN TECHNOLOGIEKEUZEN}

Ter bestudering van de kosten fungeerde het project als een business unit en kocht zorg in bij de SGKH (TMVs, infuusstandaarden, bezorgdienst), huisartsen (consulten), openbare apothekers (medicatie en infuusmaterialen), het ziekenhuis (pompen, medicatie en infuusmaterialen) en externe leveranciers (pompen en infuusmaterialen). In samenwerking met het financieel beheer van het TDC zijn de kosten per behandeling berekend en gefactureerd. De financielle administratie van de SGKH declareerde op basis hiervan bij de zorgverzekeraars en betaalde zorgverleners en zorgorganisaties. In hoofdstuk 15 worden de kosten gedetailleerd besproken. In dit hoofdstuk worden de effecten van de keuzen van de infuustechnologie en de financiering voor de diverse partijen belicht. Hierbij zijn de toegepaste technologieën en financiering vergeleken met de oorspronkelijk voorziene cassettepomp met eenmalige training van de patiênt en financiering (\$11.2-§11.4).

\subsubsection{RESULTATEN VAN FINANCIERINGS- EN TECHNOLOGIEKEUZEN}

Tabel 11.2 geeft de effecten van de keuzevarianten met betrekking tot financieringsvorm en infuustechnologie voor diverse betrokken partijen (uitgebreider bijlagen 11.4 en 11.5). Waren zoals in 'Scenario I' de oorspronkelijke technologie én financiering gekozen, dan zou het ITZ-budget bij 2.591 infuusdagen à $f 200$ zo'n $f 518.200$ zijn geweest, het reguliere budget $f 14.714$ (bijlage 11.5) en de totale bijdrage van de zorgverzekeraar maximaal

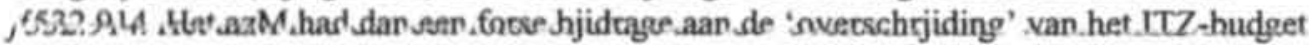
hebben moeten leveren. 'Scenario II' geeft de kostenverdeling bij de uiteindelijk gekozen financieringsafspraken in combinatie met de oorspronkelijk geplande technologie (cassettepompen). In dit geval zouden de kosten voor het project en het azM beperkter zijn geweest, maar zouden de verzekeraars bijna $40 \%$ duurder uit zijn geweest. 'Scenario III' geeft de kostenverdeling zoals die zou zijn opgetreden bij de technologieèn van het project en de voorziene financieringsafspraken. Het azM zou in dit geval waarschijnlijk geen bijdrage hebben hoeven te leveren. 'Gerealiseerd in het project' geeft de kostenverdeling op basis van de uiteindelijke financieringsafspraken en infuustechnologieěn in het project.

Tabel 11.2 Effecten van combinaties van financierings- en technologiekeuzen

\begin{tabular}{|c|c|c|c|c|c|c|c|}
\hline \multicolumn{2}{|l|}{ Kosten ${ }^{1}$} & Verz & $\mathbf{r T}$ & $\mathbf{a z M}$ & Verz & $\mathbf{r}$ & $\mathbf{a z M}$ \\
\hline & & \multicolumn{3}{|c|}{ Voorziene financiering } & \multicolumn{3}{|c|}{ Gekozen financiering } \\
\hline \multicolumn{2}{|c|}{ Voorziene technologie } & \multicolumn{3}{|c|}{ Scenario I } & \multicolumn{3}{|c|}{ Scenario II } \\
\hline Personeel & 521.341 & 302.258 & 210.000 & 0 & 338508 & 162.500 & 11.250 \\
\hline Materieel & 426.195 & 230.656 & 0 & 195.539 & 398.920 & 0 & 27.275 \\
\hline Totaal ${ }^{2}$ & 947.536 & 532.914 & 210.000 & 195.539 & 737.428 & 162.500 & 38.525 \\
\hline \multicolumn{2}{|c|}{ Gekozen technologie } & \multicolumn{3}{|c|}{ Scenario III } & \multicolumn{3}{|c|}{ Gerealiseerd in project } \\
\hline Personeel & 489.053 & 269.970 & 210.000 & 0 & 306.220 & 162.500 & 11.250 \\
\hline Materieel & 257.434 & 248230 & 0 & 0 & 228.159 & 0 & 27.275 \\
\hline Totaal $^{3}$ & 746.487 & 525.404 & 210.000 & 0 & 534.379 & 162.500 & 38.525 \\
\hline
\end{tabular}

Legenda: Verz-zorgverzekeraars, '--niet altijd het totaal van de daarop volgende kolommen (bijlage 11.5), whiervan financierde de SGKH $f 9.083$, "=hiervan financierde de SGKH $f 9.083+f 2.000=f 11.083$ (bijlage 11.5). 


\subsubsection{BESCHOUWING FINANCIERINGS- EN TECHNOLOGIEKEUZEN}

De evaluatie van de financiering geeft inzicht in de effecten van verschillende combinaties van technologieĕn en financieringsafspraken. Zij kan, analoog aan de ontwikkelingen in de ziekenhuiszorg, aanknopingspunten bieden voor een functiegerichte benadering van de financiering van IT. ${ }^{43 !}$ Ook toont zij de noodzaak aan van goede financieringsafspraken bij complexe medisch-technische behandelingen thuis. Gezien de toenemende druk op de reguliere budgetten van de meest betrokken zorgorganisaties (ziekenhuis, Groene Kruis en huisartsen) lijkt het niet realistisch ervan uit te gaan dat deze organisaties deze zorg binnen de bestaande budgetten kunnen realiseren (bijlage 11.6). ${ }^{482}$

Zoals aangetoond kan wetenschappelijk onderzoek in het kader van een innovatie- en zorgvernieuwingsproject regionale effecten hebben op de wijze van financiering. Aangezien een dergelijk project geen marktpartij is, past bescheidenheid als het op het inschatten en sturen van de uiteindelijke effecten aankomt. Gelukkig bleek de inschatting betreffende de kosten van de morfine- en mannitolinfusie achteraf vrij accuraat ( $8 \%$ overschrijding: bijlage 11.3 in vergelijking met $\$ 15.4 .1)$. De rol van sturing en van 'marktwerking' verdient enige nuancering. Indien de betrokken zorgverleners, zorgorganisaties en zorgverzekeraars zich als echte marktpartijen waren blijven opstellen, dan was de zorgverlening binnen dit project nooit gerealiseerd of tot enkele patienten beperkt gebleven. Slechts door samenwerking, goede onderlinge verhoudingen, investeringen en het opzoeken van de grenzen van de toenmalige financieringskaders kon IT doorgang vinden. ${ }^{475}$ De hier beschreven ad hoc financiering op projectbasis kan én vermag daartoe niet meer dan een aanzet geven.

\subsection{Conclusies}

Vanuit het idee van een patiëntgebonden financiering van de professionele zorg die nodig is om de bij IT optredende zelfzorgtekorten op te heffen, zijn de extra kosten voor deze behandeling geïnventariseerd. Ook de keuze van de infuustechnologie bleek van belang. De kosten zijn per patiënt aan de betrokken zorgverzekeraars voorgelegd. Vanwege het belang van de ontwikkeling van deze vorm van thuisbehandeling op de lange termijn bleken zij allen bereid om de experimentele zorg te vergoeden. 


\section{Keuze en toepassing thuiszorgtechnologie: de infuusbehandelingen}

\subsection{Doel van de behandelingen (fase 1)}

Toepassing van complexe medisch-technische handelingen bij thuiszorgtechnologie vergt samenwerking tussen patiênten, hun naasten, zorgverleners, hun organisaties en financiers. Aandachtspunt 5 betreft de zorgtechnologie en daarmee ook de technische aspecten van IT en wordt aan de hand van de innovatiecyclus (schema 2.5) besproken. Middels protocollering is standaardisering en kwaliteitswaarborging nagestreefd. ${ }^{43}$ Deze vormt dan ook het uitgangspunt voor de verdere organisatie van de zorg en daarbij benodigde informatie, scholing en financiering. Na de introductie van de protocollering wordt vanwege hun exemplarisch karakter (prototype benadering schema 2.7) achtereenvolgens dieper ingegaan op infusie van morfine, mannitol, antibiotica en hartmiddelen.

\subsection{Analyse, perspectief en concept bij de behandelingen (fase 2-4)}

Uit de voorstudies bleek dat protocollering de introductie van nieuwe behandelingen kan faciliteren. Ook het experimentele karakter vereiste een zekere standaardisering. Bij de protocollering zijn een "bottom up" en een "top down" benadering gecombineerd. Voor de ziektespecifieke invulling is de expertise van diverse zorgverleners werkzaam op dat terrein gebruikt. De procedure hiervoor had alle kenmerken van multidisciplinaire richtlijnontwikkeling in de thuiszorg (schema 12.1). ${ }^{285} \mathrm{Om}$ wat betreft de vereiste deskundigheid bij de huisarts en TMV, de logistiek, organisatie en financiering van de zorg alsmede de benodigde overhead (projectcoördinators, administratie) een voldoende kritische massa te verwerven is "top down" vanuit het project eenvormigheid nagestreefd. Bijvoorbeeld een uniform zorgmodel en modulaire handelingslijsten. Zo hoefden relatief weinig verschillende handelingen beheerst te worden en waren minder verschillende infuusmaterialen nodig. De handelingslijsten dienden zowel voor de scholing van zorgverleners als voor de instructie van patiënten en naaste verzorgers. Enerzijds kwam deze werkwijze de kwaliteit van de diverse thuisbehandelingen ten goede. Anderzijds leidde dit soms tot frictie omdat de professionals zich in hun autonomie aangetast voelden (bijvoorbeeld wanneer al een eigen thuisprotocol ontwikkeld was). Voor de diverse behandelingen is de benodigde informatie vastgelegd in behandelprotocollen met een gelijkvormige opbouw: handelingslijsten plus een samenvatting, toelichting, recepten en informatie over de organisatie (schema 12.2). Deze zijn opgenomen in een zorgdossier dat in grote lijnen overeenkomt met het NHG-zorgdossier voor intensieve thuiszorg (bijlage 8.4). ${ }^{484}$ Patiënten, naasten en zorgverleners hebben de handelingslijsten gebruikt als basis voor de infuuszorg. Ook deden zij ten behoeve van de continuîteit en samenwerking in het 
Schema 12.1 Ontwikkeling transmurale behandeling als voorbeeld van multidisciplinaire richtlijnontwikkeling in de thuiszorg.

\begin{tabular}{|c|c|c|}
\hline Ontwikkeling behandeling & Invulling behandeling & Ontwikkeling richtlijn ${ }^{23}$ \\
\hline $\begin{array}{l}\text { 1. Keuze van transmurale } \\
\text { behandeling }\end{array}$ & $\begin{array}{l}\text { Inventarisatie met vertegenwoordigers: } \\
\text {-specialisten en huisartsen } \\
\text {-vertegenwoordigers van de thuiszorg }\end{array}$ & $\begin{array}{l}\text { 1. Keuze van het } \\
\text { gezondheidsprobleem }\end{array}$ \\
\hline $\begin{array}{l}\text { 2. Formatie van transmurale } \\
\text { werkgroep }\end{array}$ & $\begin{array}{l}\text { Keuze kerngroep / contactpersonen } \\
\text { betrokken bij verdere ontwikkeling }\end{array}$ & $\begin{array}{l}\text { 2. Formatie van de } \\
\text { multidisciplinaire werkgroep }\end{array}$ \\
\hline $\begin{array}{l}\text { 3. Inhoudsbepaling van } \\
\text { transmurale behandeling en } \\
\text { takenpaketten }\end{array}$ & $\begin{array}{l}\text { Op basis van deskundigheid, } \\
\text { continuiteit en mogelijkheden tot } \\
\text { samenwerking }\end{array}$ & $\begin{array}{l}\text { 3. Inhoudsbepaling van de } \\
\text { takenpaketten }\end{array}$ \\
\hline $\begin{array}{l}\text { 4. Voorbereidingsoverleg } \\
\text { transmurale behandeling }\end{array}$ & $\begin{array}{l}\text { Indiening tussenconcepten bij: } \\
\text {-zorgpartners } \\
\text {-management \& financiers }\end{array}$ & $\begin{array}{l}\text { 4. Voorbereidingsoverleg } \\
\text { richtlijn }\end{array}$ \\
\hline $\begin{array}{l}\text { 5. Vaststelling van de } \\
\text { transmurale behandeling }\end{array}$ & $\begin{array}{l}\text { Goedkeuring eindconcept door: } \\
\text {-zorgpartners } \\
\text {-medisch ethische commissie } \\
\text {-management \& financiers }\end{array}$ & $\begin{array}{l}\text { 5. Vaststelling van de } \\
\text { interdisciplinaire richtlijn }\end{array}$ \\
\hline $\begin{array}{l}\text { 6. Eerste toepassing van } \\
\text { transmurale behandeling }\end{array}$ & $\begin{array}{l}\text { Pilotbehandeling(en) met extra } \\
\text { monitoring }\end{array}$ & $\begin{array}{l}\text { 6. Eerste toepassing van de } \\
\text { richtlijn }\end{array}$ \\
\hline $\begin{array}{l}\text { 7. Evaluatie van de } \\
\text { toepassingsfase en bijstelling } \\
\text { van transmurale behandeling }\end{array}$ & $\begin{array}{l}\text { Continue aanpassing 'kinderziekten' } \\
\text { en proces- en effectevaluaties per } \\
\text { behandeling(scluster) of 'overall' }\end{array}$ & $\begin{array}{l}\text { 7. Evaluatie van de } \\
\text { toepassingsfase en bijstelling } \\
\text { van de richtlijn }\end{array}$ \\
\hline
\end{tabular}

zorgdossier verslag van hun bevindingen.

Gegevens over de instroom, het verloop van de behandeling, (bij)werkingen en complicaties van de inzet van de thuiszorgtechnologie zijn systematisch geregistreerd via het zorgdossier en de projectadministratie. Vaak wordt hun incidentie uitgedrukt per aantal kalenderdagen waarop infusie plaats heeft of een pomp gebruikt is. De overige dataverzameling wordt in $\$ 2.6 .1$ beschreven.

Schema 12.2 Inhoudsopgave behandelprotocol.

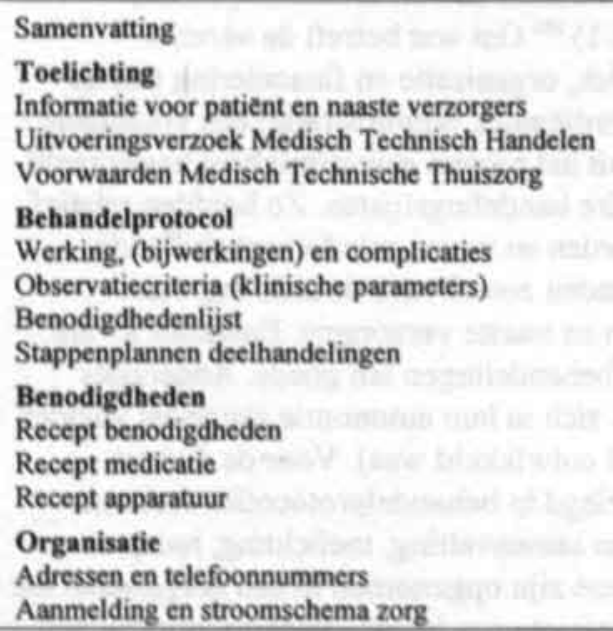


De zorguitvoering door de TMVs is vastgelegd met een modificatie van het wijk administratie systeem (WAS) om bij de verderop in dit hoofdstuk besproken behandelingen inzicht te krijgen in de frequentie van de zorgonderdelen en de daarvoor benodigde tijd (schema 12.3 plus bijlage 12.1). ${ }^{\text {as }}$

Schema 12.3 Deelactiviteiten van de TMV bij infuusbehandeling thuis.
A) Primair proces
Intakegesprekken
Zorgdragen voor verpleeghulpmiddelen
Zorgdragen voor infuusbenodigdheden (medicatie en infuusmaterialen)
Installeren infuuspomp (eenmalig) ${ }^{*}$
Voorbereiden en (assisteren bij) inbrengen infuus
(Tussentijds) verzorgen insteekopening
Programmeren infuuspomp (elke behandeling) *
Aansluiten/verwisselen infuuszak/cassette (plus klaarmaken medicatic)
Wachtrijd tijdens inlopen *
Spoelen en hepariniseren tussen en na medicatiegiften ${ }^{*}$
Verwisselen infuussysteem *
Tijdelijk aan- en afkoppelen infuus *
Verwijderen infuus
Instructie patient/naaste verzorgers
Telefonisch consult patient/naaste verzorgers
Realiseren therapic en leefregel
Begeleiden probleemsituatie
Toedienen medicatie op andere wijze ${ }^{*}$
Lichamelijk hygienische verzorging *
Evaluatiegesprekken
B) Scholing en instructie van overige zorgverleners

Instructie wijkverpleegkundige
huisarts

Telefonisch consult zorgverleners t.a.v. infuusbehandeling

C) Overleg met andere zorgverleners

$\begin{array}{ll}\text { Overleg } & \text { wijkverpleging } \\ \text { medisch behandelaar } & \text { ziekenhuis } \\ \text { eerstelijnsvoorzieningen } \\ \text { vrijwilligers } \\ \text { meerdere disciplines }\end{array}$

\section{D) Overige taken}

Bevorderen dienstverlening

Reistijd

Administratie

Afvalverwerking

Legenda: ${ }^{*}=$ komen niet steeds bij elke soort infuusbehandeling voor. 
Bij 122 patiěnten hebben 123 eerste en 50 vervolgbehandelingen plaatsgevonden. Bij drie patienten is de behandeling gestart, maar om medische(-technische) redenen vrij snel gestaakt. Bij één patiënt was het niet mogelijk om een infuuscanule in te brengen. Bij een andere patiênt met in de voorgeschiedenis niersteenproblemen traden bij proefgiften met mannitol niersteenkolieken op. Eenmaal is bij subcutane pijnbestrijding de inbreng vanuit het project gestaakt. De huisarts wenste de infusie, die niet volgens protocol geschiedde, samen met de familie uit te voeren en had alleen behoefte aan 'achterwacht' door de TMV. Tabel 12.1 geeft een overzicht van de behandelingen naar medicatiegroep en toedieningswijze. Subcutane toediening geschiedt middels een kleine vleugelnaald in het onderhuidse vetweefsel. Het is een eenvoudige, veilige techniek. Helaas is vanwege weefselreacties slechts een beperkt aantal stoffen, waaronder morfine, subcutaan toe te dienen ( $\$ 12.3 .1)$. Vrijwel alle parenterale medicatie is met een infuuscanule in een perifere ader toe te dienen. Deze techniek behoeft meer kennis en vaardigheid, zoals bij het inbrengen van de infuuscanule ( $\$ 10.6 .5)$. Ook zijn er grotere risico's bij infectie of te snelle toediening. In de beschrijving van mannitolinfusie wordt aandacht besteed aan de daarbij optredende flebitis en aan problemen met visceuze oplossingen (\$12.3.2). Bij de antibiotica-infusie (\$12.3.3) wordt ingegaan op de bestaande zorgmodellen, verschillen tussen intermitterende en continue infusie, thuis oplossen van medicatie en diverse hygiënische aspecten. Bij frequente en/of langdurige toediening en bij risico's op chemische aderontsteking of bij extravasatie (dopamine, cytostatica en parenterale voeding) verdient centraalveneuze toediening de voorkeur. Bij de infusie van hartmiddelen $(\S 12.3 .4)$ is gekozen voor een totaal onderhuidse centraal veneuze poort (CVP/Port-A-Cath(8). De kans op infectie en trombose bij dit soort systemen is $0-10 \%$ in vergelijking met $20-30 \%$ bij gedeeltelijk onderhuidse systemen (Hickman $\otimes$ en Broviac®). Tevens is bij een CVP de kans op ernstige complicaties als een forse bloeding of een luchtembolie kleiner. Indien men met het infuussysteem ergens blijft haken zal vaak de naald uit de CVP schieten.

Tabel 12.1 Toedieningswijze per medicatiegroep en naar soort infuus (per behandeling/episode).

\begin{tabular}{lc|cccc}
\hline Medicatiegroep & E/V & Subcutaan & Intraveneus & Centraalveneus & Totaal \\
Morfine * & E & 56 & 4 & 1 & 61 \\
& V & 1 & 0 & 0 & 1 \\
Mannitol & E & - & 28 & 0 & 28 \\
& $\mathrm{~V}$ & - & 16 & 2 & 18 \\
Antibiotica & $\mathrm{E}$ & - & 15 & 0 & 15 \\
& $\mathrm{~V}$ & - & 7 & 0 & 7 \\
Hartmiddelen & $\mathrm{E}$ & - & $0^{\circ}$ & 9 & 9 \\
& $\mathrm{~V}$ & - & 0 & 21 & 21 \\
Overig & $\mathrm{E}$ & 2 & 0 & 2 & 10 \\
& $\mathrm{~V}$ & 0 & $53(43 \%)$ & $12(10 \%)$ & $123(100 \%)$ \\
Subtotaal & $\mathrm{E}$ & $58(47 \%)$ & $23(46 \%)$ & $26(52 \%)$ & $50(100 \%)$ \\
Subtotaal & $\mathrm{V}$ & $1(2 \%)$ & $76(44 \%)$ & $38(22 \%)$ & $173(100 \%)$ \\
Totaal & & $59(34 \%)$ & & & 3 \\
\hline
\end{tabular}

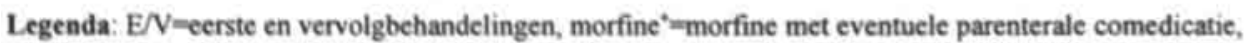
"-inclusief de medicatiegroepen vocht, anti-epileptica, virostatica en overigen, - -toediening subcutaan niet mogelijk, *-wel mogelijk maar niet gekozen wegens gevaar bij extravasatie en chroniciteit van behandeling. 


\subsubsection{Inleiding bij (subcutane) infusie van morfine}

\section{Pijn bij terminale (kanker)patiênten}

Terminale zorg (thuis) omvat onder andere pijnbestrijding. ${ }^{313,319,406}$ De meeste terminale patiënten die pijnstilling behoeven, hebben kanker (epidemiologie \$7.5.1.1). Pijn (71\%) komt bij hen na gewichtsverlies (77\%) het meest frequent voor. ${ }^{34}$ In zo'n $90 \%$ kan de pijn medicamenteus behandeld worden. ${ }^{115,457-489}$ Rond 1985 was bij ongeveer de helft van de kankerpatiênten de pijnbestrijding onvoldoende. ${ }^{316,400}$

\section{Parenterale morfinebehandeling}

Lege artis verloopt de medicamenteuze pijnbestrijding volgens de vier stappen van het WHO model. ${ }^{319}, 325,488$ Bij consequente toepassing hiervan kan zo'n $71 \%$ tot $87 \%$ van de pijn bestreden worden. ${ }^{491,42}$ Parenterale morfinebehandeling is daarin de laatste stap. Inclusiecriteria zijn: de diagnostiek ten aanzien van de oorzaak van de pijn is afgerond en er is geprobeerd oorzakelijk te behandelen, echter met onvoldoende resultaat; de eerste drie stappen van het WHO model voor pijnbestrijding zijn lege artis doorlopen; er is sprake van voor morfinomimetica (opiaat) gevoelige pijn die met enterale toediening van medicatie niet meer afdoende bestreden kan worden door onvoldoende opname (zoals slikproblemen, malabsorptie, obstructie of een bloeding in de tractus digestivus), onvoldoende effect op de pijn of teveel bijwerkingen. Bij parenterale toediening van morfine is in Nederland vooral ervaring opgedaan met de epidurale en intrathecale routes. ${ }^{91,246,315,431,493}$ Bij onderzoek onder 1205 kankerpatiënten, waarvan geschat werd dat $72 \%$ pijn had, bestond er bij maximalisatie van de pijnbestrijding bij slechts 16 patiënten $(1,8 \%)$ een indicatie voor intrathecale of epidurale toediening van morfinomimetica en had dit bij maar zes patiënten het gewenste resultaat. ${ }^{489}$ Soms kan bij ineffectieve 'spinale' toediening subcutane infusie verbetering opleveren. ${ }^{494}$ Men schat dat 11 à $12 \%$ van de maximaal behandelde kankerpatiënten in aanmerking komt voor subcutane infusie van morfine (SIM). ${ }^{487,495}$ In de dagelijkse praktijk wordt SIM niet vaak gebruikt vanwege de logistieke problemen (materiaalvoorziening, coördinatie).

\subsubsection{Vraagstellingen bij subcutane infusie van morfine}

Prospectief is onderzocht of (subcutane) infusie van morfine thuis bij terminale kankerpatiënten mogelijk (haalbaar, doeltreffend en doelmatig) is met eenvoudige middelen binnen een algemeen zorgmodel voor infusie thuis. ${ }^{496}$ Vraagstellingen betroffen de toepasbaarheid van het zorgmodel in termen van instroom, kenmerken van patiënten en behandelingen, werking, bijwerkingen en complicaties, kwaliteit van leven $(\mathrm{KvL})$ en van zorg (KvZ), kosten en tijdsbesteding van de TMVs. Zo mogelijk is vergeleken met elders.

\subsubsection{Methoden en technieken bij subcutane infusie van morfine}

\section{Techniek thuisbehandeling}

Bij de keuze tussen continue parenterale of intermitterende intramusculaire of parenterale

- Prospective study of home morphine infusion in 62 terminally ill patients. Accepted for publication in the Journal of Pain and Symptom Management / Prospectieve studie naar subcutane infusie van morfine thuis bij terminale patienten. Geaccepteerd voor publikatie in het Nederlands Tijdschrift voor Pijn en Pijnbestrijding. 
toediening van morfinomimetica zijn twee punten van belang. Ten eerste geeft een continue toediening en daarmee plasmaspiegel betere pijnstilling. ${ }^{477,497}$ Ten tweede dient ruim gedoseerd te worden om de patient pijnvrij te houden. ${ }^{497}$ Is eenmaal pijn opgetreden, dan is een hogere dosis nodig om de patient weer pijnvrij te maken, nog afgezien van de afname in het vertrouwen in de therapie. ${ }^{315,487,498,490}$ Dit pleit voor continue parenterale toediening. Subcutaan kunnen niet alle medicijnen en dagelijks slechts een halve tot één liter vocht toegediend worden. Anderzijds 'sneuvelt' een subcutane naald minder snel, is het inbrengen en verwisselen gemakkelijker en is geen infuuspomp nodig (geen directe verbinding met de bloedbaan). De effectiviteit en bijwerkingen van subcutane en intraveneuze toediening zijn vergelijkbaar. ${ }^{500}$ Daarom is SIM gekozen. Patiênt gecontroleerde toediening is niet gekozen, omdat het niet effectiever is, ${ }^{\text {s01 }}$ maar een complexere techniek (pomp), logistiek en hogere kosten met zich mee brengt.

Morfine- $\mathrm{HCl}$ zonder toevoeging is gebruikt om de kans op prikkeling van het subcutane weefsel en op reacties met eventuele toe te voegen comedicatie te verlagen. ${ }^{315}$ Voor dosisomrekeningen is bij de biologische beschikbaarheid uitgegaan van de verhouding rectaal:oraal:subcutaan/intramusculair/intraveneus=1:2:6. ${ }^{498}$ Ophogingen geschieden in stappen van $30 \%$ van de dosis van de voorafgaande dag. Bij ophoging wordt een nieuwe infuuszak bereid (druppelsnelheid blijft constant, afhankelijk van de vochtbehoefte). Indien nodig, kan bij de ophoging eenmalig een bolus van $20 \%$ van de dagdosis gegeven worden. Bij pijn bij de verzorging kan een half tot één uur tevoren een extra bolus van $10 \%$ van de dagdosis gegeven worden. De morfine wordt per 24 uur opgelost in $500 \mathrm{ml}$ $\mathrm{NaCl} 0,9 \%$. Bij uitdroging is dit volume te verhogen tot maximaal $1.000 \mathrm{ml} \mathrm{NaCl} 0,9 \%$ en/of glucose $5,0 \%$ per dag vanwege de beperkte weefselopname bij subcutane toediening. ${ }^{502,}$ s03 Indien nodig kunnen dehydrobenzperidol of haloperidol (onrust of braken), metoclopramide (braken) en diazepam (angst) worden toegevoegd. ${ }^{504-506}$

De morfine wordt standaard toegediend met een: infuusstandaard, infuuszak, $2,50 \mathrm{~m}$ lang infuussysteem met druppelregelaar en laag bijspuitpunt en een vleugelnaald (Vygon Microflex® standaard $\circledast 25 \mathrm{G}=0,5 \mathrm{~mm}$ en lengte $17 \mathrm{~mm}$ ) ingebracht in buik, borst, bovenbeen of bovenarm onder een hoek van $30-45^{\circ} .487,499,505$, 507 Het infuussysteem en de vleugelnaald worden elke vijf dagen vervangen. ${ }^{487}, 494,495,499,507$ De insteekopening wordt elke drie dagen verzorgd met chloorhexidine $0,5 \%$ in alcohol $70 \%$ en opnieuw afgeplakt. ${ }^{508}$ Vanwege de vaak geringe mobiliteit van de terminale patiënten en de geringe kans op te snelle toediening wordt niet standaard een infuuspomp ingezet. ${ }^{509} \mathrm{Ook}$ bij volledig open rollerklem loopt het infuus traag in door de subcutane tegendruk en wordt de morfine via het subcutane weefsel slechts traag opgenomen in de circulatie. Indien noodzakelijk, is een niet draagbare lineair-peristaltische elektronische infuuspomp ingezet (IVAC 591囚). ${ }^{503} \mathrm{Bij}$ intra- en centraalveneuze infusie is vanwege de kans op te snelle systemische toediening altijd een infuuspomp gebruikt.

\section{Invulling zorgmodel}

Na medische selectie (inclusiecriteria §12.3.1.1) worden patiënten via de huisarts en soms vanuit het ziekenhuis voor thuisbehandeling aangemeld bij het $\mathrm{CM}$ van de SGKH. De TMV onderzoekt daarop de mogelijkheden voor SIM en betrekt hierbij -bij aanmelding vanuit het ziekenhuis- de huisarts (schema 7.2). Bij positieve bevindingen wordt de zorgverzekeraar om vergoeding verzocht. De medicatie en infuusbenodigdheden worden via de openbare apotheek geleverd en bij de patient thuis bezorgd. De infuusstandaard komt van de SGKH en, indien nodig, kan een infuuspomp van het azM betrokken worden. 
De huisarts -verantwoordelijk voor de dosering-schrijft een uitvoeringsverzoek voor het medisch-technisch handelen. De TMV voert samen met de huisarts en geînstrueerde wijkverpleegkundigen de IT uit en verzorgt de coördinatie. Alle zorgverleners en betrokken naasten leggen de zorgverlening in een zorgdossier vast. Zo nodig kan de infusie binnen zes uur na aanmelding starten (onder voorbehoud van financiering).

\section{Meetinstrumenten}

Het klinisch effect is bij morfine-infusie afgemeten aan het aantal pijnvrije dagen. Dit zijn dagen waarop geen pijn gerapporteerd is in het zorgdossier, met uitzondering van de niet aan kanker gerelateerde hoofdpijn, spierpijn of blaaspijn (retentieblaas). De dosistoename is berekend over de gehele periode en over de periode minus de eerste en tweede dag (instelfase) en de laatste drie dagen (morfinebehoefte kan voor de dood plots stijgen). ${ }^{40}$ De overige methoden zijn in de hoofdstukken 2 en 13,14 en 15 beschreven.

\subsubsection{Resultaten subcutane infusie van morfine}

Om het accent te kunnen leggen op de subcutane infusie en vanwege de homogeniteit wordt vooral SIM besproken.

\section{Instroom}

Er zijn 72 terminale patiênten aangemeld, waarvan 65 voor morfine-infusie (tabel B12.2.1 bijlage 12.2). Daarvan zijn 69 patiênten gescreend (\$7.6.2) aan de hand van de algemene voorwaarden voor IT (schema 7.2) en 62 ten aanzien van specifieke inclusiecriteria voor morfine-infusie. Eén aangemelde patiënt is niet ingestroomd (tabel B7.6). Enkele malen heeft de subcutane infusie uitstel opgelopen of discussie opgeleverd omdat de specialist intraveneuze $(2 \mathrm{x})$ of centraalveneuze infusie ( $1 \mathrm{x}$ ) voorstond in plaats van subcutane of een infuus van drie liter per dag wilde geven (1x). Meestal werd na uitgebreide voorlichting en overleg toch gekozen voor SIM. Eenmaal is een reeds aangemelde patiënt alsnog ontslagen met subcutane injecties, maar kreeg na één dag toch SIM. Eén patiënt vanuit het ziekenhuis kreeg de 'keuze' om aangemeld te worden voor een verpleeghuis of thuisbehandeling.

\section{Kenmerken patiënten en behandelingen}

De 68 terminale patiënten zijn gemiddeld 62,0 (bereik 17-92) jaar en $54 \%$ is man. De infusies betreffen veelal morfine bij kankerpatiënten (tabel B12.2.2 + B12.2.3). Onder deze patiënten komen de meest gangbare soorten kanker voor. Van hen is $22 \%$ jonger dan 55 jaar, $65 \%$ tussen de 55 en 74 en $14 \% 75$ of ouder. De leeftijdsverhouding tussen de $55-74$ jarigen en $75^{+}$is $78: 22$. De morfine-infusies geschiedden subcutaan ( $32 \sigma^{\circ}$, waarvan één tweemaal, en $\left.24^{\circ}\right)$, intraveneus $\left(2 \sigma^{\circ}, 2^{\circ}\right)$ en centraalveneus $\left(1 \sigma^{\circ}\right)$. De niet kankerpatiënten $\left(\sigma^{*}\right)$ die SIM ontvingen leden aan hartfalen, longemfyseem en sepsis bij onbehandelbare decubitus. De dagdosis van morfine varieerde bij de start van 10 tot 480 milligram (mg), bij overlijden van 15 tot $2.100 \mathrm{mg}$ (tabel B12.2.3; uitgebreid overzicht doseringsklassen tabel B12.2.4). Bij 50\% van de patiënten volstond een maximale dagdosis van $40 \mathrm{mg}$ bij de start en van $70 \mathrm{mg}$ bij overlijden. De gemiddelde dagdosis, hier het 'gemiddelde' van start- en stopdosis, was $152 \mathrm{mg} / \mathrm{dag}$. Aan de morfine-infusie zijn vooral middelen ter bestrijding van angst, onrust en braken toegevoegd (tabel B12.2.5). Andere infusies bij kankerpatiënten betroffen: vocht subcutaan (1 $\%)$, intraveneus $\left(10^{*}, 2\right.$ \%) en tweemaal centraalveneus (1 $\left.{ }^{\circ}\right)$ en anti-epileptica (dexamethason met fenytoüne respectievelijk valproïnezuur) intraveneus $\left(1 \sigma^{\circ}, 1 \%\right)$. 
Hierna worden de data beperkt tot patiēnten met SIM. Tussen 8 oktober 1993 en 9 januari 1996 ontvingen deze 56 patiênten 57 behandelingen van maximaal 71 dagen en met een totale duur van 634 dagen, zo'n 1,7 jaar (tabel B12.2.3). Eén patiënt overleed voor het inbrengen van de vleugelnaald. Bij een ander is de inbreng vanuit het project gestaakt omdat de huisarts afweek van het protocol (veiligheid: geen infuuszak maar glazen infuusfles; infectierisico: desinfectie met eau de cologne; gebruik opgeloste infuusvloeistof gedurende 48 in plaats van maximaal 24 uur; onduidelijkheid over de achterwacht). De mogelijkheid is geboden om de patiēnt opnieuw aan te melden zodra protocollair werken mogelijk zou zijn.

\section{Klinisch effect, bijwerkingen en complicaties}

Het gemiddeld percentage pijnvrije dagen was $73 \%$. Bij zeven patiēnten (13\%) was dit percentage kleiner dan 50 (tabel B12.2.3). Vier van deze patiěnten ontvingen maximaal vier dagen infusie, de overige hadden borst- ( 7 dagen infusie) en pancreaskopkanker (16 en 30 dagen infusie). Ook de patiěnten met $100 \%$ pijnvrije dagen concentreerden zich in de eerste vier dagen (15 van de 16).

Bij de vaststelling van de medicatie week de huisarts bij $60 \%$ van de patiënten en in $5 \%$ van de infusiedagen af van het protocol. Hiervan is ongeveer de helft als ernstig aan te merken. Het betrof in $8 \%$ foute dosisomrekening van orale $(2 x)$ en rectale $(2 x)$ naar subcutane toediening (4/51; van 6 patiënten ontbraken deze data). In $9 \%$ was er orale (3x), intramusculaire ( $2 x)$ of zelfs subcutane (1x) morfinetoediening tijdens SIM, eenmaal leidend tot een tijdelijke ademdepressie. In $12 \%$ werd de dosis opgehoogd met meer dan $30 \%$ en in $12 \%$ om andere redenen dan pijn (onrust, kreunen of een onregelmatige ademhaling). Eenmaal werd de dosis opgehoogd zonder duidelijke reden. In $7 \%$ werd opgehoogd door de infusiesnelheid te verhogen in plaats van een nieuwe infuuszak klaar te maken en eenmaal werd morfine toegevoegd aan een half ingelopen infuuszak. Eenmaal werd de dosis met $30 \%$ verlaagd, maar weer hersteld toen de pijn binnen een dag terugkeerde. Tweemaal waren de overige pijnbestrijdingsmethoden nog niet volledig benut: toevoeging van paracetamol suppositoria kon een dosisophoging voorkomen en met maximale toepassing van de WHO ladder kon de morfine verlaagd worden van 170 naar $100 \mathrm{mg}$. Eenmaal werden deels hetzelfde werkzame medicaties (metoclopramide en haloperidol) toegevoegd.

Bij de bereiding van de medicatie door de verpleegkundigen is bij $18 \%$ van de patiënten en in $1,6 \%$ van de infusiedagen een fout gemaakt. Bij $5 \%$ van de patiënten en $0,5 \%$ van de infusiedagen was deze ernstig. De problemen waren: voor de verzorging toedienen van een bolus van $20 \%$ in plaats van $10 \%$ van de dagdosis ( $1 \mathrm{x}$ : TMV+WV), toedienen halve dosis $(1 \mathrm{x}: \mathrm{WV})$ en toevoegen van verschillende medicaties aan de infuuszak met dezelfde spuit (1x:WV); lekken bijspuitpunt indien veel medicatie toegevoegd was (2x:TMV $2 x: W V)$, lek prikken infuuszak ( $2 x: W V)$ of breken ampul (1x:TMV).

In totaal is de vleugelnaald 48 maal tussentijds gewisseld vanwege: vier maal hematoomvorming door raken haarvaatje (1x), stollingsstoornissen bij leukemie (1x), gebruik van afwijkende, te dikke subcutane naald ( $1 \mathrm{x})$ en uit bed vallen van de patiënt (1x); 12 maal slecht lopen infuus in twee patiēnten met ascites $(4 \mathrm{x})$, bij één patiēnt $(3 \mathrm{x})$ die 1 liter toegediend kreeg (gestopt na verminderen tot $500 \mathrm{ml}$ ) gedurende verpleging ( $2 \mathrm{x}$ ), of anders ( $3 \mathrm{x})$; 13 maal ontstoken of rode insteekopening; negen maal lekken bij insteekopening zonder oorzaak; tien maal dislokatie of accidentele verwijdering infuusnaald door de patiënt $(5 x)$, gedurende verzorging $(3 x)$ of anders $(2 x)$. Gemiddeld bleef een 
vleugelnaald 3,5 dagen in situ (634/152 gepland +48 tussentijds). Veel patiënten zijn korter dan vijf dagen in zorg en verlagen dit gemiddelde kunstmatig. Na correctie voor de geplande naalden $(634 / 5=127)$ is dit 3,6 dagen $(634 / 127+48)$. Verdere problemen met de insteekopening waren overgevoeligheid voor de afplakpleister $(1 \mathrm{x})$ of chloorhexidine (1x) en verhoogde infectiegevoeligheid bij leukemie (1x). Andere materialen en frequenter vervangen van de naald losten deze problemen op.

Van de bovengenoemde tussentijdse wisselingen hadden er 15 te maken met het infuussysteem. Daarnaast heeft het infuus ook 18 maal slecht gelopen vanwege: patięnt ligt op de infuuslijn (3x), lucht in druppelkamer of systeem ( $2 x)$, volle druppelkamer na verzorgen systeem (1x), dichtstaande druppelregelaar (2x), niet beluchte infuusfles (1x), gaas onder vleugelnaald ( $2 x)$, oedeem ( $1 x)$ en onbekend $(6 x)$. Dit is opgelost door het gehele infuussysteem te controleren (13x), de vleugelnaald opnieuw af te plakken (3x) of een nieuw systeem aan te hangen ( $2 x)$. Daarvan hebben drie patiênten pijn gekregen omdat het infuus leeg was (2x:mantel) of te langzaam liep (1x:mantel). Ook heeft het infuus 16 maal te snel ingelopen, vijfmaal (mantel) bij vier patiěnten met voorbijgaande sufheid. In totaal kwamen problemen met het infuussysteem in $89 \%(15+18+16+2 / 57)$ van de patiênten en in $8 \%$ van de infusiedagen voor. Afgemeten aan het optreden van sufheid en pijn is de incidentie van complicaties met het infuussysteem $14 \%$ per patiênt en $1,3 \%$ per infusiedag. Bij drie patiěnten (5\%) is tijdens de infusie besloten om een infuuspomp in te zetten. Bij twee patiênten vanwege herhaaldelijk onregelmatig lopen en tenminste één episode van sufheid na te snelle infusie. Eèn van hen vond de pomp onpraktisch en heeft het gebruik gestaakt. Omdat het infuus toen wederom te snel inliep met sufheid als gevolg, is het gebruik van de pomp verplicht gesteld. Bij één echtpaar, dat geen aanvullende hulp had, is de pomp ingezet ter ontlasting van de naaste verzorger gedurende de nacht. Met de infuuspomp zijn geen problemen opgetreden.

Vier maal is één liter in plaats van $500 \mathrm{ml}$ infusievloeistof toegediend. Meestal leverde dit problemen op: toename van (long)oedeem, ascites en lekken bij de insteekopening. Vooral als de vleugelnaald was ingebracht op de borst of ledematen.

\section{Kwaliteit van leven}

De resultaten zijn grotendeels in tabel B12.2.6 weergegeven (zie ook H:13). Ondanks de terminale fase kan de KvL wisselen (noot 12.2.1 vooraan bijlage 12.2). Naasten en zorgverleners schatten de ernst van de ziekte en de gezondheidsbeleving van de patiënt ongeveer hetzelfde in. Uitgaande van een grenswaarde voor de gemiddelde pijnscore van vijf op de Visueel Analoge Schaal, was de pijnstilling volgens de naaste onvoldoende en volgens de zorgverleners net voldoende. De huisarts schatte de $\mathrm{KvL}$ hoger in dan de naaste en de verpleegkundige.

Op verschillende manieren gemeten, was de belasting voor de naasten bij terminale thuiszorg hoog (\$13.5.2.3). Daarbij gaf driekwart van de naasten aan zelf ziek te zijn. Gemeten via een stelling was de praktische en emotionele steun die naasten in de terminale fase verlenen hoog. Gemeten in uren per dag (gemiddeld 16, SD 7) en via een stelling was de ervaren belasting bij de naasten hoog. Eén patiënt die in onmin leefde met de partner is onder de hoede van de huisarts toch naar huis gegaan. Omdat de patiënt opknapte en de situatie onhoudbaar werd, is de patiënt na 45 dagen opgenomen in een verpleeghuis. Een andere patiënt had volgens de partner beter in het ziekenhuis opgenomen kunnen worden. Beide partners waren bij de huisarts bekend als psychisch beperkt belastbaar. Het aantal tengevolge van de IT gestaakte sociale activiteiten was gemiddeld drie van de zeven. 
Gemeten volgens de Caregiver Strain Index (CSI) was de ervaren belasting wel aanwezig, maar laag (afkappunt 7).

\section{Kwaliteit van en tevredenheid met zorg}

Tabel B12.2.6 geeft ook de resultaten van de KvZ en tevredenheid. Uitgedrukt in rapportcijfers voor diverse zorgverleners varieert de tevredenheid van 7 tot 9 . Gemeten via de Zorg-KwaliteitsMatrix (ZKM) en de Client Satisfaction Questionnaire (CSQ) varieert de $\mathrm{KvZ}$ van 8 tot 9 .

\section{Kosten}

Van de 57 subcutane infusies van morfine zijn de kosten apart berekend. Bij de berekening wordt van 634 infusiedagen uitgegaan. Gemiddeld kostte de thuisbehandeling $f 2.661$ per behandeling en $f 239$ per infusiedag $(\$ 15.4 .1)$. De materiële kosten voor de patiënt en naasten zijn gemiddeld $f 8$ per infusiedag $(\$ 15.4 .2)$, de personele kosten variëren volgens de naaste tussen $f 60$ (produktieverlies) en $f 137$ (uurbelasting) per infusiedag (\$15.4.3). De totale maatschappelijke kosten komen zo op $f 306$ tot $f 393$ per dag (\$15.4.4). Het aandeel van de patiënt en naasten hierin varieert van $20 \%$ tot $37 \%$.

\section{Tijdsbesteding TMVs}

Tabel B12.2.7 geeft per activiteit aan hoeveel percent van de totale tijd de TMVs daaraan besteed hebben. Daarnaast zijn kenmerken van de duur (in minuten) weergegeven en het aantal maal dat een bepaalde handeling geregistreerd is. In totaal vergde deze behandeling per dag 99 minuten gespecialiseerde verpleegkundige zorg, waarvan 43 minuten $(45 \%)$ voor het primaire zorgproces.

\section{Andere studies}

De leeftijdsverhouding van de 8.000 ouderen die jaarlijks thuis overlijden aan kanker bedraagt 55-79:80+ $=70: 30 .{ }^{320}$ Andere studies over SIM (thuis) rapporteren aantallen patiënten van 7 tot 102 , sexe ratio's van $27 \%$ tot $63 \%$ mannelijk, gemiddelde leeftijden van 51 tot 61 (bereik: 14-90) en gemiddelde aantallen dagen infusie van 13 tot 68 (bereik: 1-741). ${ }^{487,494,495,499,501, ~ 503, ~ s 05, ~} 510$

De gemiddelde orale startdosering in een andere Nederlandse studie bedraagt $230 \mathrm{mg}$ MS Contin 8 , in andere studies varieert deze tussen 269 en $305 \mathrm{mg}$ morfine. ${ }^{486,499,510} \mathrm{De}$ gemiddelde dagdosering varieert elders van 22 tot $474 \mathrm{mg}$ per dag. $487,494,499,504,505$ De gemiddelde maximale dagdosering varieert elders van $305 \mathrm{mg}$ tot meer dan drie gram (range 5-7.200 mg). ${ }^{499,503,504,510}$ De gerapporteerde gemiddelde dagelijkse toename in percent van de startdosering varieert van 2,4 tot $9,3 \% .{ }^{495},{ }^{503}$ In andere studies varieert het percentage patie̋nten met adequate pijnbestrijding van 80 tot $95 \%$. ${ }^{487,503-505,510}$ Elders treedt bij 6 tot $10 \%$ van de patiènten ernstige sufheid en bij 1 tot $2 \%$ ademdepressie op. ${ }^{495}, 503,504$ Kankerpatiënten hebben een netwerk van gemiddeld 8,5 personen $(80 \%$ familieleden; $\$=71 \%){ }^{511} \mathrm{Bij}$ niet terminale kankerpatiënten is de gemiddelde praktische steun per netwerklid 3 sd 1,2 en de emotionele 4 sd 0,7 (schaal 1-5). ${ }^{511}$ Van de patiênten is $87 \%$ tevreden en verkiest $94-98 \%$ SIM boven de voorafgaande pijnbestrijding. ${ }^{437}, 495,499,503$ De besparingen door verplaatsing naar de thuiszorg zijn $33-59 \%$ en verdere besparingen zijn mogelijk door de inzet van niet draagbare infuuspompen of het gebruik van elastomeerpompen (bij therapieduur tot \pm 200 dagen) in plaats van elektronische cassettepompen. $^{495,503,512}$ 


\subsubsection{Beschouwing subcutane infusie van morfine}

In deze studie is de haalbaarheid en effectiviteit van morfine-infusies thuis onder supervisie van de huisarts en met gebruikmaking van een eenvoudige technologie bij 62 terminale patienten bestudeerd. Voor zover bekend is dit de eerste studie over de toepassing van morfine-infusies die geheel binnen de thuiszorg gerealiseerd wordt. Deze infusies kunnen veilig en effectief in deze setting gegeven worden. Eerst zal de externe validiteit van deze studie in termen van populatie, infusietechniek en morfinedosering besproken worden. Daarna wordt de effectiviteit van de behandeling beschouwd via de $\mathrm{KvL}, \mathrm{KvZ}$, tevredenheid gerelateerd aan de vereiste inspanningen en kosten.

Bij de 65 patiēnten met een maligniteit, waren de meeste vormen van kanker vertegenwoordigd. De leeftijdsverdeling van de oudere kankerpatiēnten in deze studie komt ongeveer (iets jonger) overeen met die van de 8.000 ouderen die jaarlijks thuis overlijden aan kanker. ${ }^{320}$ Andere studies over SIM rapporteren vergelijkbare aantallen patiēnten, sexe ratio's, leeftijden en aantallen dagen infusie. $477,492,495,450,501,503,505,510$

In voornoemde studies zijn vooral meer complexe infuustechnologieèn gebruikt (draagbare elektronische cassettepompen, elastomeer- of spuitpompen). De in deze studie gekozen techniek maakt flexibele SIM tot hoge doseringen (zonder irritatie aan de insteekplaats door de hoge concentratie), onder regie van de huisarts en in de meeste gevallen zonder infuuspomp mogelijk. ${ }^{503,504,513,514}$ Het subcutane weefsel kan bij de meeste patiënten 20 $\mathrm{mV} /$ uur goed absorberen. De elders gerapporteerde irritatie bij infusiesnelheden boven 1 a 2 $\mathrm{ml} /$ uur zijn waarschijnlijk toe te schrijven aan te hoge concentraties morfine-oplossing. ${ }^{507}$ Bij de hier beschreven techniek heeft de patiënt zelf geen controle over de toediening, maar is daar ook vaak niet meer goed toe in staat. ${ }^{501}$ Ook moet bij bolustoediening rekening gehouden worden met een inwerktijd van 30 tot 60 minuten ${ }^{507}$ De gemiddelde duur dat een insteekplaats gebruikt kan worden, 3,5 dagen, komt overeen met elders (gemiddeld: $2-7$ dagen; bereik: 6 uur-31 dagen) ${ }^{499,} 503,504$ Het is bij alle pijnbestrijding van belang te onderkennen dat deze door vele factoren beïnvloed wordt en op vele manieren te bestrijden is. ${ }^{325,515} \mathrm{Zo}$ zal voor een deel van de hier beschreven patiëntenpopulatie de eind 1996 beschikbaar gekomen fentanyl (Durogesic(8) pleister een alternatief vormen. ${ }^{516}$ De gemiddelde start- en dagdosering in deze studie zijn equivalent aan die in andere studies, de maximale dagdosering iets lager. ${ }^{486,487,494,499,503-505,510}$ De gemiddelde dagelijkse dosistoename is hoger dan elders, waarschijnlijk vanwege de terminale fase. ${ }^{495},{ }^{503}$ Ook correctie voor de eerste en de laatste behandeldagen verandert dit niet. ${ }^{493}$ Het optreden van ernstige sufheid verschilt niet met studies waarin een pomp gebruikt wordt. ${ }^{495}$, 503 Ademdepressie kwam slechts eenmaal voor bij foutief intramusculair bijspuiten en is vergelijkbaar met elders. ${ }^{495,503,504}$

De kwaliteit van sterven is een bijzondere soort van KvL. De patiënten zijn ook in onze studie niet altijd pijnvrij. ${ }^{487}$ Vaak is de pijn na de start van de infusie of dosisophogingen enkele dagen weg, soms is frequente dosisophoging noodzakelijk. Pijnvrije percentages kleiner dan $50 \%$ komen voor bij patiënten die overlijden voordat de pijnstilling adequaat is ingesteld en bij pancreaskopcarcinoom. Ook andere studies vermelden 'instelperiodes' van vijf dagen tot twee weken. ${ }^{495}, 510$ Het percentage patiënten met adequate pijnbestrijding en ook overige $\mathrm{KvL}$ indicatoren zijn vergelijkbaar met die in andere studies. ${ }^{487,503-505,510}$ De belasting voor de naaste hangt samen met de omvang van het relatief kleine netwerk van kankerpatiënten ook in de terminale fase..$^{511}$ De praktische en emotionele steun is hoger dan bij niet terminale kankerpatiënten. ${ }^{511}$ De belasting van IT moet gezien worden tegen de achtergrond van de totale belasting bij terminale thuiszorg. Deze situatie was voor 
naaste verzorgers in deze studie vaak erg belastend, maar draagbaar. Relationele problemen tussen de terminale patiënten en partners kwamen in zo'n 13\% voor en beletten in ons onderzoek eenmaal voortzetting van $\mathrm{IT}^{517}$ Onvoldoende draagkracht van naaste verzorgers, zoals door eigen aandoeningen, kan een reële belemmerende factor zijn. ${ }^{167,518}$ Omdat onderzoek naar kwaliteit en tevredenheid met zorgverlening kampt met overschatting, is door op verschillende wijzen te onderzoeken (triangulatie) getracht deze bias te ondervangen. ${ }^{519-522}$ In het algemeen zijn ondanks de belasting van de situatie zowel de naaste verzorger als de zorgverleners evenals in andere studies tevreden. ${ }^{487,495,499,503}$ De totale kosten van de zorg zijn meestal hoger dan hier gemeten. Buiten IT kan terminale zorg de inzet van de huisarts, wijkverpleegkundige en/of ziekenverzorgende, gezinsverzorging en eventuele nachthulp vergen. Vaak ging het ITZ-budget à $f 200$,- hier al aan op (en was er al 2,5 uur wijkzorg à $f 81,25$ per dag). Exclusief de reguliere huisartskosten komen de totale kosten voor de gezondheidszorg dan op $f 239+f 200+f 203=f 642$. Het meest vergelijkbare alternatief zou opname zijn op een verpleegafdeling. Het azM verpleegdagtarief bedroeg in de onderzoeksperiode gemiddeld $f 807$ ('besparing' $\pm 20 \%$ ). De daadwerkelijke ziekenhuiskosten (en besparingen) zijn echter moeilijk te achterhalen. In andere studies ligt het accent minder op de terminale fase en deze rapporteren veelal alleen de kosten van de SIM en daarmee hogere besparingen. ${ }^{495,503,512}$ In termen van de kosten van de SIM sec bedraagt de besparing in deze studie ook ongeveer $70 \%$ ( $f 239$ versus $f 807$ ). Hoewel besparingen bij veranderingen in de zorg voor terminale patiënten niet hoog zullen zijn, wordt geschat dat zij bij versterking van de thuiszorg in Nederland kunnen oplopen tot zo'n $15 \%$, ${ }^{321,523}$

De tijdsbesteding van de TMVs reflecteert de gekozen invulling van het zorgmodel. Vanwege het belang van een snelle pijnbestrijding is -evenals elders- de zorg opgestart door TMVs en vervolgens zoveel mogelijk overgedragen aan het reeds bestaande zorgnet rondom de terminale patiënt. ${ }^{524}$ Hierdoor is relatief veel tijd besteed aan overleg met en instructie van de wijkverpleegkundige en de huisarts. Naast de technische handelingen en de daarbij behorende begeleiding is bij een terminale patiěnt vaak veel andere (professionele) zorg nodig. Inzicht hierin ontbreekt. In termen van 'face-to-face' contacten ("primair proces plus instructie) heeft dit soort thuiszorg een 'lage' produktiviteit van omgerekend $47 \%$ (zie ook $\$ 14.5 .6$ ). ${ }^{525}$

In totaliteit levert dit zorgmodel een belangrijke bijdrage aan de in gang zijnde verschuiving van palliatieve zorg vanuit het ziekenhuis naar de eigen omgeving van de patiënt, met behoud van de kwaliteit. 6, 112, 526

\subsubsection{PARENTERALE MANNITOLINFUSIE BI] SYMPATHISCHE REFLEX DYSTROFIE ${ }^{*}$}

\subsubsection{Inleiding parenterale infusie van mannitol}

\section{Sympathische reflex dystrofie}

Sympathische reflex dystrofie (SRD), ook bekend als posttraumatische dystrofie, Südeckse atrofie, algoneurodystrofie en complex regionaal pijn syndroom type 1 , is een pijnlijke aandoening aan één of meerdere ledematen (epidemiologie \$7.5.1.2). ${ }^{527}$ De aetiologie en pathogenese zijn nog onbekend. ${ }^{325,331,528.537}$ Drie obligate criteria binnen het symptomen-

- Prospective study of 46 home mannitol infusions in 28 patients with sympathetic reflex dystrophy. Pain Clinic 1999;11(3):223-234. / Prospectieve studic van 46 infuusbehandelingen thuis bij 28 patienten met sympathische reflex dystrofic. Nederiands Tijdschrift voor Pijn en Pijnbestrijding. Ter perse. 
complex, dat vaak volgend op een letsel of operatie optreedt, zijn: de symptomen zijn aanwezig in een arm of been in een gebied ruimer dan, en in elk geval distaal van de primaire ontstaansplaats; functieverlies; een veranderde huidtemperatuur (in vergelijking met de andere extremiteit) in het aangedane gebied. ${ }^{33,527,537,538}$ Daarnaast dienen tenminste drie van de volgende criteria aanwezig te zijn: abnormale huidskleur (duidelijk roder of blauwer dan de contralaterale zijde); toegenomen haargroei; overmatig zweten; veranderde nagelgroei; lokaal oedeem; lokale pijn; overgevoeligheid voor pijnprikkels; overgevoeligheid voor aanrakingen; verlaagde gevoelszin. ${ }^{52}$ Een aantal symptomen treedt op of verergert bij inspanning.

\section{Mannitolbehandeling}

De therapie voor SRD omvat naast pijnstilling, fysiotherapie, ergotherapie, sympathicusblokkade, transcutane elektrische neurostimulatie en ruggemergsstimulatie, in Nederland parenterale infusie van mannitol, afgekort PIM (mogelijke omvang \$7.5.1.2). $323,326,530,540$ De werking van mannitol wordt toegeschreven aan de binding van vrije zuurstofradicalen (scavenger effect), vanuit de hypothese dat deze bijdragen aan de pathogenese van SRD. ${ }^{540,941}$ Anderen hebben geopperd dat de werking berust op een vermindering van het endoneurale oedeem van de aangedane zenuwen (analoog aan de werking bij hersenoedeem). ${ }^{537}$ Voor PIM wordt de patiěnt meestal opgenomen in het ziekenhuis voor zeven dagen van continue toediening ${ }^{5 / 2}$ of ontvangt vier uur PIM gedurende vijf opeenvolgende dagen, hetgeen de frequentie en ernst van de bijwerkingen verhoogt. ${ }^{126}$

\subsubsection{Vraagstellingen bij parenterale infusie van mannitol}

Prospectief werd onderzocht of PIM ook thuis mogelijk (haalbaar, doeltreffend en doelmatig) is. ${ }^{496}$ Vraagstellingen betroffen de toepasbaarheid van het zorgmodel in termen van de werking, bijwerkingen en complicaties van de thuisbehandeling, KvL, KvZ, kosten en tijdsbesteding van de TMVs. Waar mogelijk is vergeleken.

\subsubsection{Methoden en technieken bij parenterale infusie van mannitol}

\section{Techniek thuisbehandeling}

Bij PIM thuis is gekozen voor $7 \times 24$ uurs toediening. De keuze voor mannitol 5\% (2 liter; isotoon: alleen scavenger effect mogelijk) of $10 \%$ ( 1 liter hypertoon: scavenger en diuretisch effect mogelijk) is overgelaten aan de behandelend specialist. In de regel wordt behandeld met $7 \times 24$ uur mannitol $10 \%{ }^{542}$

$\mathrm{Bij}$ de eerste drie patiënten is omwille van de eenvoud van de in te zetten technologie gekozen voor een infuussysteem met druppelregelaar. Vanwege de viscositeit was dit niet mogelijk. De infusie stokte, het systeem verstopte en de luerlock-verbindigen van het infuussysteem plakten aan elkaar. Het protocol is op deze punten aangepast. De toediening geschiedt momenteel met een infuusstandaard, een niet draagbare lineair-peristaltische volumegestuurde elektronische pomp (IVAC 591®) en een infuussysteem bestaande uit infuuszakken, 3,55 m lange infuuslijn (bewegingsvrijheid) met hoog bijspuitpunt, zijlijn en driewegkraan met $10 \mathrm{~cm}$ verlengstuk (minder manipulatie aan infuuscanule) aangesloten op een gewone infuuscanule (Venflon $\otimes$ standaard $\odot 20 \mathrm{G}=1 \mathrm{~mm}$ en lengte $32 \mathrm{~mm}$; ๑22 $\mathrm{G}=0,8 \mathrm{~mm}$ en lengte $25 \mathrm{~mm}$ bij kleinere vaten). ${ }^{543} \mathrm{Om}$ problemen door de viscositeit en plakken te voorkomen wordt het infuussysteem opgebouwd met $\mathrm{NaCl} 0,9 \%$ en tot aan de infuuscanule om de dag vervangen, aan de infuuscanule een driewegkraan gekoppeld en 
een infuuspomp gebruikt. De patiënten worden eens per dag tijdelijk afgekoppeld voor lichamelijk hygiënische verzorging (doorspuiten driewegkraan en infuuscanule met $10 \mathrm{ml}$ $\mathrm{NaCl} 0,9 \%$ en daarna heparinelock van 500 IE in $2 \mathrm{ml}$ ).

Mannitol $10 \%$ is een hyperosmolaire oplossing die vaatwandirritatie kan geven. ${ }^{\text {s4. s45 }}$ Mogelijk treden hierdoor bij mannitol $10 \%$ ook iets meer bijverschijnselen door cerebrale equilibriumverschuivingen en flebitis op dan bij mannitol $5 \%$. De individuele variatie bij patienten is groot. ${ }^{546}$ Bijwerkingen van (te snelle) infusie van mannitol zijn duizeligheid, misselijkheid of hoofdpijn. ${ }^{544,546}$ Deze worden bij de 7x24-uurs toediening vanwege de lage inloopsnelheid in mindere mate verwacht. De voornaamste te verwachten complicatie is een chemische flebitis, die wisseling van de insteekplaats vereist.

\section{Invulling zorgmodel}

$\mathrm{Na}$ medische selectie (inclusiecriteria §12.3.2.1) worden patiënten via de specialist voor PIM aangemeld bij het CM van de SGKH. De TMV onderzoekt daarop de mogelijkheden voor IT en betrekt hierbij de huisarts (schema 7.2). Indien de patiënt aan de criteria voldoet, wordt de zorgverzekeraar om vergoeding verzocht. De medicatie, infuusbenodigdheden en infuuspomp worden via het ziekenhuis geleverd en door de SGKH bij de patient thuis bezorgd. De huisarts schrijft een uitvoeringsverzoek voor medischtechnisch handelen. Met het oog op eventuele overgevoeligheidsreacties ontvangen alle patienten eerst een proefdosis in het dagcentrum. De TMV voert daarna de PIM samen met de huisarts uit en zorgt voor de coördinatie. Alle zorgverleners en eventueel betrokken naasten leggen de zorgverlening in een zorgdossier vast. De behandeling vergt een voorbereidingstijd van twee weken (in verband planning dagcentrum).

\section{Meetinstrumenten}

Het effect van de behandeling is afgemeten aan een gerapporteerde verbetering van de mobiliteit in de poliklinische status. Deze is omschreven als een verbeterde beweeglijkheid volgens de patiënt. Deze werd meestal bevestigd door de behandelend fysiotherapeut en/of specialist. De overige methoden zijn in de hoofdstukken 2 en 13, 14 en 15 beschreven.

\subsubsection{Resultaten parenterale infusie van mannitol}

\section{Instroom}

Er zijn 31 patiënten gescreend aan de hand van de bovengenoemde voorwaarden voor IT en PIM bij SRD (zie ook noot 12.3.1 vooraan bijlage 12.3) ${ }^{331}{ }^{537}$ Hiervan zijn twee patiënten niet ingestroomd (tabel B7.6) en kon één vanwege obesitas (Quetelet index \pm 45 ) niet aangeprikt worden.

\section{Kenmerken patiënten en behandelingen}

Tussen $21-1-1994$ en 2-1-1996 ontvingen 28 patiênten (gemiddeld 45 jaar, $0-20=4 \%$, $21-54=71 \%$ en $55^{+}=25 \% ; ?=79 \%$ ) 46 behandelingen van maximaal acht infusiedagen met een totale duur van 338 infusiedagen, zon 0,9 jaar (tabel B12.3.1 bijlage 12.3).

De SRD volgde bij $50 \%$ op een operatie ( $14 \%$ carpale tunnel operatie), bij $29 \%$ op een fractuur ( $21 \%$ van de pols) en bij $14 \%$ op een contusie. In $7 \%$ ontstond de SRD spontaan. Bij $64 \%$ was voorafgaand enigerlei trauma opgetreden en/of behandeld. Bij $79 \%$ was één hand en/of arm en bij $7 \%$ beide, bij $11 \%$ één voet en/of been en bij $4 \%$ beide aangedaan ( $55 \%$ links en $45 \%$ rechts). Bij $14 \%$ waren meerdere ledematen nu of in het verleden 
aangedaan. Het betrof in $86 \%$ de bovenste ledematen. De patiěnten in het onderhavige onderzoek zijn vooral door de chinurgie en minder door de orthopedie verwezen.

Bij de 28 eerste thuisbehandelingen is 23 maal mannitol $10 \%$ en 6 maal mannitol 5\% (5x2 liter en $1 x 1$ liter per dag) gegeven. Eén patient ontving een proefdosis van beide concentraties. Bij de 18 vervolgbehandelingen is alleen mannitol $10 \%$ gegeven. De intraveneuze behandeling duurde gemiddeld 7,3 dagen (sd 1,5 bereik 2-8 $\mathrm{N}=44$ ). Eén chronische patiēnt was na een twintigtal intraveneuze behandelingen zo slecht aan te prikken dat de laatste twee vervolgbehandelingen van acht dagen via een daartoe geilmplanteerde Port-A-Cath zijn gegeven. In 1994 en 1995 bedroeg het aandeel van de PIM thuis uitgedrukt in aantallen patiênten en behandelingen bijna $50 \%$ (tabel B12.3.2). ${ }^{5.77}$ In infusiedagen bedroeg dit aandeel in $199455 \%$ en in $199551 \%$. ${ }^{.47}$

\section{Klinisch effect, bijwerkingen en complicaties}

De PIM thuis gaf bij $54 \%$ van de 28 patięnten en $65 \%$ van de 46 behandelingen een klinische verbetering (tabel B12.3.1). Gecorrigeerd voor de twee patiěnten die de behandeling binnen 48 uur staakten, gaf $58 \%$ van de behandelingen een klinische verbetering. Als bijwerkingen traden bij de PIM thuis in $4 \%$ hoofdpijn en in $13 \%$ lichte misselijkheid op. De 44 intraveneuze behandelingen gaven in $66 \%$ (beginnende) flebitis. Eén patiênt met nierstenen in de voorgeschiedenis ( 5 jaar daarvoor) kreeg nierkolieken tijdens de proefdosis van zowel mannitol $10 \%$ als $5 \%$ op opeenvolgende dagen. De behandeling is toen gestaakt en de patiênt is doorverwezen voor therapie. Een andere patiênt is -bij kortdurende afwezigheid van de naaste- gestruikeld en liep bij een val met de borstkas op de tafelrand een pneumothorax op. De patiënt herstelde na een korte ziekenhuisopname en heeft naderhand nogmaals een PIM thuis ontvangen. Ofschoon de gebeurtenissen niet precies te reconstrueren waren (waarschijnlijk vloermat), is de val als een 'typische' thuiszorgcomplicatie beschouwd. Bij een derde patiënt is de trouwring niet verwijderd van de infuusarm. Toen deze na een paar dagen iets opzwol, moest de ring op de eerste hulp verwijderd worden. De incidentie van complicaties was aldus $0,8 \%$ per infusiedag. Tijdens de 44 intraveneuze behandelingen ( 322 infusiedagen) is na de eerste infuuscanule 32 maal een nieuwe ingebracht vanwege een: tromboflebitis (25x); dislokatie omdat de patiënt ergens bleef haken en dergelijke (4x); accidentele verwijdering van de infuuscanule door de TMV toen de driewegkraan niet los ging (1x); te kleine infuuscanule (lx) of ongemakkelijke inbrengplaats (1x). Gemiddeld bleef de intraveneuze canule 4,2 dagen in situ. Van de intraveneuze infusies is $32 \%$ voortijdig beëindigd vanwege flebitis (12x) en subcutaan lopen (2x). Afgemeten aan het aantal nieuwe infuuscanules (25x) en het voortijdig staken (12x) bedroeg de incidentie van flebitis $11 \%$ per infusiedag. Deze flebitis was voornamelijk chemisch van origine (pijn infusie gerelateerd, geen koorts).

Tijdens de 46 behandelingen (338 infusiedagen) deden zich de volgende problemen met het infuussysteem voor: lucht (1x:patiënt of TMV) of bloed (2x:patiënt) in het systeem; niet doorgeven stilstaan van het infuus (2x:patiënt); lekkage bij lasnaad druppelkamer (1x:fabrikant) en driewegkraan (1x:TMV); accidentele verwijdering infuuscanule (1x:TMV). Meestal konden deze problemen opgelost worden door het infuussysteem door te spoelen of te spuiten met $\mathrm{NaCl} 0,9 \%$ of (deels) te vervangen. De incidentie problemen met de infuuslijnen was aldus $2,4 \%$ per infusiedag.

Met de infuuspomp (326 infusiedagen) zelf zijn geen problemen opgetreden. De facilitaire dienst van de SGKH leverde tweemaal een infuusstandaard waaraan geen pomp bevestigd kon worden. In de 326 pompdagen ( 7.800 uren) deden zich de volgende problemen voor: 
infuussysteem verkeerd om ingehangen (1x:TMV), alarm bij onvoldoende lang opladen (1x:patiënt) en is de pomp tijdens valpartijen (2x:patiënt) en verblijf in een badkamer (1x:patiênt) normaal blijven functioneren. De incidentie van problemen met de pomp was aldus $1,5 \%$ per dag.

\section{Kwaliteit van leven}

Tabel B12.3.3 geeft de resultaten (zie ook H:13). De patienten waren volgens de SIP-68 voor $25 \%$ beperkt in hun functioneren. Patiènten vonden zichzelf even ernstig ziek als de inschatting hiervan door hun naasten en zorgverleners. Wel gaven patiënten een iets slechtere gezondheid, meer pijn en een lagere $\mathrm{KvL}$ aan dan de zorgverleners. Een kwart van de naaste verzorgers gaf aan zelf ziek te zijn, doch niet ernstig. De belasting voor de naaste verzorger was gemeten in uren per dag hoog (gemiddeld $10 \mathrm{sd} 7$ ), afgemeten naar het aantal tengevolge van de IT gestaakte sociale activiteiten laag (gemiddeld 2 van de 7). De invloed van de IT en de belemmering van de ziekte konden onvoldoende gescheiden worden. Gemeten via een stelling was de ervaren belasting bij de naaste gemiddeld.

Gemeten volgens de CSI was de ervaren belasting wel aanwezig, maar laag (afkappunt 7). 'Overall' was de KvL van de naaste nauwelijks hoger dan die van de patiěnt.

\section{Kwaliteit van en tevredenheid met zorg}

Tabel B12.3.3 vat ook de resultaten van de KvZ en tevredenheid samen. Uitgedrukt in rapportcijfers voor de zorgverleners varieerde de tevredenheid bij de patiënt en naaste van 7 tot 9. De KvZ gemeten via de ZKM was omgerekend een 8 of 9 en via de CSQ een 8 .

\section{Kosten}

Van de 44 intraveneuze behandelingen ( 322 infusiedagen) zijn de kosten apart berekend. Gemiddeld waren de kosten voor de gezondheidszorg $f 1.856$ per behandeling en $f 254$ per infusiedag (\$15.4.1). De materiêle kosten voor de patiënt en naasten waren gemiddeld $f 12$ per infusiedag (\$15.4.2), de personele varieerden tussen $f 33$ en $f 135$ per infusiedag (\$15.4.3). De totale maatschappelijke kosten kwamen zo op $f 300$ tot $f 402$ per dag $(\S 15.4 .4)$. Het aandeel van de patiěnt en naasten hierin was $15-37 \%$.

\section{Tijdsbesteding TMVs}

Tabel B12.3.4 geeft per activiteit aan hoeveel percent van de totale tijd de TMVs daaraan besteed hebben. Daarnaast zijn per activiteit kenmerken van de duur (in minuten) weergegeven en het aantal keren dat een bepaalde handeling geregistreerd is.

Naast de technische handelingen en de daarbij behorende begeleiding vraagt $7 \times 24$ uurs infusie ook lichamelijk hygięnische verzorging. De reistijd besloeg $42 \%$ van de tijd. In totaal vergde deze behandeling per dag 114 minuten gespecialiseerde verpleegkundige zorg, waarvan 52 minuten ( $46 \%$ ) voor het primaire proces.

\section{Andere studies}

De leeftijds- en geslachtsverdeling van in het azM behandelde patiēnten in het jaar voor de mogelijkheid tot PIM thuis (1993) was bekend $\left(0-13=2 \%, 14-64=89 \% 65^{+}=9 \%\right.$; $q=77 \%) .{ }^{334}$ De door Veldman prospectief vervolgde 829 SRD patiënten waren gemiddeld 42 jaar $\left(0-19=6 \%, 20-59=77 \%\right.$ en $\left.60^{+}=17 \%\right)$ en voor $76 \%$ van het vrouwelijk geslacht. ${ }^{538}$ De SRD ontstond in $65 \%$ na een trauma, in $19 \%$ na een operatie en in $10 \%$ was dit onbekend. ${ }^{538}$ In $59 \%$ waren de bovenste en in $7 \%$ meerdere ledematen aangedaan. ${ }^{538}$ 


\subsubsection{Beschouwing parenterale infusie van mannitol}

Deze studie betrof een haalbaarheidsonderzoek naar PIM thuis als behandeling voor SRD met een beperkt aantal patiēnten. Zoals verwacht stelt de IT extra eisen (zie inclusiecriteria), bereikbaarheid van en overleg met andere zorgverleners en in het bijzonder de participatie van het patiêntsysteem. Ofschoon de behandeling kort duurde, bleken de patiēnt en naaste verzorgers in de technische handelingen te kunnen participeren.

De kenmerken van de patiēnten in deze studie komen wat betreft leeftijd, geslachtsverdeling, aandoening en voorafgaande gebeurtenis grotendeels overeen met de prospectief door Veldman beschreven SRD patiënten en patiënten die vóór de mogelijkheid tot IT in het azM behandeld zijn. ${ }^{334}$, s3t Hoewel de invloed van de psyche op de aetiologie soms ter discussie staat, ging meestal een fysiek fenomeen aan de SRD vooraf. ${ }^{\text {sts.s50 }}$ Bij de helft van de patiênten is een (tijdelijke) klinische verbetering gerapporteerd. Hoewel de toegepaste techniek en de toegediende medicatie complicaties en bijwerkingen gaven, zijn deze niet hoog. Ofschoon niet onderzocht gaven sommige patiěnten spontaan aan dat bij de 24-uurs IT minder bijwerkingen optraden dan bij de tot dan gangbare 4-uurs behandeling in het dagcentrum. Een veelvuldig voorkomende bijwerking bij intraveneuze toediening van mannitol $10 \%$ was flebitis veroorzaakt door de hyperosmolariteit in combinatie met de $7 \times 24$ uurs toediening. Toch gaven onze ervaringen onvoldoende aanleiding om standaard te kiezen voor centraalveneuze infusie. ${ }^{545}$ Laatstgenoemde kan ook complicaties geven en is bovendien duurder.

De afzonderlijke invloed van de IT op de KvL kon niet eenduidig vastgesteld worden. De combinatie van SRD en de PIM thuis belemmerde patiënten in termen van de SIP in vergelijkbare mate als reuma- of CVA patiënten. ${ }^{551} \mathrm{Pijn}$ is bij patiënten met SRD een bekend therapieresistent symptoom $(75 \%-97 \%)$. ${ }^{533},{ }^{538}$ De relatief lage $\mathrm{KvL}$ van de naaste verzorgers is niet alleen te verklaren uit hun leeftijd en gezondheid. De zorg voor, en het leven met de chronisch zieke patiënt zal daaraan bijdragen. De invloed van de IT hierop kon niet eenduidig vastgesteld worden.

Omdat bij onderzoek naar KvZ en tevredenheid bias in de vorm van grote tevredenheid speelt, is door op verschillende wijzen te onderzoeken getracht dit probleem te ondervangen. ${ }^{519-522}$ In het algemeen zijn zowel de patiënt en diens naaste verzorger als de TMV en de huisarts tevreden.

De daadwerkelijke ziekenhuiskosten zijn moeilijk te achterhalen. Bij behandeling in een dagcentrum gold een dagtarief van $f 375(f 2.625$ per week; 'besparing' $\pm 30 \%$ ten opzichte van $f 1.856$ ). Het meest vergelijkbare alternatief is opname op een verpleegafdeling. Het azM verpleegdagtarief was in de onderzoeksperiode gemiddeld $f 807$ ( $f 5.649$ per week; 'besparing' $\pm 70 \%$ ), de verblijfsdagprijs van het azM ( $\$ 14.5 .6)$ bedroeg ongeveer $f 432$ ( $f 3.024$ per week; 'besparing' $\pm 40 \%$ ). IT lijkt goedkoper, maar het aandeel in de kosten voor de patiënt en naasten is niet gering.

De tijdsbesteding van de TMVs reflecteert het gekozen zorgmodel. Vanwege het op peil houden van de vaardigheden en de kosten van bereikbaarheidsdiensten is gekozen voor uitvoering door een regionaal team TMVs in nauwe samenwerking met de specialist. Hierdoor is relatief weinig tijd besteed aan overleg met en instructie van de wijkverpleegkundige en de huisarts. Het aandeel van de reistijd was relatief groot. Absoluut gezien waren deze reistijden echter gelijk aan die bij andere IT in deze studie en de reistijd van wijkverpleegkundigen en wijkziekenverzorgenden bij de SGKH. In termen van 'face-toface' contacten ( $\approx$ primair proces plus instructie) had PIM een 'lage' produktiviteit van omgerekend $42 \%$ (zie ook $\S 14.5 .6)$. ${ }^{552}$ 


\subsubsection{Inleiding intraveneuze infusie van antibiotica}

\section{Infectieziekten en parenterale antibioticabehandelingen thuis}

Voor het begin van parenterale thuisbehandeling met antibiotica (HIVAT) wordt gewoonlijk verwezen naar drie studies uit de Verenigde Staten (VS) van eind jaren zeventig. ${ }^{553-555}$ De eerste vermelding van 127 thuisbehandelingen bij 62 cystic fibrosis (CF) patiënten dateert uit $1974 .{ }^{356}$ HIVAT is in de VS reeds een geaccepteerde behandeling (250.000 per jaar). ${ }^{121,}{ }^{557}$ In het begin zijn antibiotica met een klassiek infuussysteem (gebruik makend van de zwaartekracht) en een perifeer intraveneuze canule toegediend. ${ }^{119,342,553-555,558,559}$ Later zijn vanwege de kosten, de trainbaarheid van de patiënt en de vaatwandirritatie door de antibiotica(concentraties) draagbare infuuspompen, centrale perifere en centraalveneuze catheters en implanteerbare onderhuidse poortsystemen toegevoegd. ${ }^{121}$, 588, 560-562 De indicaties voor $(\mathrm{H})$ IVAT veranderen. ${ }^{.63-565}$ Ook het wijdverbreide en onjuiste antibioticagebruik hebben bijgedragen aan resistentievorming die gecombineerde en langdurige therapieën vereist. ${ }^{566}$ Naast het capaciteits- en het kostenaspect kan HIVAT ook de kans op nosocomiale infecties, flebitis en resistentievorming doen afnemen. ${ }^{567}$ Echter ook thuis kunnen dan 'nosohusiale' geheten infecties optreden. ${ }^{588}$ Intramusculaire toediening thuis is in Nederland al goed mogelijk en wordt buiten beschouwing gelaten. ${ }^{569}$ Ook in Nederland bestaan thuiszorgprogramma's voor HIVAT en kan dit deel uit (gaan) maken van de thuiszorg en de huisartsgeneeskunde. ${ }^{341,344,570,571}$ Het potentieel wordt op 1.400 patiënten (27.000 infusiedagen) per jaar geschat. ${ }^{572}$

\subsubsection{Vraagstellingen intraveneuze infusie van antibiotica}

Hoewel HIVAT in de VS aan standaarden (accomodatie, procedures en organisatie) moet voldoen, is de KvZ nog weinig bestudeerd. ${ }^{567}$ HIVAT verschilt technisch niet wezenlijk van andere infusies. Daarom is prospectief onderzocht of HIVAT mogelijk is binnen ons algemeen zorgmodel voor infusie thuis. ${ }^{496}$ De vraagstelling betreft de toepasbaarheid van het zorgmodel in termen van (bij)werkingen en complicaties, $\mathrm{KvL}, \mathrm{KvZ}$, kosten en tijdsbesteding van de TMV in vergelijking met drie andere Nederlandse en verschillende buitenlandse initiatieven.

\subsubsection{Methoden en technieken bij intraveneuze infusie van antibiotica}

\section{Techniek thuisbehandeling}

In principe kiest de verwijzend specialist een antibioticum, dagdosering, toedieningsfrequentie en behandelduur. Met de microbioloog wordt overlegd over een zo laag mogelijke toedieningsfrequentie en zo kort mogelijke inloopsnelheid. ${ }^{118}$ De minimale duur is gesteld op vijf dagen en de maximale frequentie op viermaal daags, vanwege de nachtrust van de patiënt en diens naaste. De incidentie van allergische reacties bij HIVAT is $\pm 0,5 \%$ en vergt ziekenhuisopname in $\pm 1: 10.000$ infusiedagen ${ }^{557}$. 567 Daarom is de eerste gift in het ziekenhuis of samen met de huisarts toegediend en alle giften met een infusie van minimaal 10 minuten. ${ }^{121,562,567,573,574}$ Evenals vroeger zijn de antibiotica zoveel mogelijk vlak voor toediening thuis opgelost in verband met verlies van de werkzaamheid, vorming van allergene afbraakprodukten en de noodzaak van gekoeld transport en opslag na het oplossen. ${ }^{362,371,543,554,555,558,560-562,567,575,576}$ Hierdoor zijn ook zéér kort houdbare antibiotica thuis toe te dienen. ${ }^{567}$ Bij patiënten of naasten die de antibiotica al zelf kunnen 
toedienen maar nog niet oplossen, lost de TMV deze op voor maximaal 24 uur.

Vanwege de variêteit aan indicaties en antibioticaregimes is gekozen voor een aanpasbare standaardbehandeling via een klassiek infuussysteem. Dit omvat een infuusstandaard, een niet draagbare lineair-peristaltische volumegestuurde elektronische pomp (IVAC 5918) en een infuussysteem van infuuszakken, 3,55 m lange infuuslijn (bewegingsvrijheid) met hoog bijspuitpunt, zijlijn en driewegkraan met $10 \mathrm{~cm}$ verlengstuk (minder manipulatie aan infuuscanule en door de patiěnt zelf aan te koppelen) verbonden met een perifeer intraveneuze canule (Venflon $\otimes$ standaard $\odot 20 \mathrm{G}=1 \mathrm{~mm}$ en lengte $32 \mathrm{~mm} ; \ominus 22 \mathrm{G}=0,8 \mathrm{~mm}$ en lengte $25 \mathrm{~mm}$ bij kleinere vaten) (noot 12.4 .1 in bijlage 12.4 ). ${ }^{503}$, 562.367 Tussentijds worden de patiěnten afgekoppeld (doorspoelen driewegkraan, infuuscanule en vene met tenminste $10 \mathrm{ml} \mathrm{NaCl} 0,9 \%$ waarna heparinelock van $500 \mathrm{IE}$ in $2 \mathrm{ml}) .{ }^{57}$ Met de intermitterende toediening van niet te hoge concentraties en het spoelen is getracht de vaatwandirritatie te beperken. ${ }^{554,}, 574$ Vanwege het lagere infectierisico (kans, species en resistentiepatronen) thuis en ter minimalisering van portes d'entrée naar de bloedbaan, is de infuuscanule niet preventief elke 48 tot 96 uur vervangen, maar bij klachten. ${ }^{119}$, 508, 54, 555, 560, 578, 579 Vanwege de bewegingsvrijheid is de infuuscanule niet op de hand maar in de onderarm ingebracht, ondanks het iets hogere infectiegevaar. ${ }^{580}$ Hoewel verpleegkundigen in $41 / 2$ dag kunnen leren om infuuscanules in te brengen, is dit vanwege de opvattingen van de beroepsgroepen, de regelgeving en de onzekerheid omtrent het op peil houden van de vaardigheid niet aan de TMV overgedragen. ${ }^{55,367,581}$ De insteekplaats wordt dagelijks gecontroleerd, minimaal elke drie dagen gedesinfecteerd met $0,5 \%$ chloorhexidine in alcohol $70 \%$ en bedekt met een ademende pleister met zilvercoating op de insteekplaats (Vecafix(8) en driewegkraan. ${ }^{508,567,579,582}$ Desinfecterende zalf zoals Betadine $(8)$ wordt niet gebruikt, omdat deze na uitwerking van het desinfectans gekoloniseerd kan worden. ${ }^{583}$ Vanwege de intermitterende toediening is het infuussysteem elke dag vervangen in plaats van bijvoorbeeld elke 48 uur, de driewegkraan elke drie dagen. ${ }^{508}$

\section{Invulling zorgmodel}

Verantwoorde toepassing van de techniek vergt een zorgmodel. ${ }^{584}$ Globaal zijn er drie modellen: 'infusion center' of 'office model' (polikliniek), 'visiting nurse' (verpleegkundige komt thuis), 'self administration' (patiënt zelf) en mengvormen. ${ }^{567,585-588} \mathrm{Naar}$ de zorgtheorie van Orem (patiëntsysteem centraal) is gekozen voor een 'visiting nurse' vanuit de thuiszorg en eventueel 'self administration' na training. ${ }^{164}$ Dit model is ook in de VS gangbaar ${ }^{567}$ Samenwerking verzekert de schaalvoordelen van het 'infusion center'. De TMV heeft een centrale rol bij de selectie, organisatie, uitvoering, training en coördinatie en wordt ondersteund door andere zorgverleners (specialist, microbioloog, apotheker, huisarts). ${ }^{122,}, 558,559 \mathrm{Na}$ medische selectie meldt de specialist en soms de huisarts patiënten aan bij het centraal meldpunt van de thuiszorg. Daarop onderzoekt de TMV in overleg met de huisarts de mogelijkheden (schema 7.2). ${ }^{589} \mathrm{Bij}$ geschiktheid wordt de zorgverzekeraar om vergoeding verzocht. Vanwege de geringe incidentie en de kwaliteitseisen levert het ziekenhuis (levering medicatie, infuusmaterialen en infuuspompen) de deskundigheid van de ziekenhuisapothekers en de technische dienst en investeringen (infuuspompen) en de thuiszorg de bezorgdienst. ${ }^{57,590}$ De TMV voert de HIVAT samen met de huisarts uit, verzorgt de coördinatie en begeleiding en instrueert patiënten en naasten ${ }^{591}$ De verwijzend specialist en microbioloog vervolgen de behandeling poliklinisch. Alle zorgverleners en eventueel de patiẻnt en naasten doen verslag in het zorgdossier. 


\section{Meetinstrumenten}

Het effect van de behandeling is afgemeten aan een gerapporteerde verbetering in de poliklinische status. Deze is omschreven als een somatische verbetering volgens de patiènt en de behandelend specialist (afhankelijk van het soort infectie). De overige methoden zijn in de hoofdstukken 2 en 13, 14 en 15 beschreven.

Deze studie, hierna afgekort tot "pIT", wordt vanwege het ontbreken van een controlegroep vergeleken met andere studies. Vanwege de bias door nationale verschillen in gezondheid(szorgsystemen) gebeurt dit vooral met drie andere Nederlandse studies. Twee studies betreffen CF-patiënten, één onder auspiciën van het KwaliteitsInstituut voor Toegepaste ThuisZorgvernieuwing (KITTZ) en één multicenter studie (multicenter). ${ }^{341,344}$ De derde studie door onder andere de Nederlandse organisatie voor Toegepast Natuurwetenschappelijk Onderzoek (TNO) vergelijkt thuis- en ziekenhuisbehandeling. ${ }^{570}$

\subsubsection{Resultaten intraveneuze infusie van antibiotica}

Tabel B12.4.1 geeft enkel resultaten van pIT, tabel B12.4.2 bevat ook resultaten van de andere Nederlandse studies die hiema besproken worden.

\section{Instroom}

Er zijn 16 patiënten 23 maal gescreend. Eén is niet ingestroomd omdat het medisch beleid bij aanmelding nog niet vaststond (tabel B7.6 bijlage 7.4).

\section{Kenmerken patiěnten en behandelingen}

Tussen 27 oktober 1993 en 31 december 1995 zijn 14 patiënten (leeftijd mediaan 60 , $0-20=7 \%, 21-54=40 \%$ en $55^{+}=53 \% ; \sigma^{*}=73 \% ; 3$ alleenwonend, waarvan 2 in een bejaardenhuis) éénmaal en is één patiënt achtmaal behandeld met een totale duur van 501 dagen (tabel B12.4.1). De behandeling is in $27 \%$ thuis (3x) of vanaf de polikliniek (3x) gestart en in $73 \%$ in het dagcentrum $(2 \mathrm{x})$ of het ziekenhuis $(14 \mathrm{x})$. Vier patiènten of hun naasten $(27 \%)$ hebben de HIVAT zelf uitgevoerd. Per patie̋nt is de belangrijkste verwekker in $47 \%$ Pseudomonas aeruginosa, in 20\% Borrelia spp. en in $13 \%$

Staphylococcus aureus. Tabel B12.4.2 geeft de verdeling van de verwekkers over de infecties. Binnen de 22 behandelingen zijn 23 antibioticaregimes toegepast (noot 12.4.2). De gemiddelde dagelijkse toedieningsfrequentie is 2,7. De 'netto' inlooptijd is gemiddeld per antibioticum 26,7 minuten (sd 18,4 bereik 10-120), per antibioticumtoediening van één of meerdere antibiotica 32,6 minuten (sd 19,6 bereik 20-120) en per dag 79,8 minuten (sd 26,3 bereik 25-120). Exclusief 15 tot 30 minuten per gift voor het voor-, tussen- en naspoelen met $\mathrm{NaCl} 0,9 \%$ en hepariniseren. $\mathrm{Bij}$ enkele antibiotica blijken onder supervisie van de TMV kortere inlooptijden mogelijk.

\section{Klinisch effect, bijwerkingen en complicaties}

Bij 14 patiěnten $(93 \%)$ en 21 behandelingen $(95 \%)$ trad een klinische verbetering op (noot 12.4.3). Bij de laatste thuisbehandeling van één CF-patiēnt ( $\sigma^{* 15}$ met ernstig verslechterde voedingstoestand bleef deze uit. Hij is tijdens de aansluitende ziekenhuisopname overleden. $\mathrm{Bij}$ de patiènt met urosepsis reageerde de oorspronkelijke verwekker op de therapie, maar verstoorde een nieuwe infectie met een andere verwekker het herstel. Vanwege de retentieblaas is een suprapubische catheter geadviseerd. Er is geen diagnose veranderd, in $4,5 \%(1 \mathrm{x})$ een andere verwekker gevonden, in $14 \%(3 \mathrm{x})$ de therapie gewijzigd om thuis een lagere toedieningsfrequentie te verkrijgen $(2 x)$ en vanwege resistentievorming $(1 x)$ en 
in $9 \%(2 x)$ de tobramycinedosering aangepast op geleide van de plasmaspiegel. Eén patiênt kreeg tijdens het ziekenhuisdeel een allergische reactie op piperacilline. Thuis gaf ciprofloxacine eenmaal maagpijn. Bij twee andere patiênten trad misselijkheid op, die niet aan de antibiotica toe te schrijven was. Bij zeven van de 14 patiènten is 16 maal een nieuwe infuuscanule ingebracht vanwege flebitis ( $9 x$ bij 2 patiênten), trombose $(2 x)$, subcutaan lopen $(1 \mathrm{x})$ en lekken aan de insteekplaats $(4 \mathrm{x})$. Gemiddeld kon de infuuscanule tenminste 9,9 dagen $(298 / 14+16)$ gebruikt worden en was de noodzaak tot canulewisseling $5,4 \%$ per dag. CF-patiěnt $\left(\sigma^{*} 15\right)$ ging onzorgvuldig om met de infuuscanule en is niet meegerekend. Ondanks dat hij niet aan alle criteria voldeed is de HIVAT op verzoek van de specialist gegeven (noot 12.4.4).

De incidentie van fouten bij het bereiden van de medicatie is $0,4 \%$ per infusiedag. Verpleegkundigen hebben één infuuszak lek geprikt en één ampul gebroken. De incidentie van problemen met de infuuslijnen is 1,6\% per infusiedag. Het betreft: infuuscanule geknikt of gedeeltelijk uit vat (2x:patiēnt); bloed in de driewegkraan (1x:patiēnt) of driewegkraan niet goed gesloten (1x:TMV), lucht in infuussysteem (1x:naaste); koude infuusvloeistof (1x:TMV) en tintelen bij te snelle infusie (2x:TMV). Meestal kunnen deze problemen opgelost worden door het infuussysteem te spoelen, door te spuiten of (deels) te vervangen. De incidentie van problemen met de infuuspomp ( 20 behandelingen; 401 infusiedagen) is $0,5 \%$ per infusiedag. Oorzaken waren belemmering van de doorstroom van het systeem en onvoldoende opladen van de batterij.

\section{Kwaliteit van leven}

Wat betreft de KvL zijn de patiënten volgens de SIP- 68 score voor $26 \%$ beperkt in hun functioneren (tabel B12.4.3). Patiënten vinden zichzelf even ernstig ziek, en geven eenzelfde mate van gezondheid, pijn en KvL aan als de inschatting hiervan door hun naasten en zorgverleners. De belemmering door de HIVAT en de (co)morbiditeit zijn onvoldoende te scheiden.

Naasten geven meestal een redelijk goede gezondheid aan, twee zijn zelf ziek. Gemeten via een stelling is de door de patiënt ervaren praktische steun hoog, de emotionele steun iets lager. De naaste zelf vindt dat die iets minder steun heeft gegeven. De belasting voor de naaste verzorger is gemeten in uren per dag hoog (gemiddeld $7 \mathrm{sd} \mathrm{7),} \mathrm{afgemeten} \mathrm{naar} \mathrm{de}$ gestaakte sociale activiteiten laag (gemiddeld 1 van de 7). De ervaren belasting is gemeten via een stelling hoog, via de CSI wel aanwezig, maar laag (afkappunt 7). 'Overall' lijkt de ervaren KvL van de naaste iets hoger dan die van de patiënt.

\section{Kwaliteit van en tevredenheid met zorg}

De tevredenheid uitgedrukt in rapportcijfers voor zorgverleners varieerde van 7 tot 9 (tabel B12.4.3). De KvZ was gemeten via de ZKM een $81 \frac{1}{2}$ (huisarts $71 \frac{1}{2}$ ) en via de CSQ zo'n $81 \frac{1}{2}$.

\section{Kosten}

Van alle 22 behandelingen ( 501 infusiedagen) zijn de kosten berekend. Gemiddeld kost de HIVAT $f 9.119$ per behandeling en $f 400$ per infusiedag ( $\$ 15.4 .1)$. De kosten bestaan voor eenderde uit de kosten van de antibiotica en voor de helft uit personeelskosten. De kosten voor infuusbenodigdheden en de infuuspomp zijn relatief laag. De materiële kosten voor het patiëntsysteem zijn gemiddeld $f 5$ per infusiedag (\$15.4.2). Al naar gelang de waardering van de personele kosten voor de naastenzorg, variëren deze van $f 9$ tot $f 84$ per infusiedag (§15.4.3). De totale maatschappelijke kosten komen zo op $f 414$ tot $f 489$ per 
infusiedag (\$15.4.4). Het aandeel van de patiënt en naasten hierin varieert van $2 \%$ tot $17 \%$.

\section{Tijdsbesteding TMVs}

Tabel B12.4.4 geeft hoeveel percent van de totale tijd de TMVs aan de diverse activiteiten besteed hebben. Daarnaast zijn per activiteit kenmerken van de duur (in minuten) weergegeven en het aantal keren dat een bepaalde handeling geregistreerd is.

\section{Andere Nederlandse studies}

Bij TNO betreft het 79 patiēnten ( 3 in een instelling, boot en algemeen ziekenhuis; $23 \%$ alleenwonend) met verschillende aandoeningen en behandelingen en een gemiddelde dagelijkse toedieningsfrequentie van 2,6 (tabel B12.4.2). In $1 \%$ is de diagnose gewijzigd, in $3 \%$ een andere verwekker gevonden, in $32 \%$ de medicatie en in $56 \%$ de dosering gewijzigd. Allergische reacties komen in 2,7\% en andere bijwerkingen in $24 \%$ van de behandelingen voor. Canulewisseling is nodig vanwege flebitis, onjuiste positie of verstoppen infuuscanule en onbekend. Er zijn draagbare en niet draagbare elektronische pompen, elastomeer- en veerdrukpompen, infuuszakken, spuiten en combinaties gebruikt. Bij multicenter betreft het één standaardbehandeling met draagbare elektronische pompen bij één verwekker. Klinische parameters, welbevinden, tevredenheid met activiteiten en de toestand en de algemene dagelijkse levensverrichtingen nemen tijdens de behandeling toe. Bij KITTZ is alleen het aantal antibiotica en de duur ( 14 of 21 dagen) gegeven. ${ }^{592} \mathrm{Er}$ zijn voornamelijk draagbare elektronische pompen in combinatie met centraalveneuze infusie en speciale lange perifere infuuscanules ('midline') gebruikt. ${ }^{593}$

\section{Buitenlandse studies}

Hierin variëren de dagen infusie thuis van 116 tot 10.002 , de behandelingen van 13 tot 538 en patiënten van 10 tot 538, de gemiddelde leeftijd van 23 tot 70 (bereik 3-93) en het percentage mannen van 52 tot $67.118,119,121,342,553-557,559,560,562,576,594,595$ Van de aangemelde patiënten valt 10 tot 40 percent af, maar dit aantal daalt. $558,560,595,596$ De verwekkers en

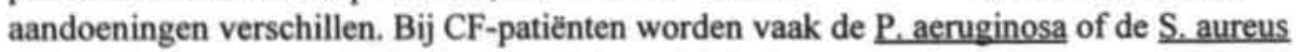

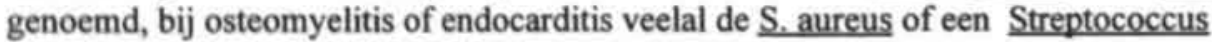
spp. ${ }^{342,553,555,556,558-560,562,567,576,595}$ De gemiddelde dagelijkse toedieningsfrequentie varieerde van 3 tot 4,4 (bereik 3-7) en de inlooptijd van 30 tot 60 minuten. ${ }^{595}$ De voorafgaande behandeling in het ziekenhuis (antecedent hospital treatment) duurt gemiddeld $\pm 2,8$ tot 22 dagen (bereik $0-41$ ). ${ }^{118,342,553-555,558,594,595}$ De thuisbehandeling duurt gemiddeld 6,6 tot 29,7 dagen (bereik 1-145). $118,119,342,553-557,559,576,594$

Meestal verbeteren de klinische toestand $(80-98,6 \%)$ en microbiologische of andere parameters. ${ }^{119,} 121,342,553,555,557-559,562,576,595$ De complicaties variëren met de antibiotica, toedieningswegen en toedieningssystemen. De perifere infuuscanules variëren van stalen vleugelnaalden tot perifere polypropyleen of teflon canules. ${ }^{119,554,559}$ Het percentage patiënten met tromboflebitis varieert van 1 tot $40 .{ }^{118,119,553-555,558-560}$ De frequentie van canulewisseling varieert van 1,1 (selectie op basis van 'goede' vaten en 'preventieve' canulewisseling elke 3 dagen) tot 2,4 ('preventieve' canulewisseling elke 2 dagen) percent per dag. ${ }^{119,554,555,559}$ Soms wordt de infuuscanule preventief elke dag tot elke vijf dagen vervangen. ${ }^{418,119,553-555,558-500}$ Zonder wisseling kan een infuuscanule ook bij CF-patiěnten 7 tot 8 dagen meegaan. ${ }^{556}$ De frequentie van canulewisseling bij Venflon $\$$ infuuscanules is $12,1 \%$ per dag en zij kunnen minimaal 3,2 dagen gebruikt worden. ${ }^{342}$ Kweken van de tips van infuuscanules (Angiocath» tefloncanule) die elke dag verwisseld worden leveren een 
vergelijkbare ( $13 \%)$ of lagere $(2,9 \%)$ kolonisatiegraad op dan kweken van infuuscanules in het ziekenhuis ( $\pm 12 \%$ voor polypropyleen en $\pm 15 \%$ voor teflon infuuscanules). ${ }^{554} .55 \%$ In het ziekenhuis treedt bijna tweemaal zoveel flebitis op dan thuis, bij ouderen is dit verschil kleiner. ${ }^{12 !}$

De patie̋nten vinden de KvL bij HIVAT hoger dan bij ziekenhuisbehandeling en kunnen vaak weer (gedeeltelijk) aan het dagelijkse leven deelnemen (school of werk in 28 tot $89 \%$ ). ${ }^{119}, 302,55,559,576,594$ Meestal zijn zij tevreden en prefereert 80 tot $98 \%$ HIVAT boven ziekenhuisbehandeling. ${ }^{322,557,559,594}$ Bovendien is HIVAT vrijwel altijd goedkoper (37$79 \%$ ). ${ }^{119,121,553-555,599,597, \text {, } 998}$ De kosten-baten verhouding kan 1:5 of gunstiger zijn. ${ }^{594}$

\subsubsection{Beschouwing intraveneuze infusie van antibiotica}

Deze studie betreft 22 behandelingen bij 15 patiênten binnen een algemeen zorgmodel voor infusie thuis via een voor HIVAT aanpasbare standaardbehandeling met een klassick infuussysteem en thuis opgeloste antibiotica. De niet gelimiteerde instroom veroorzaakt een niet homogene populatie en belemmert generalisatie. Ook verschillen het antibioticagebruik, de gezondheidszorg en de thuiszorg per land. $199,599,600$

Demografisch zijn de patiěnten qua geslacht en woonsituatie redelijk vergelijkbaar met die bij TNO, maar zijn ouder. Mogelijk omdat patiěnten en naasten niet zoals bij TNO de behandeling grotendeels zelf moeten uitvoeren. Beide andere Nederlandse studies betreffen CF-patiënten. Ook in de buitenlandse studies is er bij patiënten en behandelingen een brede variatie in aantallen en kenmerken. ${ }^{119}, 119,121,362,553-557,590,560,562,576,594,595$ Dat bij pIT vrijwel alle patiënten lijken te kunnen instromen is gunstig in verhouding met buitenlandse studies, maar wellicht zijn patiënten die niet in aanmerking kwamen niet aangemeld.

De verwekker betreft bij pIT relatief vaker dan bij TNO een $\mathrm{P}$. aeruginosa. Mogelijke oorzaken zijn een hogere verwijzingsgraad door de afdelingen longziekten en kindergeneeskunde of een hogere incidentie in het azM. In voornoemde buitenlandse studies verschillen de verwekkers en aandoeningen. ${ }^{342,553,558,556,558-560,562,567,576,595}$ De antibioticaregimes bij pIT en TNO komen ongeveer overeen. Bij pIT lijken meer aminoglycosiden toegediend. $\mathrm{Zij}$ worden echter vaak met een penicilline of cefalosporine gecombineerd en TNO vermeldt alleen het meest karakteristieke antibioticum. In voornoemde buitenlandse studies variëren met de verwekkers ook de antibiotica. De gemiddelde dagelijkse toedieningsfrequentie is vrijwel gelijk aan de intermitterende toediening bij TNO, maar de maximumfrequentie is lager dan bij TNO (5-6/dag). In tegenstelling tot bij multicenter (allen) en KITTZ en TNO (deels) zijn geen antibiotica via een continu infuus gegeven. De toedieningsfrequentie en inlooptijd komen overeen met die in buitenlandse studies. ${ }^{595}$ In tegenstelling tot bij pIT legt men de maximumfrequentie bij HIVAT zonder draagbare infuuspomp tegenwoordig meestal bij drie. ${ }^{567}$ Mogelijk verdienen de aanbevelingen over de inloopsnelheid bij HIVAT herevaluatie. $\mathrm{Bij}$ de verschillende toedieningswijzen dringt zich een vergelijking op tussen ons systeem en een cassettepomp. Het systeem in deze studie is gekozen vanwege: de kosten, flexibiliteit, de mogelijkheid om nauwkeurig en snel antibiotica toe te dienen en tussendoor te spoelen en de wettelijke beperking in Nederland bij het rechtstreeks in de bloedbaan toedienen van medicatie door verpleegkundigen. ${ }^{581} \mathrm{Bij} 24$-uurs toediening met bijvoorbeeld ceftazidim als monotherapie biedt een draagbare cassettepomp voordelen, bij combinatietherapie verminderen deze. ${ }^{592,601}$ Ook geeft een infuuspomp die intermitterend antibiotica toedient en tussendoor de vene open houdt, door de hogere concentratie en de 
langdurige expositie, een grotere kans op vaatwandirritatie. Dit kan een reden zijn om voor centraalveneuze infusie te kiezen. ${ }^{31,560,561}$ Met een klassiek infuussysteem kunnen alle antibiotica in alle concentraties en volumina worden toegediend. ${ }^{560} \mathrm{Bij}$ draagbare infuussystemen zijn de volumina vaak beperkt tot 10 à $35 \mathrm{ml}$ (spuitpomp) of 100 à $200 \mathrm{ml}$ (cassette- of elastomeerpomp). In voornoemde buitenlandse studies variëren de infuussystemen van injectiespuiten tot programmeerbare draagbare infuuspompen.

De behandeling start in $27 \%$ thuis, bij TNO in $22 \%$ thuis en in $78 \%$ volgens planning in het ziekenhuis. De groep die bij pIT thuis start omvat evenals bij TNO de ziekte van Lyme en Pseudomonas-infecties. De totale behandeling duurt iets korter dan bij TNO (exclusief 11 behandelingen voor onbepaalde tijd), maar langer dan bij multicenter en bij KITTZ. Het thuisdeel duurt iets langer dan bij TNO. Bij KITTZ en multicenter is dit niet apart vermeld. De minimaal geplande duur thuis is bij TNO 14 en bij pIT 5 dagen, de kortst gerealiseerde is bij TNO vijf en bij pIT zeven dagen. In vergelijking met buitenlandse studies waren patiënten bij pIT kort in het ziekenhuis en lang thuis. ${ }^{118}, 119,342,553-559,576,594.595$ De klinische verbeteringen in de Nederlandse en buitenlandse studies lijken vergelijkbaar. ${ }^{119,121,342,533,555,557.599,562,576,595}$ Ook de effecten van ziekenhuis- en thuisbehandeling lijken vergelijkbaar. Veranderingen betreffen minder vaak de medicatie en dosering dan bij TNO. In voornoemde buitenlandse studies komen afhankelijk van de patiěnten, aandoeningen en antibiotica ook veranderingen voor.

De complicaties in de Nederlandse studies lijken vergelijkbaar. Canulewisseling vanwege flebitis komt het vaakst voor (bij pIT drie patiennten). De bij TNO in het ziekenhuis benandeide groep neert Hebitus in $0,4 \%$ per dag en oenoert canulewisseing in $8,1 \%$ per dag. Mogelijk dat de infuuscanule thuis langer mee gaat door de andere infectierisico en de relatief grote zorg voor de insteekplaats. Flebitisfrequenties vanuit zowel ziekenhuis- als thuisbehandelingen kunnen dan ook slechts een indicatie vormen voor te verwachten frequenties bij HIVAT. ${ }^{371}$ Meestal zijn midline catheters of centraalveneuze infusie niet noodzakelijk. ${ }^{344,574}$ Temeer omdat deze invasievere technieken zwaardere complicaties kunnen geven bij trombosering en ontsteking (zie verderop). De keuze voor één toedieningssysteem lijkt minder problemen te geven. Het thuis oplossen van antibiotica omzeilt problemen met de houdbaarheid en lijkt niet meer problemen te geven. De complicaties in voomoemde buitenlandse studies variëren met de antibiotica, toedieningswegen en toedieningssystemen. In vergelijking met de buitenlandse studies treedt bij de binnen pIT gekozen techniek in verhouding weinig tromboflebitis op en gaan de infuuscanules relatief lang mee. ${ }^{119,553,554,559118,119,342,555,556,558-560}$ Met de bij pIT gekozen wijze van verzorging van de infuuscanules is bij HIVAT het preventief om de drie dagen vervangen wellicht niet nodig en kunnen zij tot zo'n acht weken in situ blijven. ${ }^{567}$ Flebitis is echter ook afhankelijk van de antibiotica, eventuele andere parenterale therapieën en de individuele gevoeligheid van de patiènt. De iets langere perifere midline catheters geven flebitis in $10-32 \% .{ }^{567}$ Centraalveneuze catheters kunnen complicaties geven bij het inbrengen en ontsteking aan de insteekplaats $(5 \%)$ en cathetersepsis $(1-6,4 \%)^{121}, 562,567,576$ Perifere centraalveneuze catheters geven minder septische flebitis $(0,7 \%)$ maar kunnen mechanische problemen opleveren $(10 \%){ }^{567}$ Daarom verdient bij lange behandeling of toediening van prikkelende antibiotica een onderhuidse centraalveneuze poort -mede gezien de ervaring hiermee in Europa- momenteel wellicht de voorkeur. ${ }^{567,589}$ Zelden worden problemen met de pomp vermeld, de gerapporteerde incidentie bij de cassettepomp is $0,1 \%$ per pompdag.

Er zijn minder heropnames dan bij TNO, wellicht door verschillen in pathologie of 
patiēntenselectie (schema 7.2). ${ }^{\text {6en }}$ Elders varièren de heropnames van één tot $32 \%$.

Wat betreft de KvL plegen vaste toedieningstijdstippen een inbreuk op het dagelijks leven, maar creēren tegelijkertijd 'rustmomenten'. Bij maximaal viermaal daagse infusie kan aan de gewone activiteiten worden deelgenomen omdat de patiěnt tussendoor afgekoppeld is. Elders wordt hiervoor vaak een 24-uurs toediening met een draagbare cassettepomp gekozen. Welke benadering de patiěnt de meeste bewegingsvrijheid en het minste ziektegevoel geeft, staat open voor discussie. Omdat bij HIVAT de patient als lid van het behandelteam medeverantwoordelijk is, maakt 24-uurs infusie iemand 24-uur per dag patiênt én behandelaar. ${ }^{\text {six }}$ De combinatie van de (co)morbiditeit en HIVAT belemmert patiēnten volgens de SIP score hetzelfde als bij reuma of een CVA. $\$$ ' Ondanks deze belasting is de KvL van de patienten en naasten evenals elders hoog. ${ }^{.19}, 362,594,598,576,594$ Het zorgdossier blijkt een belangrijke schakel in de continulteit van zorg. De KvZ en tevredenheid is bij de patiënten, hun naasten en de zorgverleners hoog. ${ }^{519,520,522}$ Door op verschillende wijzen te onderzoeken (triangulatie) is getracht het vraagstuk van de 'grote' tevredenheid te ondervangen. ${ }^{\text {s21 }}$ Ook bij TNO, multicenter en KITTZ en in buitenlandse studies is men meestal tevreden. ${ }^{362,557,559,594}$

De kosten zijn door de verschillen in patiěntenpopulaties, antibioticaregimes en thuiszorgprogramma's moeilijk te vergelijken. Standaardisatie van de methode om indirecte kosten te bepalen is gewenst. De kosten van HIVAT worden op zo'n 50 a $60 \%$ van die in het ziekenhuis geschat. Gezien de geringe participatie in de zorg van onze oudere populatie en de verschillen in antibioticaregimes zijn de kosten van ons model alleszins redelijk. De overgang van deze dure behandelingen van het ziekenhuis naar de thuiszorg vereist aandacht voor de kosteneffectiviteit en de financiering. ${ }^{603}$ HIVAT is ook in de andere Nederlandse en de buitenlandse studies goedkoper. ${ }^{119,}$ 121, 553-555, 559, 597, 598 Het aantal benodigde ziekenhuisdagen kan tot 1/3 teruggebracht worden, maar door herbezetting kunnen de totale kosten voor de zorgverzekeraars en maatschappij hoger zijn. ${ }^{595,604}$ De tijdsbesteding van de TMVs is zo'n 2,5 uur per dag. Het primair proces beslaat meer dan de helft van de tijd. Vanwege het behoud van de vaardigheden en de kosten van bereikbaarheid is gekozen voor een regionaal team TMVs, die relatief weinig zorg overdragen aan de wijkverpleegkundige en de huisarts. Een nadeel van ons model is de wachttijd tijdens de infusie. ${ }^{567}$ De reistijd is relatief lang, maar absoluut gelijk aan andere infuusbehandelingen bij pIT. Gecorrigeerd voor de grootte van het werkgebied is deze gelijk aan de reistijd van wijkverpleegkundigen en wijkziekenverzorgenden bij de SGKH..$^{532}$ In termen van 'face-to-face' contacten ( $\approx$ primair proces plus instructie) heeft dit soort thuiszorg een 'lage' produktiviteit van omgerekend $50 \%$ (zie ook §14.5.6).

\section{3 .4}

CENTRAALVENEUZE INFUSIE VAN HARTMIDDELEN BI] DECOMPENSATIO CORDIS ${ }^{\circ}$

\subsubsection{Inleiding centraalveneuze infusie van hartmiddelen}

\section{Decompensatio cordis}

De vijfjaars overleving van alle patiënten met hartfalen is $50 \%$ of minder, voor patiënten met New York Heart Association (NYHA) III is de éénjaarsoverleving $60-65 \%$ en van patiënten met NYHA IV zelfs minder dan $50 \%$ (epidemiologie $\$ 7.5 .1 .6$ ) ${ }^{364}$ Deze patiënten worden vaak langdurig in het ziekenhuis opgenomen voor uitsluitend palliatieve therapie.

Gepubliceerd in: Hartbulletin juni 1997;28(3):88-94. 
In deze studie gaat het binnen de groep patiënten met hartfalen om patiënten met decompensatio cordis die niet met orale medicatie te corrigeren is. ${ }^{366,367}$

\section{Dopamine en lasixtoediening}

De combinatietherapie van dopamine en lasix kan de decompensatie doen afnemen via verbetering van de nierfunctie. ${ }^{128,}{ }^{129,}, 005$ Contra-indicaties voor toediening van dopamine en lasix zijn: feochromocytoom, tachycardie, kamerfibrilleren, levercirrhose met elektrolytstoornissen. ${ }^{606}$ Mogelijke bijwerkingen van dopamine bij de gebruikte dosering zijn hoofdpijn, misselijkheid, braken, dyspnoe en soms angineuze klachten. Bij extravasatie kan door vasoconstrictie weefselnecrose optreden. ${ }^{606}$ Lasixtoediening kan de water- en zouthuishouding verstoren en tot dehydratie en nierfunctiestoornissen leiden ${ }^{606}$ Symptomen hiervan kunnen zijn duizeligheid, hypotensie, spierkrampen, zwakte, collaps en soms visusstoornissen. Daarnaast kunnen metabole ontregelingen als jicht en ontregeling van diabetes mellitus optreden en bijwerkingen zoals maagdarmstoornissen, pancreatitis, (verergering van) leveraandoeningen, urineretentie, hematologische stoornissen en huidreacties. ${ }^{606}$

\subsubsection{Vraagstellingen bij centraalveneuze infusie van hartmiddelen}

In 1992 was aan patiënten met zeer ernstig chronisch hartfalen (NYHA III of IV) reeds op kleine schaal dobutamine, dopamine en/of lasix intermitterend of continu thuis toegediend. ${ }^{126,127,607,608}$ Onderzocht is of dit ook in Nederland thuis mogelijk (haalbaar, doeltreffend en doelmatig) is. ${ }^{406}$ Vraagstellingen betroffen de toepasbaarheid van het zorgmodel in termen van de werking, bijwerkingen en complicaties van de thuisbehandeling, KvL, KvZ, tevredenheid, kosten en tijdsbesteding van de TMVs. Waar mogelijk is vergeleken met de bevindingen uit andere studies.

\subsubsection{Methoden en technieken bij centraalveneuze infusie van hartmiddelen}

\section{Techniek thuisbehandeling}

Tweemaal in de week worden op vaste dagen en tijden $50 \mathrm{ml}$ dopamine-oplossing en $50 \mathrm{ml}$ lasix $\otimes$ (furosemide)-oplossing in 24 uur toegediend met twee draagbare lineairperistaltische elektronische cassettepompen (CADD I囚). Zowel de dopamine- als de lasixoplossing blijven na oplossing slechts 36 uur stabiel. Bovendien inter acteren dopamine (zuur) en lasix (basisch) en mogen dus niet via één cassette of infuuslijn toegediend worden. Daarom worden de oplossingen toegediend via aparte cassettes en extensielijnen van $152 \mathrm{~cm}$ (nodig bij slapen) die via één driewegkraan en één Hübnernaald worden verbonden met een centraal veneuze poort (Port-A-Cath(B). De belangrijkste te verwachten complicaties van de infusietechniek zijn: lokale irritatie en ontsteking rondom het aanprikpunt, verstopping van de poort, trombose en problemen met de infuuspomp. Dopamine wordt toegediend op geleide van het lichaamsgewicht (aantal mg per 24 uur=aantal kilo x 1,6 microgram per kilo per minuut x 60 minuten $\times 24$ uur : 1000), lasix op geleide van de vochtbalans en de nierfunctie (tussen 5 en $10 \mathrm{mg}$ per uur). Een dag voor de infusie weegt de patiênt zich en geeft afwijkingen van meer dan twee kilo van het streefgewicht door aan de TMV. Daarop past de specialist eventueel de dosering aan. Wekelijks wordt door de prikdienst thuis of bij de huisarts bloed afgenomen voor de bepaling van natrium, kalium, kreatinine, urinezuur, albumine en magnesium. Ook wordt eenmaal per week 24-uurs-urine gespaard voor bepaling van natrium, kalium, kreatinine en volume. Verder onderzoek vindt plaats tijdens de polikliniekbezoeken. 
$\mathrm{Na}$ medische selectie worden patiēnten via de specialist voor thuisbehandeling aangemeld bij het centraal meldpunt van de SGKH. De TMV onderzoekt daarop de mogelijkheden voor IT en betrekt hierbij de huisarts. Bij positieve bevindingen wordt de zorgverzekeraar om vergoeding verzocht. De centraal veneuze poort wordt in het dagcentrum of klinisch ingebracht. Vanwege de benodigde technische ondersteuning geven de zorgverzekeraars de pompen via het facilitair bedrijf Minigas (nu Farmadomo) aan de patiēnt in bruikleen. De medicatie en infuusbenodigdheden werden door de ziekenhuisapotheek geleverd en bij de patiênt thuis bezorgd (heden via de openbare apotheek). De huisarts schrijft een uitvoeringsverzoek voor het medisch-technisch handelen. De TMV voert de behandeling uit en zorgt voor de coördinatie. Alle zorgverleners en eventueel betrokken naasten leggen de zorgverlening in een zorgdossier vast. Het voorbereidingstraject bij deze categorie patiënten bedraagt twee tot vier weken (uitgebreide selectie en voorlichting en verkrijgen toestemming thuisbehandeling en aanschaf infuuspompen).

\section{Meetinstrumenten}

Het effect van de behandeling, omschreven als een somatische verbetering volgens de patiēnt én specialist, is afgemeten aan een gerapporteerde verbetering in de poliklinische status. De overige methoden zijn in de hoofdstukken 2 en 13, 14 en 15 beschreven.

\subsubsection{Resultaten bij centraalveneuze infusie van hartmiddelen}

\section{Instroom}

Tussen 18 mei 1994 en 31 december 1995 zijn 21 patiënten voor behandeling aangemeld. Twee patiënten woonden buiten het werkgebied van de SGKH. De andere 19 patiënten zijn gescreend aan de hand van de algemene voorwaarden voor IT (schema 7.2) en bovenstaande specifieke medische contra-indicaties. De helft van de patiënten kwam -vaak om meerdere redenen- niet voor thuisbehandeling in aanmerking (\$7.6.2). Deze waren van medische of zorginhoudelijke aard of lagen op het vlak van de patiënt en/of de naaste verzorger (bijlage 7.4). Vanwege het relatief grote aantal patiënten dat niet voor IT in aanmerking kwam, zijn de thuis en niet thuis behandelde patiënten met elkaar vergeleken ten aanzien van sociaal-demografische factoren, diagnoses, symptomen, type hartfalen, medicatie bij aanmelding, functioneren en initięle reactie op de dopamine- en lasixtoediening in de kliniek (tabel B12.5.1 in bijlage 12.5). ${ }^{36,637}$ Als maat voor het functioneren is de NYHA classificatie aangehouden. ${ }^{609}$ De linker ventrikel ejectiefractie is ook meegenomen ter onderscheid tussen circulatoir en hartfalen. ${ }^{610}$ De thuis en niet thuis behandelde patiënten komen klinisch grotendeels overeen (van één thuis behandelde patiënt ontbreken enkele gegevens). Wel zijn de niet thuis behandelde patiënten ouder en vaker alleenstaand.

\section{Kenmerken patiënten en behandelingen}

Tussen 26 mei 1994 en 10 januari 1996 hebben zes mannelijke en drie vrouwelijke patiënten negen eerste en 21 vervolgbehandelingen van telkens maximaal twee maanden met centraalveneuze infusie van hartmiddelen $(\mathrm{CIH})$ ontvangen met een totale zorgduur van 1.484 dagen, zo'n vier jaar (tabel B12.5.2). Eén behandeling bestond gemiddeld uit 27,9 infusiedagen (sd 7,6 bereik 6-32 $\mathrm{N}=30$ ). Hierbij dient opgemerkt te worden dat voor de administratie iedere acht weken ( 32 infusiedagen) een nieuwe behandelepisode startte. 
Wanneer alle episoden van de negen patiēnten bij elkaar opgeteld worden dan omvatte elke behandeling gemiddeld 92,9 infusiedagen (sd 92,1 bereik 6-284 $\mathrm{N}=9$ ) en een zorgperiode van gemiddeld 164,9 dagen ( $(\mathrm{d}=155,3$ bereik 18-502 $\mathrm{N}=9$ ). In de jaren 1994 en 1995 bedroeg het aandeel van de $\mathrm{CIH}$ thuis $26 \%$ (tabel B12.5.3). ${ }^{547}$

De behandelde patiënten hadden allen een ernstig hartfalen (NYHA IV). De patiēnten waren gemiddeld 67 jaar en geen van allen meer buitenshuis werkzaam. Allen woonden samen met een partner, tweemaal waren er tevens inwonende kinderen. Een van deze laatsten was werkzaam als verpleegkundige en heeft de behandeling deels zelf uitgevoerd. De gemiddelde leeftijd van de naaste verzorger (7 partners en 1 kind) was 60 jaar. Eén patiënt kon onvoldoende door de partner (ziekte van Parkinson) ondersteund worden en werd vanuit hun aanleunwoning tijdens de behandelingen opgenomen in een verpleeghuis.

\section{Klinisch effect, bijwerkingen en complicaties}

$\mathrm{CIH}$ thuis gaf bij acht van de negen patiênten een somatische verbetering (tabel B12.5.2). De toestand van de patiěnt die in de kliniek slecht op CIH reageerde, verbeterde ook thuis niet. Stopzetten leek geen goed alternatief. Vier patiënten overleden. Tweemaal was de oorzaak waarschijnlijk cardiaal, tweemaal droeg de hartaandoening aan het overlijden bij. Bij de 30 behandelingen bij deze negen patiēnten traden de volgende problemen op. Eén poort was te hoog op de borstkas geîmplanteerd, waardoor de TMVs moeilijkheden ondervonden bij het steriel werken. Incidenteel trad irritatie rondom het aanprikpunt op, vooral vlak na het plaatsen van de poort en bij herhaald aanprikken op dezelfde plaats. Infectie en trombose traden niet op. Bij een hoge centraal veneuze druk lekte bij twee patiënten incidenteel bloed langs de naald tijdens de infusie.

In de 418 infusiedagen deden zich de volgende problemen met de infuuslijnen voor: disconnectie tussen Hübnernaald en centraalveneuze poort (3x:patiënt); disconnectie tussen Hübnernaald en driewegkraan (1x:patiënt 1x:TMV); stokken infusie door blokkeren terugslagklep extensielijn (1x), niet openzetten (1x:TMV) of dichtstoten (1x:patiënt) driewegkraan of op de lijnen liggen (1x:patiënt); infuus niet op tijd dichtgezet (2x:patiênt) of afgekoppeld (1x:TMV). Blokkades werden opgeheven en/of de poort werd opnieuw aangeprikt, doorgespoeld en gehepariniseerd. De incidentie van problemen met de infuuslijnen was aldus $2,9 \%$ per behandeldag.

In de 836 pompdagen ( 20.000 uur) deden zich de volgende problemen bij de pomp en de cassette voor: problemen met lucht of te hoge druk in de cassettes (3x) tweemaal op te lossen door ontluchting eenmaal door bereiding van een nieuwe cassette (1x); vergeten pompvergrendeling zonder gevolgen ( $3 x$ :TMV), technische storing die pompruil vereiste ( $3 x$ dezelfde oudere pomp). De incidentie van problemen met de pomp was $1,1 \%$ per pompdag en $2,2 \%$ per behandeldag.

Bij de dopaminetoediening is bij twee patie̋nten hoofdpijn en misselijkheid opgetreden bij het doorspuiten van de lijn aan het eind van de infusie. Dit kan voorkomen worden door de dopamine-infusie 'voor te laten lopen' op de lasixinfusie zodat tegen het eind van de infusie, wanneer de lijn en catheter doorgespoeld worden, daarin een geringe hoeveelheid dopamine zit. Duizeligheid, hypotensie en spierkrampen kwamen bij de in deze studie behandelde patiënten wel voor, maar konden niet aan het lasixgebruik toegeschreven worden. Een enkele keer kwam dehydratie voor als patiěnten te weinig dronken. Vooral hete zomers, koorts en diarree vergen een nauwkeurig bewaking van de vochtbalans en geregelde instructie van de patiënt. Ook bovengenoemde metabole ontregelingen en bijwerkingen zijn niet waargenomen. 


\section{Kwaliteit van leven}

De resultaten zijn grotendeels samengevat in tabel B12.5.4. De patiënten waren volgens de SIP-68 score ernstig beperkt in hun functioneren. Patiënten vonden zichzelf minder ernstig ziek en gaven minder pijn aan dan de inschatting hiervan door hun naasten en zorgverleners. Ook gaven zij een betere gezondheid en een hogere KvL aan. Drie naaste verzorgers waren zelf ziek, doch niet ernstig. Hun gezondheidsbeleving kwam hiermee overeen. De belasting van de naaste verzorger gemeten in uren per dag was hoog (gemiddeld 13 sd 8). Het aantal tengevolge van de infuuszorg extra gestaakte activiteiten was laag (gemiddeld 1 van de 7). De invloeden van $\mathrm{CIH}$ en de belemmering tengevolge van de slechte toestand van de patiênt konden hierbij onvoldoende onderscheiden worden. De ervaren belasting gemeten via een stelling was bij de naaste verzorger hoog. Edoch gemeten volgens de CSI was de ervaren belasting wel aanwezig, maar niet hoog (afkappunt 7). Eén patiënt is na 16 maanden weer in het ziekenhuis behandeld in verband met de belasting voor zijn echtgenote. 'Overall' is de KvL van de naaste nauwelijks hoger dan die van de patiênt.

\section{Kwaliteit van en tevredenheid met zorg}

Tabel B12.5.4 vat ook de resultaten over de $\mathrm{KvZ}$ van en tevredenheid met de zorg samen. De tevredenheid uitgedrukt in rapporteijfers voor zorgverleners varieerde van 7 tot 8 . De $\mathrm{KvZ}$ was gemeten via de ZKM een 7 of 8 en via de CSQ een 8.

\section{Kosten}

Van alle 30 behandelingen zijn de kosten berekend. Bij de 24-uurs toediening wordt op de ene dag aangekoppeld en de volgende afgekoppeld. Daarom wordt bij de berekening van 836 infusiedagen uitgegaan. Omdat de verplaatsing van de $\mathrm{CIH}$ naar de thuiszorg centraal stond, zijn bij de berekening overige ziekenhuisgebonden kosten (specialist, diagnostiek, etc.) buiten beschouwing gelaten. Gemiddeld kostte de $\mathrm{CIH}$ thuis $f 7.272$ per behandeling en $f 261$ per infusiedag (\$15.4.1). De materiële kosten voor het patiëntsysteem bedroegen gemiddeld $f 2$ per infusiedag $(\S 15.4 .2)$. Al naar gelang de opgave van de patiënt of de naaste varieerden de personele kosten van $f 188$ tot $f 227$ per infusiedag (\$15.4.3). De totale maatschappelijke kosten kwamen zo op $f 451$ tot $f 490$ per infusiedag $(\$ 15.4 .4)$ Het aandeel van de patiënt en naasten hierin varieerde van $42 \%$ tot $46 \%$.

\section{Tijdsbesteding}

Tabel B12.5.5 geeft per activiteit aan hoeveel percent van de totale tijd de TMVs daaraan besteed hebben. Daarnaast zijn per activiteit kenmerken van de duur (in minuten) weergegeven en het aantal keren dat een bepaalde handeling geregistreerd is.

\section{Andere studies}

In Nederland zijn de meeste patiënten die met hartfalen (ICD9: 428.0 428.1 428.9) in het ziekenhuis opgenomen worden ouder dan 65 jaar $\left(0-65: 3.87365^{+}: 21.781\right){ }^{611}$ Ook bij patiënten met hartfalen en stuwing is dit zo (ICD 428.0 0-65:870 65 $: 4.610$ ). ${ }^{611} \mathrm{Bij}$ de vooral mannelijke $\left(\sigma^{2}=77 \%\right)$ patiënten in een studie van Tandon was de gemiddelde leeftijd 60 (sd 9,4), bij Applefeld en Miller ongeveer 55 jaar. ${ }^{612}$ Bij Applefeld kon slechts ongeveer de helft van de potentiële patiënten thuis behandeld worden. ${ }^{127} \mathrm{Bij}$ Applefeld konden alle en bij Miller vier van de 11 patiënten in de infusie participeren. ${ }^{126,127}$ Tabel B12.5.6 geeft enkele complicaties van thuisbehandeling met dobutamine en dopamine in andere studies in vergelijking met die in deze studie. 


\subsubsection{Beschouwing centraalveneuze infusie van hartmiddelen}

Het betreft een haalbaarheidsonderzoek met een beperkt aantal patiēnten. De resultaten zijn dus indicatief. Zoals verwacht stelde de thuisbehandeling extra eisen.

De leeftijds- en geslachtsverdeling van de studiepopulatie komen overeen met die in de studie van Tandon en de leeftijd komt overeen met die van patiënten die in Nederland voor hartfalen in het ziekenhuis behandeld worden. ${ }^{611,612}$ Evenals bij de studie van Applefeld kon slechts ongeveer de helft van de potentiële patiënten thuis behandeld worden. ${ }^{127}$ Hoewel het een chronische situatie betrof, bleken de patiënt en naaste $(1 / 8)$ nauwelijks in de technische handelingen te kunnen participeren in vergelijking met Applefeld en Miller. ${ }^{126,}{ }^{127}$ Waarschijnlijk hangt dit samen met de hogere leeftijd in deze studie. De behandeling gaf over het algemeen een somatische verbetering. Een belangrijk voordeel van de 24-uurs $\mathrm{CIH}$ thuis in vergelijking met de tot dan gangbare 8-uurs $\mathrm{CIH}$ in het dagcentrum, is dat de patiēnten aangaven dat thuis minder bijwerkingen voorkomen. Voor sommige patiënten was het beoogde effect bovendien niet in 8 uur haalbaar en zij werden daarom anders telkens voor 12 of 24 uur op de short-stay opgenomen. Hoewel de toegepaste techniek en de medicatie complicaties en bijwerkingen gaven, zijn deze niet verontrustend in vergelijking met andere thuiszorgprojecten (tabel B12.5.6). ${ }^{126,}$, 127, 607 Catheterproblemen als infectie en trombose zijn niet en problemen met de infuuslijnen ( $2,9 \%$ per infusiedag) en de infuuspomp ( $1,1 \%$ per pompdag) even vaak voorgekomen. Indien de patienten thuis ook geĭmmobiliseerd behandeld waren, dan had wellicht een enkele disconnectie voorkomen worden. Daar stond echter een grote bewegingsvrijheid tegenover. Het instellen van de CADD I® pompen vergt oplettendheid. De mortaliteit is hoog, hetgeen gezien de ernst van de ziekte te verwachten is. ${ }^{364}$

Deze ernstig zieke patiênten gaven een relatief goede $\mathrm{KvL}$ aan. Waarschijnlijk doordat zij zich gezonder voelden dan op grond van hun ziekte te verwachten is. Dat het ernstig zieke patiênten betrof (allen NYHA IV) blijkt uit de belemmeringen in hun functioneren: 30 op de SIP- $68 \approx 44 \%$ hier ten opzichte van 12 op de SIP- $136 \approx 9 \%$ bij Tandon ( 62 patiënten met NYHA II:34 III:63 en IV:3). ${ }^{612}$ Ook bij dobutamine-infusie bij hartfalen in Nederland wordt een verlaagde KvL gerapporteerd. ${ }^{613}$ De relatief lage $\mathrm{KvL}$ van de naaste verzorgers is niet alleen te verklaren uit hun leeftijd en gezondheid. De zorg voor, en het leven met de ernstig zieke patiënt zal daaraan bijdragen. De invloed (belasting danwel ontlasting) van de IT hierop kon niet eenduidig vastgesteld worden. Wel gaf de naaste zelf bij gericht vragen hiernaar een grote belasting aan.

Zoals bij ander onderzoek naar KvZ en tevredenheid speelt ook hier het probleem van een 'grote' tevredenheid. ${ }^{519,520,522}$ Door op verschillende wijzen te onderzoeken (triangulatie) is getracht dit probleem te ondervangen. ${ }^{521}$ In het algemeen waren zowel de patiënt en diens naaste verzorger als de TMV en de huisarts tevreden.

Vergelijking van kosten van thuis- en ziekenhuisbehandelingen is moeilijk (\$14.5.6).

Koppelt men de patiēnt als alternatief voor de thuisbehandeling op een dagcentrum aan en af, dan gold daarvoor het tarief van $f 375$ per dag $(f 750$ per behandeling, 'besparing' $\pm 30 \%$ ). Bij tussentijdse problemen moet de patiënt dan terugkomen naar het ziekenhuis. 's Nachts zou teruggevallen moeten worden op de EHBO (extra kosten). Andere alternatieven waren opname op een short-stay of verpleegafdeling met een tarief van $f 807$ per dag ( $f 807$ of $f 1.614$ per behandeling, 'besparing' $\pm 35 \%$ of $\pm 68 \%$ ). Het aandeel van de kosten voor de patiênt en naaste in de totale maatschappelijke kosten was fors. Dit kwam vooral door de tijd die de naasten (overigens ook wanneer er geen infusie plaats heeft) bij de patiënt doorbrengen. 
De tijdsbesteding van de TMVs weerspiegelt de gekozen invulling van het zorgmodel. De TMVs voerden de $\mathrm{CIH}$ grotendeels zelf uit. De instructie en het overleg met de huisarts en wijkverpleging betroffen veelal de algemene toestand en hoe om te gaan met de aangekoppelde patiênt en niet de IT als zodanig. Het hoge percentage tijd besteed aan het bevorderen van de dienstverlening betrof het ophalen van de medicatiecassettes en het inleveren van de 24-uurs-urine in het ziekenhuis. In termen van 'face-to-face' contacten ("primair proces plus instructie) had $\mathrm{CIH}$ een 'lage' produktiviteit van omgerekend $43 \%$ (zie ook §14.5.6).

\section{$12.4 \quad$ Conclusies}

Het zorgmodel was breed toegankelijk wat betreft leefsituatie, aandoeningen, zelfredzaamheid en participatie van patiěnten en naasten.

Bij subcutane infusie van morfine met overdracht naar de thuiszorg lijkt het zorgmodel te passen in het streven om oncologische en met name palliatieve zorg met behoud van kwaliteit te verschuiven van het ziekenhuis naar de thuiszorg. ${ }^{6.112,526}$ Bij intraveneuze infusie van antibiotica met beperkte overdracht naar de thuiszorg sloot het zorgmodel nauw aan bij de ziekenhuisbehandeling, was breed toegankelijk, kon na twee werkdagen starten, voorziet in een adequate verdeling van taken en verantwoordelijkheden en werkte ook bij kleinere aantallen redelijk besparend. ${ }^{567}$ De bevindingen bij de intraveneuze infusie van mannitol en centraalveneuze infusie van dopamine en lasix tonen aan dat binnen het model ook complexere en ononderbroken $7 \times 24$ uurs infusies thuis mogelijk zijn.

De behandelingen bleken binnen het hier gehanteerde zorgmodel behandeltechnisch mogelijk met aanvaardbare $\mathrm{KvL}, \mathrm{KvZ}$, tevredenheid en kosten. Wel vergden zij een zorgvuldige indicatiestelling, uitgebreide voorlichting voor en tijdens de behandeling en continue bewaking van aandoening(en), behandelingen en draagkracht van de patiënt en diens omgeving. Dit alles stelt hoge eisen aan de technische deskundigheid, communicatieve vaardigheden en bereidheid tot samenwerking tussen zorgverleners en organisaties in de thuiszorg en de klinische zorg.

Kortom bij IT lijkt het zorgmodel behandeltechnische en culturele barrières tussen de thuiszorg, het ziekenhuis en financiers te kunnen slechten. ${ }^{614,615}$ 


\section{Zorgsituatie en kwaliteit van leven}

\section{$13.1 \quad$ Inleiding}

Onderzoek naar kwaliteit van leven $(\mathrm{KvL})$ kan gebruikt worden op vier niveaus: de maatschappij, de instelling, individuele ervaring ("psychisch functioneren) en het fysiek functioneren. ${ }^{57}$ Substantieel rationele doelstellingen van CMTZ thuis zijn brede toegankelijkheid voor patiënten met verschillende sociaal-demografische kenmerken en zelfzorgtekorten, en verlenging van de verblijfsduur in de thuissituatie met behoud of bevordering van de $\mathrm{KvL}$ van het patiëntsysteem. Vanuit hoofdvraagstelling III en aandachtspunten 6 en 7 zijn dan ook de zorgsituatie (leefsituatie met daarin voorkomende zelfzorgtekorten) van de verschillende patiëntencategorieën volgens henzelf en hun naaste verzorgers bestudeerd en de kwalificatie door patiënten, hun naaste verzorgers en zorgverleners van de gezondheid, de steun, de belasting, het functioneren en de KvL van de patiënt en diens naaste, het patiëntsysteem. KvL is meer bestudeerd op het niveau van de persoonlijke ervaring dan op het niveau van de fysieke activiteiten. ${ }^{57}$

\subsection{Theorie zorgsituatie en kwaliteit van leven}

In de leefsituatie van een persoon (zijn alledaagse leven) kunnen bij ziekte zelfzorgtekorten optreden waardoor deze patiënt wordt en er een zorgsituatie ontstaat. Tevens vormt de leefsituatie de basis voor de kwaliteit van leven. Omdat de leefsituatie hier een gemeenschappelijk onderliggend concept is, wordt de theorie ervan niet op zichzelf besproken. Wel wordt de inventarisatie van de zorgsituatie volgens de Stuurgroep Toekomstscenario's Gezondheidszorg (STG) beschreven. De theorie en definitie van de gehanteerde KvL volgen. Tot slot wordt vanuit STG perspectief kort ingegaan op de relaties tussen $\mathrm{KvL}$ en objectieve en ervaren gezondheid, steun en functioneren.

\subsubsection{ZORGSITUATIE VOLGENS SAMENVATTENDE ZELFZORGTEKORTEN VAN STG}

Omdat er bij CMTZ thuis zoals infuusbehandeling geen meetinstrumenten zijn voor het meten van zelfzorgtekorten volgens Orem, is uitgegaan van het STG-concept. ${ }^{176,270}$ Dit beschrijft de zorgsituatie bij complexe thuiszorg via zelfzorgtekorten met betrekking tot:

A. Gezondheid met als indicator de aan- of afwezigheid en eventuele ernst van een stoornis in engere zin (diagnose).

B. Psychosociale redzaamheid met als indicator de subjectieve gezondheid.

C. Patiënt(zorg)systeem met als indicator alleen- of samenwonen.

D. Functioneren met als indicatoren de leeftijd en het niveau van de algemene en huishoudelijke dagelijkse levensverrichtingen. 
Binnen deze studie is de voorkeur gegeven aan de term 'ervaren gezondheid' boven 'psychosociale redzaamheid'. ${ }^{616}$ Voor de consumptie van gezondheidszorg is namelijk vooral van belang hoe een patiênt zijn gezondheid ervaart. De psychosociale redzaamheid is daarvan een essentiele component. Van bovengenoemde indicatoren zijn equivalenten terug te vinden in $\mathrm{KvL}$ onderzoek. Gezondheid komt daarbij overeen met de klinische toestand ('disease'), de ervaren gezondheid met het ziek voelen ('illness') en het functioneren met de functionele toestand ('sickness'). ${ }^{511,617-619}$ Kortom: wat heb je, hoe voel je je en hoe functioneer je.

In deze studie zijn voornoemde indicatoren gemeten om de leefsituatie te beschrijven, de meest voorkomende reden voor $\mathrm{KvL}$ meting ${ }^{620}$ Ook kunnen uitkomsten van deze metingen een signaalfunctie vervullen bij het nagaan van de gevolgen van de behandeling voor de patient en de keuze van behandelingsalternatieven en beleidsbeslissingen beïnvloeden.

\subsubsection{KWALITEIT VAN LEVEN}

Met de erkenning van elk mens als individu, introduceert men diens unieke KvL. Een exacte definitie is evenals bij andere geopperde alternatieven zoals welbevinden of welzijn moeilijk, maar $\mathrm{KvL}$ is ook als primair begrip zonder exacte definitie hanteerbaar. $59,60,520$ Bij elke omschrijving zijn de theoretische uitgangspunten van belang. ${ }^{99,60,69,617,621-623} \mathrm{KvL}$ in brede zin bestrijkt vele dimensies en wordt door vele factoren beřnvloed en tegelijkertijd gevormd. Schema 13.1 geeft vaak genoemde indicatoren in hun veronderstelde samenhang, zoals onder andere de Haes die in onderzoek naar kankerpatiênten gebruikte. ${ }^{99,624}$

Schema 13.1 Indicatoren voor kwaliteit van leven naar de Haes."

\section{Aandoening en behandeling \\ Diagnose en prognose \\ Behandeling en overige zorgverlening}

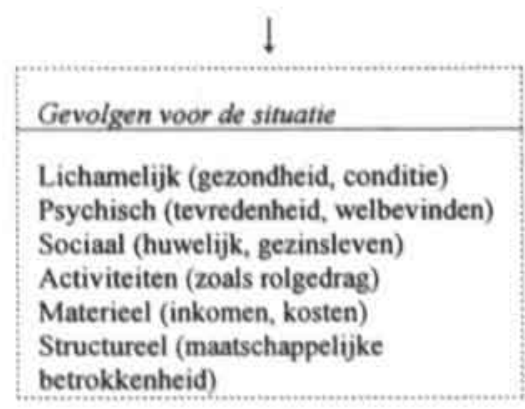

Aandoeningen en hun gevolgen

\section{Achtergrondkenmerken \\ Sociaal-demografische kenmerken (leeftijd, geslacht, opleiding, burgerlijke staat, werk) Sociale situatic (partner, gezin, omgeving) Persoonlijkheidskenmerken (gevoel van eigenwaarde, beleving interne controle) Probleemoplossend gedrag (coping. informatie zoeken, terugtrekken, berusting)}

in interactic met

\section{Persoonlijke uitgangspositie}


$\mathrm{KvL}$ onderzoek is in te delen op basis van een uni- versus een multidimensionele benadering en op basis van een subjectieve belevings- versus een objectieve toestandsbenadering. ${ }^{59}$ Indien $\mathrm{KvL}$ overlap vertoont met de functionele toestand wordt ook wel gesproken van gezondheidsgerelateerde $\mathrm{KvL}^{.23}$ Vooral in de beginfase van het KvL onderzoek is dit opgevat als een objectief meetbaar, multidimensionaal begrip met duidelijk waarneembare biologische, fysieke, psychologische en sociale aspecten. Deze $\mathrm{KvL}$ benaderde gezondheid in brede zin. Multidimensioneel onderzoek leverde echter niet de theoretisch verwachte resultaten op. Tevens ging men meer belang hechten aan het individuele, subjectieve oordeel van de patiēnt. ${ }^{226}$ Benaderd als een subjectief, unidimensioneel begrip bleek KvL beter te onderzoeken. ${ }^{62}$ Verder kan bij KvL onderscheid gemaakt worden tussen hoe mensen hun bestaan ervaren (emotioneel, geluk) en hoe ze dit waarderen (cognitief, tevredenheid). ${ }^{59,}{ }^{627}$ Ten slotte is $\mathrm{KvL}$ op te vatten als een positieve en een negatieve, gedeeltelijk van elkaar onafhankelijke, 'dimensie' of als één continuüm met een positieve en een negatieve pool. Het laatste is meer gebruikelijk. Vanwege de verschuiving van probleemgeoriěnteerde (klachten) naar doelgeoriênteerde (functioneren) zorg wordt aanbevolen om de gezondheidstoestand enerzijds te omschrijven aan de hand van de klinische en de 'objectieve' functionele toestand en anderzijds aandacht te schenken aan het ervaren functioneren en de ervaren $\mathrm{KvL}$. ${ }^{11} \mathrm{Bij} \mathrm{KvL}$ onderzoek worden bij een patięntenperspectief de subjectieve beleving en bij evaluatie van zorg het functioneren en objectieve indicatoren als uitkomstmaat aanbevolen. ${ }^{62 \mathrm{I}}$ Vanwege het inventariserend karakter zijn hier beiden bestudeerd. Bij de ervaren $\mathrm{KvL}$ in samenvattende zin is uitgegaan van $\mathrm{KvL}$ als een subjectief, tot één dimensie samengevat begrip. Emotie en cognitie en onafhankelijke positieve en negatieve dimensies zijn niet onderscheiden. KvL is in dit onderzoek gedefinieerd als de subjectieve beoordeling van het leven in haar geheel ten tijde van de infuuszorg. ${ }^{11}$ Derhalve is het perspectief van het patièntsysteem essentieel.

\subsubsection{OBJECTIEVE EN ERVAREN GEZONDHEID EN KWALITEIT VAN LEVEN}

Het begrip KvL overlapt grotendeels met begrippen als tevredenheid, geluk en gezondheid. ${ }^{59,60,629}$ Laatstgenoemde omschrijft de World Health Organization (WHO) als het totaal van het lichamelijk, psychisch en sociaal welbevinden ${ }^{61,630}$ De ervaren en de objectieve gezondheid verschillen. ${ }^{611}$ Toch komt de ervaren gezondheid redelijk overeen met meer objectieve maten als Algemeen Dagelijkse Levensverrichtingen, het functioneren en de medische consumptie. Zo blijkt een subjectieve maat overlijden beter te voorspellen dan een objectieve. ${ }^{632} \mathrm{Gevraagd}$ naar belangrijke dingen in het leven noemt de Amerikaanse bevolking vaak een gevoel van eigenwaarde en een goed huwelijks- en gezinsleven naast lichamelijke gezondheid en is laatstgenoemde niet dé voorspeller voor geluk of tevredenheid. ${ }^{59,633,634}$ De Nederlandse bevolking vond lange tijd vrede en vrijheid, gezinsleven, vriendschap, huisvesting, werk en sociale zekerheid minimaal even belangrijk als gezondheid en geld, sport en geloof minder belangrijk. ${ }^{633,634}$ Recent is gezondheid het belangrijkste geworden. ${ }^{635} \mathrm{Er}$ zijn invloeden van het huwelijks- en gezinsleven, gezondheid en biografische factoren (geslacht, leeftijd) op de KvL gevonden. ${ }^{59}$ Sociale factoren als werk en vrije tijd blijken minder belangrijk evenals tevredenheid met de samenleving en de plaats hierin. ${ }^{59}$ In het algemeen geven vrouwen, alleenstaanden en mensen uit een lagere sociale klasse een lagere $\mathrm{KvL}$ aan. ${ }^{59}$ Men schrijft dit toe aan een geringer probleemoplossend vermogen en een slechtere (ervaren) gezondheid. ${ }^{59}$ In Nederlands onderzoek houdt de ervaren gezondheid geen verband met geslacht, wel met leeftijd en sociale klasse. ${ }^{59,633} \mathrm{Zo}$ is de subjectieve gezondheid voor $5 \%$ te herleiden tot sociale klasse 
(economische positie). ${ }^{66}$ Respondenten met een hogere leeftijd of een lagere sociale klasse vermelden duidelijk meer en vrouwen iets meer klachten over de gezondheid. ${ }^{633}$

Gezonden en zieken beleven hun KvL verschillend. Bij zieken bel̆nvloeden sociaaldemografische factoren, werk en vrije tijd KvL nog minder dan bij gezonden. De gezondheid kan een grotere invloed op KvL hebben. ${ }^{59,60}$ Zieken met een vergelijkbare gezondheidsstatus kunnen die verschillend ervaren. Daarbij blijkt KvL meer samen te hangen met de ervaren dan met de objectieve gezondheid. ${ }^{59,629}$ Ervaren gezondheid en KvL worden dan ook grotendeels door dezelfde factoren beĭnvloed.

Tot slot KvL bij ernstig zieke patiênten." ${ }^{311}$ Bij bijvoorbeeld kankerpatiënten blijkt KvL in tegenstelling tot bij gezonden soms wél het sterkst samen te hangen met de ervaren gezondheid en is lichamelijk functioneren een belangrijke voorspeller voor $\mathrm{KvL} .{ }^{59} \mathrm{Het}$ beloop van de ziekte kan hierbij meespelen. ${ }^{59}$ In het acute stadium kan door het contrast met vroeger de invloed veel groter zijn, terwijl bij chroniciteit gewenning aan de nieuwe situatie kan optreden. Kankerpatiēnten, die een periode ziektevrij zijn, kunnen zelfs een hogere $\mathrm{KvL}$ rapporteren dan gezonden. ${ }^{59}$ De laatste negen en met name de laatste drie weken hebben veel terminale patiënten een slechte lichamelijke toestand met gelijke klachten (common terminal pathway). ${ }^{59} \mathrm{Na}$ gewichtsverlies beînvloedt pijn KvL het vaakst negatief. ${ }^{5,313,36,677}$ Sociale context, cultuur en ontwikkeling (leeftijd en levensfase) beïnvloeden wederom de pijnbeleving. ${ }^{325}$ Door het indringend karakter kan pijn de KvL van terminale patiênten grotendeels bepalen. ${ }^{133,638}$

$\mathrm{KvL}$ is vooral de resultante van iemands situatie -inclusief gezondheid- en diens probleemoplossend vermogen ('mastery': zelf controle over leven, 'self efficacy': zelf doelen bereiken en 'self esteem': zelfrespect, een minder neurotische en meer extraverte persoonlijkheid). ${ }^{59,639}$ De beleving van KvL wordt dus vooral bepaald door de psychische gesteldheid; kortom de tevredenheid van omgaan met de dingen van het leven en zichzelf.

\subsubsection{STEUN BINNEN HET PATIENTSYSTEEM EN KWALITEIT VAN LEVEN}

De steun binnen sociale netwerken wordt geacht $\mathrm{KvL}$ direct positief te beïnvloeden en indirect de effecten van stressvolle gebeurtenissen te helpen opvangen. ${ }^{59,640}$

Een sociaal netwerk wordt gevormd door de familie, vrienden, kennissen en zorgverleners met wie iemand min of meer duurzame relaties onderhoudt voor de vervulling van zijn dagelijkse materie̋le, affectieve en sociale behoeften. ${ }^{641}$ Zieken hebben meer moeite om het bestaande netwerk in stand te houden en nieuwe leden te rekruteren, onder andere omdat netwerken deels bestaan op basis van wederkerigheid. ${ }^{\text {.42 }}$

Sociale netwerken hebben structurele, culturele en functionele kenmerken. ${ }^{640}$ Structureel zijn de omvang, variatie, dichtheid, bereikbaarheid, frequentie en hechtheid van de interacties. ${ }^{640} \mathrm{De}$ bestudering hiervan om een relatie te leggen met gezondheid en KvL lijkt minder valide. ${ }^{63}$ De wijze waarop mensen met elkaar omgaan, hun normen en waarden, is cultureel bepaald. ${ }^{640}$ Functionele steun is onder te verdelen in instrumentele (=praktische), emotionele, adviserende en sociaal integrerende steun. ${ }^{\text {ot }}$ Praktische steun bestaat uit diensten of geld, emotionele steun uit psychische ondersteuning, waardering en aandacht. Adviserende steun is gericht op het oplossen van problemen. Sociaal integrerende steun is gericht op sociale contacten en het functioneren in de maatschappij. Vaak worden alleen instrumentele (praktische) en emotionele steun bestudeerd. ${ }^{699}, 640$ De verschillende soorten steun worden vaak samengevoegd tot het begrip 'sociale steun': "the degree to which a person's basic social needs are gratified through interaction with others". ${ }^{4} 4$, ods Patiēnten en hun naasten heffen doorgaans reeds zoveel mogelijk zelfzorgtekorten op. ${ }^{.40}$ 
De informele thuiszorg vormt dan ook het fundament voor professionele zorg. ${ }^{167,318,40,646}$ De verschillende definities van mantelzorg, informele zorg of zorg door naasten hebben gemeen dat zij vanuit een niet-professionele relatie gegeven worden. ${ }^{152}, 167,518$ In het informele zorgnetwerk van zieken is vaak én centrale persoon aanwezig. ${ }^{167,318}$ Meestal is deze de patiěnt het meest na. Ook heeft deze het breedste takenpakket: de persoonlijke verzorging, het huishouden, de praktische en de emotionele ondersteuning van de patiēnt bij de therapie en eventueel de uitvoering van (eenvoudige) verplegende en/of medischtechnische handelingen. Vaak heeft de centrale verzorger het beste overzicht en/of is het centrale aanspreekpunt bij de afstemming tussen informele en formele zorg.

Voor KvL is waarschijnlijk niet van belang of de hulp formeel of informeel is, maar dat zij aansluit op de zorgbehoefte. Ouderen kunnen zelfs de voorkeur hebben voor de zorg door professionals omdat ze niet van familieleden afhankelijk willen zijn. ${ }^{255}$ Een sociaal netwerk kan ook negatief werken op de KvL (overdreven aandacht, bemoeizucht, gevoel van iets terug te moeten doen). ${ }^{62,042}$ Het ontstaan van (chronische) ziekten kan zelfs bevorderd worden in een slecht functionerend netwerk. ${ }^{50,640}$ De relatie tussen praktische steun en KvL bij (chronisch) zieken is niet eenduidig." "I De KvL kan hoger zijn naarmate meer praktische steun gegeven wordt. ${ }^{629}$ Anderzijds wordt ook meer praktische steun gegeven naarmate een onderliggende aandoening emstiger en de $\mathrm{KvL}$ lager is. $311,092,007$ Mensen die veel emotionele steun ontvangen tenderen naar een hogere $\mathrm{KvL}^{5}{ }^{51}, 629 \mathrm{Bij} \mathrm{KvL}$ onderzoek lijkt de perceptie van de ontvangen steun vaak belangrijker dan de hoeveelheid.

\subsubsection{FUNCTIONEREN EN KWALITEIT VAN LEVEN}

Van alle tot dusver besproken factoren lijkt het functioneren nog het meest te overlappen met KvL. Ook bij het functioneren kan uitgegaan worden van het patiëntsysteem. Belemmeringen in het functioneren zijn zowel bij de patiënt als de centrale verzorger de resultante van draagkracht en draaglast. Deze worden op hun beurt bepaald door leeftijd, geslacht, gezondheid, persoonlijkheid, sociaal-demografische en maatschappelijke factoren. Deze samenhangen zijn reeds bij de relatie gezondheid en KvL aan de orde gekomen. Een aandoening kan specifieke onderdelen van het functioneren belemmeren, maar heeft minder invloed op de totale $\mathrm{KvL}^{59}$ Het functioneren en de ervaren $\mathrm{KvL}$ van de centrale verzorger worden bepaald door diens eigen situatie (en eventuele aandoening) waaronder de belasting die de steun aan de patiënt veroorzaakt. De door de centrale verzorger ervaren belasting, kan bij objectief gelijksoortige situaties sterk uiteenlopen. ${ }^{644}$ Dit hangt af van de perceptie van de belasting en de verhouding tussen draagkracht en last. Ook bij het functioneren lijkt vooral de perceptie van belang.

\subsection{Doel- en vraagstellingen}

Binnen het zorgmodel is getracht te voorzien in adequate zorg afgestemd op de objectieve en subjectieve behoeften van het patiëntsysteem (\$1.2.3). Vooraf is ingeschat dat: de patiënten overwegend zouden behoren tot een zieke, oudere populatie met dito kenmerken; de deelpopulaties niet zouden verschillen van andere populaties met dezelfde ziekte; de in de theorie reeds besproken samenhangen ook in de studiepopulatie zouden voorkomen. Eẻn doelstelling van CMTZ thuis is brede toegankelijkheid. De hieruit voortvloeiende eerste vraagstelling is of IT -op basis van de instroomcriteria (H:7)- daadwerkelijk toegankelijk is voor verschillende patiënten(groepen). Subvraagstellingen betreffen:

* Spreiding in leefsituatie ten aanzien van geslacht, leeftijd, opleiding, beroep, inkomen en soort ziektekostenverzekering; 
Sociaal-demografische kenmerken in vergelijking met die van door anderen beschreven soortgelijke patiêntengroepen (is gelijk aan de subvraagstelling over de vergelijking met de structurele steun binnen het patiëntsysteem die hierna volgt);

- Samenhangen tussen opleiding en beroep en tussen leeftijd, opleiding en inkomen, gelet op de in de literatuur bekende samenhangen.

Een tweede doelstelling is dat CMTZ thuis de KvL van het patientsysteem behoudt of bevordert. De vraagstelling hierbij omvat dan ook de zorgsituatie en KvL bij IT. De drie subvraagstellingen hierbij betreffen de ervaringen in deze studie, de vergelijking met andere studies en de onderlinge samenhangen bij:

- Objectieve gezondheid via de diagnose en het soort behandeling;

- Positief en negatief (ziekte, pijn) ervaren gezondheid;

- Structurele en de functionele steun binnen het patiëntsysteem in relatie tot de professionele steun (zie ook subvraagstelling 3 van vraagstelling 1);

- Positief (activiteitenpatroon) en negatief (belemmeringen) functioneren;

- Zorgsituatie;

- Ervaren kwaliteit van leven.

De derde -van voornoemde twee afgeleide- doelstelling van CMTZ thuis is continutteit van zorg in tijd, werkwijze en persoon. Naarmate patiënten en naaste verzorgers de zorgsituatie meer overeenkomstig inschatten, neemt de kans op passende informele zorg toe. Naarmate de zorgverleners meer overeenstemmen, neemt de kans op elkaar afgestemde professionele zorg toe. Ook neemt, naarmate de antwoorden van het patiëntsysteem en de zorgverleners meer overeenstemmen, de kans toe dat de professionele zorg aansluit op de objectieve en subjectieve behoeften van het patiěntsysteem. Dit leidt tot de derde vraagstelling die de verhouding tussen de oordelen van patiënten, hun naasten en zorgverleners betreft. $59,631,634$ De drie subvraagstellingen hierbij zijn of de antwoorden van de:

- Patiënt en naaste verzorger op basis van hun relatie meer met elkaar overeenstemmen dan met die van de zorgverleners;

- Zorgverleners vanuit hun professionele achtergrond meer met elkaar overeenstemmen dan met die van de patiënt en de naaste verzorger;

- Patiěnt en naaste verzorger overeenstemmen met die van de zorgverleners.

\subsection{Model voor borging en meting zorgsituatie en kwaliteit van leven}

De keuze van begrippen, aangegeven samenhangen en vertaling in indicatoren abstraheren en reduceren de werkelijkheid sterk. ${ }^{643}$ Voor KvL onderzoek geldt dat elk meetinstrument een of meerdere aspecten van de KvL benadert met zijn eigen validiteit en betrouwbaarheid. ${ }^{617}$ Vanwege de vergelijkbaarheid en mogelijke toepassing bij andere CMTZ (thuis) zijn alleen niet-ziektespecifieke en waar mogelijk gestandaardiseerde meetinstrumenten gekozen. ${ }^{69,617} \mathrm{Om}$ de omvang te beperken zijn vaak samenvattende maten gehanteerd. ${ }^{649}$ De gedeeltelijke overlap tussen indicatoren biedt de mogelijkheid tot data-triangulatie. ${ }^{521}$ Voortbouwend op het zelfzorgtekorten model van de STG en het KvL model van de Haes is een aantal begrippen (plus de daarbij gekozen indicatoren) kwantitatief en/of kwalitatief omschreven (schema 13.2) ${ }^{59,} 176$ In het hier gekozen zorgmodel gaat de professionele zorg uit van de zorgsituatie bij het patiěntsysteem (schema 1.1). Dit bestaat meestal uit de patiěnt en diens centrale verzorger aangeduid met 'naaste verzorger' of 'naaste 1 '. ${ }^{167}$, 518 De ervaren kwaliteit van en de tevredenheid met de professionele zorg worden in hoofdstuk 14 besproken. De variabelen die betrekking hebben op de zorgsituatie zijn grotendeels gelijk aan de variabelen betreffende de achtergrond in het gehanteerde $\mathrm{KvL}$ model. Zij 
worden daarom deels tezamen besproken. Schema 13.2 geeft de hoofdgroepen waartoe indicatoren gerekend zijn weer, de dubbele pijlen vermoede relaties.

Schema 13.2 Indicatoren zorgsituatie en $\mathrm{KvL}$ van patient en/of naaste bij infuusbehandeling thuis.

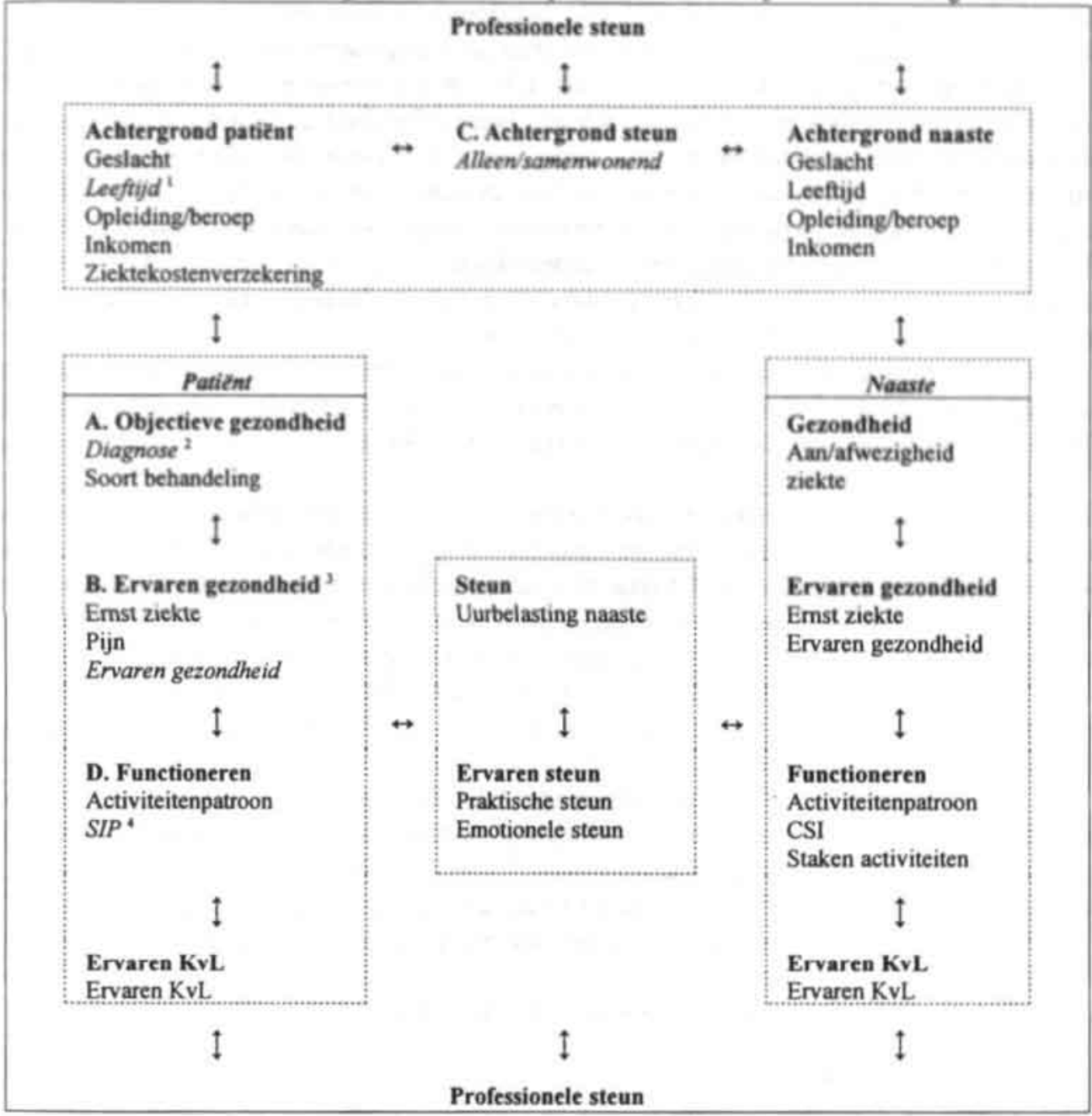

Legenda: A-D=nummering naar STG, cursief-indicator naar STG, ${ }^{14}=b i j$ STG I:valt onder functioneren 2:stoornis 3:psychosociale redzaamheid 4:huishoudelijke en algemene dagelijkse levensverrichtingen, $\mathrm{SIP}=$ Sickness Impact Profile, $\mathrm{CSI}=$ Caregiver Strain Index.

Geslacht, leeftijd, opleiding en beroep, inkomen en de verzekeringsvorm van de patient en naaste kunnen zowel van invloed zijn op de zelfzorgtekorten als op het eigen zelfzorgvermogen en daarmee op de benodigde aanvullende professionele zorg. Binnen de STG studie bleken vooral niet-stoornis gebonden tekorten zoals hoge leeftijd en het ontbreken van mantelzorg bepalend te zijn voor noodzaak tot zorg. Een essentieel verschil is dat bij CMTZ thuis zoals infusie zowel de onderliggende aandoening(en) als de vereiste behandeling vaak zelfzorgtekorten veroorzaken. $\mathrm{Zij}$ zijn daarom beide een indicator voor gezondheid (A). Omdat CMTZ thuis meestal ook naastenzorg vereist, is de gezondheid 
van de naaste verzorger vervolgd. Voor inzicht in de beleving van de aandoening (B), is gevraagd naar de pijn, ervaren ernst van de ziekte en gezondheid (de laatste twee ook bij de naaste). Bij CMTZ thuis wordt professionele zorg zoveel mogelijk aanvullend op het patiěntsysteem verleend (in deze studie volgens Orem). Daarom is, zowel bij de inventarisatie van het zorgnetwerk als bij de daardoor verleende praktische en emotionele steun (C), uitgegaan van naasten én zorgverleners. Als uitgangspunt voor het functioneren (D) van patiënt en naaste verzorger dient, naast de achtergrondvariabele leeftijd, het activiteitenpatroon. Ook omschrijft de Sickness Impact Profile (SIP) het functioneren van de patiënt in relatie tot diens ziekte. Het functioneren, de steun en de belasting van de naaste is gemeten in (gestaakte) activiteiten, tijd, de Caregiver Strain Index (CSI) en de ervaren belasting. De zorgsituatie van het patiëntsysteem is samenvattend benaderd via de STG indicatoren voor het bepalen van zelfzorgtekorten. ${ }^{176}$ Tot slot is de patiënt en naaste verzorger een samenvattend oordeel gevraagd over de tevredenheid met hun totale functioneren middels de ervaren $\mathrm{KvL}$ in engere zin.

Hierna volgt de operationalisatie van de indicatoren. Daarbij betreft $\$ 13.4 .1$ de eerste vraagstelling, \$13.4.2 de tweede vraagstelling en de subparagrafen de subvraagstellingen, $\S 13.4 .3$ de derde vraagstelling en $\$ 13.4 .4$ de statistische keuzen.

\subsubsection{OPERATIONALISATIE VAN DE ACHTERGROND (LEEFSITUATIE)}

Leeftijd en geslacht geven inzicht in de onderzoekspopulatie. De leeftijd is ingedeeld volgens de STG. ${ }^{176} \mathrm{Om}$ de sociale klasse in te schatten, is naast opleiding en inkomen (beide ingedeeld in vier klassen) gevraagd naar het (voormalige) beroep. Samen met de verzekeringsvorm verschaffen deze variabelen inzicht in de achtergrond en actuele leefsituatie. Waar relevant worden zij besproken bij gezondheid, steun of functioneren. De structurele kenmerken van het huishouden en het verdere netwerk dat steun kan verlenen is onder steun geoperationaliseerd.

Voor de externe validiteit zijn de grotere deelpopulaties (schema 2.7) waar mogelijk vergeleken met referentiegroepen uit de literatuur. Vanwege de verschillen in bevolkingsgroepen, gezondheid en gezondheidszorgsystemen is hierbij vooral gezocht naar sociaaldemografische kenmerken en kenmerken van de aandoening.

Tot slot zijn de samenhangen tussen leeftijd, opleiding en inkomen bestudeerd.

\subsubsection{OPERATIONALISATIE VAN DE ZORGSITUATIE EN DE KWALITEIT VAN LEVEN}

\subsubsection{Gezondheid}

De 'objectieve' gezondheid is gemeten via de diagnose bij aanmelding en ingedeeld in kanker, infecties en overige diagnoses. ${ }^{176}$ Omdat de medicatiegroep en toedieningswijze eveneens tot zelfzorgtekorten kunnen leiden, zijn vier prototypen van ziekte-behandelcombinaties onderscheiden (schema 2.7). ${ }^{149}$

De 'ervaren' gezondheid is gemeten met vragen naar de ervaren ernst van de ziekte, de pijn en de ervaren gezondheid: "Vindt $u$ dat uw aandoening of ziekte, in de periode van de infuuszorg ernstig was?" (vijfpuntsschaal: zeer ernstig, vrij ernstig, ernstig, nauwelijks ernstig, niet ernstig); "Kunt u de mate van pijn weergeven, die u gemiddeld had in de periode van de infuuszorg, door op onderstaande lijn een kruisje (X) op de plaats die hiermee overeenkomt." (visueel analoge schaal: geen pijn - ondraaglijke pijn); "Hoe beoordeelt u uw eigen gezondheid, in de periode van de infuuszorg?" (vijfpuntsschaal: zeer goed - zeer slecht). ${ }^{325}$ Deze stellingen zijn voorgelegd aan patiënten en naasten, 
afgeleiden hiervan aan naasten en zorgverleners. Hoewel het probleemoplossend vermogen in relatie tot de ervaren gezondheid en KvL belangrijk is, valt dit buiten het bestek van deze studie. Wel zijn de achtergrondvariabelen opleiding en inkomen gemeten vanwege hun relatie tot het probleemoplossend vermogen.

\subsubsection{Steun binnen het patiêntsysteem}

Ter operationalisatie van de structurele kenmerken van steun kan de patiënt zijn directe netwerk beschrijven via het noemen van vijf personen uit het informele netwerk en de relatie tot hen (echtgeno(o)t(e) of partner, kind, ouder, ander familielid, vriend(in), buur, vrijwilliger(ster)) en drie zorgverleners uit het professionele netwerk plus hun functie (arts, TMV, wijkverpleegkundige, overige). ${ }^{60}{ }^{40}$ De naaste verzorger is gevraagd met wie de patiênt tijdens de infuuszorg samenwoonde (alleen, met echtgeno(o)t(e)/partner, met kind(eren) jonger dan 16, met kind(eren) of anderen van 16 of ouder). Deze structurele netwerkbeschrijving is ingegeven door de discussie over de beschikbaarheid van voldoende naaste verzorgers en tracht niet de invloed op de $\mathrm{KvL}$ te bestuderen. ${ }^{\mathrm{IB}, 603}$ Functionele steun is gedefinieerd als: "de mate waarin aan iemands behoefte aan instrumentele en emotionele steun tegemoet wordt gekomen door interactie met anderen". $600,64,645$ De patient kan de hoeveelheid praktische en emotionele steun van naasten en zorgverleners aangeven (vijfpuntsschaal: geen, weinig, niet veel en niet weinig, veel, zeer veel). ${ }^{69,}{ }^{640}$ De naaste verzorger geeft op eenzelfde schaal aan hoeveel steun die verleend heeft. De begrippen 'praktische' en 'emotionele' steun zijn niet toegelicht. Omdat het doel is om inzicht te verkrijgen in de aard en de omvang van de steun, is de waardering van de steun niet gemeten.

\subsubsection{Functioneren}

Het functioneren van het patiëntsysteem plus de beïnvloedende factoren, is te omschrijven via biografische kenmerken (geslacht, leeftijd), gezondheid (lichamelijk en psychisch), persoonlijkheid (zelfvertrouwen, probleemoplossend vermogen), sociaal-demografische en psychosociale kenmerken (opleiding, inkomen, sociale klasse, samenstelling van gezin, levenscyclus, leef- en werksituatie rolfunctioneren en relaties met anderen) en sociaalmaatschappelijke kenmerken (sociale zekerheids- en gezondheidszorgsysteem). ${ }^{59}$ Analoog aan de STG dient de leeftijd als uitgangspunt voor het functioneren. ${ }^{176} \mathrm{De}$ invloed van de aandoening en de behandeling op het functioneren van de patient is vanwege de geringere belasting voor de patiënt gemeten met de verkorte SIP-68 (afgeleid van de Nederlandse SIP-136) ${ }^{650-652}$ In het onderhavig onderzoek is de aangegeven invul/afnametijd van tien minuten ruim overschreden. ${ }^{69}$ Vanwege de belasting en de verminderde validiteit bij 'proxy'-toepassing (correlatie 0.55 bij terminale patiënten), is de SIP niet toegepast bij naasten van terminale patiënten. ${ }^{68,653,654}$ De SIP wordt beschouwd als een generieke, gezondheid gerelateerde $\mathrm{KvL}$ schaal geschikt voor klinisch wetenschappelijk onderzoek naar de invloed van ziekten en geneeskundige onderzoeken en behandelingen onder allerlei groepen patiënten, waaronder die in de thuiszorg. ${ }^{60,61,621,625,654}$ De SIP meet de belemmerende invloed van aandoeningen op het functioneren, anders gezegd de dysfunctie in termen van gedrag. ${ }^{654}$ De SIP-68 bestaat uit zes subschalen (bijlage 13.1). De patiënten is gevraagd om alleen die items aan te kruisen die op hen van toepassing zijn én die met hun gezondheid te maken hebben. Een hogere score weerspiegelt een grotere dysfunctie. De ervaring met de SIP-68 is kleiner dan die met de uitgebreide Nederlandse en de oorspronkelijke Engelstalige versies, die als valide en betrouwbaar te boek staan. ${ }^{654} \mathrm{De}$ 
SIP-68 wordt eveneens valide en betrouwbaar geacht. ${ }^{655,656}$ Doordat de SIP-68 voortkomt uit multivariate analyses lijkt de inhoudsvaliditeit minder inzichtelijk. ${ }^{\oplus}$ De criteriumvaliditeit van de SIP-68 lijkt goed met betrekking tot de SIP-136 en met het eigen oordeel over de ernst van de aandoening, gezondheid, lichamelijk en psychisch functioneren, sociaal gedrag en geluk. ${ }^{651,656}$ Voordeel van de SIP is dat informatie verzameld wordt op niveau van items, subschalen en een geaggregeerde totaalscore. ${ }^{625}$ Van de SIP-68 zijn normscores beschikbaar. ${ }^{69}$ Voor de betrouwbaarheid is gekeken naar de Cronbach's $\alpha$. Een vragenlijst van 10-15 items acht Swanborn intern consistent indien de Cronbach's $\alpha$ groter is dan $0,85 .{ }^{657}$ Bij een groepsbeschrijving wordt een $\alpha$ van 0,50 voldoende geacht. ${ }^{657}$ De $\alpha$ voor de totale schaal bedraagt 0,94 . Ofschoon de $\alpha$ 's voor de subschalen van de SIP-68 redelijk zijn $(\alpha=0,72-0,93)$ bestaat er toch twijfel over de interne consistentie. Eén ernstige beperking kan namelijk het voorkomen en daarmee aankruisen van een aantal mindere beperkingen op hetzelfde gebied uitsluiten en een te lage SIP-score opleveren. Volgens de instructie bij de SIP-68 dienen de loopitems ( $29 \mathrm{t} / \mathrm{m}$ 35) als aangekruist te worden beschouwd als item 17 aangekruist is. Analoog daaraan is als volgt gehercodeerd: bij 12 ook 17, bij 14 ook 19, bij 15 ook 14, bij 17 ook 18, bij 18 ook 29, bij 21 ook 20, bij 32 ook 29 , bij 40 ook 39, bij 64 ook 65, bij 66 ook 64 én 65, bij 73 ook 62 . Hierdoor worden de $\alpha$ 's voor de subschalen niet beter, wel neemt de face-validity toe (bijlage 13.1).

De belasting van de naaste verzorger is gelinventariseerd via de uurbelasting, het opgeven van activiteiten en de ervaren belasting. Patiēnten geven aan hoeveel uur naasten tijdens de IT gemiddeld per dag extra met hen in de weer zijn geweest of extra met hen doorbrengen. Ook geven zij aan of en welke activiteiten naasten in de periode van de IT geheel of gedeeltelijk hebben gestaakt (werk, sport en/of hobby's, op bezoek gaan, bezoek krijgen, vakantie, uitgaan, studie). De naaste beantwoordt dezelfde vragen. De ervaren belasting is gemeten via de CSI. ${ }^{658}$ Deze is oorspronkelijk ontworpen om belasting te meten bij mantelzorgers van 65-plussers die thuis verzorgd worden na hospitalisatie. De items zijn geconstrueerd op basis van interviews met kinderen van deze patiènten. De definitie van 'strain' luidt: "By strain are meant those enduring problems that have the potential for arousing threat; a meaning that establishes strain and stressors as interchangeable concepts". De schaal omvat 13 dichotome items, die een stressor en/of aspect van belasting vermelden. De beaamde items worden opgeteld. Een score van 7 of hoger geeft een hoge belasting aan. Bij het bepalen van de constructvaliditeit is gekeken naar karakteristieken van de patiënt, perceptie van de naaste verzorger over de hoeveelheid zorg en de invloed hiervan op het eigen leven en de (emotionele) gezondheid van de naaste verzorger. ${ }^{658} \mathrm{De}$ interne consistentie bij 81 naasten van hartpatiënten en patiënten na een heupoperatie was hoog $(\alpha=0,86){ }^{6.58}$ De $\alpha$ van de CSI binnen deze studie is bij de 107 naaste verzorgers 0,79 , bij de 116 verpleegkundigen 0,82 en bij de 108 artsen 0,83 (subgroepen bijlage 13.2). Tot slot is de patiēnt en de naaste direct naar de belasting van de infuuszorg gevraagd: "De infuuszorg was voor ons belastend." (vijfpuntsschaal: zeer mee oneens tot zeer mee eens).

\subsubsection{Samenvattende benadering zorgsituatie}

Bij de samenvattende benadering van de zorgsituatie naar de STG, zijn voor de leeftijd en het alleen of samenwonen dezelfde klassen gebruikt. ${ }^{176}$ De vijf klassen van de ervaren gezondheid in deze studie zijn naar twee klassen gehercodeerd (slecht en zeer slecht: laag). Voor de ADL en de HDL items van de STG zijn binnen de SIP corresponderende items gezocht (bijlage 13.3). ${ }^{176}$ De gewichten van de STG zijn overgenomen (leeftijd:6,4,2; alle 
andere laag beperkt: 6 hoog beperkt:2). ${ }^{176}$ De interpretatie via Delphi-onderzoek van de STG is overgeslagen en de resulterende scores van 30 tot en met 10 zijn direct omgerekend naar vier klassen tekorten (I:30,28; II:26,24,22; III:20,18,16; IV:14,12,10). ${ }^{176}$

\subsubsection{Ervaren kwaliteit van leven}

De tevredenheid met het leven als geheel is gemeten via de stelling: "Zoals mensen een idee kunnen hebben van de kwaliteit van bijvoorbeeld fruit of wijn, zo kunnen ze ook een idee hebben over de kwaliteit van hun leven. Deze kan hoog of laag zijn, of er ergens tussenin. Zou u op de lijn hieronder met een kruisje (X) willen aangeven, hoe u de kwaliteit van uw leven in de periode van de infuuszorg gemiddeld vond." (visueel analoge schaal: laagst denkbare kwaliteit - hoogst denkbare kwaliteit). ${ }^{659}$ Zowel de patiēnt en diens naaste verzorger (beleving) als de professionele zorgverleners (toestand) hebben de KvL. beoordeeld. Het blijkt dat de op deze unidimensionele wijze gemeten ervaren KvL hoog correleert met andere schalen. ${ }^{23}$ Aan sociale wenselijkheid bij KvL dicht men in de literatuur een geringe rol toe. ${ }^{.00}$

\subsubsection{Samenhangen tussen indicatoren bij kwaliteit van leven}

Gezien de literatuur zijn geen sterke samenhangen met sociaal-demografische kenmerken verwacht. In het model is ervan uitgegaan dat de ernst van de ziekte en de pijn elkaar beïnvloeden en invloed uitoefenen op de ervaren gezondheid en $\mathrm{KvL}$. De sterkste samenhang wordt verwacht tussen ervaren gezondheid en KvL. De steun wordt geacht positief samen te hangen met de ervaren gezondheid en $\mathrm{KvL}$ van de patiènt en negatief met die van de naaste. Onder de respondenten bevinden zich geen terminale patiënten. Bij laatstgenoemden kan steun ook negatief samenhangen met de ervaren gezondheid en KvL. In de tabellen in de resultatensectie is bij de samenhangen, die in deze studie bestudeerd zijn, weergegeven welke correlaties daarbij doorgaans in de literatuur (L) vermeld worden. Deze correlaties zijn positief $(+)$, negatief $(-)$, wisselend $( \pm)$ of niet $(0)$ aanwezig.

\subsubsection{OVEREENSTEMMING TUSSEN RESPONDENTEN}

De overeenstemming in oordelen is gemeten bij de:

* Ernst van de ziekte, pijn, gezondheid en ervaren KvL van de patiënt tussen allen;

* Praktische en emotionele steun tussen de patiënt en naaste 1;

* Belasting en de KvL van naaste 1 tussen de naaste 1 , de verpleegkundige en de arts.

\subsubsection{STATISTISCHE KEUZEN}

Verschillen tussen respondenten in gemiddelden op dezelfde schalen worden als zodanig onderkend als ze $20 \%$ van de schaal bedragen (één punt bij een vijfpuntsschaal en twee bij een tienpuntsschaal). Vaak wordt naast het gemiddelde en de standaard deviatie het bereik gegeven als aanvullende maat voor de spreiding, om het verschil in individuele patiëntensituaties tot uiting te laten komen. Gezondheidszorg en ook CMTZ thuis moeten immers ook in 'uiterste' situaties zorg kunnen verlenen.

Samenhangen tussen variabelen zijn gemeten met de Spearman rangcorrelatie. De overeenstemming in oordelen is ook gemeten met de Spearman rangcorrelatie (geen correctie voor toeval) en soms met de Cohen's kappa (correctie voor toeval). De sterkte van de samenhangen en overeenstemmingen is gerelateerd aan de mate van verklarende variantie (schema 13.3). Vanwege de kleine aantallen is als significantie-niveau $\mathrm{p}<0,05$ aangehouden. De correlaties betreffende de invloed op de KvL bij de kleine aantallen respondenten met hartfalen zijn voor het overzicht ten opzichte van andere subgroepen 


\begin{tabular}{lcc}
\hline Aanduiding & Verklarende variantic in \% & Grenswaarde correlatie \\
Zeer zwak & $5 \leq x<10$ & 0.224 \\
Zwak & $10 \leq x<20$ & 0.316 \\
Vrij zwak & $20 \leq x<30$ & 0.447 \\
Vrij sterk & $30 \leq x<40$ & 0.548 \\
Sterk & $40 \leq x<50$ & 0.632 \\
Zeer sterk & $x>50$ & 0.707 \\
\hline
\end{tabular}

Legenda: "-op deze drie decimalen is afgerond, in de tabellen en tekst worden twee decimalen gegeven.

weergegeven, hoewel daar strikt genomen geen betekenis aan mag worden toegekend. Omdat de patiêntenpopulatie met een vrijwel volledige dataset klein is $( \pm 50)$, deze weer uiteenvalt in tenminste drie subpopulaties (grootste \pm 25 ), de onafhankelijke variabelen deels gecorreleerd zijn en verschillende aangetroffen correlaties overeenkomen met in de literatuur vermelde, zwakke samenhangen, is afgezien van regressie-analyse.

\subsection{Resultaten}

Voor patient wordt de afkorting pt gebruikt. De naaste verzorger, meestal de partner, wordt aangeduid met naaste 1 , andere naasten met naaste 2 tot en met naaste 4 (afkorting n1-n4). De huisarts wordt aangeduid met arts. Vanwege de onderlinge verschillen tussen de deelpopulaties, worden de uitkomsten vaak weergegeven naar medicatiegroep. Per tabel wordt daarom ook het aantal respondenten per medicatiegroep en soms per vraag gegeven.

\subsubsection{Achtergrond (leefsituatie) in deze studie}

De 173 behandelingen vonden plaats bij 63 mannen en 59 vrouwen (verdeling over aandoeningen tabel 13.4). Tabel 13.1 geeft de leeftijdsverdeling volgens STG categorieěn. ${ }^{176}$ Bij de patiènten stemt deze overeen met de onderliggende aandoeningen. Omdat de naaste 1 meestal de partner is, is diens leeftijd ongeveer gelijk aan die van de patiènt.

Tabel 13.1 Leeftijdsverdeling van patienten en naasten 1 per medicatiegroep ( $\%+j a r e n)$.

\begin{tabular}{|c|c|c|c|c|c|c|c|c|c|c|c|}
\hline \multirow[t]{2}{*}{ Leeftijd } & 1 & \multicolumn{2}{|c|}{ Morfine ${ }^{+}$} & \multicolumn{2}{|c|}{ Mannitol } & \multicolumn{2}{|c|}{ Antibiotica } & \multicolumn{2}{|c|}{ Hartmiddelen } & \multicolumn{2}{|c|}{ Totaal " } \\
\hline & & pt & n1 & pt & n1 & pt & n1 & pt & n1 & pt & n1 \\
\hline $0-20$ & $\%$ & 2 & 0 & 4 & 4 & 7 & 0 & 0 & 0 & 3 & 2 \\
\hline $21-54$ & $\%$ & 20 & 35 & 68 & 63 & 40 & 58 & 33 & 13 & 32 & 41 \\
\hline $55-74$ & $\%$ & 61 & 59 & 29 & 33 & 20 & 33 & 44 & 75 & 49 & 47 \\
\hline $75+$ & $\%$ & 17 & 6 & 0 & 0 & 33 & 8 & 22 & 13 & 16 & 6 \\
\hline Gemiddeld & jaren & 62 & 58 & 46 & 48 & 58 & 50 & 68 & 60 & 59 & 55 \\
\hline
\end{tabular}

Legenda: morfine "-morfine met eventuele parenterale comedicatie,"=inclusief de medicatiegroepen vocht, antiepileptica, virostatica en overigen. Door afronding bedraagt het totaal soms geen $100 \%$. Totaal aantal respondenten per leeftijdsklasse patient:3/39/60/20 naaste 1:2/45/51/6. Respondenten per medicatiegroep patient:59/28/15/9/122 naaste 1:51/24/12/8/104.

In de onderzoekspopulatie komen alle opleidingsniveau's voor (tabel 13.2). De verdeling over de niveau's komt voor patiěnten en naasten ongeveer overeen. Ook de spreiding bij een andere indicator voor sociale klasse, het beroep, is groot (bijlage 13.4). 


\begin{tabular}{lcccccccccc}
\hline Soort onderwijs * & \multicolumn{2}{c}{ Morfine } & \multicolumn{2}{c}{ Mannitol } & \multicolumn{2}{c}{ Antibiotica } & Hartaiddelen & \multicolumn{2}{c}{ Totaal * } \\
& pt & n1 & pt & n1 & pt & n1 & pt & al & pt & al \\
Basis & - & 27 & 36 & 42 & 33 & 17 & 88 & 75 & 42 & 32 \\
Lager & - & 40 & 44 & 38 & 20 & 58 & 0 & 13 & 32 & 41 \\
Middelbaar & - & 17 & 16 & 13 & 33 & 17 & 13 & 13 & 19 & 16 \\
Hoger & - & 15 & 4 & 8 & 13 & 8 & 0 & 0 & 6 & 11 \\
\hline
\end{tabular}

Legenda: -basis lager algemeen onderwijs lager middelbaar algemeen of lager beroepsonderwijs middelbaar hoger algemeen of middelbaar beroepsonderwijs hoger.wetenschappelijk of hoger beroepsonderwijs, morfine "-morfine met eventuele parenterale comedicatic,"-minclusief de medicatiegroepen vocht, anti-epileptica, virostatica en overigen, '-terminale patienten. Respondenten patient: $-25 / 15 / 8 / 52$ naste $1: 52 / 24 / 12 / 8 / 104$.

\section{Alle inkomensklassen zijn vertegenwoordigd (tabel 13.3). Van de patiênten is $78 \%$ (95)} ziekenfonds verzekerd. De verdeling ziekenfonds/particulier in deze klassen is gelijk.

Tabel 13.3 Netto inkomensverdeling van patienten en naasten 1 per medicatiegroep (\%).

\begin{tabular}{lrrrrrrrrrr}
\hline Inkomen & \multicolumn{2}{c}{ Morfine } & \multicolumn{3}{c}{ Mannitol } & \multicolumn{2}{c}{ Antibiotica } & Hartmiddelen & \multicolumn{2}{c}{ Totaal * } \\
& pt & n1 & pt & n1 & pt & nI & pt & nI & pt & nI \\
$<f 1000$ & - & 0 & 4 & 4 & 13 & 0 & 0 & 0 & 6 & 1 \\
$f 1000-f 1999$ & - & 23 & 24 & 8 & 20 & 17 & 75 & 63 & 34 & 21 \\
$f 2000-f 2999$ & - & 23 & 32 & 33 & 20 & 25 & 13 & 13 & 23 & 26 \\
$f 3000-f 3999$ & - & 25 & 8 & 4 & 20 & 25 & 13 & 13 & 11 & 18 \\
$>f 4000$ & - & 15 & 4 & 4 & 20 & 25 & 0 & 0 & 9 & 14 \\
Onbekend & - & 15 & 28 & 46 & 7 & 8 & 0 & 13 & 17 & 21 \\
\hline
\end{tabular}

Legenda: morfine ${ }^{*}=$ morfine met eventuele parenterale comedicatie,"=inclusief de medicatiegroepen vocht, antiepileptica, virostatica en overigen, ${ }^{\prime}=$ terminale patienten, $"=$ onbekend of wil niet antwoorden. Respondenten patięnt:- $25 / 15 / 8 / 53$ naaste $1: 53 / 24 / 12 / 8 / 106$.

\subsubsection{Vergelijking met sociaal-demografische kenmerken in andere studies}

In §12.3.1.4 bleek reeds dat de kankerpatiënten in deze studie redelijk vergelijkbaar waren met die in andere studies naar subcutane infusie van morfine en met ouderen die in Nederland aan kanker overlijden (iets jonger) ${ }^{320}$ De patiënten met SRD komen qua leeftijd en geslacht overeen met de door Veldman prospectief beschreven groep van 829 patiënten $(\S 12.3 .2 .4) .{ }^{538}$ De met antibiotica behandelde patiënten hebben diverse onderliggende aandoeningen. Hierdoor zijn ze niet goed met een referentiegroep te vergelijken $(\S 12.3 .3 .4)$. Zoals in $\S 12.3 .4 .4$ reeds bleek komen de negen patiënten met hartfalen in leeftijds- en geslachtsverdeling overeen met patiënten die in Nederland daarvoor in het ziekenhuis opgenomen worden en met die in een onderzoek van Tandon. ${ }^{611,612}$ Evenals bij Applefeld kan ongeveer de helft van de patiënten thuis behandeld worden. ${ }^{127}$

\subsubsection{Samenhangen tussen sociaal-demografische kenmerken}

Vanuit de literatuur én omdat het veelal een oudere, (chronisch) zieke populatie betreft, zijn geen sterke samenhangen verwacht tussen de sociaal-demografische kenmerken. Tussen leeftijd en opleiding bestaat bij de patiênt een tendens tot $(\rho=-0.25 n=53 \mathrm{p}=0,069)$ en bij naaste 1 een zeer zwak $(\rho=-0.30 n=103 p=0,02)$ negatieve samenhang. Tussen leeftijd en inkomen bestaat bij de patiënt een tendens tot een zeer zwakke samenhang 
$(\rho=-0.27 n=53 p=0,054)$. Bij naaste 1 ontbreekt deze samenhang $(\rho=-0.09 n=82 p=0,404)$, wellicht door de geringe leeftijdsspreiding (tabel 13.1). De samenhang tussen opleiding en inkomen is bij de patiënt zeer zwak $(\rho=0.28 \mathrm{n}=53 \mathrm{p}=0,043)$ en bij naaste 1 vrij zwak $(\rho=0.46 n=83 p<0,001)$ positief. De spreiding in beroepen komt overeen met die in opleidingsniveau (bijlage 13.4).

\subsubsection{Gezondheid in deze en andere studies}

Tabel 13.4 geeft een overzicht van de aandoeningen naar categorie, orgaansysteem en geslacht (gedetailleerd H:12). De categorie overig omvat: patiënten met SRD (28), met chronisch hartfalen (9), terminale patiënten met emfyseem, hartfalen en sepsis (30, subcutane infusie morfine) en met dehydratie ( $2 \%$, diabetes en cerebrovasculair accident). Tabel 13.5 geeft de aantallen patiênten met een bepaalde medicatie tijdens de eerste en vervolgbehandelingen weer (overzicht medicatiegroep én soort infuus tabel 12.1).

Tabel 13.4 Aantal patienten per categorie aandoening, per geslacht en per aangedaan orgaansysteem.

\begin{tabular}{lccccccc}
\hline Orgaansysteem & \multicolumn{2}{c}{ Nieuwvorming } & \multicolumn{2}{c}{ Infectic } & \multicolumn{2}{c}{ Overige } & Totaal \\
& 8 & $Q$ & $\sigma^{*}$ & 8 & 0 & 8 & \\
Centraal zenuwstelsel & 3 & 0 & 2 & 0 & 0 & 1 & 6 \\
Perifeer zenuwstelsel & 0 & 0 & 3 & 0 & 0 & 0 & 3 \\
Hart vaatstelsel & 0 & 0 & 1 & 0 & 7 & 3 & 11 \\
Ademhalingsstelsel & 7 & 4 & 4 & 1 & 1 & 0 & 17 \\
Spijsverteringsstelsel & 13 & 15 & 0 & 0 & 0 & 1 & 28 \\
Nier en urinewegen & 2 & 0 & 1 & 0 & 0 & 0 & 4 \\
Geslachtsorganen & 4 & 11 & 0 & 0 & 0 & 0 & 15 \\
Bewegingsapparaat & 0 & 0 & 1 & 3 & 8 & 20 & 32 \\
Bloed & 2 & 0 & 0 & 0 & 1 & 0 & 3 \\
Huid & 2 & 0 & 0 & 0 & 0 & 0 & 2 \\
Overig & 1 & 0 & 0 & 0 & 0 & 0 & 1 \\
Totaal & 34 & 30 & 12 & 4 & 17 & 25 & 122 \\
\hline
\end{tabular}

Tabel 13.5 Aantal behandelingen/episoden naar geslacht en in totaal per medicatiegroep.

\begin{tabular}{|c|c|c|c|c|c|c|c|c|}
\hline \multirow[b]{2}{*}{ Medicatiegroep } & \multicolumn{4}{|c|}{ Eerste behandeling/episode I } & \multicolumn{4}{|c|}{ Vervolgbehandeling/episode 2-10 } \\
\hline & $\sigma^{\circ}$ & 8 & $\begin{array}{l}\text { Totaal } \\
\text { aantal }\end{array}$ & $\begin{array}{c}\text { Totaal } \\
\%\end{array}$ & $\sigma$ & 8 & $\begin{array}{l}\text { Totaal } \\
\text { aantal }\end{array}$ & $\begin{array}{c}\text { Totaal } \\
\%\end{array}$ \\
\hline Morfine & 27 & 14 & 41 & 33 & 1 & 0 & 1 & 2 \\
\hline Morfine ${ }^{*}$ & 8 & 12 & 20 & 16 & 0 & 0 & 0 & 0 \\
\hline Vocht & 1 & 6 & 7 & 6 & 0 & 0 & 0 & 0 \\
\hline Anti-epileptica & 1 & 1 & 2 & 2 & 0 & 0 & 0 & 0 \\
\hline Mannitol & 8 & 20 & 28 & 23 & 0 & 18 & 18 & 36 \\
\hline Antibiotica & 11 & 4 & 15 & 12 & 7 & 0 & 7 & 14 \\
\hline Virostatica & 1 & 0 & 1 & 1 & 2 & 0 & 2 & 4 \\
\hline Hartmiddelen & 6 & 3 & 9 & 7 & 20 & 1 & 21 & 42 \\
\hline Doorspuiten & 0 & 0 & 0 & 0 & 0 & 1 & 1 & 2 \\
\hline Totaal & 63 & 60 & 123 & 100 & 30 & 20 & 50 & 100 \\
\hline
\end{tabular}

Legenda 13.4+13.5: $\sigma^{2}$-mannen, 8=vrouwen, morfine "-morfine met parenterale comedicatic, doorspuiten= hepariniseren centraalveneuze poort. 
Vervolgbehandelingen zijn opgedeeld in 'echte' en 'administratieve'. De laatste ontstaan doordat chronische behandelingen in episoden van acht weken zijn opgesplitst (\$8.4.2). De ernst van de ziekte van de patiènt en een eventuele ziekte bij naaste 1 , volgens henzelf en de zorgverleners, is weergegeven in tabel 13.6. De ervaren ernst van de ziekte lijkt te variëren met de ernst van de onderliggende aandoening en de daarbij behorende medicatiegroep. Bij mannitolinfusie lijken artsen een lagere gemiddelde ernst aan te geven dan patiēnten. Bij hartfalen geeft de patiěnt en lijkt naaste 1 gemiddeld een hogere ernst aan te geven dan de zorgverleners.

Tabel 13.6 Ervaren en ingeschatte ernst van de ziekte van patienten en naasten I per medicatiegrocp.

\begin{tabular}{lccccc}
\hline Beoordelaar & $\begin{array}{c}\text { Morfine } \\
\text { Envareningeschatte ernst van de ziekte van patienten * }\end{array}$ & $\begin{array}{c}\text { Mannitol } \\
\text { Antibiotica }\end{array}$ & Tartmiddelen & Totaal * \\
Patient & -1 & $3,2 / 1,4$ & $3,1 / 0,9$ & $2,9 / 1,6$ & $3,0 / 1,3$ \\
Naaste 1 & $1,5 / 0,7^{*}$ & $3,0 / 1,0$ & $3,6 / 1,2$ & $2,4 / 1,6$ & $2,0 / 1,3$ \\
Verpleegkundige & $1,3 / 0,6$ & $2,9 / 0,7$ & $3,3 / 1,2$ & $1,8 / 0,7$ & $1,9 / 1,1$ \\
Arts & $1,1 / 0,2$ & $3,6 / 0,9$ & $3,2 / 1,2$ & $1,6 / 0,8$ & $2,0 / 1,3$ \\
& Aamvezigheid en ervaren ernst van de ziekte van naasten /* & \\
Aanwezigheid \% & 38 & 25 & 17 & 43 & 35 \\
Emst & $3,2 / 1,5$ & $3,5 / 1,2$ & $4,5 / 0,7$ & $4,7 / 0,6$ & $3,4 / 1,3$ \\
\hline
\end{tabular}

Legenda: "-vijfpuntschaal 1:zeer emstig 2:vrij emstig 3:ernstig 4:nauwelijks emstig 5:niet emstig. morfine "=morfine met eventuele parenterale comedicatie,"=inclusief de medicatiegroepen vocht, anti-epileptica, virostatica en overigen, ${ }^{\prime}=$ terminale patienten, ${ }^{\circ}=$ gemiddelde/standaard deviatie. Respondenten over ernst ziekte patient: patient:-/25/15/8/52 naaste $1: 53 / 24 / 12 / 7 / 106$ verpleegkundige:55/27/15/7/116 arts:51/24/15/7/105. Respondenten over aanwezigheid en ernst ziekte naaste 1: naaste 1:53/24/12/7/105.

De patiënt, naaste 1 en zorgverleners hebben de pijn van de patiënt beoordeeld (tabel 13.7). De morfinebehandeling wordt gegeven bij ernstige pijn die niet met orale medicatie bestreden kan worden. De dosis wordt opgehoogd als er wederom pijn optreedt. Hierdoor is de patiënt niet gedurende de gehele behandeling pijnvrij. Bij mannitolinfusie lijken patiënten gemiddeld meer pijn aan te geven dan de artsen, bij hartmiddelen juist andersom.

Tabel 13.7 Ervaren en ingeschatte pijn van patienten per medicatiegroep.

\begin{tabular}{lcccc}
\hline Beoordelaar & Morfine * & Mannitol & Antíbiotica & Hartmiddelen \\
Patient & $-{ }^{-1}$ & $5,5 / 2,6 / 0,0-9,9^{*}$ & $1,4 / 2,5 / 0,0-8,0$ & $2,5 / 3,6 / 0,0-8,3$ \\
Naaste 1 & $6,3 / 3,7 / 0,0-10,0$ & $5,7 / 2,5 / 0,6-9,5$ & $1,1 / 2,5 / 0,0-8,2$ & $4,0 / 4,3 / 0,0-9,5$ \\
Verpleegkundige & $4,9 / 3,1 / 0,0-9,8$ & $4,7 / 1,9 / 1,5-7,9$ & $1,4 / 1,3 / 0,0-4,5$ & $4,5 / 3,4 / 0,2-9,7$ \\
Arts & $4,7 / 3,2 / 0,0-9,4$ & $3,6 / 2,5 / 0,0-7,5$ & $1,7 / 1,7 / 0,0-5,3$ & $4,0 / 4,3 / 0,0-9,4$ \\
\hline
\end{tabular}

Legenda: $=$ continue schaal $0 \mathrm{~cm}$ :geen pijn $10 \mathrm{~cm}$ :ondraaglijke pijn, morfine $=$ morfine met eventuele parenterale comedicatie, "=inclusief de medicatiegroepen vocht, anti-epileptica, virostatica en overigen,'=terminale patienten, "=gemiddelde/standaard deviatie/bereik. Respondenten: patient:-/25/14/8 naaste 1:51/24/12/7 verpleegkundige:54/27/15/7 arts:51/24/14/7.

Tabel 13.8 toont de ervaren gezondheid van de patiënt en naaste 1 . Tussen de groepen varieert deze met de ernst van de onderliggende aandoening (medicatiegroep). Net als bij de ernst van de ziekte en de pijn, lijken de patiënten met mannitolinfusie zichzelf minder gezondheid toe dichten dan de zorgverleners en is dit bij hartmiddelen omgekeerd. 


\begin{tabular}{lccccc} 
Beoordelaar & $\begin{array}{c}\text { Morfine } \\
\text { Ervaren/ingeschatte gezondheid van patiénten }\end{array}$ & Mannitol & Antibiotica & Hartmiddelen & Totaal \\
Patient & -1 & $2,9 / 1,0$ & $2,9 / 0,8$ & $3,1 / 1,3$ & $2,9 / 0,9$ \\
Naaste 1 & $4,9 / 0,5^{\circ}$ & $2,7 / 0,9$ & $2,8 / 0,8$ & $3,4 / 1,2$ & $3,9 / 1,3$ \\
Verpleegkundige & $4,8 / 0,4$ & $2,4 / 0,6$ & $2,9 / 0,8$ & $3,8 / 0,9$ & $3,9 / 1,2$ \\
Arts & $4,9 / 0,4$ & $2,2 / 0,8$ & $2,9 / 0,9$ & $3,7 / 0,8$ & $3,9 / 1,3$ \\
& Ervaren gezondheid van naasten $I^{*}$ & & \\
Naaste 1 & $2,5 / 1,0$ & $2,3 / 0,8$ & $2,1 / 0,7$ & $2,4 / 0,9$ & $2,7 / 0,5$ \\
\hline
\end{tabular}

Legenda: "-vijfpuntschaal 1:zeer goed 2:goed 3:nict goed en niet slecht 4:slecht 5:zeer slecht, morfine ${ }^{*}=$ morfine met eventuele parenterale comedicatie, ${ }^{4}=$ inclusief de medicatiegroepen vocht, anti-epileptica, virostatica en overigen, '-terminale patienten, "-gemiddelde/standaard deviatie. Respondenten over gezondheid patient: patient:0/25/15/8/52 naaste 1:53/24/12/8/106 verpleegkundige:55/27/15/8/116 arts:51/24/15/7/105. Respondenten over gezondheid naaste 1: naaste 1:53/24/12/7/104.

Bij de kankerpatiënten in de studiepopulatie zijn de meest voorkomende soorten kanker vertegenwoordigd $(\$ 12.3 .1 .4)$. Bij de morfinebehandeling is pijn de reden voor de infuusbehandeling en zijn de patiënten evenals elders niet altijd pijnvrij (\$12.3.1.4). De ziektekenmerken van SRD patienten in deze studie komen grotendeels overeen met de door Veidman beschreven groep $(\$ 12.3 .2 .4){ }^{538}$ Deze patiënten vinden zichzelf ernstiger ziek, rapporteren meer pijn en voelen zich minder gezond dan de arts inschat. Bii natiënten met chronische SRD is pijn een bekend therapieresistent symptoom (75\%-97\%). ${ }^{533,538}$ De met antibiotica behandelde patiënten hebben diverse onderliggende aandoeningen waardoor vergelijking moeilijk is $(\$ 12.3 .3 .4)$. Er zijn geen afwijkingen geconstateerd. De patiënten in deze studie hebben een minimaal even ernstige vorm van hartfalen als andere beschreven populaties $(\$ 12.3 .4 .4)$. Bij chronische decompensatie is de eventuele pijn evenals bij andere vormen van hartlijden toe te schrijven aan het onderliggend hartlijden of comorbiditeit. ${ }^{661}$ Ook patiènten met hartfalen in andere studies vinden hun ziekte minder ernstig en hun gezondheid beter dan de zorgverleners. ${ }^{661,662}$

\subsubsection{Steun binnen het patièntsysteem in deze en andere studies}

Er woonden 18 mensen 'zelfstandig' alleen en twee 'alleen' in een verzorgingshuis (tabel 13.9). Bij drie alleenwonenden zijn antibiotica en bij drie virostatica in giften toegediend en hoefde geen naaste aanwezig te zijn, bij de andere 14 was dit wél noodzakelijk (\$7.6).

Tabel 13.9 Woonsituatic van de patient per medicatiegroep (\% en aantal)

\begin{tabular}{lrrrrr}
\hline Woonsituatie patiěnt & Morfine & Mannitol & Antibiotica & Hartmiddelen & $\begin{array}{r}\text { Totaal * } \\
\text { Alleenwonend tijdens infusie }\end{array}$ \\
Tijdelijke ondersteuning ${ }^{*}$ & - & - & $20(3)^{*}$ & - & $5(6)$ \\
Met echtgeno(o)t(e)/partner & $15(9)$ & $11(3)$ & 0 & 0 & $11(14)$ \\
\hline Met kind(eren) jonger dan 16 & 77 & 79 & 83 & 100 & 80 \\
Met mensen van 16 of ouder & 11 & 25 & 25 & 13 & 16 \\
\hline
\end{tabular}

Legenda: "=bij samenwonend meerdere antwoorden mogelijk, morfine ${ }^{*}=$ morfine met eventuele parenterale comedicatic, "=inclusief de medicatiegroepen vocht, anti-epileptica, virostatica en overigen, ()$^{*}=$ =aantal, -familie kwam tijdelijk in huis of nam patient tijdelijk op. Naar het al dan niet alleen wonen is gevraagd tijdens de intake ( $\mathrm{n}=122)$. Gezinssamenstelling (meerdere mogelijkheden) volgens naaste 1:53/24/12/8/108. 
De patiènt is dan bij familie of bekenden in huis genomen of deze kwam tijdelijk inwonen. Vanwege de belastbaarheid van de naaste was tweemaal verhuizing naar een verpleeghuis noodzakelijk. Eenmaal vanuit een flatwoning (subcutane infusie morfine) en cenmaal vanuit een aanleunwoning (centraalveneuze infusie hartmiddelen).

Tabel 13.10 beschrijft het niet-professionele netwerk volgens de patiênt en naaste 1. Van de terminale patiënten $(64 / 119=54 \%)$ ontbreken gegevens, hoewel vele naasten daar vaak intensief zorg verlenen. De bijdrage van naaste $I$ is vanuit hun vragenlijst wel altijd bekend. De relatie van naaste 1 tot de patiēnt verschilt weinig bij in- of exclusie van de terminale patiēnten, wel neemt het percentage vrouwen toe. Van 47 van de 55 patiěnten die konden responderen is het netwerk bekend. In $81 \%$ is een tweede, in $53 \%$ een derde en in $28 \%$ een vierde naaste bij de zorg betrokken. Vooral partners, ouders en kinderen waarmee men samenwoont verlenen zorg. Daarnaast helpen familieleden en vrienden.

Tabel 13.10 Relatie van patienten tot hun naasten (\%).

\begin{tabular}{lc|cccc}
\hline Relatic & Naaste 1 & Naaste 1' & Naaste 2' & Naaste 3' & Naaste 4 \\
Partner & 74 & 77 & 5 & 0 & 0 \\
Kind & 13 & 13 & 37 & 28 & 8 \\
Ouder & 6 & 9 & 13 & 4 & 8 \\
Ander familielid & 6 & 0 & 16 & 28 & 54 \\
Vriend(in) & 1 & 2 & 16 & 20 & 31 \\
Buur & 1 & 0 & 11 & 16 & 0 \\
Vrijwilliger & 0 & 0 & 3 & 4 & 0 \\
Waarvan vrouw & 67 & 53 & 69 & 38 & 70 \\
\hline
\end{tabular}

Legenda: " $=$ volgens naaste 1, r־volgens de patient, exclusief de terminale patiênten. Respondenten over sexe naaste: naaste 1:106 patient:47/36/24/13. Respondenten over relatie naaste: naaste 1:107 patient:47/38/25/13.

In tabel 13.11 zijn de personen die steun kunnen bieden gerangschikt naar de mate van de te verwachten steun. Meestal geven naaste 1 en naaste 2 de meeste praktische steun, bij de emotionele steun varieert dit minder. Bij de zorgverleners is meer praktische steun gegeven door de TMV dan door de arts. Bij de emotionele steun is dit verschil kleiner.

In Nederland geven informele zorgverleners $80 \%$ van de thuiszorg. ${ }^{518}$ Zeker bij terminale thuiszorg speelt mantelzorg een centrale rol. ${ }^{320} \mathrm{Van}$ de bevolking verleent $10 \%$ tot $20 \%$ informele zorg (gemiddeld 3-5 uur per week) ${ }^{518}$ Hiervan behoort $5 \%$ tot de 'centrale verzorgers', hier aangeduid met naaste 1 . Meestal is dit een familielid, in $80 \%$ een partner of (schoon)dochter. 'Overall' is $75 \%$ van het vrouwelijk geslacht, onder partners ongeveer $50 \%$. Zij zijn grotendeels ouder dan 45 , hebben een relatief lage opleiding en geen of een deeltijdbaan. In het onderhavig onderzoek is de gemiddelde leeftijd van de naaste verzorgers 54,5 jaar $\left(53 \%\right.$ was $\left.55^{+}\right)$. In het algemeen zijn dit partners $(74 \%)$ of kinderen (13\%) en merendeels vrouwen (67\%). In tegenstelling tot voornoemd onderzoek zijn in deze studie de verzorgende partners wat vaker vrouwen $(63 \%) .{ }^{518}$ Op verschillende manieren gemeten, is de belasting voor de naasten bij terminale thuiszorg het hoogst. Structurele kenmerken van het patiëntennetwerk in deze studie zijn afgezet tegen een aantal vergelijkbare netwerken zoals beschreven door Courtens (kankerpatiënten), Janssen (somatisch invalide ouderen), Jansen en Woldringh (ouderen) en Robinson (65', arteriosclerotische hartaandoeningen of heupchirurgie) (tabel 13.12). ${ }^{511,644,658,663}$ 


\begin{tabular}{|c|c|c|c|c|c|}
\hline Steunveriener & Morfine* & Mannitol & Antibiotica & Hartmiddelen & Totaal * \\
\hline \multicolumn{6}{|c|}{ Ervaren praktische steun " } \\
\hline Naaste I" & $4,4 / 1,0^{\circ}$ & $4,6 / 0,7$ & $3,3 / 1,4$ & $4,3 / 1,0$ & $4,3 / 1,0$ \\
\hline Naaste 1 & $\cdot$ & $4,8 / 0,5$ & $4,8 / 0,5$ & $4,6 / 0,5$ & $4,7 / 0,5$ \\
\hline Naaste 2 & - & $4,1 / 1,2$ & $4,0 / 0,7$ & $4,4 / 0,6$ & $4,1 / 0,8$ \\
\hline Naaste 3 & $\cdot$ & $3,2 / 1,4$ & $3,3 / 1,0$ & $4,3 / 0,5$ & $3,4 / 1,3$ \\
\hline Naaste 4 & - & $2,8 / 1,5$ & $4,0 / \cdots$ & $4,5 / 0,6$ & $3,6 / 1,1$ \\
\hline Gezinsverzorgende & * & $3,0 / \bullet \bullet$ & - & $\cdot$ & $4,0 / 1,4$ \\
\hline Wijkverpleegkundige & - & $4,7 / 0,6$ & $3,0 / 1,0$ & $4,0 / \cdots$ & $4,0 / 1,0$ \\
\hline TMV & - & $4,3 / 0,8$ & $3,8 / 1,2$ & $4,2 / 0,8$ & $4,2 / 0,9$ \\
\hline Arts & $\cdot$ & $2,8 / 1,4$ & $2,8 / 1,2$ & $3,0 / 1,2$ & $2,4 / 1,3$ \\
\hline Overige zorgverieners & $\cdot$ & $4,0 / \cdots$ & $4,0 / 0,9$ & $4,3 / 0,9$ & $4,1 / 0,7$ \\
\hline \multicolumn{6}{|c|}{ Ervaren emotionele steun " } \\
\hline Naaste I" & $4,6 / 0,7$ & $4,5 / 0,7$ & $3,7 / 1,4$ & $4,1 / 1,4$ & $4,4 / 0,9$ \\
\hline Naaste I & $\cdot$ & $4,5 / 0,9$ & $4,4 / 0,8$ & $4,1 / 0,9$ & $4,5 / 0,8$ \\
\hline Naaste 2 & $\cdot$ & $4,1 / 1,1$ & $3,9 / 1,0$ & $4,2 / 0,8$ & $4,1 / 1,0$ \\
\hline Naaste 3 & $\cdot$ & $3,9 / 0,9$ & $3,8 / 0,5$ & $4,0 / 0,8$ & $3,4 / 0,5$ \\
\hline Naaste 4 & - & $4,0 / \cdots$ & $4,0 / \cdots$ & $4,5 / 0,6$ & $4,1 / 0,5$ \\
\hline Gezinsverzorgende & - & $3,0 / \bullet$ & • & - & $4,0 / 1,4$ \\
\hline Wijkverpleegkundige & - & $4,7 / 0,6$ & $2,0 / 1,4$ & $3,0 / \bullet$ & $3,8 / 1,4$ \\
\hline TMV & $\cdot$ & $4,1 / 0,9$ & $3,6 / 1,1$ & $3,8 / 1,5$ & $3,9 / 1,4$ \\
\hline Arts & - & $3,1 / 1,4$ & $2,8 / 1,6$ & $3,2 / 0,8$ & $3,2 / 1,4$ \\
\hline Overige zorgverleners & - & $4,0 / \cdots$ & $3,9 / 0,7$ & $4,2 / 0,8$ & $4,0 / 0,6$ \\
\hline
\end{tabular}

Legenda: " =vijfpuntschaal 1:geen 2:weinig 3:niet veel en niet weinig 4:veel 5:zeer veel, morfine ${ }^{*}=$ morfine met eventuele parenterale comedicatie,"=inclusief de medicatiegroepen vocht, anti-epileptica, virostatica en overigen, "-volgens naaste 1, de overige gegevens heeft de patient opgegeven, exclusief terminale patienten, "=gemiddelde/standaard deviatie, $* *$ geen berekening standaarddeviatie mogelijk. Verschilt voor praktische (p) en emotionele (e) steun het aantal respondenten, dan worden ze achtereenvolgens genoemd gescheiden door een + Respondenten naaste 1 over zichzelf $53 / 24 / 12 / 8 / 106$ en de patient over: naaste $1:-/ 24 / 12 / 7 / 47$ naaste $2: 19 / 9 p+8 \mathrm{e} / 5 / 37 \mathrm{p}+36 \mathrm{e}$ nasste $3:-/ 13 / 4 / 4 / 25$ naaste $4:-/ 4 / 2 / 4 / 13$ gezinsverzorging $-/ 1 / 0 / 0 / 2$ wijkverpleging:- $/ 3 / 3 p+2 \mathrm{e} / 1 / 9 \mathrm{p}+8 \mathrm{e}$ TMV $:-/ 23 / 10 / 6 / 42$ arts: $-/ 16 / 6 / 5 / 29$ overig: $-/ 3 / 6 / 7 / 18$.

Tabel 13.12 Structurele kenmerken patientsysteem.

\begin{tabular}{|c|c|c|c|c|c|}
\hline & $\begin{array}{l}\text { Onderhavig } \\
\text { onderzoek }\end{array}$ & Courtens ${ }^{\text {sil }}$ & Janssen $^{64}$ & $\begin{array}{l}\text { Jansen \& } \\
\text { Woldringh }\end{array}$ & Robinson ${ }^{68}$ \\
\hline $\begin{array}{l}\text { Echtgen }(o) o t(c) \\
\text { of partner }\end{array}$ & $74 \%(63 \%){ }^{*}$ & $58 \%(62 \%)$ & $46 \%(63 \%)$ & $24 \%$ & $38 \%$ \\
\hline Ouder & $6 \%(83 \%)$ & $1 \%(100 \%)$ & - & $0 \%$ & $\cdot$ \\
\hline Broer of zus & - & $3 \%(100 \%)$ & - & $\cdot$ & - \\
\hline (Schoon)kind & $13 \%(71 \%)$ & $22 \%(85 \%)$ & $40 \%(90 \%)$ & $62 \%$ & $33 \%(66 \%)$ \\
\hline Overige familie & $6 \%(83 \%)$ & $3 \%(66 \%)$ & $\cdot$ & $8 \%$ & $14 \%$ \\
\hline Buur & $1 \%(100 \%)$ & $2 \%(100 \%)$ & - & $4 \%$ & $4 \%$ \\
\hline Vriend & $1 \%(100 \%)$ & $10 \%(78 \%)$ & - & $2 \%$ & $\cdot$ \\
\hline Overig & - & $\cdot$ & $7 \%(100 \%)$ & - & $\cdot$ \\
\hline Aantal & $107(67 \%)$ & $91(71 \%)$ & $52(79 \%)$ & $91(80 \%)$ & 85 \\
\hline Lecftijd ${ }^{*}$ & $59 / 17 / 14-93$ & $58 / 11 / 28-79$ & - & $\begin{array}{l}35-54: 45 \% \\
255: 55 \%\end{array}$ & $-1-122-83$ \\
\hline
\end{tabular}

Legenda: "-gemiddelde/standaard deviatie/spreiding, ( $)^{"}=$ (waarvan percentage vrouwen). Respons naaste 1 is 107, geslacht bekend bij 105 . 
Courtens vindt bijvoorbeeld bij kankerpatiènten een vrij klein netwerk (gemiddeld 8,5; $80 \%$ familieleden; $q=71 \%$ ). Bij onderzoeken bij dementerende ouderen rapporteert men gemiddeld vier tot 11 actief participerende verzorgers. ${ }^{.64}$ In alle onderzoeken zijn verzorgers meestal directe familieleden. In ongeveer $60 \%$ krijgt de centrale verzorger hulp van andere familieleden. ${ }^{.64}$ Hier is er vanwege de inclusiecriteria $(\mathrm{H}: 7)$ in $95 \%$ een centrale verzorger. De patiènt noemt in $81 \%$ een tweede, in $53 \%$ een derde en in $28 \%$ een vierde verzorger. Door het ontbreken van een naaste verzorger was driemaal $(2,2 \%)$ geen thuisbehandeling mogelijk (bijlage 7.4 ). In $5 \%$ was thuisbehandeling vanwege het intermitterende karakter ook mogelijk bij alleenwonende patiěnten en in $11 \%$ kon er een ad hoc oplossing gevonden worden. Ook in deze studie wordt vooral zorg verleend door personen die als hoofdwerkzaamheid een eigen huishouding voeren. ${ }^{60}$ Onvoldoende draagkracht van naaste verzorgers, op basis van onder andere aandoeningen (in deze studie $35 \%$ zelf ziek, $18 \%$ in ziektewet of WAO/AWW), kan een reěle belemmerende factor zijn. ${ }^{167}$, 513 Viermaal $(2,9 \%)$ was mede hierdoor thuisbehandeling niet te realiseren (bijlage 7.4). De samenstelling en draagkracht van het ondersteunend netwerk in deze studie wijkt behoudens het hoge percentage vrouwen onder partners niet af van andere netwerken. De functionele steun die de patiěnt in deze studie van de verschillende naasten ontvangt varieert zowel praktisch ( $3,4 \mathrm{sd} 1,3$ tot 4,7 sd 0,5$)$ als emotioneel $(3,4$ sd 0,5 tot 4,5 sd 0,8$)$ van gemiddeld tot hoog. De scores van de naaste verzorgers zelf zijn ongeveer gelijk. Courtens rapporteert bij kankerpatiënten gemiddeld per netwerklid 3 (sd 1,2) aan praktische en 4 (sd 0,7$)$ aan emotionele steun." Janssen rapporteert bij gezonden gemiddeld 1,9 (sd 0,9) instrumentele (=praktische) en 3,7 (sd 0,7) emotionele steun, bij patiënten met spondylitis ankylopoetica 2,2 (sd 1,1) instrumentele en 3,7 (sd 1,0) emotionele en bij Crohn 2,2 (sd 0,8) instrumentele en 3,9 (sd 0,7) emotionele. ${ }^{644} \mathrm{CMTZ}$ thuis als infuusbehandeling lijkt in vergelijking met andere zorgsituaties van naasten meer praktische maar evenveel emotionele steun te vereisen.

\subsubsection{Functioneren in deze en andere studies}

Zelfzorgtekorten bepalen de functionele status. Zij stijgen in aard en omvang met de leeftijd. Tabel 13.1 gaf reeds de leeftijd volgens STG categorieën. ${ }^{176}$ Tabel 13.13 geeft het activiteitenpatroon van de patiënt en naaste 1. Doordat meerdere activiteiten ingevuld kunnen worden, is een totaalscore van meer dan $100 \%$ mogelijk. Omdat het opleidings-

Tabel 13.13 Activiteitenpatroon van patienten en naasten 1 per medicatiegroep (\%).

\begin{tabular}{|c|c|c|c|c|c|c|c|c|c|c|}
\hline \multirow[t]{2}{*}{ Activiteit } & \multicolumn{2}{|c|}{ Morfine ${ }^{*}$} & \multicolumn{2}{|c|}{ Mannitol } & \multicolumn{2}{|c|}{ Antibiotica } & \multicolumn{2}{|c|}{ Hartmiddelen } & \multicolumn{2}{|c|}{ Totaal } \\
\hline & $\mathrm{pt}^{\prime}$ & n1 & pt & nI & pt & n1 & pt & n1 & pt & n1 \\
\hline Betaald werk & - & 28 & 20 & 42 & 20 & 25 & 0 & 13 & 15 & 29 \\
\hline Gepensioneerd $^{\circ}$ & - & 19 & 4 & 8 & 40 & 58 & 50 & 13 & 21 & 14 \\
\hline Huishouding & - & 45 & 44 & 21 & 20 & 0 & 25 & 63 & 37 & 45 \\
\hline Vrijwilliger & - & 8 & 24 & 0 & 7 & 0 & 0 & 0 & 14 & 4 \\
\hline Studie & - & 0 & 4 & 4 & 13 & 0 & 0 & 0 & 6 & 1 \\
\hline Werkeloos & - & 2 & 4 & 0 & 0 & 0 & 13 & 0 & 6 & 2 \\
\hline Ziektewet & - & 4 & 20 & 0 & 0 & 8 & 0 & 0 & 12 & 3 \\
\hline WAO/AWW & - & 9 & 12 & 29 & 20 & 8 & 13 & 13 & 14 & 15 \\
\hline
\end{tabular}

Legenda: morfine "=morfine met eventuele parenterale comedicatie, ${ }^{\prime=i n c l u s i e f ~ d e ~ m e d i c a t i e g r o e p e n ~ v o c h t, ~ a n t i-~}$ epileptica, virostatica en overigen, ${ }^{\dagger}=$ terminale patienten, ${ }^{\circ}=$ omvat pensioen, VUT en AOW. Respondenten: patient: $-/ 25 / 15 / 8 / 52$ naaste $1: 52 / 24 / 12 / 8 / 108$. 
niveau bij ouderen niet altijd de sociale klasse weerspiegelt, is ter controle ook naar het (laatste) beroep van de patiënt en naaste gevraagd (\$13.5.1.1).

In het activiteitenpatroon van de meeste patiënten en naasten weerspiegelt zich de leeftijdsopbouw van de onderzoekspopulatie. Bij patiënten met mannitolbehandeling lijkt de aandoening deelname aan het arbeidsproces te belemmeren.

Volgens de SIP-68 scores (tabel 13.14 met hercodering; 'originele' waarden bijlage 13.1) zijn patiënten met infusie van hartmiddelen het ernstigst beperkt. Uitgedrukt in percentages van de SIP-68 scores zijn zij lichamelijk (SA+MC) 33\% beperkt, psychisch (PAC+ES) $43 \%$ en sociaal ( $\mathrm{SB}+\mathrm{MR}$ ) $62 \%$. Bij mannitol- en antibioticabehandeling zijn patiënten ongeveer evenveel beperkt: lichamelijk respectievelijk $23 \%$ en $25 \%$, psychisch $18 \%$ en $11 \%$ en sociaal $34 \%$ en $40 \%$.

Tabel 13.14 Ervaren functioneren van patienten via de gewijzigde SIP-68 per medicatiegroep.

\begin{tabular}{lcccc}
\hline Dimensie- en totaalscores * & Mannitol & Antibiotica & Hartmiddelen & Totaal * \\
Somatische autonomie (SA:17) & $3,2 / 3,0$ & $2,9 / 4,7$ & $3,6 / 2,8$ & $3,2 / 3,5$ \\
& $0-13$ & $0-13$ & $0-7$ & $0-13$ \\
Motorische controle (MC:12) & $3,5 / 2,6$ & $4,4 / 3,6$ & $6,0 / 2,9$ & $4,3 / 3,1$ \\
& $1-10$ & $0-11$ & $1-9$ & $0-11$ \\
Psychologische autonomie en & $1,2 / 1,9$ & $0,7 / 1,2$ & $4,6 / 3,9$ & $1,7 / 2,5$ \\
communicatic (PAC:11) & $0-7$ & $0-4$ & $0-8$ & $0-8$ \\
Sociaal gedrag (SB:12) & $4,2 / 2,9$ & $5,3 / 3,1$ & $8,6 / 2,9$ & $5,2 / 3,2$ \\
& $0-10$ & $0-10$ & $2-11$ & $0-11$ \\
Emotionele gedrag (ES:6) & $1,8 / 1,7$ & $1,1 / 1,9$ & $2,8 / 1,0$ & $1,7 / 1,8$ \\
& $0-5$ & $0-6$ & $1-4$ & $0-6$ \\
Mobiliteitsrange (MR:10) & $3,3 / 3,5$ & $3,5 / 4,1$ & $5,0 / 3,6$ & $3,6 / 3,7$ \\
& $0-10$ & $0-10$ & $0-10$ & $0-10$ \\
\hline Totaal volgens project (68) & $17,1 / 11,3$ & $17,9 / 14,9$ & $30,6 / 14,0$ & $19,6 / 13,3$ \\
& $3-53$ & $0-42$ & $6-45$ & $0-53$ \\
\hline
\end{tabular}

Legenda: "-schaal met 68 dichotome items bestaande uit diverse dimensies die tezamen de functionele status vormen, hoe hoger de score hoe meer beperkingen,"=inclusief de medicatiegroepen vocht, anti-epileptica, virostatica en overigen, exclusief de terminale patienten, $"$ =aantal items per schaal, " $=$ gemiddelde/standaard deviatic en bereik. Respondenten: patient:25/15/8/52.

De belasting is bestudeerd via de uurbelasting, het staken van activiteiten en de CSI. De door de patiěnt en naaste 1 zelf opgegeven aantallen uren vertonen een grote spreiding tot 24 uur toe (tabel 13.15). Ook hier ontbreken -behalve bij naaste 1- de gegevens van de terminale patiënten. Er is gevraagd naar het aantal extra uren. De naaste 1 zelf geeft een iets hoger aantal uren op dan de patient. Bij morfine (continue infusie, terminale fase) en hartmiddelen (continue infusie met draagbare pomp, ernstige invalidering) worden de meeste uren vermeld, bij mannitol iets minder (24-uurs infusie) en bij antibiotica (periodieke infusie) de minste.

Tabel 13.16 geeft de soorten en tabel 13.17 de aantallen activiteiten die naasten hebben gestaakt om de patiesnt bij te staan. Naaste 1 lijkt bij elk soort activiteit een hoger percentage op te geven dan de patiënt. Dit komt doordat de antwoorden van alle naasten 1 zijn opgenomen en bij de patiênten de antwoorden van de terminale patiënten ontbreken. Na correctie hiervoor stemmen de oordelen overeen. Ook bij de aantallen gestaakte activiteiten treedt deze vertekening op. Bij behandelingen met een continue infusie (morfine, mannitol) worden de meeste activiteiten gestaakt. 


\begin{tabular}{|c|c|c|c|c|c|}
\hline Steunverlener & Morfine * & Mannitol & Antibiotica & Hartmiddelen & Totalal \\
\hline Naaste 1 * & $\begin{array}{l}15,9 / 6,7 \\
1-24(45)^{\circ}\end{array}$ & $\begin{array}{l}10,2 / 6,6 \\
2-24(23)\end{array}$ & $\begin{array}{l}7,3 / 7,2 \\
1-24(9)\end{array}$ & $\begin{array}{c}13,3 / 8,1 \\
2-22(6)\end{array}$ & $\begin{array}{l}13,3 / 7,4 \\
1-24(91)\end{array}$ \\
\hline Naaste 1" & - & $\begin{array}{l}8,9 / 6,6 \\
1-24(22)\end{array}$ & $\begin{array}{l}5,9 / 7,3 \\
1-24(10)\end{array}$ & $\begin{array}{l}9,0 / 7,1 \\
2-24(7)\end{array}$ & $\begin{array}{l}8,0 / 6,6 \\
1-24(42)\end{array}$ \\
\hline Naaste 2" & - & $\begin{array}{l}4,1 / 2,7 \\
2-10(16)\end{array}$ & $\begin{array}{c}1,7 / 0,8 \\
1-3(6)\end{array}$ & $\begin{array}{c}7,3 / 11,2 \\
1-24(4)\end{array}$ & $\begin{array}{l}4,0 / 4,5 \\
1-24(29)\end{array}$ \\
\hline Naaste 3" & - & $\begin{array}{l}2,8 / 1,6 \\
1-6(9)\end{array}$ & $\begin{array}{c}1,5 / 0,7 \\
1-2(2)\end{array}$ & $\begin{array}{c}12,5 / 16,3 \\
1-24(2)\end{array}$ & $\begin{array}{l}4,2 / 5,6 \\
1-24(16)\end{array}$ \\
\hline Naaste 4" & - & $\begin{array}{c}2,3 / 2,5 \\
1-6(4)\end{array}$ & $\begin{array}{c}4,0 / \cdots \\
4(1)\end{array}$ & $\begin{array}{l}8,7 / 13,3 \\
1-24(3)\end{array}$ & $\begin{array}{l}4,4 / 7,1 \\
1-24(10)\end{array}$ \\
\hline
\end{tabular}

Legenda: "-uren dat naasten per dag extra in de weer zijn geweest of met de patient hebben doorgebracht vanwege de infuusbehandeling thuis, morfine "-morfine met eventuele parenterale comedicatic,"-inclusief de medicatiegroepen vocht, anti-epileptica, virostatica en overigen,"-volgens naaste 1, 'molgens de patient, exclusief de terminale patienten, " " gemiddelde/standaard deviatie en bereik (aantal respondenten), "* "-geen berekening standaarddeviatie mogelijk. Respondenten naaste I over zichzelf $45 / 23 / 9 / 6 / 91$ en patient over naste $1:-22 / 10 / 7 / 42$ naaste $2:-116 / 6 / 4 / 29$ naaste $3 ;-/ 9 / 2 / 2 / 16$ naaste $4:-/ 4 / 1 / 3 / 10$.

Tabel 13.16 Soorten door naasten geheel of gedeeltelijk gestaakte activiteiten (\%).

\begin{tabular}{lc|cccc}
\hline Activiteit & Naaste 1* & Naaste 1' & Naaste 2' & Naaste 3' & Naaste 4" \\
Werk & $19+11^{*}$ & $4+8$ & $2+8$ & $0+10$ & $0+2$ \\
Hobby & $23+15$ & $6+25$ & $0+15$ & $0+4$ & - \\
Op bezoek gaan & $38+17$ & $19+19$ & $0+12$ & $0+10$ & $0+2$ \\
Bezoek krijgen & $13+16$ & $4+6$ & $0+6$ & $2+6$ & $0+2$ \\
Vakantic & $29+2$ & $8+2$ & $2+4$ & $2+2$ & - \\
Uitgaan & $34+8$ & $13+12$ & $2+6$ & $2+4$ & $0+4$ \\
Studie & $10+2$ & $0+4$ & $0+2$ & $0+2$ & - \\
\hline
\end{tabular}

Legenda: "-volgens naaste 1, "-volgens de patient, exclusief de terminale patienten,"=geheel + gedeeltelijk gestaakt. Respondenten naaste 1 over zichzelf:106 en patient over naaste 1-4:52.

Tabel 13.17 Aantal en percentage van de zeven genoemde activiteiten die naasten staakten *

\begin{tabular}{lccccc}
\hline Steunveriener & Morfine & Mannitol & Antibiotica & Hartmiddelen & Totaal * $^{*}$ \\
Naaste 1" & $2,8(40)^{*}$ & $2,0(29)$ & $1,0(14)$ & $2,6(38)$ & $2,4(34)$ \\
Naaste 1 & - & $1,7(24)$ & $0,5(7)$ & $1,1(16)$ & $1,3(18)$ \\
Naaste 2, & - & $0,7(10)$ & $0,2(3)$ & $0,5(7)$ & $0,6(8)$ \\
Naaste 3 & - & $0,5(7)$ & $0,0(0)$ & $0,4(5)$ & $0,4(6)$ \\
Naaste 4 & - & $0,0(0)$ & $0,0(0)$ & $0,0(0)$ & $0,0(1)$ \\
\hline
\end{tabular}

Legenda: "-werk, hobby, op bezoek gaan, bezoek krijgen, vakantic, uitgaan, studie, morfine"=morfine met eventuele parenterale comedicatie, ${ }^{\prime=}$ inclusief de medicatiegroepen vocht, anti-epileptica, virostatica en overigen, "-volgens naaste 1, " $=$ volgens de patient, exclusief de terminale patienten," =gemiddeld aantal (percentage).

Respondenten naaste 1 over zichzelf:53/24/12/8/106 en patient over naaste $1-4:-/ 25 / 15 / 8 / 52$.

De belasting van naaste 1 via de CSI is aan henzelf en zorgverleners voorgelegd (tabel 13.18). Hier zijn de gemiddelde somscores gegeven (items en scores bijlage 13.2). De belasting varieert per medicatiegroep. Bij groepen patiënten, waar de huisarts relatief weinig betrokken is -mannitol en antibiotica-, schat die de belasting lager in. 


\begin{tabular}{lccccc} 
Beoordelaar & Morfine & Mannitol & Antibiotica & Hartmiddelen & Totaal \\
Naaste 1 & $4,5 / 3,2$ & $2,4 / 2,5$ & $1,5 / 1,6$ & $4,6 / 3,5$ & $3,6 / 3,0$ \\
& $0-12^{*}$ & $0-10$ & $0-4$ & $1-10$ & $0-12$ \\
Verpleegkundige & $5,2 / 3,2$ & $3,0 / 2,5$ & $2,0 / 2,7$ & $3,6 / 3,7$ & $4,0 / 3,3$ \\
& $0-13$ & $0-8$ & $0-10$ & $0-11$ & $0-13$ \\
Arts & $4,6 / 3,1$ & $1,0 / 1,3$ & $0,9 / 1,9$ & $4,1 / 2,8$ & $3,2 / 3,1$ \\
& $0-12$ & $0-4$ & $0-7$ & $0-8$ & $0-12$ \\
\hline
\end{tabular}

Legenda: "-arts is na de indicatiestelling niet altijd bij de uitvoering van infuusbehandeling thuis betrokken geweest, morfine ${ }^{*}=$ morfine met eventuele parenterale comedicatic,"=inclusief de medicatiegroepen vocht, antiepileptica, virostatica en overigen, "=gemiddelde/standaard deviatic en bereik. Respondenten: naaste 1:53/25/12/8/107 verpleegkundige:55/27/12/8/116 arts:51/24/12/8/105.

Het functioneren is bij niet-terminale patienten gemeten met de SIP-68. Een ziekenfondspopulatie in de leeftijd van 18 tot 75 scoort gemiddeld 0,8 op de SIP- $136 .{ }^{650}$ De SIP-68 score bij de patiënten met mannitolinfusie (17 sd 11) komt overeen met die van patiënten met reuma (16 sd 10) of CVA (15 sd 10), is lager dan die van dwarslaesiepatiënten (23) en is hoger dan die van patiênten met dialyse (13), spierziekten (12), kanker (11), hersenschudding (11) en de ziekte van Crohn (5). ${ }^{51}$ Patiënten met antibiotica-infusen (18 sd 15) hebben verschillende aandoeningen en ondervinden ongeveer evenveel beperkingen als patiênten met een mannitolinfuus. Bij de negen patiënten met decompensatio cordis (NYHA:IV) is de SIP-68 score gemiddeld 31 sd 14. Bij decompensatie is elders een gemiddelde score van 12 op de SIP- 136 gevonden ( 62 patiěnten, NYHA: $\mathrm{II}=34 \% \mathrm{III}=63 \%$ $\mathrm{IV}=3 \%)^{6.12}$

Bij de belasting van de naaste zijn er vergelijkingsmogelijkheden op het niveau van de CSI scores. De belasting op de CSI schaal (maximum 13) in deze studie varieert bij naaste verzorgers van 1,5 (sd 1,6) bij patiênten met antibioticabehandeling tot 4,6 (sd 3,6) bij patiênten met decompensatio cordis en is gemiddeld 3,6 (sd 3,0). Het eerste CSI onderzoek bij $65^{+}$patiênten met arteriosclerotische hartaandoeningen of heupchirurgie rapporteert gemiddeld 3,5 (sd 3,5) ${ }^{658}$ Bij een Nederlands onderzoek onder naasten van ouderen op een wachtlijst voor het bejaardentehuis of verpleegtehuis, was de CSI score 6,2 (sd 3,0) ${ }^{665} \mathrm{De}$ belasting van de naaste ( $q=63 \% ; 12 \%$ partner) was daar onafhankelijk geassocieerd met de gegeven zorg, de eigen gezondheid en gevoelens van eenzaamheid. ${ }^{665}$

\subsubsection{Samenvattende benadering zorgsituatie}

Tabel 13.19 vat de zorgsituatie samen naar de STG. ${ }^{176}$ Het lage percentage alleenstaande patiënten wordt veroorzaakt door de inclusiecriteria $(\$ 7.4)$. Bij patiënten met morfineinfusie kunnen de ervaren gezondheid en ADL en HDL beperking niet direct berekend worden, omdat zij geen vragenlijst hoefden in te vullen. Voor de ervaren gezondheid is de inschatting van naaste 1 genomen. De ADL en HDL beperkingen zijn, vanwege de terminale fase, als hoog geclassificeerd.

Tabel 13.20 geeft de verdeling over de resulterende functieklassen. De meeste patienten hebben zelfzorgtekorten op drie niveau's. Zelfzorgtekorten op vier niveau's komen bijna niet voor, omdat de infuusbehandeling meestal een inwonende naaste verzorger vereist. 


\begin{tabular}{|c|c|c|c|c|c|c|}
\hline Tekert & Morfine * & Mannitol & Antibiotica & Hartmiddelen & Totaal * & Score: \\
\hline $\begin{array}{r}0-54 \\
55-74 \\
275\end{array}$ & $\begin{array}{l}22 \\
62 \\
17\end{array}$ & $\begin{array}{r}68 \\
32 \\
0\end{array}$ & $\begin{array}{l}47 \\
20 \\
33\end{array}$ & $\begin{array}{r}0 \\
75 \\
25\end{array}$ & $\begin{array}{l}33 \\
50 \\
17\end{array}$ & $\begin{array}{l}6 \\
4 \\
2\end{array}$ \\
\hline $\begin{array}{r}\text { Gezond wel (1-3) } \\
\text { niet (4-5) }\end{array}$ & $\begin{array}{l}29 \\
71\end{array}$ & $\begin{array}{l}64 \\
36\end{array}$ & $\begin{array}{l}80 \\
20\end{array}$ & $\begin{array}{l}75 \\
25\end{array}$ & $\begin{array}{l}29 \\
71\end{array}$ & $\begin{array}{l}6 \\
2\end{array}$ \\
\hline $\begin{array}{r}\text { Alleenstaand nee } \\
\text { ja }\end{array}$ & $\begin{array}{l}85 \\
15\end{array}$ & $\begin{array}{l}88 \\
12\end{array}$ & $\begin{array}{l}67 \\
33\end{array}$ & $\begin{array}{r}100 \\
0\end{array}$ & $\begin{array}{l}84 \\
16\end{array}$ & $\begin{array}{l}6 \\
2\end{array}$ \\
\hline $\begin{aligned} \text { ADL beperkt laag } \\
\text { hoog }\end{aligned}$ & $\begin{array}{r}0 \\
100\end{array}$ & $\begin{array}{l}72 \\
28\end{array}$ & $\begin{array}{l}67 \\
33\end{array}$ & $\begin{array}{l}25 \\
75\end{array}$ & $\begin{array}{l}27 \\
73\end{array}$ & $\begin{array}{l}6 \\
2\end{array}$ \\
\hline HDL beperkt $\begin{array}{r}\text { laag } \\
\text { hoog }\end{array}$ & $\begin{array}{r}0 \\
100\end{array}$ & $\begin{array}{l}68 \\
32\end{array}$ & $\begin{array}{l}53 \\
47\end{array}$ & $\begin{array}{l}25 \\
75\end{array}$ & $\begin{array}{l}25 \\
75\end{array}$ & $\begin{array}{l}6 \\
2\end{array}$ \\
\hline
\end{tabular}

Legenda: morfine *-morfine met eventuele parenterale comedicatie,"-inclusief de medicatiegroepen vocht, antiepileptica, virostatica en overigen, Score-STG score hoe hoger hoe minder zelfzorgtekorten en hoe zelfredzamer. Respondenten patient:60/25/15/8/117.

Tabel 13.20 Functieklassen naar STG (\%).

\begin{tabular}{lccccc|c} 
Functicklasse & Morfine ${ }^{*}$ & Manaitol & Antibiotica & Hartmiddelen & Totaal & \multicolumn{2}{c}{ Score } \\
1 & 0 & 36 & 33 & 25 & 14 & $28-30$ \\
2 & 0 & 52 & 40 & 0 & 17 & $22-26$ \\
3 & 77 & 8 & 7 & 63 & 52 & $16-20$ \\
4 & 23 & 4 & 20 & 13 & 18 & $10-14$ \\
\hline
\end{tabular}

Legenda: morfine +=morfine met eventuele parenterale comedicatic,"=inclusief de medicatiegroepen vocht, antiepileptica, virostatica en overigen, Score=STG score hoe hoger hoe minder zelfzorgtekorten en hoe zelfredzamer. Respondenten patient:60/25/15/8/117.

\subsubsection{Ervaren kwaliteit van leven}

Tot slot is de patiënt en naaste 1 gevraagd naar hun KvL (tabel 13.21). De verschillen tussen de deelpopulaties komen overeen met die bij de ervaren gezondheid en ernst van de ziekte. Opvallend is ook dat de $\mathrm{KvL}$ van de naaste relatief laag wordt ervaren en ingeschat.

Tabel 13.21 Ervaren en ingeschatte kwaliteit van leven van patienten en naasten 1 per medicatiegroep.

\begin{tabular}{|c|c|c|c|c|c|}
\hline Beoordelaar & Morfine ${ }^{*}$ & Mannitol & Antibiotica & Hartmiddelen & Totaal * \\
\hline \multicolumn{6}{|c|}{ Ervaren/ingeschatte kwaliteit van leven van patiënten ${ }^{\circ}$} \\
\hline Patient & -1 & $4,9 / 2,6$ & $6,9 / 2,5$ & $5,9 / 3,5$ & $5,6 / 2,8$ \\
\hline Naaste 1 & $2,6 / 3,3^{\circ}$ & $4,9 / 2,3$ & $7,0 / 3,0$ & $5,1 / 3,5$ & $3,8 / 3,3$ \\
\hline Verpleegkundige & $2,8 / 2,8$ & $6,7 / 2,4$ & $7,4 / 2,2$ & $3,7 / 2,1$ & $4,4 / 3,2$ \\
\hline Arts & $4,0 / 2,9$ & $6,1 / 1,8$ & $5,6 / 2,0$ & $4,4 / 2,6$ & $4,8 / 6,3$ \\
\hline \multicolumn{6}{|c|}{ Ervaren/ingeschatte kwaliteit van leven van naasten $1^{\circ}$} \\
\hline Naaste 1 & $5,5 / 2,7$ & $5,4 / 2,6$ & $8,6 / 1,3$ & $5,9 / 3,3$ & $5,8 / 2,7$ \\
\hline Verpleegkundige & $5,1 / 2,6$ & $7,1 / 2,0$ & $8,6 / 1,6$ & $7,1 / 2,4$ & $6,2 / 2,6$ \\
\hline Arts & $5,8 / 2,3$ & $7,2 / 1,6$ & $7,5 / 1,5$ & $5,0 / 2,6$ & $6,3 / 2,2$ \\
\hline
\end{tabular}

Legenda: ${ }^{2}=$ continue visueel analoge schaal $0 \mathrm{~cm}$ :laagst denkbare kwaliteit $10 \mathrm{~cm}$ :hoogst denkbare kwaliteit, morfine ${ }^{*}=$ morfine met eventuele parenterale comedicatie,"=inclusief de medicatiegroepen vocht, anti-epileptica, virostatica en overigen, ${ }^{\prime}=$ terminale patienten, ${ }^{*}=$ gemiddelde/standaard deviatic. Respondenten over $\mathrm{KvL}$ patient: patiēnt:-24/14/7/49 naaste $1: 50 / 24 / 11 / 8 / 101$ verpleegkundige:54/27/15/8/115 arts:50/24/15/7/103.

Respondenten over KvL naaste 1: naaste 1:50/24/11/8/102 verpleegkundige:54/27/12/8/113 arts:50/23/12/7/100. 


\subsubsection{Samenhangen tussen KvL-indicatoren in deze en andere studies}

In de nu volgende tabellen worden de correlaties gegeven tussen de in de eerste kolom genoemde items en het in de kopregel genoemde item. De tweede kolom geeft aan welke samenhang a priori vanuit de literatuur is verwacht. De derde en volgende kolommen geven weer bij welke respondent een bepaalde correlatie bepaald is. Soms hebben de vanuit de literatuur verwachte correlatie en de in de tabel volgende correlaties vanwege de wijze van vraagstelling een tegengesteld teken terwijl ze toch toch in dezelfde richting wijzen. Dit wordt aangegeven door een uitroepteken achter de literatuurcorrelatie. Onder de responderende patiënten bevinden zich geen terminale patiënten.

Bij de sociaal-demografische kenmerken onderling (geslacht, leeftijd, opleiding, inkomen) is er alleen bij de patiënt een zwakke samenhang tussen pijn en vrouw zijn ( $\rho=0.36 n=51$ $p=0,01$ ). Waarschijnlijk doordat SRD meer bij vrouwen en dus in deze studie voorkomt. $\mathrm{Er}$ is geen samenhang gevonden tussen de ervaren ernst van de ziekte en de gezondheid van de patiēnt en sociaal-demografische kenmerken. Waarschijnlijk komt dit door de homogeniteit van de groepen en de relatief lage aantallen.

De ernst van de ziekte en de pijn van de patiěnt hangen bij de naaste 1 vrij zwak ( $\rho=0.45$ $n=103 p<0,001)$ en bij de verpleegkundige zwak samen $(\rho=0.36 n=103 p<0,001)$, bij de patiënt zelf is er een tendens tot een zeer zwakke samenhang $(\rho=0.26 n=51 p=0,069)$, bij de arts is er geen samenhang $(\rho=0.19 n=103 p=0,055)$. Niet iedere patiênt heeft pijn en SRD patiënten hebben wel pijn, maar zijn niet ernstig ziek.

Bij de patiënt hangt de ervaren gezondheid zwak samen met de ernst van de ziekte (tabel 13.22) en vrij zwak met de pijn (exclusief terminale patiënten). Bij naasten en zorgverleners worden grotere samenhangen gevonden tussen de gezondheid van de patiënt met de ernst van de ziekte dan met de pijn. Dit verschil is te verklaren doordat niet alle patiënten pijn hebben. De gezondheid die naaste 1 zelf ervaart lijkt zeer zwak samen te hangen met de door de patiënt zelf ervaren gezondheid, maar niet met de door de naaste 1 ingeschatte gezondheid van de patiënt. Het eerste is te verklaren uit de overeenkomst in sociaaldemografische kenmerken en leefsituatie tussen patiënten en naasten, het tweede lijkt erop te duiden dat de naaste de gezondheid van de patiënt niet goed kan inschatten.

Tabel 13.22 Samenhangen met de ervaren/ingeschatte gezondheid van patienten per respondent.

\begin{tabular}{ll|cccc}
\hline Item & L & Patiënt & Naaste 1 & Verpleegkundige & Arts \\
Emst ziekte patient & - & $-.30 / 52 /, 029^{\circ}$ & $-.78 / 106 /, 000$ & $-.78 / 104 /, 000$ & $-.88 / 104 /, 000$ \\
Pijn patient ' & -1 & $.47 / 51 /, 001$ & $.38 / 103 /, 000$ & $.26 / 103 /, 000$ & $.19 / 103 /, 049$ \\
Gezondheid naaste 1 & + & $+.30 / 44 /, 049$ & $.06 / 103 /, 540$ & & - \\
\hline
\end{tabular}

Legenda: L-literatuur, " $=$ door de naaste 1 zelf opgegeven, $"=p$-correlatic / aantal respondenten / p-waarde, '=positieve correlatie betekent hoe meer pijn hoe minder gezond.

De gegeven danwel ontvangen praktische en emotionele steun hangen bij de patiēnt $(\rho=0.61 n=47 p<0,001)$ en naaste $1(\rho=0.54 n=105 p<0,001)$ vrij sterk samen. Tabel 13.23 geeft andere samenhangen met steun aan. In het algemeen belemmert een slechte gezondheid het geven van fysieke maar niet van emotionele steun, voorts is het geven van steun fysiek vermoeiend maar geeft emotionele bevrediging. In deze studie ontvangt de patiênt meer praktische en vooral meer emotionele steun naarmate de naaste verzorger meer verwant is (rangschikking naaste 1 in aflopende volgorde volgens tabel 13.10: 
praktisch $\rho=0.38 n=43 p=0,012$ en emotioneel $\rho=0.51 n=43 p<0,001) .{ }^{\infty 60}$ Er zijn vrijwel geen samenhangen aangetroffen tussen de steun en de ernst van de ziekte, de pijn en de gezondheid van de patiênt. Waarschijnlijk hangt de benodigde steun evenzeer samen met de belemmering van de diverse infuusbehandelingen zelf (zie tekst bij tabel 13.24). Bij de patiënt is er een zeer zwakke samenhang (emotioneel) en een tendens daartoe (praktisch) tussen de ontvangen steun en de ervaren gezondheid (minder steun als gezonder). Bij de naaste verzorger is er alleen een zwakke samenhang tussen de ernst van de ziekte van de patiênt en de hoeveelheid gegeven praktische steun (minder steun als ernstiger ziek). Wellicht geven naasten (zorgverleners nemen over) minder steun bij ernstig zieken omdat professionele zorgverieners dit overnemen of onderwaarderen zij de gegeven steun omdat zij het gevoel hebben tekort te schieten. Kortom, zowel de richtingen als verklaringen voor eventuele samenhangen met steun zijn ook in dit onderzoek niet eenduidig.

Tabel 13.23 Samenhangen met de ervaren praktische en emotionele steun per respondent.

\begin{tabular}{|c|c|c|c|c|c|}
\hline \multirow[b]{2}{*}{ Item } & \multirow[b]{2}{*}{ L } & \multicolumn{2}{|c|}{ Praktrische Steun } & \multicolumn{2}{|c|}{ Emotionele Steun } \\
\hline & & Patient & Naaste 1 & Patient & Naaste 1 \\
\hline Ernst ziekte patient ${ }^{1}$ & $\pm !$ & $-21 / 44 / .175^{\circ}$ & $.29 / 106 /, 002$ & $.12 / 44 /, 435$ & $.19 / 106 /, 052$ \\
\hline Pijn patient & + & $-.09 / 44 /, 543$ & $19 / 103 /, 050$ & $-.12 / 44 /, 460$ & $21 / 103 /, 030$ \\
\hline Gezondheid patient ${ }^{2}$ & -1 & $.29 / 44 / .055$ & $-19 / 106 / .046$ & $30 / 44 /, 045$ & $.21 / 106 /, 035$ \\
\hline Gezondheid naaste $1^{-3}$ & $\pm !$ & - & $-.02 / 104 / .876$ & . & $.16 / 106 /, 108$ \\
\hline KvL naaste $\mathrm{t}^{*}$ & - & - & $-.12 / 102 /, 250$ & - & $-.04 / 102 /, 717$ \\
\hline
\end{tabular}

Legenda: L=literatuur, " =door de naaste 1 zelf opgegeven, $"=\rho$-correlatie / aantal respondenten / $p$-waarde, I=negatieve correlatie betekent hoe emstiger ziek hoe meer steun, ${ }^{2}=$ positieve correlatie betekent hoe gezonder hoe minder steun, ${ }^{3}=$ negatieve correlatic betekent hoe gezonder hoe meer steun gegeven wordt.

Ook is gekeken naar eventuele samenhangen tussen leeftijd, ziekte en behandeling en het ervaren functioneren van de patiënt (tabel 13.24). In deze volgorde worden infusie van hartmiddelen ( $2 \times 24$ uur per week), antibiotica (giften elke dag) en mannitol ( $7 \times 24$ uur) geacht toenemend (hogere SIP-68 score) te beperken (positieve correlatie), de ernst van de aandoening afnemend (negatieve correlatie). Deze tegengestelde effecten heffen elkaar op, hun onderlinge correlatie is niet significant $(\rho=-0.21 \mathrm{n}=52 \mathrm{p}=0,135)$. De uiteindelijke functiebeperking lijkt eerder toe te rekenen aan de ernst van het onderliggend lijden dan aan de behandeling. Bij de SIP-136 zijn Pearson correlaties van 0.35-0.67 met de ernst van de ziekte en van 0.35-0.63 met de ervaren gezondheid gevonden. ${ }^{629,631,653}$ In het onderhavig onderzoek met de SIP-68 is dit niet reproduceerbaar. Waarschijnlijk wederom door de homogeniteit. Er is alleen een vrij zwakke samenhang aangetroffen tussen een hogere leeftijd en slechter functioneren (Spearman rangcorrelatie).

Tabel 13.24 Samenhangen met het ervaren positieve functioneren (SIP-68)

\begin{tabular}{lc|cccc}
\hline Variabele & L & Mannitol & Antibiotica & Hartmiddelen & Totaal * \\
Leeftijd patient & - & $-.33 / 25 /, 113^{*}$ & $-.65 / 15 /, 008$ & $.08 / 8 /, 853$ & $-.49 / 52 /, 000$ \\
Ernst ziekte patiēnt & - & $-.30 / 25 /, 142$ & $-.20 / 15 /, 473$ & $-.57 / 8 /, 142$ & $-.21 / 52 /, 135$ \\
Pijn patient & - & $.05 / 25 /, 818$ & $-.17 / 14 /, 556$ & $-.48 / 8 /, 230$ & $-.09 / 51 /, 528$ \\
Gezondheid patient & + & $.31 / 24 /, 136$ & $-.09 / 15 /, 748$ & $.44 / 8 /, 274$ & $.23 / 51 /, 110$ \\
\hline
\end{tabular}

Legenda: L=literatuur, "=gespiegelde SIP-68 score: hoge score is hier beter functioneren,"=inclusief de medicatiegroepen vocht, anti-epileptica, virostatica en overigen, $"=p$-correlatie / aantal respondenten / p-waarde. 
Tussen de sociaal-demografische kenmerken en de ervaren $\mathrm{KvL}$ van de patiënt is geen samenhang aangetroffen. Wel zijn bij verschillende respondenten de verwachte samenhangen gevonden tussen de KvL van de patiënt met ernst van de ziekte (zeer zwak tot vrij sterk), pijn (niet tot vrij sterk), ervaren gezondheid (zwak tot vrij sterk) en functioneren (SIP-68), maar ook bijvoorbeeld met een hogere KvL van naaste 1 (tabel 13.25). Bij reumapatiēnten zijn bij dezelfde samenvattende vraag naar $\mathrm{KvL}$ significante samenhangen met sociaal economische status, ervaren ernst van de aandoening en de SIP-136 gevonden. ${ }^{318} \mathrm{Bij}$ onderzoek onder kankerpatiënten hing meer emotionele steun samen met een hogere $\mathrm{KvL} .{ }^{311} \mathrm{Er}$ is in deze studie geen relatie tussen steun en $\mathrm{KvL}$ gevonden. Waarschijnlijk omdat andere factoren (pijn, ernst van ziekte en ervaren gezondheid) een sterkere invloed hadden. Want hoewel steun geacht wordt de KvL te verhogen, wordt ook meer steun gegeven naarmate de toestand van de patiẻnt slechter en daarmee diens KvL lager is. Deze tegengestelde effecten kunnen zich uitmiddelen.

Tabel 13.25 Samenhangen met de ervaren/ingeschatte kwaliteit van leven van patienten per respondent.

\begin{tabular}{|c|c|c|c|c|c|}
\hline Item & $\mathbf{L}$ & Patient & Naaste 1 & Verpleegkundige & Arts \\
\hline Emst ziekte patient ${ }^{\prime}$ & -1 & $30 / 49 /, 040^{\circ}$ & $.50 / 101 /, 000$ & $.58 / 115 /, 000$ & $.34 / 103 /, 000$ \\
\hline Pijn patient & - & $-62 / 49 /, 000$ & $-.41 / 98 /, 000$ & $-.31 / 114 /, 000$ & $-12 / 102 /, 193$ \\
\hline Praktische steun & \pm & $.19 / 43 /, 233$ & $-.06 / 101 /, 573$ & $\cdot$ & - \\
\hline Emotionele steun & \pm & $.20 / 43 / .204$ & $-.04 / 101 /, 708$ & - & - \\
\hline Gezondheid patient ${ }^{2}$ & +1 & $.62 / 49 /, 000$ & $.52 / 101 /, 000$ & $-.58 / 115 /, 000$ & $-.40 / 103 /, 000$ \\
\hline Functioneren ${ }^{\infty}$ & + & $.33 / 49 /, 021$ & - & - & - \\
\hline Gezondheid naaste $1^{\circ 2}$ & +1 & $-.33 / 43 /, 300^{3}$ & $-.27 / 99 /, 006^{4}$ & $\cdot$ & - \\
\hline KvL naaste $1^{\circ}$ & + & $.54 / 43 /, 000^{3}$ & $.59 / 100 /, 000^{4}$ & - & - \\
\hline
\end{tabular}

Legenda: "-opgave door naaste I zelf, " =gespiegelde SIP-68 score: hoge score is beter functioneren, " $=p$-correlatie / aantal respondenten / p-waarde, "=positieve correlatie betekent hoe ernstiger ziek hoe lager de $\mathrm{KvL},{ }^{2}=$ negatieve correlatie betekent hoe gezonder hoe hoger de $\mathrm{KvL}$, ${ }^{1}=$ gezondheid en $\mathrm{KvL}$ van de patient zoals ingeschat door naaste 1 , ${ }^{4}$ gezondheid en $\mathrm{KvL}$ van naaste 1 zelf.

Bij mogelijke invloeden op de ervaren $\mathrm{KvL}$ van naaste 1 is vooral gekeken naar eventuele samenhangen met belasting (tabel 13.26). De ervaren gezondheid van naaste 1 hangt vrij zwak samen met de ernst van diens eigen ziekte $(\rho=-0.51 \mathrm{n}=36 \mathrm{p}=0,001)$. Bij naaste 1 hangt de ervaren, doch redelijk concreet via de CSI gemeten, belasting zwak met de ernst

Tabel 13.26 Samenhangen met de ervaren/ingeschatte belasting (CSI) van de naasten 1 per respondent.

\begin{tabular}{|c|c|c|c|c|}
\hline Item & L & Naaste 1 & Verpleegkundige & Arts \\
\hline Praktische steun & + & $.20 / 106 /, 033^{\circ}$ & - & - \\
\hline Emotionele steun & + & $.06 / 106 /, 518$ & - & - \\
\hline Emst zickte naaste $1^{\prime}$ & +1 & $-.35 / 37 /, 033$ & - & - \\
\hline Gezondheid naaste $1^{2}$ & -1 & $.45 / 104 /, 000$ & $\therefore$ & $\therefore$ \\
\hline Ernst ziekte patient ' & +1 & $-.45 / 106 /, 000$ & $-38 / 116 /, 000$ & $-.54 / 105 /, 000$ \\
\hline Pijn patient & + & $.36 / 103 /, 000$ & $.38 / 115 /, 000$ & $.17 / 104 /, 091$ \\
\hline Gezondheid patient ${ }^{2}$ & -1 & $-.40 / 106 / .000$ & $-.41 / 116 /, 000$ & $-.46 / 105 /, 000$ \\
\hline KvL patient & - & $-.38 / 101 /, 000$ & $-.30 / 115 /, 001$ & $-.15 / 103 /, 136$ \\
\hline
\end{tabular}

Legenda: " $-\rho$-correlatic / aantal respondenten / p-waarde, '-negatieve correlatic betekent hoe emstiger ziek hoe belastender, "-positieve correlatie betekent hoe gezonder hoe minder belastend. 
van een eventuele eigen aandoening en vrij zwak met de eigen gezondheid samen. Even grote samenhangen (zeer zwak tot vrij zwak) worden bij naaste 1 en vaak bij de zorgverleners gevonden tussen de ervaren belasting van naaste 1 en de ernst van de ziekte, de pijn, de gezondheid en de KvL van de patient. Opvallend is dat het geven van praktische en emotionele steun de naaste niet lijkt te belasten (verklarende variantie op CSI $\$ 5 \%$ ). Wel is er een vrij sterke samenhang gevonden tussen slecht functioneren (SIP-68) van de patiênt en de ervaren belasting van naaste $1(\rho=0.55 n=46$ ps 0,001$)$.

Tussen de ervaren $\mathrm{KvL}$ van naaste 1 en sociaal-demografische kenmerken (geslacht, leeftijd, opleiding, inkomen) is geen samenhang gevonden. De 'verwantschap' van patiēnten en naasten uit zich bij de KvL van naaste 1, die evenveel lijkt samen te hangen met de toestand en KvL van degene die ze bijstaan, veelal hun partner, als met de eigen toestand. Samenhangen tussen de $\mathrm{KvL}$ van naaste 1 en de door de patiënt ervaren gezondheid (zwak: $\rho=0.32 n=44 p=0,037$ ) en pijn ( $z w a k: \rho=0.42 n=44 p=0,005$ ) en KvL (vrij sterk: $\rho=0.54 n=43 p<0,001$ ) lijken dit te staven. Het geven van praktische en emotionele steun lijkt de KvL van naaste 1 niet te verlagen. Mede gezien de in vele gevallen ernstige onderliggende aandoening en daaruit reeds voortkomende zelfzorgtekorten is de belasting van de gehele zorg inclusief de infuuszorg, gemeten via de invloed van de CSI op de KvL van naaste 1, klein $\left(\approx 10 \%\right.$ verklarende variantie). ${ }^{32}$ Het lijkt derhalve aannemelijk dat de naastenzorg ten aanzien van infuuszorg thuis de KvL van naaste 1 niet vermindert.

Tabel 13.27 Samenhangen met de ervaren/ingeschatte kwaliteit van leven van naasten I per respondent.

\begin{tabular}{|c|c|c|c|c|}
\hline Item & $\mathbf{L}$ & Naaste 1 & Verpleegkundige & Arts \\
\hline Ernst ziekte naaste I' $^{\prime}$ & -1 & $.03 / 37 /, 859^{\circ}$ & $\cdot$ & • \\
\hline Gezondheid naaste $I^{2}$ & +1 & $-.36 / 99 /, 000$ & - & - \\
\hline Praktische steun & - & $-.12 / 102 /, 250$ & - & - \\
\hline Emotionele steun & - & $-.04 / 102 /, 717$ & $\cdot$ & $\cdot$ \\
\hline Belasting (CSI) naaste I & $\cdot$ & $-.32 / 102 /, 001$ & $-.18 / 89 /, 085$ & $-.14 / 89 /, 188$ \\
\hline Emst ziekte patiênt ${ }^{1}$ & -1 & $.26 / 102 /, 008$ & $.39 / 113 /, 000$ & $.27 / 99 /, 007$ \\
\hline Pijn patient & - & $-.34 / 99 /, 001$ & $-.17 / 112 /, 090$ & $-.19 / 99 /, 056$ \\
\hline Gezondheid patient ${ }^{2}$ & +1 & $-.24 / 102 /, 016$ & $-.44 / 113 /, 000$ & $-.33 / 99 /, 001$ \\
\hline KvL patient & + & $.59 / 100 /, 000$ & $.49 / 112 /, 000$ & $.65 / 99 /, 000$ \\
\hline
\end{tabular}

Legenda: $\mathrm{L}=$ literatuur, $"=\rho$-correlatic / aantal respondenten / $\mathrm{p}$-waarde, ${ }^{\prime}=$ positieve correlatie betekent hoe emstiger ziek hoe lager de $\mathrm{KvL}$, ${ }^{2}=$ negatieve correlatie betekent hoe gezonder hoe hoger de $\mathrm{KvL}$.

\subsubsection{OVEREENSTEMMING TUSSEN RESPONDENTEN IN DEZE EN ANDERE STUDIES}

De overeenstemming tussen de verschillende respondenten binnen het patiênt- en het zorgsysteem en tussen beide systemen is gemeten bij diverse indicatoren (correlaties tabel 13.28 verklarende varianties bijlage 13.5). Degene die de patiënt als naaste 1 aangeeft is soms niet degene die als naaste 1 de vragenlijst heeft ingevuld (tabel 13.10). Over alle respondentenparen bezien is de overeenstemming over de ervaren ernst van de ziekte en gezondheid van de patiënt het hoogst ( $\rho$-correlatie opgeteld en gedeeld door zes $=0.54$ ), die over de pijn iets minder $(\rho \approx 0.46)$ en over KvL nog minder $(\rho \approx 0.30)$. Ook de overeenstemming over de belasting $(\rho=0.30)$ en $\operatorname{KvL}(\rho \approx 0.23)$ van de naaste zijn laag. Het kunnen inschatten van met name de belasting van naasten door zorgverleners is van belang. 
$\mathrm{Bij}$ verdeling van de CSI totaalscore in een hoge (zeven en hoger) en een lage score, blijkt de overeenstemming tussen beoordelaars (na correctie voor het toeval) tussen naaste verzorgers en zorgverleners en tussen zorgverleners onderling zeer laag (kappa: 0,10 tot 0,27 ). Op itemniveau stemt hun oordeel ook nauwelijks overeen (kappa: $-0,1$ tot 0,38 ).

Tabel 13.28 Overeenstemming tussen oordelen van respondenten in paren.

\begin{tabular}{|c|c|c|c|}
\hline \multicolumn{4}{|c|}{ Exclusief terminale patienten } \\
\hline Item & Patiěnt-Naaste 1 & Patiēnt-Verpleegk. & Patiěnt-Arts \\
\hline Ernst ziekte patient & $.45 / 45 /, 002^{\circ}$ & $.40 / 45 /, 007$ & $.20 / 45 /, 184$ \\
\hline Pijn patient & $.74 / 44 /, 000$ & $.44 / 44 /, 003$ & $.40 / 43 / .007$ \\
\hline Gezondheid patient & $.33 / 45 /, 030$ & $.16 / 45 /, 281$ & $.29 / 45 /, 057$ \\
\hline Praktische steun & $35 / 44 /, 019$ & - & - \\
\hline Emotionele steun & $30 / 44 /, 047$ & - & - \\
\hline KvL patient & $.26 / 43 /, 094$ & $.22 / 42 /, 154$ & $.45 / 42 /, 003$ \\
\hline \multicolumn{4}{|c|}{ Inclusief terminale patiênten } \\
\hline Item & Naaste 1-Verpleegk. & Naaste 1-Arts & Verpleegk-Arts \\
\hline Emst zickte patient & $.69 / 93 /, 000$ & $.74 / 93 /, 000$ & $.76 / 104 /, 000$ \\
\hline Pijn patient & $.42 / 90 /, 000$ & $.44 / 90 /, 000$ & $.33 / 102 /, 001$ \\
\hline Gezondheid patient & $.78 / 93 /, 000$ & $.81 / 93 /, 000$ & $.87 / 104 /, 000$ \\
\hline KvL patient & $.34 / 88 /, 001$ & $.28 / 86 /, 009$ & $.23 / 102 /, 019$ \\
\hline Belasting naaste I & $21 / 95 /, 038$ & $.29 / 95 /, 004$ & $39 / 104 /, 000$ \\
\hline KvL naaste I & $.20 / 88 /, 059$ & $.37 / 86 /, 000$ & $13 / 97 /, 189$ \\
\hline
\end{tabular}

Legenda: verpleegk.=verpleegkundige, $"=\rho$-correlatie / aantal respondenten / p-waarde.

Elders meldt men dat de patiënt diens gezondheid positiever inschat dan de arts, maar dat zij toch redelijk overeenstemmen (58-77\% overeenstemming inclusief toeval). ${ }^{634}$ In het onderhavig onderzoek is deze overeenstemming lager (verklarende variantie $8 \%$ ). Dit verschil is slechts ten dele te verklaren doordat professionele zorgverleners meer de 'disease' beoordelen en de patiënt en naaste 1 meer de 'illness'. ${ }^{618,619,666}$ Hiervoor pleit dat het oordeel van naaste 1 over de gezondheid van de patiënt tussen het eigen oordeel van de patiênt en dat van de zorgverleners in ligt (tabel 13.8). Mogelijk kunnen echter ook de tot somatisering neigende persoonlijkheid van SRD patiënten ( $55 \%$ van de groep waaruit de correlatie voortkomt) en de in zekere mate berustende en mogelijk ontkennende patiënten met hartfalen ( $18 \%$ van de groep) het verschil deels verklaren. ${ }^{548-550}$ De kans op passende professionele zorg is dan ook moeilijk in te schatten. De gevonden overeenstemming tussen patiënten en zorgverleners zijn enerzijds vrij zwak, maar anderzijds vergelijkbaar met die tussen de patiěnt en naaste zelf.

\subsection{Beschouwing}

Bij de bestudering van de spreiding van sociaal-demografische kenmerken, de onderlinge verbanden, en de vergelijking met patiëntengroepen in andere studies zijn geen aanwijzingen gevonden dat CMTZ in de vorm van IT binnen het hier gekozen zorgmodel niet breed toegankelijk is voor verschillende patiènten(groepen). Wel is de aanwezigheid van een naaste verzorger ook in de toekomst van cruciaal belang. Ten aanzien van de objectieve en ervaren gezondheid, de steun binnen, het functioneren en de KvL van het patiëntsysteem, de vergelijking daarvan met uitkomsten van andere studies en de 
onderlinge samenhangen zijn geen aanwijzingen gevonden dat CMTZ als IT binnen het gekozen zorgmodel de $\mathrm{KvL}$ van de patiěnt of naaste verzorger negatief beînvloed. Wel kan de gehele zorgsituatie behoorlijk belastend zijn. De continulteit binnen de professionele en niet-professionele en tussen beide zorgsystemen zoals gemeten via de overeenstemming ten opzichte van de patient in oordelen over gezondheidsaspecten en $\mathrm{KvL}$ is laag. Ten opzichte van de naaste en onderling stemmen zorgverleners goed overeen over de gezondheid van de patiënt en minder over de belasting van de naaste. Ten aanzien van de KvL van de patiènt en naaste stemt de huisarts nog het meest overeen.

De onderzoekspopulatie omvat alle patie̋nten die tijdens de projectperiode aangemeld zijn en die aan de instroomcriteria voldeden (\$7.4). De non-respons is met $6 \%$ tot $13 \%$ aanvaardbaar (\$7.6.3). Bij de drie voortijdig beęindigde behandelingen zijn de redenen bekend en waren deze niet toe te schrijven aan het zorgmodel. De beperking van patiënten tot de regio 'Heuvelland' en het hoge percentage samenwonenden komen voort uit de instroomcriteria. De vorm van de ziektekostenverzekering kan gezien de verdeling over de inkomensklassen, niet als indicator voor de sociaal economische klasse dienen. Wel geeft deze inzicht in eventuele bias tengevolge van het feit dat een bepaalde soort zorg door éen van beide verzekeringsvormen niet (volledig) vergoed wordt. Op grond van de sociaaldemografische kenmerken zijn er geen aanwijzingen dat de onderzoekspopulatie afwijkt van de regionale bevolking met dezelfde onderliggende aandoeningen. Op grond van opleiding en inkomen is te veronderstellen dit ook voor de coping geldt. Vanuit de literatuur zijn geen sterke samenhangen tussen sociaal-demografische kenmerken bekend. De aangetroffen samenhangen zijn waarschijnlijk zwakker dan in de bevolking omdat het veelal een oudere, (chronisch) zieke populatie betreft. De daadwerkelijke toegang tot de zorg wordt dan ook voornamelijk beperkt door het exclusiecriterium alleen wonen (H:7).

De voornaamste moeilijkheid bij het meten van $\mathrm{KvL}$ is: "Measuring the undefinable: quantifying the quality" ${ }^{57,667}$ In deze studie zijn geen voor deze populatie gevalideerde meetinstrumenten gebruikt. Wel zijn een aantal vanuit de theorie veronderstelde samenhangen tussen demografische kenmerken, gezondheid, ziekte, pijn, steun, belasting en $\mathrm{KvL}$ aangetroffen die pleiten voor een afdoende constructvaliditeit (schema 13.2).

Het was niet mogelijk deze patiënten te vergelijken met patiënten die eenzelfde behandeling in het ziekenhuis ontvingen (\$2.5). Ten aanzien van patiěnten met kanker, SRD en hartfalen is een vergelijking met door anderen beschreven groepen mogelijk. De vergelijking bij deze deelpopulaties geeft geen aanwijzingen dat de sociaal-demografische en ziektekenmerken en de opvattingen over de gezondheid van de studiepopulatie afwijken van elders. Er bestaat aldus geen indicatie voor een beperkte toegankelijkheid van zorg of een afwijkende zorgsituatie of KvL.

Structurele kenmerken van het patiëntennetwerk in deze studie zijn afgezet tegen andere zorgnetwerken. Behoudens een iets hoger percentage vrouwen onder partners wijkt het niet wezenlijk af. Gezien de samenstelling en draagkracht van het ondersteunend netwerk binnen deze studie, kunnen de vergrijzing en de toename van het alleen wonen in de toekomst een potentieel probleem voor de daadwerkelijke toegankelijkheid van CMTZ thuis zoals IT vormen.

In vergelijking met andere zorgsituaties lijkt IT van naasten meer praktische maar evenveel 
emotionele steun te vereisen. Op verschillende manieren gemeten, is de belasting voor de naasten bij terminale thuiszorg het hoogst. Met name de hoeveelheid praktische steun die IT vereist, kan de daadwerkelijke toegang beperken. Ook lijkt IT zonder uitgebreide ondersteunende professionele zorg vaak niet mogelijk ( $\mathrm{H}: 8,15)$.

Uiteindelijk kunnen de beperkingen van aandoeningen en hun behandelingen tot uiting komen in het functioneren van patiénten..$^{311,618,619}$ Het advies om de COOP/WONCA kaart als maat voor functioneren te laten meelopen dateert van na de start van het onderzoek. ${ }^{668}$ De gezondheidsgerelateerde $\mathrm{KvL}$ in termen van algemeen functioneren gemeten volgens de SIP-68 lijkt bij patiennten met CMTZ thuis zoals IT lijkt behoorlijk beperkt. Waarschijnlijk speelt het onderliggend lijden hierin een belangrijke rol. De belemmering tengevolge van de infuusbehandeling hierin wordt op maximaal tien punten van de SIP-68 geschat. De SIP-68 valt in het gebruik tegen (zowel de belasting voor patiênten als de validiteit van de uitkomsten). De samenhangen tussen de SIP-68 als globale indicator voor het functioneren en andere variabelen zijn lager dan verwacht. Voor toepassing zoals in dit onderzoek lijkt de SIP-68 minder valide (constructvaliditeit; zie ook §13.4.2.3).

Bij naasten is vooral de belemmerende invloed van het geven van steun op hun eigen functioneren onderzocht. Van alle naaste verzorgers geeft ongeveer $75 \%$ aan betaald werk te hebben, het huishouden te voeren en/of vrijwilligerswerk te doen. Van deze respondenten geeft $40 \%$ aan die werkzaamheden tijdens de infuuszorg geheel of gedeeltelijk gestaakt te hebben. Bij de vraag over de uurbelasting lijken de opgaven aan de hoge kant, omdat gevraagd is naar het aantal extra uren en naaste 1 vaak een huisgenoot is. De belasting van de gehele zorgsituatie gemeten volgens de CSI komt wel degelijk tot uiting in het functioneren van naasten (voor financiêle waardering zie $\mathrm{H}: 15$ ). Toch lijkt het geven van steun niet als te belastend ervaren te worden.

Een samenvattende benadering van de uitgangspositie van het patiëntsysteem op basis van zelfzorgtekorten volgens de STG is arbeidsintensief. Ter vereenvoudiging hebben wij de resultaten niet gebruikt voor Delphi-onderzoek, maar direct in klassen omgerekend. In plaats van ADL en HDL schalen hebben wij SIP-68 items gebruikt. De verdeling is dan: klasse $1: 14 \% 2: 17 \% 3: 52 \%$ en $4: 18 \%$. In het oorspronkelijk STG onderzoek is er geen verschil in zelfzorgbehoeften tussen klasse 3 en 4 patiënten, wel is de overeenstemming in het Delphi-onderzoek hoger. In deze studie vallen veel patiênten in klasse 3 en niet in 4 omdat men vanwege de behandeling meestal niet alleen mag wonen. Onze methode lijkt ook in de praktijk toepasbaar en kan gebruikt worden om de zelfzorgtekorten van en tussen categorieěn patiënten bij CMTZ thuis te vergelijken en om de aard van de eventueel benodigde zorg vast te stellen. Bijvoorbeeld psychosociale begeleiding bij een als slecht ervaren gezondheid en praktische ondersteuning bij ADL en/of HDL beperkingen.

Een belangrijke factor bij $\mathrm{KvL}$, de coping, is niet direct gemeten. Op grond van opleiding en inkomen is verondersteld dat deze niet afwijkt. In het algemeen is de KvL van de patienten met infuuszorg thuis laag. Vaak is dit te verwachten gezien de ernst van de aandoening (kanker, hartfalen). Doch ook bij SRD patiënten is de KvL opvallend laag. Bij de naaste verzorgers van kankerpatiennten en hartfalen is gezien de oudere leeftijd en de zorgsituatie een lagere KvL verwacht. Opvallend is dat zij hun $\mathrm{KvL}$ met een onvoldoende waarderen. Ook valt op dat de naasten van $S R D$ patiěnten hun KvL gemiddeld het laagst waarderen. Wellicht voelen zij zich het meest door de IT in hun vrijheid beknot vanwege 
Het vergelijken van de meningen van de verschillende respondenten geeft inzicht in het niet-professionele en het professionele perspectief en is te gebruiken voor data-triangulatie omdat een basale overeenstemming verwacht mag worden. Een belangrijke kanttekening is dat er per categorie respondenten vanuit de verschillende achtergronden (naaste versus zorgverlener) en een verschillende beleving van dezelfde situatie (huisarts komt bijvoorbeeld minder frequent en vaker 's middags) verschillend geantwoord kan worden op 'dezelfde vraag'. Een beter inzicht hierin vereist meer onderzoek onder grotere aantallen respondenten met aandacht voor deze aspecten. In het algemeen stemmen de oordelen van respondenten minder overeen naar gelang de concepten minder concreet zijn (tabel 13.28). Meestal stemt het oordeel van naaste 1 redelijk overeen met dat van de patiënt. Over zaken als praktische en emotionele steun is de overeenstemming lager. Soms is echter degene die de patiěnt als naaste 1 opgeeft niet degene die als naaste 1 de vragenlijst heeft ingevuld. De basis voor passende informele zorg lijkt aanwezig.

De zorgverleners onderling stemmen goed met elkaar overeen wat de ervaren ernst van de ziekte en de gezondheid betreft maar zijn het minder eens over de KvL en de pijn. Dit laatste is mogelijk te verklaren doordat de verpleegkundige meer tijd met de patiēnt doorbrengt dan de arts. Ook de overeenstemming over de ernst van de ziekte, pijn en gezondheid van de patiènt is redelijk. Al met al is de basis voor op elkaar afgestemde professionele zorg aanwezig, maar is deze zeker voor verbetering vatbaar. Bijvoorbeeld door meer overleg en een meer gezamenlijke beleidsbepaling.

Hoewel de CSI niet voor zorgverleners ontwikkeld is, is hen gevraagd de belasting van de naaste verzorger in te schatten. De overeenstemming over deze variabele is lager dan over andere. Bij de CSI items en de totaalscore is de overeenstemming tussen beoordelaars na correctie voor toevallige overeenstemming (kappa) tussen zorgverleners onderling en tussen naaste verzorgers en zorgverleners zeer laag. Dit kan betekenen dat het meetinstrument zoals toegepast niet valide is. Waarschijnlijker is dat de zorgverleners de toestand van naaste 1 minder goed kunnen inschatten dan die van de patiënt. De kans dat de naaste passende professionele steun ontvangt lijkt dan ook lager dan bij de patiënt.

\subsection{Conclusies}

De STG methodiek voor het bepalen van zelfzorgtekorten is ook in praktijkonderzoek toepasbaar en kan gebruikt worden om de zorgsituatie van en tussen categorieën patiënten te vergelijken en om de aard van de eventueel benodigde zorg te kunnen inschatten. $\mathrm{Er}$ vallen weinig patiënten af door toetsing aan de voorwaarden en tijdens de behandeling. Het zorgmodel is dan ook breed toepasbaar bij verschillende aandoeningen, behandelingen, patiëntsystemen en achtergronden. Naasten geven veel steun aan de patiënten, maar dit wordt niet als te belastend ervaren. Wel is het zorgmodel door de benodigde steun van naasten kwetsbaar omdat het professioneel equivalent thuis maatschappelijk onbetaalbaar is. Zorgverleners blijken de belasting van naasten moeilijk te kunnen inschatten. Er zijn geen aanwijzingen gevonden dat de thuisbehandeling het functioneren of de $\mathrm{KvL}$ van patiënten en/of naasten in zodanige mate vermindert, dat thuisbehandeling daarom niet verantwoord zou zijn. Deze conclusie wordt gesteund door de uitkomsten van de evaluaties in hoofdstuk 8 en 14 . In deze studie lijken aandoening en behandeling de $\mathrm{KvL}$ slechts ten dele te bepalen. Indien de coping in strikte zin was gemeten met daartoe geěigende meetinstrumenten waren betekenisvollere uitspraken mogelijk geweest. 


\section{Zorg: kwaliteit, tevredenheid en doelmatigheid *}

\subsection{Inleiding}

Substantieel rationele doelen in de gezondheidszorg zijn het: voorkomen en behandelen van morbiditeit, streven naar zo min mogelijk functionele beperkingen en bevorderen van persoonlijk welbevinden. ${ }^{.60}$ Geconstateerd is dat IT als voorbeeld voor CMTZ $(\mathrm{H}: 4,6)$ aangeboden wordt in het licht van de door de modernisering veranderende relatie tussen patiënten, zorgverleners en overheid tegen een achtergrond van een maximaliserende individuele aanspraak (patiěntenemancipatie, zorg op maat, zorggroei) versus een minimaliserend collectief aanbod (doeltreffend, doelmatig, maatschappelijke grenzen aan zorg). IT dient -naast breed toegankelijk- kwalitatief verantwoord én doelmatig te zijn voor patiënten met verschillende niveau's van zelfzorgtekorten en sociaal-demografische kenmerken. ${ }^{66}$ Enerzijds is het persoonlijk welbevinden van patiënten bestudeerd ( $\left.\mathrm{H}: 13\right)$, anderzijds de infuuszorg zelf. Aandachtspunt 8 binnen hoofdvraagstelling III betrof de kwalificatie van zorg door patiënten, hun naasten en zorgverleners. Daarom worden in dit hoofdstuk de kwaliteit en doelmatigheid van en de tevredenheid met IT besproken.

\subsection{Theoretisch kader}

\subsubsection{THEORETISCH KADER KWALITEIT EN DOELMATIGHEID VAN ZORG}

Kwaliteit stamt af van het Latijnse qualitas dat "hoedanigheid" betekent. ${ }^{670} \mathrm{Kwaliteit}$ van zorg $(\mathrm{KvZ})$ is als een kameleon. ${ }^{671}$ Is zij goed dan gaat zij in de omgeving op, bij een manco steekt zij schril af. Kwaliteit is globaal gezien enerzijds een oordeel, een subjectgebonden mening: "in the eye of the beholder", anderzijds een eigenschap, een objectgebonden begrip: "intrinsiek kenmerk". De inhoud van het begrip kwaliteit hangt samen met de positie van waaruit, de context waarin, het niveau waarop en de doelstelling waarbinnen men tot een uitspraak over het begrip kwaliteit of de meting daarvan tracht te komen. ${ }^{660}$ Ook de bestudering van gezondheidszorg is sterk afhankelijk van de gekozen invalshoek. ${ }^{520}$ Hierna volgen verschillende modellen en hun belangrijkste implicaties. Algemene modellen voor de bestudering van (een deel van) de gezondheidszorg zijn: de sandwich-, de ijsberg-, Donabedian's en de aspectbenadering. ${ }^{520}$ In het sandwichmodel (drie lagen) wordt de áán- of afwezigheid van ziekten in de samenleving (de volksgezondheid) enerzijds bepaald door determinanten als schoon drinkwater of medische zorg en komt anderzijds tot uiting in indicatoren als sterfte, gebruik van voorzieningen,

- Een samenvatting van dit hoofdstuk is eerder verschenen in Kwaliteit \& Zorg 1997;5(3):100-14. 
functionele status, het algemeen welbevinden en tevredenheid met de zorg. Veelal bestudeert $\mathrm{KvZ}$ onderzoek deze indicatoren. Het ijsbergmodel is van belang vanwege de aandacht voor het verschil tussen het totaal aan aandoeningen zoals dat in de bevolking voorkomt en dat deel dat in de gezondheidszorg behandeld wordt, alsook de mogelijke verklaringen daarvoor (bijvoorbeeld cultureel en individueel ziektegedrag, verwijspatroon huisartsen, enzovoorts). Donabedian heeft ten behoeve van (onderzoek naar) KvZ de gezondheidszorg ingedeeld in structuur, proces en uitkomst (resultaat) ${ }^{672}$ De structuur omvat de gehele materiêle en immateriêle context (organisatie) van de behandeling en bevat elementen als toegankelijkheid, bereikbaarheid en continulteit van zorg. Binnen de behandeling, ook wel het primair proces genoemd, wordt aandacht besteed aan de definiêring van professionele standaarden omtrent therapeutisch handelen, bejegening, scholing, veiligheid van middelen en apparatuur, communicatie en samenwerking. Uitkomst- of resultaatmaten zijn metingen van het resultaat van behandeling, door Lohr onderscheiden in: "death, disease, disability, discomfort en dissatisfaction". ${ }^{673}$ Deze vijf vormen nog altijd de meest gemeten uitkomstparameters. De relaties tussen structuur, proces en uitkomst zijn niet altijd eenduidig: de uitkomst van één proces (wetgeving) kan deel uitmaken van de structuur van een ander proces (gezondheidszorg). Voorts hebben structuur, proces en uitkomst onderling niet altijd een sterke relatie. In de gezondheidszorg heeft lange tijd vooral de kwaliteitsbewaking op proces- en in mindere mate structuurniveau op de voorgrond gestaan ${ }^{62}$ Bij bestudering van $\mathrm{KvZ}$ zijn echter zowel de organisatie, het zorg'produktie'proces als het eindprodukt van belang.

Aspectbenaderingen bewegen zich op het grensgebied van bovengenoemde algemene en specifieke modellen. De gezondheidszorg wordt in onderdelen opgedeeld en bij elk onderdeel worden voor $\mathrm{KvZ}$ van belang zijnde eigenschappen -aspecten- benoemd. ${ }^{441,42}$ Specifieke modellen voor bestudering van $\mathrm{KvZ}$ richten zich op de zorguitvoering, de organisatie of uitkomsten van de zorg zoals de patiëntsatisfactie. Zij worden dan ook ingedeeld in zorginhoudelijke (realiseren goede zorg), bedrijfskundige (verbeteren organisatie) en dienstverlenende benaderingen (afstemmen op wensen cliênt) ${ }^{674} \mathrm{De}$ Nationale Raad voor de Volksgezondheid (NRV) heeft bij de beroepsuitoefening KvZ ingedeeld in methodisch-technisch (vakinhoudelijk) handelen, de attitude (houding) van de beroepsbeoefenaar en de organisatie van de beroepsuitoefening. ${ }^{400}$ Van elk zijn verschillende aspecten onderscheiden. ${ }^{440}$ Het meest bekende en door Mintzberg uitgebreid bestudeerde specifieke organisatiemodel is dat van de professionele bureaucratie waarin (groepen) professionals vrij autonoom werken binnen een faciliterende organisatie die zorgdraagt voor zaken als administratie, huisvesting en algemene bedrijfsvoering (bijvoorbeeld ziekenhuis). ${ }^{675} \mathrm{~K}$ waliteit is vanuit patienntenorganisaties gedefinieerd als aandacht voor individuele verschillen, autonomie, zelfbeschikking en ondeelbaarheid van het individu bij de voorwaarden, het proces en het produkt. ${ }^{676}$

\subsubsection{Definitie VAN KWALITEIT EN DOELMATIGHeid VAN ZORG}

Gezien het bovenstaande is kwaliteit niet eenduidig te definiëren. Van oudsher gold: "Hoog gekwalificeerde zorg is die zorg die al de relevante kennis en technieken aanwendt die ter beschikking staan van de gezondheidszorg" ${ }^{67}$ In de zorginhoudelijke benadering heeft Donabedian gesteld dat het bij KvZ gaat om: "de mate van overeenkomst tussen de doelen van de gezondheidszorg en de werkelijk verleende zorg", ofwel de doeltreffendheid. ${ }^{678,679}$ Williamson introduceerde vanuit een pragmatische invulling ook de doelmatigheid en daarmee het bedrijfskundig aspect in de definitie van KvZ: "kwaliteit is 
de mate van overeenkomst tussen gestelde en bereikte doelen in de zorgverlening met vermijding van onnodig gebruik van middelen" ${ }^{680}$ Een stelling die Donabedian in latere publikaties onderschrijtt. ${ }^{\text {772 }}$ Berwick introduceerde in de jaren 80 een afgeleide bedrijfskundige benadering. ${ }^{61,002} \mathrm{Na}$ een uitvoerige beschouwing definiêren Harteloh en Casparie $\mathrm{KvZ}$ als: "Er is sprake van kwaliteit, indien er een optimale verhouding bestaat van het gerealiseerde ten opzichte van verwachtingen, met betrekking tot een bepaald aspect van de gezondheidszorg". ${ }^{520}$ Ook in deze definitie is kwaliteit ingegeven door het streven naar het beste. Een neutralere definitie, waarin het gehanteerde perspectief het optimum bepaalt, ontleent de NRV aan NEN/ISO normen: "Kwaliteit is de mate waarin de eigenschappen van (gezondheids)zorg voldoen aan de eisen of behoeften, die vanuit het perspectief van de betrokkenen zijn gesteld". onderzoek (RGO) en de Nederlandse organisatie voor Wetenschappelijk Onderzoek (NWO) sluiten hierbij aan. ${ }^{41,42}$ Volgens de Kwaliteitswet Zorginstellingen dient er sprake te zijn van verantwoorde zorg, en dient zij in ieder geval doeltreffend, doelmatig en patienntgericht te worden verleend en afgestemd te zijn op de reelle behoefte van de patient (art.2). ${ }^{66}$ Op basis hiervan kan KvZ 'geoperationaliseerd' worden in een zorginhoudelijk (doeltreffend), bedrijfskundig (doelmatig) en dienstverlenend (patięntgericht) domein. Hier wordt KvZ bij de op de zorgverleningstheorie van Orem gebaseerde CMTZ gedefinieerd als: een zorginhoudelijk, bedrijfskundig en dienstverlenend optimale verhouding tussen de individuele op zelfzorgbehoeften gebaseerde zorgvraag van de patiênt en de aangeboden gestandaardiseerde zorg (schema 1.3).

\subsubsection{THEORETISCH KADER EN DEFINITIE VAN TEVREDENHEID}

Aandacht voor de $\mathrm{KvZ}$ en de toegenomen mondigheid van patiënten vinden elkaar in het tevredenheidsonderzoek. Terwijl KvZ onderzoek ook 'objectievere' aspecten bestudeert, omvat tevredenheidsonderzoek vrijwel altijd 'subjectieve' oordelen. Tevredenheid wordt dan ook wel de kameleon onder de uitkomstmaten van $\mathrm{KvZ}$ genoemd ${ }^{633}$ Andersom is veel $\mathrm{KvZ}$ onderzoek als tevredenheidsonderzoek te bestempelen. In navolging van Visser nemen Lemmens en Donker de kwaliteitsbeoordeling door de patiënt als ervaringsdeskundige tot uitgangspunt: "een patiënt beoordeelt op een eigen waarderingsschaal met eigen maatstaven, hoe tevreden die is met ieder aspect van de hulpverlening" ${ }^{660,684}$ Patiënten oordelen binnen hun normen, waarden en vaardigheden. ${ }^{685}$ Deze hangen af van biografische, sociaal-demografische en psychologische factoren. ${ }^{686}$

Normaliter wordt tevredenheid gezien als het bevredigd zijn van een verlangen ofwel voldoening over het gebodene. ${ }^{677}$ Evenals bij $\mathrm{KvZ}$ speelt ook bij de definiëring van tevredenheid de verhouding tussen de verwachte en de gerealiseerde zorg. ${ }^{688}$ Donabedians drie-componenten model over KvZ komt terug in Pascoe's definitie van tevredenheid: "a health care recipient's reaction to salient aspects of the context, process, and result of their service experience" ${ }^{689}$ Tevredenheid is echter niet alleen afhankelijk van het behandelingsresultaat, het heeft ook invloed daarop en op het gebruik van zorg. ${ }^{689,690}$ Analoog aan Harteloh en Casparie bij KvZ benadrukt Linder-Pelz bij tevredenheid de gerichtheid op het positieve: "a positive evaluation of distinct dimensions of the health care". 520,691 Tevredenheid is op te vatten als een attitude. ${ }^{692}$ Daarbij kan de aandacht op het affect liggen: "a general evaluation or feeling of favorableness or unfavorableness towards the object in question". ${ }^{689}$ Pascoe onderscheidt tevens een cognitief aspect: "This comparitive process is ... assumed to include two interrelated psychological activities: a cognitively based evaluation or grading .. and an affectively based response or emotional reaction..". 
Harteloh en Casparie definiëren tevredenheid dan ook als een attitude met affectieve, cognitieve en conatieve (wils)elementen. ${ }^{520}$ Daarop variërend onderscheidt Philipsen: objectief/cognitief (waarheid), subjectief/affectief (waarachtigheid) en evaluerend/normatief (gerechtvaardigdheid) ${ }^{693}$ Samenvattend hangen attitude, cognitie en evaluatie als volgt samen: "a person's attitude toward an object is related to his beliefs that the object possesses certain attributes and his evaluation of those attributes". 692

$\mathrm{Bij}$ al deze benaderingen speelt de afweging tussen het gewenste dan wel verwachte en het ontvangene een rol (contrastmodel). ${ }^{69}$ Verwachtingen kunnen gericht zijn op minimale (basispakket) zorg, gerechtvaardigde (aanspraak/recht op) zorg, reēle zorg (gebaseerd op ervaring) en optimale zorg. ${ }^{609}$ Hun invloed op tevredenheid lijkt echter gering. ${ }^{64,691,694696}$ Zo kunnen verwachtingen tijdens de zorg veranderen. ${ }^{600}$ Ook kunnen patiēnten spanningen die discrepanties tussen het verwachte en het gebodene teweegbrengen verminderen door de beleving van zorg bij te stellen (assimilatiemodel, op basis van cognitieve dissonantietheorie). ${ }^{69}{ }^{67} \mathrm{Bij}$ contrast, hetzij assimilatie, zijn de eigen beheersbaarheid, voortduring en opzet van de stressor van belang. ${ }^{67}$ Het gecombineerde contrast-assimilatiemodel verklaart waarom kleine verschillen niet beleefd worden (assimilatie), maar grote wel (contrast). ${ }^{69}$ Hier wordt tevredenheid met de zorg bij de op de zorgverleningstheorie van Orem gebaseerde CMTZ gedefinieerd als: De algemene evaluatie van de zorg of het algemene gevoel van wel- of onbehagen daarbij.

\subsubsection{VALLITIEIT EN BETROUWBaARHEID}

In het algemeen dienen gelijksoortige meetinstrumenten bij dezelfde populatie overeenkomstige resultaten te geven. Ook dienen een meetinstrument en haar indicatoren voldoende onderscheid te maken tussen populaties. ${ }^{698}$ Omdat $\mathrm{KvZ}$ een moeilijk te bepalen concept is, dient zeker bewaakt te worden dat het meetinstrument vanuit de theorie te begrijpen uitkomsten geeft. Daarbij dienen theoretische verbanden tussen verschillende indicatoren voldoende tot uiting te komen. De relatie met de hulpverlener, het voortduren van de behandeling, de meetomgeving en het meetmoment kunnen leiden tot vertekeningen. Het oordeel kan veranderen tijdens de zorg ('response shift') en is bijvoorbeeld kort na afloop positiever dan tijdens de zorg ('hello-goodbye effect'). ${ }^{699}$ Daarnaast kan aandacht alleen al tot 'resultaten' leiden ('Hawthorne effect'). Ten slotte kunnen de verwachtingen van de onderzoeker de resultaten beïnvloeden. ${ }^{69}$

Qua betrouwbaarheid lijken schalen betere resultaten op te leveren dan meetinstrumenten met éen of slechts enkele items. ${ }^{689}, 700$ Wel dient bij de constructie van een schaal de interne consistentie bewaakt te worden en dient het meetinstrument voldoende gevoelig te zijn. Ook kunnen andere betrouwbaarheidsmaten zoals de intra- en interbeoordelaars overeenstemming van belang zijn.

$\mathrm{Bij} \mathrm{KvZ}$ zijn de volgende overwegingen met name van belang. Bij KvZ kan gevraagd worden naar het oordeel over de gezondheidszorg in het algemeen of specifieker naar een oordeel gebaseerd op eigen ervaringen. ${ }^{519} \mathrm{Bij}$ algemene kwaliteitsbeoordeling zou de invloed van andere factoren zoals de Kwaliteit van Leven $(\mathrm{KvL})$ op de $\mathrm{KvZ}$ groter zijn. Ook veronderstelt men dat de oordeelsvorming veel genuanceerder is dan een algemene houding kan uitdrukken: men is niet (on)tevreden maar men is (on)tevreden met iets. ${ }^{655,695}$ Specifieke aspecten bieden meer aanknopingspunten voor kwaliteitsbevordering. ${ }^{659} \mathrm{KvZ}$ kan onderscheiden worden in domeinen. Daarbinnen kunnen weer dimensies onderscheiden worden. ${ }^{519}$ Meerdere dimensies of items verhogen de inhoudsvaliditeit, wel kan de keuze van de juiste aspecten problemen opleveren. ${ }^{519}$ Meerdere items lijken de respons 
niet nadelig te belinvloeden. ${ }^{519}$ Ook is een multidimensionele score om te zetten in een 'unidimensionele' totaalscore. ${ }^{700}$ Empirisch komen echter niet steeds dezelfde dimensies naar voren of blijken oordelen over bepaalde aspecten sterk samen te hangen. ${ }^{319} \mathrm{De}$ discussie of patięnten een oordeel kunnen uitspreken over technisch-inhoudelijk handelen of onderscheid kunnen maken tussen vaktechnische en interpersoonlijke aspecten is bijvoorbeeld nog niet gesloten. ${ }^{62,519,683,680,701}$

Bij tevredenheidsonderzoek verdient de validiteit extra aandacht, aangezien meestal $75 \%$ of meer van de respondenten tevreden is. ${ }^{34 .}{ }^{002}$ Is men werkelijk tevreden, voelt men zich tevreden of laat de validiteit van de onderzoekstechnieken te wensen over? $199,600,600,702 \mathrm{Via}$ frequentieverdelingen -of grover het bereik- kan sociale wenselijkheid (alleen maar hoge scores) op het spoor worden gekomen.

Hoewel het verband op zich klein is, hangt tevredenheid nog het sterkst samen met de tevredenheid met $\mathrm{KvL}$ en het vertrouwen in de gezondheidszorg. ${ }^{\mathrm{as}}$ De samenhang met gezondheid is nog onduidelijk, meestal hangt een betere gezondheid samen met hogere tevredenheid. ${ }^{103}$ Vrouwen, ouderen, mensen met een lagere sociaal economische status en kerkelijken zijn tevredener en geven meer sociaal wenselijke antwoorden. ${ }^{64,046}, 004$ Het beste lijkt een combinatie van kwalitatief en kwantitatief onderzoek waarbij de unieke ervaringen van de patiēnt behouden blijven. ${ }^{600}$ Het vragen naar een mening over stellingen verdient de voorkeur boven het directe vragen. $\mathrm{Er}$ bestaat geneigdheid in te stemmen met opinie-uitspraken ongeacht de inhoud en geneigdheid om steeds hetzelfde antwoord te geven. ${ }^{600,}$, 059,705 Bij de beantwoording van vragen naar ontevredenheid is er minder sociale wenselijkheid. ${ }^{63}$ Het noemen van de respondent in de vraag kan leiden tot een specifieker oordeel, maar ook tot hogere sociale wenselijkheid. ${ }^{660,689}$ Confronterende methoden zoals een interview geven een grotere respons, maar meer sociaal wenselijke antwoorden dan bijvoorbeeld een postenquête. Open vragen leiden tot minder sociale wenselijkheid, maar belemmeren toepassing op grote schaal en leiden tot minder betrouwbare uitspraken. In tevredenheidsonderzoek speelt sociale wenselijkheid een geringere rol dan meestal wordt aangenomen. Het verklaart over het algemeen maar zo'n $5 \%$ van de variantie. ${ }^{706}$

\subsection{Doel- en vraagstellingen}

Kwaliteit van zorg is vanuit een zorginhoudelijke (kwaliteit), een dienstverlenende (tevredenheid) en een bedrijfskundige (efficiëntie) optiek benaderd. ${ }^{674}$

1) Een wettelijk verankerde doelstelling van het verlenen van zorg is dat deze doeltreffend is. ${ }^{66}$ De eerste vraagstelling betreft dan ook of IT vanuit de zorginhoudelijke benadering kwalitatief verantwoord is. Zij omvat subvraagstellingen over specifieke (plus hun totaalscore) en samenvattende aspecten van de kwaliteit en de belasting van de zorg. Om de zorginhoudelijke aspecten binnen de $\mathrm{KvZ}$ te bestuderen is een model en meetinstrument ontwikkeld. Om eventuele 'Diskwaliteit van Zorg' te meten is samenvattend gevraagd naar de belasting door de infuuszorg. ${ }^{693}$

2) Eveneens dient de zorg patiëntgericht te zijn. ${ }^{66}$ Daarom is de tweede vraagstelling of IT vanuit een dienstverlenende benadering kwalitatief verantwoord is. Zij omvat subvraagstellingen over de tevredenheid met en oordelen over de zorgverlening. Daartoe zijn een algemeen oordeel over de tevredenheid met de zorg via een tevredenheidsvragenlijst én rapportcijfers over de zorgverleners en over de organisatie (alleen aan de zorgverleners) gevraagd.

3) Bovenstaande twee benaderingen hebben ieder hun eigen invalshoek en voor- en nadelen. Een derde vraagstelling is dan ook hoe de uitkomsten van de zorginhoudelijke 
( $\approx$ kwaliteit op onderdelen) en dienstverlenende ( $\approx$ tevredenheid over het geheel) benadering zich verhouden. Daartoe is hun samenhang bestudeerd (statistiek §2.6.2).

4) Omdat deze studie niet vergelijkend opgezet is, betreft de vierde vraagstelling de vergelijking met andere vormen van (regionale) klinische en thuiszorg.

5) Ook dient de zorg afgestemd te zijn op de reëele behoefte van de patiënt. ${ }^{66}$ De vijfde vraagstelling is dan ook hoe de oordelen van patiènten, hun naasten en zorgverleners zich verhouden. Ter bestudering hiervan, zijn diverse items aan allen voorgelegd.

Subvraagstellingen hierbij zijn of de antwoorden van de patiënt en de naaste vanuit hun relatie meer met elkaar overeenstemmen dan met die van de zorgverleners, of de antwoorden van de zorgverleners vanuit hun professie meer met elkaar overeenstemmen dan met die van de patiënt en de naaste, én in hoeverre de antwoorden van het patiënt- en het zorgsysteem overeenstemmen. Naarmate patiēnten en naasten meer overeenstemmen neemt de kans op passende informele zorg toe. Naarmate de zorgverleners meer overeenstemmen neemt de kans op onderling afgestemde professionele zorg toe. Tot slot neemt, naarmate de antwoorden van het patiëntsysteem en zorgverleners meer overeenstemmen, de kans toe dat de professionele zorg aansluit op de behoeften van het patiëntsysteem.

6) Tot slot dient zorg doelmatig te zijn. ${ }^{6}$ De zesde vraagstelling is dan ook of de verleende zorg vanuit bedrijfskundige optiek kwalitatief verantwoord is.

Hierna volgen de gebruikte meetinstrumenten en hun validiteit en betrouwbaarheid.

14.4 Overkoepelend aspectmodel voor borging en meting kwaliteit van zorg Getracht is de zorginhoudelijke, dienstverlenende en bedrijfskundige benaderingen te integreren in één overkoepelende aspectbenadering. Om gedetailleerd uitspraken te kunnen doen over onderdelen van de zorg én omdat het patiëntperspectief centraal staat, is primair uitgegaan van de zorginhoudelijke aspectbenadering vanuit de patiěnt naar analogie van de NRV, RGO en NWO (schema 14.1). ${ }^{18,40-412}$ Afhankelijk van het aspect zijn ook dienstverlenende en bedrijfskundige eigenschappen te bestuderen en zijn de uitkomsten ook bruikbaar voor zorgverleners, instellingen, verzekeringen en overheid. Om die reden is niet alleen onderzocht hetgeen patiènten zelf van belang vinden. ${ }^{707}$

Schema 14.1 Groepsindeling kwaliteitsaspecten.

\begin{tabular}{llll}
\hline NRV to & RGO & NW & Infuuszorg Thuis" \\
Methodisch-technisch & Medisch-Technisch & Zorg-Technisch & Kennis \& Kunde \\
Attitude & Bejegening & Relationeel & Atittude \\
Organisatic & Samenwerking & Samenwerking & Samenwerking \\
& Organisatorisch & Organisatorisch & Organisatorisch \\
\hline
\end{tabular}

In schema 14.2 zijn de kwaliteitsaspecten naar bovenstaande groepsindeling in vier hoofdcategorieen ingedeeld. Per kwaliteitsaspect is aangegeven of dit volgens RGO/NWO vanuit het perspectief van de patiênt, de zorgverlener, de instelling of de overheid van belang is. Ook is aangegeven op welke wijze en in welk hoofdstuk aan een aspect aandacht besteed is en of hiervoor een indicator beschikbaar is. Een indicator is gedefinieerd als "een meetbaar element van de zorgverlening dat functioneert als een mogelijke aanwijzing voor de KvZ". ${ }^{411}$ Indicatoren kunnen 'objectiever' of 'subjectiever' van aard zijn. 'Objectief' zijn bijvoorbeeld financiele toegankelijkheid, infectie-incidentie, bijwerkingen en complicaties. 'Subjectief' zijn bijvoorbeeld bejegening en verantwoordingsbereidheid van de zorgverleners. Enige voornamelijk 'objectievere' indicatoren zijn veelal direct 
gemeten. Deze zijn reeds gedeeltelijk in de procesbeschrijving in deel III aan de orde gekomen. Andere 'subjectievere' indicatoren zijn via stellingen ondergebracht in een

Schema 14.2 Kwaliteit van complexe medisch-technische zorg (primair vanuit patientperspectief).

\begin{tabular}{|c|c|c|c|c|c|}
\hline $\begin{array}{l}\text { Aspect naar analogie van } \\
\text { NRYRGONWO/nrT }\end{array}$ & Persp & Activiteit & Hifds & Meting & Hifds \\
\hline \multicolumn{6}{|l|}{ A. Vakinhoudelijke kennis en kande } \\
\hline indicatiestelling (3) & pz & informatic, intake & $7,8,9$ & $\mathrm{~N}$-, instroom & 2 \\
\hline voorkomen overbodige zorg (23) & pv & informatie, intake & $7,8,9$ & $\mathrm{~N}+$ & 14 \\
\hline doeltreffendheid (1) & $p z$ & protocollering & $6,8,12$ & No, complicaties & $7-12$ \\
\hline veiligheid (5) & pavo & protocollering & $7,8,12$ & $\begin{array}{l}\mathrm{N}-\text {, complicaties, } \\
\text { ZKM }\end{array}$ & 12 \\
\hline deskundigheid: kennis+kunde (2) & pzvo & scholing & 10 & N-, proces, ZKM & 10 \\
\hline geschiktheid (4) & $p z$ & sollicitatie & 8 & rapportcijfer & 14 \\
\hline hygiene (21) & p & handelingslijst & 8 & $\mathrm{~N}-$, infecties & 12 \\
\hline materiele privacy (20) & p & instructic & 8 & ZKM & 14 \\
\hline $\begin{array}{l}\text { B. Aminude van zorgverleners } \\
\text { zorgvuldigheid }(6)^{1}\end{array}$ & pz & protocollering & 8 & $\begin{array}{l}\mathrm{N} \text {-, complicaties, } \\
\mathrm{ZKM}\end{array}$ & 12,1 \\
\hline inlevingsvermogen (24) & p & instructie & 6.8 & $\mathrm{~N}+$ & 8 \\
\hline bejegening (7) & pzV & instructie & 6,8 & $\mathrm{~N}+, \mathrm{ZKM}$ & 14 \\
\hline informatiebereidheid (8) & pzv & instructic & 6,8 & $\mathrm{~N}+, \mathrm{ZKM}$ & 14 \\
\hline verantwoordingsbereidheid (11) & pzvo & instructic & 6,8 & $\mathrm{~N}-, \mathrm{ZKM}$ & 14 \\
\hline vertrouwensrelatic (9) & $\mathrm{pz}$ & $\cdot$ & & $\mathrm{N}+$ & 8 \\
\hline cooperatiebereidheid $(10)^{2}$ & pz & instructic & $5,6,8$ & $\mathrm{~N}-, \mathrm{ZKM}$ & 14 \\
\hline zelf beslissen door patient ( 26 ) & $p$ & instructie & $5,6,8$ & $\mathrm{~N}+, \mathrm{ZKM}$ & 14 \\
\hline $\begin{array}{l}\text { betrokkenheid patient bij zorg }{ }^{3} \\
\text { en bevorderen zelfzorg }{ }^{3}\end{array}$ & p & instructie & $5,6,8$ & $\mathrm{~N}+, \mathrm{ZKM}$ & 14 \\
\hline \multicolumn{6}{|c|}{ C. Samenwerking zorgverleners en instellingen } \\
\hline taakafbakening $(28)^{\circ}$ & $i\left(p^{\dagger}\right)$ & protocollering & 6,8 & No, ZKM & 14 \\
\hline continurteit (12) & pzo & overdracht & 8 & $\mathrm{~N}-$, proces & 8,14 \\
\hline integrale zorg (afstemming) (15) & pzi & protocollering & 8 & $\mathrm{~N}=, \mathrm{ZKM}$ & 14 \\
\hline \multicolumn{6}{|c|}{ D. Functionele organisatie en inrichting van de zorg } \\
\hline beschikbaarheid (13) & pz & intake & 8 & instroom & 13 \\
\hline gelijk recht op zorg (31) & 0 & intake & 8 & $\mathrm{~N}-$, instroom & 13 \\
\hline financiele toegankelijkheid (18) & p & financiering & 11 & $\mathrm{~N}-$, kosten & 15 \\
\hline bereikbaarheid (16) & pio & samenwerking & $5,6,8$ & $\mathrm{~N}-$ & 8 \\
\hline accommodatic (19) & pi & nvt & & nvt & \\
\hline voeding (22) & p & nvt & & nvt & \\
\hline management (27) & $\mathrm{i}$ & begeleidingscie & 8 & - & \\
\hline interne kwaliteitsbewaking (29) & $\mathrm{i}$ & $\begin{array}{l}\text { peer review, } \\
\text { overleg }\end{array}$ & 8 & $\mathrm{~N}-$ & 8 \\
\hline leiding doet aan kwaliteit (33) & i & $\cdot$ & & - & \\
\hline ondersteunen mantelzorg ${ }^{3}$ & p & zorgmodel & $4,6,8$ & CSI & 13 \\
\hline belasting patient ( 25 ) & P & zorgmodel & $4,6,8$ & No, belasting & 13 \\
\hline patièntensatisfactie (17) & piv & zorgmodel & $4,6,8$ & No, CSQ & 14 \\
\hline doelmatigheid (14) & pzvo & protocollering & 8,11 & kosten & 14,15 \\
\hline
\end{tabular}

Legenda: pIT=project 'Infuusbehandeling Thuis', Persp=perspectief, Hfds=hoofdstuk, 0 =NRV/RGO nummer 1-15:NRV aspecten 16-33:door RGO toegevoegd waarbij aspect 32 ontbreekt, p=patient, z=zorgverlener, $i=$ instelling, v=verzekeraar, $\mathrm{o}=$ overheid, $\mathrm{N}-$-notulen onderzocht en problemen aangetroffen, No=notulen onderzocht en geen betrouwbare uitspraak te doen, $\mathrm{N}+=$ notulen onderzocht en geen problemen aangetroffen, $\mathrm{ZKM}=$ stellingen op grond van de zorg-kwaliteitsmatrix in schema 14.3, ${ }^{1}=$ rekent NRV tot methodisch-technisch kwaliteitsaspect, "-vanwege het accent op de relationele kant is "bereidheid" aan "cooperatie" toegevoegd, 1=door NWO toegevoegd aan RGO aspecten," =complementaire samenwerking is voor de patient van belang. -geen activiteiten ontplooid, nvt=niet van toepassing vanwege thuiszorg, cie=commisic, -niet gemeten, $\mathrm{CSI}=$ Caregiver Strain Index, CSQ=Client Satisfaction Questionnaire. 
Zorg-KwaliteitsMatrix die hierna besproken wordt (schema 14.3). Naar deze aspecten verwijst schema 14.2 als " $Z \mathrm{KM}$ ". Een aantal kwaliteitsaspecten betreft de vakinhoudelijke kennis en kunde van de zorgverleners. De indicatiestelling is op geprotocolleerde wijze uitgevoerd op basis van criteria voor doelgroepen en individuele patiënten. $\mathrm{Zij}$ is bestudeerd via kenmerken van de aangemelde, de ingestroomde en de tijdens de behandeling uitgevallen patiënten (\$7.6). Overbodige zorg is zowel vanwege de aard van de behandeling als vanwege het zorgverleningsperspectief van Orem minder waarschijnlijk. Zorg is zoveel mogelijk overgedragen naar het patiëntsysteem of andere professionele zorgverleners. De doeltreffendheid van de thuis toegepaste behandelingen betreft dan ook niet zozeer de medische effectiviteit, maar de verplaatsing van zorg. Bij de beschrijving van de diverse onderdelen van het innovatieproces in deel III is daarom aangegeven of en soms in hoeverre deze mogelijk is. In het kader van doeltreffendheid zijn wel eventuele complicaties bestudeerd. Vanwege de veiligheid hebben de thuisbehandelingen na selectie van de doelgroepen en de behandelingen geprotocolleerd plaatsgevonden. De bijwerkingen en complicaties van IT zijn geregistreerd (\$12.3). Vanwege de geschiktheid zijn de TMVs speciaal voor het project geworven. Binnen de zorgprotocollen zijn de medisch-technische handelingen via stappenplannen (processchema's) beschreven. Hierin is aandacht voor de hygiêne en eventuele infecties (\$12.3). Aan de materięle privacy (beheer van persoonlijke gegevens) is middels instructie over de dossiervoering aandacht besteed. Bij de attitude is via de protocollering gestreefd naar zorgvuldigheid bij deze CMTZ $(\mathrm{H}: 8,12)$. Ook daarom zijn complicaties onderzocht. Het inlevingsvermogen zelf is moeilijk te objectiveren. Wel beǐnvloedt dit aspecten als de bereidheid tot informatie en verantwoording. Bij de ontwikkeling van het zorgmodel en in de scholing en instructie van de TMVs en in mindere mate bij de huisartsen is aandacht besteed aan de bejegening, de informatie- en verantwoordingsbereidheid, de coöperatiebereidheid en de betrokkenheid van de patiënt en diens omgeving vanuit het zelfzorgconcept. De vertrouwensrelatie is niet apart uitgewerkt. Op het gebied van samenwerking van de zorgverleners en instellingen zijn vooral de taakafbakening, de continulteit en de integrale zorg van belang. Aan deze drie aspecten is binnen de modelontwikkeling ruimschoots aandacht besteed (deel II). Ten aanzien van de organisatie en inrichting van de zorg zijn niet alle door de RGO/NWO genoemde aspecten van toepassing (accommodatie, voeding) of direct relevant (management doet aan kwaliteit). De (financiesle) toegankelijkheid tot de zorg is gereguleerd via centrale aanmelding, intake en financiering en geěvalueerd $(\mathrm{H}: 8,11)$. Het management van de instellingen is via de begeleidingscommissie betrokken bij het project. Interne kwaliteitsbewaking geschiedde via peer review bij de ontwikkeling van de zorgprotocollen en het wekelijks werkoverleg van de TMVs $(\S 8.4)$. De belasting van het patiëntsysteem is gemeten via een expliciete stelling over de belasting door de infuuszorg en de Caregiver Strain Index (CSI). De CSI is alleen bij de beschrijving van de leefsituatie en in relatie tot de $\mathrm{KvL}(\$ 13.4 .2 .3)$ gebruikt, omdat deze gericht is op de totale situatie. Ook is vanwege de totale omvang van de vragenlijst de CSI niet aan de patiënt voorgelegd.

Binnen bovenstaande -primair zorginhoudelijke- aspectbenadering is de indicator patiêntsatisfactie verbreed tot het dienstverlenend domein en is de tevredenheid met de zorg onderzocht via de Client Satisfaction Questionnaire (CSQ) en rapportcijfers aan de zorgverleners. De zorgverleners hebben ook de organisatie een rapportcijfer gegeven. Op dezelfde wijze is binnen bovenstaande -primair zorginhoudelijke- aspectbenadering de indicator doelmatigheid verbreed tot een bedrijfskundig domein. De beschrijvingen van de financiering $(\mathrm{H}: 11)$ en kosten $(\mathrm{H}: 15)$ geven een indicatie van de doelmatigheid. In dit 
hoofdstuk zijn de kosten van IT vergeleken met referentiekaders ontleend aan tarieven en kosten van thuis- en voor ziekenhuiszorg.

\subsubsection{INDICATOREN EN OPERATIONALISATIE ZORGINHOUDELIJKE KWALITETT}

Binnen het zorginhoudelijk domein van $\mathrm{KvZ}$ zijn de hoofddimensies zorgprocessen en kwaliteitsaspecten onderscheiden. De hoofddimensie zorgprocessen is onderverdeeld in vier subdimensies (verlenen van directe zorg, verstrekken van informatic, signaleren van veranderingen en ondernemen van gerichte actie, psychosociale begeleiding) naar Orem. De hoofddimensie kwaliteitsaspecten is onderverdeeld in vier subdimensies naar de categorieên kwaliteitsaspecten in schema 14.2. Deze hoofd- en subdimensies zijn gecombineerd in een Zorg-KwaliteitsMatrix (ZKM). Door deze uniforme indeling is een zo hoog mogelijke face-validity nagestreefd. Vanuit de ZKM met zijn acht subdimensies en zestien 'Zorg-KwaliteitsKruisingen' (schema 14.3) zijn ter operationalisatie stellingen geformuleerd. Voorbeeld voor kruising Al: "De zorgverleners hadden voldoende kennis en vaardigheid om alle handelingen die direct met het infuus te maken hadden goed uit te voeren" (overige stellingen \$14.5.1). De respondent beoordeelt de stellingen middels een vijfpunts Likertschaal (zeer mee oneens-zeer mee eens). ${ }^{519,640,708}$ Dit schaaltype wordt bij $80 \%$ van het huidige tevredenheidsonderzoek gebruikt. ${ }^{600} \mathrm{Om}$ antwoordtendentie te voorkomen zijn positieve en negatieve stellingen in de vragenlijst afgewisseld. ${ }^{519} \mathrm{Ter}$ berekening van totaalscores voor de subdimensies (elk vier tot acht items) en de overall totaalscore (23 items) zijn de antwoorden op de negatief geformuleerde stellingen omgekeerd (gespiegeld). Zoals aanbevolen bij de Likertschaal, zijn de items daarbij niet gewogen. ${ }^{660} \mathrm{Om}$ de respondenten gelegenheid te geven om hun antwoorden toe te lichten, is bij elke stelling ruimte voor opmerkingen gelaten en is aan het eind van de vragenlijst nogmaals expliciet naar eventuele op- en of aanmerkingen gevraagd. ${ }^{519}$ Hierdoor kunnen de (kwantitatieve) stellingen (kwalitatief) toegelicht worden. 34, 660

Schema 14.3 Kwaliteitsaspecten bij soorten zorg: de Zorg-KwaliteitsMatrix.

\begin{tabular}{|c|c|c|c|c|c|}
\hline \multirow[b]{2}{*}{$\begin{array}{l}\text { Soorten zorg } \\
\text { naar Orem }\end{array}$} & \multicolumn{5}{|c|}{ Aspecten van en voorwaarden voor kwaliteit naar NRV/RGO/NWO/IT ${ }^{\circ}$} \\
\hline & Kennis en Kunde & Attitude & Samenwerking & Organisatie & Totaal \\
\hline Directe zorg & $1(\mathrm{Al})^{*}$ & 1 (B5) & $1(\mathrm{C} 9)$ & 2 (D13) & 5 \\
\hline Informatic & $1(\mathrm{E} 2)$ & 3 (F6) & $2(\mathrm{Gl})$ & $2(\mathrm{H} 14)$ & 8 \\
\hline $\begin{array}{l}\text { Signalering/ } \\
\text { Doorverwijzing }\end{array}$ & $1(13)$ & 1 (J7) & $1(\mathrm{~K} 11)$ & 2 (L15) & 5 \\
\hline $\begin{array}{l}\text { Psychosociale } \\
\text { begeleiding }\end{array}$ & $1(\mathrm{M} 4)$ & $2(\mathrm{~N} 8)$ & $1(012)$ & 1 (P16) & 5 \\
\hline Totaal & 4 & 7 & 5 & 7 & 23 \\
\hline
\end{tabular}

Legenda: ${ }^{\circ}$-zie schema $14.1,{ }^{\infty}$-zie schema $4.2, "=$ aantal items gevoigd door de code van de desbetreffende Zorg-KwaliteitsKruising (stellingen zie tabellen 14.1 tot en met 14.4).

Hoewel de gemiddelde scores op de stellingen hoog zijn en de spreiding relatief klein, is in $63 \%$ het bereik 1 of 2 tot 5 op de vijfpuntsschaal (tabellen 14.1-14.4). De totale schaal is intern zeer consistent (patiënt $\alpha=0,97 n=51$, naaste $\alpha=0,97 n=101$, verpleegkundige $\alpha=0,95 n=116$ en arts $\alpha=0,95 n=104)$. ${ }^{660,}, 689$ De totaalscores op de twee hoofd- en acht subdimensies verschillen echter bij meting onvoldoende van elkaar $(\rho=0.50-0.93)$ om ze als afzonderlijke dimensies te kunnen beschouwen. Indien de items op grond van deze 
bevindingen teruggebracht wordt tot éen -meest representatief geacht- item per 'kruising', verbeteren de resultaten niet. Dit betekent dat de onderverdeling in deze hoofd- en subdimensies in dit onderzoek statistisch niet wordt ondersteund.

Naast de 23 specifieke stellingen, is ook samenvattend gevraagd naar de zorgprocessen en kwaliteitsaspecten. Vanuit de twee hoofddimensies plus hun subdimensies (schema 14.3) zijn acht samenvattende items geformuleerd (tabel 14.6). Worden deze acht items opgevat als een maat voor het zorginhoudelijke domein, dan is de interne consistentie goed (patiënt $\alpha=0,82 \mathrm{n}=49$, naaste $\alpha=0,82 \mathrm{n}=101$, verpleegkundige $\alpha=0,88 \mathrm{n}=112$ en arts $\alpha=0,88$ $\mathrm{n}=104)$. Zij verschillen onderling voldoende om verschillende aspecten te meten (allen $\rho \leq 0.70$ en p 0,05 ). Binnen de hoofddimensies zorgprocessen en kwaliteitsaspecten is de onderlinge overeenstemming tussen de vier subdimensies (van elk één item) van de 'eigen' hoofddimensie niet hoger dan die met subdimensies van de 'andere' hoofddimensie. De onderverdeling in een zorg- en een kwaliteitsdimensie wordt ook bij de samenvattende items in dit onderzoek statistisch niet ondersteund.

Tot slot is ook een negatief geformuleerd globaal kwaliteitsoordeel gevraagd. Aan alle respondenten is de stelling "De infuuszorg was belastend." op een vijfpuntsschaal voorgelegd, als algemene maat voor de 'Diskwaliteit van Zorg'.

\subsubsection{INDICATOREN EN OPERATIONALISATIE TEVREDENHEID MET DE DIENSTVERLENING}

Om de in deze studie gekozen gedetailleerde zorginhoudelijke benadering te kunnen 'ijken', is bij de tevredenheidsmeting vanuit de dienstverlenende benadering een bestaande, korte lijst gebruikt die reeds eerder in thuiszorg en in Nederland is toegepast, de CSQ. ${ }^{709-711} \mathrm{De}$ CSQ is ontworpen in de Verenigde Staten op basis van deels reeds in $\$ 14.2 .3$ besproken literatuuronderzoek. ${ }^{709}$ Vanuit negen categoriee̋n van tevredenheid (accommodatie, ondersteunend personeel, mogelijkheden dienstverlening, de behandelaars, kwaliteit dienstverlening, hoeveelheid dienstverlening, resultaat van dienstverlening, algemene tevredenheid, procedures) werden per categorie negen items gecreěerd waaruit deskundigen er 31 kozen. Hieruit werden acht items geselecteerd met een vierpuntsschaal zonder de mogelijkheid van een neutraal antwoord. Er is ook een verkorte versie van drie items mogelijk (vraag 3,7,8). In onderzoek bij 248 patiěnten in de geestelijke gezondheidszorg bleek één factor $75 \%$ van de variantie te verklaren. In Nederlands onderzoek naar tevredenheid bij RIAGG-cliënten is eveneens één factor gevonden met een verklarende variantie van $63 \% .{ }^{110} \mathrm{Er}$ bestond een verband tussen de CSQ en klachten- en symptomenlijsten. Voorts kwamen meningen van patiënten en behandelaars overeen $(r=0.56 n=248 p<0,01){ }^{709}$ Voor de validiteit in deze setting pleit dat de CSQ hoewel algemeen van aard, geen mening vraagt over gezondheidszorg in het algemeen, maar over de eigen ervaringen daarmee ${ }^{688}$ In onderzoek correleert de CSQ dan ook hoog met een globaal oordeel over de tevredenheid in de vorm van rapportcijfers $(r=0.84 n=64$ $\mathrm{p}<0,001) .^{\mathrm{71}, 712}$ Nadelen van de CSQ zijn dat de mening van de patiěnt niet bij de constructie gebruikt is en de vragen vrij abstract zijn. Ook zijn de gevonden verbanden tussen de CSQ en sociaal-demografische factoren inconsistent. ${ }^{600}$ De relatie tussen de CSQ en KvL ("satisfaction with life and well-being") is verder onduidelijk. . $^{90,}, 713$ Omdat de Nederlandse versie toegespitst is op de geestelijke gezondheidszorg is de oorspronkelijke lijst in deze studie met behulp van een vertaler aangepast (tabel 14.8). Hulp(verlening) is vervangen door infuuszorg, om de overige hulpverlening buiten beschouwing te kunnen laten. Zowel in het oorspronkelijke $(\alpha=0,93)$ als in Nederlands onderzoek $(\alpha=0,89-0,93)$ was de betrouwbaarheid hoog. ${ }^{709}$, 711 De interne consistentie van 
de CSQ- 8 in deze studie komt daarmee overeen (patiênt $\alpha=0,87 n=51$, naaste $1 \alpha=0,87$ $\mathrm{n}=84$, verpleegkundige $\alpha=0,90 \mathrm{n}=101$, arts $\alpha=0,90 \mathrm{n}=94$ ). Ook bij de verkorte CSQ-3 blijft de interne consistentie redelijk tot goed (patiēnt $\alpha=0,76$, naaste $1 \alpha=0,63$, verpleegkundige $\alpha=0,77$, arts $\alpha=0,85$; n zie CSQ-8). Ook correleert de één item CSQ-1 "Wat vond u van de kwaliteit?" evenals in ander onderzoek vrij hoog met de rest van de vragen (allen $p<0,001$ : patiênt $\rho=0.55 n=51$, naaste $1 \rho=0.69 n=93$, verpleegkundige $\rho=0.80 \mathrm{n}=109$, arts $\rho=0.75 \mathrm{n}=99$ ). ${ }^{\text {"I }}$ De lagere correlatie bij de patiênt wordt veroorzaakt door de SRD patiēnten ( $\rho=0.48 \mathrm{n}=25 \mathrm{n}$.s; overige patiēnten $\rho=0.64 \mathrm{n}=26 \mathrm{p}<0,001)$. Ter vergelijking met zowel de CSQ als de zorginhoudelijk toegepaste methoden zijn daarnaast rapportcijfers gevraagd. Patiënten, naasten, huisartsen en verpleegkundigen is gevraagd om de betrokken zorgverleners een rapporteijfer te geven. De zorgverleners kunnen zichzelf hierbij ook een punt geven. Het laten geven van rapportcijfers lijkt een valide methode. Rapportcijfers hebben een ingebouwde norm: een 5 vertegenwoordigt een onvoldoende, een 6 of meer op zijn minst een voldoende. Ook is de antwoordtendentie minder en de invloed van sociale wenselijkheid te verwaarlozen. ${ }^{\text {pot }}$ Aan zorgverleners is tevens gevraagd om de organisatie van de infuuszorg een rapporteijfer te geven.

\subsubsection{INDICATOREN EN OPERATIONALISATIE DOELMATIGHEID VAN DE ZORG}

De kosten voor de gezondheidszorg bestaan bij traditionele thuiszorg vooral uit arbeidskosten. CMTZ als IT is kapitaal-intensiever (medicatie, apparatuur). ${ }^{74}$ Bij thuis- en ziekenhuisbehandeling verschillen deze kosten per behandeling en per organisatie of afdeling en zijn moeilijk vergelijkbaar. ${ }^{481,715,716}$

Als indicator voor doelmatigheid ten opzichte van andere vormen van thuiszorg is gekozen voor de produktiviteit van de TMVs. Voor 1996 werd in de thuiszorg uitgegaan van een 37 urige werkweek, op jaarbasis 1.932 uren. Na correctie voor vakantie $(24 \times 7,4)$, vergrijzing $(2 \times 7,4)$, feestdagen $(6 \times 7,4)$, bijzonder verlof $(1 \times 7,4)$ en netto ziekteverzuim $(7 \%)$ resteren 1.553 uren per jaar: de bruto werktijd ( $80 \%$ van de betaaluren). ${ }^{525}$

Als indicator voor doelmatigheid ten opzichte van andere vormen van complexe thuiszorg is gekozen voor het verschil in kosten met het toenmalige tarief voor de intensieve thuiszorg (ITZ) en voor de produktiviteit van de TMVs.

Als indicatoren voor doelmatigheid ten opzichte van ziekenhuiszorg is gekozen voor vergelijking met tarieven en kosten daarvan. Er is niet vergeleken met verpleeghuiszorg, omdat deze zorgsetting organisatorisch niet primair op infusies is ingesteld of daarvoor beschikbaar is. De aard van de onderliggende aandoening, de gekozen behandeling (duur, frequentie, ingezette apparatuur, enzovoorts) en de benodigde controles geven een indicatie of thuisbehandeling vergelijkbaar is met behandeling in het dagcentrum, de shortstay of een verpleegafdeling ( $\mathrm{H}: 12)$. Omdat in de regio 'Heuvelland' thuisbehandeling ziekenhuisdagen verving maar niet bespaarde (bedden direct weer bezet), is uitgegaan van een ligdagprijs en niet van bijvoorbeeld een marginale kostenberekening. ${ }^{475,}{ }^{717}$ Daar thuis weinig diagnostiek of andere behandelingen plaatsvinden, is vergeleken met verpleegdagtarieven. Vanwege het ontbreken van een landelijke 'gouden standaard' en het regionale karakter zijn de azM tarieven gehanteerd. Van 1 oktober 1993 tot en met 31 december 1995 was het gewogen gemiddelde dagtarief voor het dagcentrum $f 375$, voor de short-stay en de verpleegafdeling $f 807$ (klasse 3B ziekenfonds). ${ }^{718}$ Ook is vergeleken met een schatting van de werkelijke kosten van een verblijfsdag in het azM (bijlage 14.2) en met alleen het dagbehandelingstarief. ${ }^{719}$

Voor de verdere operationalisatie van de kosten wordt verwezen naar $\$ 15.2$ en $\$ 15.3$. 


\subsection{Resultaten}

De dataverzameling en respons zijn reeds besproken in §2.6.1 en §7.6.3.

\subsubsection{ZORGINHOUDELIJKE KWALITEIT}

Vraagstelling één betreft de zorginhoudelijke benadering van KvZ en omvat subvraagstellingen over specifieke (een aantal stellingen representeert samen één dimensie) en samenvattende (elke stelling beslaat één hele dimensie) kwaliteitsaspecten en de belasting.

\subsubsection{Zorginhoudelijke kwaliteit via specifieke stellingen}

Op grond van de theoretische onderverdeling van zorgprocessen en kwaliteitsaspecten zijn zestien Zorg-KwaliteitKruisingen onderscheiden (schema 14.3). De relatie tussen de veronderstelde kwaliteits- en zorgdimensies is reeds besproken (\$14.2). Voor het overzicht worden de resultaten per item gerangschikt naar de vier zorgsoorten: directe zorg, informeren, signaleren en veranderen, psychosociale begeleiding (tabel 14.1-14.4). Ter illustratie is het aan de stellingen toegevoegd commentaar van voornamelijk patiënten en naasten weergegeven. Het commentaar van de zorgverleners is vaak concreter en meer procesgericht en is reeds grotendeels verwerkt in de hoofdstukken 8 en 12. Letterlijk weergegeven commentaar staat tussen aanhalingstekens.

Zowel bij de stellingen over de directe zorg als in hun commentaar zijn patiēnten en naasten in het algemeen (zeer) tevreden (tabel 14.1). Vooral over de zorg thuis en over de TMVs: "prettige en deskundige lieden, betrouwbaar, welbespraakt en netjes gekleed". Het transport door de ambulancedienst van het ziekenhuis naar thuis verloopt niet altijd vlekkeloos. Deskundigheid en ervaring van de zorgverleners spelen een belangrijke rol. Vooral bij de eerste keren dat men deze soort zorg uitvoert uit zich dit: "Het voorgesprek was niet goed, de TMV kwam onzeker over". In de tijd neemt bij met name de TMVs de ervaring toe en worden ze inzake de infuuszorg deskundiger geacht dan de wijkverpleging en soms de huisarts. Gesignaleerde problemen betreffen: het kiezen van en inbrengen van de infuusnaald door de huisarts, het kapotprikken van infuuszakjes en het instellen van de druppelsnelheid door verpleegkundigen. Bij het aspect attitude wordt soms een te geringe

Tabel 14.1 Specifieke stellingen over de directe zorg bij infuuszorg thuis. •

\begin{tabular}{|c|c|c|c|c|}
\hline Stelling & Patiēnt & Naaste 1 & Verpl. & Arts \\
\hline $\begin{array}{l}\text { Al De zorgverleners hadden voldoende kennis en } \\
\text { vaardigheid om alle handelingen die direct met het } \\
\text { infuus te maken hadden goed uit te voeren. }\end{array}$ & $\begin{array}{c}4,3 / 0,9 \\
1-5^{\circ}\end{array}$ & $\begin{array}{c}4,4 / 0,8 \\
1-5\end{array}$ & $\begin{array}{c}4,0 / 0,7 \\
1-5\end{array}$ & $\begin{array}{c}4,2 / 0,7 \\
1-5\end{array}$ \\
\hline $\begin{array}{l}\text { B5 De zorgverleners voerden alle handelingen die direct } \\
\text { met het infuus te maken hadden zorgvuldig uit. }\end{array}$ & $\begin{array}{l}4,5 / 0,6 \\
2-5\end{array}$ & $\begin{array}{c}4,5 / 0,7 \\
2-5\end{array}$ & $\begin{array}{c}4,2 / 0,5 \\
3-5\end{array}$ & $\begin{array}{c}4,3 / 0,5 \\
3-5\end{array}$ \\
\hline $\begin{array}{l}\text { C9 De zorgverleners waren het er bij alle handelingen, } \\
\text { die direct met het infuus te maken hadden, onderling } \\
\text { over eens wie wat moest doen. }\end{array}$ & $\begin{array}{l}4,4 / 0,7 \\
3-5\end{array}$ & $\begin{array}{c}4,4 / 0,8 \\
1-5\end{array}$ & $\begin{array}{c}4,0 / 0,7 \\
1-5\end{array}$ & $\begin{array}{c}4,1 / 0,6 \\
3-5\end{array}$ \\
\hline $\begin{array}{l}\text { D13 Alle handelingen die direct met het infuus te maken } \\
\text { hadden, werden op een veilige en verantwoorde wijze } \\
\text { uitgevoerd. }\end{array}$ & $\begin{array}{l}4,5 / 0,6 \\
2-5\end{array}$ & $\begin{array}{c}4,5 / 0,7 \\
2-5\end{array}$ & $\begin{array}{c}4,2 / 0,5 \\
1-5\end{array}$ & $\begin{array}{c}4,3 / 0,6 \\
3-5\end{array}$ \\
\hline $\begin{array}{l}\text { D13 Bij dringende vragen of in geval van nood, konden } \\
\text { (wii) altijd terugvallen op de zorgverleners. }\end{array}$ & $\begin{array}{l}4,5 / 0,6 \\
3-5\end{array}$ & $\begin{array}{c}4,5 / 0,7 \\
1-5\end{array}$ & $\begin{array}{c}4,3 / 0,5 \\
3-5\end{array}$ & $\begin{array}{c}4,3 / 0,6 \\
3-5\end{array}$ \\
\hline
\end{tabular}

Legenda: Verpl.=verpleegkundige, "-vijfpuntsschaal 1:zeer mee oneens 2 :mee oneens 3 -niet mee eens en niet mee oneens 4 :mee eens 5 :zeer mee eens, (wij)=bij de zorgverleners staat "de patient en diens naasten",

"-gemiddelde/standaarddeviatic en bereik. Respondenten patiēnt:50-51 naaste:104-105 verpleegkundige:115116 arts: 105 . 
betrokkenheid van de huisarts gemeld. De meeste opmerkingen betreffen de aspecten samenwerking en organisatie. In de samenwerking "liepen dingen soms wat langs elkaar". Hierdoor komt eenmaal "de bloedprikdienst niet opdagen", "werkten wijkverpleging en gezinszorg langs elkaar heen" en levert de overdracht van infuuszorg aan de wijk problemen op. Toch wordt soms het theoretisch model benaderd: "Ikzelf (naaste) heb bijna alles van de TMV overgenomen. Dit in samenwerking met de huisarts". Over de organisatie verschillen de meningen: "De opzet was buitengewoon snel en men was zeer flexibel." tot "Er was niets geregeld". De organisatie vereist veel afstemming en coordinatie. Hierdoor ontbreken soms materialen of lopen zorgverleners elkaar mis bij de patiênt. Kortom: "In het begin was er nog veel onduidelijk en ging er van alles mis, naarmate de tijd verstreek ging het steeds beter".

Ook de zorgverleners zijn bij de stellingen en in hun commentaar over directe zorg in het algemeen (zeer) tevreden. Een aantal opmerkingen komt overeen met die van de patiēnt en naaste. Zowel de huisartsen en de wijkverpleegkundigen zelf als de TMVs geven meermaals aan dat instructie door de TMV bijgedragen heeft aan hun kennis en kunde over de infuusbehandeling en de organisatie daarvan. In de praktijk blijken, ondanks de voorafgaande scholing, het protocol en de mogelijkheid tot instructie aan het bed (voor wijkverpleegkundigen en huisartsen), soms toch hiaten in de deskundigheid te bestaan (TMV signaleert flebitis te laat; huisarts kan infuusnaald niet inbrengen; huisarts dient oraal of intramusculair dezelfde analgetica toe als in het infuus). Soms loopt de samenwerking stroef als de huisarts een ander behandeldoel heeft (geen pijnbestrijding maar euthanasie) of de richtlijnen voor het delegeren van medisch-technisch handelen aan verpleegkundigen niet naleeft (geen uitvoeringsverzoek schrijven, de verpleegkundige zelfstandig de dosis willen laten aanpassen). Ook levert de 'discontinulteit' van zorg bij wijkverpleegkundigen en huisartsen 's avonds en in het weekend problemen op.

De patiënt en naaste vinden het informeren gemeten via stellingen over het algemeen goed en hebben weinig commentaar daarover (tabel 14.2). Van groot belang zijn een goede informatievoorziening over: het verschil tussen pijnbestrijding met morfine en euthanasie en over de verschillen in bevoegdheid bij medisch-technisch handelen door patienten en naasten zelf, gezins- en ziekenverzorgenden, verpleegkundigen en artsen. Een enkele keer geeft de naaste aan niet te weten waar die bij het infuus op moet letten of vervoegt zich per fiets bij de apotheek om te ontdekken dat het infuuspakket te groot is voor de bagagedrager. De zorgverleners beamen bovenstaande in hun stellingen en in hun commentaar over het informeren. Een enkele patient is "goed voorgelicht, maar probeert liever zelf eerst iets uit alvorens te overleggen". Dit introduceert soms risico's.

Hoewel de patiënt en naaste de stellingen over de signalering en doorverwijzing positief beoordelen, schiet volgens hun commentaar vooral het (her)indiceren van pijnbestrijding meermaals te kort (tabel 14.3). "De begeleiding van de huisarts en specialist was minimaal, zowel wat betreft vaststellen welke medicatie als welk infuus nodig was". "De huisarts had ons eerder moeten inlichten over dit project, dan was veel pijn bespaard gebleven. Dat hebben wij hem kwalijk genomen". Net als bij de start kunnen bij de bee̋indiging van de zorg problemen optreden. Zoals wanneer zorgverleners niet op de hoogte zijn gebracht van het overlijden van de patiènt.

Ook de zorgverleners beoordelen de stellingen over de signalering en doorverwijzing positief. In hun commentaar merken enkele van hen (huisartsen, wijkverpleegkundigen of 
Tabel 14.2 Specifieke stellingen over de informatieverstrekking bij infuuszorg thuis,

\begin{tabular}{|c|c|c|c|c|}
\hline Stelling & Patient & Naaste 1 & Verpl. & Arts \\
\hline $\begin{array}{l}\text { E2 De zorgverleners wisten voldoende om (onze) vragen } \\
\text { goed te kunnen beantwoorden. }\end{array}$ & $4,5 / 0,5$ & $\begin{array}{c}4,6 / 0,5 \\
3-5\end{array}$ & $\begin{array}{c}4,0 / 0,5 \\
2-5\end{array}$ & $\begin{array}{c}4,2 / 0,6 \\
1-5\end{array}$ \\
\hline $\begin{array}{l}\text { E6 De zorgverleners gingen met alles wat zij over (onze) } \\
\text { situatic wisten zorgvuldig om. }\end{array}$ & $\begin{array}{c}4,5 / 0,6 \\
3-5\end{array}$ & $\begin{array}{c}4,6 / 0,6 \\
2-5\end{array}$ & $\begin{array}{l}4,2 / 0,5 \\
3-5\end{array}$ & $\begin{array}{c}4,3 / 0,6 \\
3-5\end{array}$ \\
\hline $\begin{array}{l}\text { E6 De zorgverleners waren, zowel uit zichzelf als } \\
\text { wanneer (wij) daarom vroegen, bereid informatic te } \\
\text { geven. }\end{array}$ & $\begin{array}{c}4,5 / 0,5 \\
3-5\end{array}$ & $\begin{array}{c}4,6 / 0,5 \\
3-5\end{array}$ & $\begin{array}{c}4,2 / 0,5 \\
3-5\end{array}$ & $\begin{array}{c}4,3 / 0,6 \\
3-5\end{array}$ \\
\hline $\begin{array}{l}\text { E6 De zorgverleners waren bereid te verantwoorden wat } \\
\text { zij deden en waarom zij iets deden. }\end{array}$ & $\begin{array}{l}4,5 / 0,5 \\
3-5\end{array}$ & $\begin{array}{c}4,6 / 0,5 \\
3-5\end{array}$ & $\begin{array}{c}4,2 / 0,5 \\
3-5\end{array}$ & $\begin{array}{c}4,3 / 0,6 \\
3-5\end{array}$ \\
\hline $\begin{array}{l}\text { G10 De zorgverleners gaven geen tegenstrijdige } \\
\text { informatic. }\end{array}$ & $\begin{array}{c}4,4 / 0,6 \\
3-5\end{array}$ & $\begin{array}{c}4,4 / 0,7 \\
1-5\end{array}$ & $\begin{array}{l}3,9 / 0,6 \\
2-5\end{array}$ & $\begin{array}{c}3,9 / 0,7 \\
1-5\end{array}$ \\
\hline $\begin{array}{l}\text { G10 Het totaal aan informatie dat door de verschillende } \\
\text { zorgverleners gegeven werd, was voldoende. }\end{array}$ & $\begin{array}{c}4,3 / 0,7 \\
1-5\end{array}$ & $\begin{array}{c}4,4 / 0,6 \\
2-5\end{array}$ & $\begin{array}{c}4,1 / 0,4 \\
2-5\end{array}$ & $\begin{array}{c}4,0 / 0,6 \\
2-5\end{array}$ \\
\hline $\begin{array}{l}\text { H14 De zorg vond soms, zonder dat (wij) daarvan op de } \\
\text { hoogte waren, niet op het afgesproken tijdstip plaats." }\end{array}$ & $\begin{array}{c}4,4 / 0,8 \\
1-5\end{array}$ & $\begin{array}{c}4,1 / 1,1 \\
1-5\end{array}$ & $\begin{array}{c}4,1 / 0,6 \\
2-5\end{array}$ & $\begin{array}{c}4,0 / 0,7 \\
2-5\end{array}$ \\
\hline $\begin{array}{l}\text { H14 (Wij) werden voldoende voorgelicht over veilig- } \\
\text { heidsapecten van de infuuszorg en bij dringende vragen } \\
\text { of in geval van nood wisten (wij) wat we moesten doen. }\end{array}$ & $\begin{array}{c}4,5 / 0,6 \\
2-5\end{array}$ & $\begin{array}{c}4,4 / 0,8 \\
1-5\end{array}$ & $\begin{array}{c}4,2 / 0,6 \\
2-5\end{array}$ & $\begin{array}{c}4,1 / 0,7 \\
3-5\end{array}$ \\
\hline
\end{tabular}

Legenda: Verpl -"verpleegkundige, "-vijfpuntsschaal I:zeer mee oneens 2:mee oneens 3:niet mee eens en niet mee oneens 4 :mee eens 5 zeer mee eens, (wij)-bij de zorgverleners staat "de patient en diens naaste verzorger" of "de patient en diens naasten", (onze)=bij de zorgverleners staat "de", "=gemiddelde / standaarddeviatie en bereik, "=deze negatieve stelling is ter vergelijking omgecodeerd, een hoog getal drukt dus tevredenheid uit. Respondenten patient:50-51 naaste: 105 verpleegkundige:114-116 arts:104-105.

TMVs) op dat specialisten onvoldoende ingevoerd zijn dan wel affiniteit hebben met de behoeften en behandelmogelijkheden van een patiēnt in de stervensfase in de thuissituatie (centraalveneuze infusie van morfine en $\mathrm{Kcl}$ in 2 liter $\mathrm{NaCl} 0,9 \%$ afgewisseld met

Tabel 14.3 Specifieke stellingen over de signalering en doorverwijzing bij infuuszorg thuis. ${ }^{\circ}$

\section{Stelling \\ 13 De zorgverleners hadden voldoende kennis om veranderingen in de situatie op te merken en om de infuuszorg daarop aan te passen of andere zorg in te schakelen.}

17 De zorgverleners hadden oog voor veranderingen in de situatie en waren bereid om de infuuszorg daarop aan te passen of andere zorg in te schakelen.

KU De zorgverleners werkten goed samen om veranderingen in de situatie op te merken en de infuuszorg daarop aan te passen of andere zorg in te schakelen.

h. Indien (wij) of de zorgverieners vonden dat de zorg aangepast moest worden of dat andere zorg ingeschakeld moest worden, dan gebeurde dit snel en goed.

L15 De zorgverleners letten er voldoende op dat de veiligheid tijdens de infuuszorg niet in gevaar kwam.

\begin{tabular}{|c|c|c|c|}
\hline Patiēnt & Naaste 1 & Verpl. & Arts \\
\hline $\begin{array}{c}4,4 / 0,6 \\
3-5\end{array}$ & $\begin{array}{c}4,5 / 0,6 \\
2-5\end{array}$ & $\begin{array}{c}4,1 / 0,5 \\
3-5\end{array}$ & $\begin{array}{c}4,2 / 0,6 \\
2-5\end{array}$ \\
\hline $\begin{array}{c}4,3 / 0,8 \\
1-5\end{array}$ & $\begin{array}{c}4,5 / 0,6 \\
3-5\end{array}$ & $\begin{array}{c}4,1 / 0,6 \\
2-5\end{array}$ & $\begin{array}{c}4,2 / 0,6 \\
2-5\end{array}$ \\
\hline $\begin{array}{c}4,3 / 0,7 \\
2-5\end{array}$ & $\begin{array}{c}4,5 / 0,6 \\
2-5\end{array}$ & $\begin{array}{c}4,0 / 0,6 \\
2-5\end{array}$ & $\begin{array}{c}4,1 / 0,6 \\
2-5\end{array}$ \\
\hline $\begin{array}{c}4,2 / 0,8 \\
3-5\end{array}$ & $\begin{array}{c}4,3 / 0,9 \\
1-5\end{array}$ & $\begin{array}{c}4,0 / 0,5 \\
3-5\end{array}$ & $\begin{array}{c}3,9 / 0,6 \\
2-5\end{array}$ \\
\hline $\begin{array}{c}4,5 / 0,5 \\
3-5\end{array}$ & $\begin{array}{c}4,5 / 0,7 \\
1-5\end{array}$ & $\begin{array}{c}4,1 / 0,5 \\
2-5\end{array}$ & $\begin{array}{c}4,2 / 0,5 \\
3-5\end{array}$ \\
\hline
\end{tabular}

Legenda: Verpl.-verpleegkundige, -vijfpuntsschaal 1:zeer mee oneens 2:mee oneens 3:niet mee eens en niet mee oneens 4:mee cens 5 :zeer mee cens, (wij) =bij de zorgverleners staat "de patient en diens naaste verzorger", "-gemiddelde / standaarddeviatie en bereik. Respondenten: patiènt:47-51 naaste:101-105 verpleegkundige:110116 arts:104-105. 
Glucose $5 \%$ tegenover subcutane infusie van morfine in 0,5 liter $\mathrm{NaCl} 0,9 \%$ ). Anderzijds zijn de voor bepaalde behandelingen te consulteren specialisten redelijk bereikbaar voor overleg over veranderingen in de toestand van de patiěnt. Soms ontbreekt een adequate overdracht tussen ziekenhuis en thuiszorg en vice versa.

Hoewel alle respondenten de stellingen over de psychosociale begeleiding positief beoordelen, blijkt uit hun commentaar dat de zorgverleners zich dienen te realiseren in welke situatie de zorg verleend wordt en hoe deze ervaren wordt (tabel 14.4). In de voorgeschiedenis spelen zaken als eerdere zorgervaringen, de wens van patienten en/of naasten om eigenlijk in het ziekenhuis behandeld te worden (of al eerder ontslagen te worden) en -bij terminale patiênten- verschillende verwachtingen over pijnbestrijding en euthanasie een rol. De technologie en behandeling boezemen soms angst in: "dat ik met het infuus rondliep gaf me toch de rillingen en bij het verwisselen van de pleister trok ik al wit weg van de schrik het infuus te zien". Een ander voelde zich thuis "net een gevangene". Extra aandacht is soms nodig bij terminale patienten, patiententen met hartfalen, patienten met een andere etnische achtergrond of met kleine kinderen in huis. De steun door de eigen huisarts wordt niet altijd als voldoende ervaren. Toch is zij essentieel en wordt indien gegeven zeer op prijs gesteld: "De voortdurende begeleiding van de huisarts (hij kwam twee- à driemaal per etmaal, dag en nacht) speelde een wezenlijke rol". Ook de attitude verdient aandacht. Soms wensen met name chronische patiënten meer inspraak. Ook hier wordt soms het theoretisch ideaal benaderd: “... geen betuttelende controle en waar mogelijk wel deskundige zorg en adviezen. Ik voelde me mens en geen patie̋nt bij haar (TMV), dat is voor mij de perfecte zorg als het niet zelfstandig mag of kan".

Tabel 14.4 Specifieke stellingen over de psychosociale begeleiding bij infuuszorg thuis. *

\begin{tabular}{|c|c|c|c|c|}
\hline Stelling & Patiént & Naaste 1 & Verpl. & Arts \\
\hline $\begin{array}{l}\text { M4 De zorgverleners wisten voldoende om (ons) te } \\
\text { begeleiden bij de infuuszorg en wat daar zoal bij komt } \\
\text { kijken. }\end{array}$ & $\begin{array}{c}4,5 / 0,5 \\
4-5^{\circ}\end{array}$ & $\begin{array}{c}4,4 / 0,7 \\
1-5\end{array}$ & $\begin{array}{c}4,1 / 0,5 \\
2-5\end{array}$ & $\begin{array}{c}4,1 / 0,7 \\
2-5\end{array}$ \\
\hline $\begin{array}{l}\text { N8 De zorgverleners gaven (ons) voldoende } \\
\text { mogelijkheid om invloed uit te oefenen op de situatic en } \\
\text { reageerden correct op wensen of klachten. }\end{array}$ & $\begin{array}{l}4,4 / 0,7 \\
2-5\end{array}$ & $\begin{array}{c}4,6 / 0,6 \\
2-5\end{array}$ & $\begin{array}{c}4,1 / 0,6 \\
2-5\end{array}$ & $\begin{array}{c}4,2 / 0,6 \\
2-5\end{array}$ \\
\hline $\begin{array}{l}\text { N8 De zorgverleners beschouwden (ons) als } \\
\text { gelijkwaardige gesprekspartners. }\end{array}$ & $\begin{array}{c}4,5 / 0,6 \\
3-5\end{array}$ & $\begin{array}{c}4,6 / 0,5 \\
3-5\end{array}$ & $\begin{array}{l}4,2 / 0,6 \\
2-5\end{array}$ & $\begin{array}{c}4,2 / 0,7 \\
1-5\end{array}$ \\
\hline $\begin{array}{l}012 \text { De totale begeleiding die (wij) van de verschillende } \\
\text { zorgverleners ontvingen, was goed op elkaar afgestemd } \\
\text { en voldoende. }\end{array}$ & $\begin{array}{c}4,2 / 0,7 \\
2-5\end{array}$ & $\begin{array}{c}4,4 / 0,8 \\
1-5\end{array}$ & $\begin{array}{c}4,0 / 0,7 \\
2-5\end{array}$ & $\begin{array}{c}4,1 / 0,7 \\
2-5\end{array}$ \\
\hline $\begin{array}{l}\text { P16 De zorgverleners stelden (ons) voldoende gerust } \\
\text { over de veiligheid van de infuuszorg. }\end{array}$ & $\begin{array}{l}4,5 / 0,7 \\
2-5\end{array}$ & $\begin{array}{c}4,4 / 0,6 \\
1-5\end{array}$ & $\begin{array}{c}4,1 / 0,5 \\
2-5\end{array}$ & $\begin{array}{c}4,1 / 0,5 \\
3-5\end{array}$ \\
\hline
\end{tabular}

Legenda: Verpl.=verpleegkundige, 9 vijfpuntsschaal 1:zeer mee oneens 2 :mee oneens 3:niet mee eens en niet mee oneens 4:mee eens 5 :zeer mee eens, (ons) of (wij)=bij de zorgverleners staat "de patient en diens naasten", "=gemiddelde / standaarddeviatic en bereik. Respondenten: patient:49-51 naaste:102-105 verpleegkundige:115. 116 arts: 105 .

Ten slotte is analoog aan andere instrumenten ook de gemiddelde totaalscore over de 23 items berekend (tabel 14.5). In de incidentele gevallen waarin een antwoord ontbreekt is dit opgevat als "ik weet niet / niet van toepassing" en gecodeerd als "niet mee eens en niet mee oneens". Het gemiddelde oordeel is (zeer) positief. De gemiddelden over alle items zijn voor patiënten 4,5 , voor naasten 4,4 en voor zowel verpleegkundigen als artsen 4,1 . 


\section{Patiènt}

Naaste 1

$102,0 / 11,2 / 72-115$
Verpleegkundige

$94,2 / 8,3 / 69-115$
Arts

$95,3 / 9,7 / 71-115$

Legenda: "-kan varieren van 23 tot 115," "memiddelde / standaarddeviatic / bereik. Respondenten: patiênt:51 naaste: 105 verplecgkundige:116 arts:105.

\subsubsection{Zorginhoudelijke kwaliteit via samenvattende stellingen}

Ook is samenvattend -elke stelling beslaat één hele dimensie- gevraagd naar de vier binnen het model onderscheiden soorten kwaliteit en zorg (tabel 14.6). Het oordeel hierover is overwegend (zeer) positief, de verpleegkundigen scoren iets lager. Over het algemeen wordt de attitude van de zorgverleners en de directe zorg het hoogst gewaardeerd en lopen de meningen hierover het minst uiteen (behorend tot de items met de kleinste standaarddeviaties). De samenwerking tussen de zorgverleners en het geven van informatie wordt over het algemeen het laagst gewaardeerd en de meningen hierover lopen ook het meest uiteen (behorend tot de items met de grootste standaarddeviaties).

Tabel 14.6 Samenvattende stellingen over de kwaliteitsaspecten en zorgprocessen. *

\begin{tabular}{|c|c|c|c|c|}
\hline Stelling & Patient & Naaste 1 & Verpl. & Arts \\
\hline $\begin{array}{l}1 \text { De zorgverleners waren goed op hun taak berekend. } \\
\text { (Kennis en kunde: } 1-4 \text { ). }\end{array}$ & $\frac{4,4 / 0,6}{2-5^{\circ}}$ & $\begin{array}{c}4,3 / 1,0 \\
2-5\end{array}$ & $\begin{array}{c}4,0 / 0,7 \\
1-5\end{array}$ & $\begin{array}{c}4,2 / 0,7 \\
2-5\end{array}$ \\
\hline $\begin{array}{l}2 \text { De zorgverleners gingen met respect met (ons) om. } \\
\text { (Attitude: } 5-8 \text { ). }\end{array}$ & $\begin{array}{c}4,7 / 0,5 \\
3-5\end{array}$ & $\begin{array}{l}4,6 / 0,6 \\
2-5\end{array}$ & $\begin{array}{c}4,2 / 0,6 \\
2-5\end{array}$ & $\begin{array}{c}4,4 / 0,7 \\
1-5\end{array}$ \\
\hline $\begin{array}{l}3 \text { De zorgverleners werkten slecht met elkaar samen." } \\
\text { (Samenwerking: 9-12). }\end{array}$ & $\begin{array}{c}4,3 / 0,9 \\
1-5\end{array}$ & $\begin{array}{c}4,1 / 1,1 \\
1-5\end{array}$ & $\begin{array}{c}4,0 / 0,8 \\
1-5\end{array}$ & $\begin{array}{c}4,3 / 0,5 \\
3-5\end{array}$ \\
\hline $\begin{array}{l}4 \text { De organisatie van de infuuszorg was slecht." } \\
\text { (Organisatie: 13-16). }\end{array}$ & $\begin{array}{c}4,4 / 0,9 \\
1-5\end{array}$ & $\begin{array}{c}4,3 / 0,9 \\
1-5\end{array}$ & $\begin{array}{c}4,2 / 0,8 \\
1-5\end{array}$ & $\begin{array}{c}4,4 / 0,7 \\
2-5\end{array}$ \\
\hline $\begin{array}{l}5 \text { (lk) werd goed behandeld en verzorgd. } \\
\text { (Directe zorg: A-D). }\end{array}$ & $\begin{array}{c}4,5 / 0,9 \\
1-5\end{array}$ & $\begin{array}{c}4,6 / 0,6 \\
1-5\end{array}$ & $\begin{array}{c}4,3 / 0,7 \\
1-5\end{array}$ & $\begin{array}{c}4,4 / 0,6 \\
1-5\end{array}$ \\
\hline $\begin{array}{l}6(\text { Wij) werden slecht geinformeerd over de infuuszorg." } \\
\text { (Informatie: E-H). }\end{array}$ & $\begin{array}{c}4,0 / 1,2 \\
1-5\end{array}$ & $\begin{array}{c}4,2 / 1,0 \\
1-5\end{array}$ & $\begin{array}{c}4,2 / 0,7 \\
1-5\end{array}$ & $\begin{array}{c}4,2 / 0,6 \\
3-5\end{array}$ \\
\hline $\begin{array}{l}\text { I Veranderingen in de situatie werden goed opgemerkt } \\
\text { en zo nodig werd de infuuszorg aangepast of andere zorg } \\
\text { ingeschakeld. } \\
\text { (Signaleren en doorverwijzen: I-L). }\end{array}$ & $\begin{array}{c}4,3 / 0,9 \\
1-5\end{array}$ & $\begin{array}{c}4,3 / 0,9 \\
1-5\end{array}$ & $\begin{array}{c}4,1 / 0,6 \\
3-5\end{array}$ & $\begin{array}{c}4,1 / 0,8 \\
1-5\end{array}$ \\
\hline $\begin{array}{l}8 \text { (Wii) werden goed begeleid. } \\
\text { (Psychosociale begeleiding: M-P). }\end{array}$ & $\begin{array}{l}4,4 / 0,6 \\
2-5\end{array}$ & $\begin{array}{c}4,5 / 0,8 \\
2-5\end{array}$ & $\begin{array}{c}4,1 / 0,5 \\
2-5\end{array}$ & $\begin{array}{c}4,2 / 0,5 \\
3-5\end{array}$ \\
\hline
\end{tabular}

Legenda: Verpl.=verpleegkundige, "-vijfpuntsschaal 1:zeer mee oneens 2 :mee oneens 3 -niet mee eens en niet mee oneens 4 :mee eens $5: z e e r$ mee eens, (ons)=bij de zorgverleners staat "de patient en diens naasten", (Ik)=bij de naaste en/of zorgverleners staat "De patiēnt", (Wij)=bij de zorgverleners staat "De patient en diens naasten", "mgemiddelde / standaarddeviatic en bereik, "=deze negatieve stelling is ter vergelijking omgecodeerd, een hoog getal drukt dus tevredenheid uit. Respondenten patient:51 naaste:102-106 verpleegkundige:113-116 arts: 105 .

\subsubsection{Zorginhoudelijke kwaliteit via vraag naar belasting}

Over het algemeen vindt men de IT gemiddeld belastend (tabel 14.7) of samengevat door een patiěnt: "Het viel allemaal wel mee". Bij terminale patiěnten is vooral de gehele situatie waarvan de infuuszorg deel uit maakt belastend: "De infuuszorg was niet belastend, het proces was belastend." of "In latere instantie kwam ik (echtgenote) rust tekort. Ondanks de moeilijke situatie, was ons gevoelsleven van hoge kwaliteit. Ik zou 


\begin{tabular}{lcccc} 
Stelling & Patient & Naaste & Verpt. & Arts \\
De infuuszorg was voor (ons) belastend. & $3,6 / 1,3$ & $3,9 / 1,1$ & $3,4 / 1,1$ & $3,4 / 1,1$ \\
& $1-5^{*}$ & $1-5$ & $1-5$ & $1-5$ \\
\hline
\end{tabular}

Legenda: Verpl--verpleegkundige, "-exclusief de terminale patienten, (ons)"bij de zorgverieners staat "de patient en diens naaste verzorger", -vijfpuntsschaal 1 zeer mee eens 2 -mee eens 3 -niet mee eens en niet mee oneens 4 :mee oneens 5 :zeer mee oneens, "-gemiddelde / standaarddeviatie en bereik. Respondenten patient:51 naaste: 105 verpleegkundige: 116 arts: 105 .

iemand zeker aanraden het te doen". Toch overheerst: "Hij (de patiěnt) zou het in dezelfde situatie weer zo doen". Ook voor naasten verschilt de belasting. "Ik hoefde me niet zo te haasten dan als mijn vrouw in het ziekenhuis lag." of "Voor mijzelf vind ik het infuus thuis zeer belastend. Je zit een week gebonden aan huis, dat is soms erg moeilijk". Soms willen buren helpen maar is deze zorg achteraf gezien te belastend: "Mevrouw kan helemaal niet alleen zijn. Ze kon helemaal niet lopen, aankleden, wassen, brood en koffie maken. Er moet de hele dag iemand bij zijn en dat ben ik. Ik heb gehuild, mijn man wil ook hebben dat ik eten maak en poets, dat spreekt vanzelf. Daarom vraag ik alstublieft meer hulp, want ik kan dat niet langer, dat wordt teveel want ik ben ook al 65 jaar en dat gaat niet". ${ }^{312}$ Sommige patiënten zijn zo zorgbehoeftig dat naaste verzorgers niet bij de infuuszorg betrokken worden: "Moeder is slechthorend, slechtziend en slechtlopend. De TMVs waren tijdens de infusie aanwezig, zodat wij daar weinig omkijken naar hadden". Ook 'teveel' zorg kan belastend zijn: "We deden alles liever zelf, in die zin was de zorg voor ons belastend." of "Te goed, we konden het zelf". Een ziekenhuisbehandeling vindt men meestal belastender: "lk had al viermaal mannitol infuus in het ziekenhuis gehad maar vind dit veel prettiger." of "Thuis heb je meer vrijheid dan in het ziekenhuis, waardoor de tijd sneller omgaat, tevens hebben de huisgenoten veel mindere loperij". Kortom "Het ziekenhuis brengt voor de patiênt meer belasting met zich mee, liever thuis dan in het ziekenhuis".

\subsubsection{TEVREDENHEID MET DE DIENSTVERLENING}

Vraagstelling twee betreft de dienstverlenende benadering van kwaliteit van zorg en omvat subvraagstellingen over de tevredenheid met en oordelen over de zorgverlening.

\subsubsection{Tevredenheid via Client Satisfaction Questionnaire}

Gemeten via de CSQ-8 is men overwegend (zeer) tevreden (tabel 14.8). Patiënten en naasten zijn het meest tevreden, daarna volgen de artsen en tenslotte de verpleegkundigen. Evenals in ander onderzoek zijn de resultaten scheef verdeeld. ${ }^{710-712}$ Tachtig percent scoort hoger dan het midden van de schaal (totaal $=20$ ).

\subsubsection{Tevredenheid via oordeel in rapportcijfers}

In tabel 14.9 volgt tot slot een oordeel over de diverse zorgverleners van de patiënt, de naaste en de zorgverleners in de vorm van een rapportcijfer. Wanneer men de gemiddelden van de verschillende respondenten optelt en door vier deelt 'scoort' de huisarts een 7,9, de TMV en de wijkverpleegkundige een 8,6 en een 8,5 en de specialist en de ziekenhuisverpleegkundige een 8,1 en een 8,2 . Ook over de organisatie van de infuuszorg zijn zowel de verpleegkundigen als de artsen tevreden (tabel 14.9). 


\begin{tabular}{lcccc} 
Vraag & Patiént & Naaste & Verpl. & Arts \\
1 Wat vond (U) van de kwaliteit van de infuuszorg & $3,4 / 0,7$ & $3,3 / 0,7$ & $3,1 / 0,7$ & $3,3 / 0,6$ \\
die (U) heeft ontvangen? & $2-4$ & $1-4$ & $1-4$ & $2-4$ \\
2 Heeft (U) het soort infuuszorg ontvangen dat (U) & $3,6 / 0,7$ & $3,6 / 0,6$ & $3,4 / 0,7$ & $3,5 / 0,6$ \\
wilde? & $1-4$ & $1-4$ & $1-4$ & $1-4$ \\
2 In hoeverre heeft de infuuszorg aan de behoeften & $3,5 / 0,9$ & $3,4 / 0,7$ & $3,2 / 0,7$ & $3,4 / 0,7$ \\
van (U) voldaan? & $1-4$ & $1-4$ & $1-4$ & $1-4$ \\
4 Stel dat een van (uw) kennissen dezelfde infuus- & $3,5 / 0,6$ & $3,5 / 0,7$ & $3,3 / 0,6$ & $3,3 / 0,6$ \\
zorg nodig heeft, zou (U) dan deze infuuszorg & $2-4$ & $1-4$ & $1-4$ & $2-4$ \\
aanbevelen? & & & & \\
5 Hoe tevreden was (U) met de hoeveelheid zorg die & $3,5 / 0,7$ & $3,6 / 0,6$ & $3,3 / 0,6$ & $3,2 / 0,7$ \\
is ontvangen? & $1-4$ & $2-4$ & $1-4$ & $1-4$ \\
6 Heeft de infuuszorg (U) geholpen om beter met & $3,3 / 0,8$ & $3,2 / 0,8$ & $3,1 / 0,8$ & $3,3 / 0,8$ \\
(uw) situatie om te gaan? & $2-4$ & $1-4$ & $1-4$ & $1-4$ \\
Z Hoe tevreden was (U) in het algemeen (over het & $3,6 / 0,7$ & $3,5 / 0,7$ & $3,3 / 0,7$ & $3,4 / 0,6$ \\
geheel genomen), met de ontvangen infuuszorg? & $2-4$ & $1-4$ & $1-4$ & $2-4$ \\
8 Stel dat (U) weer vergelijkbare infuuszorg nodig & $3,3 / 1,0$ & $3,4 / 0,7$ & $3,2 / 0,7$ & $3,3 / 0,7$ \\
zou hebben, zou (U) dan weer hiervoor kiezen? & $1-4$ & $2-4$ & $1-4$ & $1-4$ \\
Totaalscore * & $27,6 / 4,3$ & $27,5 / 3,9$ & $25,9 / 4,1$ & $26,7 / 3,9$ \\
& $17-32$ & $16-32$ & $12-32$ & $16-32$ \\
\hline
\end{tabular}

Legenda: "-vierpuntsschaal de antwoordmogelijkheden varietren per item, hier zijn de waardes weergegeven op een schaal van I:negatief tot 4:positief (precieze antwoordmogelijkheden bijlage 14.1), "=exclusief de terminale patienten, $(U)=$ bij de naaste en zorgverleners staat "de patient" of "hij/zij", (uw)=bij de naaste en zorgverleners staat "zijn/haar"," "gemiddelde / standaarddeviatie en bereik, "=totaalscore 8-20:laag 21-26:gemiddeld 27-32: hoog hiervoor dienen de respondenten alle items te hebben ingevuld. Respondenten vragen patient:51 naaste:94-104 verpleegkundige:106-113 arts:98-102. Respondenten totaalscore patient:51 naaste:84 verpleegkundige: 101 arts:94.

Tabel 14.9 Rapportcijfers voor de verschillende zorgverleners en de organisatic. *

\begin{tabular}{|c|c|c|c|c|}
\hline Beoordeelde & Patiênt & Naaste 1 & Verpleegkundige & Huisarts \\
\hline Huisarts & $8,1 / 1,7 / 3-10^{\circ}$ & $8,3 / 2,1 / 0-10$ & $7,4 / 1,3 / 2-10$ & $7,9 / 1,0 / 6-10$ \\
\hline TMV & $9,1 / 1,0 / 7-10$ & $9,0 / 1,1 / 6-10$ & $8,0 / 0,7 / 6-9$ & $8,3 / 0,8 / 6-10$ \\
\hline Wijkverpleegkundige & $8,9 / 1,1 / 7-10$ & $8,9 / 1,1 / 7-10$ & $7,8 / 0,8 / 6-10$ & $8,3 / 0,8 / 7-10$ \\
\hline Gezinsverzorgende & $8,3 / 1,3 / 7-10$ & - & $7,5 / 1,3 / 6-10$ & $8,2 / 0,8 / 7-10$ \\
\hline Specialist & $8,4 / 1,4 / 6-10$ & $8,9 / 1,5 / 4-10$ & $7,5 / 0,9 / 5-9$ & $7,6 / 1,5 / 4-10$ \\
\hline Ziekenhuisverpl. ${ }^{*}$ & $8,1 / 1,7 / 5-10$ & $8,6 / 1,2 / 6-10$ & $7,3 / 1,6 / 5-10$ & $8,6 / 1,1 / 7-10$ \\
\hline Nachtzorg & 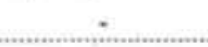 & $7,9 / 2,0 / 3-10$ & $\therefore$ & $\therefore$ \\
\hline $\begin{array}{l}\text { Rapportcijfer organisatic } \\
\text { infuuszorg thuis. }\end{array}$ & - & - & $\begin{array}{c}8,0 / 0,8 \\
6-10\end{array}$ & $\begin{array}{c}8,2 / 0,8 \\
6-10\end{array}$ \\
\hline
\end{tabular}

Legenda: "-schaal 0-10, Ziekenhuisverpl.=ziekenhuisverpleegkundige, "=ofschoon deze zorgverieners vaak niet bij de infuuszorg betrokken zijn geweest, wordt er (tegen de instructie in) toch vaak een rapportcijfer aan gegeven, "-gemiddelde / standaarddeviatic / bereik. Respondenten per beoordeelde zorgveriener N:40/89/95/50, $\mathrm{N}: 49 / 106 / 98 / 95, \mathrm{~N}: 11 / 58 / 56 / 45, \mathrm{~N}: 9 / 23 / 15 / 20, \mathrm{~N}: 25 / 29 / 31 / 28 \mathrm{~N}: 20 / 16 / 17 / 10, \mathrm{~N}: 0 / 10 / 0 / 0$. Respondenten organisatic verplecgkundige: 112 arts:101.

\subsubsection{VERGELIJKING ZORGINHOUDELIJKE EN DIENSTVERLENENDE KWALITEIT}

Er zijn bij de meting van $\mathrm{KvZ}$ verschillende methoden gehanteerd om een indruk te verkrijgen van zowel het zorginhoudelijke als het dienstverlenende domein. Vraagstelling 
drie betrof hun onderlinge samenhang (tabel 14.10).

De uitgebreide CSQ-8 en verkorte CSQ-3 en de uitgebreide ZKM-it23 en samenvattende ZKM-it8 correleren onderling het hoogst. Gemiddeld over de respondenten is de correlatie ook groter dan 0,50 tussen de CSQ-8 en de ZKM-it23 en ZKM-it8 en tussen het rapportcijfer voor de organisatie en dat gemiddeld over de zorgverleners.

Bij de verpleegkundigen correleert het organisatie-item significant (gemiddelde $\rho=0.37$ allen ps 0,001 ) met oordelen over de acht samenvattende kwaliteits- en zorgitems behalve bij 'reageren' (item 7 tabel 14.6). Bij de arts correleert het organisatie-item slechts significant (gemiddelde $\rho=0.35$ allen $p<0,05$ ) met de items 'kennis en kunde', 'organisatie' en 'directe zorg' (items 1, 4 en 5 tabel 14.6) en niet met de andere vijf. In tegenstelling tot het item belasting correleert de belasting gemeten met de CSI niet of zwak negatief met de CSQ (naaste $\rho=-0.13, n=84 p=0,227$, verpleegkundige $\rho=-0.35 n=81 p=0,001$, arts $\rho=0.09$ $\mathrm{n}=88 \mathrm{p}=0,410$ ).

Als indicatie voor de invloed van de TMV zijn enkele aanvullende correlaties bepaald. De correlatie tussen het rapportcijfer voor de organisatie van IT en dat voor de zorgverleners

Tabel 14.10 Correlaties tussen de meetinstrumenten voor zorginhoudelijke kwaliteit en tevredenheid.

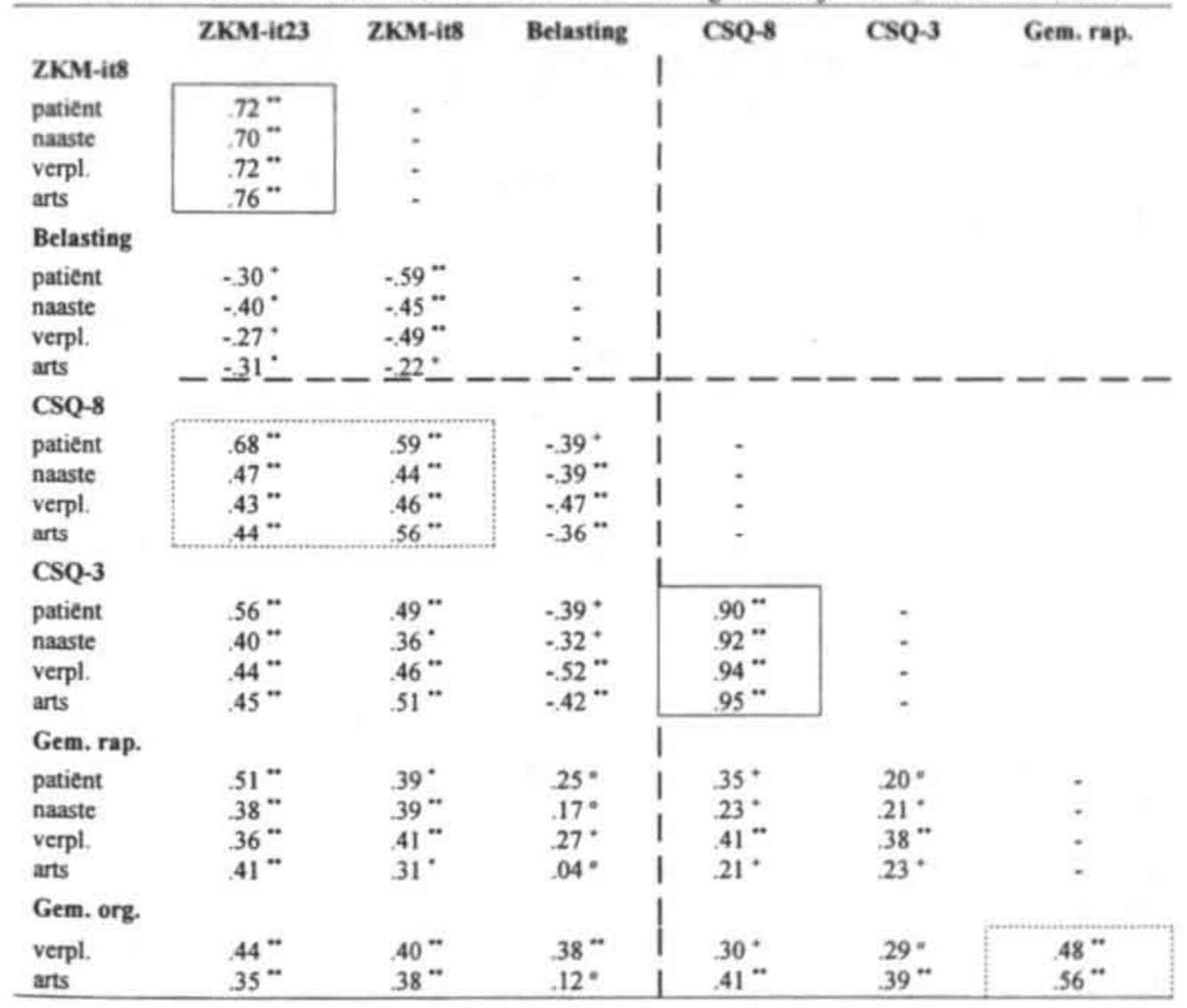

Legenda: +=gestippeld kruis scheidt de kwaliteits- en de tevredenheidsmetingen, ZKM-i2.3 23 specifieke stellingen, ZKM-it8 $=8$ samenvattende stellingen, CSQ-8=volledige CSQ, CSQ-3=verkorte CSQ. $\mathrm{Verpl}=$ =verpleegkundige, Gem. rap.=gemiddeld rapportcijfer aan zorgverleners, Gem. org.=gemiddeld rapportcijfer organisatie, "-niet significant, "=ps $0,05, "=p s 0,01, "=p s 0,001$. 
volgens henzelf, is zowel bij verpleegkundigen (huisarts $\rho=0.34 n=92 p=0,001$, TMV $\rho=0.76 \mathrm{n}=95 \mathrm{p}<0,001$, wijkverpleegkundige $\rho=0.38 \mathrm{n}=54 \mathrm{p}=0,004)$ als bij huisartsen (huisarts $\rho=0.30 \mathrm{n}=47 \mathrm{p}=0,044$, TMV $\rho=0.59 \mathrm{n}=92 \mathrm{p}<0,001$, wijkverpleegkundige $\rho=0.17$ $\mathrm{n}=45 \mathrm{p}=0,279)$ het hoogst voor de TMV. Het rapportcijfer voor de TMV komt overeen met de CSQ-8 bij de patient, naaste en verpleegkundige (patiënt $\rho=0.44 n=49 p=0,01$, naaste $\rho=0.36 n=84 p=0,01$, verpleegkundige $\rho=0.41 n=95 p<0,001$; arts $\rho=0.19 n=89$ $p=0,63$ ). Het rapportcijfer voor de TMV correleert bij de verpleegkundigen significant negatief met het item belasting $(\rho=0.39 n=98 p<0,001)$. Anders gezegd hoe hoger het cijfer voor de TMV, hoe lager de score voor de belasting.

\subsubsection{VERGELIJKING MET ANDERE STUDIES}

Vraagstelling vier betreft de vergelijking met andere vormen van klinische en thuiszorg. De studie van Visser biedt een mogelijkheid tot vergelijking met de tevredenheid van patiënten over hun ziekenhuisverblijf (tabel 14.11). ${ }^{644}$ Deze studie dateert weliswaar uit 1984 en intussen is ziekenhuiszorg veranderd. Ook wordt aangenomen dat patiënten de afgelopen jaren kritischer zijn geworden. Verder verschilt de vraagwijze. Wanneer men de scores op de stellingen uit deze studie in rapportcijfers uitdrukt, lijkt de tevredenheid over IT vergelijkbaar met die bij een ziekenhuisopname. De waardering van patiënten en naasten uitgedrukt in rapportcijfers (tabel 14.9) voor de zorgverleners bij IT is ook tenminste vergelijkbaar met de waardering voor zorgverleners in het ziekenhuis bij Visser.

Tabel 14.11 Vergelijking met patientenoordelen over ziekenhuisverblijf in Nederland.

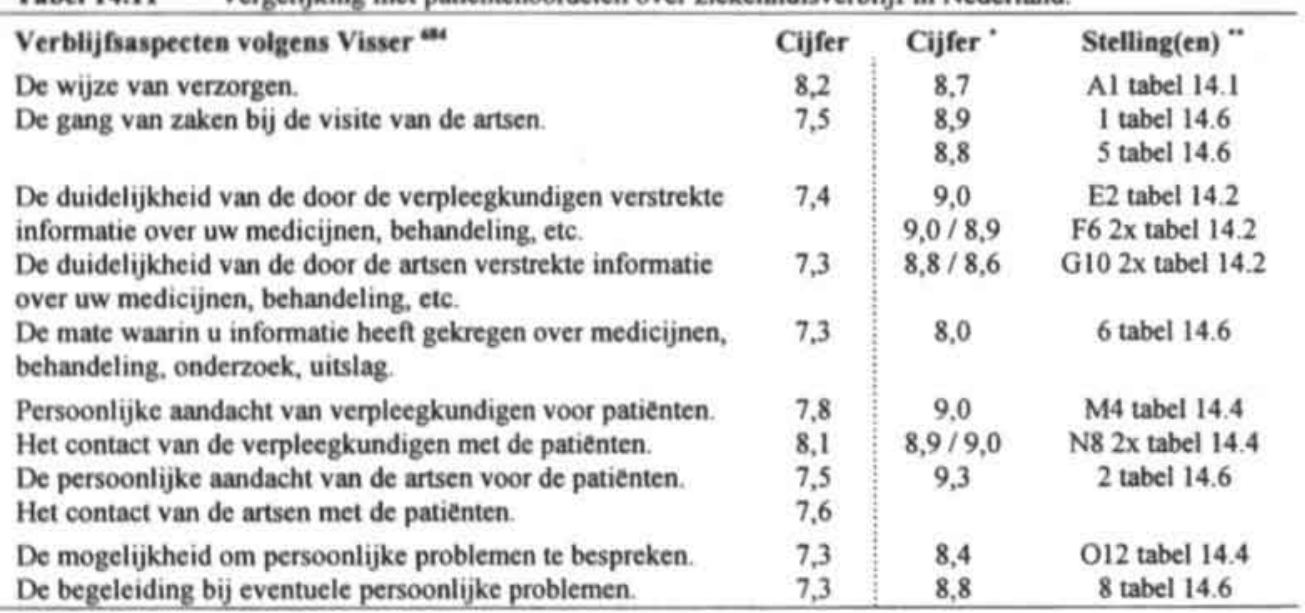

Legenda: "=score op ZKM-it23 of ZKM-it8 stelling omgerekend naar rapporteijfer,"=soms wordt verwezen naar twee stellingen.

Lokale en recente referentiekaders bieden ook twee regionale onderzoeken naar de tevredenheid met de zorg.

In 1993 is bij patiênten $(\mathrm{n}=402)$ in het azM de tevredenheid onderzocht. ${ }^{720}$ De stellingen zijn anders geformuleerd, maar redelijk vergelijkbaar. De tevredenheid met IT lijkt zeker niet kleiner dan die met ziekenhuiszorg in dezelfde regio in dezelfde tijd (tabel 14.12). 


\begin{tabular}{|c|c|c|c|}
\hline Onderwerp in azM onderzoek ma & Score : & Score ${ }^{*}$ & Stelling(en) \\
\hline $\begin{array}{l}\text { Medisch-technisch handelen arts. } \\
\text { Verpleegkundig handelen verpleegkundige. }\end{array}$ & $\begin{array}{l}4,0 \\
3,9\end{array}$ & 4,4 & $\begin{array}{l}\text { Gemiddelde score patient } \\
\text { Al tot D13 tabel } 14.1\end{array}$ \\
\hline $\begin{array}{l}\text { Verstrekken van informatie door arts. } \\
\text { Verstrekken van informatie door verpleegkundige. }\end{array}$ & $\begin{array}{l}4,0 \\
4,0\end{array}$ & 4,5 & $\begin{array}{l}\text { Gemiddelde score patient } \\
\text { E2 tot } \mathrm{HI} 4 \text { tabel } 14.2\end{array}$ \\
\hline $\begin{array}{l}\text { Algemene waardering voor de arts. } \\
\text { Algemene waardering voor de verpleegkundige. }\end{array}$ & $\begin{array}{l}4,1 \\
4,0\end{array}$ & 4,5 & $\begin{array}{l}\text { Gemiddelde totaalscore } \\
\text { patient tabel } 14.5\end{array}$ \\
\hline
\end{tabular}

Legenda: "-score op vijfpuntsschaal.

Ook is in 1995 de tevredenheid onder SGKH-cliênten $(n=572)$ onderzocht volgens de kwaliteitsaspecten van de Landelijke Vereniging van Thuiszorg. ${ }^{71,}{ }^{722}$ Het SGKH onderzoek was enkel gericht op verpleegkundige zorgverlening, ons onderzoek op meerdere disciplines. Ook verschillen de meetmethoden. De tevredenheid met IT lijkt vergelijkbaar met de tevredenheid over algemene thuiszorg in dezelfde regio in dezelfde tijd (14.13).

Tabel 14.13 Vergelijking " met patientenoordelen over regionale thuiszorg.

\begin{tabular}{|c|c|c|c|}
\hline Onderwerp in SGKH onderzoek ${ }^{m}$ & Score ${ }^{*}$ & Score & Stelling(en) \\
\hline $\begin{array}{l}\text { Bereikbaarheid. } \\
\text { Telefonische bereikbaarheid. }\end{array}$ & $\begin{array}{l}3,5=88 \% \\
3,1=78 \%\end{array}$ & $\begin{array}{l}4,5=90 \% * \\
3,9=78 \% *\end{array}$ & $\begin{array}{l}\text { ZKM-i223 item D13 tabel } 14.1 \\
\text { Centraal Meldpunt tabel } 8.3^{\prime}\end{array}$ \\
\hline $\begin{array}{l}\text { Tijd besteed aan zorg. } \\
\text { Verpleegkundige zorg. }\end{array}$ & $\begin{array}{l}3,3=83 \% \\
3,6=90 \%\end{array}$ & $\begin{array}{l}3,5=88 \% \\
3,6=90 \%\end{array}$ & $\begin{array}{l}\text { CSQ item } 5 \text { tabel } 14.8 \\
\text { CSQ item } 7 \text { tabel } 14.8\end{array}$ \\
\hline $\begin{array}{l}\text { Continulteit. } \\
\text { Samenwerking met andere zorgverleners. }\end{array}$ & $\begin{array}{l}3,2=80 \% \\
3,3=83 \%\end{array}$ & $\begin{array}{l}4,3=86 \% * \\
4,3=86 \% "\end{array}$ & $\begin{array}{l}\text { ZKM-it8 item } 7 \text { tabel } 14.6 \\
\text { ZKM-it8 item } 4 \text { tabel } 14.6\end{array}$ \\
\hline $\begin{array}{l}\text { Algemene waardering verpleegkundige } \\
\text { zorgverlener. }\end{array}$ & $3,6=90 \%$ & $9,0=90 \%{ }^{2}$ & $\begin{array}{l}\text { Gemiddeld rapportcijfer TMV en } \\
\text { wijkverpleegkundige tabel } 14.9\end{array}$ \\
\hline
\end{tabular}

Legenda: " $=$ omdat verschillende scores worden vergeleken worden zij allen ook in $\%$ van hun maximumscore weergegeven, ${ }^{\prime=}=$ score op vijfpuntsschaal, $"=$ score op vierpuntsschaal, $"$-score van zorgverieners: dit item is niet aan patienten voorgelegd maar ook zij vonden de bereikbaarheid niet altijd optimaal, ${ }^{2}$-rapporteijfer.

In een onderzoek van de consumentenbond uit oktober 1993 vinden cliënten bij wijkverpleging een snelle beschikbaarheid $\left(8 \frac{1}{2}\right)$, aandacht voor problemen $(81 / 2)$, respect $(81 / 2)$, kennis van verpleegartikelen ( 8 ) en continuiteit $\left(7 \frac{1}{2}\right)$ het belangrijkst. ${ }^{12}$ Ook de toen gegeven scores (tussen haakjes) zijn vergelijkbaar met de resultaten in deze studie.

\subsubsection{OVEREENSTEMMING TUSSEN RESPONDENTEN}

Vraagstelling vijf betreft de overeenstemming tussen respondenten vanwege de afstemming van zorg op de behoeften van de patientnt (correlaties tabel 14.14 verklarende varianties bijlage 14.2). Patiēnten en naasten stemmen redelijk overeen (subvraastelling 1). De tweede subvraagstelling, of verpleegkundigen en artsen -als zorgsysteem- overeenkomstig oordelen, wordt daarentegen niet bevestigd. Ook stemt bij individuele patiēnten het rapportcijfer over de organisatie van de infuuszorg van verpleegkundigen niet overeen met dat van artsen $(\rho=-0.05 n=97 p=0,625)$. Bij combinaties tussen het patiënt- en het professionele zorgsysteem (derde subvraagstelling), komen de oordelen van patienten en verpleegkundigen nog het meest overeen. In het algemeen is de overeenstemming van de verschillende paren bij de CSQ-8 het hoogst en bij de vraag naar de belasting het laagst. 


\begin{tabular}{lccc}
\hline Item & Patient-Naaste I & Patiēnt-Verpleegk. & Patiënt-Arts \\
Totaalscore ZKM-it23 & $.48 / 45 /, 000^{\circ}$ & $.49 / 43 /, 000$ & $.02 / 44 /, 884$ \\
Totaalscore ZKM-it8 & $.56 / 43 /, 000$ & $.43 / 46 /, 020$ & $-.02 / 43 /, 907$ \\
Belasting infuuszorg & $.38 / 45 /, 011$ & $.12 / 50 /, 411$ & $.25 / 45 /, 097$ \\
CSQ-8 & $.81 / 45 /, 000$ & $.59 / 50 /, 000$ & $.42 / 44 /, 005$ \\
CSQ-3 & $.75 / 43 /, 000$ & $.57 / 49 /, 000$ & $.40 / 42 /, 009$ \\
Rapportcijfer huisarts & $.64 / 30 /, 000$ & $.25 / 30 /, 193$ & $.40 / 16 /, 128$ \\
Rapporteijfer TMV & $.66 / 43 /, 000$ & $.34 / 42 /, 028$ & $-.10 / 39 /, 546$ \\
Rapportcijfer WV & $.78 / 8 /, 022$ & $.34 / 6 /, 506$ & $.06 / 3 /, 962$ \\
Gemiddeld rapportcijfer & $.50 / 44 /, 001$ & $.22 / 49 /, 138$ & $.34 / 41 /, 030$ \\
\cline { 2 - 4 } Item & Naaste 1-Verpleegk. & Naaste 1-Arts & Verpleegk.-Arts \\
Totaalscore ZKM-it23 & $.20 / 88 /, 056$ & $.01 / 98 /, 922$ & $.11 / 103 /, 273$ \\
Totaalscore ZKM-it8 & $.15 / 95 /, 162$ & $-.19 / 91 /, 077$ & $.17 / 101 /, 088$ \\
Belasting infuuszorg & $.16 / 103 /, 108$ & $.22 / 94 /, 034$ & $.27 / 104 /, 006$ \\
CSQ-8 & $.39 / 89 /, 000$ & $.21 / 80 /, 060$ & $.16 / 91 /, 141$ \\
CSQ-3 & $.27 / 78 /, 018$ & $.05 / 73 /, 647$ & $.22 / 84 /, 044$ \\
Rapportcijfer huisarts & $.28 / 75 /, 016$ & $.27 / 40 /, 093$ & $.38 / 44 /, 011$ \\
Rapportcijfer TMV & $.21 / 88 /, 054$ & $-.26 / 85 /, 018$ & $.08 / 81 /, 464$ \\
Rapportcijfer WV & $.04 / 44 /, 797$ & $-.11 / 36 /, 542$ & $.24 / 37 /, 149$ \\
Gemiddeld rapportcijfer & $.11 / 103 /, 267$ & $-.10 / 88 /, 373$ & $.07 / 97 /, 504$ \\
\hline
\end{tabular}

Legenda: verpleegk -verpleegkundige, " $=\rho$-correlatic / aantal respondenten / p-waarde.

\subsubsection{DOELMATIGHEID VAN ZORG}

Vraagstelling zes betreft de doelmatigheid van de geleverde zorg. Hiertoe is vergeleken met de produktiviteit van de reguliere thuiszorg en met tarieven voor andere complexe thuiszorg en voor ziekenhuiszorg.

Tabel 14.15 vergelijkt de situatie voor TMVs $(1994+1995)$ en wijkverpleegkundigen (1996) van de SGKH. Bij de SGKH was in 1996 de 'face to face produktiviteit' onder reguliere wijkverpleegkundigen uitgaande van de bruto werktijd ongeveer $67 \%$ ('norm'produktiviteit is $65 \%$, maximaal haalbaar is $70 \%$ ). ${ }^{552} \mathrm{Bij}$ gedifferentieerd werkend wijkverpleegkundigen, die naast hun wijkverpleegkundige taken een speciaal aandachtsgebied hebben, was deze produktiviteit in 1994 ongeveer $61 \%$.

De kosten voor de gezondheidszorg van IT via de SGKH bij het hier gehanteerde zorgmodel varie̋ren van $f 218$ tot $f 420$ per dag (tabel 14.16).

Meestal overstijgen de kosten voor thuisbehandeling het ITZ tarief van $f 200$ per dag. ${ }^{474} \mathrm{De}$ gemiddelde dagprijs van $f 286$ benadert de dagprijzen van de oorspronkelijke experimenten thuisverpleging: Breda $f 172$, Groningen $f 241$, Amsterdam $f 341$ en gemiddeld $f 238$ (de 1988 prijzen van $f 146, f 204, f 289$ en gemiddeld $f 202$ zijn allen geïndexeerd met CBS prijsindex consumenten 1994-1988=117,8/99,8=1,18). ${ }^{74,}{ }^{725}$ Het van deze experimenten afgeleide ITZ tarief zou bij indexering in $1995 f 238$ hebben bedragen. In dat geval zou de overschrijding zo'n $f 50$ per dag, dus ongeveer $20 \%$ hebben bedragen.

Bij ziekenhuisbehandeling worden morfine (SI morf) en overige intraveneuze toediening (IV ov) vrijwel altijd op de verpleegafdeling (dagtarief $f 807$ ) gegeven. Mannitol (IV man) kan in dagbehandeling (dagtarief $f 375$ ) toegediend worden, maar is dan eigenlijk niet vergelijkbaar met thuisbehandeling ( $\$ 12.3 .2)$. Antibiotica (IV ab) kunnen afhankelijk van 
Tabel 14.15 De 1.553 uren bruto werktijd onderverdeeld naar activiteiten (pereentage). ${ }^{1}$

\begin{tabular}{|c|c|c|c|c|c|c|c|}
\hline \multicolumn{5}{|c|}{ Thansmuraal infunoverpleegkiandigen } & Totaal & $\begin{array}{l}\text { Totaal } \\
\text { Wijuer }\end{array}$ & $\begin{array}{l}\text { Activiteit } \\
\text { ecgkundigen }\end{array}$ \\
\hline $\begin{array}{l}\text { Primair proces } \\
+ \text { instructie zorgverleners }\end{array}$ & 47 & 42 & 50 & 43 & 46 & 67 & Face to face \\
\hline $\begin{array}{l}\text { Overieg andere zorgverleners } \\
\text { + bevorderen dienstverlening } \\
\text { + afval }\end{array}$ & 12 & 6 & 5 & 11 & 9 & 5 & Coordinatic \\
\hline Onderling werkoverleg ${ }^{2}$ & 9 & 9 & 9 & 9 & 9 & 6 & Werkoverieg? \\
\hline Verlies & $\bullet$ & • & • & • & - & 1 & Verlies \\
\hline Administratic & 6 & 4 & 3 & 7 & 5 & 4 & Administratic \\
\hline Scholing ${ }^{4}$ & 1 & 1 & 1 & 1 & 1 & 1 & Scholing * \\
\hline Reistijd & 24 & 38 & 32 & 29 & 31 & 14 & Reistijd \\
\hline
\end{tabular}

Legenda: Morf-subcutane infusie van morfine, Mann-intraveneuze infusie van mannitol, AB-intraveneuze infusie van antibiotica, Dolan-centraalveneuze infusie van dopamine en lasix, Totaal=alle behandelingen in het project, *=kleiner dan $1 \%$, $=$ kolomtotaal varieert door afronding van $99 \%$ tot $101 \%$, ${ }^{2}$ wekelijks werkoverleg behalve met feestdagen: 45 weken $\times$ ( 2 uur gezamenlijk + I uur onderling in de dienst).'-wekelijks werkoverleg behalve met feestdagen: 45 weken $\times 2$ uur, "-scholing voor TMVs op hetzelfde aantal uren gesteld als voor reguliere wijkverpleegkundigen.

het toedieningsschema in dagbehandeling, op de short-stay of op de verpleegafdeling gegeven worden. Omdat bij antibiotica alle ziekenhuisalternatieven voorkomen, dient met

Tabel 14.16 Gemiddelde kosten per dag van infuusbehandelingen thuis (guldens).

\begin{tabular}{|c|c|c|c|c|c|c|c|}
\hline Kostensoort & SI morf & IV man & IV $\mathbf{a b}$ & IV ov & CV dola & CV ov & Totaal \\
\hline TMV & 134 & 154 & 207 & 295 & 124 & 80 & 151 \\
\hline Huisartsconsult dag & 17 & 6 & 4 & 16 & 3 & 3 & 7 \\
\hline avond & 9 & 1 & 1 & 20 & - & 1 & 3 \\
\hline weekend & 11 & 2 & $\bullet$ & 9 & $\bullet$ & - & 3 \\
\hline totaal & 38 & 8 & 5 & 44 & 3 & 5 & 14 \\
\hline Coordinatie & 16 & 21 & 10 & 17 & 15 & 13 & 15 \\
\hline Proefgift dagcentrum & - & 34 & - & - & - & 3 & 4 \\
\hline EHBO consult & - & 1 & 1 & 0 & - & - & 0 \\
\hline EHBO iv naald & - & 3 & 3 & 0 & - & - & 1 \\
\hline Personeel totaal & 188 & 220 & 227 & 356 & 142 & 100 & 186 \\
\hline Medicatie & 27 & 19 & 135 & 20 & 8 & 73 & 43 \\
\hline Infuusmateriaal & 20 & 5 & 32 & 37 & $85^{1}$ & 42 & 44 \\
\hline CADD 19 pomp & - & - & - & - & 24 & - & 8 \\
\hline IVAC 5918 pomp & • & $4^{2}$ & $4^{2}$ & 3 & - & 1 & 2 \\
\hline Infuusstandaard & 2 & 2 & 1 & 1 & - & $\cdot$ & 1 \\
\hline Afval & 2 & 3 & 1 & 2 & 2 & 2 & 2 \\
\hline Materieel totaal & 51 & 34 & 174 & 64 & 119 & 118 & 99 \\
\hline Totaal & 239 & 254 & 400 & 420 & 261 & 218 & 286 \\
\hline Behandelingen/patienten & $57 / 56$ & $44 / 28$ & $22 / 15$ & $10 / 10$ & $30 / 9$ & $8 / 4$ & $173 / 123$ \\
\hline Totaal infusiedagen & 634 & 322 & 501 & 118 & 836 & 166 & 2591 \\
\hline Totaal zorgdagen & 701 & 567 & 551 & 132 & 1535 & 232 & 3734 \\
\hline
\end{tabular}

Legenda: *=kleiner dan $f 1,{ }^{1}=$ inclusief disposable pompreservoir, ${ }^{2}=$ pomp niet altijd gebruikt. 
een gemiddelde daarvan $(f 807+f 807+f 375) / 3=f 663)$ vergeleken te worden. Dopamine en lasix (CV dola) en overige centraalveneuze infusies (CV ov) kunnen meestal in dagbehandeling of op de short-stay toegediend worden. Bij dagbehandeling blijft de infusie van hartmiddelen beperkt tot het aan- en afkoppelen van het centraalveneuze infuus. Ook bij antibiotica-infusie moeten patiēnten voor elke gift naar het ziekenhuis komen (bij de behandelde patiěnten één- tot viermaal per dag). Tussendoor en 's nachts zal teruggevallen dienen te worden op de EHBO. Bij ziekenhuisbehandeling nemen buiten de kosten voor gezondheidszorg de reiskosten van het patiëntsysteem toe. Als alternatief is naast het verpleegdagtarief ook vergeleken met een schatting van de werkelijke verblijfsdagprijs van $f 432$ (bijlage 14.2) en met het dagbehandelingstarief van $f 375$. Vergeleken met de ziekenhuisalternatieven is de gemiddelde besparing voor de gezondheidszorg bij vergelijking met de verpleegdagprijs $44 \%$ ( 30 tot $70 \%$ ) of $37 \%$ ( 23 tot $46 \%$ ), met de verblijfsdagprijs $34 \%$ ( 3 tot $50 \%$ ), en met het dagbehandelingstarief $24 \%(-12$ tot $42 \%)$ (bijlage 14.4$)$.

\subsection{Beschouwing}

Ook in deze studie is men overwegend tevreden over de diverse aspecten van de IT zoals die binnen dit zorgmodel voor CMTZ thuis is aangeboden. De variatie van de gemiddelde score voor de vier respondentgroepen in percentage van de maximumscore is: ZKM-i23: 82-90, CSQ-8: 81-86, rapportcijfer huisarts: 74-83, TMV: 80-91, wijkverpleegkundige: 78-89 en organisatie: 80-82. Wat betreft kwaliteit en tevredenheid kan IT de vergelijking met andere vormen van landelijke en regionale klinische en thuiszorg zeker doorstaan. In verband met de continuiteit van zorg blijft de overeenstemming tussen zorgverleners onderling en tussen het patiênt- en het zorgsysteem ondanks een zeer patiēntgericht zorgmodel aandacht verdienen. IT kan via dit zorgmodel doelmatig worden geleverd.

Binnen KvZ zijn de zorginhoudelijke en dienstverlenende domeinen bestudeerd. In de hoofdstukken 8 en 12 zijn sommige aspecten daarvan al besproken. Bij de hier gehanteerde uitgangspunten en meetinstrumenten lopen de beoordeling van de kwaliteit van de zorg en tevredenheid in elkaar over. Onderzoek naar tevredenheid met zorg levert meestal zo'n $75 \%$ tevredenen op. ${ }^{710}$ Ook in het onderhavig onderzoek is men overwegend tevreden. Visser vond onder patiënten in ziekenhuizen slechts $16,5 \%$ ontevredenen. ${ }^{704}$ Ondanks dat het vaak chronisch en ernstig zieken betreft, is men ook in het onderhavig onderzoek weinig 'ontevreden' (infuuszorg belastend: $21-33 \%$ ).

Het creëren van een schaal op basis van kwaliteitsaspecten naar NRV/RGO/NWO en diverse onderdelen van de zorg blijkt theoretisch mogelijk. De door voornoemde organisaties onderscheiden dimensies zijn in de praktijk goed toepasbaar, maar worden in deze studie statistisch niet ondersteund. Oorzaken kunnen zijn dat alle respondenten over alle aspecten werkelijk gelijkelijk tevreden zijn of dat er sprake is van antwoordtendentie (waardoor de dimensies niet tot uiting komen) of dat zij de verschillende dimensies daadwerkelijk niet duidelijk onderscheiden. Gezien het grote aantal onderscheiden aspecten plus de mogelijkheid tot reactie bij elke vraag, lijkt de kans klein dat dit veroorzaakt wordt door een geringe inhoudsvaliditeit. Bij gebruik van de samenvattende ZKM-it8 in plaats van de gespecificeerde ZKM-it23, worden de subdimensies binnen de kwaliteits- en de zorgdimensie iets beter onderscheiden. De ZKM-i23 en de ZKM-it8 komen onderling goed overeen (tabel 14.10). Dit biedt de mogelijkheid om al naar gelang van de gewenste detaillering voor één van beide te kiezen. De overeenstemming met de CSQ ondersteunt, dat de uit zorginhoudelijke items opgebouwde ZKM-lijsten evenzeer het dienstverlenend 
domein -de tevredenheid- weerspiegelen.

Men kan diverse aspecten van de zorg verschillend beoordelen. De tevredenheid in het algemeen en met medische zorg is meestal hoog, die met verpleegkundige zorg lager. ${ }^{604}$ Daarnaast is men tevredener over handelen dan bijvoorbeeld informeren. Op grond van de rapportcijfers is men in het onderhavige onderzoek niet tevredener met de medische zorg. Men geeft eveneens geen hoger punt voor items inzake het directe handelen dan over het informeren, signaleren en veranderen en psychosociale begeleiding.

Ook in deze studie correleert de CSQ-8 goed met diens verkorte versie (CSQ-3) en minder met de één item CSQ-1 (\$14.4.2). ${ }^{100}$ In dit type onderzoek zou vanwege de verminderde belasting met de drie item versie kunnen worden volstaan. In ander onderzoek correleerde de CSQ-8 hoog met rapportcijfers $(r=0.84),{ }^{711}, 712$ In deze studie correleert de CSQ slecht met het gemiddeld rapportcijfer. Dit gemiddeld rapportcijfer is echter opgebouwd uit de rapportcijfers voor de afzonderlijke zorgverleners en niet voor de zorg in z'n geheel. De CSQ-8 blijkt wel overeen te komen met het rapportcijfer voor de TMV bij de patiênt, naaste en verpleegkundige. Dit is te verklaren vanuit de prominente rol van de TMV in het zorgproces. Bij de overige zorgverleners wordt geen significant verband aangetroffen. De correlatie tussen het rapportcijfer voor de zorgverleners en dat voor de organisatie van de IT zoals de zorgverleners die zelf geven, benadrukt eveneens de belangrijke rol van de TMV. Zowel bij verpleegkundigen als bij huisartsen zijn deze correlaties het hoogst voor de TMV. Evenzo correleert het item belasting alleen bij de verpleegkundigen significant negatief met het rapportcijfer voor de TMV. Anders gezegd hoe hoger het cijfer voor de TMV, hoe lager de score voor de belasting.

Buiten het bezwaar van het ontbreken van het oordeel van de patiënt lijkt het een goede keuze de CSI vanwege de gerichtheid op de hele zorgsituatie niet als maat voor de belasting van de infuuszorg mee te nemen. De belasting gemeten volgens de CSI correleert niet of zwak (alleen bij de verpleegkundige) negatief met de CSQ. De negatieve correlaties van zowel de CSQ-8 als de CSQ-3 met de specifieke vraag naar de belasting van de infuuszorg (tabel 14.10) zijn dan ook voor alle respondenten hoger.

$\mathrm{Er}$ is geen aparte vraag naar de ontevredenheid met de zorg opgenomen, omdat de stelling over de belasting indirect naar de 'diskwaliteit' informeert en als zodanig als een vraag naar 'ontevredenheid' is op te vatten, en bovendien via rapportcijfers voor zorgverleners een oordeel is gevraagd met ingebouwde norm. ${ }^{693}$

De hier gehanteerde vergelijking met andere studies verdient voorzichtige interpretatie door de verschillen in meetinstrumenten, soort zorg en tijd (zie ook \$2.5). Door op het niveau van stellingen te vergelijken en gericht te zoeken naar metingen in dezelfde zorgregio en tijd kunnen deze bezwaren deels opgeheven worden.

Vanzelfsprekend is de overeenstemming in het oordeel over de zorg slechts een grove indicator voor de afstemming van zorg. Toch kan op deze wijze inzicht worden verkregen zonder de respondenten met extra vragen te belasten. De overeenstemming tussen patiênt en naaste is redelijk tot goed, die tussen zorgverleners en tussen het patiënt- en het zorgsysteem slechter (tabel 14.14). Voor het zorgmodel pleit dat de patiênt en verpleegkundige gedeeltelijk overeenstemmen. De overeenstemming tussen verpleegkundigen en huisartsen stelt teleur. Het is reěel te veronderstellen dat ook de IT niet altijd optimaal afgestemd is op hetgeen het patiëntsysteem wenst. Enerzijds kan niet altijd aan alle wensen tegemoet gekomen worden. Anderzijds zullen professionele zorgverleners in een aantal 
gevallen tekortschieten, omdat ze de behoeften van het patiëntsysteem onvoldoende kunnen inschatten of de zorg onvoldoende op elkaar afstemmen. De afstemming en daarmee de continutheit van de zorg lijkt voor verbetering vatbaar.

De TMVs hebben een lagere 'face to face produktiviteit' door het benodigde extra overleg binnen het team en met andere zorgverleners, maar vooral door de extra reistijd. Men zou kunnen proberen het aandeel van de reistijd te verlagen door binnen een regio diverse teams te laten opereren. Dit zou echter in totaal meer personeel vereisen en daarmee ook hogere kosten voor aanstelling, scholing en bereikbaarheid en pér individueel teamlid minder ervaring opleveren met gevaar voor de deskundigheid. Al met al bevestigt de aangetroffen tijdsverdeling de 50/50 verhouding tussen de zorg bij de patiënt thuis en de daarvoor benodigde overige taken, waarvoor gespecialiseerd en gedifferentieerd werkende verpleegkundigen vaak pleiten.

In vergelijking met het geldende ITZ tarief van $f 200$ was IT $f 86$ of $40 \%$ duurder. Zou het van de oorspronkelijke experimenten afgeleide ITZ tarief echter voor prijsstijgingen geindexeerd zijn, dan zou dit in $1995 f 238$ hebben bedragen. ${ }^{224}$ In dat geval zou de overschrijding $f 50$ per dag oftewel ongeveer $20 \%$ hebben bedragen.

In de kostenvergelijking wordt thuisbehandeling via een 'organisatie' in een pioniers- en differentiatiefase vergeleken met die via een academisch ziekenhuis in een differentiatie en integratiefase. ${ }^{480}$ In combinatie met de in de operationalisatie en resultaten vermelde aannames leidt dit er toe dat de uitkomsten met voorzichtigheid benaderd dienen te worden. Evenals elders blijken de kosten van thuisbehandeling in vergelijking met verpleegtarief, verblijfsdagprijs en dagbehandelingstarief lager. ${ }^{597,726}$ Andere studies rapporteren besparingen van $20-75 \% .{ }^{47,}{ }^{512}, 598,727 \mathrm{Bij}$ intraveneuze infusie van antibiotica zijn de besparingen van thuisbehandeling binnen deze studie ( $40 \%$; verpleegdagtarief) ondanks de kleinere schaalgrootte vergelijkbaar met een Leids zusterproject $(39 \%){ }^{570}$ Over de projectperiode gerekend resulteert dit afhankelijk van het scenario in 'besparingen' van $f 230.000$ tot $f 670.000$ ten opzichte van ziekenhuisbehandeling (bijlage 14.4). ${ }^{512}$ Ondanks dat thuiszorg doorgaans goedkoper is, blijft er een respectabel dagbedrag nodig om kwalitatief verantwoorde zorg te verlenen. Het patiëntsysteem kan de behandeling immers zelden grotendeels zelf overnemen. Daarom dient er per individuele patiëntsituatie afgewogen te worden of de thuiszorg naast een goede ook een goedkopere optie is. Vooral waar veel logistieke voorbereiding nodig is en de behandelduur relatief kort is, zou thuisbehandeling even duur of zelfs duurder kunnen zijn dan ziekenhuisbehandeling. $\mathrm{Al}$ met al lijkt IT via dit zorgmodel echter doelmatig te kunnen worden geleverd.

\subsection{Conclusies}

Er zijn geen aanwijzingen dat IT volgens het hier beschreven model zorginhoudelijk kwalitatief minder verantwoord of doelmatig is of minder gewaardeerd wordt dan andere soorten klinische en thuiszorg. De kwaliteit van en tevredenheid met de zorg variëren echter met de wijze van vragen en per soort respondent. Ook in deze studie is men over het algemeen tevreden. Zoals verwacht treden de belangrijkste problemen op ten aanzien van transities in de zorg en betreffen veelal de communicatie en samenwerking.

De beoordeling van de $\mathrm{KvZ}$ en tevredenheid in het patiëntsysteem stemt overeen. Helaas geldt dit niet voor de overeenstemming binnen het professionele zorgsysteem en tussen dit en het patiëntsysteem, hetgeen problemen bij de continuitteit van zorg kan opleveren. IT is via het gekozen zorgmodel doelmatig te leveren. 


\section{Kosten voor de gezondheidszorg, patiënt en maatschappij}

\section{$15.1 \quad$ Inleiding}

$\mathrm{Na}$ de kwaliteit van leven en van zorg gaat dit hoofdstuk vanuit functionele rationaliteit (aandachtspunt 9 uit hoofdvraagstelling III) in op de kosten van IT. Aangezien tot dusverre een reguliere financieringsgrondslag ontbreekt, is de kostenopbouw bestudeerd. Omdat met de overgang van klinische zorg naar thuiszorg naar verwachting kosten van de professionele zorg naar het patiēntsysteem verschuiven, is een maatschappelijk perspectief gekozen. Na de beschrijving van de theorie, vraagstelling en operationalisatie worden de kosten voor de gezondheidszorg, het patiêntsysteem en de maatschappij besproken.

\subsection{Theorie bij studie naar kosten van gezondheidszorg}

Drummond et al. delen economische evaluaties in de gezondheidszorg in op grond van het onderwerp van studie en eventuele vergelijking (schema 15.1$)^{496}, 72 s$ Studie van één behandeling kan leiden tot een kosten- of uitkomstenbeschrijving; die van meerdere tot een kostenvergelijking, werkzaamheids- of effectiviteitsevaluatie én 'volledige economische evaluatie'. Een economische evaluatie omvat bij voorkeur ook studie naar de werkzaamheid, effectiviteit en beschikbaarheid van een behandeling. Drummond et al onderscheiden de volgende kostensoorten: kosten van het organiseren en verlenen van gezondheidszorg; kosten die patiënten en hun families maken (tijd die zij investeren en inkomsten die zij mislopen) en overige kosten in de maatschappij. ${ }^{496}$ Kosten zijn boekhoudkundig (nadruk op waarde) of via de kasgeldmethode (nadruk op geldstromen) te benaderen. ${ }^{73,}, 70$

Schema 15.1 Onderscheidende kenmerken van studies naar kosten in de gezondheidszorg.

\begin{tabular}{|c|c|c|c|}
\hline \multirow[b]{3}{*}{$\begin{array}{l}\text { Gén vergelijking } \\
\text { alternatieven }\end{array}$} & \multicolumn{2}{|c|}{ Kosten of effecten } & \multirow{3}{*}{$\begin{array}{l}\text { Kosten én effecten } \\
\text { Kosten uitkomst beschrijving }\end{array}$} \\
\hline & Alléén kosten & Alletn effecten & \\
\hline & Kosten beschrijving & Uitkomst beschrijving & \\
\hline $\begin{array}{l}\text { Wel vergelijking } \\
\text { alternatieven }\end{array}$ & Kosten vergelijking & $\begin{array}{l}\text { Werkzaamheid en } \\
\text { doeltreffendheid }\end{array}$ & $\begin{array}{l}\text { Volledig evaluatie } \\
\text {-kostenminimalisatic } \\
\text {-kosteneffectiviteit } \\
\text {-kostenutiliteit } \\
\text {-kostenbenefit }\end{array}$ \\
\hline
\end{tabular}

\section{3} Vraagstelling, indicatoren en operationalisatie

De vraagstelling betreft de kosten van IT voor de gezondheidszorg, voor patiěnten en hun naaste verzorgers en kosten voor de maatschappij. In deze studie is niet de werkzaamheid, 
maar de toepassing thuis bestudeerd. Effectiviteit en brede toegankelijkheid bij toepassing thuis zijn bewaakt via: instroom, klinisch resultaat, bijwerkingen en complicaties. Door uitkomsten en kosten niet te koppelen, is een volledige economische evaluatie niet mogelijk. Wel is getracht de kosten vanuit maatschappelijk perspectief te beschrijven. Daartoe zijn kosten van de organisatie en daadwerkelijke verlening van gezondheidszorg alsook materiële en personele (geĭnvesteerde tijd) kosten die patiënten en hun families maken, gemeten. Buiten het 'produktieverlies' door de inzet van naaste verzorgers zijn geen andere kosten 'elders in de maatschappij' berekend. Voor inzicht in de kostprijzen is zoveel mogelijk de kasgeldmethode gebruikt. Omdat de kosten tijdens het project nauwelijks veranderden, is niet gedisconteerd naar 'net present value'. ${ }^{72}$ Belastingen (loonbelasting en sociale premies) en overhead zijn alleen bij de TMVs berekend. Ook in de gehanteerde tarieven kunnen deze voorkomen. BTW is niet berekend. Kosten van infusie thuis en in het ziekenhuis zijn in het kader van doelmatigheid vergeleken (H:14).

\subsubsection{INDICATOREN EN OPERATIONALISATIE KOSTEN IN DE GEZONDHEIDSZORG}

De kosten tijdens de projectperiode zijn gebaseerd op een aantal aannamen (\$11.2-\$11.4). Voor de TMVs en voor aan de wijkverpleegkundigen overgedragen infuuszorg gold een uurtarief van $f 55$ (bijlage 15.1). Bij de huisartsen gold overdag bij ziekenfondspatiënten het Intensieve Thuiszorg (ITZ) tarief van $f 34,25$, later $f 34,50$; bij particulieren het consulttarief van $f 51$, later $f 52,50$; 's avonds en in het weekend was dit het dubbele. Bij behandelingen tot en met 2, 4 en 8 weken zijn respectievelijk 3, 6 en 9 uur coördinatie (uurtarief $f 50$ ) omgeslagen. Voor een proefgitt in het dagcentrum stond een tarief van f375. Bij de medicatie is uitgegaan van de ziekenhuisverrekenprijs plus $15 \%$ vulkosten, bij infuusmaterialen van de ziekenhuisverrekenprijs plus $20 \%$ handelingskosten (project als 'externe afnemer'). De infuusstandaard kostte $f 8$ per week, de IVAC $591 \otimes$ infuuspomp $f 5$ per dag. Bij patiênten met hartfalen kochten zorgverzekeraars de CADD $1 \otimes$ pompen en gaven ze aan de patiěnten in bruikleen (bijlage 11.1: maandbedrag $f 165$ per stuk). De afvalverwerking via het ziekenhuis kostte $\pm f 25$ per patiënt per maand (bijlage 15.2).

\subsubsection{INDICATOREN EN OPERATIONALISATIE MATERIELLE KOSTEN PATIENTSYSTEEM}

Tot het patiëntsysteem zijn de patiěnt en diens naaste verzorgers gerekend. De meeste direct aan de behandeling gekoppelde kosten zijn meegenomen: de kosten van het lidmaatschap van het Groene Kruis, de eigen bijdrage voor de huisarts en reis-, telefoonen afvalkosten. De eigen bijdragen voor infuusmaterialen (verbandmiddelen en dergelijke) zijn niet tot de kosten van de patient gerekend, aangezien deze bij ziekenhuis vervangende zorg eigenlijk altijd vergoed zouden moeten worden. Voor de huisarts is geen eigen bijdrage gerekend aangezien het intensieve thuiszorg betrof. Ook is bij de patiěnten met hartmiddelen geen rekening gehouden met een eventueel af te sluiten kostbaarhedenverzekering voor de in bruikleen gekregen cassettepompen (gezamenlijke nieuwwaarde rond $f 20.000$ ). In de projectperiode hoefden patiënten geen lid te zijn van het Groene Kruis ( $f 54,75$ in 1995), bij de voortzetting als reguliere zorg wel. ${ }^{31}$ Bij continue infusie van hartmiddelen is de contributie per patiênt berekend. Bij andere IT is uitgegaan van het aantal behandelingen, zodat deze kosten iets te hoog uitvallen (vervolgbehandeling binnen 1 jaar normaal geen extra kosten). Entreegeld is niet opgenomen ( $f 70,50$ in 1995), hoewel dit verschuldigd was bij zorg binnen drie maanden na het begin van het lidmaatschap. Reiskosten naar het ziekenhuis voor een proefgift, het opnieuw inbrengen van een infuusnaald op de EHBO of een EHBO-consult, zijn vermenigvuldigd met de gemiddelde 
reisafstand tot het ziekenhuis op basis van de regionale verdeling van de patiēnten (tabel 8.1 gemiddelde enkele reisafstand $7,1 \mathrm{~km}$ ). De reiskosten zijn berekend à $f 0,59$ cent per kilometer. ${ }^{72}$ Patiēnten konden zelf de infuusstandaard bij het Groene Kruis halen of terugbrengen. Thuis bezorgen en weer ophalen kostte $f 5$, later $f 7,50$ per keer. De telefoonkosten konden niet precies vastgesteld worden en zijn daarom op $f 1$ per dag gesteld (coördinatie). Voor dit bedrag kan binnen kantooruren ongeveer 5 minuten gebeld worden buiten het basis-tariefgebied (erbinnen 15 minuten). ${ }^{m}$

Niet alle afval is als ziekenhuisafval verwerkt (bijlage 15.2). Vanwege de hygiēne wordt eens per week een aparte vuilniszak gebruikt. Bij niet continue infusie stijgt daardoor de prijs per dag. De kosten van de afvalzak zijn op $f 2$ per week gesteld. ${ }^{m 4}$

\subsubsection{INDICATOREN EN OPERATIONALISATIE PERSONELE KOSTEN PATIENTSYSTEEM}

Ter inschatting van de personele kosten van patiênten en naasten kan gekeken worden naar tijdsinvestering, hier 'uurbelasting' genoemd. Ook kan gekeken worden naar het niet beschikbaar zijn voor de arbeidsmarkt, hier 'produktieverlies' genoemd. Overige maatschappelijke activiteiten (studeren, vakantie) zijn moeilijker in geld waardeerbaar. Voor de patiënt zijn de kosten van diens 'arbeidsongeschiktheid' niet berekend aangezien het niet aannemelijk is dat de patient bij een ziekenhuisopname wel had kunnen werken (incidenteel kon men door de thuisbehandeling juist wel werken). Bij berekening van de personele kosten van de naasten is zowel naar de uurbelasting (tabel 13.15) als het produktieverlies gekeken (tabel 13.16). Omdat niet iedereen voltijds werkt, zal het produktieverlies iets overschat worden. Bij 'gedeeltelijk' produktieverlies is gerekend met $50 \%$. Als maat is de full-time equivalent (fte), overeenkomend met 8 uur per dag, gehanteerd. Met de verhouding tussen de naasten is rekening gehouden (tabel 13.10) omdat niet bij iedere patiënt een tweede, derde en vierde naaste aanwezig is, maar de fte's wel per patie̋nt berekend worden. Om het verschil te illustreren tussen de uurbelasting van de thuiszorg en het produktieverlies daardoor en ter controle van de interne validiteit is per soort infusie de verhouding tussen beiden berekend. Bij de door de patiěnt verstrekte gegevens zijn de gegevens van naasten 1-4 opgenomen, bij de door de naaste 1 verstrekte gegevens alleen die van naaste 1 zelf.

$\mathrm{Er}$ is nog volop discussie over de waardering van zelf- en mantelzorg. ${ }^{496,735-737}$ Op grond van bovenstaande en kenmerken van patiënten en naasten kan voorondersteld worden dat zorguren door naasten anders niet $100 \%$ produktief zouden zijn geweest (\$13.5.2.3). Verlies aan werktijd wordt wel op $50 \%$ gewaardeerd en verlies aan vrije tijd op $35 \%$. ${ }^{7 s}$ Vanwege de intermediaire positie van huishoudelijke activiteiten en vrijwilligerswerk zijn deze op 42,5\% gewaardeerd. Uit tabel 13.13 (cijfers in tabel zijn afgerond) is ongeveer het waarderingspercentage voor de onderzoekspopulatie te bepalen: $28,7 \times 0,50 \%+(44,8+3,7)$ $\mathrm{x} 0,425 \%+(13,9+0,9+1,9+2,8+14,8) \times 0,35 \%= \pm 47 \%$ (vóór correctie) $= \pm 42 \%$ (na correctie omdat de percentages totaal naaste 1 samen $111,5 \%$ zijn). Bij een gemiddeld brutosalaris van $f 44.300$ en 1.442 werkuren per jaar (alle werkenden), bedragen de maatschappelijke kosten van één gemiste werkdag $f 246$ (voltijds werkenden zelfs $f 56.300 / 1.732 \times 8=f 260$ ), omgerekend per kalenderdag $f 121 .^{739}$ Bij waardering op $42 \%$ is dit $f 103$ (voltijds $f 109$ ) per werkdag en $f 51$ (voltijds $f 55$ ) per kalenderdag.

\subsubsection{INDICATOREN EN OPERATIONALISATIE TOTALE MAATSCHAPPELIJKE KOSTEN}

De geschatte totale maatschappelijke kosten zijn hier gelijk gesteld aan de kosten van de gezondheidszorg en de materiēle en personele kosten voor het patiëntsysteem. 


\subsection{Resultaten}

De kosten verschillen per behandeling. Subcutane infusie van morfine/vocht, intraveneuze infusie van mannitol en antibiotica en centraalveneuze infusie van hartmiddelen zijn in deze volgorde opgestart (\$7.6.1). De instroom stabiliseerde zich in de tijd (figuur 8.1). De piek begin 1994 markeert het wegwerken van een wachtlijst voor mannitolinfusie. De maximale behandelduur is om administratieve redenen beperkt tot 8 weken $(\mathrm{H}: 8)$. Bij langere behandelingen of vervolgbehandelingen ging daarna een nieuwe episode in.

\subsubsection{KOSTEN IN DE GEZONDHEIDSZORG}

De kosten op basis van de in de operationalisatie genoemde prijsafspraken zijn via individuele kostenoverzichten aan de zorgverzekeraars gedeclareerd. Bij 173 infuusbehandelingen in iets meer dan twee jaar bedragen zij in totaal $f 623.000$, per infusiedag $f 240$ (bijlage 15.3). De individuele kostenoverzichten geven echter niet alle kosten weer. Met name de salariskosten van de verpleegkundige infuuszorg geven een zodanige onderschatting van de totale kosten dat deze gecorrigeerd zijn (bijlage 15.3). De kosten na deze correctie bedragen ruim $f 740.000$ of $f 286$ per infusiedag. Tabel 15.1 geeft de gemiddelde kosten ( 8 ) en de standaarddeviaties (sd) na deze correctie.

\begin{tabular}{|c|c|c|c|c|c|c|}
\hline \multirow[t]{2}{*}{ Kostensoort } & \multicolumn{2}{|c|}{ SI morfine } & \multicolumn{2}{|c|}{ IV mannitol } & \multicolumn{2}{|c|}{ IV antibiotica } \\
\hline & \& & sd & \& & sd & \& & sd \\
\hline TMV/wijkverpleegkundige & 1.498 & 1.755 & 1.126 & 359 & 4.724 & 3.526 \\
\hline $\begin{array}{rr}\text { Huisartsconsult } & \begin{array}{r}\text { dag } \\
\text { avond } \\
\text { weekend } \\
\text { totaal }\end{array}\end{array}$ & $\begin{array}{l}191 \\
104 \\
123 \\
418\end{array}$ & $\begin{array}{l}204 \\
217 \\
187 \\
499\end{array}$ & $\begin{array}{r}42 \\
6 \\
11 \\
59\end{array}$ & $\begin{array}{l}36 \\
20 \\
36 \\
52\end{array}$ & $\begin{array}{r}82 \\
14 \\
9 \\
106\end{array}$ & $\begin{array}{r}69 \\
37 \\
30 \\
105\end{array}$ \\
\hline TDC Coordinatic & 176 & 70 & 150 & 0 & 232 & 111 \\
\hline Proefgift dagcentrum & - & - & 247 & 197 & $\cdot$ & - \\
\hline EHBO consult & - & - & 5 & 20 & 32 & 81 \\
\hline EHBO iv naald ' & $\therefore$ & $\therefore$ & 22 & 32. & 71 & 112 \\
\hline Personeel subtotaal & 2.092 & 2.053 & 1.610 & 479 & 5.164 & 3.656 \\
\hline Medicatic & 302 & 595 & 136 & 23 & 3.079 & 2.766 \\
\hline Infuusmateriaal ${ }^{2}$ & 219 & 222 & 38 & 22 & 725 & 555 \\
\hline CADD 10 cassettepomp & - & - & - & - & - & - \\
\hline IVAC 5918 infuuspomp & 3 & 15 & 32 & 8 & 91 & 67 \\
\hline Infuusstandaard & 18 & 16 & 15 & 8 & 29 & 18 \\
\hline Afval & 27. & 8 & 25 & 0 & 31 & 11 \\
\hline Materieel subtotaal & 568 & 824 & 247 & 33 & 3.955 & 3.307 \\
\hline Totaal & 2.661 & 2.816 & 1.856 & 476 & 9.119 & 6.092 \\
\hline Behandelingen / patienten & $57 / 56$ & & $44 / 28^{3}$ & & $22 / 15$ & \\
\hline $\begin{array}{r}\text { Aantal dagen infusie totaal } \\
\text { gemiddeld } \\
\text { standaard deviatic } \\
\text { bereik }\end{array}$ & $\begin{array}{r}634 \\
11,12 \\
13,91 \\
1-69\end{array}$ & & $\begin{array}{r}322 \\
7,32 \\
1,49 \\
2-8\end{array}$ & & $\begin{array}{r}501 \\
22,77 \\
14,87 \\
5-57\end{array}$ & \\
\hline Totale zorgduur & 701 & & 567 & & 551 & \\
\hline
\end{tabular}

Legenda: '-voor het inbrengen van een intraveneuze canule gold een tarief van $f 40,{ }^{2}=$ inclusief disposable pompreservoirs: bij CADD 18 de $50 \mathrm{ml}$ cassettes, bij de Sidekick de $100 \mathrm{ml} ; 100 \mathrm{ml} /$ uur infuuszakjes, 
De 57 periodes met subcutane infusie van morfine en overige medicatie zijn geheel binnen de thuiszorg georganiseerd. Alleen voor coördinatie, inzet van een infuuspomp met bijbehorende infuuslijnen en afvalvoorziening is teruggevallen op het ziekenhuis. De kosten van adviezen aan huisartsen ( \pm 10 stuks) en huisbezoeken ( \pm 3 stuks) van de pijnconsulent zijn niet in de kosten opgenomen. Gemiddeld kost subcutane infusie van morfine per behandeling $f 2.661$ en per infusiedag $f 239$. Verschillen in behandelduur veroorzaken de grote standaarddeviatie. Twee patiênten ontvingen subcutane infusie van vocht. Gemiddeld kost dit per behandeling $f 1.085$ en per infusiedag $f 155$. Mannitol (44) en antibiotica (22) zijn intraveneus toegediend met een infuuspomp. Deze zorg is vooral vanuit het ziekenhuis verleend (proefdosis, medicatie, materialen, pompen, afvalverwerking). Moest een nieuwe infuuscanule ingebracht worden en wilde of kon de huisarts dit niet, dan werd teruggevallen op de EHBO. De gemiddelde kosten per behandeling en infusiedag zijn bij mannitol respectievelijk $f 1.856$ en $f 254$ en bij antibiotica 'gemiddeld' $f 9.119$ respectievelijk $f 400$. Verschillen in aantallen, frequentie en prijzen van antibiotica veroorzaken de grote standaarddeviatie. Ook de overige intraveneuze behandelingen $(\S 12.3)$ verschillen sterk en zijn vooral vanuit het ziekenhuis begeleid. $\mathrm{Zij}$ kosten 'gemiddeld' $f 4.962$ per behandeling en $f 420$ per infusiedag.

Tabel 15.1 vervolg Kosten van de gezondheidszorg per infuusbehandeling thuis (guldens)

\begin{tabular}{|c|c|c|c|c|c|c|c|}
\hline \multicolumn{2}{|c|}{ IV overig } & \multicolumn{2}{|c|}{ CV dopamine/lasix } & \multicolumn{2}{|c|}{$\mathrm{CV}$ overig } & \multicolumn{2}{|c|}{ Alle behandelingen } \\
\hline \& & sd & x & sd & \& & sd & 8 & sd \\
\hline 3.486 & 5.362 & 3.445 & 1.152 & 1.666 & 2.310 & 2.264 & 2.485 \\
\hline 184 & 147 & 74 & 84 & 69 & 98 & 111 & 146 \\
\hline 232 & 385 & 10 & 27 & 26 & 73 & 54 & 166 \\
\hline 106 & 128 & 5 & 25 & 9 & 24 & 52 & 126 \\
\hline 522 & 591 & 88 & 102 & 103 & 173 & 217 & 367 \\
\hline 195 & 101 & 420 & 73 & 263 & 155 & 224 & 121 \\
\hline - & - & - & $\cdot$ & 47 & 133 & 65 & 148 \\
\hline 0 & 0 & - & $\cdot$ & $\cdot$ & $\cdot$ & 5 & 32 \\
\hline 0 & 0 & $\therefore$ & $\therefore$ & $\therefore$ & $\therefore$ & 15 & 48 \\
\hline 4.203 & 5.594 & 3.953 & 1.200 & 2.078 & 2.344 & 2.790 & 2.612 \\
\hline 236 & 324 & 233 & 80 & 1.510 & 1.963 & 650 & 1.468 \\
\hline 446 & 690 & 2.376 & 775 & 874 & 999 & 653 & 952 \\
\hline - & - & 663 & 131 & - & - & 115 & 258 \\
\hline 36 & 56 & - & - & 24 & 34 & 24 & 41 \\
\hline 14 & 11 & $\cdot$ & - & 10 & 14 & 15 & 15 \\
\hline 28 & 8 & 46 & 9 & 34 & 13 & 30 & 11 \\
\hline 760 & 921 & 3.318 & 948 & 2.454 & 2.946 & 1.488 & 2.058 \\
\hline 4.962 & 6.468 & 7.272 & 2.078 & 4.532 & 3.278 & 4.278 & 4.195 \\
\hline $10 / 10$ & & $30 / 9$ & & $8 / 4^{\prime}$ & & $173 / 123^{\circ}$ & \\
\hline 118 & & 836 & & 166 & & 2.591 & \\
\hline 11,80 & & 27,87 & & 20,75 & & 14,98 & \\
\hline 12,86 & & 7,61 & & 15,67 & & 13,36 & \\
\hline $2-34$ & & $6-32$ & & $1-40$ & & $1-69$ & \\
\hline 132 & & 1.535 & & 232 & & 3.734 & \\
\hline
\end{tabular}

Legenda vervolg: ${ }^{1}=$ ten patient kreeg eerst intraveneuze en later centraalveneuze mannitolinfusies, ${ }^{4}=$ inclusief subcutane behandelingen zonder morfine bij twee patienten. 
De 30 periodes met infusie van hartmiddelen omvatten 418 behandelingen. Bij de 24-uurs toediening wordt op de ene dag aangekoppeld en de volgende afgekoppeld. Daarom is bij de berekening van 836 infusiedagen uitgegaan. De gemiddelde kosten zijn $f 7.272$ per behandeling en $f 261$ per infusiedag. Omdat de verplaatsing van de behandeling naar de thuiszorg centraal staat, zijn de kosten die niet verschuiven (specialist, diagnostiek, etc) buiten beschouwing gelaten. Ook de kosten voor indicatiestelling bij patiënten met chronisch hartfalen (gemiddeld 3,5 uur à $f 81,25=f 285$ ) die niet voor IT in aanmerking komen (bijlage 7.4) zijn niet doorberekend.

De overige 8 centraalveneuze behandelingen betreffen vochttoediening $2 x$, virostatica $3 x$, mannitol $2 \mathrm{x}$ en doorspuiten $1 \mathrm{x}$. Zij variëren van 1 dag (doorspuiten) tot 40 infusies in twee maanden (virostatica). 'Gemiddeld' kosten zij $f 4.532$ per behandeling en $f 218$ per dag.

\subsubsection{MATERIELLE KOSTEN PATIÉNTSYSTEEM}

De aan de IT verbonden materiële kosten voor het patiëntsysteem variëren van $f 2$ tot $f 12$ en zijn gemiddeld $f 5$ (tabel 15.2). De berekening is slechts indicatief en hangt sterk af van de keuze voor de kosten en de wijze waarop deze vervolgens berekend worden. De belangrijkste kosten die niet zijn berekend, zijn reiskosten van naaste verzorgers. Deze woonden op grond van de selectiecriteria meestal bij de patiênt in huis (H:13). Verdere aandacht verdienen eigen bijdragen aan de kosten van de huisarts en infuusmaterialen. Indien deze in de toekomst aan de patiěnt in rekening worden gebracht, dan zullen de kosten voor hem fors toenemen. ${ }^{727}$

Tabel 15.2 Materiele kosten voor patienten en naaste verzorgers per infusiedag (guldens).

\begin{tabular}{lccccccc}
\hline Kostensoort & SI morf & IV man & IV ab & IV ov & CV dola & CV ov & Totaal \\
TMV (lidmaatschap) & 4,92 & 7,48 & 2,40 & 4,64 & 0,65 & 2,64 & 2,60 \\
Coordinatic (telefoon) & 1,00 & 1,00 & 1,00 & 1,00 & 1,00 & 1,00 & 1,00 \\
Proefgift dagcentrum & - & 0,75 & - & - & - & - & 0,09 \\
EHBO consult & - & 0,08 & 0,15 & 0,00 & - & - & 0,04 \\
EHBO iv naald ${ }^{2}$ & - & 0,62 & 0,65 & 0,00 & - & - & 0,20 \\
Infuusstandaard & 1,35 & 2,05 & 0,69 & 1,27 & - & - & 0,78 \\
Afval & 0,29 & 0,29 & 0,29 & 0,29 & 0,50 & 0,29 & 0,36 \\
Totaal & 7,56 & 12,27 & 5,18 & 7,20 & 2,15 & 3,93 & 5,07 \\
\hline Behandelingen/patienten & $57 / 56$ & $44 / 28$ & $22 / 15$ & $10 / 10$ & $30 / 9$ & $8 / 4$ & $173 / 122$ \\
Totaal infusiedagen & 634 & 322 & 501 & 118 & 836 & 166 & 2.591 \\
\hline
\end{tabular}

Legenda: '=voorbeeld lidmaatschap morfine: tabel 15.1 vermeidt 57 behandelingen en $57 x f 54,75=f 3.121$ is $f 3.121 / 634=f 4,92$ per infusiedag, ${ }^{2}=$ voorbeeld EHBO iv naald bij mannitol: bijlage 15.3 vermeldt $f 960$ dat overeenkomt met $f 960 / f 40=24$ consulten die een reisafstand van $24 \times 7,1 \times 2=341$ kilometer vergen leidend tot $341 \times f 0,59=f 201$ aan totale kosten is $f 201 / 322=f 0,62$ per infusiedag, ${ }^{3}=$ voorbeeld infuusstandaard bij morfine: 57 behandelingen komen overeen met $57 \times f 7,50 \times 2=f 855$ aan totale kosten is $f 855 / 634=f 1,35$ per infusiedag.

\subsubsection{PERSONELE KOSTEN PATIENTSYSTEEM}

De uurbelasting en het produktieverlies zijn bij ernstig zieke patiennten hoger (tabel 15.3; berekening bijlage 15.4). De patiěnt geeft een lagere werkbelasting voor naaste 1 op dan naaste 1 zelf. De personele kosten gemeten in uurbelasting bedragen volgens de patiênt $f 85$, volgens naaste 1 is diens eigen inbreng $f 35$ hoger $(0,67 \mathrm{fte}$; bijlage 15.4$)$. Samen met de naasten $2-4$ van de patiênt bedragen de kosten dan $f 120$. Gemeten in produktieverlies bedragen de personele kosten volgens de patiënt $f 18$, volgens naaste 1 zelf is diens 
inbreng $f 20$ hoger $(0,17 \mathrm{fte}$; bijlage 15.4$)$. Samen met de naasten $2-4$ van de patiěnt bedragen deze kosten dan $f 38$. De verhouding tussen de uurbelasting en het produktieverlies bedraagt bij de patiênt voor alle soorten infusies ongeveer $5: 1$, bij de naaste 1 zelf ongeveer 3:1.

Indien men de personele inzet van naasten zo waardeert, kost mannitolinfusie gemeten via de uurbelasting (schaduwprijs via marktsubsitutie) volgens de patiênt $7 \times f 86=f 600$, volgens de naaste 1 zelf (naasten $2-4$ via patiënt) $7 \times f 94 \approx f 660$ per week. ${ }^{73}$ Meet men het produktieverlies via het hebben moeten opgeven van werk (opportunity costs), dan kost dezelfde mannitolinfusie volgens de patiēnt zo'n $7 \times f 23=f 160$ en volgens de naaste 1 zelf (naaste $2-4$ via patient) $7 \times f 39=f 270$ per week. ${ }^{75}$ Ook wanneer een naaste vakantie of zorgverlof neemt of zichzelf 'ziek meldt' blijven deze kosten vanuit maatschappelijk economisch perspectief bestaan.

Tabel 15.3 Personele kosten voor patienten en naste verzorgers per infusiedag (guldens)

\begin{tabular}{|c|c|c|c|c|c|c|c|c|}
\hline \multicolumn{2}{|l|}{ Arbeid } & SI morf & $r V$ man & $\mathbf{I V} \mathbf{a b}$ & IV ov & CV dola & $\mathrm{CV}$ ov & Totaal \\
\hline \multicolumn{9}{|c|}{ Volgens patiênt (naaste $1-4$ ) } \\
\hline \multirow[t]{5}{*}{ Uurbelasting } & naaste 1 & $\bullet$ & 57 & 38 & • & 58 & • & 50 \\
\hline & naaste 2 & & 19 & 7 & & 27 & & 18 \\
\hline & naaste 3 & & 7 & 2 & & 23 & & 10 \\
\hline & naaste 4 & & 3 & 3 & & 23 & & 51 \\
\hline & totaal (a) & & 86 & 48 & & 130 & & 85 \\
\hline \multirow[t]{5}{*}{ Produktieverlies } & naaste I & - & 15 & 8 & • & - & • & 10 \\
\hline & naaste 2 & & 7 & 4 & & . & & 6 \\
\hline & naaste 3 & & 2 & - & & - & & 4 \\
\hline & naaste 4 & & - & - & & - & & 0 \\
\hline & totaal (b) & & 23 & 10 & & - & & 18 \\
\hline \multicolumn{2}{|c|}{ Verhouding totaal $\mathbf{a} \cdot \mathbf{b}$} & • & 4 & 5 & • & - & $\cdot$ & 5 \\
\hline \multicolumn{9}{|c|}{ Volgens naaste I (naaste I) } \\
\hline \multicolumn{2}{|c|}{ Uurbelasting (c) } & 101 & 65 & 47 & • & 85 & $\bullet$ & 85 \\
\hline \multicolumn{2}{|c|}{ Produktieveriies (d) } & 41 & 30 & 5 & • & $\cdot$ & • & 30 \\
\hline \multicolumn{2}{|c|}{ Verhouding $\mathrm{c}: \mathrm{d}$} & 2 & 2 & 9 & - & $\therefore$ & - & 3 \\
\hline \multicolumn{2}{|c|}{ Behandelingen/patienten } & $57 / 56$ & $44 / 28$ & $22 / 15$ & $10 / 10$ & $30 / 9$ & $8 / 4$ & $173 / 122$ \\
\hline \multicolumn{2}{|c|}{ Totaal infusiedagen } & 634 & 322 & 501 & 118 & 836 & 166 & 2.591 \\
\hline
\end{tabular}

Legenda: *niet berekend, = antwoordmogelijkheid komt niet voor. Nota bene I: door afronding kunnen totalen afwijken van de som van individuele getallen. Nota bene 2: precieze berekening in tabel B15.5 bijlage 15.4.

\subsubsection{TOTALE MAATSCHAPPELIJKE KOSTEN}

De kosten van de gezondheidszorg bedragen per infusiedag gemiddeld $f 286$, de materiële kosten voor het patiëntsysteem gemiddeld $f 5$.

De personele kosten op basis van de uurbelasting zijn volgens de patiënt $f 85$ en volgens naaste $1 f 120$. Opgeteld variëren de totale maatschappelijke kosten dan van $f 376$ tot $f 411$. De bijdrage van patiënten en verzorgers varieert van $24 \%$ tot $30 \%$.

Het -via het hebben moeten opgeven van werk gemeten- produktieverlies kost volgens de patiënt $f 18$ en volgens naaste $1 f 38$. Opgeteld variëren de totale maatschappelijke kosten dan van $f 309$ tot $f 329$ en de bijdrage van patiënten en verzorgers hierin van $7 \%$ tot $13 \%$. 


\subsection{Beschouwing}

Bij de berekening van de kosten van thuisbehandelingen kan het zorgverleningsmodel van Orem gehanteerd worden. ${ }^{164}$ Een kostenoverzicht als het hier gepresenteerde levert geen richtprijzen op voor de financiering van IT. De kosten zijn namelijk gerealiseerd binnen én bepaald zorgmodel en met behandelingen onder de 'optimale omstandigheden' van een onderzoekssetting. Inzicht is verkregen in de kosten van enkele subcutane, intraveneuze en centraalveneuze 'standaardbehandelingen' en er wordt een methode aangereikt waarmee de kosten van andere thuisbehandelingen berekend kunnen worden.

De kosten van de gezondheidszorg bij thuis- en ziekenhuisbehandeling verschillen per behandeling en organisatie of afdeling en zijn moeilijk vergelijkbaar. De kosten voor de gezondheidszorg bestaan bij traditionele thuiszorg vooral uit arbeidskosten. CMTZ als IT is kapitaal-intensiever (medicatie, apparatuur) ${ }^{114}$ Hier bedragen de arbeidskosten van de TMVs ruim $50 \%$ en de overige personele kosten $10-15 \%$ van het totaal; die van apparatuur, medicatie en infuusmaterialen ongeveer $35 \%$ van het totaal.

Bij de kostprijsbepaling van complexe medisch-technische behandelingen in de thuiszorg dient expliciete aandacht uit te gaan naar de kosten van reizen, overdracht, overleg en coőrdinatie. Bij vanuit het Groene Kruis aangeboden transmuraal infuusverpleegkundige zorg is het, vanwege de kosten van het produktieproces, aan te bevelen tenminste het COTG-richttarief van $f 81,25$ te volgen bij bepaling van de uurprijs (integrale kostprijs zorguur per deskundigheidsniveau). ${ }^{74,715,740} \mathrm{En}$, hoewel de tarieven voor huisartsgeneeskundige zorg kostendekkend lijken en de omvang van de huisartsgeneeskundige zorg (aan de hand van consulten) relatief beperkt, dienen ook deze kosten in de toekomst voor de beroepsgroep declarabel te zijn. ${ }^{n 7}$

De kosten van de gezondheidszorg van IT via de SGKH bij het hier gehanteerde zorgmodel variëren van $f 218$ tot $f 420$ per dag (tabel 14.16). De vergelijking met tarieven en kosten voor andere complexe thuiszorg en ziekenhuiszorg viel gunstig uit (H:14). Vanwege de vaste kosten (investeringen, aanstelling TMVs) is thuisbehandeling alleen goedkoper bij een voldoende aantal patienten. ${ }^{512}$ Binnen het project ligt het minimum aantal benodigde infusiedagen op \pm 215 per jaar (bijlage 15.5). Binnen het project zijn echter de basisaanstellingen van de TMVs klein $(0,1 \mathrm{fte})$ en daarmee de vaste kosten laag. Bij grotere vaste dienstverbanden vallen besparingen lager uit als onproduktiviteit optreedt door bijvoorbeeld de grillige instroom (figuur 8.1). Thuisbehandeling wordt echter pas onrendabel bij hoge onproduktiviteit en lage besparingen (bijlage 15.5).

De materiële kosten voor het patiëntsysteem zijn wellicht niet allemaal in kaart gebracht. Een gemiddeld dagbedrag van $f 5$ aan materiěle kosten voor het patiëntsysteem lijkt laag. Toch kan dit voor mensen met een laag inkomen en andere hoge kosten tengevolge van hun ziekte, problematisch zijn. Zo zijn de kosten voor de chronische patie̋nten gemiddeld lager, maar zullen door het hogere aantal infusiedagen veelal hoger uitvallen (infusie hartmiddelen 52 weken $\times 4$ dagen $\times f 2,15=f 450$ ). Ook een ziekenhuisverblijf brengt materiële kosten voor de patie̋nt (huur telefoon $f 3$ per dag voor de eerste 14 dagen) en de naasten (reiskosten) met zich mee. ${ }^{741}$

Bij de personele kosten voor het patiēntssysteem is alleen gekeken naar maximaal vier naaste verzorgers. Ook de basisgegevens waarop de berekeningen gebaseerd zijn (H:13), kunnen zeker ter discussie gesteld worden. De discussie over de waardering van zelf- en 
mantelzorg is reeds genoemd. $40.73-237$

De belasting in uren blijkt beduidend groter dan uitgedrukt in het produktieverlies. Een van de oorzaken is dat een beperkt aantal naasten werk had tijdens de infuusbehandeling (tabel 13.12). Ook duidt dit er op dat een netwerk van naasten een bepaalde hoeveelheid zorg kan verlenen zonder het werk te hoeven staken. Bij de uurbelasting is expliciet gevraagd naar de extra uren die de naaste met de patiênt doorbrengt. De opgaven betreffende de uurbelasting zouden aan de hoge kant kunnen zijn. Toch lijkt hun onderlinge verhouding voor de verschillende behandelingen redelijk constant en intern consistent. De hogere verhoudingen bij antibiotica zijn waarschijnlijk te wijten aan de kleine aantallen patiēnten, het percentage werkende naasten is namelijk niet onevenredig groter (tabel 13.13).

Gekeken naar de uurbelasting van naasten (met alle voorbehouden) blijkt thuiszorg zonder naasten incidenteel misschien net betaalbaar, maar structureel zeker 'onbetaalbaar'.

Maatschappelijk gezien zijn niet-professionele personele kosten -ook al zijn deze beperkt tot de belasting van de naasten- wel degelijk aanwezig. Afhankelijk van de berekening kunnen deze voor afzonderlijke infusies oplopen tot maximaal $36 \%(136 /(239+8+136))$ en over alle infusies bekeken tot zo'n $29 \%(119 /(286+5+119))$ van de totaalprijs (uurbelasting ingeschat door naaste). Ook bij gematigde aannamen (produktieverlies ingeschat door naaste) bedragen deze over alle infusies bekeken zo'n $12 \%(39 /(286+5+39))$. Dit 'werkverzuim' kan maatschappelijk economisch gezien tot forse kosten leiden.

\subsection{Conclusies}

Ook de kosten van IT kunnen in kaart gebracht worden vanuit het zorgverleningsmodel van Orem. ${ }^{164}$ Dit kostenoverzicht levert geen richtprijzen op voor de financiering, maar geeft wel inzicht én de methode kan bij de berekening van kosten van andere behandelingen gebruikt worden.

Bij CMTZ als IT bestaan de kosten van de gezondheidszorg voor het grootste deel uit personele kosten (65\%). In dit zorgmodel vormt de TMV de grootste kostenpost.

De materiēle kosten voor de patiěnten en hun naasten zijn in deze studie niet hoog. Ook treedt een aantal bij ziekenhuisbehandeling niet op (bezorgkosten, lidmaatschap thuiszorg) en zullen andere afhankelijk zijn van eigen bijdragensystemen (thuisverpleging, verbandmateriaal).

De totale maatschappelijke kosten bedragen ongeveer $f 330(286+5+39)$, indien men er bij de personele kosten vanuit gaat dat de naaste voor naastenzorg niet betaald hoeft te worden, maar naasten hiervoor ook geen inkomsten hoeven te derven (keuze voor produktieverlies) én ervan uitgaat dat de naaste een accuratere inschatting van diens eigen belasting kan geven dan de patiënt. Het aandeel van patiënten en naasten in de vorm van hun materièle en personele kosten bedraagt dan zo'n $12 \%$ van de totale maatschappelijke kosten.

Al met al lijkt echter ook dit thuiszorgprogramma goed te passen binnen het wereldwijde streven naar een kosteneffectieve reductie of stabilisatie van het aantal ziekenhuisbedden. $^{742}$ 


\section{Slotbeschouwing en aanbevelingen}

\section{$16.1 \quad$ Inleiding}

De doelstelling van het onderzoek binnen het project Infuusbehandeling Thuis was het ontwikkelen van een kader waarmee complexe medisch-technische zorg (CMTZ) thuis bij patiēnten, naasten, zorgverleners en organisaties gelintroduceerd kan worden. Daarbij zijn drie aspecten onderscheiden: ontwikkeling, innovatie en evaluatie. ${ }^{10}$ Analoog aan het gehele onderzoek is deze driedeling ook in de beschouwing aangehouden. $\mathrm{Na}$ de belangrijkste conclusies worden de methoden beschouwd. Daarna worden de bevindingen besproken in relatie tot de literatuur en het maatschappelijk perspectief. Tot slot volgen voor de onderdelen gezamenlijk de belangrijkste aanbevelingen voor implementatie van medische technologie in de thuiszorg, verder onderzoek daarnaar en onderwijs daarover.

\subsection{Ontwikkeling zorginnovatie}

Ten aanzien van hoofdvraagstelling I kunnen de volgende conclusies getrokken worden. Via inventarisatie-onderzoek (literatuur, interviews, enquêtes) naar thuiszorgtechnologie, naar innovaties en naar medische en verpleegkundige zorgverlening konden kaders geformuleerd worden om de ontwikkeling, implementatie en evaluatie van de voorgenomen zorginnovatie infuusbehandeling thuis (IT) vorm te geven (hoofdvraagstelling I). Tijdens de inventarisatie bij de start van deze studie bleek het aantal publikaties over toepassing van hoogwaardige medische technologie thuis in Nederland nog gering. Enkele voorwaarden werden vaak genoemd. Belangrijk is, dat de patie̋t en diens naasten het gevoel hebben dat bij het vertrek uit het ziekenhuis naar huis de zorg en veiligheid worden gecontinueerd. Dit kan worden bewerkstelligd door de combinatie van transmuraal werkende verpleegkundigen en een efficiënt 24-uurs meldpunt. Voorlichting, scholing en instructie van zorgverleners, alsook de patiēnt en naasten, zijn onmisbaar. Thuiszorg dient te worden aangeboden als een samenhangend geheel. Standaardisatie en afstemming tussen klinische en thuiszorg kunnen een caleidoscopisch aanbod van formulieren, procedures en zorgaanbieders voorkomen. Verschuiving van CMTZ van het ziekenhuis naar thuis vereiste fundamentele veranderingen in de visie op de organisatie, de werkwijze en takenpakketten, de professionele invulling en opinies ten aanzien van de uitgangspunten bij de huidige zorgverlening.

Vanuit de verpleegkundige zorgtheorie van Orem, die van zelfzorgtekorten uitgaat, werd een algemeen zorgmodel voor CMTZ ontwikkeld waarin patiěnten, naasten, verpleegkundigen en artsen gezamenlijk in de benodigde (zelf)zorg voorzien. Dit bood een operationeel kader voor individuele zorgverlening, maar dient per type behandeling 
geconcretiseerd te worden. Deze zorgverlening vergde ondersteuning vanuit het middenkader- en macroniveau. Vanwege de benodigde specifieke deskundigheid, intensieve samenwerking en continunteit kon een transmuraal werkende, gespecialiseerde verpleegkundige (TMV) het zorgproces structureren en daarin een centrale rol spelen. De benodigde zorgorganisatie kan als transmuraal geclassificeerd worden. Hoewel de term "transmuraal" inmiddels breed is geaccepteerd, is deze een uiting van de tweedeling in ziekenhuis- en thuiszorg en verwijst expliciet naar de obstakels, de muren, tussen beiden. De term "transitioneel" zou vanwege verandering als hét centrale concept wellicht breder en neutraler zijn $(\$ 6.4)$.

Bij de methoden is door de breedte van de doelstelling vooral gekozen voor klassieke Medical Technology Assessment (MTA). ${ }^{15}$ Ogenschijnlijk bestaat bij MTA grote overeenstemming over de inhoud. Een verklaring hiervoor kan zijn dat vaak dezelfde personen en instanties onderzoek verrichten én beleid ontwikkelen. Een andere uitleg kan gelegen zijn in de open formulering van de begrippen. Daarnaast vallen de uitgestrektheid en complexiteit op. Vanuit diverse invalshoeken is vanuit verschillende (soorten) wetenschappen kennis verzameld. Daar tegenover staat de eis dat de op deze wijze verkregen bevindingen tot een eenduidig geheel zijn te combineren en zo gepresenteerd worden dat niet-ingewijde belangengroepen kunnen mee discussiëren. Vanwege deze kanttekeningen zijn in dit onderzoek niet alle binnen MTA mogelijke aspecten bestudeerd en zijn soms alternatieve benaderingswijzen in de vorm van Constructive Technology Assessment gebezigd (zie ook $\S 1.2 .3$ ). ${ }^{23-25}$ Ten slotte heeft deze studie, door de aandacht voor de werkwijze en het effectieve en efficiënte gebruik van mensen en middelen daarin, eveneens kenmerken van operational research. ${ }^{744}$

Zoals vermeld zijn bij de modelontwikkeling een literatuur-inventarisatie, een enquête onder beroepsbeoefenaren en een netwerkanalyse gebruikt. Voor een breder draagvlak hadden deze bevindingen via andere inventarisatiemethoden als Delphi-rondes of invitational conferences bevestigd dienen te worden. Voor de ontwikkeling van zorgmodel en innovatie is daarnaast een uitgebreid netwerk binnen en rondom het academisch ziekenhuis Maastricht (azM) en de Universiteit Maastricht (UM) gebruikt waarvan alleen de structuur beschreven is (bijlagen 1.1 en 2.1). De onderlinge invloeden verdienen nadere bestudering. Medisch en verpleegkundig technisch handelen lijkt ogenschijnlijk geregeld middels beroepsprofielen en wettelijke regelgeving. Zelfs in combinatie met een algemeen zorgmodel kunnen echter per technologie onduidelijkheden over verdeling van taken en verantwoordelijkheden tussen artsen en verpleegkundigen blijven bestaan. Het zoeken naar een gemeenschappelijk draagvlak via een landelijke enquête onder zorgverleners geeft snelle resultaten, maar om consensus te inventariseren zouden Delphi- en focusonderzoek meer valide zijn geweest. Alle draagvlakmetingen vergen simplificatie en interpretatie. Ook kan de uitkomst conflicteren met de wijze waarop één en ander op dat moment en op die geografische plaats in werkelijkheid geregeld is of zou moeten zijn.

De CMTZ binnen het hier ontwikkelde zorgmodel is geordend rondom de patiënt, maar vooral vanuit de medische en verpleegkundige beroepsuitoefening. Professies (in opkomst) kunnen bestudeerd worden middels een functionele, kenmerken- en machtsbenadering. ${ }^{200}$ Deze benaderingen zouden ook geldigheid moeten hebben ten aanzien van subspecialisaties. Bezien vanuit de functionele benadering behartigen TMVs een maatschappelijk belang waarvoor gespecialiseerde deskundigheid nodig is, namelijk medisch-technische thuiszorg. ${ }^{153}$ Omschrijving van de zorgverlener-patiēnt relatie via de 
consensustheorie van Parsons schiet echter te kort. ${ }^{245} \mathrm{CMTZ}$ thuis is vanwege de toegenomen interdependentie in de professionele zorgverlening niet mogelijk bij een zuiver functionele specificiteit (focus op eigen specialisme). Omdat de zorg in aansluiting op de eigen zelfzorg en in de thuissituatie verleend wordt, zijn ook universaliteit (zorgverlener treedt iedere patient op dezelfde wijze tegemoet) en affectieve neutraliteit (objectief afstandelijke houding zorgverlener) moeilijk hanteerbaar. Tenslotte is er, zelfs bij CMTZ thuis die verleend wordt vanuit traditionele zorgverleners of instanties vanwege de marktwerking geen volledige oriēntatie op collectiviteit (geen eigenbelang zorgverlener) meer. Als zodanig is traditioneel ideaaltypische zorgverlening zeldzaam geworden. Deze studie kan dan ook meer gerekend worden tot de kenmerkbenadering, omdat getracht is de TMV te onderscheiden van anderen en middels analyse van functies, structuren en culturen te komen tot de constructie van een ideaaltype. ${ }^{154}$ Ook hier blijkt deze benadering bruikbaar bij zich ontwikkelende professionals en professies. Bezien vanuit de machtsbenadering is door de keuze van de zorgverleningstheorie van Orem getracht de ongelijkheid binnen de zorgverlener-patiênt relatie (begrippen als dominantie en autoriteit) 20 veel mogelijk te beperken. ${ }^{155} \mathrm{Er}$ is naar gestreefd om al naar gelang de behoefte uit te gaan van een actief-passief (patienntsysteem doet niets), een sturend-samenwerkend (patiēntsysteem neemt deels over) en een wederzijds participatie model (patiëntsysteem en hulpverlenerssysteem werken samen en vullen elkaar aan). ${ }^{196}$ In relatie tot de specialisaties in de medische en verpleegkundige professies die hun nut al bewezen hebben, bleek er vanwege de hernieuwde functionele en structurele differentiatie wel degelijk sprake van machtsvraagstukken. Gelet op bovenstaande benaderingen en de resultaten van deze studie, is de hedendaagse werkelijkheid bij zorgverlening slechts te benaderen door deze te beschouwen als een systeem van professies. ${ }^{156}$ Hierdoor zijn de interacties tussen professies opgenomen en wordt aandacht besteed aan structurele, culturele, maar ook intra-, inter-, en transprofessionele krachten (functionele en structurele differentiatie, marktwerking, autonomie van de patient) alsmede de onderlinge complexe verbindingen (autonomie, arbeidsdeling en coördinatie). Wij pleiten er vanuit de zorgverleningstheorie van Orem voor bij CMTZ thuis ook patiènten en naasten in deze werkelijkheid een plaats te geven, vooral nu deze delen van de professionele zorgverlening over gaan nemen. De zorg kan eveneens geordend worden vanuit de wettelijke beroepsuitoefening, de organisatie, de kwaliteit van zorg (KvZ), de kosten of vanuit het bestaansrecht van zorgverleners en instellingen. Deze andere ordeningsprincipes zijn niet nader onderzocht. De IT was zoveel mogelijk patiënt georiënteerd en er is onder andere aandacht besteed aan de continuilteit van zorg en de attitude van de zorgverleners. Anderzijds was de zorg ook technisch georiënteerd en episodisch van karakter. Evenals alle voornoemde ordeningen herbergt toch ook de hier gekozen ordening en de daarbij gekozen onderzoeksmethoden het gevaar van preferentie van instrumentele (haalbaarheid, effectiviteit, efficiêntie) boven expressieve (betekenisvolheid, welzijn, solidariteit) waarden. ${ }^{2}$ Vooral wanneer de grenzen van de curatieve mogelijkheden bereikt zijn -zoals bij chronisch zieken of stervenden- kan een te functioneel rationeel ingestelde gezondheidszorg in conflict komen met de identiteit en leefwereld van de patiënt.

In de literatuur onderkennen ook anderen de fundamentele veranderingen tot op het niveau van de uitgangspunten voor zorgverlening, die bij dit type zorg nodig zijn. ${ }^{74}$ Voor specialistische thuiszorg, zoals CMTZ thuis, zijn bij andere innovaties gelijkluidende voorwaarden geformuleerd, zoals: deskundigheid, scholing en instructie, een adequate 
logistiek en coördinatie van mensen en middelen op basis van een zorgplan en zorgdossier, 24-uurs achterwacht en de mogelijkheid tot spoedopname. ${ }^{2,383,747-750}$ Ook elders zijn bij thuiszorgtechnologie voor verschillende behandelingen gelijkvormige protocollen ontwikkeld. ${ }^{222}, 283,747,751$ Soms is daarbij het inbrengen van het infuus wél aan gespecialiseerd werkende verpleegkundigen overgedragen.

Dat een zorgmodel alleen werkt als alle betrokken zorgverleners en organisaties er baat bij hebben is eveneens door anderen vastgesteld. ${ }^{452}, 752$ Ondanks ondersteuning van het innovatieve idee, blijven bij de instellingen en beroepsgroepen soms reserves bestaan. Het azM zag bijvoorbeeld -gezien haar academische functie en de beddendruk- geen kans om in de door de zorgverzekeraars zo gewenste structurele financiering middels beddenreductie te voorzien. De huisartsen ervoeren de zorg als een extra belasting en vreesden dat de zorgverzekeraar -evenals elders- deze verzwaring van het takenpakket niet zodanig inschat, dat dit structurele financiering behoeft. ${ }^{\text {II }}$ Hetgeen dan ook geschiedde. Daarom dient bij de ontwikkeling van de innovatie veel aandacht besteed te worden aan de structurele voortzetting en dienen hierover afspraken gemaakt te worden.

\section{Maatschappelijk gezien kan zorg voor patiënten die CMTZ behoeven in termen van} ziekenhuiszorg niet arbeidsintensief zijn en in termen van thuiszorg juist wel. Gegeven de hoge werkdruk kan een patiënt met zo'n zorgbehoefte in de thuiszorg niet 'welkom' zijn en de overgang van ziekenhuis- naar thuiszorg belemmeren. ${ }^{753}$ Daarnaast blijkt de instroom van patiënten achteraf tegen te vallen, ook indien een betrouwbare inschatting mogelijk is (Amsterdamse zusterproject). ${ }^{424} 754$ Blijkens deze studie staan de organisatorische haalbaarheid en betaalbaarheid van CMTZ thuis in de reguliere gezondheidszorg onder de huidige omstandigheden nog ter discussie bij beperking tot één technologie (infusie) en één regio. Om voldoende schaalgrootte te bereiken kan één team verschillende technologieěn of ook andere taken uitvoeren. ${ }^{333}$ Incidenteel kan dit problemen met de acute bereikbaarheid opleveren. Boven regionaal werken kan het aantal patiënten vergroten, maar laat ook de reisafstand en complexiteit toenemen. ${ }^{383}$

Ook een al wat verder ontwikkelde thuiszorgtechnologie als sondevoeding thuis laat regionaal nog grote verschillen zien. ${ }^{735}$ In deze studie is de zorg door naasten, evenals elders, één van de belangrijkste voorwaarden voor CMTZ thuis. Op termijn kan deze zorg -vooral die in de terminale fase- onder druk komen te staan door een oudere, meer alleen of met een zieke partner wonende bevolking. ${ }^{320,}{ }^{756} \mathrm{Het}$ is discutabel of de naastenzorg door partners en bloedverwanten in de toekomst door anderen gegeven zal worden. ${ }^{167}$ Volledige vervanging van naasten door vrijwilligers bij bijvoorbeeld terminale zorg lijkt nauwelijks haalbaar. ${ }^{320}$ Men vindt dat zorgverlof mogelijk moet zijn en de intensieve thuiszorg bij terminale zorg uitgebreid moet worden. ${ }^{320}$

In het algemeen wordt in de relatie tussen arts en verpleegkundige van een zekere hiërarchie uitgegaan. Geprotocolleerd uit te voeren specialistische werkzaamheden kunnen gelijkwaardige of zelfs omgekeerde deskundigheidsverhoudingen introduceren. Binnen het hier gehanteerde zorgmodel treden daardoor soms conflicten op binnen en tussen disciplines ten aanzien van deskundigheidsgebieden, takenpakketten, en regelgeving. Door de huisartsen wel en de TMVs niet te scholen in het inbrengen van een infuus is daaromtrent in deze studie stelling genomen. Na het advies van de BIG-Raad lijkt deze handeling echter niet langer alleen voorbehouden aan artsen. Toch blijft het inbrengen van een infuuscanule één van de medisch-technische handelingen die een behoorlijke vaardigheid vereist. Het is de vraag of (voomamelijk) in de thuiszorg werkende en daarvoor 
opgeleide verpleegkundigen ook na een scholing aan het bekwaamheidscriterium kunnen (blijven) voldoen. Mutatis mutandis geldt dit-gezien de huidige praktijkvoering en opleiding-ook voor huisartsen. In dit opzicht kan, binnen de continu benodigde scholing, de verplichte klinische periode in de driejarige huisartsopleiding een eerste aanzet bieden. Voor beide diseiplines is continue deskundigheidsbevordering gewenst.

\subsection{Proefimplementatie en procesevaluatie zorginnovatie}

$\mathrm{Nu}$ volgen conclusies bij hoofdvraagstelling II en de daarbij behorende aandachtspunten. Het zorgmodel is nader uitgewerkt tot een proefimplementatie die gekenmerkt werd door een echelon-overstijgend zorgaanbod dat tegemoet kwam aan het brede scala van individuele zorgvragen.

De keuze van behandelingen vergde inzicht in behandeltechnische ontwikkelingen (nieuwe medicamenten en toedieningswijzen) en een afweging op maatschappelijk niveau van effecten op de kwaliteit van leven, van zorg en de kosten (aandachtspunt 1). Om de expertise te waarborgen (bijvoorbeeld keuze voor uitvoering door gespecialiseerde of door de reguliere professionals) vereiste IT een zekere schaalgrootte. De inschatting van de omvang van patiêntenaantallen per soort behandeling op jaarbasis was daarom van belang. Deze inschatting was echter zeer moeilijk. De volgende prototypen infusen $(\$ 2.3 .4)$ zijn uitgebreid bestudeerd: subcutaan morfine en vocht, intraveneus mannitol (SRD) en antibiotica, en centraalveneus hartmiddelen (hartfalen). Daarvoor werden minder patienten aangemeld dan theoretisch berekend. Bij subcutane infusie van morfine en intraveneuze infusie van mannitol is ongeveer de helft van de potentiele patienten thuis behandeld. Oorzaken van deze selectie waren niet alleen de onbekendheid met de innovatie, maar ook onbekendheid met de procedures, het extra werk, de aversie tegen protocollair werken en conflicterende belangen zoals eigen wetenschappelijk onderzoek. Meer incidenteel zijn uitgevoerd: intraveneuze infusie van anti-epileptica bij craniale tumoren, van vocht bij dehydratie; centraalveneuze infusie van mannitol, van virostatica bij cytomegalieretinitis en van vocht bij dehydratie. Om uiteenlopende redenen waren niet haalbaar: intraveneuze infusie van cytostatica, van heparine (diep veneuze trombose), van xanthinederivaten en corticosteroilden (COPD); centraalveneuze infusie van cytostatica en voeding. Net als bij alle individuele gezondheidszorg bleek CMTZ thuis per patiënt(systeem) een inschatting van de haalbaarheid te vergen. Als selectiecriteria bij individuele patienten zijn geformuleerd: medische en persoonlijke toestand van de patient en de mantel, en de inhoud, organisatie en financiering van de zorg. De selectiecriteria voor de individuele patiënten bleken goed bruikbaar en voorkwamen uitval tijdens de behandeling. Naast de technische mogelijkheden bepaalden de kosten én de vierhoeksrelatie tussen patiënten, zorgverleners, verzekeraars en de overheid de veranderingen bij CMTZ thuis (aandachtspunt 2). De ordening hiervan was dan ook zowel te baseren op de verhouding tussen individualiteit (maximale aanspraak) en solidariteit (gepast gebruik in de context van de maatschappij) als op die tussen overheid en marktpartijen.

De theorie van Orem bood een bruikbaar kader voor de analyse en beschrijving van de zorgverlening bij CMTZ thuis aangezien alle vereiste medische en verpleegkundige activiteiten opgevat konden worden in termen van bij de patiënt en/of diens naaste(n) optredende en/of dreigende zelfzorgtekorten.

In de totale zelfzorgbehoefte van patięnten met CMTZ thuis kon -vanwege de benodigde kennis, vaardigheden en continulteit van zorg- alleen worden voorzien door patiènten, hun naasten, verpleegkundigen en artsen gezamenlijk, als deze na afdoende scholing, op 
geprotocolleerde wijze, 24 uur per dag samenwerkten. Het zorgproces kon vanwege de vereiste deskundigheid en samenwerking, continuîteit en flexibiliteit, bereikbaarheid en beschikbaarheid én het kostenaspect, worden vormgegeven door een team van specifiek deskundige verpleegkundigen die echelon overstijgend werkzaam waren in een gezamenlijke 24-uursdienst. Zij werkten daarbij nauw samen met huisartsen, specialisten (soms verpleeghuisartsen), apothekers, technici en eventuele andere zorgverleners. Het gekozen zorgmodel bood de mogelijkheid een dergelijke zorg vorm te geven.

De bij CMTZ benodigde consensus over de organisatie van de zorg kostte veel tijd en tact. Liefst zouden de partijen vooraf de garantie hebben dat één en ander in de praktijk functioneert. De door alle partijen gestelde voorwaarden in combinatie met tijdsdruk zijn ten koste gegaan van potentiele patiěntengroepen. Zorgverleners waren in de praktijk soms weinig bereid de eigen handelwijze ten bate van standaardisering te veranderen en de -gezamenlijk overeengekomen- protocollen na te leven. De eis tot consequente toepassing van de protocollen heeft hun keuze tot deelname negatief beïnvloed en is ten koste gegaan van de instroom van patiënten.

De informatievoorziening en scholing van patiënten, naasten en zorgverleners bleek noodzakelijk (aandachtspunt 3). De informatievoorziening en scholing hebben bijgedragen aan het streven om het project regionaal bij de zorgverleners bekend te maken, om draagvlak te verkrijgen en aanvragen uit het veld te genereren en met name voor het verkrijgen en behouden van parate kennis over de procedures op de werkvloer.

Deskundigheidstekorten bleken in de praktijk de echte 'bottleneck' voor de toepassing van thuiszorgtechnologie, Scholing beklijfde te weinig, met name bij huisartsen maar ook bij de TMVs. Oorzaken hiervan waren dat beiden voornamelijk alleen werken en de frequentie van sommige handelingen te laag is om de vaardigheden op peil te houden. Probleem is dat professionals dit soms niet onder- of erkennen. TMVs bleken huisartsen en wijkverpleegkundigen 'on the patient' te kunnen scholen. Dit vereist wel voldoende formatie van verpleegkundigen van het eerste deskundigheidsniveau in de thuiszorg en voldoende tijd voor instructie.

Vanuit het idee van een patięntgebonden financiering van de professionele zorg die nodig is bij IT, zijn de kosten voor deze behandeling geïnventariseerd (aandachtspunt 4). De keuze van de specifieke infuustechnologie bleek hierbij van belang. Uitvoering van het project was alleen mogelijk door een gezamenlijke inspanning van de diverse betrokken zorgorganisaties en financiers ( $(8.3){ }^{451}$ De complexiteit van zorg en de coördinerende taken hadden een lage 'face to face produktiviteit' van de TMVs in vergelijking met de wijkverpleegkundigen tot gevolg. Specifiek voor thuiszorgtechnologie geoormerkte financiering was en is dan ook een voorwaarde voor zowel projectmatige innovatie als structurele implementatie.

Het ontwikkelde zorgmodel voor CMTZ bleek concreet toepasbaar bij IT (aandachtspunt 5). Voor het creëren van de noodzakelijke randvoorwaarden dienden ter zake verantwoordelijken van de betrokken partijen bindende afspraken te maken omtrent de zorgverlening en financiering. Een centraal meldpunt (CM) faciliteerde de aanmelding en de zorguitvoering. Met de gezinszorg bestonden afspraken over de intake voor deze zorg door de TMV. Dit liep vooruit op een gezamenlijke indicatiestelling zoals nu door de Regionale Indicatie Organen (RIOs).

Multidisciplinaire protocollering en verslaglegging dienden als hulpmiddel voor standaardisering en kwaliteitsborging en lieten transities tussen generalistische en specialistische zorg soepel verlopen. Wel verwaterde op termijn bij patiěnten, naasten en zorgverleners de 
geprotocolleerde toepassing en waren zij moeilijker te corrigeren. In het integrale zorgproces konden in teamverband werkende TMVs een spilfunctie vervullen. Deze functie kon zeer wel in de thuiszorg geintegreerd worden. Soms trad echter vanwege de vermeende taakverschraling en een gevoel van inbreuk op de professionele autonomie frictie op tussen de wijkverpleegkundige en de TMV. Wel bleek de zorgorganisatie bij een dergelijk gespecialiseerd team coördinatie en bewaking te behoeven. Een structurele werkbespreking bood daarbij als instrument voor continue kwaliteitsverbetering uitkomst. Ondanks dat er problemen in de zorgverlening optraden, waren deze niet emstig en/of omvangrijk. Enerzijds absorbeerde het zorgmodel een aantal problemen zodanig dat het patiêntsysteem deze niet ervoer. Anderzijds kon het patièntsysteem in deze studie zodanig met problemen omgaan, dat deze veelal geaccepteerd werden.

Vanuit methodologisch oogpunt bleek de daadwerkelijke toepassing van het algemeen voor CMTZ ontwikkelde model in de praktijk zeer wel mogelijk maar vereist concretisering voor de diverse patiêntengroepen middels protocollering. ${ }^{13,14,757}$ Nadelen van de gehanteerde -op inspraak en overleg gerichte- werkwijze (het cultureel-politieke perspectief) zijn de benodigde tijd en de vereiste consensus. Daardoor zijn alleen nogal vaak voorkomende, relatief ongecompliceerde infusies uitgevoerd. De toepasbaarheid bij onder andere bloedtransfusie, cytostatica en voeding is daarom in deze studie niet bestudeerd. Vanuit een machtsperspectief hadden deze ook opgelegd kunnen worden, maar dan had een daadwerkelijk draagvlak ontbroken. Een continue monitoring van de innovatie via overlegvormen, zoals gestructureerde patiëntenbesprekingen, geeft de mogelijkheid om deze tijdens de toepassing verder te ontwikkelen, maar belemmert wetenschappelijke evaluatie in de vorm van een vergelijkend experiment.

De inclusiecriteria voor individuele patiěnten waren goed bruikbaar, maar de algemene formuleringen vereisen bij toepassing een medische of verpleegkundige achtergrond in combinatie met een gedetailleerd inzicht in de praktijk van de toegepaste behandeling. Het is de vraag hoe dit zich verhoudt tot het ideaal van een integrale en objectieve indicatiestelling. ${ }^{758} \mathrm{Bij}$ langdurige therapie is herhaalde toetsing nodig.

De evaluatie van de informatievoorziening leverde bruikbare inzichten op over hetgeen na het informeren van een doelgroep beklijft. Het concept van de informatie-enquête blijkt ook goed bruikbaar bij de meting van het effect van de informatie over nieuwe richtlijnen in de ziekenhuishygiène onder verpleegkundigen verricht in het kader van een ander onderzoek. ${ }^{759}$ Het geeft ook aldaar een hoge respons, een hoge naamsbekendheid, en eenzelfde klein percentage respondenten dat precies van de procedures op de hoogte is. ${ }^{759}$ Voorts blijkt de lijst bij herhaalde toepassing gevoelig voor verandering en bruikbaar om effecten van het geven van informatie te kwantificeren. ${ }^{759}$ De informatievoorziening ware beter te evalueren geweest als buiten de azM-artsen ook de huisartsen en verpleegkundigen hierbij betrokken waren geweest.

De inschatting van de (toename) van de deskundigheid door de huisartsen zelf is als maat minder valide dan objectieve maten zoals observatie aan de hand van observatiescorelijsten die bijvoorbeeld bij de scholing en examens van de TMVs gebruikt werden en voor huisartsen in ontwikkeling zijn. ${ }^{499}$

De gehanteerde patiëntgerichte financieringsmodellen maakten de kosten inzichtelijk. Zij kunnen bij innovatieprojecten tot ingrijpende keuzen leiden. Zolang de bij voortzetting benodigde structurele financiering niet patiêntgericht is, hebben zij echter een beperkte waarde voor verdere implementatie in de reguliere zorg. 
De innovatie blijkt op grond van het stagnerende vervolg onvoldoende uitgekristalliseerd voor structurele implementatie. De daarvoor benodigde consensus zou de innovatie nog verder vertraagd hebben..$^{52}$

Uit de literatuur komt naar voren dat de hier beschreven innovatie deel uitmaakt van een landelijke beweging. ${ }^{760}$ De drie fasen van modelontwikkeling, innovatie met empirische toetsing en effectevaluatie zijn ook bij de introductie van andere thuiszorgtechnologieĕn beschreven. ${ }^{761} \mathrm{Bij}$ de introductie van grensverleggende dagverpleging worden als succesfactoren genoemd: de win-win positie van alle deelnemers aan het project, een sterke, goed georganiseerde thuiszorg (netwerkmodel), de bereidheid van de zorgverzekeraar om de extra belasting voor de eerstelijn te vergoeden (uiteindelijk is thuiszorg goedkoper), de aanwezigheid van een kristallisatiepunt (Coördinatiepunt Thuiszorg) en het belang van een projectleider. ${ }^{72}$ Ook het project Infuusbehandeling Thuis is positief bel̈nvloed door een goed georganiseerde thuiszorg, extra honorering door de zorgverzekeraars, een $\mathrm{CM}$ bij het Groene Kruis (in combinatie met een projectbureau in het transmuraal centrum van het ziekenhuis) en een medische en een verpleegkundige projectcoördinator. ${ }^{51}$ De voornoemde factoren zijn voorwaarden voor een succesvolle innovatie van CMTZ thuis. Wel blijkt ook bij de introductie van andersoortige richtlijnen dat het veel inspanningen vergt om zorgverleners protocollair te laten werken. ${ }^{763}$

Maatschappelijk gezien past deze studie in het functioneel rationele streven naar meer thuiszorg om gezondheidszorg haalbaar en betaalbaar te houden. ${ }^{666,742,764}$ Daarnaast is vanuit het substantieel rationele concept van continuitteit van (zelf)zorg en zorgverlening getracht de professionele en niet- professionele zorg zoveel mogelijk te verlenen als een gecoördineerde en ononderbroken opvolging van activiteiten die afgestemd zijn op de behoeften van de patiënt gedurende diens behandeltraject. ${ }^{2} \mathrm{Zo}_{\mathrm{o}}$ is door een expliciete aandacht voor een gestandaardiseerde werkwijze, voorlichting en instructie aan de patiënt, de continue telefonische bereikbaarheid en door frequent onderling overleg van de zorgverleners getracht de bij $7 \times 24$ uurs zorg onafwendbare discontinuitteit in de persoon van de hulpverlener te compenseren.

Regionaal vergt het invoeren van dit soort nieuwe zorgvormen -ook gegeven een zorgmodel en technologie- aanpassingen. Een economisch verantwoorde inzet van een in één thuiszorgtechnologie gespecialiseerd team van verpleegkundigen vereist bovendien een voldoende groot adherentiegebied. Indien daarvoor meerdere ziekenhuizen, thuiszorgorganisaties en regionale verenigingen van huisartsen en apothekers moeten meedoen neemt de cultureel-politieke complexiteit toe, hetgeen de zorgontwikkeling kan vertragen. Specifieke patiëntengroepen die in aanmerking komen voor thuiszorgtechnologieën zoals infusie leveren momenteel regionaal te kleine aantallen op en er zal zoals in het Utrechtse zusterproject naar combinaties gezocht moeten worden. ${ }^{383}$

Professionele zorgverlening kan de kwaliteit van leven $(\mathrm{KvL})$ van het patiëntsysteem maar deels beinnvloeden. Wel dienen professionele zorgverleners de ontlastende en belastende invloeden te onderkennen en daarnaar, binnen hun professionele verantwoordelijkheid, te handelen. Zo vergt de inschatting tot de noodzaak van pijnbestrijding die het leven kan verkorten voorzichtigheid. Soms prefereren patiěnten namelijk een langer leven boven verlichting van pijn en ongemak. ${ }^{62}$ Hoewel de World Health Organization (WHO) het streven "Kankerpijn de wereld uit in 2000" te optimistisch gesteld heeft, kan subcutane infusie van morfine hieraan bijdragen. Een verpleegkundige kan bij pijnbestrijding 
uitstekend participeren, maar heeft bij expliciete keuze voor levensbekorting momenteel slechts een signalerende rol. ${ }^{765}, 706$ Een uitgebreide beschouwing hierover valt buiten deze studie, temeer daar het debat over euthanasie door artsen nog in volle gang is. ${ }^{70,708}$ Over het algemeen kan subcutane infusie van morfine zelfstandig door de huisarts, TMVs en thuiszorgverpleegkundigen samen uitgevoerd worden. ${ }^{256}, 760$ Intra- en centraalveneuze infuusbehandelingen behoeven evenwel op zijn minst medebehandeling vanuit een ziekenhuis. ${ }^{603}$ Parenterale antibioticabehandeling is door de variêteit aan en wisseling van indicaties lastig te protocolleren. De potentiele omvang is vrijwel zeker groter dan de instroom in dit onderzoek doet vermoeden. Gezien de lengte van de behandelduur zijn bij deze patièntengroep bovendien grote aantallen ligdagen per patiěnt te besparen. Een gerichte werving voor deze categorie patiênten verdient dan ook aanbeveling. Het lijkt het meest zinvol te werven onder artsen op verpleegafdelingen aangezien zij veelal de indicatie stellen of via medisch microbiologen omdat zij vaak bij langdurige antibioticainfusies betrokken zijn. Bij chronische patiënten met bijvoorbeeld hartfalen interfereert de behandeling sterk met het dagelijks leven. Omdat deze behandelingen om onder andere economische redenen zoveel mogelijk overdag worden gegeven, kan dit conflicten opleveren (\$8.4.5). Voor zover deze discrepanties niet oplosbaar zijn, verdienen deze vanaf de eerste voorlichting en tijdens de begeleiding aandacht.

Algemeen beschouwd bleek het zorgmodel op projectbasis haalbaar en betaalbaar bij bovenstaande vier prototypen van behandelingen. Na afloop van het project verviel de financiering door de zorgverzekeraars en hebben de Stichting Groene Kruis Heuvelland en het azM de thuisbehandeling binnen de bestaande budgetten gefinancierd. ${ }^{70}$ Een teruglopende instroom, de 'knip' in de thuiszorg vanaf 1 januari 1997 én de voor financiering vereiste centrale indicatiestelling via het RIO bemoeilijkten verdere implementatie. In de Nederlandse bevolking is ongeveer de helft voorstander van verhoging van de algemene uitgaven, zeker voor verplegend personeel en medische apparatuur. ${ }^{m 1}$ Ook stijgt het totale gezondheidszorgbudget en komt daarbinnen meer ruimte voor care. ${ }^{m 2}$ Het zou dan ook wenselijk zijn voor dit type zorg en voor andere samenwerkingen tussen instellings- en thuiszorg financieringsvormen te ontwikkelen. Het schrappen van de toegangsbijdrage bij thuiszorg is een stap op de goede weg, de ingevoerde uurbijdrage voor wijkverpleging niet.

\subsection{Effectevaluatie zorginnovatie}

Hier volgen enkele conclusies ten aanzien van hoofdvraagstelling III en de bijbehorende aandachtspunten. Ondanks de conceptuele complexiteit en onderlinge interactie van de begrippen $\mathrm{KvL}, \mathrm{KvZ}$, tevredenheid en kosten, bleek het mogelijk deze in onderlinge samenhang te bestuderen binnen de context van zorgvraag en zorgaanbod.

De zorgsituaties van de behandelde patiěnten en hun naasten gaven aan dat het zorgmodel zowel sociaal-demografisch als wat betreft de aandoeningen breed toegankelijk was (aandachtspunt 6). Door de technologie als uitgangspunt te nemen, toonden de kenmerken van de totale patiëntenpopulatie wel een brede spreiding. Er waren geen aanwijzingen dat de behandelde deelpopulaties afwijken van vergelijkbare patientengroepen elders. Op basis van onderzoek naar zelfzorgtekorten door de STG en naar KvL, is een gecombineerd model ontwikkeld om de zorgsituaties en de KvL bij CMTZ thuis te onderzoeken (aandachtspunt 7). Het zorgmodel was breed toepasbaar bij verschillende aandoeningen, behandelingen, patiëntsystemen en achtergronden. Toetsing van de patiënten aan de voorwaarden voor de instroom en tijdens de behandeling bleek een bruikbaar instrument, aangezien weinig patiënten de IT voortijdig staakten. Er zijn geen 
aanwijzingen gevonden dat de thuisbehandeling het functioneren of de KvL van patiènten en/of naasten zodanig verminderde dat thuisbehandeling daarom niet verantwoord zou zijn. De STG methode voor het bepalen van de zelfzorgtekorten bleek ook in praktijkonderzoek toepasbaar om de zorgsituatie van en tussen categorieën patiênten te vergelijken. Naasten gaven veel steun aan de patiënten, maar ervoeren dit niet als te belastend. Binnen de totale belasting voor de naaste verzorger, leek het aandeel van de IT in ieder geval niet groot. Door de benodigde steun van naasten is het zorgmodel wel kwetsbaar, omdat het professioneel equivalent thuis maatschappelijk onbetaalbaar is. $\mathrm{Bij}$ categorieën van zorgsituaties bleken zorgverleners de belasting van naasten enigszins te kunnen inschatten, bij individuele zorgsituaties zeer moeilijk.

De $\mathrm{KvZ}$ is in deze studie zowel zorginhoudelijk, dienstverlenend, als wat betreft doelmatigheid bestudeerd (aandachtspunt 8). Er waren geen aanwijzingen dat IT volgens het hier beschreven model zorginhoudelijk kwalitatief minder verantwoord of doelmatig was of door patiênten minder gewaardeerd werd dan ziekenhuis- of andere thuiszorg. Het bleek mogelijk de zorginhoudelijke kwaliteit te bestuderen door de kwaliteitsaspecten in te delen in kennis en kunde, attitude, samenwerking en organisatie en door de zorg onder te verdelen in directe zorg, informeren, signaleren en doorverwijzen, en psychosociale begeleiding. Middels gedetailleerde foutenanalyse is getracht het zorgmodel te monitoren en bij te stellen. Patiënten, naasten en zorgverleners bleken goed te kunnen aangeven waar verbeteringen mogelijk zijn. Zoals verwacht traden de belangrijkste problemen op bij transities in de zorg en lagen veelal op het gebied van de communicatie en samenwerking. Meestal betroffen deze afstemming en communicatie tussen het patiënt- en het professionele zorgsysteem, en binnen het laatsgenoemde.

De kwaliteit van en tevredenheid met de zorg varieerden met de wijze van vragen en per soort respondent. Gezien de algemeen te constateren teruggang in tevredenheid over de gezondheidszorg is dit een goede prestatie te noemen. ${ }^{73}$

Zoals verwacht stemde de beoordeling van de $\mathrm{KvZ}$ en tevredenheid in het patiëntsysteem overeen. Helaas gold dit minder voor de overeenstemming binnen het professionele zorgsysteem en tussen beide systemen.

De doelmatigheid in termen van vergelijking met de tarieven voor andere (complexe) thuiszorg en ziekenhuiszorg bleek alleszins acceptabel. Evenals in andere gebieden van de gezondheidszorg conflicteerde bij chronisch zieken de door hen gewenste zorg op maat soms met het leveren van doelmatige zorg.

Kosten van CMTZ als van IT konden beschreven worden vanuit het zorgverleningsmodel van Orem (aandachtspunt 9). ${ }^{164} \mathrm{Zij}$ werden vanuit maatschappelijk perspectief onderscheiden in de materiêle (apparatuur, medicatie en infuusmaterialen) en personele (thuiszorgverpleegkundige, huisarts) kosten van de geleverde gezondheidszorg en de materiële (reis-, telefoon-, huur-, lidmaatschaps- en bezorgkosten) en personele kosten (tijd besteed aan mantelzorg) van de patiënt en naaste. Dit leverde geen defintieve richtprijzen op, maar gaf wel inzicht daarin. Ook bij CMTZ bestonden de kosten voor de gezondheidszorg voor het grootste deel uit personele kosten (in dit zorgmodel de TMV). 'Gemiddeld' kostte een infusiedag de gezondheidszorg $f 100$ materieel en $f 186$ personeel, de patie̋nt en naaste kostte het $f 5$ materieel en $f 20$ personeel. In totaal derhalve $f 286$ voor de gezondheidszorg en $f 25$ voor het patientsysteem. Voor de gezondheidszorg was IT goedkoper, deels omdat de kosten verschoven richting patiënt en naaste. De materiële kosten van IT voor de patiênten en hun naasten waren in deze studie weliswaar laag. Toch zouden een aantal kosten bij ziekenhuisbehandeling niet zijn opgetreden en waren anderen afhankelijk van 
eigen bijdragensystemen. Maatschappelijk economisch gezien waren de personele kosten van IT -hier beperkt tot de belasting van de naasten- wel degelijk aanwezig en varieerden van $12-36 \%$ van de totale kosten. Zelfs al zouden deze kosten door de patiènt en naasten gedeclareerd kunnen worden, dan nog bleef thuisbehandeling vaak goedkoper.

Vanuit methodologisch oogpunt is in deze studie het experiment weliswaar prospectief vervolgd, maar met alle nadelen van een niet vergelijkend onderzoek (overwegingen \$2.5). Voor een groot aantal data was er helaas slechts sprake van één meetpunt. ${ }^{33}$ Waar mogelijk zijn daarom vergelijkingen met referentiedata en groepen getroffen. Deze studie moet dan ook gezien worden als een exemplarische kwalitatieve beschrijving met kwantitatieve informatie. Door de continue ontwikkeling en de vele tussentijdse veranderingen waren gerandomiseerde, concurrente of pre- postvergelijkingen wetenschappelijk niet haalbaar en verantwoord. Bij eventuele vervolgstudies volgens het hier ontwikkelde model zou naar een vergelijkende opzet gestreefd dienen te worden. Essentieel is echter dat de autonomie van de patiênt in zijn eigen leefwereld centraal blijft staan; doelmatigheid en kwaliteit van zorg als criteria van formele rationaliteit mogen niet boven geschikt zijn aan kwaliteit en betekenis van het leven, solidariteit of handhaving van de identiteit als criteria van substantiele rationaliteit. Deze criteria maken deel uit van een paradigma voor zorg(evaluatie). ${ }^{2}$ Overwogen dient te worden of het in deze studie ontwikkelde model nader te toetsen is op basis van criteria voor substantiele rationaliteit. ${ }^{2}$ Onderzoek bij thuiszorg biedt de juiste omgeving om dergelijke zorgevaluaties nader uit te werken.

Omdat over diverse aspecten van de KvL bij IT nog weinig bekend is en deze behandeling in de toekomst waarschijnlijk toeneemt, is het klinisch relevant deze te onderzoeken. ${ }^{74}$ Door meting bij toepassing in een zorginnovatie is deze behandeling op een voor de praktijk relevante wijze onderzocht. ${ }^{774}$ Het in deze studie gehanteerde model voor de bestudering van de KvL sluit aan bij het WHO-model van de International Classificiation of Impairments Disabilities and Handicaps dat gevolgen van ziekten vastlegt in drie hiërarchisch geordende deelclassificaties: stoornissen, beperkingen en handicaps. ${ }^{775} \mathrm{Het}$ sluit ook aan bij KvL-modellen die de gevolgen van ziekten opsplitsen in uiteenlopende dimensies van de persoonlijke situatie, zoals lichamelijke, psychische en sociale aspecten. Het biomedisch model is, in tegenstelling tot bijvoorbeeld het Amsterdamse zusterproject, nauwelijks gebruikt omdat de medische effectiviteit niet tot onze vraagstelling behoort." ${ }^{3.2}$ $\mathrm{Bij} \mathrm{KvL}$ onderzoek past een aantal kritische opmerkingen: men beoogt geen patienten, maar behandelingen te evalueren; men meet niet de KvL, maar afzonderlijke effecten daarop; KvL onderzoek leent zich niet voor individuele behandelingsbeslissingen. ${ }^{64}$ In deze studie zijn mogelijke invloeden op afzonderlijke aspecten van $\mathrm{KvL}$ tijdens de behandeling bestudeerd, echter niet op langere termijn. Aspecten van KvL waren meetbaar, maar door de wijze van onderzoek in deze studie was het afzonderlijke effect van IT moeilijk na te gaan. De keuze om KvL niet bij terminale patiënten zelf te meten blijkt ethisch en onderzoekstechnisch juist. Vaak staan pijn, onnust, angst, misselijkheid en braken tengevolge van het gemetastaseerde kankerproces op de voorgrond. Het doel bij deze behandeling is primair om het lijden te verlichten en een humaner sterven mogelijk te maken; we nemen aan dat hiermee de KvL verhoogd wordt.

Hoewel KvZ (onderzoek) breed gedragen wordt, is operationalisatie geenszins eenvoudig. Ter bestrijding van de overschatting van de kwaliteit van en tevredenheid met de zorg zijn deze op verschillende manieren benaderd. Toch sluit dit vertekening niet uit. Theoretisch 
blijkt het mogelijk om via de aspectbenadering binnen kwaliteit en handelen diverse dimensies te onderscheiden en te operationaliseren. Binnen de aspectbenadering zijn echter ook andere manieren om dienstverlening te meten mogelijk ${ }^{776}$ Onduidelijk is of patiënten, naasten en zorgverleners deze in de (onderzoeks)praktijk ook onderkennen. De foutenanalyse op basis van de notulen van de werkbespreking van de TMVs kan vertekening vanuit hun perspectief geven. Daar staat tegenover dat de TMVs voldoende zelfkritisch waren en de werkbesprekingen voor continue kwaliteitsbewaking zijn gebruikt. De berekende kosten van IT beperken zich tot het primair zorgproces en het volgen van de geldstromen via marktprijzen en tarieven. Er zijn ook boekhoudkundigere benaderingen mogelijk, die andere plaatjes kunnen opleveren. ${ }^{177}$ De beperking tot vooral de direct meetbare kosten van de infuuszorg geeft weinig zicht op kosten elders in de gezondheidszorg en de maatschappij.

In de literatuur zou men de overeenstemming over de te bestuderen aspecten van MTA terug verwachten in de resultaten van MTA-onderzoeken. ${ }^{16,26}$ MTA-studies komen echter niet waardevrij of op louter wetenschappelijke gronden tot stand, maar hebben meestal sterk maatschappelijke wortels. ${ }^{26} \mathrm{Ook}$ in het 'Stimuleringsprogramma Thuiszorgtechnologie' richten de verschillende onderzoeken zich op diverse aspecten. ${ }^{12,77}$ Mogelijk wordt dit veroorzaakt door de mate van ervaring met MTA. Men zou bij 'routiniers' een bredere bestudering vanuit meerdere wetenschappelijke disciplines verwachten, doch ook deze brengen beperkingen aan. ${ }^{105,777,778,779}$ Vaak staat de beschikbare subsidie, evenals in dit onderzoek, een brede bestudering vanuit verschillende disciplines in de weg. ${ }^{780} \mathrm{De}$ verschillen in toegepaste methoden en bestudeerde technologieën binnen het Stimuleringsprogramma verhinderen vergelijking, combinatie en generalisatie van de onderzoeksresultaten, bijvoorbeeld in een meta-analyse, zonder meer.

Vanuit maatschappelijk oogpunt wordt -vanwege de omvang van het onderzoeksterreinmedische technologie bij voorkeur onderzocht vanuit centra waarin de benodigde disciplines samenwerken. De kiem voor MTA in het Maastrichtse lijkt gelegd met toenmalige Instituut voor MTA, een samenwerkingsverband met de Erasmus Universiteit. ${ }^{16}$ De UM koppelt deze interesse aan die voor huisartsen- en thuiszorg. ${ }^{781}$

\subsection{Eindconclusie}

In zijn totaliteit bezien is de proefimplementatie van de innovatie infuusbehandeling thuis geslaagd te noemen. Aansluitend op de afzonderlijke besprekingen van de ontwikkeling, invoering en evaluatie, beschouwt tabel 16.1 vanuit de innovatie- en implementatieliteratuur samenvattend in welke mate de belangrijkste processen aan de invoering hebben bijgedragen (zie ook schema 2.9). ${ }^{13}, 14,29,30,782.784 \mathrm{Er}$ worden aspecten en partijen op macro(strategisch), middenkader (taktisch) en individueel (operationeel) niveau onderscheiden. Ofschoon de directies van de verschillende organisaties, verenigd in de begeleidingscommissie (BC), vonden dat IT paste in hun beleid, bleek het moeilijk om gezamenlijk vast te stellen langs welke wegen dit gerealiseerd kon worden op een zodanige wijze dat zij daar vat op hadden. De nieuwe ontwikkeling viel namelijk buiten de bestaande praktijk, waardoor externe beheersing in de vorm van bureaucratisering moeilijk bleek. ${ }^{200} \mathrm{De}$ zorgverzekeraars waren weliswaar via de VGZ in de BC vertegenwoordigd, maar de door de VGZ gemaakte afspraken golden niet automatisch voor andere zorgverleners. Daarom is de Stuurgroep Transmurale Zorg (STZ) opgericht waarin door het middenmanagement 
Macro: begeleidingscommissie (BC), samemwerkingsverband transmunale zorg (STZ), zorgveraekeraars (ZV) en ministerie (Minj) van WVC mu VWS

\begin{tabular}{|c|c|c|c|c|c|c|c|c|}
\hline Niveau en factor & BC & & 87 & & $7 \mathbf{Y}+2$ & Min & Geslaged & Hofs \\
\hline Besluitvorming & & & & & & & & \\
\hline -past in beleid organisaties & $H^{\prime}$ & & + & & + & + & + & 8 \\
\hline hoe realiseren & $\cdot$ & & + & & + & . & + & \\
\hline $\begin{array}{l}\text { Controleprocessen } \\
\text {-aansluiting organisaties }\end{array}$ & - & & \pm & & \pm & $H$ & \pm & 8,11 \\
\hline beheersbaarheid & - & & + & & \pm & + & 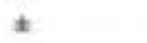 & \\
\hline Allocatie mensen / middelen & & & & & & & & \\
\hline -ontwikkeling zorg & \pm & & . & & . & + & + & $8,11,15$ \\
\hline -uitvoering zorg & \pm & & + & & + & . & + & \\
\hline evaluatic zorg & . & & & & & \pm & \pm & \\
\hline Relatie omgeving & & & & & & & & \\
\hline -publieke opinie & + & & . & & . & , & + & 9 \\
\hline -patient opinie & . & & . & & . & & . & \\
\hline Middenkader: $B C, S T Z$ medisch & (MS) & verples & gkind: & $(V S)$ & taven & & & \\
\hline Niveau en factor & BC & STZ & MS & & vs & & Geslaagd & Hids \\
\hline Attitude management & + & + & \pm & & + & & + & 7,8 \\
\hline Dagelijkse routine & & & & & & & & \\
\hline -noodzaak protocollering & + & + & + & & + & & + & 7,8 \\
\hline thoe te realiseren & & + & \pm & & \pm & & $\neq$ & \\
\hline Pasvorm innovatie & & & & & & & & \\
\hline -aansluiting beroepsopvatting & + & + & + & & + & & + & $\$ 2.3$ \\
\hline -aansluiting beroepsuitoefening & \pm & + & \pm & & \pm & & + & 5.8 \\
\hline Groepsnormen & & & & & & & & \\
\hline -identificatie innovatie & . & . & \pm & & + & & + & 8,12 \\
\hline Individueel: patiěnten $(\mathrm{P} t)$, naas & $n(\mathrm{Na}$ & speciali & $\operatorname{ten}(S)$ & huisc & $\operatorname{sen}(h$ & wijkve & oleegk. $(W v)$, & TMVs \\
\hline Niveau en factor & $\mathbf{P t}$ & $\mathrm{Na}$ & Sp & Ha & $\mathbf{W v}$ & Tmv & Geslaagd & Hifds \\
\hline Kennis en kunde & & & & & & & & \\
\hline -instructie & + & + & . & + & + & . & + & $8,13,14$ \\
\hline -scholing & . & . & . & + & . & $H$ & + & \\
\hline -ervaren competentie & + & + & . & \pm & \pm & + & + & \\
\hline Attitude & & & & & & & & \\
\hline -identificatic bij zorgvraag & + & $H$ & \pm & + & $H$ & $H$ & H & $8,13,14$ \\
\hline -behoud profess. autonomie & . & . & \pm & \pm & \pm & + & \pm & \\
\hline -bchoud privacy & + & + & . & . & . & . & + & \\
\hline Communicatie & & & & & & & & \\
\hline -voorlichting & + & + & + & + & + & + & + & 12 \\
\hline -presentaties & , & . & + & + & + & . & + & \\
\hline Morele steun & & & & & & & & \\
\hline begeleiding & + & + & \pm & + & + & + & + & 8,14 \\
\hline Materiêle beloning & - & - & $\therefore$ & + & + & . & + & 11 \\
\hline
\end{tabular}

Legenda: '=vijfpuntsschaal - : zeer negatief tot ++ ; zeer positief, , =niet van toepassing, Hfds=hoofdstuk, profess.=profesionele

afspraken zijn gemaakt over de concrete invulling. Deze afspraken zijn door de BC bekrachtigd. Belemmerende factoren waren, dat geen van de partijen kon overzien wat de schaalgrootte en de kosten van IT zouden zijn en dat IT niet binnen de door de regelgeving bepaalde financieringskaders en budgetten viel. Bevreesd voor de omvang van de kosten wensten de zorgverzekeraars per patiênt vooraf een begroting en gaven per patiěnt toestemming. Met de VGZ zijn voor enkele patiëntengroepen gelimiteerde aantallen 
afgesproken. Vanuit het Stimuleringsprogramma Thuiszorgtechnologie had het ministerie van WVC (nu VWS) een beperkt budget beschikbaar gesteld voor ontwikkeling en evaluatie én een geringe bijdrage aan de zorguitvoering. De relatie met de omgeving is vooral vanuit het projectbureau verzorgd met enige steun vanuit de BC.

Financiering is op macroniveau het centrale externe beheersingsproces waarin alle belangen en opvattingen van de samenleving, zorgorganisaties en beroepsgroepen bij thuiszorgtechnologie in balans gebracht worden.

Over het algemeen was de attitude van hoofden en medische en verpleegkundige staven ten opzichte van IT positief. Het management en de medische staf van het azM wisselden in hun attitude wat betreft de wenselijkheid en haalbaarheid van IT. Hetgeen gezien de verschillende onderzochte behandelingen voorstelbaar was omdat een groot deel van de zorg buiten het ziekenhuis plaats vond. Een ieder was het er vanuit het oogpunt van interne beheersing over eens dat de zorg geprotocolleerd diende te worden, maar over de invulling verschilden de meningen. ${ }^{200}$ De protocollering is door alle partijen ook als middel gehanteerd om invloed te doen gelden. Dit had er alles mee te maken dat een nieuwe aansluiting moest worden gevonden met de beroepsopvatting en uitoefening. Bij de medische en verpleegkundige beroepsgroep contrasteerde de aansluiting bij de groepsnormen, omdat met de toepassing van IT een deel van de taken en specifieke deskundigheid naar de verpleegkundige beroepsgroep verschoof.

Protocollering is op middenkader niveau het centrale interne beheersingsproces waarin alle belangen en opvattingen van beroepsgroepen en organisaties bij thuiszorgtechnologie in balans gebracht worden.

De patiènt en naaste voelden zich met de gegeven instructie en begeleiding redelijk competent om IT te ondergaan. Bij de huisarts en wijkverpleegkundige was dat, ondanks scholing en instructie, minder het geval. De frequentie waarmee handelingen in de praktijk voorkomen is hier mogelijk debet aan. De in deze studie geboden training voor TMVs is een noodzakelijke voorwaarde om hen in de praktijk adequaat te laten functioneren. Voor een dergelijke functie is eigenlijk "education permanente" gewenst. Indien zich een potentięle patiênt voor IT aandiende, was men over het algemeen geneigd daaraan mee te werken. Alleen de specialisten hebben naar verwachting niet bij alle potentiële patiënten aan IT gedacht, waarschijnlijk omdat deze buiten hun domein en daarmee gezichtsveld valt. Mogelijk heeft dit ook te maken met de professionele autonomie. Hetzelfde treedt op binnen de thuiszorg, waar de TMV het domein van de huisartsen en wijkverpleegkundigen betreedt. Op soortgelijke wijze dringt IT naast het lichaam ook de leefwereld van de patient en naasten binnen, tast het ritme van het dagelijks leven aan en bedreigt daarmee naast de lichamelijk integriteit ook de privacy. Derhalve is communicatie uitermate van belang om de techniek, leefwereld en beroepsopvattingen met elkaar in overeenstemming te brengen. Adequate voorlichting en gerichte presentaties in het algemeen en bij concrete patienten is daarvoor noodzakelijk. Naast voorlichting en instructie heeft de morele steun in de vorm van begeleiding aan patiênten, hun naasten en de zorgverleners en de materiēle beloning van de zorgverleners aan het welslagen van IT bijgedragen.

Omdat zij moeilijk beheersbaar is, is de bel̈nvloeding van de attitude (denkbeelden, gevoelens, gedragingen) op individueel niveau het centrale proces waarin ook bij thuiszorgtechnologie de belangen en opvattingen van patiënten, naasten, zorgverleners en organisaties in balans gebracht worden. 


\subsection{Aanbevelingen voor de gezondheidszorg, onderzoek en onderwils}

A) Ten eerste volgen aanbevelingen bij de implementatie van CMTZ thuis.

Bij proefimplementatie van nieuwe of reimplementatie van beproefde thuiszorgtechnologie dient bij uitstek aandacht besteed te worden aan de financiering, de protocollering en de attitudevorming (1). Voorafgaand aan de keuze van een technologie, dient de omvang van de potentiěle doelgroep(en) zo betrouwbaar mogelijk ingeschat te worden (2a). Voor de daadwerkelijke instroom van patiênten is in de beginfase een intensieve samenwerking met indicerende specialisten en afdelingen en op termijn het inbedden van de verwijzing naar de behandeling thuis in de polikliniek- of afdelingsroutines noodzakelijk ( $2 \mathrm{~b}$ ). Standaardisering via protocollering van de behandeling en de daarbij behorende materialen in overleg met de werkvloer, maar vanuit een centrale regie is gewenst (3a). Een modulaire toepassing kan -ondanks een beperkte assortimentskeuze- een variatie aan behandelingen mogelijk maken, de veiligheid vergroten, instructie vergemakkelijken en kosten besparen (3b). Goede informatievoorziening aan potentiěle behandelaars over de mogelijkheden van en procedures bij thuisbehandeling is wenselijk (4a). Hét middel om een thuiszorgtechnologie bij beroepsbeoefenaars onder de aandacht te brengen, is het aanbieden van scholing, liefst binnen het reguliere programma (4b). Extra aandacht voor CMTZ in de palliatieve zorg blijft zowel in de medische als de verpleegkundige (na)scholing gewenst (4c). ${ }^{6}, 112,526,735$ Een gedegen financiering zonder 'schotten' is een voorwaarde voor structurele toepassing van thuiszorgtechnologie (5). ${ }^{\text {7to }}$

B) Daarnaast zijn aanbevelingen voor verder wetenschappelijk onderzoek mogelijk. Ook bij bestudering van thuiszorgtechnologie is meer inzicht nodig in de maatschappelijke gevolgen, waaronder kosten, van chronische ziekten (6a). In verder onderzoek dient het hier ontwikkelde zorgmodel getoetst en verfijnd te worden ten aanzien van bredere toepassing bij gecompliceerdere infuusbehandelingen, andere thuiszorgtechnologieën en andere zorgomgevingen (6b). Ook zou binnen deze vervolgstudies gestreefd dienen te worden naar een vergelijkende opzet (6c). Tot slot verdient het aanbeveling bij onderzoek naar implementatie van thuiszorgtechnologie naast parameters voor functionele rationaliteit (techniek) ook parameters voor substantiēle rationaliteit (leefwereld patiënt) te bestuderen (6d). Of een apart team van verpleegkundigen voor CMTZ thuis de voorkeur verdient boven gedifferentieerd werkend wijkverpleegkundigen in de reguliere wijkzorg, zo ja of dit dan beter vanuit een ziekenhuis dan wel vanuit een thuiszorgorganisatie kan opereren en waar de regie het beste kan liggen zou eveneens in een vergelijkende studie onderzocht dienen te worden (7). ${ }^{383,}{ }^{787}$ Voorts verdienen de materielle en logistieke aspecten van CMTZ thuis vanuit de thuiszorg versus vanuit het ziekenhuis nadere bestudering (8).

C) Tot slot kunnen ook voor het onderwijs enige aanbevelingen gegeven worden. De toepassing van CMTZ thuis dient voorafgegaan te worden door scholing en toetsing van huisartsen en verpleegkundigen op basis van voor thuiszorg ontwikkelde protocollen met bijbehorende observatiescoringslijsten en de vereiste organisatie (9a). Binnen de huisartsopleiding en deskundigheidsbevordering voor huisartsen zal daarnaast structureel aandacht besteed dienen te worden aan complexe medisch-technische handelingen ( $9 \mathrm{~b})$. Eenzelfde aanbeveling kan gegeven worden voor verpleegkundigen die IT thuis gaan verlenen (9c). Het verdient aanbeveling in het onderwijs aan beroepsbeoefenaars aandacht te besteden aan attitudevorming (10). Dit is vooral van belang omdat met de modernisering van de samenleving de zorg voortdurend zal veranderen. Zorgverleners moeten patiënten en naasten daarbij begeleiden, maar ook zelf kunnen omgaan met veranderingen in hun eigen beroepsprofielen en in die van anderen.' 


\section{Samenvatting}

\section{DEEL. I: INLEIDING EN METHODEN}

Hoofdstuk $I$ introduceert het onderzoeksproject Infuusbehandeling Thuis. In Nederland vindt complexe medisch-technische zorg (CMTZ) vooralsnog overwegend klinisch plaats. In de kliniek dient de technologie voornamelijk voor toepassing van diagnostiek en therapie. Bij thuisbehandeling dient expliciet rekening gehouden te worden met de autonomie en zelfredzaamheid van de patiënt in diens omgeving. Zorgverleners en organisaties zijn nog onvoldoende toegerust voor deze nieuwe vormen van zorgverlening in de thuiszorg. Aanbod, inhoud en structuur van de zorg dienen geĩnnoveerd te worden. Daarom hebben de vakgroep Huisartsgeneeskunde van de Universiteit Maastricht (UM), het Transmuraal \& Diagnostisch Centrum (TDC) van het academisch ziekenhuis Maastricht (azM) en de Stichting Groene Kruis Heuvelland (SGKH) binnen het Stimuleringsprogramma Thuiszorgtechnologie via infuusbehandeling thuis (IT) een kader ontwikkeld om CMTZ thuis te introduceren en te bestuderen. Doelstellingen waren ontwikkeling (voorwaarden formuleren), implementatie (op proef) en evaluatie (proces en effecten) van deze innovatie. Vanwege het exploratieve karakter is het een exemplarisch beschrijvend onderzoek vanuit Medical Technology Assessment (MTA) perspectief. Hoofdvraagstelling I luidde: "Wat is er bij de start van het project bekend over de ontwikkeling, invoering, toepassing en evaluatie van innovaties op het gebied van CMTZ thuis?" en omvatte alle volgende aandachtspunten. Hoofdvraagstelling II luidde: "Op welke wijze kan zo'n innovatie ontwikkeld, geïntroduceerd en toegepast worden en wat zijn ervaringen daarbij?" en betrof: benoeming van potentiële doelgroepen, omschrijving van individuele selectiekenmerken en inschatting van aantallen patiënten (1); organisatorische en logistieke vormgeving van de zorgverlening alsmede de protocollering en afstemming daarvan (2); informatie en scholing van patiēnten, hun naasten en zorgverleners (3); vormgeving van de financiering (4); keuze voor en toepassing van een zorgtechnologie thuis (5). Hoofdvraagstelling III luidde: "Hoe kunnen kwaliteit van leven (KvL), kwaliteit van en tevredenheid met zorg (KvZ) en kosten bij de introductie en toepassing van zo' $n$ innovatie gemeten worden en wat zijn ervaringen daarbij?" en betrof: kenmerken van patiënten, hun naasten en zorgverleners (6); kwalificatie van het leven van patiënten en hun naasten (7); kwalificatie van de zorg wat betreft kwaliteit, tevredenheid en doelmatigheid (8); kosten voor de gezondheidszorg en het patiëntsysteem in maatschappelijk perspectief (9). Er is vanuit gegaan dat in het zorgproces een min of meer gestandaardiseerd zorgaanbod (1-5) interacteert met op basis van aandoeningen en kenmerken individuele zorgvragen van patienten (6) en dat dit via de leefsituatie (7), zorg (8) en kosten (9) is te bestuderen (schema 1.3). 
Hoofdstuk 2 leidt het inventarisatie-, implementatie- en effectonderzoek bij de innovatie in. De introductie van CMTZ thuis is opgevat als een innovatie. Innovaties hebben drie hoofdfasen. De innovatiefase (fase I) gaat vooraf aan het besluit een verandering of vernieuwing (inclusief ontwikkeling) in te voeren. Het implementatieproces (fase II) omvat de toepassing van de innovatie. Tot slot volgt de rejectie of continuering (fase III). Deze fasen zijn gekoppeld aan de voornoemde drie soorten onderzoek.

Bij veranderingsprocessen zijn zeven kernactiviteiten te onderscheiden: ontwikkelen innovatief idee; analyseren vernieuwingssituatie; ontwikkelen innovatieperspectief; ontwikkelen innovatieprogramma of -concept; verspreiden innovatie of concept; implementeren innovatie; evalueren proces en effect (schema 2.3). Innoverende organisaties zijn op te vatten als een sociaal systeem met kenmerken op macro-, middenkader- en individueel niveau. Bij een innovatie als IT zijn de context, vernieuwing, doelgroep en veranderaar ("agent of change") te beschrijven in termen van structuur, cultuur en beïnvloedingswijze (schema 2.4). IT beweegt zich op het grensvlak van de klinische zorg en de thuiszorg en de medische en verpleegkundige professie. De samenwerking bij en vormgeving van thuisbehandeling kan hierdoor noch door één centrale besluitvormer opgelegd worden, noch volledig vanuit de doelgroep zelf ontstaan. Het cultureel-politieke perspectief lijkt het meest geschikt om deze innovatie in te voeren en te bestuderen (schema 2.5). Ter concretisering zijn allereerst de keuze van de patiëntengroepen en de daarbij te hanteren infusietechnieken van belang. Daarna kan via protocollering bepaald worden welke zorg vereist is en hoe deze vorm te geven. Staat de beoogde werkwijze vast, dan dient deze mogelijk gemaakt te worden door te informeren, te scholen en de financiêle randvoorwaarden te vervullen (schema 2.6). Vanwege het exemplarisch karakter is gekozen voor een viertal prototypen, die tezamen een brede variatie in ziektes, infuusbehandelingen en potentiële overdracht van professionele naar niet professionele zorg vertegenwoordigen: morfine subcutaan, antibiotica en mannitol intraveneus, en hartmiddelen (dopamine en lasix) centraalveneus (schema 2.7). De onderzoeksmethoden zijn onderverdeeld naar de innovatiefasen (ontwikkeling, proefimplementatie en continuering/rejectie) en naar gelang zij op de innovatie zelf of op de evaluatie daarvan betrekking hadden (schema 2.10).

\section{DEEL II: INVENTARISATIE EN MODELONTWIKKELING}

Hoofdvraagstelling I vergt inventarisatie-onderzoek omtrent de ontwikkeling, invoering, toepassing en evaluatie van thuiszorgtechnologie. Bij MTA kunnen via 'syntheseonderzoek' nieuwe gegevens verzameld worden of oude opnieuw geraadpleegd, zoals via (meta)analyse van literatuur en meningsonderzoek bij de doelgroep en deskundigen.

Hoofdstuk 3 beschrijft een literatuurinventarisatie van de ervaringen met CMTZ thuis. Het aantal publikaties over concrete ervaringen in Nederland was destijds nog relatief gering. Het betrof veelal eerste rapportages en een enkele eindevaluatie. Geen enkel project leverde een volledige blauwdruk. Een aantal bevorderende factoren werd vaak genoemd. Belangrijk is, dat de patient en diens naasten het gevoel hebben dat bij het vertrek uit het ziekenhuis naar huis de zorg en veiligheid worden gecontinueerd. Dit kan middels transmuraal werkende verpleegkundigen (TMVs) en een efficiënt 24-uurs meldpunt. Voorlichting en scholing van zorgverleners, alsook voorlichting en instructie van de patient en naasten, zijn onmisbaar. Thuiszorg dient te worden aangeboden als een samenhangend geheel. Standaardisatie en afstemming kunnen voorkomen dat er een caleidoscopisch aanbod van formulieren, procedures en zorgaanbieders ontstaat. Tevens 
kan zo optimalisatie van de kosten en baten nagestreefd worden. Vanuit de literatuurinventarisatie en de contacten bleek verdieping gewenst over de kaders bij CMTZ en de taak- en verantwoordelijkheidsverdeling bij infuusbehandeling.

In hoofdstuk 4 worden de kaders uitgewerkt. Bij de theorie is in navolging van Fawcett een hiêrarchische structuur van de verpleegkundige en medische kennisontwikkeling aangehouden. Ten eerste is er uitgegaan van het gezondheidskundig metaparadigma waarin de medische en/of verplegende activiteiten in de context van gezondheid plaatsvinden in relatie met de patiēnt en zijn omgeving. Daarbinnen is als paradigma gekozen voor de driedeling in zelfzorg, mantelzorg en professionele zorg van Hattinga Verschure. Tot slot is, omdat de geneeskunde en de verpleegkunde als praktijkdisciplines nauw verwant zijn en de onderzochte handelingen van beide disciplines bij CMTZ een continuäm vormen, gekozen voor de zorgtheorie van Orem. Vanuit deze theorie wordt het zelfzorgvermogen van de patiênten en/of hun naasten zo optimaal mogelijk benut en wordt de zorgverlening gebaseerd op gehele of gedeeltelijke compensatie van en educatie bij zelfzorgtekorten. Deze uitgangspunten maken een functiegerichte zorgbenadering mogelijk. Ook de feitelijke zorgkaders in Nederland kunnen naar Orem beschreven worden via de driedeling in sociaal-maatschappelijke, interpersonele en zorgtechnologische kaders. Binnen het sociaal-maatschappelijk kader is het belangrijkste structurele kenmerk van voorzieningen de kleine overheid en grote collectieve sector. Cultureel beînvloedende factoren zijn de: verzorgingsstaat, sectoralisering van de samenleving, pluralisme en individualiteit. De gezondheidszorg zelf is bovendien structureel gescheiden in algemene en specialistische zorg. Zij wordt bepaald door de verdeling van taken, verantwoordelijkheden en bevoegdheden tussen de patiënt, de niet-professionele en de professionele zorgverleners en belangenbehartiging door beroepsgroepen en organisaties. De belangrijkste ontwikkelingen zijn de herstructurering en de patięntenemancipatie.

Professionele verantwoordelijkheid en al dan niet autonoom handelen bepalen grotendeels de interpersonele kaders. Deels zijn deze omschreven in takenpakketten (verantwoordelijkheden en vereiste kennis en vaardigheden). Het medisch en verpleegkundig handelen heeft via de wet Beroepen in de Individuele Gezondheidszorg (BIG) een wettelijke en deels strafrechtelijke grondslag. Van oudsher staan de verpleegkundigen in dienst van patiênten en naasten. Momenteel handelen zij in hun eigen beroepsuitoefening professioneel, maar niet autonoom indien zij medische handelingen van artsen overnemen. Dit vereist afbakening. Tot slot wordt de interactie tussen patięnten en zorgverleners gezien als contractuele hulpverlening met privaatrechterlijke waarborgen.

Het zorgtechnologische kader omvat de visie op de zorgverlening en stuurt de inhoudsbepaling en vormgeving van de zorg. De inhoud volgt uit de zelfzorgbehoeften. De indeling van het zorgproces en de zorgverleningsmethoden bepalen de vormgeving.

Hoofdstuk 5 beschrijft een landelijke enquête onder verpleegkundigen en artsen over de taken en verantwoordelijkheden bij de medisch-technische en verpleegtechnische handelingen bij infusie. De respons is, conform de inschatting vooraf, laag. Gezien het inventariserende doel van de enquête behoeft dit geen belemmering te zijn voor de validiteit van de uitkomsten bij de gewenste situatie.

Een centrale rol bij vormgeving vanuit de thuiszorg is weggelegd voor de huisarts en de TMV. Bij de laatste gaat de voorkeur uit naar een bij de thuiszorg werkende verpleegkundige, die deskundig en bekwaam is op het gebied van het medisch-technisch handelen 
bij infusies. Het is aan te bevelen een CMTZ als IT, vanwege de vereiste kennis, kunde en continuinteit uit te voeren binnen een transmuraal zorgmodel waarin zorgverleners na afdoende scholing, op geprotocolleerde wijze, 24 uur per dag samenwerken.

Bij vergelijking van de Wet Uitoefening Geneeskunst (WUG) en de BIG, hun maatschappelijke vertaling en de dagelijkse praktijk, sluit de BIG meer aan op de praktijk dan de WUG. Worden tevens hun maatschappelijke vertalingen bezien, dan zijn de onderlinge verschillen kleiner. Als zodanig kan de BIG beschouwd worden als de wettelijke vastlegging van de bestaande maatschappelijke vertaling van de WUG, die ook al ten dele in de regelgeving was opgenomen. Bij de huidige stand van zaken blijft binnen de BIG verschil van interpretatie mogelijk. Bij voorbehouden handelingen, zoals bij infusie, is nadere precisering gewenst.

Op basis van alle verzamelde informatie wordt ten slotte in hoofdstuk 6 een algemeen zorgmodel voor CMTZ (thuis) uitgewerkt via inhoud, proces en organisatie van deze zorg. De zorginhoud is geconcretiseerd via het zelfzorgconcept van Orem. Om bij CMTZ in de zelfzorgbehoeften door de aandoening en behandeling te voorzien, zijn kennis en vaardigheden op diverse gebieden vereist (schema 6.1). Bij het zorgproces wordt het patiêntsysteem en de professionele zorgverlening onderscheiden (schema 6.2). Nieuw is dat eerstgenoemden ook actief deelnemen aan het opheffen van zelfzorgtekorten bij CMTZ. Door deze betrokkenheid worden zij (mede)behandelaar. Dit stelt eisen aan het waarnemings-, het inschattings-, het verwerkings- en het leervermogen.

Het zorgproces is naar Orem en McFarland en McFarlane ingedeeld in indicatiestelling en zorguitvoering en evaluatie (schema 4.1). Als zorgverleningsmethoden zijn geoperationaliseerd: directe zorguitvoering, informeren, het opmerken van veranderingen en aanpassen van zorg, én psychosociale begeleiding (schema 4.2).

De indicatiestelling koppelt de individuele zorgbehoeften aan de beschikbare soorten en omvang van de zorgverlening. Actuele en/of potentiële zelfzorgtekorten in het lichamelijk, psychisch, huishoudelijk en sociaal functioneren van het patiëntsysteem worden naar aard en oorzaak geanalyseerd. Met het patièntsysteem worden doelen geformuleerd en de benodigde interventies afgesproken en vastgelegd in een zorgplan. De indicatiestelling is te bevorderen door aanmelding via een centraal meldpunt (CM), door omschrijving van de totaal bij CMTZ benodigde zorg in een multidisciplinair zorgprogramma en vastlegging daarvan in een zorgplan.

In de zorguitvoering en evaluatie dienen binnen multidisciplinaire samenwerking de door het patiënt- én professionele zorgsysteem gezamenlijk geformuleerde doelstellingen gerealiseerd te worden. Deze worden geëvalueerd en zo nodig bijgesteld door de zorgcoördinator in overleg met de andere betrokkenen. Een ieder kan bij voldoende kennis en vaardigheden CMTZ uitvoeren. De verpleegkundige mag medisch-technische handelingen in opdracht uitvoeren. Schieten kennis of vaardigheden tekort, dan moet ondersteuning gezocht worden. Telefonische consultatie, klinische presentatie of opname, of thuisbezoek door een expert zijn enkele mogelijkheden. Bij CMTZ is continuîteit van essentieel belang. Ten eerste de herkenbare voortzetting van de zorgverlening in een andere setting.

Daarnaast de continuliteit in tijd, werkwijze en zoveel mogelijk persoon. Een continue bereik- en beschikbaarheid zijn nodig ter eventuele ondersteuning van het patiěntsysteem en bij calamiteiten. Ten slotte de continutteit in het leven van het patiëntsysteem tegen de achtergrond van levensloop en levensstijl.

Een dergelijke zorgorganisatie is als transmuraal te kenschetsen. 


\section{DEEL III: PROCESBESCHRUJVING EN PROCESEVALUATIE INNOVATIE}

Vooral vanuit hoofdvraagstelling II (en deels vanuit III) richt zich dit deel op de beschrijving en evaluatie van het proces waarin aandacht voor de situatie, het perspectief en de strategie bij de vernieuwing alsmede het ontwikkelen, toepassen en evalueren volgens een omschreven werkplan.

In hoofdstuk 7 wordt de keuze van doelgroepen en omschrijving van individuele selectiecriteria besproken. Op het niveau van patientengroepen zijn behoudens bij de kwaliteit van zorg bij alle aandachtspunten selectiecriteria geformuleerd (schema 7.1). Bij de introductie van CMTZ thuis dient ten eerste rekening gehouden te worden met behandeltechnische ontwikkelingen. Ten tweede is een genuanceerde afweging op maatschappelijke niveau gewenst van de voor uitvoering vereiste schaalgrootte en effecten op de kwaliteit van leven per patiëntsysteem, de kwaliteit van zorg en de kosten. Een inschatting van de omvang per soort behandeling op jaarbasis is van belang. De verhouding tussen deze schattingen en de daadwerkelijke instroom varieerde grofweg tussen de 2:1 en de 4:1. Op basis van de omvang kan gekozen worden voor uitvoering door gespecialiseerde artsen en/of verpleegkundigen of door de reguliere professionals.

Daarnaast is ook CMTZ individuele gezondheidszorg die per patiěntsysteem een inschatting van de haalbaarheid vergt. Ook hiervoor zijn praktisch toepasbare selectiecriteria vereist. Op dit niveau zijn criteria onderscheiden voor: de aandoening plus behandeling en persoon van de patiënt, diens omgeving, en de inhoud, organisatic en financiering van de zorg (schema 7.2). Van de 155 patiěnten die in de periode 1993-1995 aangemeld zijn, kwamen er 19 niet (meer) voor behandeling in aanmerking en voldeden 14 niet aan de voorwaarden. Zesmaal was infusie mogelijk ondanks het feit dat een naaste verzorger ontbrak. De non-respons bij patiênten en naaste verzorgers is vooral te wijten aan overlijden, hoge leeftijd, ziekte, een korte behandeling of het tekortschieten van het begripsvermogen (tabel 7.3). De mening van de terminale patiěnten ontbreekt door de evaluatie na afloop van de behandeling. Soms waren naasten van overleden patiënten verhuisd of konden een interview niet aan. Bij huisartsen komt de non-respons vooral voort uit onbekendheid met de patiëntsituatie.

De organisatie van de zorg in de praktijk volgt in hoofdstuk 8. Het ontwikkelde model voor CMTZ (thuis) was concreet toepasbaar IT. Voor het creëren van de noodzakelijke randvoorwaarden dienen ter zake verantwoordelijken van de betrokken partijen bindende afspraken te maken omtrent de zorgverlening en financiering. Een slagvaardig werkend $\mathrm{CM}$ faciliteert zowel de aanmelding als de zorguitvoering. Multidisciplinaire protocollen en verslaglegging dienen als hulpmiddelen voor standaardisering en kwaliteitsborging. In het integrale zorgproces kunnen in teamverband werkende TMVs een spilfunctie vervullen. Deze functie kan zeer wel in de bestaande thuiszorg geĭntegreerd worden. Ook in de aansturing van een dergelijk gespecialiseerd team en de coördinatie en bewaking van de zorgorganisatie moet voorzien worden. Een structurele werkbespreking is daarbij als instrument voor continue kwaliteitsverbetering goed bruikbaar.

De problemen die optraden in de zorgverlening waren niet ernstig en/of omvangrijk. Het patièntsysteem was overwegend tevreden. Het zorgmodel kon een aantal problemen absorberen, waardoor het patiëntsysteem deze niet ervaarde. Ook kon het patiëntsysteem op acceptabele wijze met problemen omgaan, waardoor deze geaccepteerd werden. Tot slot was het patiêntsysteem ook in deze studie positief in diens oordeel. 
Vanuit het zorgmodel is geprotocolleerde zorg meestal op maat te leveren. Evenals in de overige gezondheidszorg conflicteerde echter met name bij chronisch zieken de door hen gewenste zorg op maat soms met het leveren van doelmatige zorg. Al met al is het alleszins verantwoord om IT onder de beschreven condities thuis uit te voeren.

De in hoofdstuk 9 besproken informatievoorziening had twee doelen: naamsbekendheid om het project in de regionale gezondheidszorg te plaatsen, het draagvlak onder zorgverleners, organisaties en financiers te vergroten en aanvragen uit het veld te genereren; daarnaast het bieden van informatie om de uitvoering van de patiêntenzorg soepel te laten verlopen. Het laatstgenoemde is als onderdeel van het zorgproces in andere hoofdstukken meegenomen. Onder de voornaamste verwijzers, de azM-artsen, had het project een goede naamsbekendheid. Ofschoon dit niet direct gemeten is, leken de naamsbekendheid van IT onder huisartsen en het draagvlak bij zorgverleners, organisaties en financiers voldoende.

Een zorginnovatie zoals IT kan alleen dan kwalitatief verantwoord plaatsvinden als het benodigde medisch-technisch handelen adequaat uitgevoerd wordt. Daarom wordt in hoofdstuk 10 aandacht besteed aan de vereiste scholing. Deze had tot doel om door kennis, vaardigheid en uniformering in de handelwijze thuisbehandeling met participatie van patięnten en naasten mogelijk te maken. Een meerderheid van de regionale huisartsen had bij diverse inventarisaties behoefte aan scholing betreffende infusie en $41 \%$ heeft daadwerkelijk aan een scholing deelgenomen. $Z_{i j}$ waardeerden de combinatie van kennis- en vaardigheidsonderwijs, maar gaven aan dat het tempo hoog lag. Er was een duidelijk scholingseffect. De idealistische scholingsdoelstellingen van het project zijn slechts gedeeltelijk bereikt. Het is niet realistisch te verwachten dat huisartsen zich in slechts enkele uren de vereiste kennis en vaardigheden voldoende eigen kunnen maken. De scholing maakt aanvullende ondersteuning bij een concrete patiënt niet overbodig. De huisartsen werden ondersteund door TMVs met een uitgebreidere scholing en training in het geven van instructies. Deze instrueren ook de patiënten, hun naasten en de in de zorg participerende wijkverpleegkundigen. Over hun scholing zijn de TMVs tevreden. Toch blijft, ondanks de scholing van huisartsen en TMVs, bij sommige patiënten specialistische aanvullende ondersteuning vanuit het ziekenhuis of het Groene Kruis nodig. Ook blijft, zelfs bij uitgebreide protocollen en daarop afgestemde scholing zoals in dit project, inter individuele variatie bij medisch-technische handelen bestaan.

In hoofdstuk $/ /$ blijkt dat de juiste combinatie van technologie (soort en toepassing techniek) en financiering (soort en verdeling over de partijen) essentieel is. Zij kan aanknopingspunten bieden voor een functiegerichte benadering van de financiering. De inschattingen betreffende de kosten van morfine- en mannitolinfusie bleken achteraf vrij accuraat. Door de toenemende druk op de reguliere budgetten van de meest betrokken zorgverleners, huisartsen, thuiszorg en ziekenhuizen, was en is het onrealistisch ervan uit te gaan dat zij CMTZ thuis binnen de bestaande budgetten kunnen realiseren. Als de betrokken zorgverleners, organisaties en verzekeraars zich dan ook als marktpartijen waren blijven opstellen, dan was de zorg binnen dit project nooit gerealiseerd of tot enkele patiënten beperkt gebleven. Slechts door samenwerking, goede onderlinge verhoudingen, personele, materiēle of financiēle investering en het opzoeken van de grenzen van de toenmalige financieringskaders kon IT doorgang vinden. 
Hoofdstuk 12 beschrijft de toegepaste behandelingen met aandacht voor de thuiszorgtechnologie en praktijkervaringen hiermee. Ook worden van de vier prototypes van ziektebehandelcombinaties de KvL, KvZ en kosten kort besproken. In deze samenvatting volgen deze onder hoofdstuk 13-15.

In deze studie heeft van de 98 huisartsen $58 \%$, van de 66 praktijken $76 \%$ en van de 14 huisartsgroepen $100 \%$ één of meerdere patiēnten met IT gehad. De infusie van morfine (Morf) en antibiotica (AB) waren vanaf september 1993 mogelijk, die van mannitol (Man) vanaf januari 1994 en van hartmiddelen (Dola) vanaf mei 1994. Bij de 122 patiênten zijn 123 eerste (één patiênt ontving mannitol eerst intra- en later centraalveneus) en 50 vervolg. behandelingen gestart (tabel 8.2 en 12.1). Bij drie patiênten is de behandeling om medischtechnische redenen vrij snel gestaakt $(\$ 12.3)$. Van de 68 terminale patiěnten overleden er 64 tijdens de behandeling. Het betrof 60 patiènten met infusie van morfine en eventueel andere medicatie en vier met vochtinfusie. Vervolgbehandelingen komen vooral voor bij antibiotica, mannitol en hartmiddelen. Vanwege de voorbereiding en afwikkeling beperken de werkzaamheden bij IT zich niet tot die dagen waarop infusie plaats heeft. Daarom is de zorgperiode langer dan de infusieduur.

In algemene zin is gekeken naar de verdeling van de problemen via 93 zorgaspecten (§8.4.6). Naarmate een infusie complexer is, treden ogenschijnlijk meer problemen op. Het gemiddeld aantal problemen per behandeling was voor subcutane, perifeer intraveneuze en centraalveneuze infusie, en in totaal respectievelijk $1,1,1,9,2,4$ en 1,7. In relatie tot de 93 aspecten die per behandeling gescoord zijn, valt dit alleszins mee. Ook hing het aantal problemen sterk samen met de zorgduur en traden in de beginfase van elke behandeling relatief meer problemen op. Het gemiddeld aantal absolute problemen per dag was voor subcutane, perifeer intraveneuze en centraalveneuze infusie, en in totaal echter respectievelijk $0,10,0,16,0,09$ en 0,12 . In tegenstelling tot de zorgduur, bleek de complexiteit bij relatieve vergelijking niet van belang. Wel waren de perifeer intraveneuze, subcutane en centraalveneuze infusies in deze volgorde toenemend strakker geprotocolleerd en werden voor een groter deel door de TMVs uitgevoerd. Deze werkwijze voorkwam problemen. Ter preventie is voorts van belang na te gaan of de problemen zich clusteren bij bepaalde soorten infusie of typen patiënten. Deze clustering trad met name op bij enige patiënten met infusie van hartmiddelen. Die bevinding is niet onverwacht. Het betreft hier immers een ernstig zieke categorie mensen, waarbij de aandoening en complexe behandeling ingrijpend zijn voor het dagelijks functioneren. Gerichte aandacht kan dit mogelijk deels voorkomen.

\section{DEEL IV: EFFECT-EVALUATIE}

Bij de evaluatie van gezondheidszorg komen menselijkheid, technologie en middelen samen. Onderzoek naar medische technologie, zorgvernieuwing en kwaliteitsverbetering betreft dan ook vaak de kwaliteit van leven en van zorg en de kosten. Hierop richt zich hoofdvraagstelling III.

Hoofdstuk 13 beschrijft de evaluatie van de leefsituatie én de KvL van de patiènt en van diens naasten via één model (schema 13.2). $\mathrm{KvL}$ is gedefinieerd als "de subjectieve beoordeling van het leven in haar geheel ten tijde van de zorg". De methode van de Stuurgroep Toekomstscenario's Gezondheidszorg om zelfzorgtekorten te meten is ook in praktijkonderzoek toepasbaar en kan gebruikt worden om de zorgsituatie van categorieën patiênten te vergelijken (tabel 13.19). Het zorgmodel is breed toepasbaar bij verschillende 
aandoeningen, behandelingen en patiëntsystemen. Terminale patiënten met morfine-infusie en patiënten met chronisch hartfalen hebben veel zelfzorgtekorten en een laag niveau van functioneren. Toch voelen laatstgenoemden zich relatief gezond. Patiënten met infusie van mannitol en antibiotica hebben minder zelfzorgtekorten en een hoger functioneringsniveau. Vanwege het intermitterend karakter van de infusie was infusie van antibiotica relatief vaker ook verantwoord toe te passen bij alleenstaanden. Naasten steunen de patiênten veel, maar ervaren dit niet als te belastend. Wel is het zorgmodel door de benodigde steun van naasten kwetsbaar. Zorgverleners kunnen de belasting van naasten moeilijk inschatten. Ook in deze studie bepaalden de aandoening en behandeling de $\mathrm{KvL}$ slechts ten dele. Er was weinig uitval tijdens de behandeling en geen aanwijzingen dat thuisbehandeling het functioneren of $\mathrm{KvL}$ van patiënten en/of naasten zodanig verminderde dat deze niet verantwoord was. De uitkomsten van de evaluaties in de hoofdstukken 8 en 14 steunen deze conclusie.

Over het algemeen is de overeenstemming tussen oordelen over KvL-items lager naar mate de onderliggende concepten minder concreet zijn (tabel 13.28 en bijlage 13.5). Het oordeel van de naaste stemt nog het meest overeen met dat van de patiënt. Voor vergelijking tussen naasten en zorgverleners en zorgverleners onderling, zijn meer oordelen beschikbaar. De overeenstemming over zaken als ernst van de ziekte, pijn en gezondheid van de patiënt is redelijk, die over de belasting van de naaste en $\mathrm{KvL}$ is laag.

In hoofdstuk 14 komen de kwaliteit, tevredenheid en doelmatigheid van de zorg aan bod. $\mathrm{KvZ}$ is gedefinieerd als de "zorginhoudelijk, bedrijfskundig en dienstverlenend optimale verhouding tussen de individuele op zelfzorgbehoeften gebaseerde zorgvraag van de patiënt en de aangeboden gestandaardiseerde zorg". Het ontwikkelde aspectmodel voor borging en meting van $\mathrm{KvZ}$ combineert dan ook een zorginhoudelijke, dienstverlenende (tevredenheid) en bedrijfskundige (doelmatigheid) benadering (schema 14.2). Vanwege de invloed van de sociaal wenselijke antwoorden is op verscheidene manieren gemeten (tabel 14.10). Zorginhoudelijk is geěvalueerd via een Zorg-Kwaliteitsmatrix waarbij de zorg is onderverdeeld in directe zorg, informeren, signaleren/verwijzen en psychosociale begeleiding, en de kwaliteit in kennis en kunde, attitude, samenwerking en organisatie. Dienstverlenend werd geěvalueerd via de Client Satisfaction Questionnaire en rapportcijfers. Bedrijfskundig is geěvalueerd via vergelijking met klinische en thuiszorg. Kwaliteit en tevredenheid verschillen wanneer daar op verschillende manier naar is gevraagd en per soort respondent. Bij de morfine-infusie is het oordeel van de naaste gebruikt om dat van de overleden patiënt te benaderen. Omgerekend variëren de uitkomsten van 7 tot $91 / 2$, veelal een $81 / 2$. Er zijn geen aanwijzingen dat IT volgens het hier beschreven model zorginhoudelijk kwalitatief minder verantwoord of doelmatig is of minder gewaardeerd wordt dan andere klinische en thuiszorg. De belangrijkste problemen treden op bij transities in de zorg en betreffen veelal de communicatie en samenwerking.

Zoals verwacht stemt binnen het patiëntsysteem de beoordeling van de zorginhoudelijke $\mathrm{KvZ}$ en tevredenheid overeen (tabel 14.14 en bijlage 14.3). Helaas geldt dit niet voor de overeenstemming tussen het patiënt- en het professionele zorgsysteem, en binnen het zorgsysteem. Dat de patiènt en verpleegkundige gedeeltelijk overeenstemmen pleit voor het zorgmodel. IT zal dus niet altijd optimaal afgestemd zijn en soms tekortschieten, omdat zorgverleners onvoldoende de behoeften van het patiëntsysteem kunnen inschatten of onderling overeenstemmen. 
Ook de in hoofdstuk 15 besproken kosten van IT kunnen in kaart gebracht worden vanuit het zorgverleningsmodel van Orem. Dit levert geen richtprijzen op voor de financiering, maar geeft wel inzicht én de methode kan bij de berekening van kosten van andere behandelingen gebruikt worden. De kosten zijn gedefinieerd als "de personele en materiële kosten van de zorgverlening binnen de gezondheidszorg en voor het patiěntsysteem". Bij CMTZ als IT bestaan de kosten van de gezondheidszorg voor het grootste deel (65\%) uit personele kosten (tabel 15.1). In dit zorgmodel vormde de TMV de grootste kostenpost. De kosten van de gezondheidszorg varieerden van gemiddeld $f 218$ tot $f 420$ per dag, in totaal zijn zij gemiddeld $f 286$. Bij de antibiotica waren de personele kosten vanwege de intermitterende giften hoog, bij de overige behandelingen door het benodigde overleg en coördinatie. Materieel waren de kosten van antibiotica hoog, bij de hartmiddelen de kosten van de infuusmaterialen en pomp. Afgezet tegen het tarief van een vergelijkbare ziekenhuisbehandeling (dagbehandeling à $f 375$, opname à $f 807$ ) varieerden de besparingen van $20 \%$ tot $70 \%$. Meestal overstegen de kosten voor thuisbehandeling het Intensieve Thuiszorg tarief (ITZ) van $f 200$ per dag. Het van de oorspronkelijke experimenten afgeleide ITZ tarief zou bij indexering in $1995 f 238$ hebben bedragen. In dat geval zou de overschrijding zo'n $f 50$ per dag oftewel ongeveer $20 \%$ hebben bedragen. De materiêle kosten voor de patiěnten en hun naasten waren in deze studie niet hoog (gemiddeld $f 5$ per dag). Toch treedt een aantal kosten bij ziekenhuisbehandeling niet op (lidmaatschap thuiszorg, bezorgkosten) en zullen andere afhankelijk zijn van eigen bijdragensystemen (thuisverpleging, verbandmateriaal). Maatschappelijk gezien waren niet-professionele personele kosten -ook al zijn deze beperkt tot de belasting van de naasten- wel degelijk aanwezig. Afhankelijk van de berekening lopen deze op tot $36 \%$ van de totaalprijs, maar ook bij gematigde aannamen bedragen deze $12 \%$. Dit 'werkverzuim' kan maatschappelijk economisch gezien tot forse kosten leiden. Al met al lijkt echter ook dit thuiszorgprogramma goed te passen binnen het streven naar een kosteneffectieve reductie of stabilisatie van het aantal ziekenhuisbedden.

\section{DEEL V: BESCHOUWING EN SAMENVATTING}

Hoofdstuk 16 geeft een algemene beschouwing waarin de driedeling in ontwikkeling, implementatie en evaluatie is aangehouden. Telkens worden na de belangrijkste bevindingen de methoden beschouwd. Daarna worden de bevindingen besproken in relatie tot de literatuur en het maatschappelijke nut. In zijn totaliteit bezien is de proefimplementatie van de innovatie infuusbehandeling thuis geslaagd te noemen.

Tot slot volgen voor alle onderdelen gezamenlijk de belangrijkste aanbevelingen. Bij proefimplementatie van nieuwe of reimplementatie van beproefde thuiszorgtechnologie dient bij uitstek aandacht besteed te worden aan de financiering, de protocollering en de attitudevorming. Verdere aanbevelingen bij de implementatie van CMTZ thuis richten zich op: de inschatting van de omvang van de doelgroepen en actieve werving; gecoördineerde modulaire protocollering mét de werkvloer; informatievoorziening en scholing; en tot slot een 'schotten'loze financiering.

Aanbevelingen voor verder onderzoek betreffen: chronische ziekten, andere technologieën, vergelijkende studies, en aandacht voor de leefwereld van het patiëntsysteem; de rol van transmuraal verpleegkundigen; logistiek.

Aanbevelingen voor onderwijs betreffen de: wijze van scholing en structurele aandacht binnen de curricula; het belang van attitudevorming. 


\section{Summary}

\section{PART I: INTRODUCTION AND METHODS.}

Chapter 1 introduces the research project Infusion Therapy at Home (ITH). Until now complex medical technical care (CMTC) in the Netherlands has primarily taken place in a clinical setting. In the clinic technology is mainly used for diagnostic and therapeutic purposes. In home treatment, however, explicit attention needs to be paid to the patient's autonomy and ability to live independently in his environment. Professional caregivers and organisations are still inadequately equipped for this new forms of care at home. The supply, content, and structure of care demand innovation. Hence a programme to promote home care technology was set up. Within this programme the Department of Family Practice of Maastricht University (UM), the Transmural and Diagnostic Centre (TDC) of the University Hospital Maastricht (azM) and the Green Cross Foundation Heuvelland (SGKH) established a framework to introduce and study CMTC through the ITH project. The objectives of the study were to develop (formulate prerequisites), implement (experimentally), and evaluate (both process and effect) this innovation. The study's explorative nature characterises it as exemplary descriptive research from a Medical Technology Assessment (MTA) perspective. The first main research question was "At the start of the project what is known about the development, introduction, application and evaluation of innovations in the field of CMTC at home?" and included all the points listed under the second and third research questions. The second main research question was: "In which way can such an innovation be developed, introduced and applied, and what are the experiences?". This question covered five points: identifying potential patient target groups, defining individual selection criteria and estimating numbers of patients (1); organisational and logistic design of the care as well as protocol design and fine-tuning (2); informing and teaching the patients, their closest others and caregivers (3); structuring the financing (4); choosing and applying a care technology at home (5). The third main research question was "How can one measure the Quality of Life (QoL), the Quality of and satisfaction with the Care $(\mathrm{Q} \circ \mathrm{C})$ and costs at the introduction and application of such an innovation, and what are the outcomes?". The question included four further points: the characteristics of the patients, their closest others, and caregivers (6); description of the life of the patients and their closest others (7); description of the quality of and satisfaction with the care (8); the health care costs from a societal perspective (9). The hypothesis was that within the care process a more or less standardised care supply (1-5) interacts (see figure 1.3; figures and tables are in Dutch) with individual care demands that vary 
according to differing underlying diseases and backgrounds of patients (6) and that this interaction can be studied through the life situation (7), care (8), and costs (9).

Chapter 2 introduces the inventory, implementation, and effect research in innovations. The introduction of CMTC at home has been interpreted as an innovation. Innovations have three main phases. The innovation phase (I) precedes the decision to introduce a change or modernization (including development). The implementation process (phase II) covers the application of the innovation. At the end comes rejection or continuation (phase III). These phases are coupled with the three kinds of research mentioned above. In change processes seven main activities can be distinguished: development of an innovative idea; analysis of the innovation environment; development of an innovation perspective; development of an innovation programme or concept; dissemination of the innovation or concept; implementation of the innovation; evaluation of process and effects (figure 2.3). Innovating organisations can be regarded as social systems with characteristics on macro, middle management and individual levels. In an innovation like ITH, the context, renewal, target group, and 'agent of change' can be described in terms of structure, culture and way of influencing (figure 2.4). ITH concerns the interfaces of clinical and home care and of the medical and nursing profession. The required collaboration and design of the home treatment can therefore neither be imposed by one central decision maker, nor can it fully evolve from the target group itself. Thus the most appropriate context to introduce and study this innovation seems to be the cultural-political perspective (figure 2.5 ). In the practical application one first has to select patient groups and matching infusion

techniques. Afterwards one can determine via the protocol which care is needed and how it should be designed. If the intended procedures are clear, then they should be facilitated by meeting the required informational, educational, and financial conditions (figure 2.6). Because of the exemplary nature of the study four prototypes were chosen, which together represented a broad variety of diseases, infusion treatments, and potential transfers of professional to non-professional care: subcutaneous infusion of morphine, peripheral intravenous infusion of antibiotics and mannitol, and administration of cardiac medication (dopamine and furosemide) by central intravenous line (figure 2.7). The research methods are classified according to the innovation phases (development, experimental implementation, and continuation/rejection) and whether they concerned the innovation itself or its evaluation (figure 2.10).

\section{PART II: INVENTORY AND MODEL DEVELOPMENT}

The first main research question requires the setting up of an inventory of the research into the development, introduction, application and evaluation of home care technology. In MTA new data can be gathered or old data can be consulted via 'synthesis research', such as (meta-)analysis of the literature and opinion research with the target group or experts.

Chapter 3 describes a literature search of the experiences with CMTC at home. At the time of the search, the number of publications about concrete experiences in the Netherlands were still relatively scarce. It mainly concerned preliminary reports and a few end evaluations. No project yielded a complete blueprint. A number of facilitating factors were frequently mentioned. It is important that patients and their closest others feel that the care and safety are continued when the treatment is transferred from the hospital to their homes. 
This can be achieved via a transmural infusion nurse (TIN) and an efficient 24-hour call centre (transmural = transitional: i.e. combining elements of specialistic and generalistic health care). Information and education of the professional caregivers, as well as information and instruction of the patients and their closest others are essential. Home care has to be offered as a coherent whole. Standardisation and coordination can prevent a kaleidoscope of forms, procedures, and suppliers of care from arising. In this way costs and benefits can be optimized. From the literature search and contacts it appeared desirable to gain more in-depth knowledge about the general framework of CMTC and the division of tasks and responsibilities in ITH.

In chapter 4 we elaborate on the frameworks. In line with Fawcett, a hierarchical structure of nursing and medical knowledge development underlay the theory. We started from the health care metaparadigm in which medical and/or nursing activities take place in the context of health and in relation to the patient and his or her environment. We chose Hattinga Verschure's paradigmatic division in three kinds of care: self-care, care by the closest other, and professional care. Our theoretical framework was completed with Orem's self-care deficit theory, since medicine and nursing, both being practical disciplines, are closely related and the actions under study from both disciplines form a continuum in CMTC. In Orem's theory the self-care capability of patients and/or their closest others is used as optimally as possible, and the care given is based on the total or partial compensation of and education in self-care deficits. These principles permit a functional care approach.

The factual boundaries of care in the Netherlands can also be described in Orem's terms with the tripartite division in societal, interpersonal, and care technology boundaries. Within the societal boundaries, the most important structural characteristic of the social services is the small government and the large collective sector. Factors influencing the culture are the welfare state, the compartmentalisation of society, pluralism, and individuality. In addition health care itself is structurally divided in general and specialist care. It is determined by the division of tasks, responsibilities, and competence between the patient, non-professional and professional caregivers and protection of interests by professional groups and organisations. The most important trends are restructuring and patient emancipation.

Secondly, the interpersonal boundaries are largely determined by professional responsibilities, whether or not by autonomous acting. Partly these are specified in sets of tasks (responsibilities and the knowledge and skills required). Medical and nursing actions are grounded in law, even partly in criminal law, under the so-called "BIG" law (Individual Health Care Act, wet Beroepen in de Individuele Gezondheidszorg: BIG). From time immemorial nurses have been in the service of patients and their closest others. Currently they act profesionally within their own occupation, but are not autonomous if they take over medical actions from doctors. This calls for demarcation. Finally the interaction between patients and professional caregivers is regarded a contractual caregiving with private law guarantees.

Thirdly, the care technology boundaries include the vision on care provision, and steer the choice of content and design of care. The content evolves from the self-care needs. The design is determined by the arrangement of the care process and the methods of providing care. 
Chapter 5 describes a survey of nurses and doctors concerning the tasks and responsibilities in medical-technical and nursing-technical actions in infusion. In line with the a priori estimation, the response was small. Given the inventory-making goal of the survey, this does not necessarilyconfound the validity of the outcomes concerning the desired situation.

The general practitioner and the TIN have a central role in organizing the care from the home care service. The TIN should preferably be a nurse working within a home care service organisation with expertise and skills in the field of medical-technical actions in infusion. Because of the expertise, skills, and continuity required in CMTC like ITH, it is desirable to offer this care within a 'transmural' care model within which caregivers with adequate education cooperate 24 hours a day, on the basis of a protocol. When comparing daily medical practice under the old law on medical practice (Wet Uitoefening Geneeskunst: WUG) and the BIG, we may conclude the BIG meshes better with daily practice than the WUG. If their societal interpretations are also taken into account, the difference is substantially smaller. As such, the BIG can be seen as a legal update of the existing societal interpretation of the WUG, which already had been incorporated in existing legislation. With the current state of affairs the BIG still allows differences in interpretation. In restricted actions, like in $\mathrm{ITH}$, further specification is needed.

On the basis of all the information gathered chapter 6 presents a general care model for CMTC (at home) structured according to the content, process and organisation of the care. The care content has been founded on Orem's self-care concept. In CMTC, meeting the patient's self-care needs concerning the disease and treatment requires expertise and skills in several areas (figure 6.1). The care process differentiates the patient and the professional caregiving systems (figure 6.2). What is new is that the patient system actively participates in CMTC in order to remove the self-care deficits. This involvement makes them cotreaters, which makes demands on their powers of observation, estimation, information processing, and learning.

Following Orem and McFarland and McFarlane, the care process has been divided into indication and rendering and evaluating care (figure 4.1). The methods of caregiving are operationalized as: direct caregiving, informing, observing changes and adjusting care, and psychosocial support (figure 4.2). In the indication procedure the individual care needs are coupled to the kinds and amount of care available. Actual or potential self-care deficits in the physical, psychological, housekeeping, and social functions of the patient system are analysed for nature and origin. Together with the the patient system targets are formulated and necessary interventions are arranged and laid down in a care plan. The indication procedure can be facilitated by contacting a call centre, by specifying all the care that is needed for CMTC in a multidisciplinary care programme, and laying this down in a care plan.

By giving and evaluating care within a multidisciplinary cooperative framework, one strives to realize the targets that the patient and professional care systems jointly formulated. These are evaluated and if necessary adjusted by the care coordinator after consultation with all involved. Given adequate expertise and skills everybody can implement CMTC. The nurse is authorised by the physician to conduct medical technical actions. If expertise or skills fail, back up should be sought. Consultation via telephone, clinical presentation or admission, or a house call by an expert are some of the 
possibilities. In CMTC continuity is essential. Firstly, this is a recognisable continuation of care in another setting. Secondly, this is continuation in time, working method, and as far as possible in person. Continuous attainability and availability are needed to support the patient system if necessary and in case of emergency. Finally, the continuity in the life of the patient from the perspective of their course of life and style of living needs to be assured. Such an organisation of care can be characterized 'transmural'.

\section{PART III: DESCRIPTION AND EVALUATION OF THE INNOVATION PROCESS}

With particular respect to the second main research question (and partly the third), this part is aimed at describing and evaluating the process with attention to the situation, perspective, and strategy regarding the innovation as well as developing, implementing, and evaluating according to a defined work plan.

Chapter 7 describes the choice of the target groups and the formulation of the individual selection criteria. On the patient groups level selection criteria were formulated for all the points of attention except the QoC (figure 7.1). When introducing CMTC at home one should first address technical treatment developments. Second, careful judgement at societal level is desirable in order to assess the required level of scale and potential effects on the QoL of the patient system, the QoC, and the costs. An estimation of the size on a yearly basis per kind of treatment is important. In practice, the proportion between these estimates and the actual intake varied roughly from 2:1 to 4:1. On the basis of the size a choice can be made between implementation by specialised doctors and/or nurses on the one hand and implementation by regular professionals on the other.

In addition CMTC is also individual health care, demanding a feasibility assessment for each patient. This requires selection criteria that are practicable. At this level we distinguished criteria for the disease plus treatment and the patient him- or herself, his/her environment, and the content, organisation, and finance of the care (figure 7.2). Of the 155 patients in the period 1993-1995, 19 were not eligible for treatment (anymore) and 14 did not meet the criteria. Infusion was possible six times even in absence of a nearest caregiver. Non-reponse among patients and closest others can be primarily attributed to death, advanced age, illness, a short period of treatment, or lack of comprehension capabilities (table 7.3). The opinion of the terminally ill patients is lacking because the evaluation occurred after the end of the treatment. Sometimes the closest others of deceased patients had moved or could not cope with an interview. Among general practitioners the non-response mainly stems from unfamiliarity with the patient's situation.

Chapter 8 describes the organisation of care in practice. The model developed for CMTC (at home) was indeed applicable in ITH. In general, in order to create the necessary preconditions those responsible among all the parties involved should make binding agreements on the supply and finance of this care. A decision-taking call centre facilitates both the indication procedure and the care process. Multidisciplinary protocols and reporting serve as aids for standardisation and quality assurance. In this integrated care process, teams of TINs can act as key figures. Their functioning can be well integrated in the existing home care. The management of such a specialised team and the coordination and monitoring of the organisation of care should be ensured. Discussing progress in a structured way is a useful instrument for continuous quality improvement. 
The problems that occurred in delivering care were neither serious nor large. On the whole the patient was satisfied. The care model was able to absorb a number of problems, such that the patient did not notice them. The patient system was also able to deal with a number of problems adequately, which made them acceptable. Finally, in this study the patient system was positive in its judgement.

Within this care model protocolled care can usually be adjusted to the individual needs. As in other kinds of health care, conflicts between desirability and efficiency arose in chronically ill patients. On the whole it is completely safe to implement ITH under the conditions formulated.

The informational activities described in chapter 9 had two purposes: creating awareness of the name in order to place the project on the regional health care map and enlarge the support of professional caregivers, organisations and financers, and to generate demand in the field; and offering information in order to facilitate patient care. The latter objective has been incorporated in the care process and as such has been covered in other chapters. The project was well known among the most important group of referents, the azM physicians. Moreover, although not directly measured, awareness of the name among general practitioners and the support from the caregivers, organisations, and financers seemed to suffice.

A care innovation like ITH is only qualitatively sound if the medical-technical actions are executed adequately. Chapter 10 addresses the education required to achieve this. The goal was to enable home treatment with the participation of the patients and closest others by providing knowledge, skills and uniformity in procedures. A majority of the regional general practitioners expressed the need for education in ITH on several occasions, and $41 \%$ actually attended the training. They were satisfied with the combined teaching of knowledge and skills, but found the pace rather fast. The education had a clear effect. But the idealistic educational targets of the project were only partly achieved. It is not realistic to expect general practitioners to obtain the expertise and skills required in only a few hours. The education did not make additional assistance in a particular patient unnecessary. The general practitioners were supported by TINs who had a broader education and training in giving instructions. The TINS instructed the patients, their closest others and the home nurses that participated in the care. The TINS were satisfied with their education. Despite the education of general practitioners and TINS, however, some patients required additional specialist assistance from the hospital or home nursing organisation. Even with detailed protocols and matching education as in this project, interindividual variation in medical-technical actions remains.

Chapter 11 demonstrates that the appropriate combination of technology (kind and application) and finance (kind and distribution over parties) is essential. The combination can provide insight into a functional approach to the finance. In retrospect, the cost estimations for the morphine and mannitol infusions proved to be pretty accurate. Due to the increasing pressure on the regular budgets of the caregivers, general practitioners, home care, and hospitals most involved, it is unrealistic to assume that they could or can realize CMTC within the existing budgets. If the caregivers, organisations and insurers involved had acted to maintain market positions, then the care within the project would 
never have been realized or would have been limited to only a few patients. Only by cooperation, good mutual relations, personal, material, or financial investments, and probing the then boundaries of the health insurance coverage, could ITH be realized.

Chapter 12 describes the treatments used with respect to the home care technology and practical experiences with it. The QoL, QoC, and costs of the four prototypes of diseasetreatment combinations are briefly discussed. Here they are summarized under chapters 13-15.

In this study $58 \%$ of the 98 general practitioners, $76 \%$ of the 66 practices, and $100 \%$ of the 14 duty groups, had one or more patients with ITH. Infusion of morphine (Morf) and antibiotics (AB) was possible from September 1993, mannitol (Man) from January 1994, and cardiac drugs from May 1994. One hundred and twenty-two patients received 123 first treatments (one patient received mannitol intravenously, first peripheral and later central) and 50 follow-up treatments (tables 8.2 and 12.1). In three patients the treatment was quickly discontinued for medical-technical reasons $(\$ 12.3)$. Of the 68 terminally ill patients 64 died during the treatment ( 60 patients with infusion of morphine and sometimes other medication, and 4 patients with a hydration infusion). Follow-up treatments mainly consisted of infusion of antibiotics, mannitol and cardiac drugs. Because of preparation and completion the work in ITH is not confined to days on which infusion actually takes place. The care period is longer than the infusion period.

In general we looked at the distribution of problems in the light of 93 care aspects (\$8.4.6). The more complex the infusions, the more problems seemed to arise. The mean number of absolute problems per treatment for subcutaneous, peripheral intravenous, and central intravenous infusion and in total were 1.1, 1.9, 2.4, and 1.7. In relation to the 93 aspects scored per treatment, this is very reasonable. The number of problems also strongly correlated with the length of care and a relatively large number of them occurred in the beginning of each treatment. The mean number of problems per day, however, for subcutaneous, peripheral intravenous, central intravenous infusion, and in total was 0.10 , $0.16,0.09$, and 0.12 . In contrast to the care period, the complexity proved of no importance in the relative comparison. However, the peripheral intravenous, subcutaneous, and central intravenous infusions were protocolled in increasing detail in this order and were largely implemented by the TINs. This method of working prevents problems. For preventive purposes it is important to check whether problems cluster in certain kinds of infusions or patients. Clustering occurred mainly in some patients with cardiac drug infusion. This finding was not unexpected. It concerns a category of seriously ill people, in which the disease and complex treatment have a large impact on the daily living activities. Focused attention could partly prevent this.

\section{PART IV: EVALUATION OF EFFECTS}

In the evaluation of health care humanity, technology, and means come together. Research in medical technology, innovation of care, and quality improvement therefore often addresses quality of life and quality of care, and the costs. This is the focus of the third main research question.

Chapter 13 describes the evaluation of the life situation and the QoL of the patient and his or her spouse or immediate family be means of one model (figure 13.2). QoL is defined as 
"the subjective assessment of the life as a whole during the infusion care". The method used by the Steering Committee on Future Scenarios in Health Care (STG) to measure self-care deficits is also applicable in practice research and can be used to compare the care situations of patient categories (table 13.19). The care model is widely applicable in different diseases, treatments, and patient systems. Terminally ill patients with morphine infusion and patients with chronic heart failure have many self-care deficits and a low level of functioning. Despite this the latter feel relatively healthy. Patients with infusion of mannitol and antibiotics have fewer self-care deficits and a higher level of functioning. Because of the intermittent nature, antibiotics infusion could also be given in quite a number of patients who lived alone. The closest members of the family support the patients a lot, but do not experience this as too burdensome. The care model is vulnerable since it requires support of the closest others. It is difficult for professional caregivers to assess the burden of the closest other. Moreover, in this study the disease and treatment only partly determine the QoL. There were few drop outs during the treatment and no signals that the treatment at home diminished the functioning or QoL of patients and/or closest others to such an extent that it was not wise. The outcomes of the evaluations in chapter 8 and 14 support this conclusion.

In general the concordance of opinions on QoL items is lower as the underlying concepts are less concrete (table 13.28 and addendum 13.5). The opinion of the closest other corresponds best with that of the patient. Comparisons of opinions between closest others and professional caregivers, and amongst caregivers themselves, reveal some variation. The agreement on matters like the severity of the disease, pain, and health of the patient is reasonable, that on the burden of the closest other and $\mathrm{QoL}$ is low.

Chapter 14 addresses the QoC, satisfaction, and efficiency of the care. QoC is defined as "the optimal fit in terms of care content, management, and service between the individual care demand of the patient based on self-care needs and the standardised care supply". The model developed to assure and monitor the QoC therefore combines care content, service (satisfaction), and managerial (efficiency) approaches (figure 14.2). Due to the influence of socially desirable answers, we measured in several ways (table 14.10). Care content was evaluated by means of a Care-Quality matrix in which the care is subdivided in direct actions, informing, monitoring and referring, and psychosocial support, and the quality is subdivided in knowledge and skills, attitude, cooperation, and organisation.Service was evaluated by means of the Client Satisfaction Questionnaire and report marks. The managerial perspective was evaluated by comparing home and hospital care.

Differences are revealed in quality and satisfaction when different ways are used to assess them, and also with regard to the kind of respondent. In morphine infusion the opinion of the closest other was used to approximate that of the deceased patient. After conversion the outcomes vary from 7 to $9 \frac{1}{2}$, usually an $81 / 2$. There are no indications that ITH in the care model presented is qualitatively less sound or less efficient or is less appreciated than other clinical or home care. The main problems occur at care transitions and concern communication and cooperation.

As expected, the opinions on $\mathrm{QoC}$ and satisfaction within the patient system correspond (table 14.1 and addendum 14.3). Unfortunately this does not apply to the agreement between the patient and the professional care system, nor within the latter care system. The fact the patient and the nurse agree to a certain extent argues in favour of the care model. 
Therefore ITH will not always be optimally customised and will sometimes fall short because the professional caregivers cannot adequately assess the needs of the patient system or do not agree amongst themselves.

The costs of $\mathrm{TTH}$ discussed in chapter 15 can also be depicted on the basis of Orem's care model. This does not yield target prices for financing this kind of care, but it does provide some insight and the method can be used in calculating the costs of other treatments. The costs are defined as "personnel and material costs within the health care and for the patient system". In CMTC like ITH the largest proportion of the health care costs (65\%) are personnel costs (table 15.1). In this care model the TINs formed the largest cost. The mean health care costs varied from $f 218$ to $f 420$ a day, the overall mean is $f 286$ (roughly \$143) a day. In the case of antibiotics the personnel costs were high because of the intermittent dosing, while this was so in other treatments due to the consultation and coordination required. The material costs of antibiotics were high, as were the costs of infusion materials and pumps required to administer the cardiac medications. Compared to the rates for a similar hospital treatment (day care $f 375$ and admission $f 807$ a day), the savings ranged from $20 \%$ to $70 \%$. Usually the costs of the home treatment exceeded the Intensive Home Care Tariff (ITZ) of $f 200$ a day. Indexed for 1995, the ITZ tariff of the original experiments would have been $f 238$. In that case, the overspending was about $f 50$ a day or approximately $20 \%$. The material costs of the patients and their closest others in this study were not high (mean $f 5$ a day). Nevertheless a number of costs would not have arisen in hospital care (membership of home care organisation, costs of deliveries) and other costs depend on own contributions (home care, dressing material). From a societal perspective, non-professional personnel costs -although they were restricted to the burden of the closest others- certainly exist. Depending on how they are calculated, these could reach $36 \%$ of the total price, but even using moderate assumptions they remained at $12 \%$. This 'omission of work' can lead to high socio-economic costs. On the whole the home care programme seems fit in neatly with the striving for a cost-effective reduction or stabilisation of the number of hospital beds.

\section{PART V: DISCUSSION AND SUMMARY}

Chapter 16 gives a general discussion in which the three-way division in development, implementation, and evaluation is maintained. Following a summary of the most important findings, the methods are discussed. Subsequently, we look at the findings in relation to the literature and the social utility. All things considered, the experimental implementation of the innovation ITH can be called successful.

The chapter concludes with the most important recommendations. In the experimental implementation of new or the re-implementation of well-tried home care technology, most attention should be paid to the finance, the protocolling process, and attitude building. Further recommendations for implementing CMTC at home are: estimating the numbers of potential patients and active enrollment; coordinated protocollising together with the implementing professionals; providing information and training; mixed financing. Recommendations for further research include: chronically ill patients, other technologies, comparitive studies, and attention for the life situation of the patient; the role of 'transmural' nurses; logistics. Recommendations for research are: the method of training and structural attention within regular curricula; the importance of attitude building. 


\section{Dankwoord}

"Hartelijk bedankt allemaal voor jullie zorg, hulp, steun, luisterend oor en advies, en het er zijn als jullie nodig waren", stond er op één van de bedankkaarten die wij na afloop van de partner van een overleden patiênt ontvingen. Dit geeft enerzijds aan dat door de inzet van alle betrokkenen de menselijke kant van de zorg niet heeft geleden onder het technisch karakter van het onderzoek. Anderzijds herinnert het ons eraan dat wij vanuit het project precies dezelfde dank verschuldigd zijn aan alle patienten, hun naasten, zorgverleners en andere betrokkenen. Omdat dit onmogelijk is, wil ik U per groep bedanken.

\section{Patiēntenzorg}

Patiënten en hun naasten in de regio Heuvelland en soms daarbuiten.

Dank voor het vertrouwen dat $U$ ondanks uw vaak ernstige ziekte hebt gesteld in een nieuwe zorgvorm met al zijn kinderziektes. Helaas is het vanwege de anonimiteit niet mogelijk dit persoonlijk te doen. Aan alle partners, kinderen, (schoon)broers en zussen, ouders, verdere familie, buren en bekenden, dank voor uw steun. Zonder deze steun zou infuuszorg thuis vaak niet mogelijk zijn geweest.

Zorgverleners en instellingen.

Zoals uit bijlage 2.1 moge blijken is het niet mogelijk om $U$ allen te noemen. Velen van $U$ zijn in de regio Heuvelland werkzaam als huisarts, bij de Stichting Groene Kruis Heuvelland of bij het academisch ziekenhuis Maastricht. Bedankt voor uw steun en scepsis bij het ontwikkelen, invoeren, uitvoeren en kritisch evalueren van hetgeen als project Infuusbehandeling Thuis te boek staat. Als gezicht van het project naar velen van $\mathrm{U}$ wil ik de transmuraal infuusverpleegkundigen in het bijzonder vermelden: Terry Brouwers, Gerard Marinus, Mia Munnix, Marij Valkenburg en Karla Wehnert (eerste lichting) en Fieke Damoiseaux, Ingrid Kitzen, Gerda Martinussen, Anneke Soeters en Bianca Vostermans (tweede lichting). In de organisaties zijn er enkelen die ik vanwege hun dagelijkse betrokkenheid eveneens wil noemen.

Bij het Transmuraal \& Diagnostisch Centrum zijn dat Gitte Pfeiffer en Arnim van Lieshout van de automatisering, de 'dedicated ' baliemedewerkers en collega onderzoekers, Peter Reniers voor zijn creatieve ondersteuning bij het complexe financiêle beheer, en van het secretariaat Willeke Ellenbroek, Anneke Fokkema en Isi Vos. Bedankt voor de jaren dat ik samen met jullie heb mogen werken.

Bij het Groene Kruis Heuvelland betreft dat Mariêt van Daal-Dabekausen en Jan Gooyen 
van de automatisering, Simone Bogman, Ellen van Kruiningen, Maria Vonken en andere medewerkers van het centraal meldpunt, Marleen Jansberg, directeur, Theo Mestrom, Fred Tomasoa en overige medewerkers van de facturering, Jos Lenaards, hoofd algemene zaken, en Bert Ritzen, hoofd wijkzorg (en visionair), Wil Feijt en Jan Smeets van personeelszaken, Julia Schmidt en de andere transferverpleegkundigen, de verpleegkundig specialisten Lisette Arts, Emmy Derckx, Rita Fleur en Elleke Knapen, en tot slot Tiny Romans, Wil Quaaden, Willy Zwarts en overige medewerkers van de uitleen.

In het academisch ziekenhuis Maastricht zijn dat: de apothekers Ton Beysens, Eugène Hardy, Karen Takx en de apothekersassistenten, Leon Maas en de medewerkers van de afdeling afvalverwerking, Yvonne Becker, Leon Habets, Math Janissen, John Smeets en Leon Ubachs van de dienst Financiën en Economie, Jo Koene en de overige medewerkers van het magazijn, Herman van de Klij en Jo Urlings voor hun bemoeienis met de medische aparatuur, Sjoerd Bulstra, Wout Dingemans, Hans Fiolet, Han Hendriks, Jan Jacobs, Liang Kho, Wibo Mulder, Willem Weber, Frans van den Wildenberg en de overige leden van de medische staf, Bertie Lemmens en de overige verpleegkundige staf en Theo van den Boorn $†$ en Huub Visschers van de afdeling ziekenhuishygiěne.

\section{Zorgverzekeraars.}

Dank voor de financiering van de patienntenzorg via de intensieve thuiszorg regeling of uit coulance, waarmee $\mathrm{U}$ liet blijken zorgvernieuwingen als de onderhavige -tot aan de grenzen van het $U$ officieel toegestane- daadwerkelijk te steunen. Een speciaal woord van dank wil ik richten tot Haye van der Werf van VGZ voor zijn grote hulp om de zorgfinanciering vorm te geven. Helaas heeft het opheffen van de intensieve thuiszorg regeling en de eigen bijdrage problematiek in de thuiszorg een succesvolle voortzetting als reguliere zorgverlening belemmerd.

\section{Onderzoek}

\section{Nimfen}

Emmy Derckx en Corina Wolters die met mij als leeuwinnen gevochten hebben om dit project tot een succes te maken en mij tot nu toe met raad, daad en snoep terzijde hebben gestaan. Vanwege ons vele gezamenlijke optreden en jullie stempel op het proefschrift -het had een 'triple'promotie kunnen zijn- kan ik jullie ook tijdens de promotie niet ontberen.

\section{Universiteit Maastricht}

Dank aan mijn (co)promotoren die met mij een lange weg zijn gegaan en mij hebben geholpen om van mijn verslag een proefschrift te maken. George Beusmans heeft met zijn enthousiasme in het veld menig lans voor mij gebroken. George, bedankt dat je me ingewijd hebt in de wegen die naar consensus leiden. Maar ja, je bottelt dan ook wel meer verschillende soorten vruchten tot aimabele wijnen. Peter Pop heeft een centrale rol vervuld bij het vertalen van behandelingen van het ziekenhuis naar thuis en bleek een pleitbezorger van formaat in het ziekenhuis. Beste Peter, bedankt dat je me in 'jouw' TDC onderdak hebt geboden. Deze springplank was een goede entree tot het azM. Ron Winkens heeft mij terzijde gestaan met kritisch wetenschappelijk advies, met name op het gebied van studie-opzetten. Ron, bedankt voor je hulp om de omvang naar een enigzins hanteerbare vorm terug te brengen. Harry Crebolder heeft als een pater familias gefungeerd voor het gehele project, de projectmedewerkers en zeker voor mij persoonlijk. Beste Harry, je 
bent mijn academische vader en hebt me van het begin tot het eind gecoacht -ik kan U verzekeren dat dit geen sinecure was-. Ik ben je daar zeer erkentelijk voor en hoop ook in de toekomst bij je te mogen aankloppen.

Mijn mental coach Frans van der Horst, medisch socioloog vakgroep Huisartsgeneeskunde, heeft mij ingewijd in de wereld van het innovatie- en implementatic-onderzoek alsmede enige beginselen van de medische sociologie. Frans, je inspireerde mij tot de huidige indeling van het proefschrift en behield in ogenblikken van vertwijfeling mijnerzijds het overzicht betreffende het excideren, verplaatsen of accentueren van onderdelen. Tienwerf dank daarvoor.

De leden van de beoordelingscommissie dank ik voor hun kritische aanbevelingen. Gezien de omvang, zal het beoordelen van dit proefschrift een flinke impact op de kwaliteit van leven van hen en hun naasten hebben gehad. Vooraleerst wil ik professor Huyer als voorzitter van de beoordelingscommissie bedanken voor de soepele organisatie hiervan. Daarnaast heeft zij het verpleegkundig wetenschappelijk kader tegen het licht gehouden. Dr. Carpay heeft er op aan gedrongen om de laatste puntjes op de i te zetten bij de kostenstudie. Professor Schadé heeft al bij de start van het programma Thuiszorgtechnologie de zusterprojecten bij elkaar gebracht om uitwisseling van onderzoeksplannen te faciliteren en overlap te voorkomen. Professor Spreeuwenberg heeft de procesevaluatie onder de loep genomen. Beste Cor, ook bedankt voor je aanmoedigingen en belangstelling als je me op het TDC aan het proefschrift zag ploeteren. Tot slot zou ik professor Philipsen willen bedanken. Zijn 'substantiele' inbreng heeft bijgedragen tot verdere theoretische en vooral sociologische verdieping.

Binnen de vakgroep huisartsgeneeskunde gaat mijn dank uit naar mijn kritische collega's. Daarnaast zijn er inspanningen geleverd vanuit de vakgroepen anaesthesiologie en pijnbestrijding, chirurgie, interne geneeskunde, kindergeneeskunde, longziekten en neurologie. Een forse pro bono inspanning is ook geleverd door André Ament van de vakgroep Beleid en Economie van de Gezondheidszorg. André bedankt voor je zowel kwalitatief als kwantitatief essentiële bijdrage aan de kostenstudie. Voor de kostenstudie gaat mijn dank ook uit naar Jack Bibo en de 'MTA-club' van het academisch ziekenhuis Maastricht. Bij het achterhalen van vele cijfers van velerlei aard kon ik ook altijd aankloppen bij John Vossen van de medische administratie van het azM en Patrick Bongers van het MEMIC. Tot slot Nicole Bijl en Frans van Wijmen van de vakgroep Gezondheidsrecht: bedankt voor jullie hulp bij de 'BIG' job!

Zorgvernieuwers en academici in den lande en daarbuiten.

Hoewel ik in de tekst veelvuldig naar U verwijs, nogmaals dank voor uw uitgangspunten waarop ik verder kon bouwen, uw vernieuwende inzichten die mij scherpten, maar bovenal ook voor de herbevestiging van hetgeen ik trots als eerste uitgedacht dacht te hebben.

Ministerie van Welzijn, Volksgezondheid en Cultuur (nu Sport).

Dank voor de subsidie die het onderzoeksgedeelte mogelijk maakte en dank voor de mogelijkheid om de looptijd van het project van 3 naar 4 jaar te verlengen.

\section{Familie en vrienden.}

Bedankt Karla, kinderen, (schoon)ouders, broers en zussen en overige familie en vrienden voor alle steun en excuses voor alle keren dat ik ontbrak vanwege het werken aan mijn proefschrift. 


\section{Curriculum Vitae}

Patrick Smeets is op 10 april 1965 in het dorp Hulsberg (Zuid-Limburg) geboren als oudste van drie kinderen uit een klein middenstanders gezin. Na het doorlopen van de St. Clemens basisschool te Hulsberg (1971-1977), volgde hij de gymnasium B opleiding aan het St. Maartenscollege te Maastricht (1977-1983).

In 1983 werd hij uitgeloot voor geneeskunde en startte als beursstudent een studie Scheikunde aan de Rijksuniversiteit Leiden. Middels een naplaatsing kon hij alsnog starten met Geneeskunde aan de Rijksuniversiteit Utrecht (propedeuse 1984, doctoraal 1987 en artsexamen 1990). Deze studie combineerde hij met vakantie- en uitzendwerk, voornamelijk als verpleeghulp in bejaarden-, verzorgings- en verpleeghuizen alsook psychiatrische instellingen. Tevens was hij als penningmeester en voorzitter actief bij 'Dit voor Dat', een nonprofit ruildiensten bemiddelingsorganisatie, en als bestuurslid, penningmeester en waarnemend secretaris bij 'Huis Vaartserijn', een opvanghuis voor daklozen.

$\mathrm{Na}$ het artsexamen behaalde hij een propedeuse Rechtsgeleerdheid (1991) aan de Rijksuniversiteit Utrecht en een Master's Degree in Business Administration (1992) aan de Rotterdam School of Management (Erasmus Universiteit). Voor de laatsgenoemde studie ontving hij een VSB beurs voor een verblijf van vier maanden aan de Haas Business School van de University of California in Berkeley. Tevens deed hij marktonderzoek voor bedrijven naar de toepassing van medische apparatuur buiten het ziekenhuis en het imago van de thuiszorg onder de Nederlandse bevolking en de kwaliteitsperceptie bij clienten.

Aldus geëquipeerd begon hij in 1992 als coördinator en arts-onderzoeker samen met Emmy Derckx, verpleegkundig coördinator gedetacheerd vanuit de Stichting Groene Kruis Heuvelland, en Corina Wolters, onderzoeksassistente, aan het project. Tijdens de afronding van het proefschrift is hij in het academisch ziekenhuis Maastricht werkzaam geweest bij zorgvernieuwingsprojecten naar de toepassing van het Appropriateness Evaluation Protocol, een instrument ter meting van de noodzaak van ziekenhuiszorg (1996-1997) en thuisbehandeling bij diep veneuze trombose (1997-1998). Daarnaast was hij vanaf januari 1998 tot september 1998 werkzaam als transmuraal coördinator van het St. Annaziekenhuis te Geldrop. Vanaf die tijd volgt hij de huisartsopleiding aan de Universiteit Maastricht.

Hij woont met Karla en hun drie kinderen, Jim, Anne en Lara in Maastricht. 


\section{Afkortingen (abbreviations)}

\begin{tabular}{|c|c|}
\hline & academisch ziekenhuis Maastricht / academic hospital of Maastricht \\
\hline BC & BegeleidingsCommissie / support committee \\
\hline BIG & wet Beroepen in de Individuele Gezondheidszorg / law on individual health care \\
\hline ВОНH & Bureau Ondersteuning Huisartsen RHV Heuvelland / support bureau practitioners \\
\hline $\mathrm{CIH}$ & Centraalveneuze Infusie van Hartmiddelen / centralvenous infusion heart medication \\
\hline COPD & Chronic Obstructive Pulmonary Disease \\
\hline $\mathrm{CM}$ & Centraal Meldpunt / calling centre SGKH \\
\hline CMTC & Complex Medical Technological Care \\
\hline CMTZ & Complexe Medisch-Technische Zorg / CMTC \\
\hline CSI & Caregiver Strain Index \\
\hline $\operatorname{CSQ}$ & Client Satisfaction Questionnaire \\
\hline $\mathrm{CV}$ & CentraalVeneus / CentralVenous \\
\hline HIVAT & Home IntraVenous Antibiotic Therapy is IT met antiobiotica \\
\hline IT & Infuuszorg Thuis waarvan infuusbehandeling thuis deel uitmaakt / ITH \\
\hline $\mathrm{ITH}$ & Infusion Therapy at Home \\
\hline IV & IntraVeneus / IntraVenous \\
\hline $\mathrm{KvL}$ & Kwaliteit van Leven / QoL \\
\hline $\mathrm{KvZ}$ & Kwaliteit van Zorg / QoC \\
\hline MEMIC & Medisch En Maatschappelijk Informatie Centrum / information centre \\
\hline MTA & Medical Technology Assessment \\
\hline PIM & Parenterale Infusie van Mannitol / parenteral infusion of mannitol \\
\hline $\mathrm{pIT}$ & project Infuusbehandeling Thuis / research project ITH \\
\hline RL & Rijksuniversiteit Limburg nu UM \\
\hline SC & SubCutaan / SubCutaneous \\
\hline SGKH & Stichting Groene Kruis Heuvelland / Green Cross Foundation Heuvelland \\
\hline SIM & Subcutane Infusie van Morfine / subcutaneous infusion of morphine \\
\hline SRD & Sympathische Reflex Dystrofie / reflex sympathetic dystrophy \\
\hline STG & Stuurgroep Toekomstscenario's Gezondheidszorg / research and planning committee \\
\hline STZ & $\begin{array}{l}\text { Samenwerkingsverband later Stuurgroep Transmurale Zorg / cooperation of regional } \\
\text { health care providers }\end{array}$ \\
\hline TDC & Transmuraal \& Diagnostisch Centrum / transmural and diagnostic centre \\
\hline $\mathrm{TIN}$ & Transmural Infusion Nurse \\
\hline TMV & TransMuraal Infuusverpleegkundige / TIN \\
\hline UM & Universiteit Maastricht / University of Maastricht \\
\hline vws & ministerie van Volksgezondheid, Welzijn en Sport / new ministry of health care \\
\hline WGBO & Wet op de Geneeskundige BehandelingsOvereenkomst / law on treatment intentions \\
\hline WHO & World Health Organisation \\
\hline WUG & Wet op de Uitoefening van de Geneeskunst / old law on medicine \\
\hline WV & WijkVerpleegkundige / home nurse \\
\hline WVC & ministerie van Welzijn, Volksgezondheid en Cultuur / old ministry of health care \\
\hline Qol & Quality of Life \\
\hline QoC & Quality of Care \\
\hline ZHV & ZiekenHuisVerpleegkundige / hospital nurse \\
\hline ZKM & Zorg-K waliteitsMatrix / care quality matrix \\
\hline
\end{tabular}




\title{
Bijlagen bij hoofdstuk 1
}

\section{Achtergrond, probleemstelling en opbouw}

\author{
Bijlage 1.1: Achtergrond project
}

\section{INITIATIEFNEMERS, ONDERZOEKSINSTELLING EN CONTACTADRES}

Het project is geïnitieerd en uitgevoerd door de vakgroep Huisartsgeneeskunde (HAG) van de Universiteit Maastricht (UM) en het Transmuraal \& Diagnostisch Centrum (TDC) van het academisch ziekenhuis Maastricht (azM). Het maakte deel uit van het facultair hoofdproject 'Evaluatie van diagnostiek en interventies in de eerste lijn'. Momenteel is het project opgenomen in divisie 2 'Samenhang 1'-2' lijn' van ExTra (instituut voor EXtramuraal en TRAnsmuraal gezondheidszorg onderzoek). ExTra maakt deel uit van de onderzoeksschool CARE (Netherlands school of primary CARE research). Het onderzoek is gefinancierd vanuit het Stimuleringsprogramma Thuiszorgtechnologie van het voormalige Ministerie van Welzijn, Volksgezondheid en Cultuur (nu Sport). De onderzoeksregio 'Heuvelland' omvat het werkgebied van de SGKH, de gemeenten: Eijsden, Gulpen, Maastricht, Margraten, Meerssen, Vaals, Valkenburg, Wittem (208.623 inwoners). ${ }^{336}$ Het project duurde van oktober 1992 tot oktober 1996.

Informatie over de huidige stand van zaken:

Coördinator Transmurale Zorg

Transmuraal \& Diagnostisch Centrum academisch ziekenhuis Maastricht

Postbus 5800, 6202 AZ Maastricht

Telefoon: $\quad 043-3877388$

Fax: $\quad 043-3877380$

\section{PROJECTGROEP}

Dr. GHMI Beusmans; huisarts, universitair docent UM/TDC ${ }^{*}$

Prof. dr. HFJM Crebolder; huisarts, hoogleraar huisartsgeneeskunde UM *

Mw. drs. EWCC Derckx; gezondheidswetenschapper, verpleegkundig coördinator vanuit SGKH

Dr. FGEM v.d. Horst; medisch socioloog, universitair docent UM

Prof. dr. P Pop; internist, hoogleraar transmurale geneeskundige zorg TDC/azM *

Drs. PMJH Smeets; arts, projectcoördinator en onderzoeker UM

Mw. drs. CAM Wolters; gezondheidswetenschapper, onderzoeksassistent UM

$\because$ projectleiding.

\section{BEGELEIDINGSCOMMISSIE}

Mw. dr. AM Courtens, universitair docent vakgroep Verplegingswetenschap UM

Dhr. W. Dankers, rayonmanager Stichting Thuiszorg Zuid-Limburg

Dr. GL Engel, algemeen secretaris Raad van Bestuur azM

Mw. drs. MCH Jansberg, directeur SGKH (na 1/6/95)

Mw. BJM Lemmens, coördinator a.i. Stafburo Zorgmanagement azM

Mw. PMHM van Lin, inspecteur Volksgezondheid voor Limburg

Drs. H Plagge, adviserend geneeskundige LIASS later $\mathrm{CZ}$ groep

Mw. B Ritzen, hoofd wijkzorg SGKH (tot 1/6/95)

Drs. JRAY van Rooij, bestuurslid Regionale Huisartsenvereniging Heuvelland

Drs. $\mathrm{H}$ van der Werf, adviserend geneeskundige VGZ 
Bijlage 1.2: Medical Technology Assessment/Technology Assessment in Health Care MTA is in de zestiger jaren in Amerika ontstaan toen het Congres zich onvoldoende in staat achtte om (de gevolgen van) technologische ontwikkelingen te overzien. Zij heeft daartoe het Congress's Office of Technology Assessment (OTA) opgericht. In het handboek "Assessing Medical Technologies" verstaat de OTA onder 'medical technology": "techniques, drugs, equipment, and procedures used by health-care professionals in delivering medical care to individuals, and the systems within which such care is delivered" is De OTA omschrijft 'assessment' als: "any process of examining and reporting properties of a medical technology used in health care, such as safety. efficacy, feasibility, and the indications for use, cost, and cost-effectiveness, as well as social. economic, and ethical consequences, whether intended or unintended". 15 Deze definitic geeft vooral aan wat er gedaan wordt. Meer doel- en contextgericht is de definitie van de Raad voor Gezondheidsonderzoek (RGO): "MTA omvat al die activiteiten die bijdragen aan het systematisch verhelderen van de gevolgen van toepassing van medische technologie, ten behoeve van de personen en instanties die betrokken zijn bij besluitvorming in en over de gezondheidszorg" 16 Ook de begrippen 'Medical Technology Assessment' en 'Technology Assessment in Health Care' verschillen. Hoewel laatstgenoemde term een breder begrip omschrijt, wordt de eerstgenoemde in het angelsaksische spraakgebruik veel frequenter gebruikt en vaak in dezelfde betekenis. De verschillen vergroten bij vertaling. In het begrippenkader van met name de Verenigde Staten leveren de meeste personen werkzaam in de gezondheidszorg (health care) medische zorg (medical care). Bijrijders op de ambulance heten bijvoorbeeld paramedics. In Nederland is de medische zorg én van de te onderscheiden soorten binnen de totale gezondheidszorg. Ook zijn de systeem- en de organisatie-aspecten waarbinnen de medische zorg wordt toegepast, niet automatisch inbegrepen ${ }^{16}$ 


\section{Bijlagen bij hoofdstuk 2}

\section{Methoden}

\section{Bijlage 2.1: Het netwerk van het project Infuusbehandeling Thuis}

\section{Zorgverleners en hun organisaties}

academisch ziekenhuis Maastricht

Administratic en Bedrijfsbeheer

AIDS verpleegkundige

Dienst Opleidingen

Dietetick

Ergotherapie

Fysiotherapie

Inkoop

Instrumentele dienst

Laboratorium Klinische Chemic

Logistieke dienst

Maatschappelijk werk

Medisch Ethische Commissie

Medische administratie

Medische microbiologie

Specialisten

- anesthesiologie/pijnbestrijding

- algemene heelkunde

- algemene interne geneeskunde

- cardiopulmonale chirurgie

- gerontologie

- hematologie

- kinderlongziekten

- longziekten

- oncologic

- orthopedic

Stafbureau Zorgmanagement

Sterilisatic en desinfectie afdeling

Verpleging

- chirurgie

- dagcentrum

- interne geneeskunde

- kindergeneeskunde

- longziekten

Verpleegkundig managers en unithoofden

Voedingsteam

Voorlichting en Public Relations

Ziekenhuisapothekers

Ziekenhuishygiēne

\section{Apothekers}

Apotheckhoudende huisartsen

Apothekers in de thuiszorg

Apothekers- en Voorlichtingscentrum Maastricht
Gezinszorg: Stichting Thuiszorg Zuid-Limburg Intakers

Rayonmanager

\section{Huisartsen}

Districts Huisartsen Vereniging Limburg

Regionale Huisartsen Vereniging Heuvelland

Werkgroep Deskundigheidsbevordering Huisartsen van de RHV

Kruiswerk: Stichting Groene Kruis Heuvelland Centraal Meldpunt

Clustermanagers en hoofd wijkzorg

Dienst automatisering Wijk Administratie Systeem Financiele dienst

Functionaris Intensieve Thuiszorg

Intakers

Verpleegkundig specialisten voor: CARA, oncologie/AIDS en Medisch-Technisch Handelen

Leveranciers en facilitaire bedrijven

Baxter later Caremark

Braun

Minigas

NPBI

Ohmeda

Pharmacia

Provema

Spruyt Hillen

\section{Verzekeraars en hun organen}

IZA Limburg

$\mathrm{KLOZ} / \mathrm{KPZ}$ regiovertegenwoordiger

LIASS opgegaan in CZ groep

Nederlands Technisch Advies College (NTAC)

VGZ

Overige zorgverleners en hun organisaties

Stichting SAmenwerkingsverband eerste en tweede lijn voor REgionale geZOndheidszorg (SAREZO)

Stichting Amsterdams Kruiswerk

Stichting Hulpnet te Sittard

Stichting Thuiszorg Oostelijk Zuid Limburg

De Weverziekenhuis te Heerien 


\section{Universiteit Masstricht \\ -Skillslab}

-vakgroepen Economie van de Gezondheidszorg.

Gezondheidsrecht, Medische Sociologie en

Verplegingswetenschap

-Werkgroep Onderzoek Kwaliteit (samenwerking

vakgroep huisartsgeneeskunde UM met Katholieke

Universiteit Nijmegen)

\section{Overige instituten}

Onderzocksschool CARE

Kwaliteits Instituut voor Toegepaste

ThuisZorgvemieuwing (KITTZ)

Zusterprojecten Stimuleringsprogramma

Thuiszorgtechnologie

\section{Cursussen / Congressen / Symposia}

Achtereenvolgens worden genoemd. Titel. Organisator of initiaticfnemer. Plaats: datum. Opsomming vindt in chronologische volgorde plaats.

\section{Bezocht}

Van Ziekenhuiszorg naar Thuiszorg. Stichting Medische Technologic. Gorinchem: 2/10/92

Toekomstscenario's voor Eerstelijnszorg en Thuiszorg: Verwachtingen en gevolgen voor de praktijk. Academisch Medisch Centrum. Amsterdam: 8/10/92.

Thuiszorg, huisartsen en AZU. DHV Utrecht/Kruiswerk Stad Utrecht/vakgroep algemene gezondheidszorg en epidemiologie/Academisch Ziekenhuis Utrecht. Utrecht: 15/10/92

Cursus Stervensbegeleiding. Postgrade. Weert: 20/10/92.

Cursus Pijnbestrijding. Postgrade. Weert: 29/10/92.

Workshop Academisering. Vakgroep Huisartsgeneeskunde RL. Maastricht: 4/11/92

Thuis in pijnbehandeling. Zutphen: 26/11/92

Symposium Bloedontstollend. Stichting Medische Congres Organisatic. Utrecht: 9/3/93.

Randwijckcursus longziekten. Vakgroep Huisartsgeneeskunde RL. Maastricht: 11/3/93.

Beter Samen? Samen beter! Vijf jaar experimenteren met zorgvemicuwing. SARFZO. Brunssum: 12/3/93

Medica. Utrecht: $18 / 3 / 93$.

Vaardigheidscursus voor huisartsen. Werkgroep Onderzoek Kwaliteit Huisartsgeneeskunde. Klinisch

Trainingscentrum. Nijmegen: 28/4/93.

Thuiszorgtechnologie in de praktijk. KITTZ/LSOB. Utrecht: 29/4/93.

Randwijckcursus oncologie. Vakgroep Huisartsgeneeskunde RL. Maastricht: 3/6/93.

SGO cursus onderdeel kosteneffectiviteit. SGO. Epen: 25/6/93.

Symposium "Innovatie Thuiszorg" voor chronisch zieke ouderen. Rijksuniversiteit Limburg. Maastricht: 30/6/93.

Home IntraVenous Antibiotic Treatment symposium. Glaxo. Zeist: 1/10/93.

Academiseringsdag Huisartsgeneeskunde. RL. Maastricht: 10/11/93.

Transmurale Zorg Modellen en Projecten (Studiedag). Vakgroep Algemene Gezondheidszorg Universiteit Utrecht. Utrecht: 16/12/1993.

Resultaten van concrete transmurale projecten. Beatrix ziekenhuis Gorinchem. Rotterdam: 25/1/94

Parenterale voeding in het ziekenhuis en thuis. PAOG Heyendael. Nijmegen:31/3/95.

Cursus Beroepenwetgeving in ontwikkeling. Evaluaties halverwege het invoeringstraject, van de wet BIG.

Vakgroep Gezondheidsrecht, Faculteiten der Gezondheidswetenschappen, Rechtsgeleerdheid en Geneeskunde

Rijksuniversiteit Limburg. Maastricht: 21-22/3/96.

Verpleegkundig infuusmanagement. PAOG Heyendael. Nijmegen: 19/4/96.

\section{Bijdragen}

Thuiszorg met technische hulpmiddelen (voordracht). Symposium Huisarts-Specialist 1993. Thema:

Communicatie en samenwerking tussen huisarts en specialist. Diagnostisch Centrum / Stuurgroep $1 *-2 *$ lijn /

KNMG. Maastricht: 17/4/93.

Chronic diseases and changing care patterns in an ageing society (poster). Institute of Social Medicine University of Amsterdam. Amsterdam: 9-11/6/93.

Infusion Therapy at Home (poster). WONCA/SIMG Congres. Den Haag: 13-17/6/93.

Technologische vernieuwingen in de thuiszorg (voordracht). Second European Congress. Closing the gap between institutional care and home care. European association of Organizations for Home Care and Help at Home. Maastricht: 6-7/10/94.

Project 'Infuusbehandeling Thuis' (voordracht). NHG-Referatendag. NHG. Maastricht: 2/6/95.

Project 'Infuusbehandeling Thuis' (voordracht). Onderzoekschooldag. Care. Utrecht. 16/6/95. 
Thuiszorg: infuusbehandeling thuis als voorbeeld (voordracht). SAN bezoek aan TDC. Maastricht: 14/11/95. Invitational Meeting Transmurale Farmacie. Klinische Farmacie en Toxicologie azM. Maastricht: 22/11/95. Wie is met thuisbehandeling beter af? (voordracht) Congres "Samenwerking huisarts-specialist". NHG. Rotterdam: 1/12/95.

Medische Technologie in de Thuiszorg: welke voordelen biedt infuusbehandeling thuis voor u en de patient? (voordracht) Congres "Intensieve samenwerking binnen de zorgketen". Institute for International Research. Amsterdam: 2-4/12/97.

Complexe medisch-technische zorg thuis: modelontwikkeling, implementatie en effect-evaluatie (voordracht). Invitational conference implementatic en implementatie-onderzoek. Synchron. Hoensbroek: 26/3/99. Infuus in de thuiszorg: een transmuraal project (voordracht). Randwijckcursus Transmurale zorg en disease management. Vakgroep huisartsgeneeskunde UM. Maastricht: 15 april 1999.

\section{Publikaties / Rapportages / Vernoemingen}

Thuiszorg met behulp van technologische hulpmiddelen. Informatiebulletin Diagnostisch Coordinerend Centrum juli 1992:14(1):20.

Integraal Kankercentrum Limburg. Werkgroep pijnbestrijding bij kankerpatienten. Jaarverslag 1992:14.

Apothekersvereniging Maastricht. Jaarverslag 1992:6-7.

Diagnostisch Coordinerend Centrum. Jaarverslag april 1992-1993:31.

Project 'Infuusbehandeling Thuis', Nieuwsbrief Regionale Huisartsen Vereniging Heuvelland

1993;9(1):ongenummerd.

Smeets PMJH, GHMI Beusmans, Crebolder HFJM, Pop P, Derclox EWCC en Wolters CAM. Project Infusion Therapy at Home (poster 18). In: Bos GAM van den, Limburg LCM, Velden J van der en Verkleij H (eds).

Chronic diseases and changing care patterns in an ageing society. Tijdschrift voor Sociale Gezondheidszorg juni 1993;71(4 Suppl):6.

Smeets PMJH, Warndorff DK en Beusmans GHMI. Infuusbehandeling thuis. Ervaringen met de toepassing van medisch technologie. Medisch Contact juli 1993;48(29/30):905-7.

Smeets PMJH, Warndorff DK en Beusmans GHMI. Infuusbehandeling thuis. De implementatic van technologie in de thuiszorg. Medisch Contact augustus 1993;48(31/32):944-6.

Nieuwsbrief I Project 'Infuusbehandeling Thuis' augustus 1993.

Project 'Infuusbehandeling Thuis'. Nieuwsbrief Regionale Huisartsen Vereniging Heuvelland augustus 1993;9(4):ongenummerd.

Nieuwsbrief 2 Project 'Infuusbehandeling Thuis' 8 oktober 1993 (officiele startdatum).

Cann J van. 'Infuusbehandeling Thuis' van start. Traject (informatiebulletin azM) oktober 1993;8(9):17.

Nieuwsbrief 3 Project 'Infuusbehandeling Thuis' december 1993.

Integraal Kankercentrum Limburg. Werkgroep pijnbestrijding bij kankerpatienten. Jaarverslag 1993:7.

Apothekersvereniging Maastricht. Jaarverslag april 1993-1994:7.

Diagnostisch Coordinerend Centrum. Jaarverslag 1993:38.

academisch ziekenhuis Maastricht. Jaarverslag 1993:32.

Cann J van. Relatie van infuusverpleegkundige met patient is de spil van het hele project. Traject

(informatiebulletin azM) april 1994;9(4):15.

Crouzen B. Huisarts wordt deskundiger. De Limburger 2 juni 1994.

Nieuwsbrief 4 Project 'Infuusbehandeling Thuis' oktober 1994.

Ortjens W. Maastricht was een schone slaapster onder spinnenwebben. Mediscope (informatiebulletin faculteit geneeskunde RL) 4 november 1994;(3):4-7.

Apothekersvereniging Maastricht. Jaarverslag april 1994-1995:9.

Diagnostisch Coordinerend Centrum. Jaarverslag 1994:37-8.

Servais J. Patient bij behandeling betrekken. Traject (informatiebulletin azM) januari 1995;10(1):8-9.

Crouzen B. Experiment met thuis-infuus is cen succes. De Limburger 30 juni 1995.

Friele RD en Kerssens JJ. Techniek in de thuiszorg, een evaluatie van het stimuleringsprogramma thuiszorgtechnologic. Utrecht: NIVEL, augustus 1995.

Ministerie van Volksgezondheid, Welzijn en Sport. Stimuleringsprogramma Thuiszorgtechnologic, projectresultaten 1991-1994. Groningen: KITTZ, 1995.

Nieuwsbrief 5 Project 'Infuusbehandeling Thuis' \& Stuurgroep Transmurale Zorg 1 februari 1996.

Project 'Infuusbehandeling Thuis' NHG verenigingsverslag. Ned Tijdschr Geneeskd maart 1996;140(13):750.

Peeters-Udding LM. Transmurale Farmacic. Pharmaceutisch Weekblad 1996;131(6):170-2.

Kruyt J en Slingerland P. Transmurale zorg in de praktijk. Tussen thuis en ziekenhuis. Utrecht: NIZW/LVT, 1996.

Loo ME van. Registratie wetenschappelijk onderzoek cerstelijnsgezondheidszorg 1994-1995. Nivel: 1996:23. academisch ziekenhuis Maastricht. Kwaliteitsjaarverslag 1995:18. 
academisch ziekenhuis Maastricht. Jaarverslag 1995:32.

Diagnostisch Coordinerend Centrum. Jaarverslag 1995:41-2.

Apothekersvereniging Maastricht. Jaarverslag 1995:9.

Zutphen $\mathrm{H}$ van en Smeets PMJH. Infuusbehandeling thuis, van project naar reguliere zorg. Handboek Thuiszorg: B9.2-1 $\mathrm{t} / \mathrm{m}$ B9.2-8.

Smeets PMJH, Detckx EWCC, Wolters CAM, Pop P, Beusmans GHMI en Crebolder HFJM. Taken en verantwoordelijkheden bij infuusbehandeling thuis, Artsen en verpleegkundigen: de wet en de praktijk. Medisch Contact maart 1997;52(10):324-6.

Smeets PMJH, Kho TL, Wolters CAM en Pop P, Infuusbehandeling thuis bij chronisch hartfalen. Hartbulletin juni 1997;28(3):88-94.

Francke AL, Persoon A, Temmink D en Kerkstra A. Palliatieve zorg in Nederland. Een inventarisatiestudie naar palliatieve zorg, deskundigheidsbevordering en zorg voor zorgenden. Utrecht: NIVEL, juli 1997.

Smeets PMJH, Wolters CAM, van der Horst FGEM, Crebolder HFJM. Kwaliteit van en tevredenheid met de zorg bij infuusbehandeling thuis. Kwaliteit en Zorg september 1997;5(3):100-14.

Smeets PMJH, Derckx EWCC, Wolters CAM. Complexe medisch-technische zorg: het ontwikkelen, invoeren en evalueren van infuusbehandeling thuis. Handboek Thuiszorg 1999; HAT 34/51-84 G6.4 1-34.

\section{Bijlage 2.2: Overzicht onderzoeksmethoden}

Schema B2.1 geeft een overzicht van gehanteerde onderzoeksmethoden.

Schema B2.1 Gehanteerde onderzoeksmethoden.

(Sub)vraagstelling

Methode

Heofdstuk

Theorievorming bij het zorgmodel

Inleiding op het inventarisatie-onderzoek

Ervaringen met complexe medisch-technische zorg thuis

CIL

2

Kaders bij complexe medisch-technische zorg (thuis)

L

3

L 4

Taken en verantwoordelijkheden bij infuusbehandeling thuis

E

5

Een zorgmodel voor complexe medisch-technische zorg (thuis)

CIL

6

Beschrijving en evaluatie van het innovatieproces

Inleiding op het innovatie-onderzoek

CIL

2

Keuze doelgroepen en omschrijving criteria

$1 \mathrm{Nb} / \mathrm{tz}$

Organisatie van de zorgverlening

Informatievoorziening over het project en de behandelingen

I Nb/t/z Vz W

8

$\mathrm{EINb} / \mathrm{Vz}$

$\mathrm{E} 1 \mathrm{Nb} / \mathrm{Vz} \quad 10$

Technologie en financiering

I Nb/fOR

C IL Nb/tO $\mathrm{Vp} / \mathrm{n} / \mathrm{z}$

Evaluatie van effecten wan het zorgmodel

Inleiding op de effectevaluatic

IL

Zorgsituatie en kwaliteit van leven

A Nt O Vp/n/z Z

13

$\mathrm{Nt} V \mathrm{p} / \mathrm{n} / \mathrm{z}$

14

O R $V_{p} / n$

15

Legenda: $A=$ aanmeldingsformulier, $\mathrm{C}=$ =ongresbezoek, $\mathrm{E}$ =enquête, $\mathrm{I}=$-interview, $\mathrm{L}$-literatuur, $\mathrm{N}$-notulen $\mathrm{Nb}$ :overleg projectgroep en begeleidingscommissic Nf:overleg/correspondentic financiers Nt:werkoverleg transmuraal infuusverpleegkundigen $\mathrm{Nz}$ : overleg zorgverleners en organisaties, O-overige algemene administratic, $\mathrm{R}=$ rekening infuusbehandeling thuis, $\mathrm{V}=\mathrm{vragenlijst/vraaggesprek}$ aan eind van behandeling $V_{n}$ :naaste $V_{p}$ :patient Vz:zorgverlener, $\mathrm{W}=$-wijkadministratiesysteem, $\mathrm{Z}$-zorgdossier thuiszorg (logboek). 


\section{Bijlagen bij hoofdstuk 4}

\section{Kaders bij complexe medisch-technische zorg: de zorgverleningstheorie van Orem}

Bijlage 4.1: Het gezondheidskundig metaparadigma

Schema 4.1 Het gezondheidskundig metaparadigma. ${ }^{19}$

Medische of verplegende actie

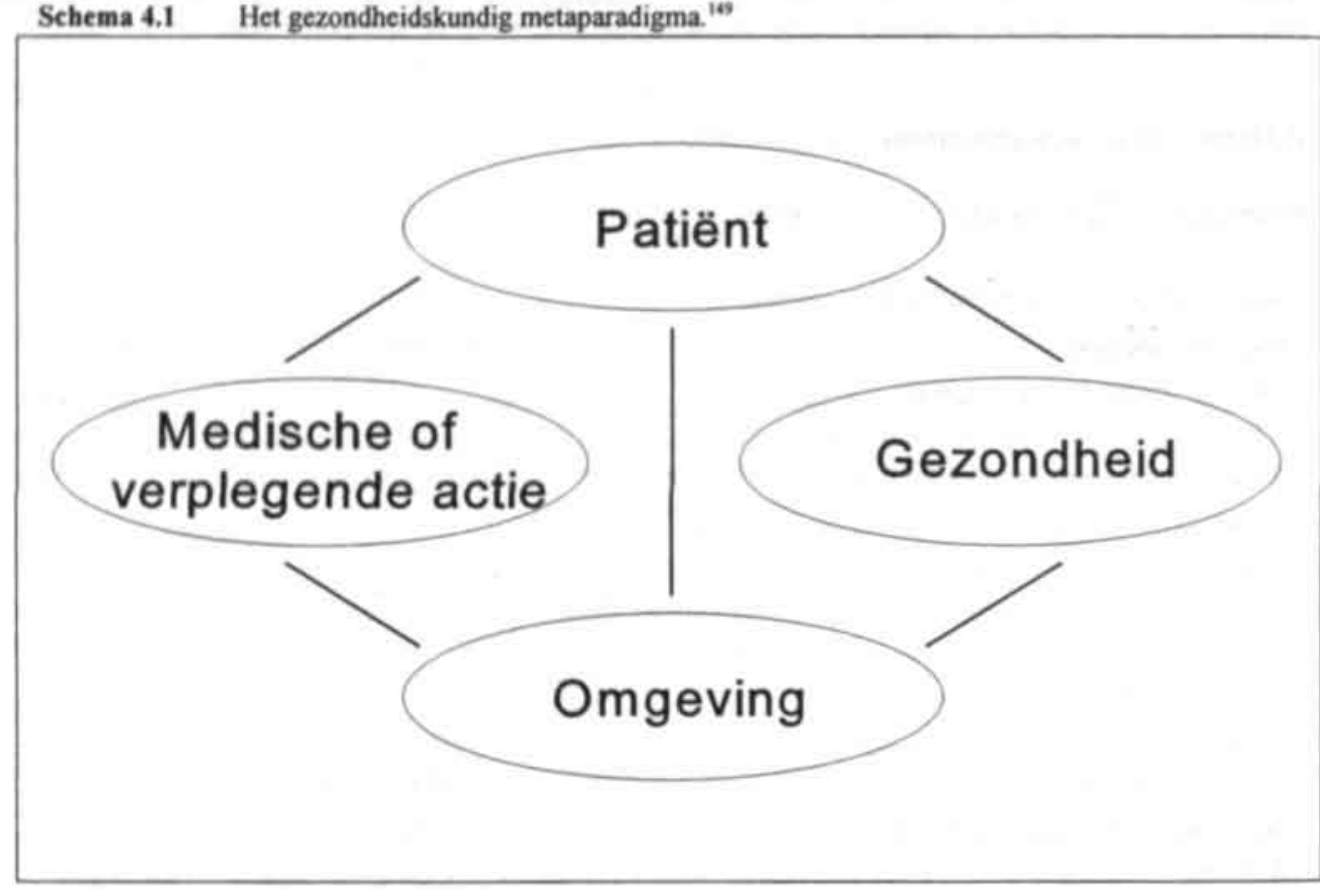




\section{Bijlage 4.2: Noten bij hoofdstuk 4}

1 Drie betroffen de relatie huisarts-patiēnt: discongruentie tussen opleiding en praktijkvoering, communicatie en het helpen van kankerpatiènten. ${ }^{73-200}$ Twee betroffen gedragsbeìnvloeding in de thuiszorg door samenwerking tussen de huisarts en het maatschappelijk werk (eenmaal ook de wijkverpleging). ${ }^{\mathrm{mi}, \mathrm{m} 2}$

2) De World Health Organisation (WHO) geeft een ruime definitic van het beroep huisarts: "General Practice is the front line of medical care and in some form or other exists in every part of the world. As a rule, it is not limited to patients with specific diseases within specific age-groups. It is in the field of medical practice where the patient usually makes his first contact with the doctor, and he has direct access to him. The goal of general practice is to provide continuing and comprehensive care for the individual, family and community" ${ }^{\prime 61}$ Tijdens de Second European Conference on the teaching of General Practice heeft de Leeuwenhorst groep deze vertaald voor Europa: "The general practitioner is a licensed medical graduate who gives personal, primary and continuing care to individuals, families and a practice population, irrespective of age, sex and illness. It is the synthesis of these functions which is unique. He wil attend his patient in the consulting room and in their homes and sometimes in a clinic or a hospital. His aim is to make early diagnoses. He will include and integrate physical, psychological and social factors in his consideration about health and illness. This will be expressed in the care of his patients. He will make an initial decision about every problem which is presented to him as a doctor. He will undertake the continuing management of his patient with chronic, recurrent and terminal illnesses. Prolonged contact means that he can use repeated opportunities to gather information at a pace appropriate to each patient and build up a relationship of trust which he can use professionally. He will participate in cooperation with other colleagues, medical and nonmedical. He will know how and when to intervene through management, prevention and education to promote the health of his patients and their families. He will recognise that he also has a professional responsibility to the community" 161 Vanaf 1991 is de Primary Health Care Unit van het Europese regiokantoor van de WHO bezig met een consultatieproces om te komen tot een "Framework for professional and administrative development of general practice/family medicine". Als kenmerken voor de huisartsgeneeskunde worden hierin genoemd: general, continuous, comprehensive, coordinated, collaborative, family-oriented, and community-oriented. ${ }^{163}$ Ook worden condities voor de ontwikkeling van de huisartsgeneeskunde genoemd op het gebied van structuur, organisatie en professionele ontwikkeling.

3) In 1942 introduceerde een Britse staatscommissie onder leiding van William Beveridge de verzorgingsstaat om de burger te vrijwaren voor verregaande gevolgen van werkeloosheid, ziekte, invaliditeit en ouderdom én om de staat te stabiliseren. ${ }^{12}$ In West-Europa hebben vooral de noordelijke staten dit model sterk doorgevoerd en zijn de aanspraken gestegen. De gestage kwantitatieve groei is vooral te wijten aan de bevolkingsopbouw, de kwalitatieve groei aan de uitbreiding van aanspraken door de lange periode van toenemende welvaart.

4) De gedachte van een staat bestaande uit de som der (in maatschappelijke groeperingen georganiseerde) burgers is overgegaan in het centraal stellen van het individu. In deze toenemend complexe maatschappij is de invloed van maatschappelijke groeperingen (kerk), die voorzieningen baseren op fundamentele waarden (substantiēle rationaliteit) en onderlinge solidariteit, afgenomen. Vooruitgang en welvaart worden niet langer als een dynamisch gegeven gezien, maar tot norm verheven. Tegelijkertijd is de invloed van een steeds centraler opererende overheid sterk toegenomen.

5) De belangrijkste ontwikkelingen in de geîndustrialiseerde landen in het afgelopen decennium betroffen de automatisering, de val van de Berlijnse muur en de General Agreement on Trade and Tariffs onderhandelingen. ${ }^{793-79}$ Daardoor verdwenen veel centraal geleide economietn en nam de kans om de eigen economie te beschermen af. De concurrentie uit Amerika, Azię en aan de oostgrens van Europa nam toe en heeft de totstandkoming van de Europese Unie bespoedigd. ${ }^{79}$ Maar ook binnen de afgeschermde markt van de Europese Unie concurreerde Nederland, door de uitgebreide en stringente regelgeving en hoge loonkosten, moeizaam. Hele bedrijfstakken stonden onder druk of waren onrendabel geworden. Veel werknemers die overbodig werden of de druk niet aan konden zijn vervroegd gepensioneerd of (on)terecht arbeidsongeschikt verklaard. ${ }^{96}$ Het daaruit voortvloeiende 
grotere beroep op voorzieningen heeft tot onvolkomenheden in de uitvoering geleid. ${ }^{174}$

'Doorcalculerende' burgers kregen de mogelijkheid zonder werk in het levensonderhoud te voorzien. 'Frauderende' burgers zagen de uitkering als een basisinkomen en werkten voor aanvullende luxe. Economisch wordt dit gedrag met de term "free ride" aangeduid. ${ }^{171}$ Dit kan op kleine schaal en zolang er partijen zijn die schade kunnen lijden. In een sociaal-maatschappelijk stelsel als de Nederlandse verzorgingsstaat kan dit niet lang op grote schaal bestaan.

6) Op basis van ontwikkelingsstadium en rationele besteding op grond van de hoogste gezondheidswinst per geĭnvesteerd bedrag -waaronder de hogere opbrengsten voor de staat door de verbetering van de volksgezondheid- is hierin een gradering aan te brengen. Ten eerste de zorg voor water-en voedselvoorziening en het beheer van energie en afvalverwijdering. Vervolgens preventieve gezondheidszorg in de vorm van voorlichting, controles en vaccinaties. Omdat ziekten vaak vanzelf overgaan, volgt aandacht voor verzorging van zieken en in laatste instantie de genezing van zieken.

7) De "eerstelijns gezondheidszorg" is integraal, continu en generalistisch en beslaat de gehele levensloop. Huisartsen, wijkverpleegkundigen en anderen verlenen deze zorg zo veel mogelijk thuis of in vergelijkbare omgevingen. Thuiszorg dient de hulpvrager in staat te stellen zich thuis te handhaven." De "tweedelijns gezondheidszorg" betreft vooral de tijdelijke, curatieve en palliatieve specialistische zorg (waaronder complexe medisch-technische) in ziekenhuizen. De "derdelijns gezondheidszorg" biedt uitgebreide en/of langdurige en/of gespecialiseerde revalidatie, verpleging en verzorging in revalidatie-, verpleegklinieken en instellingen voor chronische aandoeningen.

Basisgezondheidsdiensten leveren specifieke preventie.

8) In het westen is het verlenen van (gezondheids)zorg ontstaan uit christelijke naastenliefde aan 'minder bedeelden' waarbij niet-professionele zorgverleners de zorg (tijdelijk) overnamen. Hun kennis, kunde en macht groeiden allengs. Door de technologische ontwikkelingen, de industrialisatie en de ontkerkelijking is de zorgverlening vooral na de tweede wereldoorlog snel overgegaan in professionele hulpverlening met eenzelfde ongelijke verdeling van kennis, kunde en macht. ${ }^{45,46}$ Momenteel ontstaat geleidelijk een zorgverlening vanuit een meer gelijkwaardige samenwerking tussen autonome patiěnten, niet-professionele en professionele zorgverleners. Toch voeren artsen en verpleegkundigen behandelingen en zeker complexe medisch-technische veelal uit zonder of met geringe betrokkenheid van de patiěnt en naaste(n).

2) Vanaf de "Nota Volksgezondheid" (1966) nam de bemoeienis van de overheid met de volksgezondheid toe. ${ }^{24}$ Vanaf de "Structuumota Gezondheidszorg" (1974) heeft de overheid met wettelijke maatregelen de soorten en hoeveelheid gezondheidszorg bepaald en genormeerd: ziekenhuisvoorzieningen (WVZ:1977), tarieven (WTG:1982) en voorzieningen (WVG:1984). ${ }^{185}, 224$ Deze macro-economische volumebeheersing resulteerde slechts ten dele in een verlaging danwel zo rationeel mogelijke besteding van de gezondheidszorguitgaven. 


\section{Bijlage bij hoofdstuk 5}

\section{Enquête naar taken en verantwoordelijkheden bij infuusbehandeling}

\section{Bijlage 5.1: Analyse respons}

Tabel B5.1 geeft per respondent de ervaring met infuusbehandeling (thuis), leeftijd, geslacht, opleiding, werkervaring en werkplek en $z 0$ mogelijk referentiecijfers (legenda volgende pagina).

Tabel B5.1 Achtergrondkenmerken respondenten plus referentiecijfers.

\begin{tabular}{|c|c|c|c|c|c|c|}
\hline Variabele plus eenheid & & $\begin{array}{l}S P \\
n=52\end{array}$ & $\begin{array}{l}\text { HA } \\
\mathbf{n}=64\end{array}$ & $\begin{array}{l}\mathbf{Z H V} \\
\mathrm{n}=112\end{array}$ & $\begin{array}{l}\text { WV } \\
n=87\end{array}$ & $\begin{array}{l}\text { Allen } \\
n=315\end{array}$ \\
\hline Ervaring infuus thuis & $\%$ & $\cdot$ & 20 & $\cdot$ & 33 & $13 *$ \\
\hline Ervaring infuus ziekenhuis & $\%$ & 65 & 2 & 94 & 5 & 46 \\
\hline Ervaring thuis en ziekenhuis & $\%$ & 14 & 2 & 2 & 15 & 7 \\
\hline Geen ervaring & $\%$ & 21 & 77 & 5 & 47 & 34 \\
\hline$<5$ jaar geleden infuus thuis & $\%$ & 15 & 22 & 5 & 48 & 22 \\
\hline Geslacht: vrouw - man & $\%$ & $14-87$ & $\begin{array}{l}14-86 \\
15-85^{+}\end{array}$ & $\begin{array}{l}74-26 \\
75-25=\end{array}$ & $\begin{array}{l}90-10 \\
94-6^{*} \\
97-3\end{array}$ & $56 \cdot-44$ \\
\hline Leeftijd: range & j & $34-74$ & $\begin{array}{l}31-63 \\
28-65^{+}\end{array}$ & $\begin{array}{l}22-56 \\
20-64\end{array}$ & $\begin{array}{l}24-57 \\
20-64^{\circ} \\
22-59^{\circ}\end{array}$ & $22 \cdot 74$ \\
\hline Leeftijd: $₹ /$ sd & j & $49 / 10$ & $\begin{array}{l}45 / 8 \\
44 / 7^{\circ}\end{array}$ & $\begin{array}{l}36 / 8 \\
37 / 9^{\circ}\end{array}$ & $\begin{array}{l}38 / 8^{\circ} \\
39 / 9^{\circ} \\
36 / 9^{\circ}\end{array}$ & $40 / 10$ \\
\hline Dienstjaren: range & j & $8 \cdot 46$ & $4 \cdot 37$ & $1 \cdot 39$ & $2 \cdot 33$ & $1-46$ \\
\hline Dienstjaren: $x /$ sd & j & $22 / 9$ & $18 / 8$ & $16 / 8$ & $17 / 8$ & $17 / 8$ \\
\hline Werkervaring in fte: range & j & $8-35$ & $3 \cdot 37$ & $1 \cdot 39$ & $1 \cdot 32$ & $1 \cdot 39$ \\
\hline Werkervaring in fte: $\& /$ sd & j & $20 / 8$ & $17 / 9$ & $14 / 7$ & $13 / 7$ & $15 / 8$ \\
\hline Nu werkzaam: range & $\%$ & $0-100$ & $50 \cdot 100$ & $25-100$ & $0-100$ & $0 \cdot 100$ \\
\hline Nu werkzaam: $\bar{x}$ / sd & $\%$ & $90 / 26$ & $93 / 16$ & $83 / 20$ & $73 / 22$ & $84 / 22$ \\
\hline Algemeen ziekenhuis & $\%$ & 70 & $\cdot$ & 77 & $\cdot$ & 39 \\
\hline Academisch ziekenhuis & $\%$ & 21 & - & 16 & - & 9 \\
\hline Categoraal ziekenhuis & $\%$ & 6 & $\bullet$ & 5 & • & 3 \\
\hline Particuliere instelling & $\%$ & 2 & • & 2 & $\cdot$ & 1 \\
\hline Kruisvereniging & $\%$ & • & - & - & 84 & 23 \\
\hline Gefuseerde thuiszorg & $\%$ & - & - & - & 8 & 2 \\
\hline Solist & $\%$ & 10 & $58 / 52^{\circ}$ & • & • & 12 \\
\hline Associatic / maatschap & $\%$ & 87 & $25 / 39^{\circ}$ & • & - & 5 \\
\hline Gezondheidscentrum & $\%$ & - & $11 / 11^{*}$ & $\cdot$ & 7 & 4 \\
\hline A-opleiding & $\%$ & - & - & 96 & 64 & • \\
\hline $\mathrm{HBO} \cdot \mathrm{V}$ & $\%$ & - & • & 5 & 32 & • \\
\hline EMGZ & $\%$ & • & • & 1 & 61 & - \\
\hline Overige opleidingen & $\%$ & - & $\cdot$ & 24 & 21 & $\bullet$ \\
\hline
\end{tabular}


Legenda B5.1: SP=specialist, HA=huisarts, ZHV=ziekenhuisverpleegkundige, WV=wijkverpleegkundige, "-niet van toepassing, "=respons onder huisartsen en wijkverpiecgkundigen samen is $27 \%$, sd=standaard deviatie, $\mathrm{j}=\mathrm{jaar}, "=$ landelijke verdeling, $=$ steekproefverdeling, werkervaring in fte=opgedane ervaring omgerekend naar $100 \%$ dienstverband. Door afronden of doordat meerdere altematieven mogelijk zijn, is het totaaipercentage soms geen $100 \%$.

In 1993 werkten van de 9.245 geregistreerde huisartsen 6.595 als zodanig. ${ }^{79}$ Van de 211 aangeschreven huisartsen retourneerden 64 bruikbare vragenlijsten. Vanwege verhuizing (7) en beeindiging praktijk (3) zijn 10 vragenlijsten niet ingevuld. De respons bedraagt $32 \%$. De respons komt behoudens Gelderland (1), Noord-Holland (1) en Zeeland (1) overeen met het aantal huisartsen per provincie en de verdeling bij de verzending. ${ }^{m / 1}$ Geslacht, leeftijd en praktijkvorm van de respondenten komt redelijk overeen met de landelijke verdeling hiervan. ${ }^{797}$ Van de respondenten heeft $24 \%$ overwegend oudere en $31 \%$ overwegend jongere patiënten. Drie huisartsen zijn alleen verbonden aan een verpleeghuis (dienstverband $56 \%, 70 \%$ en $100 \%$ ).

De verdeling van de responderende specialisten in getal en full-time equivalenten komt overeen met die van de geregistreerde specialisten (allen 1993)(tabel B5.2). ${ }^{250.79}$ Van de 13.238 geregistreerde specialisten vallen er $7.719(58 \%)$ en van de 8.928 full-time equivalenten 5.811 (65\%) binnen de door ons benaderde specialismen. De 389 aangeschreven specialisten retourneerden 52 bruikbare vragenlijsten. Vanwege overlijden (1), misdruk (1), verhuizing (16) en beëindiging praktijk (7) zijn 25 vragenlijsten niet ingevuld. Een aantal specialisten vulde de enquête niet in, maar gaf aan weinig gemotiveerd te zijn voor thuiszorg of samenwerking met de huisarts (o.a. door de werkdruk, de voortdurende druk vanuit de politiek op de inkomenspositie en uitspraken van de LHV voorzitter ten tijde van de enquête). De respons is $14 \%$. De respons komt behoudens Groningen ( 1 ), Drenthe ( 1 ), Utrecht (1) en Limburg (1) overeen met het aantal gevestigde specialisten per provincie en de verdeling bij verzending. Van de respondenten werkt $64 \%$ zelfstandig, is $33 \%$ in loondienst en werkt $4 \%$ niet meer als specialist. Landelijke referentiecijfers over geslacht, leeftijd en werksituatie zijn niet voorhanden.

Tabel B5.2 Verdeling specialismen in aantallen en percenten.

\begin{tabular}{lccc|ccc}
\hline Specialisme & Register & FTE & Respons & Register & FTE & Respons \\
Anesthesiologie & 995 & 760 & 6 & $13 \%$ & $13 \%$ & $12 \%$ \\
Cardiologie & 573 & 470 & 3 & $8 \%$ & $7 \%$ & $6 \%$ \\
Chirurgie & 1030 & 790 & 8 & $14 \%$ & $13 \%$ & $15 \%$ \\
Inwendige geneeskunde & 1674 & 1096 & 10 & $19 \%$ & $22 \%$ & $19 \%$ \\
Kindergeneeskunde & 836 & 566 & 5 & $10 \%$ & $11 \%$ & $10 \%$ \\
Medische microbiologic & 202 & 128 & 2 & $2 \%$ & $3 \%$ & $4 \%$ \\
Longziekten & 361 & 276 & 3 & $5 \%$ & $5 \%$ & $6 \%$ \\
Gastro-enterologic & 58 & 76 & 0 & $1 \%$ & $1 \%$ & $0 \%$ \\
Neurologie & 482 & 465 & 5 & $8 \%$ & $6 \%$ & $10 \%$ \\
Orthopedie & 402 & 327 & 3 & $6 \%$ & $5 \%$ & $6 \%$ \\
Urologie & 269 & 234 & 1 & $4 \%$ & $3 \%$ & $2 \%$ \\
Verloskunde/gynaecologie & 790 & 596 & 5 & $10 \%$ & $10 \%$ & $10 \%$ \\
Klinische geriatrie & 47 & 27 & 1 & $0 \%$ & $1 \%$ & $2 \%$ \\
Totaal 1993 & 7719 & 5811 & 52 & $100 \%$ & $100 \%$ & $100 \%$ \\
\hline
\end{tabular}

Legenda: FTE-omgerekend naar $100 \%$ dienstverband. Door afronden is het totaalpercentage soms niet $100 \%$.

Omdat aanvankelijk is uitgegaan van een gelijke verdeling tussen verpleegkundigen en verzorgenden, zijn in totaal 611 wijkverpleegkundigen en/of ziekenverzorgenden benaderd. In 1993 waren 6.202 wijkverpleegkundigen (HBO-V, MGZ-AGZ of VHBO-V opleiding) en 2.017 
verpleegkundigen-in-de-wijk (in service A-opleiding) in dienst en bezetten 5.434 fulltime equivalenten (fte's). ${ }^{m / 1}$ Beiden worden hierna met de naam wijkverpleegkundige aangeduid. Er waren 2.933 wijkziekenverzorgenden (1.854 fte's). Uitgaande van deze verhouding in fte's, wordt nu aangenomen dat er $\pm 35 \%$ (214) wijkziekenverzorgenden in de steekproef zaten. ${ }^{\mathrm{N} 7}$ Vanwege de veronderstelde aanschrijving als zickenverzorgende (214), verblijf in het buitenland (4), werkzaamheid in de jeugdgezondheidszorg (7), kraamzorg (6) of anderszins (38) zijn 269 vragenlijsten niet in de responsberekening meegenomen. De respons bedraagt daarom bij 87 bruikbare teruggestuurde vragenlijsten $\pm 26 \%$. Behoudens Groningen (1), Zeeland (1), Noord-Brabant ( 1 ) en Limburg ( 1 ) is de landelijk spreiding acceptabel. Er responderen iets meer mannen, maar de leeftijdverdeling is gelijk aan die in de steekproef en een eerdere landelijke steekproef. ${ }^{797}$ De opleiding van de respondenten komt overeen met die van wijkverpleegkundigen in een eerdere enquête over dit onderwerp. ${ }^{27}$ Buiten èén werkzoekende, werken de respondenten in Verplegen en Verzorgen of Patientenzorg (48\%), all-round (32\%) en de Jeugdgezondheidszorg of Ouder en Kindzorg (20\%). In de afgelopen 5 jaar heeft $86 \%$ gewerkt in Verplegen en Verzorgen of Patièntenzorg. Van de respondenten werkt $16 \%$ full-time. Landelijk is dat voor wijkverpleegkundigen en voor verpleegkundigen-in-de-wijk tezamen omgerekend $20 \%$. ${ }^{\text {"7 }}$

In 1993 waren 131.258 A-verpleegkundigen geregistreerd. ${ }^{m}$ Het aantal HBO-V verpleegkundigen en het aantal verpleegkundigen dat in 1993 in ziekenhuizen werkte is ons onbekend. Binnen de algemene, de academische en de categorale ziekenhuizen werkten in 199365.828 personen (47.753 full-time equivalenten) in verpleegkundige, opvoedkundige en verzorgende personeelsfuncties. ${ }^{7 m} \mathrm{De}$ verhouding tussen verpleegkundigen (66.738) en verzorgenden (2.374) in ziekenhuizen in 1988 wordt ook voor de steekproef verondersteld. ${ }^{100}$ De 650 aangeschreven verpleegkundigen en verzorgenden retoumeerden 112 bruikbare vragenlijsten. Vanwege aanschrijving als verzorgende (22) of verblijf in het buitenland (5) zijn 27 vragenlijsten niet ingevuld. De respons bedraagt $\pm 18 \%$. Behoudens Groningen ( 1 ) is de respons landelijk voldoende gespreid. Leeftijd en geslacht in de steekproef en onder de respondenten komen overeen. Van de respondenten werkt $41 \%$ fulltime. De respondenten werken op gecombineerde afdelingen (18\%), intensive care (15\%), inwendige geneeskunde (12\%), chirurgie ( $11 \%)$, kindergeneeskunde $(9 \%)$, verloskunde en gynaecologie $(7 \%)$, operatiekamer $(6 \%)$, neurologie $(6 \%)$ en verder op spoedeisende/eerste hulp, dagbehandeling/shortstay, cardiologie, dialyse, klinische geriatrie, psychiatrie, anesthesiologie, gastro-enterologie, longziekten en orthopedie. 


\title{
Bijlage bij hoofdstuk 6
}

\section{Model voor complexe medisch-technische zorg}

\author{
Bijlage 6.1: Definities \\ De beschrijving van een zorgmodel bij CMTZ in de thuissituatie noopt tot definiëring van de \\ begrippen zorginnovatie, model, complex, medisch-technisch, zorg en thuissituatie. \\ De te ontwikkelen zorg is op te vatten als een zorginnovatie $(\mathrm{H}: 2)$ en kan omschreven worden als: \\ "een op elkaar afgestemd geheel van doelstellingen, middelen en materialen, een onderliggende \\ theorie en een ideologische rechtvaardiging, dat bedoeld is om aspecten van de zorg te veranderen, \\ en dat door het uitvoerend niveau binnen de zorg als nieuw wordt ervaren". ${ }^{13}$ Een zorginnovatie \\ bestaat in deze definitie uit concrete entiteiten met complexe samenhang en kan aldus bestudeerd \\ worden door haar weer te geven als een empirisch zorgmodel. ${ }^{\text {sol }}$ \\ Een model is volgens Swanborn "een systeem van elementen (eenheden, variabelen) en relaties \\ tussen die elementen, dat zoveel mogelijk lijkt op het systeem waarvan het een model is; dat echter \\ eenvoudiger is, behendiger is of gemakkelijker te hanteren valt" 450 Een van de functies van dit \\ zorgmodel is dan ook de werkelijkheid toegankelijk te maken middels een gereduceerde beschrijving \\ van de elementen en hun onderlinge samenhang. \\ Aggleton en Chalmers definiěren een model "als een voorstelling van iets. Het is een middel \\ waarmee gepoogd wordt iets uit te leggen om tot een beter begrip te komen. Sommige modellen zijn \\ stoffelijk. Ze kunnen aangeraakt, gehanteerd, uit elkaar genomen worden en weer in elkaar worden

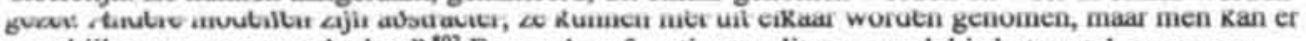 \\ naar kijken en erover nadenken" ${ }^{02}$ Een andere functie van dit zorgmodel is het vertalen van een \\ ideeêngoed in een, in de werkelijkheid hanteerbare en bestudeerbare, experimentele toepassing. \\ Naar analogie van Verran en Reid wordt onder complexiteit van zorg verstaan: "de mate van \\ routine, uniformiteit, voorspelbaarheid en kennis die betrokken is bij het leveren van verpleeg- \\ kundige en medische activiteiten. De belangrijkste determinant is de mate waarin kennis is vereist \\ om effectief medische en verpleegkundige interventies te kunnen toepassen". "Me3 "Mische" is door \\ ons aan de definitie toegevoegd.
}

Medisch-technische zorg thuis omvat medisch-technische en verpleegtechnische handelingen. Laatstgenoemden worden tot het verpleegkundig beroepsdomein gerekend. ${ }^{216}$ Onder medischtechnische handelingen worden verstaan: "Handelingen op het gebied van de geneeskunde die door de arts al dan niet aan de verpleegkundige gedelegeerd kunnen worden".226

Zorg is: "Het streven en de pogingen die men aanwendt, de moeite die men doet om iets in stand of in goede conditie te houden, of zo goed mogelijk te doen zijn of te maken. Synoniemen zijn behartiging, aandacht, verzorging". ${ }^{37}$ Zorg kan volgens Hattinga Verschure onderverdeeld worden op basis van degene die hem uitvoert. ${ }^{152} \mathrm{Bij}$ zelfzorg voorziet het individu zelf in diens eigen behoefte aan zorg. Mantelzorg wordt verleend binnen een kleine groep waarvan de leden met elkaar in relatie staan. Deze zorgverlening geschiedt op basis van emotionele banden en veelal ook op basis van (bereidheid tot) wederkerigheid. Professionele zorg betreft -een vaak tot één soort beperkte-zorg die uit hoofde van een beroep verleend wordt. Hierbij zijn de rol van zorgverlener en zorgontvanger niet uitwisselbaar.

Bij de definitie van thuissituatie speelt de afbakening met ziekenhuis- en andere institutionele situaties een rol. ${ }^{n}$ Kenmerkend voor een thuissituatie is dat de inrichting en het gebruik van de woonsituatie meer gericht is op het zelfstandig leven dan op eventuele professionele zorg die geboden dient te worden. Men zou kunnen zeggen dat in een thuissituatie de patiènt autonoom over zijn woon- en leefsituatic beslist en bijvoorbeeld bepaalt of de voordeur opengaat. In Nederland kan men op grond van dit criterium onder de thuissituatie verstaan: alle zelfstandige woonvormen, alsook bejaarden-, verzorgingshuizen en aanleuncomplexen. Tot de institutionele verblijfsituaties kunnen verpleeghuizen en alle ziekenhuizen gerekend worden. 


\title{
Bijlagen bij hoofdstuk 7
}

\section{Selectie van doelgroepen en patiënten}

\section{Bijlage 7.1: Selectielijst doelgroepen}

\author{
Keuze doelgroepen en omschrijving criteria (I) \\ Pathologie
}

COMPLEXITEIT (CO)MORBIDITEIT: Komt de aandoening die infuusbehandeling behoeft meestal alleen voor of in combinatie met anderen? Indien er meer aandoeningen zijn, veroorzaakt de aandoening die infuusbehandeling behoeft de hoofdpathologie? (12)

ERNST (CO)MORBIDITEIT: Vereist de onderliggende (co)morbiditeit stringente behandeling of hospitalisatie om andere redenen dan de infuusbehandeling? (13)

PROGNOSE OVERLIJDEN: Kan de onderliggende (co)morbiditeit tot plotselinge dood leiden? (14)

PROGNOSE ACUTE COMPLICATIES: Kan de onderliggende (co)morbiditeit acuut verslechteren waardoor acute behandeling of hospitalisatie nodig is? (15)

BEHANDELMOGELUKHEDEN ACUTE COMPLICATIES: Indien acute verslechtering optreedt. wat is dan de prognose en wat zijn de behandelmogelijkheden? (16)

\section{Behandeling + Effecten}

BEHANDELING: Waaruit bestaat de behandeling precies? (21)

FREQUENTIE: Wat is de frequentie van de behandeling? (18)

DUUR: Wat is de duur van de behandeling? (19)

TOEDIENINGSTIJDSTIPPEN: Op welke tijdstippen van de dag dient de behandeling plaats te hebben? (20)

BIJWERKINGEN EN COMPLICATIES: Kan de behandeling gepaard gaan met bijwerkingen of complicaties zoals collapsneiging, allergie, enzovoort? (22)

EFFECT FOUTIEF HANDELEN: Kan de behandeling bij verkeerde uitvoering ernstige gevolgen hebben?(23)

Patiënt + Naaste verzorger(s)

LEEFTIJDSCATEGORIE: Wat is de leeftijdscategorie van de patiēnten? (1)

WOONSITUATIE: Is het verblijf institutioneel of niet (zelfstandig wonend, bejaarden, verzorgingshuis versus ziekenhuis, verpleegkliniek en verpleeghuis)? (2)

LEEFSITUATIE: Is er bij de patiěntencategorie in de regel een naaste verzorger(s) aanwezig? Wat zijn de meest voorkomende gezinsfasen (kind, jong volwassenen, samenwonend met of zonder kinderen, kinderen uit huis fase, jong bejaarden, hoogbejaarden) en activiteitenpatronen? (3)

Maatschappelijke relevantie

INCIDENTIE EN PREVALENTIE: Hoeveel patiěnten in Nederland hebben deze aandoening? (6) LANDELIJK EN REGIONAAL AANTAL BEHANDELINGEN: Hoeveel patienten worden er nu per jaar landelijk en in het ziekenhuis behandeld? (7)

MAATSCHAPPELIJKE RELEVANTIE ONDERZOEK: Is het onderzoek maatschappelijke relevant? (58)

Zo ja, hoe relevant? (59)

PUBLIEKE OPINIE: Hoe zal de publieke opinie reageren op thuisbehandeling van deze patiëntengroep? (60)

OVERALL RELEVANTIE: Inschatting van de totale maatschappelijke relevantie door de

interviewer zelf. 


\section{Wetenschappelijke evaluatie}

RESULTATEN EERDER ONDERZOEK: Is er al eerder onderzoek gedaan? (50)

$\mathrm{Zo} \mathrm{ja,} \mathrm{wat} \mathrm{waren} \mathrm{de} \mathrm{vorm} \mathrm{en} \mathrm{resultaten} \mathrm{van} \mathrm{dit} \mathrm{onderzoek?} \mathrm{(51)}$

WETENSCHAPPELIJKE RELEVANTIE ONDERZOEK: Zal dit onderzoek voor de diverse beroepsgroepen relevant zijn? (53)

RANDOMISATIE MOGELIJKHEID: Is er de mogelijkheid de patiěnten te randomiseren wat betreft thuis en ziekenhuisbehandeling? (8)

BELASTING ONDERZOEK: Wat zijn de extra handelingen die door de zorgverleners ten behoeve van het onderzoek gedaan moeten worden? (47)

BEHOEFTE, BELASTING EN FINANCIERING ANDER WETENSCHAPPELIJK ONDERZOEK: Wordt bij de betrokken patiëntengroep nog meer wetenschappelijk onderzoek gedaan? (54)

Zo ja, wat voor onderzoek? (55)

Is dit ander onderzoek voor de patiënt belastend? Te denken valt aan laboratoriumbepalingen, vragenlijsten, beeldvormende technieken. (56)

Hoe is dit ander onderzoek gefinancierd? (57)

\section{Technische voorzieningen en hulpmiddelen (2) \\ Technische voorzieningen}

TECHNOLOGISCHE COMPLEXITEIT: Is er bij de infusie veel technologie nodig of niet? Ten eerste wordt onderscheid gemaakt tussen subcutane, perifere en centraalveneuze infusie, ten tweede tussen een infusie met een druppelteller, een spuitpomp, een (draagbare) mechanische of elektronische infuuspomp, plus eventueel bewaking op afstand. (24)

MONITORING BEHOEFTE: Zijn er controlehandelingen zoals laboratoriumbepalingen, tensiemetingen, enzovoort, nodig? (25)

OVERIGE TECHNOLOGIE: Is er buiten de infuustechnologie nog andere technologie nodig? (26) Zo ja, welke andere technologie is nog benodigd? (27)

\section{Hulpmiddelen}

AANPASSINGEN EN HULPMIDDELEN: Zijn speciale aanpassingen en hulpmiddelen in de woning nodig? (28)

\section{Protocollering van de zorgverlening (3) \\ Complexiteit behandeling}

INTENSITEIT BEHANDELING: Is de aanwezigheid/betrokkenheid van een verpleegkundige of arts tijdens de gehele behandeling vereist? (17)

MEDISCH DESKUNDIGHEIDSNIVEAU: Kan de huisarts met steun van de specialist de behandeling alleen uitvoeren of dienen zij de patiênt samen te behandelen? (30) VERPLEEGKUNDIG DESKUNDIGHEIDSNIVEAU: Volstaat een (wijk)verpleegkundige of is er een gespecialiseerd (wijk)verpleegkundige zoals een transmuraal infuusverpleegkundige nodig? (30A)

DESKUNDIGHEIDSNIVEAU PATIENT EN NAASTE VERZORGER(S): Kunnen de patiēnt en/of de naaste verzorger(s) een deel van de taken bij de infuusbehandeling en de overige benodigde zorg overnemen? (35)

INDICATIE GEZINSVERZORGING: Is een indicatie voor gezinsverzorging te voorzien? (38) Zo ja, hoeveel gezinsverzorging zal gemiddeld nodig zijn (tijd en frequentie)? (39)

INDICATIE FYSIOTHERAPIE: Is een indicatie voor fysiotherapie te voorzien? (40)

Zo ja, hoeveel fysiotherapie zal gemiddeld nodig zijn (tijd en frequentie)? (41)

Zo ja, moet de fysiotherapeut in huis komen of niet? (42)

INDICATIE PSYCHOSOCIALE BEGELEIDING: Is begeleiding door maatschappelijk werk, psycholoog, geestelijk raadsman, enzovoort, voorzienbaar? (43)

Zo ja, moet de psychosociale begeleiding thuis plaatsvinden of niet? (44)

Complexiteit logistiek

INSTROOM: Hoe is de instroom van de patiēnten? Vindt deze schoksgewijs en plotseling plaats of is er een voorspelbare en overzienbare instroom? (9) 
MEDISCHE OVERDRACHT: Kan de medische overdracht met de gewenste snelheid plaatsvinden?

(34)

VERPLEEGKUNDIGE OVERDRACHT: Kan de verpleegkundige overdracht met de gewenste snelheid plaatsvinden? (37)

MEDICATIE EN INFUUSBENODIGDHEDEN: Hoe dient de toelevering van medicatic en infuusbenodigdheden te geschieden.

MEDISCHE BEREIKBAARHEID: Dient de arts tijdens de hele behandeling aanwezig te zijn of alleen bij het begin en/of het einde of alleen op afroep? (31)

VERPLEEGKUNDIGE BEREIKBAARHEID: Dient de verpleegkundige tijdens de hele behandeling aanwezig te zijn of alleen bij het begin en/of het einde of alleen op afroep? (36)

Complexiteit organisatie

ORGANISATORISCHE COMPLEXITEIT: is bij uitgebreide behandelingen met veel diagnostiek, specialistische controle, enzovoort, een deel van de infuusbehandeling te combineren met dit polikliniekbezoek, een dagbehandeling, of anderszins? (29)

TAAKVERDELING: Hoe is de taakverdeling tussen (gespecialiseerde) artsen en verpleegkundigen zowel intra- als interdisciplinair en wat is de rol van de patiènt, diens naaste verzorger(s) en de gezinsverzorging?

Samenwerking 2 lijn

MOTIVATIE $2^{*}$ LIN : Zijn de betrokken intramurale zorgverleners gemotiveerd om aan de infuusbehandeling thuis medewerking te verlenen? (45)

WERKDRUK $2^{e}$ LIJN: Staat de huidige werkdruk het de intramurale zorgverleners toe om aan infuusbehandeling thuis medewerking te verlenen? (46)

INSTRUCTIE $2^{*}$ LIJN: Kunnen de intramurale zorgverleners patiènten en/of naaste verzorger(s) instrueren? (48)

OVERDRACHT $2^{*}$ LIJN: Hoc kan de overdracht tussen $2^{*}$ en $1^{*}$ lijn optimaal plaatsvinden? (49)

Informatievoorziening en Deskundigheidsbevordering (4)

INFORMATIEBEHOEFTE: Moeten de huisarts, de wijkverpleegkundige, de gezinsverzorgende, enzovoort, voorgelicht worden?

DESKUNDIGHEIDSBEHOEFTE: Moet de huisarts als (mede)behandelaar speciale deskundigheid verwerven of niet? (32)

\section{Financiering (5)}

FINANCIERING: Hoe is de financiering van de huidige patienten geregeld en wat zijn de verwachtingen ten aanzien van de thuisbehandeling? (10)

VERGOEDING HUISARTS/SPECIALIST: Indien de huisarts en specialist participeren in de thuisbehandeling en daarvoor betaald krijgen, uit welke gelden wordt deze dan betaald? (33)

\section{Kwaliteit van leven (6)}

BEĨNVLOEDING KWALITEIT VAN LEVEN: Wat is de verwachting met betrekking tot de verandering van de kwaliteit van leven door de thuisbehandeling? (4)

BEIINVLOEDING LEVENSVERWACHTING: Is er door thuisbehandeling een verminderde levensduur te verwachten in vergelijking met de ziekenhuisbehandeling? (5)

\section{Kosteneffecten (7)}

EFFECT OP KOSTEN: Wordt er bespaard bij behandeling van patienten thuis of is er een dusdanige ondercapaciteit dat de dagbehandeling of ziekenhuisplaatsen direct weer bezet zijn door andere patiēnten of patiēntgroepen? (11) 


\section{Bijlage 7.2: Toepassing selectiecriteria doelgroepen}

Tabel B7.1 Criteria ter selectie van patient en naaste verzorger(s)

Item
Pathologie
Complexiteit pathologie
Ernst (co)morbiditeit
Prognose overijden
Kans op acute
complicaties
Behandeling
complicaties

Morfine

$\begin{array}{|cc|}\text { hoog } & \text { laag } \\ \text { hoog } & \text { laag } \\ \text { hoog } & \text { laag } \\ \text { vele mogelijke } & \text { geen } \\ \text { complicaties } \\ \text { hoogstens } \\ \text { symptomatisch }\end{array}$

Thuisbehandeling en effecten

Behandeling
Frequentie behandeling
Duur in dagen
Toedieningstijdstip
Bijwerkingen
complicaties

Effect fout handelen

\begin{tabular}{|c|c|}
\hline $\begin{array}{l}\$ 12.3 .1 \\
\text { continu }\end{array}$ & $\begin{array}{l}\$ 12.3 .2 \\
\text { continu }\end{array}$ \\
\hline $1-14$, kan langer & 7 \\
\hline dag+nacht & dag en/of nacht \\
\hline $\begin{array}{l}\text { obstipatic } \\
\text { verwardheid } \\
\text { sufheid }\end{array}$ & 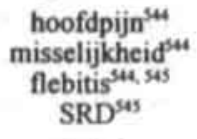 \\
\hline $\begin{array}{c}\text { pijn of } \\
\text { overdosering }\end{array}$ & flebitis \\
\hline
\end{tabular}

Patient en naaste verzorgers

Leeftijdsklasse(n)

Woonsituatie

Leefsituatic

$\begin{array}{ccc}\begin{array}{c}55 \text { en ouder }^{321} \\ \text { thuis of } \\ \text { bejaardenhuis }\end{array} & \begin{array}{c}20-54 \\ \text { thuis }\end{array} & \begin{array}{c}\text { alle } \\ \text { thuis }\end{array} \\ \begin{array}{c}\text { vaak alleen met } \\ \text { partner en vaak al } \\ \text { ITZ zorg }\end{array} & \text { vaak gezin } & \text { alle vormen } \\ \text { mogelijk }\end{array}$

$\$ 12.3 .3$

1-6x per dag niet voorspelbaar dag+nacht

flebitis overgevoeligheid

flebitis

\section{COPDmedicatie}

gemiddeld

gemiddeld

laag

pneumonie, thuis minder infecties acute heropname

Maatschappelijke relevantie thuisbehandeling inclusief effecten op levenskwaliteit en kosten

\begin{tabular}{|c|c|c|c|c|}
\hline Incidentic & $24.500^{312014}$ & $7.500^{331}$ & $C F \pm 1: 3.600$ & $2-3 \% 0^{352}$ \\
\hline Prevalentie & nvt & niet bekend & $\mathrm{CF} \pm 1.000$ & $12-19 \% 0^{352}$ \\
\hline Potenticel landelijk/jaar & $\begin{array}{c}2.500^{313} \\
4.000-8.000^{322} \\
2.500-5.500^{\mathrm{ps}}\end{array}$ & $\begin{array}{c} \pm 700^{n 3.12} \\
3.500-4.000^{\text {p...1.1 }}\end{array}$ & & minimaal \\
\hline Potenticel regionaal/jaar & $33,40-80^{322}$ & $10-50 \mathrm{~F} \times 12$ & $10-20$ & minimaal \\
\hline Effect levenskwaliteit & hoger ${ }^{312}$ & gelijk/hoger & gelijk/hoger & onvoorspelbaar \\
\hline Effect levensduur & wellicht korter & gelijk & gelijk & gelijk \\
\hline Effect kosten & hoger & lager & onvoorspelbaar & onvoorspelbaar \\
\hline Publieke opinie & positief & ongewis ${ }^{204}$, nos & positief & positief \\
\hline 'Overall' relevantie & groot & gemiddeld $^{305}$ & gemiddeld $\$ 06,510$ & klein \\
\hline \multicolumn{5}{|c|}{ Wetenschappelijke relevantie: alleen indien tevens wetenschappelijke doeleinden } \\
\hline Eerder onderzoek & ja & ja & ja & nee \\
\hline Relevantic dit onderzoek & ja & $\mathrm{ja}^{331}$ & ja & nee \\
\hline Randomisatie mogelijk & neen & nauwelijks & nauwelijks & nauwelijks \\
\hline Belasting onderzoek & gering & gering & gering & gering \\
\hline Aanvullend onderzoek & nee & ja & nee & nee \\
\hline
\end{tabular}




\begin{tabular}{|c|c|c|c|c|}
\hline Heparine & Dopamine/lasix & Virostatica & Cytostatica & Voeding \\
\hline \multicolumn{5}{|l|}{ Pathologie } \\
\hline laag & gemiddeld & hoog & hoog & gemiddeld \\
\hline gemiddeld & hoog & hoog & hoog & gemiddeld \\
\hline gemiddeld & gemiddeld & gemiddeld & gemiddeld & laag \\
\hline $\begin{array}{c}\text { trombose } \\
\text { longembolie }\end{array}$ & $\begin{array}{l}\text { ritmestoornis } \\
\text { recidiefinfarct }\end{array}$ & $\begin{array}{l}\text { uitbreiding en } \\
\text { andere infecties }\end{array}$ & $\begin{array}{l}\text { vele mogelijke } \\
\text { complicaties }\end{array}$ & infecties ${ }^{n 11}$ \\
\hline acute heropname & acute opname & acute heropname & soms & heropname \\
\hline \multicolumn{5}{|c|}{ Thuisbehandeling en effecten } \\
\hline$\$ 7.5 .1 .5$ & $\$ 12.3 .4$ & $\$ 7.5 .1 .7$ & $\$ 7.1 .5 .8$ & $\$ 7.5 .1 .9$ \\
\hline continu & $2 \times$ per week & 5x per week & in kuren & wisselend ${ }^{\operatorname{en} x}$ :II \\
\hline maximaal 5 dagen & levenslang & levenslang & niet voorspelbaar & chronisch \\
\hline dag+nacht & dag en/of nacht & overdag & overdag & nacht en/of dag \\
\hline blocding of embolie & $\begin{array}{l}\text { hoofdpijn, infectic } \\
\text { duizeligheid }\end{array}$ & flebitis, sepsis & $\begin{array}{l}\text { flebitis, } \\
\text { eytotoxiciteit }\end{array}$ & $\begin{array}{l}\text { embolie, flebitis, } \\
\text { infectic, sepsis }\end{array}$ \\
\hline flebitis & $\begin{array}{c}\text { dehydratic, } \\
\text { infectie, sepsis }\end{array}$ & flebitis, sepsis & flebitis & $\begin{array}{c}\text { embolie, infectie. } \\
\text { sepsis }\end{array}$ \\
\hline \multicolumn{5}{|c|}{ Patient en naaste verzorgers } \\
\hline $20^{\circ}$, meestal $60^{\circ}$ & $40-90$ & $20-54$ & alle leeftijden & $20-54$ \\
\hline $\begin{array}{c}\text { thuis of } \\
\text { bejaardenhuis }\end{array}$ & $\begin{array}{c}\text { thuis of } \\
\text { bejaardenhuis }\end{array}$ & thuis & $\begin{array}{c}\text { thuis of } \\
\text { bejaardenhuis }\end{array}$ & thuis \\
\hline $\begin{array}{c}\text { meestal alleen met } \\
\text { partner }\end{array}$ & $\begin{array}{c}\text { in } 70 \% \text { alleen met } \\
\text { partner }\end{array}$ & vaak alleenwonend & $\begin{array}{l}\text { alle vormen } \\
\text { mogelijk }\end{array}$ & $\begin{array}{l}\text { alle vormen } \\
\text { mogelijk }\end{array}$ \\
\hline \multicolumn{5}{|c|}{ Maatschappelijke relevantie inclusief effecten op levenskwaliteit en kasten } \\
\hline $1-2 \%$ & $?$ & $\pm 300^{m n}$ & verschilt per kanker & $?$ \\
\hline onbekend & ? & $\begin{array}{c}1.400-1.600^{374} \\
800 \text { of meer }{ }^{m}, 3 n\end{array}$ & & 40 a $50^{400}$ \\
\hline $3.750-7.500^{350} \times 175.15$ & $\begin{array}{c}3.000-4.00057 .516 \\
\pm 900 \text { Fis. }\end{array}$ & $150-375$ D.5.7 & $2.500-5.000^{\mathrm{m}}$ & $\begin{array}{l}40 \text { a } 50^{400} \\
200-500^{m}\end{array}$ \\
\hline $50-100^{338 \times 675}$ & $10-20^{200} 861$ & 1 a 2 & $25-50^{12}$ & enkele \\
\hline gelijk & gelijk & gelijk/hoger & onvoorspelbaar & thuis hoger \\
\hline gelijk & gelijk & gelijk & gelijk & gelijk \\
\hline lager & lager & lager & onvoorspelbaar & hoger \\
\hline ongewis & positief ${ }^{312}$ & positief ${ }^{n}$ & ongewis & positief ${ }^{43}$ \\
\hline klein & groot ${ }^{34}$ & laag & groot & kdein \\
\hline \multicolumn{5}{|c|}{ Wetenschappelijke relevantie; alleen indien tevens wetenschappelijke doeleinden } \\
\hline ja & ja & ja & ja & ja \\
\hline onzeker & ja & nee & groot & klein \\
\hline mogelijk & mocilijk & niet mogelijk & mogelijk & niet mogelijk \\
\hline gering & gering & gering & gering & gering \\
\hline nee & ja & nee & nee & nee \\
\hline
\end{tabular}




\begin{tabular}{|c|c|c|c|c|}
\hline Item & Morfine & Mannitol & Antibiotica & COPDmedicatic \\
\hline \multicolumn{5}{|c|}{ Technische voorzieningen } \\
\hline Complexiteit infusie & laag & gemiddeld & gemiddeld & gemiddeld \\
\hline Monitoring behoefte & neen & neen & soms spiegels & hoog \\
\hline Overige technologie & geen & geen & geen & reeds aanwezig \\
\hline \multicolumn{5}{|c|}{ Hulpmiddelen en aanpassingen } \\
\hline Hulpmiddelen & meestal aanwezig & geen & geen & geen \\
\hline Aanpassingen & bergruimte & geen & soms bergruimte & geen \\
\hline \multicolumn{5}{|c|}{ Complexiteit behandeling } \\
\hline Intensiteit & hoog & laag & gemiddeld & gemiddeld \\
\hline Med. deskundigheid & huisarts $^{26}$ & specialist & specialist/huisarts & specialist/huisarts \\
\hline Verp. deskundigheid & TMV/wijk & TMV & $\mathrm{TMV} / \mathbf{w i j k}$ & TMV/SV \\
\hline $\begin{array}{l}\text { Overdracht aan } \\
\text { patient of naaste }\end{array}$ & incidenteel & deels & deels & incidenteel \\
\hline Gezinsverzorging & vaak & incidenteel & incidenteel & vaak \\
\hline Fysiotherapie & geen & voorafgaand & soms & eigenlijk nodig \\
\hline $\begin{array}{l}\text { Psychosociale } \\
\text { begeleiding }\end{array}$ & $\begin{array}{l}\text { geestelijke, } \\
\text { nachthulp }\end{array}$ & geen & geen & $\begin{array}{l}\text { CARA-team, } \\
\text { huisarts }\end{array}$ \\
\hline \multicolumn{5}{|c|}{ Complexiteit logistiek en organisatie } \\
\hline Instroom & niet te plannen & goed te plannen & matig te plannen & matig te plannen \\
\hline $\begin{array}{l}\text { Medicatic en } \\
\text { infuusmaterialen }\end{array}$ & $\begin{array}{c}\text { eenvoudig } \\
\text { standaardpakket }\end{array}$ & standaardpakket & $\begin{array}{l}\text { per behandeling } \\
\text { wisselend }\end{array}$ & standaardpakket \\
\hline Med. overdracht & $\begin{array}{l}\text { alleen bij ontslag } \\
\text { uit ziekenhuis }\end{array}$ & $\begin{array}{l}\text { bij voornemen } \\
\text { thuisbehandeling }\end{array}$ & $\begin{array}{l}\text { bij ontslag uit } \\
\text { ziekenhuis }\end{array}$ & $\begin{array}{l}\text { bij ontslag uit } \\
\text { ziekenhuis }\end{array}$ \\
\hline Verp. overdracht & idem & geen & idem & idem \\
\hline Med. bereikbaarheid & $\begin{array}{l}\text { huisarts continu } \\
\text { ivm stervensfase }\end{array}$ & op afroep & op afroep & $\begin{array}{l}\text { huisarts bewaking } \\
\text { therapic }\end{array}$ \\
\hline Verp. bereikbaarheid & continu & continu & tijdens infusie & continu \\
\hline Taakverdeling & variabel & duidelijk & duidelijk & variabel \\
\hline Totale complexiteit & hoog & laag & laag & hoog \\
\hline \multicolumn{5}{|c|}{ Samemwerkingsmogelijkheden vamuit de kliniek } \\
\hline Motivatie & hoog & hoog & variabel & variabel \\
\hline Werkdruk belemmert & nee & nee & soms & soms \\
\hline Instructie & pijnconsulent & nee & soms & afdeling \\
\hline Vorm overdracht & ontslagberichten & brief specialist & ontslagberichten & ontslagberichten \\
\hline \multicolumn{5}{|c|}{ Informatievoorziening en scholingsbehoefte huisarts } \\
\hline Informatiebehoefte & hfds 9 & hfds 9 & hfds 9 & $\cdot$ \\
\hline $\begin{array}{l}\text { Scholingsbehoefte } \\
\text { huisarts }\end{array}$ & $\begin{array}{l}\text { subcutane infusie } \\
\text { pijnbestrijding }\end{array}$ & $\begin{array}{c}\text { intraveneuze } \\
\text { infusic }\end{array}$ & $\begin{array}{c}\text { intraveneuze } \\
\text { infusie }\end{array}$ & $\begin{array}{c}\text { intraveneuze } \\
\text { infusic, COPD }\end{array}$ \\
\hline \multicolumn{5}{|l|}{ Financiering } \\
\hline Thuiszorg & $\begin{array}{l}\text { ITZ + materieel: } \\
\text { AWBZ }^{11}\end{array}$ & $?$ & $?$ & $\begin{array}{l}\text { fysiotherapic } \\
\text { weinig vergoed }\end{array}$ \\
\hline Specialisthuisarts & thuisconsult:ITZ & $?$ & $?$ & $?$ \\
\hline
\end{tabular}

Legenda tabel B7.1: Med,-medisch, Verp,=verpleegkundig, TMV=transmuraal medisch-technisch handelen verpleegkundige in casu èn voor infuusbehandeling. $S V=$ specialistisch verpleegkundige, ivm=in verband met, 


\begin{tabular}{|c|c|c|c|c|}
\hline Heparine & Dopamine/lasix & Virostatica & Cytostatica & Voeding \\
\hline \multicolumn{5}{|c|}{ Technische voorzieningen } \\
\hline gemiddeld & hoog & gemiddeld & gemiddeld/hoog & hoog \\
\hline hoog & hoog & laag & hoog & hoog \\
\hline geen & geen & geen & geen & geen \\
\hline \multicolumn{5}{|c|}{ Hulpmiddelen en aanpassingen } \\
\hline hoog/laagbed & weegschaal & geen & geen & geen \\
\hline geen & bergruimte & bergruimte & geen & bergruimte \\
\hline \multicolumn{5}{|c|}{ Complexiteit behandeling } \\
\hline hoog & gemiddeld & laag & hoog & gemiddeld \\
\hline specialisthuisarts & specialist & specialist & specialist & specialist \\
\hline TMV/wijk & TMV"1s & TMV/SV & TMV/SV & TMV/SV \\
\hline gevaarlijk & incidenteel & geheel & gevaarlijk & voorkeur \\
\hline vaak & vaak & incidenteel & soms & soms \\
\hline geen & geen & geen & geen & geen \\
\hline geen & huisarts & $\begin{array}{l}\text { AIDS-team, } \\
\text { buddy, huisarts }\end{array}$ & $\begin{array}{c}\text { oncologie-team, } \\
\text { huisarts }\end{array}$ & voedingsteam \\
\hline
\end{tabular}

\begin{tabular}{|c|c|c|c|c|}
\hline \multicolumn{5}{|c|}{ Complexiteit logistiek en organisatie } \\
\hline niet te plannen & goed te plannen & matig te plannen & goed te plannen & goed te plannen \\
\hline standaardpakket & $\begin{array}{c}\text { complex } \\
\text { standaardpakket }\end{array}$ & standaardpakket & $\begin{array}{l}\text { per behandeling } \\
\text { wisselend }\end{array}$ & $\begin{array}{c}\text { complex } \\
\text { standaardpakket }\end{array}$ \\
\hline noodzakelijk & noodzakelijk & bij ontslag & geen & geen \\
\hline noodzakelijk & geen & geen & geen & geen \\
\hline $\begin{array}{c}\text { huisarts bewaking } \\
\text { therapic }\end{array}$ & op afroep & op afroep & tijdens infusie & op afroep \\
\hline continu & continu & tijdens infusie & tijdens infusie & tijdens infusic \\
\hline variabel & duidelijk & duidelijk & duidelijk & duidelijk \\
\hline hoog & hoog & laag & hoog & hoog \\
\hline \multicolumn{5}{|c|}{ Samenwerkingsmogelijkheden vanuit de kliniek } \\
\hline hoog & hoog & variabel & variabel & hoog \\
\hline nee & nee & nee & nee & nee \\
\hline nvt & dagcentrum & AIDS-consulent & nvt & voedingsteam \\
\hline ontslagberichten & bericht specialist & ontslagbericht & bericht specialist & bericht specialist \\
\hline \multicolumn{5}{|c|}{ Informatievoorziening en scholingsbehoefte huisarts } \\
\hline- & hfds 9 & hfds 9 & hfds 7 & $\cdot$ \\
\hline $\begin{array}{l}\text { intraveneuze } \\
\text { infusie, trombose }\end{array}$ & $\begin{array}{c}\text { centraalveneuze } \\
\text { infusie }\end{array}$ & $\begin{array}{c}\text { centraalveneuze } \\
\text { infusie }\end{array}$ & $\begin{array}{l}\text { intra/centraal- } \\
\text { veneuze infusic }\end{array}$ & $\begin{array}{l}\text { centraalveneuze } \\
\text { infusic }\end{array}$ \\
\hline \multicolumn{5}{|l|}{ Financiering } \\
\hline$?$ & $?$ & $?$ & soms & na machtiging \\
\hline$?$ & $?$ & $?$ & soms & $?$ \\
\hline
\end{tabular}

nvt=niet van toepassing. ITZ=intensieve thuiszorg. =-literatuur- of paragraafverwijzing. 


\section{Bijlage 7.3: Enquête thuisbehandeling met cytostatica}

\section{Vraagstelling en methode}

In 1994 ontvingen 205 patienten 1.893 infuusbehandelingen met cytostatica in het dagcentrum van het azM. ${ }^{116} \mathrm{Bij} 47$ patiênten waren bovendien 125 infuusbehandelingen met bloedprodukten nodig. Vanuit de projectgroep en de vakgroep Interne Geneeskunde leidde dit tot de vraagstelling: Hoeveel oncologiepatiënten, met cytostatica-infusie in het dagcentrum van het azM, zouden in aanmerking kunnen en willen komen voor $\Gamma$, mits de behandeling hiervoor geschikt is? Hiertoe zijn oncologiepatienten die tenminste één dag chemotherapie ontvangen hadden geënquêteerd:

1. Wat vinden de patiënten ervan om infuusbehandeling thuis te ontvangen?

2. Wat zijn volgens de patiēnten de voor- en nadelen van infuusbehandeling thuis?

3. Welke randvoorwaarden voor IT zijn per patie̋nt te onderscheiden: medische (diagnose, duur en frequentie van reeds ontvangen therapie, comorbiditeit) en demografische, sociale en psychische factoren (leeftijd, geslacht, opleiding, gezins- en woonsituatie, intelligentie, psychische toestand, mogelijkheid en wil tot participatie van patiēnt en naaste)?

Tussen 22 mei en 9 juni 1995 zijn bijna alle patiēnten die toen in het dagcentrum een cytostaticainfusie ontvingen, benaderd voor een vraaggesprek op basis van een semi-gestructureerde vragenlijst.

\section{Onderzockspopulatie}

Hierna worden de respondenten meestal in drieěn verdeeld op grond van het antwoord op de stelling: "Als het technisch goed uitgevoerd wordt en verantwoord is, wil ik voortaan de infuusbehandeling liever thuis ontvangen". De antwoordcategorieěn zijn: "eens" of "zeer mee eens" (groep 1), "niet mee eens en niet mee oneens" (groep 2), "mee oneens" of "zeer mee oneens" (groep 3). Tabel B7.2 geeft het geslacht, de leeftijd, de opleiding en de soort kanker per groep. De totale groep respondenten is divers qua samenstelling. Omdat bijna alle in die periode behandelde patiènten geinterviewd zijn, lijken de respondenten $(32 / 205=15 \%$ jaartotaal) representatief voor de doelgroep. Mannen lijken vaker dan vrouwen IT te willen ontvangen. Leeftijd lijkt geen invloed te hebben op deze keuze. In verhouding lijkt groep 3 iets hoger opgeleid. Vanwege de kleine populatie kunnen

Tabel B7.2 Kenmerken per groep.

\begin{tabular}{|c|c|c|c|c|c|c|c|c|}
\hline Kenmerk & \multicolumn{2}{|c|}{$\begin{array}{c}\text { Groep 1 } \\
17(53 \%)\end{array}$} & \multicolumn{2}{|c|}{$\begin{array}{c}\text { Groep 2 } \\
3(9 \%)\end{array}$} & \multicolumn{2}{|c|}{$\begin{array}{c}\text { Groep 3 } \\
12(38 \%)\end{array}$} & \multicolumn{2}{|c|}{$\begin{array}{c}\text { Totaal } \\
32(100 \%)\end{array}$} \\
\hline $\begin{array}{l}\text { Leeftijd } \\
\text { Gemiddeld } \\
\text { Spreiding } \\
\text { Onbekend }\end{array}$ & \multicolumn{2}{|c|}{$\begin{array}{c}56 \\
17-79\end{array}$} & \multicolumn{2}{|c|}{$\begin{array}{c}71 \\
66-73\end{array}$} & \multicolumn{2}{|c|}{$\begin{array}{c}54 \\
26-78 \\
1\end{array}$} & \multicolumn{2}{|c|}{$\begin{array}{c}57 \\
17-79 \\
1\end{array}$} \\
\hline $\begin{array}{l}\text { Opleiding } \\
\text { I } \\
\text { II } \\
\text { III } \\
\text { IV } \\
\text { Onbekend }\end{array}$ & & & & & & & & \\
\hline $\begin{array}{l}\text { Soort kanker } \\
\text { Mamma } \\
\text { Colon/sigmoid } \\
\text { Rectum } \\
\text { Long } \\
\text { (Non)Hodgkin } \\
\text { CLL/CML } \\
\text { Rest } \\
\text { Onbekend } \\
\text { Totaal }\end{array}$ & $\begin{array}{l}8 \\
2 \\
2 \\
1 \\
1 \\
\vdots \\
2 \\
2 \\
8\end{array}$ & $\begin{array}{l}8 \\
\dot{2} \\
2 \\
2 \\
1 \\
2 \\
\dot{9}\end{array}$ & $\begin{array}{l}1 \\
1 \\
1 \\
\vdots \\
\vdots \\
2\end{array}$ & $\begin{array}{l}0 \\
i \\
\vdots \\
\vdots \\
- \\
i\end{array}$ & $\begin{array}{l}9 \\
4 \\
1 \\
\vdots \\
1 \\
1 \\
1 \\
1 \\
9\end{array}$ & $\begin{array}{l}0 \\
i \\
\vdots \\
\vdots \\
\vdots \\
3\end{array}$ & $\begin{array}{l}8 \\
7 \\
2 \\
2 \\
2 \\
\vdots \\
1 \\
3 \\
1 \\
19\end{array}$ & $\begin{array}{l}0 \\
5 \\
5 \\
2 \\
2 \\
2 \\
1 \\
2 \\
5 \\
13\end{array}$ \\
\hline
\end{tabular}

Legenda: "=l:Lager algemeen onderwijs (lagere school, basisschool) II:MULO MAVO of lager beroepsonderwijs (huishoudschool, technische school) III:HBS MMS HAVO VWO of middelbaar beroepsonderwijs IV:Hoger beroepsonderwijs of wetenschappelijk onderwijs. 
over deze verschillen geen harde uitspraken gedaan worden. Tot slot enkele opmerkingen bij de groepen. Groep 1: Twee respondenten werden door de chemotherapie onwel, waardoor het interview niet volledig kon worden afgerond. Twee patiēnten gaven te kennen terminaal te zijn en wilden graag thuis sterven. Eén patiēnt zou bij onveranderde toestand IT willen, bij bedlegerigheid niet. Groep 2: Eén patiënt met de ziekte van Moschcowitz (TTP) kreeg een eenmalige cytostaticakuur. Groep 3: Eén patiēnt kreeg twee keer per week een cytostatica-infuus, waarna twee behandelvrije weken volgden. Deze frequentie werd te laag gevonden voor IT. Drie patiènten (waaronder een nierpatiēnt die op verzock van de nefroloog voor iedere behandeling naar het azM $\mathrm{kwam}$ ) wilden alleen in het $a z \mathrm{M}$ en niet thuis met hun ziekte geconfronteerd worden. Eén patiēnt weigerde antwoord te geven op bijna alle vragen en was beledigd omdat die vond dat $\Pi$ alleen uit bezuiniging zou worden uitgevoerd. Bovendien twijfelde deze patiênt aan de technische kwaliteit van de TMVs, waardoor die thuisbehandeling onverantwoord vond. Deze patiênt vergeleek de wijkverpleging met cen melkboer.

\section{Therapic}

Tabel B7.3 geeft per diagnose de toegepaste behandeling(en). Aan de hand van deze informatie kan bepaald worden welke patiënten geschikt zouden zijn voor IT gelet op de verstrekte medicatie en de duur en frequentie van de behandeling. De volgende cytostatica zijn gebruikt: generiek (specialité): aantal maal, fluorouracil (5 FU):15, cyclofosfamide (Endoxan):10, doxorubicine (Adriamycine):9, methotrexate (MTX):4, vincristine (Oncovin):6, bleomycine:3, epirubicine (Epi-adriamycine):2, etoposide (VP-16)(EPEG):2, dacarbazine (DTIC):2, lomustine (CCNU) oraal:1, dexamethason:1, taxotère (Taxol): 1 en onbekend: 1 . Tevens zijn er toevoegingen gebruikt: isovorin:5, zofran:5, kytril:5 en leucovorine:1.

Uit de (Amerikaanse) literatuur blijkt dat bijna alle cytostatica (al dan niet in combinatie) wel eens thuis worden gegeven. Ook uit deze enquête blijkt dat de medicatie divers is en er vaak middelen worden gecombineerd. Dit maakt eventuele IT gecompliceerder. Vanwege de monotherapie met fluoruracil bij colon/sigmold- en rectumcarcinomen lijkt het aan te bevelen om bij IT deze therapie eerst te ontwikkelen. Ook qua aantallen is dit een geschikte groep. Indien bij IT voor dezelfde behandelduur gekozen wordt, lijkt het gezien de duur (gemiddeld 11\% uur) geen bezwaar om de TMV continu aanwezig te laten zijn. Hierdoor zouden meer patiënten thuis behandeld kunnen worden, omdat dan de eisen aan de patiěnt en diens omgeving minder hoog kunnen zijn. De vraag is echter of de behandelduur en frequentie in het dagcentrum, altijd de meest adequate zijn. Er zijn aanwijzingen dat continue toediening van fluoruracil beter werkt. ${ }^{362}$

\section{Voor-en nadelen chemotherapie thuis}

Tabel B7.4 geeft de antwoorden op de open vragen: "Welke voordelen ziet u bij infuusbehandeling thuis?" en "Welke nadelen ziet u bij infuusbehandeling thuis?". De meest genoemde voordelen zijn het minder reizen en het in de eigen omgeving meer op het gemak zijn. Het meest genoemde nadeel is dat er iets mis kan gaan. De gehele populatie noemt gemiddeld evenveel voor- als nadelen $(0,9)$. Groep 3 geeft bijna geen voordelen, terwijl groep 1 wel nadelen kan bedenken. Hieruit is te concluderen dat groep 1 wellicht een genuanceerder oordeel heeft. Groep 2 noemt alleen voordelen.

\section{(Rand)voorwaarden met betrekking tot thuisbehandeling}

Per patiënt is per (rand)voorwaarde (naar oordeel van de patient of de interviewer) ingeschat in hoeverre die geschikt zou zijn voor IT indien de benodigde medicatie en de duur en frequentie van de kuur geen beletsel zouden vormen. Omdat iedere patiènt telefoon had, is deze randvoorwaarde niet verder in de overwegingen opgenomen. Hetzelfde geldt voor de bereidheid om extra te betalen voor IT. De antwoorden hierop varieerden van "nee" tot " $f 500$ ". Geanalyseerd zijn:

1. Participeren (inschatting patiēnt): willen en kunnen de patiēnt en/of de mantelzorger zodanig bij IT betrokken worden, dat de verpleegkundige niet tijdens de gehele infusie aanwezig hoeft te zijn.

2. Emotioneel/Psychisch (inschatting interviewer); is de patiênt, gerelateerd aan de psychische toestand tijdens deze (en eventueel vorige) kuren, in staat IT te ondergaan. Met andere woorden zijn er ernstige psychi(atri)sche complicaties, die IT zouden kunnen belemmeren. 


\begin{tabular}{|c|c|c|c|}
\hline Soort kanker & Medicatie & Duur ${ }^{*}$ & \\
\hline $\begin{array}{l}\text { Mamma } \\
\text {-geen metastasen }\end{array}$ & $\begin{array}{l}\text {-cyclofosfamide, fluorouracil } \\
\text {-cyclofosfamide, dexamethason, epirubicine, fluorouracil }\left(K^{\prime}\right) \\
\text {-cyclofosfamide, fluorouracil, methrotrexate } \\
\text {-cyclofosfamide, epirubicine }\left(Z^{\prime}\right) \\
\text {-cyclofosfamide, doxorubicine, methotrexate }(Z) \\
\text {-cyclofosfamide, fluorouracil, methotrexate } \\
\text {-cyclofosfamide, doxorubicine }\end{array}$ & $\begin{array}{l}1 \% \times 2 \\
1 \% \times 2 \\
11 / 2 \times 1 \\
21 \% \times 1 \\
1 \% \times 1 \\
\pm 2 \times 1 \\
11 / 2 \times 1 \\
1 \% 2 \times 1\end{array}$ & $\begin{array}{l}1: 3 \\
1: 3 \\
1: 3 \\
1: 3 \\
1: 3 \\
2: 4 \\
2: 5 \\
1: 4\end{array}$ \\
\hline $\begin{array}{l}\text {-metastase lever } \\
\text {-peritonitis carc. } \\
\text {-sigmold }\end{array}$ & $\begin{array}{l}\text {-fluorouracil } \\
\text {-fluorouracil } \\
\text {-fluorouracil }\left(\mathrm{I}^{\prime}\right) \\
\text {-fluorouracil }\left(\mathrm{I}^{\prime}\right) \\
\text {-fluorouracil, methotrexate } \\
\left.\text {-fluorouracil ( } \mathrm{I}^{\prime}\right) \\
\text {-fluorouracil }\left(\mathrm{L}^{\prime}\right)\end{array}$ & $\begin{array}{l}1 / 2 \times 5 \\
1 / 2 \times 1 \\
1 / 2 \times 5 \\
1 / 2 \times 5 \\
1 \times 2 \\
1 \times 5 \\
\mid \times 1\end{array}$ & $\begin{array}{l}1: 4 \\
1: 1 \\
1: 4 \\
1: 4 \\
1: 3 \\
1: 4 \\
1: 1\end{array}$ \\
\hline $\begin{array}{l}\text { Rechum } \\
\text {-geen metastasen } \\
\text {-metastase lever } \\
\text {-metastase onbekend }\end{array}$ & $\begin{array}{l}\text {-fluorouracil } \\
\text {-fluorouracil } \\
\text {-fluorouracil ( }\left(^{\prime}\right) \\
\text {-fluorouracil }\left(\mathrm{d}^{\mathrm{T}}\right)\end{array}$ & $\begin{array}{l}3 / 2 x 1 \\
3 / x x 1 \\
1 \times 5 \\
1 \times 5\end{array}$ & $\begin{array}{l}1: 1 \\
1: 1 \\
1: 4 \\
1: 3\end{array}$ \\
\hline $\begin{array}{l}\text { Long } \\
\text {-kleincellig } \\
\text {-niet kleincellig IIIa } \\
\text {-niet gespecificeerd }\end{array}$ & $\begin{array}{l}\text {-cyclofosfamide, doxorubicine, etoposide } \\
\text {-cyclofosfamide, doxorubicine, etoposide } \\
\text {-taxotere } \\
\text {-onbekend }\end{array}$ & $\begin{array}{l}11 / \times x^{3} \\
3 \times 3 \\
13 / 4 \times 1 \\
3 / 2 \times 2\end{array}$ & $\begin{array}{r}1: 4 \\
1: 4 \\
1: 4 \\
2: 3^{4}\end{array}$ \\
\hline $\begin{array}{l}\text { Leukemie } \\
\text {-CLL } \\
\text {-CML }\end{array}$ & $\begin{array}{l}\text {-cyclofosfamide, doxorubicine, vincristine } \\
\text {-doxorubicine, Oncovin }\left(\mathrm{Z}^{\prime}\right)\end{array}$ & $\begin{array}{l}11 / 2 \times 5 \\
21 / 2 \times 1\end{array}$ & $=1: 6^{3}$ \\
\hline $\begin{array}{l}\text { Lymfatisch } \\
\text {-Hodgkin } \\
\text {-non-Hodgkin }\end{array}$ & $\begin{array}{l}\text {-bleomycine, doxorubicine, dacarbazine, vincristine (Z) } \\
\text {-fluorouracil }\end{array}$ & $\begin{array}{l}21 / 2 \times 1 \\
1 \times 5\end{array}$ & $\begin{array}{l}1: 2 \\
1: 4\end{array}$ \\
\hline $\begin{array}{l}\text { Overige } \\
\text {-melanoom } \\
\text {-morbus Kahler } \\
\text {-seminoma testis } \\
\text {-slecht gediff. adenoca. } \\
\text {-TTP }\end{array}$ & $\begin{array}{l}\text {-bleomycine, lomustinc', dacarbazine, vincristine } \\
\text {-doxorubicine, vincristine } \\
\text {-bleomycine } \\
\text {-cyclofosfamide, doxorubicine }\left(Z^{\prime}\right) \\
\text {-vincristine }\end{array}$ & $\begin{array}{l}1 \times 5 \\
1 / 2 \times 5 \\
1 / 2 \times 1 \\
1 / 2 \times 1 \\
1 / 2 \times 4\end{array}$ & $\begin{array}{l}1: 4 \\
1: 4 \\
2: 4 \\
1: 4\end{array}$ \\
\hline $\mathrm{N}=31^{3}$ & 'Doorsnee' behandeling: & $11 / 021 / 2$ & $1: 3$ \\
\hline
\end{tabular}

Legenda tabel B7.3: "=aantal uur $x$ aantal dagen behandeling per week daarna duur van de behandeling in weken:de totale cyclus van de kuur, gediff. adenoca.=gedifferentieerd adenocarcinoom, ${ }^{\prime}=Z: Z$ ofran (antiemeticum) K:Kytril (anti-emeticum) I:Isovorin (vitaminepreparaat) L:Leucovorine (vitaminepreparaat), ${ }^{2}=$ oraal, '-van éen patient is de diagnose onbekend, '=in 'rustweek' opname in azM, '=is nog niet tenuggeweest frequentie onzeker in ieder geval langer dan 6 weken, ${ }^{6}=$ overleden, 7 eeenmalige behandeling (TTP).

3. Verpleegkandige (inschatting interviewer): moet tijdens de hele infusie een verpleegkundige aanwezig zijn.

4. Specialist: Soms werd, zonder dat hierna gevraagd werd, een veelvuldig contact met de behandelend specialist als eis gesteld. In de thuissituatie zou men dit niet willen missen.

5. Psychosociale begeleiding (inschatting interviewer): is bij thuisbehandeling begeleiding nodig? Bijvoorbeeld als de patiēnt uitdrukkelijk aangeeft de begeleiding door de verpleegkundigen van het dagcentrum te missen.

6. Medepatiēnten (inschatting patiènt): enkele patiênten vermeldden spontaan dat men contact met de medepatiěnten ook bij thuisbehandeling een vereiste vindt. 


\section{Voordelen}

-in de eigen omgeving meer op gemak

-ik hoef minder te reizen/ reizen is bezwaarlijk

-meer contact met eigen huisarts

-chemokuur kan doorgaan ondanks ziekte

Gemiddeld aantal voordelen

Nadelen

-er kan iets mis gaan met het infuus -geen contact meer met medepatienten -mist contact met verpleging dagcentrum -mist geruststellende aanwezigheid specialist te weinig morele steun van naaste verzorger -deskundigheid verpleegkundige onvoldoende -huis is te klein

Gemiddeld aantal nadelen

\section{Groep 1}

\section{Groep 2}

Groep 3

Totaal

Gemideld aantal nadelen

7. Comorbiditeit (inschatting interviewer): een andere ziekte of handicap die IT belemmert.

Tabel B7.5 geeft per groep weer hoeveel patiènten aan de verschillende randvoorwaarden voldeden. Ook is per patiènt een 'overall score' toegekend uitmondend in drie klassen:

1: Voldoet aan alle (rand)voorwaarden; de patiènt is geschikt is voor IT.

2: Voldoet niet aan maximaal 2 (rand)voorwaarden; de patient is mogelijk geschikt voor IT.

3: Voldoet niet aan meer dan 2 (rand)voorwaarden; de patiènt is vooralsnog ongeschikt voor IT.

De grens van twee belemmeringen is gekozen, omdat in het merendeel van de gevallen twee belemmeringen opgeheven zouden kunnen worden. Het opheffen van meer dan twee belemmeringen (zo al mogelijk), zou té belastend zijn voor én de patiěnt zelf én voor de organisatie van de IT.

Alle patiënten in groep 1 en 2 hebben twee of minder belemmeringen, in groep 3 slechts $25 \%$. Volgens het 'overall' klassegemiddelde lijkt groep 1 geschikt voor IT en groep 3 juist niet. De mening van patiènten blijkt dus overeen te stemmen met een 'objectievere' vaststelling van de mate waarin aan (rand)voorwaarden is voldaan. Het verdient daarom aanbeveling om bij de screening van patiēnten terdege met hun mening rekening te houden. Groep 1 en groep 2 hebben ongeveer hetzelfde 'overall' gemiddelde. Wellicht komt ook groep 2 in aanmerking voor IT. Deze tendens bleek ook al uit tabel B7.4.

Tabel B7.5 Aantal voorwaarden voor IT waaraan huidige patienten in het dagcentrum voldoen.

Randvoorwaarden vervuld

1. Participeren

2. Emotioneel/psychisch

3. Verpleegkundige

4. Specialist

5. Psychosociale begeleiding

6. Medepatienten

7. Comorbiditeit Groep $1^{*}$ Groep 2 Groep $3^{* *}$ Totaal

Verdeling in klassen

1, geen belemmeringen

2. eten of twee belemmeringen

3. drie of meer belemmeringen

Overall score in klassen

\begin{tabular}{cccc}
11 & 1 & 5 & 17 \\
16 & 3 & 5 & 24 \\
9 & 2 & 2 & 13 \\
14 & 3 & 7 & 24 \\
13 & 3 & 7 & 23 \\
13 & 3 & 5 & 21 \\
15 & 3 & 7 & 25 \\
& & & \\
6 & 1 & 0 & 7 \\
11 & 2 & 3 & 16 \\
0 & 0 & 9 & 9 \\
1,6 & 1,7 & 2,8 & 2,0 \\
\hline
\end{tabular}

Legenda: "=van 2 respondenten ontbreken antwoorden, " $=$ van 5 respondenten ontbreken antwoorden. 
De 'overall' score van groep 1 en 2 zou dichter de 1 kunnen benaderen (=geschikt), indien de verpleegkundige gedurende het hele infuus aanwezig zou kunnen zijn. Dit is afhankelijk van de soort medicatie, de duur en frequentie van de behandeling, de reisafstand tussen patiēnten en financiên.

\section{Conclusies}

Door het kleine aantal respondenten zijn geen harde uitspraken mogelijk over de invloed van leeftijd, geslacht en opleiding op de mening van patiēnten over IT. Vrouwen en hoger opgeleiden lijken minder geneigd tot IT. De mening van de individuele patiěnt komt veelal overeen met een 'objectievere' vaststelling van de mate waarin aan de (rand)voorwaarden voor IT is voldaan. De patienten die twijfelen, zouden waarschijnlijk overtuigd kunnen worden, aangezien ze enerzijds alleen maar voordelen aangeven en anderzijds voldoen aan de (rand)voorwaarden.

\section{Bijlage 7.4: Toepassing selectiecriteria individuele patiênten}

Tabel B7.6 geeft enkele kenmerken van patiěnten waarbij niet aan de instroomcriteria voor verantwoorde thuisbehandeling kon worden voldaan.

Tabel B7.6 Patienten waarbij niet aan de instroomcriteria voor thuisbehandeling voldaan kon worden.

\begin{tabular}{|c|c|c|c|}
\hline Pt & Med & No & Voorwaarden waaraan niet voldaan kon worden \\
\hline $0^{*} 65$ & morf & 1 & patient wilde niet $(p)$ \\
\hline$\sigma 29$ & ab & 1 & medisch beleid niet duidelijk (m) \\
\hline 845 & $\operatorname{man}$ & 1 & afgezegd vanwege vakantie $(p)$ \\
\hline 852 & $\operatorname{man}$ & 1 & uitgesteld tot na onderzoeksperiode (p) \\
\hline 860 & dola & 1 & screening wikkelhart en harttransplantatic (m) \\
\hline o 74 & dola & 1 & Staphylococcus aureus infectie: implantatie centraalveneuze poort uitgesteld (m) \\
\hline 887 & dola & 4 & $\begin{array}{l}\text { zeer slechthorend }(m) \text {, beperkt begripsvermogen }(p) \text {, alleenstaand }(0) \text {, } \\
\text { achterwacht bejaardenhuis onvoldoende }(z)\end{array}$ \\
\hline 869 & dola & 3 & $\begin{array}{l}\text { slechthorend en vergeetachtig ( } m \text { ), alleenstaand (o), achterwacht bejaardenhuis } \\
\text { onvoldoende ( } \mathrm{z} \text { ) }\end{array}$ \\
\hline 072 & dola & 3 & slechthorend (m), niet therapietrouw (p), alleenstaand (o) \\
\hline 073 & dola & 3 & slechthorend (m), niet therapietrouw (p), echtgenote angstig en slechthorend (o) \\
\hline 880 & dola & 2 & $\begin{array}{l}\text { slechthorend }(m) \text {, echtgenote vergeetachtig en onvoldoende andere naaste } \\
\text { verzorgers }(0)\end{array}$ \\
\hline 881 & dola & 3 & durfde het niet aan (p), zus ook angstig (o), onvoldoende voorgelicht (z) \\
\hline 964 & dola & 1 & liever in dagcentrum $(p)$ \\
\hline$\circ 70$ & dola & 1 & echtgenote ook hartpatiente en angstig (o) \\
\hline
\end{tabular}

Legenda: Pt=geslacht en leeftijd patiênt, Med=medicatie: morf=morfine, ab=antibiotica, man=mannitol, dolamdopamine/lasix, No=aantal klassen voorwaarden waar niet aan kon worden voldaan: (m) medisch, (p)=persoonlijk, (o)=omgeving. (z)=zorginhoudelijk. 


\section{Bijlagen bij hoofdstuk 8}

\section{Organisatie van zorg}

\section{Bijlage 8.1: Kenmerken Stichting Groene Kruis Heuvelland}

Tabellen B8.1 en B8.2 geven enige structurele en produktiekenmerken van de SGKH (financięle kenmerken bijlage 11.6).

Tabel B8.1 Structurele kenmerken SGKH 1993-1995.

\begin{tabular}{lrrr}
\hline Structuurkenmerk & 1993 & 1994 & 1995 \\
Vast personeel & & & 4 \\
Management en staf & 4 & 26 & 24 \\
Algemene zaken & 24 & 18 & 19 \\
Personeelszaken & 121 & 111 & 103 \\
Ouder en kindzorg & 119 & 112 & 181 \\
Wijkzorg (tvoorlichting) & 288 & 271 & 331 \\
Totaal & 191 & 184 & 190 \\
Fulltime equivalent & & & \\
Anderen & 112 & 139 & 135 \\
Oproepmedewerkers & 56 & 63 & 67 \\
Vrijwilligers/detacheringen & & & \\
\hline
\end{tabular}

Tabel B8.2 Produktiekenmerken SGKH 1993-1995.

\begin{tabular}{lrrr}
\hline $\begin{array}{l}\text { Produktiekenmerk } \\
\text { Voedingsvoorlichting }\end{array}$ & 1993 & 1994 & 1995 \\
Individuele contacten & 3.814 & \pm 3.550 & \\
Groepsgewijze bijeenkomsten & 264 & \pm 200 & 5.503 \\
Gezondheidsvoorlichting & & & \pm 225 \\
Deelnemers & 402 & 712 & \\
Cursussen & 44 & 78 & 927 \\
Ouder en kindzorg & & & 107 \\
Aantal geboorten & 2.168 & 2.173 & \\
Aantal gezinnen in zorg & 1.507 & 1.680 & 2.138 \\
Gemiddelde verzorging (dagen) & 7,3 & 7,3 & 1.571 \\
Verplegen en verzorgen & & & $\pm 7,4$ \\
Zorguren 08.00-12.00 & 44.771 & 45.708 & \\
Zorguren 12.00-18.00 & 13.573 & 8.045 & 60.993 \\
Zorguren avond/nacht & 3.723 & 5.607 & 7.454 \\
Zorguren weekend & 7.713 & 9.324 & 10.579 \\
Totaal aan zorguren & 69.780 & 68.684 & 13.381 \\
Totaal aantal contacten & 72.715 & 129.503 & 92.587 \\
-waarvan medisch-technisch & $3.1 \%$ & $2,6 \%$ & 169.222 \\
Clienten ouder dan 60 & $\pm 80 \%$ & $\pm 80 \%$ & $1,6 \%$ \\
\hline
\end{tabular}


Bijlage 8.2: Kenmerken academisch ziekenhuis Maastricht

Tabellen B8.3 en B8.4 geven enige structurele en produktiekenmerken van het azM (financięle kenmerken bijlage 11.6).

Tabel B8.3 Structurele kenmerken azM 1993-1995.

\begin{tabular}{|c|c|c|c|}
\hline Structuurkenmerk & 1993 & 1994 & 1995 \\
\hline \multicolumn{4}{|l|}{ Bedden } \\
\hline Somatische bedden & 633 & 633 & 653 \\
\hline Bedden dagbehandeling & 32 & 32 & 32 \\
\hline PAAZ bedden & 20 & 20 & 20 \\
\hline Wiegen & 10 & 10 & 10 \\
\hline Totaal & 695 & 695 & 715 \\
\hline \multicolumn{4}{|l|}{ Personeel } \\
\hline Management en administratic & 478 & 461 & 451 \\
\hline Civiele dienst & 297 & 284 & 274 \\
\hline Technische dienst & 50 & 49 & 46 \\
\hline Instrumentele dienst & 38 & 38 & 41 \\
\hline Overige algemene dienst & 68 & 66 & 71 \\
\hline Verpleging & 993 & 964 & 1.018 \\
\hline Paramedisch dienst & 96 & 96 & 98 \\
\hline Operatieve dienst & 198 & 197 & 189 \\
\hline Poliklinische dienst & 193 & 192 & 196 \\
\hline Laboratoria & 389 & 377 & 418 \\
\hline Logistieke dienst & 61 & 57 & 55 \\
\hline Medische staf & 376 & 400 & 425 \\
\hline Totaal & 3.237 & 3.181 & 3.282 \\
\hline Fulltime equivalent & 2.741 & 2.654 & 2.738 \\
\hline Vrouw & $64 \%$ & $64 \%$ & $64 \%$ \\
\hline \multicolumn{4}{|c|}{ Produktiekenmerken azM 1993-1995. } \\
\hline Produktiekenmerk & 1993 & 1994 & 1995 \\
\hline Opnames & 20.101 & 20.440 & 21.359 \\
\hline Patienten regio Heuvelland & $70 \%$ & $69 \%$ & $68 \%$ \\
\hline Verpleegdagen & 204.098 & 195.175 & 199.184 \\
\hline Gemiddelde opname (dagen) & 10,2 & 9,5 & 9,3 \\
\hline Bedbezetting & $85,6 \%$ & $81,9 \%$ & $81,1 \%$ \\
\hline Aantal dagverplegingen & 5.849 & 5.518 & 5.684 \\
\hline Operaties poliklinisch & 4.525 & 4.454 & 4.178 \\
\hline Operaties klinisch & 15.756 & 16.880 & 17.309 \\
\hline $\begin{array}{l}\text { Eerste polikliniekbezock } \\
\text { Controle polikliniekbezoek }\end{array}$ & $\begin{array}{r}62.812 \\
255.609\end{array}$ & $\begin{array}{r}65.945 \\
259.735\end{array}$ & $\begin{array}{r}66.575 \\
259.294\end{array}$ \\
\hline EHBO algemeen, & 22.248 & 23.050 & 25.015 \\
\hline waarvan opgenomen & 4.210 & 4.319 & 4.569 \\
\hline EHBO eerste harthulp & 2.632 & 3.037 & 3.456 \\
\hline Diagnostische/functietesten & 198.054 & 204.003 & 205.037 \\
\hline Radiodiagnostiek & 118.520 & 119.673 & 120.763 \\
\hline MRI & 2.199 & 2.860 & 3.318 \\
\hline Pathologische tests & 29.799 & 30.174 & 30.132 \\
\hline
\end{tabular}




\section{Bijlage 8.3: Structuur werkoverleg}

Het genotuleerde werkoverieg van de TMVs vond wekelijks plaats bij het wisselen van de dienst. Bij het werkoverleg was én van de projectcoordinatoren aanwezig.

Doeien van het werkoverleg:

- Op de hoogte brengen collega's

- Signaleren algemene aandachtspunten

- Inventarisatic problemen in de zorguitvoering

Structuur van het werkoverleg:

- Opening en aanvullende agendapunten

- Notulen vorige werkoverleg

- Patientenbespreking

- Mededelingen en ingekomen stukken

- Aandachtspunten TMVs

- Bijvullen materiaalkoffers

- Rondvraag en sluiting

Structuur binnen de patiēntenbespreking:

- Patienten waarbij de zorg afgesloten is

- Patiénten die al langer in zorg zijn

- Patiennten die nieuw in zorg zijn

Binnen elke groep zijn patienten gerangschikt op volgorde van startdatum.

Structuur per individuele patiēnt:

- Naam patiēnt

- Reden, soort en frequentie infusie

- Start- en stopdatum

- Intake:

verioop aanmelding

andere disciplines: betrokkenen, afspraken en participatie

mantelzorg: aanwezigheid, afspraken en participatie

- Proces:

verloop infuusbehandeling

- Evaluatic:

realisatie gemaakte afspraken bij intake

tevredenheid/knelpunten

- Zo nodig bijzonderheden 
Schema B8.1 Inhoudsopgave Zorgdossier Thuiszorg.

\author{
Algemeen \\ AJgemene gegevens patient en contactpersonen / naaste verzorgers / betrokkenen bij de thuiszorg \\ Planning \\ Zorgplan \\ Planrooster \\ Werkrooster \\ Lijsten \\ Medicatie \\ Klinische observatielijsten \\ Rapportage \\ Vragen en berichten \\ Beginafspraken huisarts plus rapportagebladen huisarts \\ Beginafspraken verpleging plus rapportagebladen verpleging \\ Beginafspraken gezinsverzorging plus rapportagebladen gezinsverzorging \\ Rapportagebladen naaste verzorgers \\ Rapportagebladen fysiotherapie \\ Rapportagebladen maatschappelijk werk \\ Rapportagebladen ......(overigen) \\ Behandelprotocol \\ Mogelijkheid om behandelprotocollen in te voegen
}

\title{
Algemene gegevens
}

\section{Datum}

A. Personalia cliènt: naam, geslacht, geboortedatum, adres, postcode, woonplaats, चprivé, चwerk; zorgverzekeraar, ziekenfonds/particulier, cliěntnummer, contactpersoon, चwerk, चfax; soort ITZ,

ITZ-functionaris, चwerk, चfax; thuiszorg, cliēntnummer, diagnose, allergieẽn, dieet, bijzonderheden. B. Contactpersonen / Naaste verzorgers (2x): naam, partner/ouder/kind/familie/buur/ander, adres, woonplaats, चprivé, zwerk.

C. Coördinator van de thuiszorg: naam, discipline, adres, woonplaats, चwerk, चprivé.

D. Betrokkenen bij de thuiszorg onderverdeeld in overige naaste verzorgers, ziekenhuis- en thuiszorgdisciplines: naam en functic, wwerk.

\section{Zorgplan}

\section{Datum}

A. Kernproblemen zorgsituatie (vier regels).

B. Samenvattend kunnen de activiteiten aangegeven worden, per regel: datum, wie?, wat?, wanneer? Tevens staat onderaan: evaluatiedatum, tijd en plaats.

Toelichting: "Het zorgplan geeft samen met het planrooster een overzicht van de totale rond de cliënt georganiseerde zorg. De nadruk ligt op samenwerking, onderlinge afstemming en taakafbakening. De zorg bestaat uit mantelzorg en betaalde zorg. De betaalde zorg wordt geleverd door gezondheidswerkers uit de thuiszorg en eventueel het ziekenhuis, alsmede door medewerkers van facilitaire (ondersteunende) bedrijven en instanties. Voor gedetailleerde overzichten van de te leveren en geleverde zorg wordt verwezen naar de rapportagebladen".

\section{Planrooster}

Geldigheidsduur en evalutiedatum.

Geplande zorg in uren per weekdag onderverdeeld in morgen, middag, avond en nacht. Kolommen voor: familie; vrienden, buren, kennissen en vrijwilligers; gezinszorg/ $\alpha$-hulp; wijkverpleegkundige/ziekenverzorgende; TMV; huisarts; blanco. Onderaan mogelijkheid tot totaliseren. Aandachtspunten: Begin- en eindtijd per bezoek aangeven. Voorbeelden van vijf tot twintig over acht 's ochtends wordt $08.05-08.20$ en van kwart over negen 's avonds tot één uur 's nachts wordt 21.15-01.00. Verklaring van de gebruikte afkortingen.

\section{Werkrooster}

Periode.

Voorts identiek aan planrooster behalve dat hier de geboden zorg geregistreerd wordt. 
Per medicament één regel met: start op, wijzig op, stop op, naam medicijn, sterkte medicijn, toedieningstijdstip(pen) plus een lege regel voor opmerkingen.

Aandachtspunten: Bij wijzigen of staken van medicatie de hele regel doorhalen en een nieuwe regel gebruiken. Toedieningstijdstip(pen) dienen in een 24-uurs aanduiding te geschieden, voorbeeld: 8u-16u-22u. Bij "opmerkingen" kunt U aanwijzingen voor het gebruik noteren.

Liisten: Pijnevaluatie + Pijnscorelijst

Op het pijnevaluatieformulier is per regel plaats voor: datum en tijd, pijnscore, bijzonderheden.

Toelichting: Pijnbestrijding dient altijd plaats te vinden op geleide van het klinisch beeld.

Pijnmeting door middel van de VAS-meting (visual analogue scale) kan hierbij een hulpmiddel zijn. Indien van de VAS-meting gebruik gemaakt wordt, dient de pijn gemeten te worden voor het starten of veranderen van de therapic. Daarna kan de pijn vervolgd worden aan de hand van een regelmatige pijnmeting. De absolute pijnscore is hierbij niet zozeer van belang. Deze is per patiēnt verschillend. wel van belang is het verschil in pijnscore dat bij de patient optreedt. Er dient naar gestreefd te worden dat de pijn minimaal twee punten daalt. Instructic: de patient wordt verzocht een kruis te zetten op een lijn van tien centimeter met als uiterste waarden: geen pijn en ondraaglijke pijn. Daarna wordt de waarde bepaald met behulp van de meegeleverde meetlat en in hele cijfers aan gegeven (geen pijn is 0 en ondraaglijke pijn is 10).

Op de pijnscorelijst staan cen aantal VAS-schalen: Kunt U de mate van pijn weergeven, die u op dit moment heeft door op onderstaande lijn een kruisje $(\mathrm{X})$ te zetten op de plaats die hiermee overeenkomt. Lijn van $10 \mathrm{~cm}$ met als uitersten geen pijn en ondraaglijke pijn.

Liisten: Dagstaat vochtbalans + Verzamelstaat vochtbalans

Op de verzamelstaat vochtbalans kan genoteerd worden: vochtbeleid in liter per 24 uur, afwijkende tijden vochtbalansen, verantwoordelijke voor verzamelstaat. Tabel met kolommen: vochtopname: datum, per os of per sonde, aangesloten infuus, ingelopen infuus; vochtverlies: urine, braken, ontlasting; bijzonderheden. Onderaan mogelijkheid tot totaliseren.

Aandachtspunten: Bij dreigende problemen rond vochtopname en/of uitscheiding kan een vochtbalans worden bijgehouden. Hiertoe dient de dagstaat vochtbalas. De hoeveelheden opgenomen en uitgescheiden vocht worden vanaf de dagstaat overgenomen op de verzamelstaat. De staten dienen op dezelfde tijd te beginnen en te eindigen. Tenzij anders aangegeven duren de periodes 24 uur en gaan steeds in om 12 uur 's nachts. Het invullen van de verzamelstaat dient zoveel mogelijk door één en dezelfde persoon te gebeuren.

Op de dagstaat kan ook de dag worden ingevuld, voor de rest is deze identiek aan de verzamelstaat vochtbalans, maar dient om de vochtbalans van éen dag bij te houden.

\section{Vragen en berichten}

Hiermee kunnen zorgverleners communiceren; kolommen met: datum, aan, vraag/bericht, van.

\section{Rapportagebladen}

Er zijn rapportagebladen voor de: huisarts, wijkverpleging, gezinsverzorging, naaste verzorgers, fysiotherapie, maatschappelijk werk en overigen.

Voorts zijn er beginafspraken huisarts. Hierin dienen de volgende vijf punten omschreven te zijn:

1. De zorgvraag van de cliênt en/of diens familie/betrokkenen, plus ziektebeeld en medisch beleid.

2. De met de medisch behandeling beoogde doelen, plus effecten en bijwerkingen.

3. De medische activiteiten die door cliênt en/of diens familie/betrokkenen zelf ondernomen worden.

4. De medische activiteiten die worden verricht door de huisarts.

5. De benodigde medische hulpmiddelen (medicatie op apart formulier).

Ook zijn er beginafspraken wijkverpleging om de volgende vijf punten te omschrijven:

1. De zorgvraag van de cliênt en/of diens familie/betrokkenen.

2. De verpleegdoelen die afgesproken zijn.

3. De verpleegactiviteiten die door cliênt en/of diens familie/betrokkenen zelf ondernomen worden.

4. De verpleegactiviteiten die worden verricht door de wijkverpleging.

5. De benodigde hulpmiddelen of woningaanpassingen.

Op beide formulieren worden datum, naam en bereikbaarheid van de opsteller ingevuld.

Aandachtspunten: De afspraken worden met de cliênt en familie of naaste verzorger(s)

doorgenomen. Bij de activiteiten worden ook de tijdstippen en de duur aangegeven. Nieuwe afspraken worden vermeld op het rapportageblad huisarts. 


\section{Bijlage 8.5: Verdeling van het aantal problemen}

Tabel B8.5 geeft aan in hoeveel percent van de behandelingen een bepaald aantal problemen is opgetreden.

Figuur B8.1 geeft aan bij hoeveel percent van de verschillende soorten infusie een bepaald aantal problemen of minder opgetreden is (hoe meer problemen, hoe meer de curve naar rechtsonder verschuift).

Tabel B8.5 Absolute en percentuele verdeling van de behandelingen naar het aantal problemen.

\begin{tabular}{lcccccccc}
\hline Problemen & SC abs & SC $\%$ & IV abs & IV \% & CV abs & CV $\%$ & Tot abs & Tot \% \\
0 & 26 & 44 & 14 & 18 & 8 & 21 & 48 & 28 \\
1 & 19 & 32 & 16 & 21 & 10 & 26 & 45 & 26 \\
2 & 8 & 14 & 25 & 33 & 3 & 8 & 36 & 21 \\
3 & 2 & 3 & 12 & 16 & 7 & 18 & 21 & 12 \\
4 & 2 & 3 & 4 & 5 & 3 & 8 & 9 & 5 \\
5 & 0 & 0 & 3 & 4 & 3 & 8 & 6 & 4 \\
6 & 1 & 2 & 1 & 1 & 2 & 5 & 4 & 2 \\
7 & 0 & 0 & 0 & 0 & 2 & 5 & 2 & 1 \\
8 & 1 & 2 & 1 & 1 & 0 & 0 & 2 & 1 \\
Totaal & 59 & 100 & 76 & 100 & 38 & 100 & 173 & 100 \\
\hline
\end{tabular}

Figuur B8.1 Cumulatieve verdeling van soorten infusie naar het aantal problemen (\%).

Cumultatief percentage van behandelingen

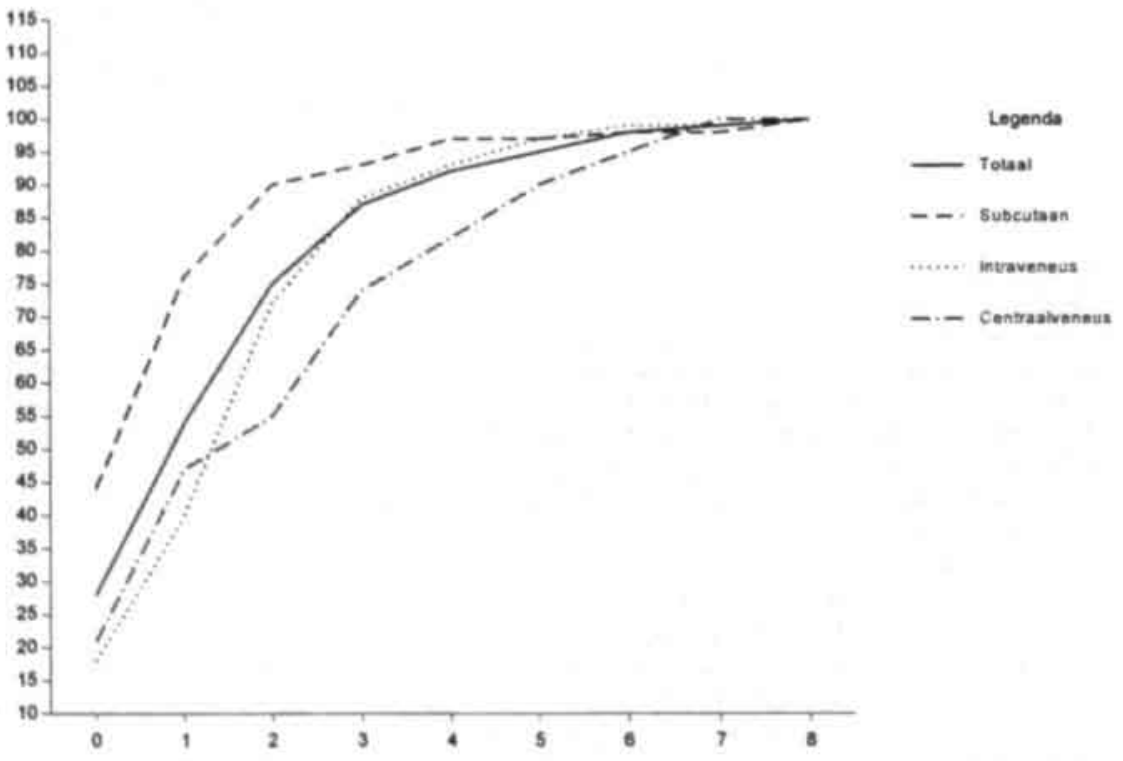

Aantal problemen 
Tabel B8.6 geeft aan in hoeverre een bepaalde probleemklasse (het aantal behandelingen met eén fout, twee fouten, enzovoorts) bijdraagt aan het totaal aantal problemen per soort infusie en in totaal. Figuur B8.2 geeft deze verdeling nogmaals grafisch weer.

Tabel B8.6 Absolute en percentuele verdeling per probleemklasse van het aantal problemen afgezet tegen het totaal aantal problemen per soort behandeling en voor het totaal.

\begin{tabular}{|c|c|c|c|c|c|c|c|c|}
\hline Problemen & $S C$ abs & SC $\%$ & IV abs & $\mathbf{n} \%$ & $\mathrm{CV}$ abs & $\mathrm{CV} \%$ & Tot abs & Tot $\%$ \\
\hline 0 & 0 & 0 & 0 & 0 & 0 & 0 & 0 & 0 \\
\hline 1 & 19 & 30 & 16 & 11 & 10 & 11 & 45 & 15 \\
\hline 2 & 16 & 25 & 50 & 34 & 6 & 7 & 72 & 24 \\
\hline 3 & 6 & 10 & 36 & 24 & 21 & 23 & 63 & 21 \\
\hline 4 & 8 & 13 & 16 & 11 & 12 & 13 & 36 & 12 \\
\hline 5 & 0 & 0 & 15 & 10 & 15 & 17 & 30 & 10 \\
\hline 6 & 6 & 10 & 6 & 4 & 12 & 13 & 24 & 8 \\
\hline 7 & 0 & 0 & 0 & 0 & 14 & 16 & 14 & 5 \\
\hline 8 & 8 & 13 & 8 & 5 & 0 & 0 & 16 & 5 \\
\hline Totaal & 63 & 100 & 147 & 100 & 90 & 100 & 300 & 100 \\
\hline Per behandeling & 1,07 & & 1,93 & & 2,37 & & 1.73 & \\
\hline Per infusiedag & 0,097 & & 0,156 & & 0,090 & & 0,116 & \\
\hline Infusiedagen & 648 & & 941 & & 1002 & & 2591 & \\
\hline
\end{tabular}

Legenda: - =deelt de klassen ongeveer in tweeen, "=het gemiddeld aantal problemen per behandeling

Figuur B8.2 Verdeling van het aantal problemen ten opzichte van het totaal.

Total aantal problemen

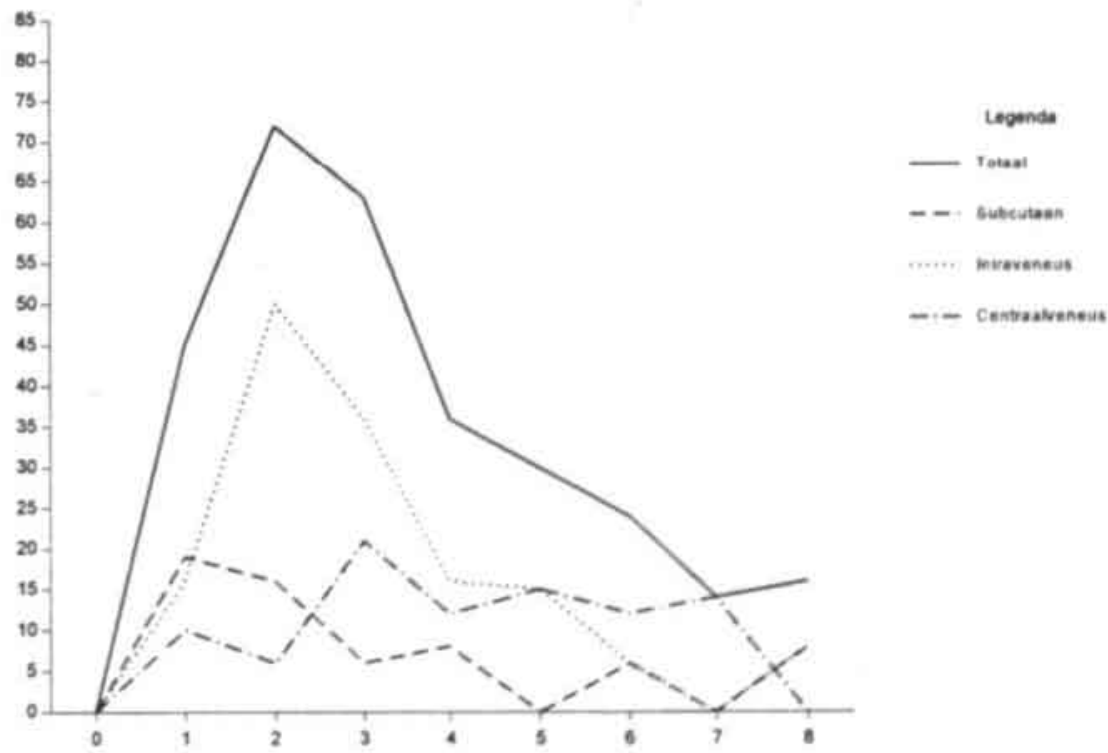

Aantal problemen per behandeling 


\section{Bijlagen bij hoofdstuk 9}

\section{Informatievoorziening}

\section{Bijlage 9.1: Chronologisch overzicht verspreide informatie}

Tabel B9.1 geeft een chronologisch overzicht van de over het project verspreide informatie. Tevens is aangegeven of de informatie algemeen ( $\mathrm{Al}$ ) van aard en/of op de behandeling (Be) gericht was.

Tabel B9.1 Regionaal verspreide algemene en behandelingsgerichte informatie.

Informatie in chronologische volgorde

Thuiszorg met behulp van technologische hulpmiddelen. Informatiebulletin Diagnostisch

Coordinerend Centrum juli 1992:14(1):20.

Derckx EWCC. Project 'Thuiszorgtechnologie Infuussystemen'. Informatief (informatiebulletin personeel SGKH) november 1992;(11):21.

Integraal Kankercentrum Limburg. Werkgroep pijnbestrijding bij kankerpatienten. Jaarverslag 1992:14.

Apothekersvereniging Maastricht. Jaarverslag 1992:6-7.

Derckx EWCC. Voortgang project 'Infuusbehandeling Thuis'. Informatief februari 1993;(2):11.

Diagnostisch Coordinerend Centrum. Jaarverslag april 1992-1993:31.

Project 'Infuusbehandeling Thuis'. Nieuwsbrief Regionale Huisartsen Vereniging Heuvelland 1993:9(1):ongenummerd.

Thuiszorg met technische hulpmiddelen (voordracht). Symposium Huisarts-Specialist 1993. X Thema: Communicatie en samenwerking tussen huisarts en specialist. Diagnostisch Centrum / Stuurgroep 1'-2* lijn / KNMG. Maastricht: 17 april 1993.

Nieuwsbricf 1 Project 'Infuusbehandeling Thuis' augustus 1993.

Derckx EWCC. Voortgang project 'Infuusbehandeling Thuis'. Informatief augustus 1993;(7):7.

Project 'Infuusbehandeling Thuis'. Nieuwsbrief Regionale Huisartsen Vereniging Heuvelland augustus 1993;9(4):ongenummerd.

Nieuwsbrief 2 Project 'Infuusbehandeling Thuis' 8 oktober 1993 (officięle startdatum).

Derckx EWCC. Voortgang project 'Infuusbehandeling Thuis'. Informatief oktober 1993;(9):14.

Cann J van. 'Infuusbehandeling Thuis' van start. Traject (informatiebulletin personeel azM) X oktober 1993;8(9):17.

Nieuwsbrief 3 Project 'Infuusbehandeling Thuis' december 1993.

Integraal Kankercentrum Limburg. Werkgroep pijnbestrijding bij kankerpatienten.

Jaarverslag 1993:7.

Apothekersvereniging Maastricht. Jaarverslag april 1993-1994:7.

Diagnostisch Coordinerend Centrum. Jaarverslag 1993:38.

academisch ziekenhuis Maastricht. Jaarverslag 1993:32.

Derckx EWCC. Project Infuusbehandeling Thuis. Informatief februari 1994;(2):12.

Cann J van. Relatie van infuusverpleegkundige met patient is de spil van het hele project. Traject april 1994;9(4):15.
Al

$\mathrm{X}$

$\mathrm{X}$

$\mathrm{X}$

$$
\mathrm{x}
$$

$\mathrm{X} \quad \mathrm{X}$

$\mathrm{X}$

$\mathrm{X}$

$\mathrm{X}$

$\mathrm{x}$ 
Informatie in chronologische volgorde

Derckx EWCC. Project Infuusbehandeling Thuis. Informatief juli 1994:(6):12-3.

Technologische vernieuwingen in de thuiszorg (lezing). Second European Congress.

Closing the gap between institutional care and home care. European association of

Organizations for Home Care and Help at Home. Maastricht: 6-7 oktober 1994

Nieuwsbrief 4 Project 'Infuusbehandeling Thuis' oktober 1994

Ortiens W. Maastricht was een schone slaapster onder spinnenwebben. Mediscope (informatiebulletin faculteit geneeskunde RL) 4 november 1994;(3);4-7.

Apothekersvereniging Maastricht. Jaarverslag april 1994-1995:9.

Diagnostisch Coordinerend Centrum. Jaarverslag 1994:37-38.

Anoniem. Sneller naar huis. Kruiswerk en ziekenhuizen werken nauwer samen. Gezond Thuis (informatieblad voor leden SGKH) januari 1995;4.

Servais J. Patient bij behandeling betrekken. Traject januari 1995;10(1):8-9. Overdruk in $\quad X \quad X$ Informatief januari 1995;(1):17-8.

Project 'Infuusbehandeling Thuis' (voordracht). NHG-Referatendag. NHG. Maastricht: $2 \quad X \quad X$ juni 1995 .

Crouzen B. Experiment met thuis-infuus is een succes. De Limburger 30 juni 1995.

Derckx EWCC. Project 'Infuusbehandeling Thuis'. Informatief juli 1995,(7):5.

$\mathrm{X} \quad \mathrm{X}$

Derckx EWCC. Infuusproject. Informatief oktober 1995;(10) 2.

$\mathrm{x} \quad \mathrm{x}$

Invitational Meeting Transmurale Farmacic. Klinische Farmacie en Toxicologie azM. Maastricht. 22 november 1995.

Themanummer Transmurale zorg. azM Select (uitgave azM voor relaties) december $1995 ; 4(16)$.

Nieuwsbrief 5 Project 'Infuusbehandeling Thuis' \& Stuurgroep Transmurale Zorg 1 februari 1996. Overdruk in Informatief februari 1996;2:8,11.

Anoniem. Het persoonsgebonden budget. Zelf uw zorg inkopen. Gezond Thuis mei 1996;17.

Legenda: $\mathrm{Al}=$ algemene informatie, $\mathrm{Be}=$ behandelingsgerichte informatic. 


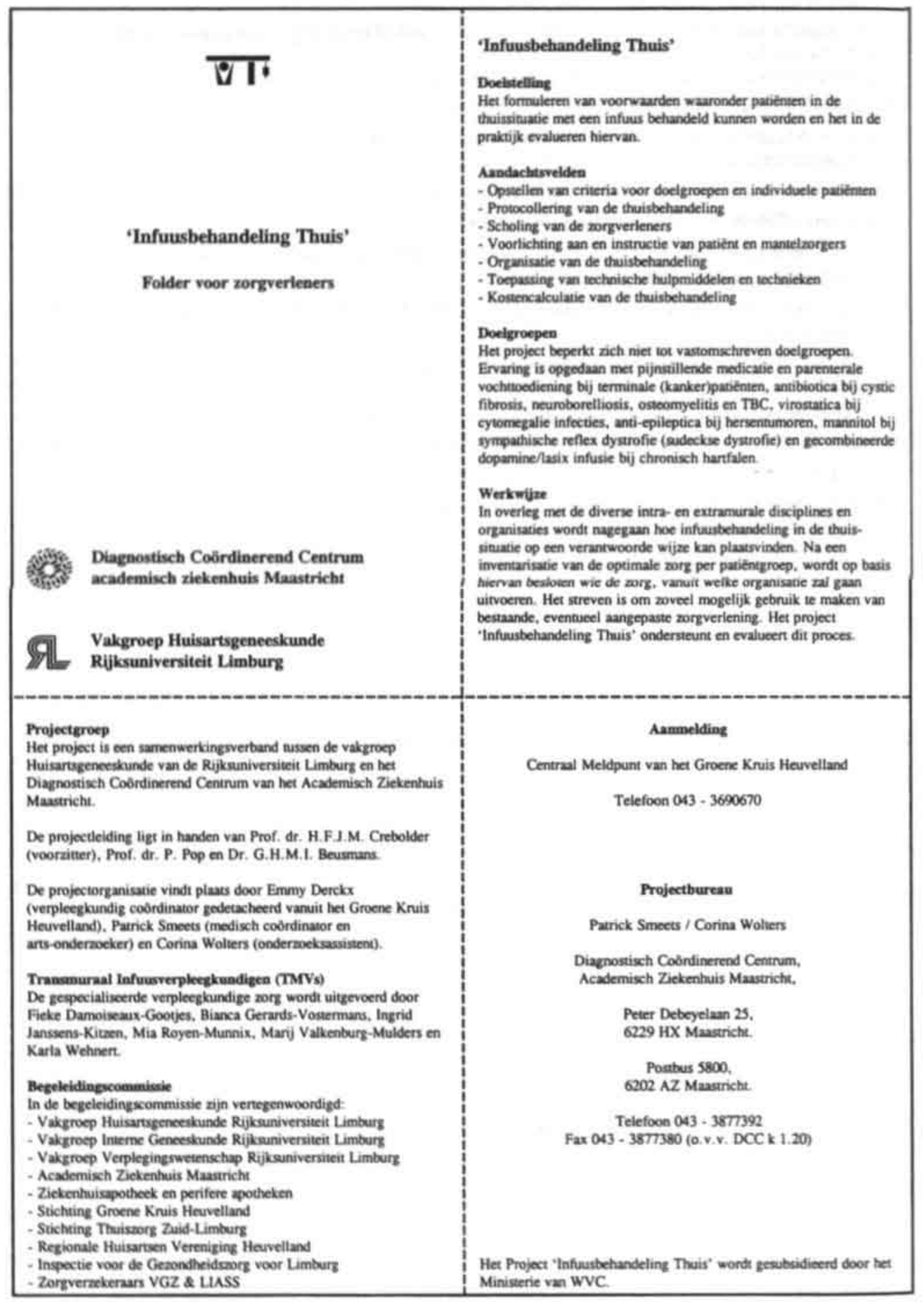




\title{
$\overline{\nabla T}$
}

\section{Project 'Infuusbehandeling Thuis'}

\author{
Diagnostisch Coördinerend Centrum azM \\ Vakgroep Huisartsgeneeskunde
}

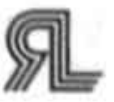

A. In welk (deel)specialisme bent $\mathrm{U}$ werkzaam:

B. Wat is Uw functic-omschrijving ?

$\square$ Specialist $\square$ Agio $\square$ Agnio $\square$ Anders, te weten:

1. Hebt U wel eens van het project 'Infuusbehandeling Thuis' gehoord ?

$\square$ JA $\square$ NEE, ga verder met vraag 9

2. Is het U bekend hoe het project 'Infuusbehandeling Thuis' in de praktijk te werk gaat ?

$\square$ JA $\square$ NEE, ga verder met vraag 9

3. Is het $U$ bekend door wie patiènten officieel voor het project kunnen worden aangemeld ?

$\square$ NEE $\square$ JA, te weten:

4. Is het $U$ bekend waar patiènten voor het project kunnen worden aangemeld ?

$\square$ NEE $\square J A$, te weten:

5. Zijn er wel eens patienten van $U$ in het project opgenomen ?

$\square$ NEE $\square$ JA

6. Welke infuusbehandelingen kunnen volgens $U$ via het project thuis gegeven worden ?
$\square$ Antibiotica
$\square$ Mannitol
$\square$ Morfine
$\square$ Cytostatica
$\square$ Dopamine en/of lasix
$\square$ Andere, te weten:

7. Ziet $\mathrm{U}$ nog mogelijkheden voor andere infuusbehandelingen thuis ?

$\square$ NEE $\square J A$, te weten:

8. Hebt $\mathrm{U}$ opmerkingen en/of suggesties ten aanzien van eventuele verbetering van het project ?

$\square$ NEE $\square J A$, en wel:

9. Hebt U behoefte aan meer informatie over het project 'Infuusbehandeling Thuis' ?

$\square$ NEE $\square$ JA, ten aanzien van: 


\section{Bijlage 9.4: Uitkomsten informatie-enquête}

Tabel B9.2 geeft de respons op de enquête over de bekendheid met de naam en inhoud van het project onder artsen in het azM. Bij de vakgroep Interne Geneeskunde zijn de deelspecialismen onderscheiden.

Tabel B9.3 geeft de naamsbekendheid van het project onder artsen binnen het azM. Binnen de vakgroep Interne Geneeskunde zijn wederom de deelspecialismen onderscheiden.

Tabel B9.4 geeft de informatiebehoefte van artsen in het azM over het project naar soort.

Tabel B9.2 Respons per functic en per klinisch specialisme.

\begin{tabular}{|c|c|c|c|c|c|c|c|}
\hline Klinisch specialisme & Spec & Agio & Agnio & Overig & $\begin{array}{l}\text { Tot } \\
\text { Abs }\end{array}$ & $\begin{array}{l}\text { Tot } \\
\%\end{array}$ & $\begin{array}{l}\text { Verz } \\
\text { Abs }\end{array}$ \\
\hline Anaesthesiologie & 11 & 11 & $\cdot$ & - & 22 & $65 \%$ & 34 \\
\hline Cardiologic & 10 & 5 & - & $\cdot$ & 15 & $39 \%$ & 39 \\
\hline Cardio-pulmonale chirurgie & 2 & 1 & 2 & - & 5 & $42 \%$ & 12 \\
\hline Dermatologie & 4 & 4 & - & - & 8 & $73 \%$ & 11 \\
\hline Heelkunde & 10 & 9 & 3 & - & 22 & $60 \%$ & 37 \\
\hline Intensive Care (agnio) & $\cdot$ & - & 0 & - & 0 & $0 \%$ & 1 \\
\hline Interne Geneeskunde (subtotaal): & 27 & 18 & $\cdot$ & 1 & 46 & $71 \%$ & 65 \\
\hline $\begin{array}{l}\text { - algemeen interne gen. } \\
\text { - endocrinologie } \\
\text { - gasto-entroilgaie } \\
\text { - geriatrie } \\
\text { - hematologie/oncologie } \\
\text { - nefrologie } \\
\text { - reumatologie } \\
\text { - niet nader gespecificeerd }\end{array}$ & $\begin{array}{l}2 \\
4 \\
4 \\
1 \\
6 \\
4 \\
4 \\
2\end{array}$ & $\begin{array}{l}\dot{1} \\
\dot{1} \\
\dot{1} \\
2 \\
13\end{array}$ & $\begin{array}{l}- \\
- \\
\dot{-} \\
\dot{.} \\
\dot{.}\end{array}$ & $\begin{array}{l}\dot{ } \\
\dot{-} \\
i \\
\dot{y}\end{array}$ & $\begin{array}{c}2 \\
5 \\
5 \\
1 \\
7 \\
5 \\
6 \\
15\end{array}$ & $\begin{array}{c}40 \% \\
71 \% \\
100 \% \\
100 \% \\
88 \% \\
83 \% \\
100 \% \\
56 \%\end{array}$ & $\begin{array}{c}5 \\
7 \\
5 \\
1 \\
8 \\
6 \\
6 \\
27\end{array}$ \\
\hline Keel-neus-oorheelkunde & 4 & 3 & - & $\cdot$ & 7 & $70 \%$ & 10 \\
\hline Kindergeneeskunde & 9 & 5 & 3 & - & 17 & $74 \%$ & 23 \\
\hline Longziekten & 5 & 4 & 1 & - & 10 & $77 \%$ & 13 \\
\hline Mondziekten en Kaakchirurgie & $\cdot$ & $\cdot$ & $\cdot$ & $\cdot$ & 0 & $0 \%$ & 2 \\
\hline Neurochirurgie & 4 & 1 & - & - & 5 & $71 \%$ & 7 \\
\hline Neurologie & 6 & 3 & 5 & 1 & 15 & $68 \%$ & 22 \\
\hline Obstetrie en Gynaecologie & 9 & 6 & $\cdot$ & $\cdot$ & 15 & $58 \%$ & 26 \\
\hline Oogheelkunde & 6 & 5 & $\cdot$ & - & 11 & $58 \%$ & 19 \\
\hline Orthopaedie & 7 & 7 & $\cdot$ & - & 14 & $88 \%$ & 16 \\
\hline Plastische chirurgie & $\cdot$ & 1 & $\cdot$ & - & 1 & $25 \%$ & 4 \\
\hline Revalidatic & 3 & 1 & $\cdot$ & - & 4 & $100 \%$ & 4 \\
\hline Urologie & 3 & 4 & $\therefore$ & $\therefore$ & 7 & $70 \%$ & 10 \\
\hline Totaal per functie absoluut & 120 & 88 & 14 & 2 & 224 & $63 \%$ & 355 \\
\hline Totaal per functie \% & $64 \%$ & $65 \%$ & $52 \%$ & $50 \%$ & $63 \%$ & & \\
\hline Totaal per functie verzonden & 188 & 136 & 27 & 4 & 355 & & \\
\hline
\end{tabular}

Legenda: Specespecialist, Ag(n)io=assistent geneeskundige (niet) in opleiding, Tot=totaal, Abs=absoluut, Verz"verzonden, gen. "geneeskunde. 


\begin{tabular}{|c|c|c|c|c|c|c|}
\hline Klinisch specialisme & $\begin{array}{c}\text { Spee } \\
(\mathrm{n}=120)\end{array}$ & $\underset{(n=87)}{\text { Agio }}$ & $\begin{array}{l}\text { Agnio } \\
(\mathrm{n}=14)\end{array}$ & $\begin{array}{c}\text { Overig } \\
(n=2)\end{array}$ & $\begin{array}{l}\text { Tot Abs } \\
(n=223)\end{array}$ & Tot \% \\
\hline Anaesthesiologic & 8 & 7 & $\cdot$ & - & 15 & $68 \%$ \\
\hline Cardiologie & 6 & 4 & - & * & 10 & $67 \%$ \\
\hline Cardio-pulmonale chirurgie & 2 & $\cdot$ & 2 & - & 4 & $80 \%$ \\
\hline Dermatologie & 4 & 4 & - & - & 8 & $100 \%$ \\
\hline Heelkunde & 10 & 9 & 2 & - & 21 & $96 \%$ \\
\hline Inteme Geneeskunde (subtotaal): & 25 & 13 & - & 1 & 39 & $87 \%$ \\
\hline $\begin{array}{l}\text { - algemeen interne gen. } \\
\text { - endocrinologic } \\
\text { - gastro-enterologie } \\
\text { - geriatric } \\
\text { - haematologie/oncologie } \\
\text { - nefrologie } \\
\text { - reumatologie } \\
\text { - niet nader gespecificeerd }\end{array}$ & $\begin{array}{l}2 \\
4 \\
3 \\
1 \\
6 \\
4 \\
4 \\
1\end{array}$ & $\begin{array}{l}\dot{1} \\
1 \\
1 \\
i \\
2\end{array}$ & $\dot{:}:$ & $\dot{:}:$ & $\begin{array}{l}2 \\
5 \\
4 \\
1 \\
7 \\
5 \\
6 \\
9\end{array}$ & $\begin{array}{l}100 \% \\
100 \% \\
80 \% \\
100 \% \\
100 \% \\
100 \% \\
100 \% \\
64 \%\end{array}$ \\
\hline Keel-neus-oorheelkunde & 4 & 2 & - & - & 6 & $86 \%$ \\
\hline Kindergeneeskunde & 9 & 5 & 1 & - & 15 & $88 \%$ \\
\hline Longziekten & 5 & 3 & - & * & 8 & $80 \%$ \\
\hline Neurochirurgic & 2 & 1 & - & * & 3 & $60 \%$ \\
\hline Neurologie & 5 & 2 & 5 & - & 12 & $80 \%$ \\
\hline Obstetrie en Gynaecologie & 7 & 5 & - & - & 12 & $80 \%$ \\
\hline Oogheelkunde & 3 & 4 & - & - & 7 & $64 \%$ \\
\hline Orthopacdie & 7 & 6 & - & - & 13 & $93 \%$ \\
\hline Revalidatie & 3 & - & - & - & 3 & $75 \%$ \\
\hline Urologie & 3 & 3 & $\therefore$ & - & 6 & $86 \%$ \\
\hline Totaal per functie absoluut & 103 & 68 & 10 & 1 & 182 & $82 \%$ \\
\hline Totaal per functic \% & $86 \%$ & $77 \%$ & $71 \%$ & $50 \%$ & $82 \%$ & \\
\hline
\end{tabular}

Legenda: Spec-specialist, Ag(n)iomassistent geneeskundige (niet) in opleiding. Tot Abs / Tot \%-totale absolute I totale percentuele aantal respondenten dat met de naam bekend was, gen -geneeskunde.

Tabel B9.4 Informatiebehoefte naar soon

\begin{tabular}{lcc}
\hline Omschrijving informatiebehoefte & Frequentie & Percentage \\
Nee & 111 & $50 \%$ \\
Ja, niet nader gespecificeerd & 37 & $17 \%$ \\
Algemeen & 35 & $16 \%$ \\
Soorten infusen & 13 & $6 \%$ \\
Relevantie eigen vakgebied & 9 & $4 \%$ \\
Aanmelding & 8 & $3 \%$ \\
Overig: uitvoering, criteria, etc & 7 & $3 \%$ \\
Onbekend & 3 & $1 \%$ \\
Totaal & 223 & $100 \%$ \\
\hline
\end{tabular}




\section{Bijlagen bij hoofdstuk 10}

\section{Scholing}

\section{Bijlage 10.1: Oordeel van huisartsen over de ontvangen scholing}

Tabel B10.1 geeft de toename in deskundigheid door de scholing zoals de huisartsen die zelf aangeven plus het verschil tussen de door hen gewenste en behaalde deskundigheidstoename.

Tabel B10.1 Door huisartsen $(\mathrm{N}=25)$ bereikte scholingsniveau's (\%).

\begin{tabular}{lccc} 
& $\begin{array}{c}\text { Subcutaan } \% \\
\text { Toename in het deskundigheidsniveau van de huisartsen door de scholing (na-voor) }\end{array}$ & $\begin{array}{c}\text { Cntraveneus } \% \\
\text { Niet van tocpassing }\end{array}$ \\
Geen & 12 & 4 & 0 \\
I niveau & 20 & 16 & 28 \\
2 niveau's & 16 & 60 & 64 \\
Verschil tussen het door huisartsen behaalde en het door hen & gewenste deskandigheidsniveau (na-wens) \\
2 niveau's lager & 52 & 0 & 8 \\
1 niveau lager & 16 & 24 & 16 \\
Gelijk & 8 & 64 & 60 \\
1 niveau hoger & 68 & 8 & 16 \\
2 niveau's hoger & 8 & 4 & 0 \\
\hline
\end{tabular}

Legenda: "=dit percentage huisartsen gaf voor de scholing aan reeds het hoogste deskundigheidsniveau te bezitten; voor hen was bij deze meting geen toename mogelijk. 
Bijlage 10.2: Oordeel van TMVs over de ontvangen scholing

Elke scholingsmodule is beoordeeld op de cursusinhoud, de docent en de lesorganisatie (tabel B10.2). Het oordeel kan slecht (3), onvoldoende (4\%), voldoende (6), goed (7\%/2) of zeer goed (9) zijn. Daarnaast geeft elke TMV in een eindoordeel aan of de cursus volledig (10), grotendeels (7\%), ten dele (5) of niet $(0)$ aan de verwachtingen heeft voldaan. De getallen tussen haakjes zijn later toegekend om de resultaten te kunnen vergelijken. De laatste kolom geeft het groepsgemiddelde per onderdeel. Op de voorlaatste regel is het -op basis van de beoordeling van de afzonderlijke modulesberekende gemiddelde voor de totale scholing per cursist weergegeven, op de laatste regel het algemene eindoordeel. De scholing als geheel is door de TMVs als goed beoordeeld. Het onderdeel 'Perifere Infusie' is lager beoordeeld. Bij navraag blijkt dit grotendeels terug te voeren op de docent. Het door de TMVs gegeven eindoordeel komt goed overeen met het uit de onderdelen berekende gemiddelde.

Tabel B10.2 Oordeel van TMVs $(\mathrm{N}=5)$ over de scholing per onderdeel en in zijn geheel.

\begin{tabular}{|c|c|c|c|c|c|c|}
\hline & Cursist A & Cursist B & Cursist C & Cursist D & Cursist E & Totaal \\
\hline \multicolumn{7}{|c|}{ Medisch-technisch handelen } \\
\hline - cursusstof & 7,5 & 7,5 & 6,0 & 9,0 & 7,5 & 7,5 \\
\hline - docent & 9,0 & 7,5 & 7,5 & 9,0 & 7,5 & 8,1 \\
\hline - lesorganisatic & 9,0 & 7,5 & 7,5 & 9,0 & 7,5 & 8.1 \\
\hline \multicolumn{7}{|c|}{ Perifere infusie (subcutane en intraveneuse infusie) } \\
\hline • cursusstof & 6,0 & 7,5 & 6,0 & 7,5 & 7,5 & 6,9 \\
\hline - docent & 4,5 & 4,5 & 6,0 & 6,0 & 7,5 & 5,7 \\
\hline - lesorganisatic & 4,5 & 7,5 & 6,0 & 6,0 & 7,5 & 6,3 \\
\hline \multicolumn{7}{|c|}{ Centraalveneuse infusie (Port-A-Cath\$) } \\
\hline - cursusstof & 7,5 & 7,5 & 7,5 & 9,0 & 9,0 & 8,1 \\
\hline - docent & 9,0 & 7,5 & 7,5 & 9,0 & 9,0 & 8,4 \\
\hline - lesorganisatic & 9,0 & 7,5 & 7,5 & 9,0 & 9,0 & 8,4 \\
\hline \multicolumn{7}{|c|}{ Produkten en hulpmiddelen (pompen, etc) } \\
\hline - cursusstof & 7,5 & 9,0 & 7,5 & $\therefore$ & 9,0 & 8,3 \\
\hline - docent & 9,0 & 9,0 & 9,0 & $\therefore$ & 9.0 & 9,0 \\
\hline - lesorganisatie & 9,0 & 9,0 & 7,5 & $\therefore$ & 9,0 & 8,6 \\
\hline \multicolumn{7}{|c|}{ Aanleren van vaardigheden (instructie geven) } \\
\hline * cursusstof & 9,0 & 9,0 & 7,5 & 9,0 & 7,5 & 8,4 \\
\hline - docent & 9,0 & 9,0 & 7,5 & 9,0 & 7,5 & 8,4 \\
\hline - lesorganisatic & 9,0 & 9.0 & 7,5 & 9,0 & 7,5 & 8,4 \\
\hline \multicolumn{7}{|l|}{ Totaalscores } \\
\hline - berekend gemiddeide & 7,9 & 7,9 & 7,2 & 8,4 & 8,1 & 7,9 \\
\hline - eindoordeel cursist & 7,5 & 7,5 & 7,5 & 10,0 & 7,5 & 8,0 \\
\hline
\end{tabular}

Legenda: alle regels behalve de laatste 3:slecht 4\%:onvoldoende 6:voldoende 71/2: goed 9 zeer goed, laatste regel 0 :niet $2 \frac{1}{2}$ :ten dele $71 / 2$ :grotendeels 10 :volledig,"=cursusdeel niet bijgewoond. 


\section{Bijlagen bij hoofdstuk 11}

\section{Financiering}

\section{Bijlage 11.1: Prijzen van pompsystemen}

Tabel B11.1 geeft de begroting van materiaalkosten voor 120 infuusbehandelingen (1.065 infusiedagen; bij 200 behandelingen 1.775 infusiedagen) met een cassettepomp. De gewogen dagprijs is $f 90$. Tabel B11.2 bevat een kostprijsvergelijking van een cassette-, een elastomeer- en een veerpomp bij een maximum dagprijs van $f 90$.

Tabel B11.1 Begroting materiaalkosten van 120 infuusbehandelingen exclusief medicatic (guldens).

\begin{tabular}{lccccc}
\hline Medicatie & Per dag & Aantal dagen & Per behandeling & Aantal patiēnten & Begroot \\
Cytostatica & 100 & 6 & 600 & 30 & 18.000 \\
Morfine & 75 & 20 & 1.500 & 25 & 37.500 \\
Voeding & 125 & 4 & 500 & 30 & 15.000 \\
Antibiotica & 95 & 7 & 665 & 15 & 10.000 \\
Heparine & 95 & 8 & 750 & 20 & 15.000 \\
\hline Totaal & $90^{\prime}$ & $9^{\prime}$ & $796^{1}$ & 120 & 95.500 \\
\hline
\end{tabular}

Legenda: '=gewogen gemiddelde.

Tabel B11.2 Prijzen pompsystemen per stuk: apotheek inkoopprijs inclusief BTW (guldens).

\begin{tabular}{lrcc} 
Soort pompsysteem & & Reservoir + pomp + draagtas & Rest infuusmateriaal + vullen \\
Cassettepomp' & & $63,87+5,42+0,19$ & 20,52 \\
Elastomeerpomp & gift $^{2}$ & $77,91 / 64,13+0,00+0,00$ & $12,09 / 25,87$ \\
& 24 uur $^{3}$ & $95,40+0,00+0,00$ & $-5,40$ \\
Veerpomp & gift $^{\text {' }}$ & $38,19+1,83+0,73$ & 49,25 \\
& 24 uur $^{3}$ & $57,24+8,83+0,73$ & 23,20 \\
\hline
\end{tabular}

Legenda: "-dit bedrag resteert voor alle overige benodigde infuusmaterialen inclusief het vullen van de systemen door de apotheker maar exclusief medicatie en infuusvloeistof.

ImPharmacia Deltec CADD 18 cassette $50 \mathrm{ml}+$ extensielijn $152 \mathrm{~cm}$ rechtstreeks via Pharmacia betrokken; pomphuur berekend $f 9900$ aanschafprijs plus technisch onderhoud 5 jaar via Minigas liniaire afschrijving op 1.826 dagen (utilisatie $100 \% 1$ ); draagtas $f 69,90$ liniaire afschrijving op 365 dagen (1995 prijzen).

2=Homepump\$ A2002 $100 \mathrm{ml}, 100 \mathrm{ml} / \mathrm{u}$ minimumafname 24 stuks voor $f 1.869,84$ in 1995 minimumafname 12 stuks voor $f 769,56$ in 1996; draagtas gratis.

=Homepump $\$$ A2007 $100 \mathrm{ml}, 5 \mathrm{ml} / \mathrm{u}$ minimumafname 24 stuks voor $f 2.289,60$; draagtas gratis (1996 prijs).

-Sidekick $100 \mathrm{ml}, 100 \mathrm{ml} / \mathrm{u}$ systeem via Spruyt Hillen minimumafname 5 stuks; eenmalige aanschaf pompdoos Sidekick\$ $f 55$ plus draagtas $f 22$ beide liniair afgeschreven op 30 dagen (1994 prijzen).

=Paragon $100 \mathrm{ml}, 4 \mathrm{ml} / \mathrm{u}$ systeem via Spruyt Hillen minimumafname 5 stuks; eenmalige aanschaf pompdoos Paragon $\delta 265$ plus draagtas $f 22$ beide liniair afgeschreven op 30 dagen (1994 prijzen). 
Bijlage 11.2: Bijdrage aan zorgverlening vanuit project

Tabel B11.3 geeft de oorspronkelijke, tabel B11.4 de gewijzigde projectbegroting.

Tabel B11.3 Bijdrage aan zorgverlening volgens oorspronkelijke projectbegroting (guldens), ${ }^{\text {in }}$

\begin{tabular}{lcccc}
\hline $\begin{array}{l}\text { Kosteapost } \\
\text { Huisartsen, wijkverpleegkundigen, }\end{array}$ & Jaar I & Jaar II & Jaar III & Totaal \\
gezinsverzorgenden & 50.000 & 100.000 & 50.000 & 200.000 \\
Deskundigheidsbevordering & 16.000 & 4.000 & 4.000 & \\
Coordinator 0,5 & 40.000 & 40.000 & 40.000 & 24.000 \\
Totaal & 106.000 & 144.000 & 94.000 & 120.000 \\
\hline
\end{tabular}

Tabel B11.4 Bijdrage aan zorgverlening volgens gewijzigde projectbegroting (guldens),

\begin{tabular}{|c|c|c|c|c|c|}
\hline Kostenpost & Jaar 1 & Jaar II & Jaar III & Jaar IV & Totaal \\
\hline Basisaanstelling TMVs $4 \times 0,1^{\prime}$ & $\therefore$ & 40.000 & 40.000 & 40.000 & 120.000 \\
\hline Deskundigheidsbevordering TMVs² & 10.000 & - & - & - & 10.000 \\
\hline Investeringen' & $*$ & 10.000 & - & - & 10.000 \\
\hline $\begin{array}{l}\text { Coordinator medisch } 0,3^{*} \\
\text { Coordinator verpleegkundig } 0,1^{4} \\
\text { Secretaresse } 0,25^{\circ}\end{array}$ & $\begin{array}{r}24.000 \\
8.000 \\
12.500\end{array}$ & $\begin{array}{r}24.000 \\
8.000 \\
12.500\end{array}$ & $\begin{array}{r}24.000 \\
8.000 \\
12.500\end{array}$ & $\begin{array}{r}24.000 \\
8.000 \\
12.500\end{array}$ & $\begin{array}{l}96.000 \\
32.000 \\
50.000\end{array}$ \\
\hline Materieel naar rato ${ }^{4}$ & 4.200 & 4.200 & 3.600 & 3.600 & 15.600 \\
\hline Totaal & 58.700 & 98.700 & 88.100 & 88.100 & 333.600 \\
\hline Reservering onvoorzien & $\cdot$ & 5.000 & 5.000 & 5.000 & 15.000 \\
\hline
\end{tabular}

Legenda: $=7 \times 24$-uurs bereikbaarheidsdienst inclusief wekelijks werkoverleg, ${ }^{2}=$ details hoofdstuk 10 ,

'secomputer $\beta 3.000$, faxen $f 2.300$, semafoons $f 1.600$, afvalboxen $f 1.250$, inhoud koffers TMVs $f 700$, steekwagens $f 400$, overig $f 750, "=$ zorgcoordinatic naar rato van verhouding zorgverlening en onderzoek verdeeld: alleen de zorgverlening is weergegeven.

Bijlage 11.3: Kostenraming morfine- en mannitolbehandeling

Tabel B11.5 geeft de kostenraming van de morfine- en de mannitolbehandeling gebaseerd op een behandelduur van respectievelijk 10 en 7 dagen. ${ }^{61}$

Tabel B11.5 Kostenraming per morfine- en mannitolbehandeling (guldens).

\begin{tabular}{|c|c|c|}
\hline & Subcutane infusie morfine 10 dagen & Intraveneute infusie mannitol 7 dagen \\
\hline Kostensoort & Berekening $\quad$ Bedrag & Berekening Bedrag \\
\hline TMV zorguren & $\begin{array}{l}\text { intake } 2 \text { uur }+9 \text { dagen } 40 \\
\text { minuten; } 55 \text { per uur }\end{array}$ & $\begin{array}{l}\text { intake } 2 \text { uur }+18 \text { bezoeken } \\
\text { van } 1 \text { uur, } 55 \text { per uur }\end{array}$ \\
\hline Huisartsconsult & $\begin{array}{l}8 \text { weekvisites a } 30 \text { en } 2 \\
\text { weekendvisites a } 60 \mathrm{ITZ}\end{array}$ & $\begin{array}{l}3 \text { weekvisites a } 30 \text { en } 1 \\
\text { weekendvisites a } 60 \text { ITZ }\end{array}$ \\
\hline Dagcentrum & Niet nodig & Proefdosis a 375 \\
\hline Medicatie & Dagdosis $\neq 20 \mathrm{mg}$ & Mannitol $10 \%$ azM \\
\hline Infuusmateriaal & Standaardpakket apotheek & Standaardpakket azM \\
\hline $\begin{array}{l}\text { Infuusstandaard en } \\
\text { pomp }\end{array}$ & $\begin{array}{l}\text { Huur standaard } 8 \text { per week; } \\
\text { halen en bezorgen } 5\end{array}$ & $\begin{array}{l}\text { Huur standaard } 8 \text { per week; } \\
\text { halen en bezorgen } 5\end{array}$ \\
\hline Afval & Per patient 25 & Per patient 25 \\
\hline Administratic & Per patient 100 & Per patient 100 \\
\hline Totaal & 1.300 & 2.075 \\
\hline
\end{tabular}




\section{Bijlage 11.4: Berekening effect van technologiekeuze}

Tabel B11.6 geeft het verschil tussen de gerealiseerde en de oorspronkelijk geplande technologie (\$11.2). Eerst is het variabele deel van de materiêle kosten op basis van de individuele kostenoverzichten van 2.591 infusiedagen ( 173 behandelingen) weergegeven. Vervolgens zijn de kosten terug gerekend naar de oorspronkelijk geplande technologie. Hierbij golden de volgende aannamen: 1) Alle toegediende medicatie kan per cassettepomp toegediend worden; 2) Per infusiedag zouden één cassette en pomp benodigd zijn, behalve bij de dopamine/lasix infusie twee; 3) De kosten van de cassettepomp plus materialen zijn geschat op $f 90$ per dag plus 3 uur instructie à $f 262,50$ bij de eerste behandeling van een patiënt $(\$ 11.2) ; 4)$ De overige kosten blijven gelijk.

Tabel B11.6 Materiele kosten van parenterale thuisbehandelingen (guldens).

\begin{tabular}{|c|c|c|c|c|c|c|}
\hline Kostensoort & SI morf & IV man & IV ab & CV dola & Overig & Totaal \\
\hline \multicolumn{7}{|l|}{ Gerealiseerde technologie } \\
\hline Infuusmateriaal ${ }^{*}$ & 12.380 & 1.684 & 15.944 & 71.271 & 11.657 & 113.038 \\
\hline CADD $1 \%$ pomp & • & - & - & 19.903 & - & 19.903 \\
\hline IVAC 5910 pomp & 175 & 1.425 & 2.005 & - & 555 & 4.160 \\
\hline Infuusstandaard & 1.008 & 680 & 632 & • & 248 & 2.568 \\
\hline Totaal & 13.563 & 3.789 & 18.581 & 91.174 & 12.460 & 139.669 \\
\hline \multicolumn{7}{|l|}{ Geplande technologie } \\
\hline Cassettepomp & 57.060 & 28.980 & 45.090 & 150.480 & 26.820 & 308.430 \\
\hline Instructie & 14.700 & 7,350 & 3.938 & 2.363 & 3.938 & 32.288 \\
\hline Totaal & 71.760 & 36.330 & 49.028 & 152.843 & 30.758 & 340.718 \\
\hline Verschil inclusief instructic & 58.197 & 32.541 & 30.447 & 61.669 & 18.298 & 201.049 \\
\hline Verschil exclusief instructie & 43.497 & 25.191 & 26.509 & 59.306 & 14.360 & 168.761 \\
\hline Totaal aantal dagen infusic & 634 & 322 & 501 & 836 & 298 & 2.591 \\
\hline
\end{tabular}

Legenda: "-inclusief disposable pompreservoirs.

Op de aannamen is kritiek mogelijk. Ten eerste zouden niet alle behandelingen via een cassette (maximum $200 \mathrm{ml}$ ) op een pomp mogelijk zijn (aanname 1). Bijvoorbeeld 1 à 2 liter mannitol of vocht. Deze zouden met een infuusstandaard en infuuszakken dienen te worden toegediend. De cassettepomp zou als gewone infuuspomp functioneren. Ook zou niet in alle gevallen een cassette per dag nodig zijn (aanname 2). Bij de morfinebehandeling zou langer met één cassette kunnen worden toegekomen. Anderzijds werd bij deze terminale patiênten vaak de morfinedosis verhoogd, medicatie aan het infuus toegevoegd en enige hydratie bewerkstelligd door de $500 \mathrm{ml} \mathrm{NaCl} 0,9 \%$ waarin deze opgelost waren. Ook diverse antibiotica die in combinatie in giften zijn gegeven mochten niet met elkaar gemengd worden of 24 uur van te voren opgelost worden. De kostprijzen zijn vergeleken met een offerte van een facilitair bedrijf en zouden in werkelijkheid zowel hoger als lager kunnen zijn. Kosten voor instructie zijn natuurlijk ook binnen het project gemaakt. Toch zijn deze hier extra opgevoerd omdat toepassing van cassettepompen bij patiēnten met hartfalen een ruimere instructie vereiste. Wordt bij de berekening van het verschil de instructie niet meegerekend dan daalt het verschil met 16\%. Dat personeelskosten gelijk blijven (aanname 4 ) is moeilijk te onderbouwen. Een aantal bezoeken van de arts en verpleegkundige zou door de geautomatiseerde toediening overbodig kunnen zijn. Anderzijds bleek het aansluiten en instellen van een cassettepomp in de praktijk langer te duren in vergelijking van toepassing van andere infuustechnieken. Voorts was de techniek minder gemakkelijk over te dragen naar andere (professionele) zorgverleners. Tevens was het verwisselen van de infuuszak of cassette maar één van de redenen voor een bezoek van de verpleegkundige of arts. 
Bijlage 11.5: Berekening effecten technologie- en financieringskeuzen

Tabel B11.7 geeft de effecten van technologie-en financieringskeuzen (toelichting \$11.5) voor de verzekeraars (Verz), het project Infuusbehandeling Thuis (IT) en het azM.

Tabel B11.7 Effecten van technologie- en financieringskeuzen (guldens).

\begin{tabular}{|c|c|c|c|c|c|c|c|}
\hline \multirow{2}{*}{\multicolumn{2}{|c|}{ Gekozen technologie }} & \multirow{2}{*}{\multicolumn{3}{|c|}{$\begin{array}{l}\text { Gekosen financiering } \\
\text { Gerealiseerd in project }\end{array}$}} & \multirow{2}{*}{\multicolumn{3}{|c|}{$\begin{array}{c}\text { Voorsiene financiering } \\
\text { Scenario III }\end{array}$}} \\
\hline & & & & & & & \\
\hline & Kosten & Verz & $\mathbf{I T}$ & $\mathbf{a z M}$ & Verz & $\mathbf{I T}$ & $\mathbf{a z} \mathbf{M}$ \\
\hline Basis TMVs' & 123.800 & & 123.800 & & & 123.800 & \\
\hline TMV zorguren & 265.155 & 265.155 & & & 217.655 & 47.500 & \\
\hline Huisartsconsult & 37.601 & 37.601 & & & 37.601 & & \\
\hline Zorgcoordinatic & 38.700 & & 38.700 & & & 38.700 & \\
\hline Dagcentrum & 11.250 & & & 11.250 & $11.250^{\circ}$ & & \\
\hline EHBO & 3.464 & 3.464 & & & $3.464^{6}$ & & \\
\hline \multicolumn{8}{|c|}{ Declaratic SGKH ${ }^{2} 9.083$} \\
\hline Personeel & 489.053 & 306.220 & 162.500 & 11.250 & 269.970 & 210.000 & 0 \\
\hline Medicatie & 112.490 & 112.490 & & & 112.490 & & \\
\hline Infuusmateriaal' & 113.038 & 91.038 & & 22.000 & 113.038 & & \\
\hline CADD 10 pomp & 19.903 & 19.903 & & & 19.903 & & \\
\hline IVAC 5910 pom! & 4.160 & 4.160 & & & 4.160 & & \\
\hline Infuusstandaard ${ }^{*}$ & 2.568 & 568 & & & 568 & & \\
\hline Afval & 5.275 & & & 5.275 & 5.275 & & \\
\hline Materieel & 257.434 & 228.159 & 0 & 27.275 & 255.434 & 0 & 0 \\
\hline Totaal $^{24}$ & 746.487 & 534.379 & 162.500 & 38.525 & $525.404^{7}$ & 210.000 & 0 \\
\hline \multicolumn{2}{|c|}{ Voorziene technologie } & \multicolumn{3}{|c|}{ Scenario II } & \multicolumn{3}{|c|}{ Scenario I } \\
\hline & Kosten & Verz & IT & $\mathbf{a z M}$ & Verz & IT & azM \\
\hline Basis TMVs ${ }^{1}$ & 123.800 & & 123.800 & & & 123.800 & \\
\hline TMV zorguren & 265.155 & 265.155 & & & 249.943 & 15.212 & \\
\hline Pompinstructie & 32.288 & 32.288 & & & & 32.288 & \\
\hline Huisartsconsult & 37.601 & 37.601 & & & 37.601 & & \\
\hline Zorgcoordinatie & 38.700 & & 38.700 & & & 38.700 & \\
\hline Dagcentrum & 11.250 & & & 11.250 & $11.250^{6}$ & & \\
\hline EHBO & 3.464 & 3.464 & & & $3.464^{6}$ & & \\
\hline \multicolumn{8}{|c|}{ Declaratie SGKH ${ }^{2} 9.083$} \\
\hline Personeel & 521.341 & 338.508 & 162.500 & 11.250 & 302.258 & 210.000 & 0 \\
\hline Medicatic & 112.490 & 112.490 & & & 112.490 & & \\
\hline Infuusmateriaal $^{s}$ & 308.430 & 286.430 & & 22.000 & 112.891 & & 195.539 \\
\hline Afval & 5.275 & & & 5.275 & 5.275 & & \\
\hline Materiecl & 426.195 & 398.920 & 0 & 27.275 & 230.656 & 0 & 195.539 \\
\hline Totaal $^{2}$ & 947.536 & 737.428 & 162.500 & 38.525 & $532.914^{?}$ & 210.000 & 195.539 \\
\hline
\end{tabular}

Legenda: $=2$ jaar: $f 80.000$ bereikbaarheid, $f 16.000$ verpleegkundig specialist, $f 17.800$ materieel, $f 10.000$ scholing. ${ }^{2}=$ de SGKH financierde de declaraties a $/ 9.083$, ${ }^{2}=$ inclusief disposable pompreservoirs, ${ }^{4}=$ de SGKH finaneierde de infuusstandaard van leden a $f 2.000,{ }^{1}=$ CADD 18 pomp plus alle infuusmateriaal, 4 -kosten dagcentrum en EHBO bij voorziene financiering in regulier budget, '-maximaal ITZ-budget $f 518.200+$ regulier budget $f 11.250+f 3.464$ is maximaal totaal budget van $f 532.914$. 


\section{Bijlage 11.6: Resultatenrekeningen van het azM en de SGKH}

Tabel B11.8 geeft de resultatenrekeningen van het azM en tabel B11.9 van de SGKH over de jaren waarin het project Infuusbehandeling Thuis is uitgevoerd.

Tabel B11.8 Resultatenrekeningen academisch ziekenhuis Maastricht 1993-1995, ${ }^{\text {19 }}$

1993

1994

1995

Lasten

Salarissen

$\begin{array}{r}144.587 .767 \\ 43.133 .108 \\ 3.842 .819 \\ 6.404 .297 \\ 15.815 .351 \\ 51.519 .604 \\ 8.551 .930 \\ 81.380 .977 \\ 1.903 \\ \hline\end{array}$

145.568 .862

52.896 .339

3.753 .027

Voeding

Andere hotelmatige kosten

6.663 .742

16.869 .464

Algemeen

53.839 .011
11.571 .388

Terrein en gebouwen

Afschrijving, huur, lease

80.486 .765

Andere

Voordelig saldo

4.273

153.763 .630

Baten

Wettelijk budget

249.463.000

Rijksbijdrage

92.612 .492

7.789 .110

4.805 .473

Afschrijving

211.849

355.832

259.248 .000

91.107 .269

8.400 .703

4.775 .080

$-3.331 .248$

Nadelig saldo

11.453 .067

Totaal

355.237 .756

371.652 .871

47.360.447

3.699 .195

7.828 .285

18.052 .287

57.160 .102

11.986 .491

80.584 .298

53.770

1.310 .949

270.226 .000

94.079 .911

7.618 .558

4.701 .012

5.173 .973

381.799 .454

Tabel B11.9 Resultatenrekeningen Stichting Groene Kruis Heuvelland 1993-1995 200

1993

1994

1995

Lasten

Salarissen en beloningen

13.509.136

12.982 .000

13.815 .000

Overige personele kosten

1.014.032

Huisvestingskosten

798.723

1.882 .000

2.401 .000

Rente en afschrijvingskosten

1.047 .480

915.000

1.052 .000

Materiaalkosten

Algemene kosten

-

880.000

838.000

$-20.000$

$-62.000$

Voordelig saldo

193.307

2.082 .000

395.000

2.027 .000

331.000

Baten

Contributies

2.034 .166

2.379.000

2.369 .000

36.708

38.000

44.000

110.892

141.000

Huren

69.527

150.000

303.803

388.000

527.000

6.000

Overige baten

3.774 .166

3.791 .000

988.000

Omzet kraam

11.874 .677

12.229 .000

3.830 .000

AWBZ

18.203.939

19.116 .000

12.638 .000

Totaal

18.203 .939

20.402 .000 


\title{
Keuze en toepassing thuiszorgtechnologie: de infuusbehandelingen
}

\author{
Bijlage 12.1: Aanpassingen op het Wijk Administratie Systeem \\ Het wijkadministratiesysteem ' 92 (WAS) is aangepast om infuuszorg ten behoeve van \\ infuusbehandeling thuis te kunnen scheiden van reguliere wijkzorg: \\ - Er zijn cliēntgerichte WAS-registratieformulieren gebruikt; \\ - Activiteiten voor infuusbehandeling zijn met cen casusnummer gescheiden van reguliere wijkzorg: \\ - Verschillende soorten activiteiten vallend binnen één huisbezoek zijn per activiteit geregistreerd; \\ - Door een aparte functionariscode zijn TMVs gescheiden van gewone wijkverpleegkundigen; \\ - De reistijd is aangegeven via een aparte code om te voorkomen dat deze in de totaalcijfers van \\ zorgverlening werd opgenomen; \\ - (Medisch-technische) handelingen bij infuusbehandeling thuis zijn verder gespecificeerd;
}

Sommige bestaande WAS-codes zijn anders, andere zijn niet gebruikt (schema's B $12,1.1+B 12,1,2$ ).

Schema B12.1.1 Interpretaties bij de WAS instructie bij rubriek 25 en 26.

\section{Code Omschrijving}

Codes die in rubriek 25 anders gebruikt of toegelicht zijn

10-96 Uitvoering van verpleegkundige interventies bij infuusbehandeling thuis en zo nodig uitvoering van overige verpleegkundige zorg plus het bijhouden van de bijbehorende rapportage

20 MTH-algemeen: bij infuusbehandeling thuis verdere specificatic

40 of 50 Begeleiding en advisering van patient en naaste verzorger(s) met aandacht voor de kwaliteit van leven van de patient

61 Voorlichting, instructic algemeen wordt wanneer niet betrekking hebbend op infuusbehandeling thuis gerekend tot individuele GVO

81 Onderlinge patientenoverdracht

81-85 Discipline- en organisatie overstijgend overleg en afstemming met betrokken zorgverieners Coordinatie zorgverlening

Zorg voor een soepele overdracht tussen $1^{\prime}$ en $2^{\circ}$ lijn / voorbereiden thuiskomst

91 Het voeren van een intake-gesprek met patienten die voor infuusbehandeling thuis in aanmerking wensen te komen en hun naaste verzorger(s): anamnese afnemen, afchecken van de voorwaarden voor infuusbehandeling thuis, verpleegkundige diagnose(s) stellen, verpleegdoelen en interventies bepalen en plannen, evaluatiemomenten afspreken plus het vastleggen van dit alles in het zorgplan

92 Intake-activiteiten, patient uiteindelijk niet in zorg

97 Evaluatie van verpleegkundige interventies en verpleegdoelen en zo nodig bijstelling van de zorg plus het bijhouden van de bijbehorende rapportage

99 Reistijd

$1 x$ invullen (heenreis) als vanuit de patient naar een volgende patient gegaan wordt. Bij de volgende patient wordt de tussenliggende reis als heenreis ingevuld

$2 \mathrm{x}$ invullen (heen-en terugreis) als vanuit de patient weer naar huis gegaan wordt. Voor vertrek wordt voor de terugreis dan hetzelfde ingevuld als voor de heenreis

Codes die in rubriek 26 niet gebrutkt mochten worden

209 Toedienen van een hypodermoclyse

211 Assisteren bij toediening intraveneus infuus

256 Voorbereiden en assisteren bij het uitvoeren van het aanleggen van een intraveneus infuus 
Codes die in rubriek 26 toegevoegd sijn als specificatie van code 20 in rubriek 25

270

271

272

273

274

\title{
Subcutane Infusie
}

Instructie subcutaan infuus patiênt/naaste verzorgers

Instructie subcutaan infuus wijkverpleegkundige Instructie subcutaan infuus huisarts Voorbereiden en inbrengen subcutaan infuus Tijdelijk aan- en afkoppelen subcutaan infuus Verwijderen subcutaan infuus

\section{Perifere Infusie}

Instructic perifeer infuus patient/naaste verzorgers Instructie perifeer infuus wijkverpleegkundige Instructic perifeer infuus huisarts Voorbereiden van/assisteren bij inbrengen perifeer infuus Tijdelijk aan- en afkoppelen perifeer infuus en hepariniseren Verwisselen perifeer infuussysteem Verwijderen perifeer infuus

\section{Centraal Veneuze Infusie}

Instructie centraal veneuze poort patient/naaste verzorgers

Instructie centraal veneuze poort wijkverpleegkundige Voorbereiden en aanprikken centraal veneuze poort Verwisselen centraalveneus infuussysteem Afkoppelen centraal veneuze poort Hepariniseren (doorspuiten) centraal veneuze poort

\author{
Algemeen \\ Verzorgen insteekopening \\ Aansluiten/verwisselen infuuszak/fles/cassette plus klaarmaken medicatie \\ Installeren infusiepomp \\ Zorgdragen voor verpleeghulpmiddelen \\ Zorgdragen voor infuusbenodigdheden (medicatie en infuusmaterialen) \\ Consult patient/naaste verzorgers t.a.v. infuusbehandeling bij patient in zorg \\ Consult zorgverleners t.a.v. infuusbehandeling bij patient in zorg \\ Consult patient/naaste verzorgers t.a.v. infuusbehandeling bij patient niet in zorg \\ Consult zorgverleners t.a.v. infuusbehandeling bij patient niet in zorg \\ Afvalverwerking \\ Evaluatic zorg
}

Legenda: t.a.v. $=$ ten aanzien van. 


\section{Bijlage 12.2: Subcutane infusie van morfine}

\section{Noot 12.2.1:}

Het kan een dankbare periode zijn. Zo hebben patiènten een bedrijfsjubileum gevierd of zijn met de familie gaan picknicken. Eén patiěnt was ten tijde van de instroom stervende, maar wilde perse naar huis en is dan ook binnen enkele uren overieden. Vanuit professioneel oogpunt woog de belasting van het vervoer en het opstarten van IT niet op tegen de 'winst' van het thuis sterven, maar is deze wens gerespecteerd.

Vanwege het overzicht geeft tabel B12.2.1 de instroom van alle terminale patiênten weer. Het tweede deel van het schema bevat de onderverdeling van de behandelde patiēnten naar soort infusie.

Tabel B12.2.1 Instroom terminale patienten

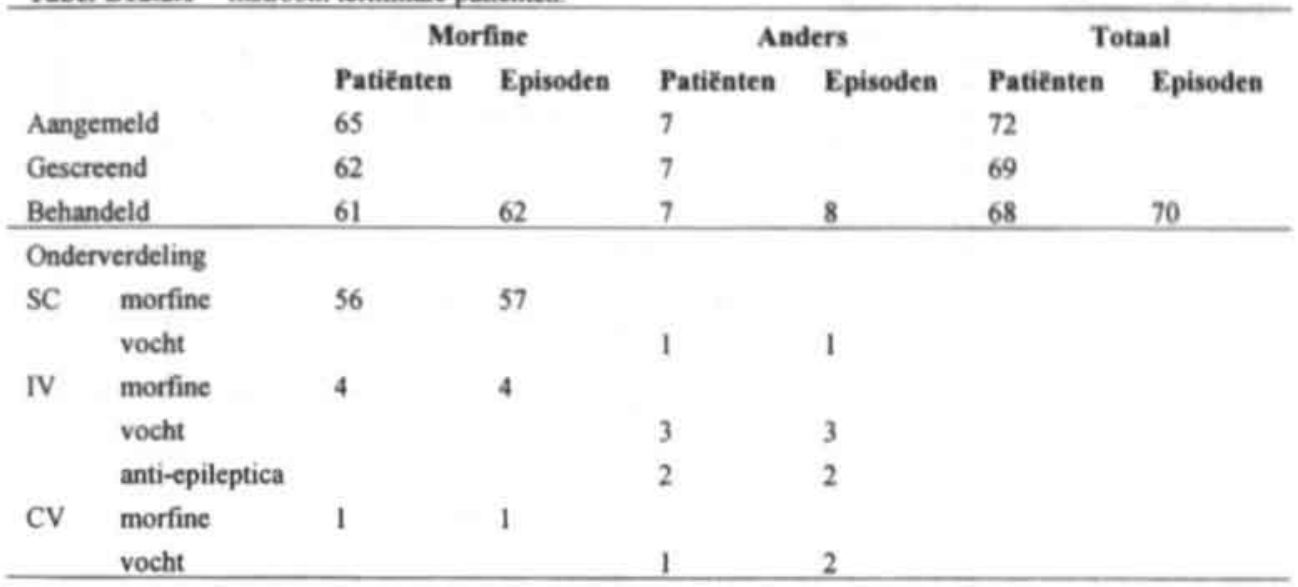

Legenda: $\mathrm{SC}=$ subcutaan, $\mathrm{IV}=$ intraveneus, $\mathrm{CV}=$ centraalveneus. 
Tabel B12.2.2 geeft enkele kenmerken van de kankerpatiënten in deze studie.

Tabel B12.2.2 Kanker bij mannen en vrouwen per orgaansysteem.

\begin{tabular}{|c|c|c|c|}
\hline Orgaansysteem* & Tumor: omschrijving (metastasen) + comorbiditeit & $\sigma^{\circ}$ & \& \\
\hline Centraal zenuwstelsel & astrocytoom graad IV $1 x^{6}$ & 3 & \\
\hline Ademhalingstelsel & $\begin{array}{l}\text { bronchus: grootcellig (supracl. lymfe, hersenen) + hartinfaret } \\
\text { bronchus (diffuus, hersenen) + longoedeem + ascites } \\
\text { long: grootcellig (rug, hersenen) } \\
\text { long: kleincellig (lymfe, hersenen) } \\
\text { long (lever, hersenen) + links verlamd } \\
\text { long (lever, hersenen) + ascites } \\
\text { long (n.n.o.) } \\
\text { status na resectie linker long (bot, wervelkolom) } \\
\text { long (bot) }\end{array}$ & $\begin{array}{l}1 \\
1 \\
1 \\
1 \\
1 \\
2\end{array}$ & i \\
\hline Spijsverteringstelsel & $\begin{array}{l}\text { tong (lokaal) } \\
\text { oesofagus (lever) } \\
\text { oesofagus } \\
\text { maag (lever) } 1 \text { o }^{4} x^{+} \\
\text {maag (lever, hersenen) + rechts verlamd na CVA } \\
\text { maag + mechanische ileus } \\
\text { pancreasstaart + ingroei in maag } \\
\text { pancreaskop } \\
\text { pancreaskop (lever) } \\
\text { pancreaskop (n.n.o.) + mechanische ileus } \\
\text { pancreas (maag, buik) } \\
\text { caecum (lever, peritoneum) + mechanische ileus } \\
\text { colon (diffuus, lever) + mechanische ileus }{ }^{2} \\
\text { colon (long) } \\
\text { colon (lever) } \\
\text { sigmold (beide longen, bot, huid) } \\
\text { sigmold (lever) + ascites } \\
\text { rectum (lever, peritoneum, bot) + diabetes } \\
\text { rectum (lever) } \\
\text { rectum met lokaal recidief } \\
\text { primair onbekend: adeno (lever) } \\
\text { primair onbekend: adeno (lever) + ascites } \\
\text { primair onbekend: adeno (n.n.o.) + ascites } \\
\text { primair onbekend: adeno (n.n.o. } \\
\text { primair onbekend (hersenen, longen, bot) + maagperforatic' }\end{array}$ & $\begin{array}{l}1 \\
1 \\
1 \\
1 \\
1 \\
1 \\
1 \\
1\end{array}$ & $\begin{array}{l}1 \\
1 \\
2 \\
1 \\
1 \\
1 \\
1 \\
1 \\
1 \\
1 \\
1\end{array}$ \\
\hline Nier en urinewegen & $\begin{array}{l}\text { status na nefrectomie links: Grawitz (buik, longen) } \\
\text { blaas (bot) } \\
\text { blaas (n.n.o.) + maagbloeding }\end{array}$ & $\stackrel{1}{1+1}$ & 1 \\
\hline Geslachtsorganen & $\begin{array}{l}\text { cervix recidief } \\
\text { mamma (lever) } 1 x^{3} \\
\text { mamma (n.n.o.) } \\
\text { mamma (n.n.o. + pleuritis carcinomatosa } \\
\text { mamma (n.n.o.) + rheuma } \\
\text { ovarium (buik) + ascites + oedeem benen } \\
\text { ovarium stadium III (n.n.o) + ascites + oedeem benen/longen } \\
\text { ovarium (n.n.o.) + peritonitis carcinomatosa + ileus }{ }^{3} \\
\text { ovarium (n.n.o.) + ileus } \\
\text { prostaat : urotheel (bot) + pleuritis carcinomatosa } \\
\text { prostaat (n.n.o.) } \\
\text { prostaat (lever, bot) }\end{array}$ & $\begin{array}{l}1 \\
2 \\
1\end{array}$ & $\begin{array}{c}1 \\
2+1 \\
2 \\
1 \\
1 \\
1 \\
1 \\
1 \\
1\end{array}$ \\
\hline Bloed & $\begin{array}{l}\text { chronisch plus acute myeloride leukemie (bot) } \\
\text { acute lymfatische leukemic }\end{array}$ & 1 & \\
\hline Huid & $\begin{array}{l}\text { melanoom rechter bovenbeen (hele lichaam, longen) } \\
\text { melanoom (hersenen) }\end{array}$ & $\begin{array}{l}1 \\
1\end{array}$ & \\
\hline Overig & sinus maxillaris & 1 & \\
\hline Totaal & & $34+1$ & $31+1$ \\
\hline
\end{tabular}

Legenda: *volgens ICPC, $\sigma^{*}=$ mannen, $8=$ =vrouwen, n.n.o.=niet nader omschreven, $x+y=a a n t a l$ eerste + vervolgbehandelingen bij dezelfde patient, altijd subcutane infusie morfine behalve: ${ }^{1=i n t r a v e n e u s ~ m o r f i n e, ~}$ $2^{2}=$ centraalveneus morfine, ${ }^{m}=$ subcutaan vocht, $=$ intraveneus vocht, "mcentraalveneus vocht, ${ }^{6}=$ intravencus anti-epilcptica. 
Tabel B12.2.3 geeft enkele kenmerken van de morfine-infusies in deze studie.

Tabel B12.2.3 Enkele kemgetallen betreffende de morfine-infusies.

\begin{tabular}{|c|c|c|c|}
\hline Item & $\begin{array}{l}\text { Gehele groep } \\
\mathrm{N}=62^{\circ}\end{array}$ & $\begin{array}{l}\text { Kankerpatiênten } \\
\mathrm{N}=59^{\circ}\end{array}$ & $\begin{array}{l}\text { Subcutane infusic } \\
\mathrm{N}=57^{\circ}\end{array}$ \\
\hline mannelijk & $57 \%$ & $55 \%$ & $57 \%$ \\
\hline $\begin{array}{r}\text { bereik } \\
\text { gemiddelde } \\
\text { standaard deviatie } \\
25 / 50 / 75 \% \text { percentiel } \\
<40\end{array}$ & $\begin{array}{l}17-92 \\
62,0 \\
14,1 \\
55 / 62 / 72 \\
4,9 \%\end{array}$ & $\begin{array}{l}17-92 \\
61,5 \\
14,3 \\
55 / 62 / 69,5 \\
5,2 \%\end{array}$ & $\begin{array}{l}17-88 \\
61,5 \\
13,9 \\
55 / 62 / 70,5 \\
<5,4 \%\end{array}$ \\
\hline $\begin{array}{r}\text { Infusie in dagen } \begin{array}{r}\text { bereik } \\
\text { gemiddelde }\end{array} \\
\text { standaard deviatic }\end{array}$ & $\begin{array}{l}1-71 \\
11,0 \\
13,6 \\
2 / 6 / 16\end{array}$ & $\begin{array}{l}1-71 \\
11,4 \\
13,8 \\
2 / 6 / 16\end{array}$ & $\begin{array}{l}1-71 \\
11,1 \\
14,0 \\
2 / 6 / 16\end{array}$ \\
\hline $\begin{array}{r}\text { bereik } \\
\text { gemiddelde } \\
\text { standaard deviatic } \\
25 / 50 / 75 \% \text { percenticl }\end{array}$ & $\begin{array}{l}10-480 \\
72,3 \\
90,9 \\
20 / 40 / 82,5\end{array}$ & $\begin{array}{l}10-480 \\
74,2 \\
92,7 \\
20 / 40 / 90\end{array}$ & $\begin{array}{l}10-480 \\
75,1 \\
93,8 \\
20 / 40 / 85\end{array}$ \\
\hline $\begin{array}{rr}\text { Stopdosis in mg } & \begin{array}{r}\text { bereik } \\
\text { gemiddelde }\end{array} \\
\text { standaard deviatic }\end{array}$ & $\begin{array}{l}15-2.100 \\
230,9 \\
422,8 \\
40 / 70 / 200\end{array}$ & $\begin{array}{l}15-2.100 \\
241,3 \\
430,7 \\
40 / 70 / 200\end{array}$ & $\begin{array}{l}15-1.800 \\
210,5 \\
360,0 \\
40 / 70 / 200\end{array}$ \\
\hline $\begin{array}{r}\text { Toename ' in mg per dag } \begin{array}{r}\begin{array}{r}\text { bereik } \\
\text { gemiddelde }\end{array} \\
\text { standaard deviatic }\end{array} \\
25 / 50 / 75 \% \text { percentiel } \\
>10\end{array}$ & $\begin{array}{l}0-167 \\
11,0 \\
23,7 \\
0 / 5 / 10 \\
21,0 \%\end{array}$ & $\begin{array}{l}0-167 \\
11,4 \\
24,2 \\
0 / 5 / 10 \\
22,0 \%\end{array}$ & $\begin{array}{l}0-77 \\
8,8 \\
12,9 \\
0 / 5 / 10 \\
21,1 \%\end{array}$ \\
\hline $\begin{array}{r}\text { Toename }{ }^{1} \text { in percent per dag } \begin{array}{r}\text { bereik } \\
\text { gemiddelde }\end{array} \\
\text { standaard deviatic } \\
0 \\
>0 \text { en } \leq 10 \\
>10 \text { en } \leq 25 \\
>25\end{array}$ & $\begin{array}{l}0-210 \\
23,9 \\
39,5 \\
30,6 \% \\
14,6 \% \\
27,2 \% \\
24,2 \%\end{array}$ & $\begin{array}{l}0-210 \\
24,3 \\
40,1 \\
28,8 \% \\
15,3 \% \\
32,2 \% \\
23,7 \%\end{array}$ & $\begin{array}{l}0-210 \\
21,2 \\
35,3 \\
29,8 \% \\
15,8 \% \\
31,6 \% \\
22,8 \%\end{array}$ \\
\hline $\begin{array}{r}\begin{array}{l}\text { Stabiele toename }^{2} \text { in mg per dag bereik } \\
\text { gemiddelde }\end{array} \\
\text { standaard deviatic } \\
\leq 10 \\
>10 \text { en } \leq 50 \\
>50\end{array}$ & $\begin{array}{l}0-204 \\
19,8 \\
42,3 \\
68 \% \\
24 \% \\
8 \%\end{array}$ & $\begin{array}{l}0-204 \\
19,8 \\
42,3 \\
68 \% \\
24 \% \\
8 \%\end{array}$ & $\begin{array}{l}0-80 \\
12,7 \\
19,2 \\
68 \% \\
27 \% \\
5 \%\end{array}$ \\
\hline $\begin{array}{r}\text { Pijnvrije dagen in percent } \begin{array}{r}\begin{array}{r}\text { bereik } \\
\text { gemiddelde }\end{array} \\
\text { standaard deviatic }\end{array} \\
25 / 50 / 75 \% \text { percentiel } \\
<50\end{array}$ & $\begin{array}{l}0-100 \\
72,7 \\
25,7 \\
58 / 73 / 100 \\
12,1 \%\end{array}$ & $\begin{array}{l}0-100 \\
72,7 \\
25,7 \\
58 / 73 / 100 \\
12,1 \%\end{array}$ & $\begin{array}{l}0-100 \\
73,2 \\
26,2 \\
60 / 79 / 100 \\
13,2 \%\end{array}$ \\
\hline
\end{tabular}

Legenda: mg=miligram, "=respondenten tenzij hiema aangegeven (telkens gehele groep, kankerpatienten en subcutane infusie): leeftijd en geslacht: $61 / 58 / 56$ toename periode: $25 / 25 / 22$ pijnvrij: $58 / 58 / 53$ pijnscore naaste: 52/50/47 pijnscore arts:53/50/48, '=tussen begin en einddosering, ${ }^{2}=$ in de periode minus de eerste en tweede dag (instelfase) en de laatste drie dagen (morfinebehoefte kan voor de dood plots stijgen). 
Tabel B12.2.4 geeft voor de start- en de einddosering aan hoeveel percent van de diverse patièntengroepen in een bepaalde klasse vielen.

Tabel B12.2.4 Start en einddosering van morfine in procenten per klasse en in milligram.

\begin{tabular}{l|cc|cc|cc}
\hline & \multicolumn{2}{c}{$\begin{array}{c}\text { Kehele groep } \\
N=62\end{array}$} & \multicolumn{2}{c}{ Kankerpatiénten } & \multicolumn{2}{c}{ Subcutane infusie } \\
Milligram per dag & Start & Stop & Start & Stop & Start & Stop \\
$0-10$ & 6,5 & - & 6,8 & - & 5,3 & - \\
$11-20$ & 25,8 & 11,3 & 25,4 & 11,9 & 24,5 & 10,5 \\
$21-30$ & 12,9 & 8,1 & 11,9 & 6,8 & 14,1 & 8,8 \\
$31-40$ & 8,1 & 12,9 & 8,5 & 11,9 & 8,8 & 14,0 \\
$41-50$ & 6,5 & 3,2 & 6,8 & 3,4 & 5,3 & 1,8 \\
$51-60$ & 11,3 & 8,1 & 10,2 & 6,8 & 12,3 & 8,8 \\
$61-70$ & 1,6 & 9,7 & 1,7 & 10,2 & 1,8 & 8,8 \\
$71-80$ & 3,2 & 4,8 & 3,4 & 5,1 & 3,5 & 3,5 \\
$81-90$ & 1,6 & 1,6 & 1,7 & 1,7 & 1,8 & 1,8 \\
$91-100$ & 4,8 & 3,2 & 5,1 & 3,4 & 3,5 & 3,5 \\
$101-150$ & 6,5 & 4,8 & 6,8 & 5,1 & 7,0 & 5,3 \\
$151-200$ & 4,8 & 9,7 & 5,1 & 10,2 & 5,3 & 10,5 \\
$201-250$ & 1,6 & 4,8 & 1,7 & 5,1 & 1,8 & 5,3 \\
$251-500$ & 4,8 & 4,8 & 5,1 & 5,1 & 5,3 & 5,3 \\
$501-750$ & - & 6,5 & - & 6,8 & - & 7,0 \\
$751-1.000$ & - & 1,6 & - & 1,7 & - & 1,8 \\
1.800 & - & 3,2 & - & 3,4 & - & 3,5 \\
2.100 & - & 1,6 & - & 1,7 & - & - \\
\hline
\end{tabular}

Legenda: Start=begindosering, Stop=einddosering, ...=mediaan.

Tabel 12.2.5 geeft een overzicht van de aan de morfine-infusies toegevoegde soorten medicatie.

\begin{tabular}{|c|c|c|c|c|}
\hline $\begin{array}{l}\text { Generieke naam } \\
\text { medicament }\end{array}$ & Reden(en) & $\begin{array}{l}\text { Bereik dosis in } \\
\text { mg per dag }\end{array}$ & Soort infuus & Aantal patiěnten \\
\hline \multirow{2}{*}{ atropine } & retentieblaas & $0,5-1,5$ & SC & 1 \\
\hline & slijmvorming & $1,0-2,0$ & $\mathrm{SC}+\mathrm{IV}$ & $1+1$ \\
\hline dehydrobenzperidol & braken/onrust & $5-20$ & SC & 2 \\
\hline dexamethason & hersenoedeem & 4 & SC & 1 \\
\hline diazepam & angst & $5-80$ & $\mathrm{SC}+\mathrm{IV}$ & $10+1$ \\
\hline haloperidol & onrust/braken & $4-10$ & SC & 3 \\
\hline metoclopramide & braken & $10-40$ & $\mathrm{SC}+\mathrm{IV}$ & $4+1$ \\
\hline ondansetron & braken & 16 & IV & 1 \\
\hline
\end{tabular}

Legenda: $\mathrm{SC}=$ subcutaan, $\mathrm{IV}=$ intraveneus, $\mathrm{CV}=$ centraalveneus. 
Tabel B12.2.6 vermeldt kenmerken van de kwaliteit van leven en van zorg van patiènten en naasten volgens henzelf, de ander en zorgverleners.

Tabel B12.2.6 Kwaliteit van leven en kwaliteit van zorg bij thuisbehandeling met morfine.

\begin{tabular}{|c|c|c|c|}
\hline \multicolumn{4}{|c|}{ Kenmerken van patienten volgens han naasten en zorgwerleners } \\
\hline Item & $\begin{array}{l}\text { Naaste } \\
(n=50-53)\end{array}$ & $\begin{array}{l}\text { Verplecgkundige * } \\
\text { (n-54-55) }\end{array}$ & $\begin{array}{l}\text { Huisarts } \\
(\mathrm{n}=50-51)\end{array}$ \\
\hline Emst zickte $(1-5)^{*-1}$ & $1,5 / 0,7 / 1-5 \cdots$ & $1,3 / 0,6 / 1 \cdot 3$ & $1,1 / 0,2 / 1-2$ \\
\hline Pijn $(0-10)^{2}$ & $6,3 / 3,7 / 0,0-10,0$ & $4,9 / 3,1 / 0,0-9,8$ & $4,7 / 3,2 / 0,0-9,4$ \\
\hline Gezondheidsbeleving $(1-5)^{3}$ & $4,9 / 0,5 / 2-5$ & $4,8 / 0,4 / 4-5$ & $4,9 / 0,4 / 3-5$ \\
\hline Kwaliteit van leven $(0-10)^{*}$ & $2,6 / 3,3 / 0,0-10,0$ & $2,8 / 2,8 / 0,0-9,8$ & $4,0 / 2,9 / 0,3-10,0$ \\
\hline \multicolumn{4}{|c|}{ Kenmerken en belasting van naasten volgens hentelf en zorgverleners } \\
\hline Item & $\begin{array}{l}\text { Naaste } \\
(\mathrm{n}=50-53)\end{array}$ & $\begin{array}{l}\text { Verpleegkundige } \\
\text { (a-54-55) }\end{array}$ & $\begin{array}{l}\text { Huisarts } \\
(\mathrm{n}=13,51,50)\end{array}$ \\
\hline Praktische steun (1-5)' & $4,4 / 1,0 / 1-5$ & nvt & nvt \\
\hline Emotionele steun (1-5)" & $4,6 / 0,7 / 2-5$ & nvt & nvt \\
\hline Belasting $\operatorname{CSI}(0-13)^{6}$ & $4,5 / 3,2 / 0-12$ & $5,2 / 3,2 / 0-13$ & $4,6 / 3,1 / 0-12$ \\
\hline Infuuszorg belastend (1-5)? & $4,2 / 1,0 / 1-5$ & $3,6 / 1,0 / 1-5$ & $3,9 / 0,9 / 1-5$ \\
\hline Naaste ziek & 38 van de 53 & nvt & nvt \\
\hline Emst ziekte $(1-5)^{1}$ & $3,2 / 1,5 / 1-5(n=20)$ & nvt & nvt \\
\hline Gezondheidsbeleving (1-5)' & $2,5 / 1,0 / 1-5$ & nvt & nvt \\
\hline Kwaliteit van leven $(0-10)^{4}$ & $5,5 / 2,7 / 0,0-10,0$ & $5,1 / 2,6 / 0,4-10,0$ & $5,8 / 2,3 / 1,0-10,0$ \\
\hline \multicolumn{4}{|c|}{ Kwaliteit van zorg volgens naasten en zorgverleners } \\
\hline Item & $\begin{array}{l}\text { Naaste }(n=53 \\
51,13,53,33)\end{array}$ & $\begin{array}{l}\text { Verpleegkundige } \\
(\mathrm{n}=45,50,7,55,43)\end{array}$ & $\begin{array}{l}\text { Huisarts }(n=46 \text {, } \\
27,15,51,46)\end{array}$ \\
\hline Rapportcijfer TMV & $9,1 / 0,9 / 6-10$ & $8,0 / 0,7 / 6-9$ & $8,4 / 0,8 / 6-10$ \\
\hline Rapportcijfer huisarts & $8,6 / 2,0 / 2-10$ & $7,5 / 1,3 / 4-10$ & $8,0 / 0,9 / 6-10$ \\
\hline Rapportcijfer specialist & $8,5 / 1,9 / 4-10$ & $7,3 / 0,8 / 6-8$ & $7,6 / 1,4 / 5-10$ \\
\hline RGO/NWO $(32-160)^{7}$ & $141 / 16 / 96-160$ & $130 / 11 / 96-156$ & $137 / 12 / 107-160$ \\
\hline $\operatorname{CSQ}(4-32)^{3}$ & $28 / 3 / 17.32$ & $26 / 4 / 12-32$ & $28 / 4 / 16-32$ \\
\hline
\end{tabular}

Legenda: *-wijkverpleegkundige of TMV, $\cdots$ "scoremogelijkheden, $\cdots *$-gemiddelde / standaard deviatic / bereik, nvt-niet gevraagd, $=1$ :zeer ernstig 2:vrij ernstig 3 emstig 4 :nauwelijks emstig 5 :niet emstig, ${ }^{2} m 0$ :geen pijn 10:ondraaglijke pijn, ${ }^{3}=1$ :zeer goed 5: zeer slecht, ${ }^{2}=0$ : slechts denkbare kwaliteit 10:hoogst denkbare kwaliteit, "=1:geen 2:weinig 3:niet veel en niet weinig 4:veel 5:zeer veel, ${ }^{4}=$ hoe hoger hoe belastender, ' $=1: z e e r$ mee oneens 5:zeer mee eens, "-vierpuntsschaal. 
Tabel 12.2.7 geeft een overzicht van de verpleegkundige activiteiten bij infuusbehandeling thuis.

Tabel B12.2.7 Verpleegkundig zorgproces bij subcutane infusie van morfine thuis.

\begin{tabular}{|c|c|c|c|c|c|}
\hline Activiteit & $\%$ totaal & $\bar{x}$, & $\mathbf{S D}^{2}$ & Bereik ${ }^{3}$ & Aantal ${ }^{4}$ \\
\hline \multicolumn{6}{|l|}{ Primair proces } \\
\hline Intakegesprekken & 3,3 & 35,34 & 19,89 & $5-90$ & 58 \\
\hline Zorgdragen voor verpleeghulpmiddelen & 0,2 & 22,50 & 19,94 & $10-60$ & 6 \\
\hline $\begin{array}{l}\text { Zorgdragen voor infuusbenodigdheden } \\
\text { (medicatie en infuusmaterialen) }\end{array}$ & 2,9 & 12,93 & 6,72 & $5-45$ & 138 \\
\hline Installeren infusiepomp & 0,1 & 8,75 & 4,79 & $5-15$ & 4 \\
\hline Voorbereiden en inbrengen infuus & 4,3 & 16,02 & 7,89 & $5-45$ & 166 \\
\hline Verzorgen insteekopening & 1,0 & 8,00 & 3,68 & $5-20$ & 75 \\
\hline $\begin{array}{l}\text { Aansluiten/verwisselen infuuszak plus } \\
\text { klaarmaken medicatie }\end{array}$ & 18,7 & 19,29 & 10,12 & $5-70$ & 595 \\
\hline Tijdelijk aan-en afkoppelen infuus & 1,7 & 12,80 & 6,18 & $5-40$ & 84 \\
\hline Verwijderen infuus & 1,5 & 8,26 & 3,60 & $5-25$ & 112 \\
\hline Instructie patient/naaste verzorgers & 1,4 & 13,95 & 7,42 & $5-45$ & 62 \\
\hline Realiseren therapie en leefregel & 3,7 & 12,81 & 7,18 & $5-50$ & 176 \\
\hline Begeleiden probleemsituatie & 4,5 & 17,92 & 9,91 & $5-65$ & 154 \\
\hline Toedienen medicatie op andere wijze & 0,1 & 7,14 & 3,93 & $5-15$ & 7 \\
\hline Evaluatie zorg & $2,0 \quad 45,4$ & 25,10 & 13,87 & $5-70$ & 50 \\
\hline \multicolumn{6}{|l|}{ Instructie van andere zorgverleners } \\
\hline Wijkverpleegkundige & 6,1 & 35,52 & 22,78 & $5-100$ & 106 \\
\hline Huisarts & 0,9 & 18,00 & 11,57 & $5-60$ & 30 \\
\hline Telefonisch consult zorgverleners & $0,2 \quad 7,2$ & 14,29 & 7,87 & $5-30$ & 7 \\
\hline \multicolumn{6}{|l|}{ Overleg met andere zorgverleners } \\
\hline Wijkverpleging & 3,1 & 12,37 & 8,69 & $5-60$ & 152 \\
\hline Medisch behandelaar & 2,8 & 10,65 & 6,76 & $5-50$ & 162 \\
\hline Ziekenhuis & 0,2 & 11,00 & 3,94 & $5-20$ & 10 \\
\hline Eerstelijnsvoorzieningen & 0,4 & 14,69 & 11,32 & $5-35$ & 16 \\
\hline Vrijwilligers & 0,4 & 12,50 & 9,93 & $5-40$ & 20 \\
\hline Meerdere disciplines & $0,8 \quad 7,7$ & 20,87 & 14,90 & $5-60$ & 23 \\
\hline Overige taken & & & & & \\
\hline Bevorderen dienstverlening & 4,6 & 13,77 & 11,65 & $5-80$ & 204 \\
\hline Reistijd & 27,1 & 20,22 & 9,25 & $5-55$ & 825 \\
\hline Administratie & 7,0 & 14,13 & 9,93 & $5-80$ & 305 \\
\hline Afvalverwerking & $1,0 \quad 39,7$ & 13,11 & 8,41 & $5-60$ & 45 \\
\hline
\end{tabular}

634 infusiedagen / 57 behandelingen / 56 patienten / 61.480 minuten $=1.025$ uur $/ 3.597$ handelingen

Legenda: '=gemiddelde tijd in minuten, ${ }^{2}=$ standaard deviatie in minuten, ${ }^{3}=$ in minuten, $=$ aantal maal dat cen activiteit geregistreerd is. 


\section{Bijlage 12.3: Parenterale infusie van mannitol}

\section{Noot 12.3.1}

Oorspronkelijk waren de inclusiecriteria strikter geformuleerd en zouden enkel patiènten met een matige of ernstige vorm van SRD, stadium II (dystrofe fase) of III (atrofe fase) behandeld gaan worden. ${ }^{325,326,525,529}$ Tevens zouden zij voorafgaand aan de mannitolinfusie behandeld moeten worden met (combinaties van) pijnstilling, fysiotherapie en de orale toediening (acetyleysteine: tenminste vier weken $3 \times 600 \mathrm{mg}$ per dag) of lokale applicatic (DMSO 50\%: tenminste vier weken tweemaal daags) van zuurstofradicale scavengers en deze onvoldoende resultaat opleveren. ${ }^{32 .}$.46 Deze inclusiecrieria zijn echter vrij snel verlaten, toen aannemelijk werd dat mannitol via aangrijping op het endoneuraal oedeem zou kunnen werken en niet via het scavenger effect. 
Tabel B12.3.1 Klinische gegevens van patienten met mannitoltoediening thuis.

\begin{tabular}{|c|c|c|c|c|c|}
\hline Pt & Lidmaat & Vermoedelijke aanleiding & Beh & $\begin{array}{l}\text { Ef } \\
f\end{array}$ & Bij \\
\hline 858 & $\mathrm{R}$ hand & contusie & $1^{1}$ & + & $\mathbf{F}$ \\
\hline 837 & & contusie van met name dig. $\mathrm{H}+\mathrm{II}$ & 1 & 0 & $\mathrm{~F}, \mathrm{M}$ \\
\hline 843 & & contusie met hyperextensie dig. III+IV & 3 & + & F1 \\
\hline 854 & & fractuur pols (radiuskop in twee richtingen) & 1 & + & $\cdot$ \\
\hline 836 & & $\begin{array}{l}\text { fractuur eindphalanx dig. II na klemtrauma en } \\
\text { K-draad fixatic voor malletstand }\end{array}$ & 1 & + & F \\
\hline 827 & & operatie cyste os naviculare na trauma & 1 & $0^{2}$ & - \\
\hline 830 & & onbekend & 1 & + & $\mathrm{F}, \mathrm{H}, \mathrm{M}$ \\
\hline o 59 & $\mathrm{R}$ arm & onbekend (klieven flexor peesschede dig. I links) & 1 & + & F \\
\hline$\sigma 48$ & $\mathrm{R}$ hand+arm & fractuur pols (communitieve radiuskop) & $1 * 5 \%$ & 0 & $\mathrm{~F}$ \\
\hline 858 & & fractuur pols (radiuskop) & $10^{3}$ & + & F5 \\
\hline 819 & L hand & fractuur wijsvinger (avulsie) & 2 & 0 & F2 \\
\hline$\circ 53$ & & operatic carpaal tunnel stenose & 1 & 0 & - \\
\hline 852 & & $\begin{array}{l}\text { operatie carpaal tunnel stenose (Dupuytren+trigger } \\
\text { finger) }\end{array}$ & 1 & 0 & $\mathrm{~F}, \mathrm{M}$ \\
\hline 832 & & operatic zenuw- en extensorpeesletsel dig. II+III & $1 *$ & $0^{5}$ & 's \\
\hline 947 & & $\begin{array}{l}\text { operaties zenuw- en peesletsel uinair plus } \\
\text { zenuwtransplantatie }\end{array}$ & $\begin{array}{c}1 \cdot 5 \% \\
1^{6}\end{array}$ & $\begin{array}{l}0 \\
0\end{array}$ & $\begin{array}{l}F^{7} \\
F\end{array}$ \\
\hline 822 & & operatie pols (ganglion dorsum) & 1 & 0 & $\mathrm{~F}$ \\
\hline$\sigma 30$ & & operaties pols (onder andere botverwijdering) & 1 & + & $\mathrm{F}$ \\
\hline 828 & & $\begin{array}{l}\text { operatie pols (afvlakken ulnakopje na verzwikken } \\
\text { bij op krukken lopen) }\end{array}$ & 1 & + & $\mathrm{F}$ \\
\hline$\$ 57$ & $\mathrm{~L}$ arm & fractuur pols & 4 & + & $\mathrm{F} 1, \mathrm{M} 1$ \\
\hline 873 & & fractuur pols (Colles) & 1 & + & F \\
\hline 838 & & $\begin{array}{l}\text { fractuur pols (intra-articulaire communitieve } \\
\text { radiuskop/Colles) }\end{array}$ & 2 & + & $\mathrm{F}$ \\
\hline 848 & L hand+arm & operatie carpaal tunnel stenose & 1 & 0 & $\mathrm{~F}, \mathrm{M}$ \\
\hline 868 & Beide handen & $\begin{array}{l}\text { operatie carpaal tunnel stenose links, na auto- } \\
\text { ongeluk rechts }\end{array}$ & $1 * 5 \%$ & 0 & F \\
\hline 850 & & $\begin{array}{l}\text { operatie tendovaginitis stenovans dig. III+IV rechts, } \\
\text { overbelasting door op krukken lopen links }\end{array}$ & $1 * 5 \%$ & 0 & - \\
\hline 849 & $R$ voet & contusie na trauma & 1 & + & $\mathrm{F}, \mathrm{H}$ \\
\hline$\& 65$ & L been & operaties heup, gips en trombosebeen & 2 & 0 & $\mathrm{~F} 1$ \\
\hline 847 & Beide benen & $\begin{array}{l}\text { arthroscopie voor voorste kruisband letsel rechts } 2 x \\
\text { plus klachten links, beide na ski-ongeval }\end{array}$ & $1 \cdot 5 \%{ }^{*}$ & + & F \\
\hline 831 & Armen+Benen & $\begin{array}{l}\text { operatie dig. II (Homan osteotomie), in verleden } \\
\text { linker hand na distorsic }\end{array}$ & 1 & + & $\mathrm{F}, \mathrm{M}$ \\
\hline
\end{tabular}

Legenda: $\mathrm{Pt}=$ geslacht $\sigma^{*}$ :man $\$$ :vrouw en leeftijd patiênt, $\mathrm{R}=$ rechter, $\mathrm{L}=$ linker, dig $=$ digitus, $B$ eh=behandeling. Eff=klinisch effect 0:geen effect +; wel effect, Bij=bijwerkingen F:flebitis H:hoofdpijn M:misselijkheid 1-5:bij meerdere behandelingen het aantal waarin dit optrad, ${ }^{1}=$ aantal behandelingen mannitol $10 \% 1$ liter per dag of bij: - $5 \%$ mannitol $5 \% 2$ liter per dag, ${ }^{2}=$ behandeling binnen 48 uur gestaakt bij subcutaan lopen infuus, ${ }^{3}=$ waarvan 2 centraalveneus, "-zowel proefdosis mannitol $10 \%$ als $5 \%$, "=behandeling binnen 48 uur gestaakt vanwege niersteenkolieken, ${ }^{6}$-eerste behandeling $5 \%$ daarna $10 \%,{ }^{7}=$ pneumothorax na val, ${ }^{2}=1$ liter per dag. 
Tabel B12.3.2 Verdeling van mannitolbehandelingen over zickenhuis en thuis.

\begin{tabular}{lccc}
\hline Plaats behandeling & 1993 & 1994 & 1995 \\
Verplecgafdeling azM & $11 / 12 / 63^{*}$ & $7 / 7 / 33$ & $7 / 9 / 60^{\prime}$ \\
Dagcentrum azM & $38 / 51 / 252$ & $21 / 25 / 118$ & $12 / 15 / 71$ \\
Thuis & $0 / 0 / 0$ & $18 / 25 / 185$ & $16 / 21 / 153^{2}$ \\
Totaal & $49 / 63 / 315$ & $46 / 57 / 336$ & $35 / 45 / 284$ \\
\hline
\end{tabular}

Legenda: "-aantal patienten / aantal behandelingen / aantal dagen infusie per jaar binnen de regio Heuvelland, tetwee behandelingen van meer dan 8 dagen, ${ }^{2}=137$ intraveneus en 16 centraalveneus.

Tabel B12.3.3 Kwaliteit van leven en kwaliteit van zorg bij thuisbehandeling met mannitol.

\begin{tabular}{|c|c|c|c|c|}
\hline \multicolumn{5}{|c|}{ Kenmerken van patiènten volgens henzelf, hun naasten en zargverleners } \\
\hline Item & $\begin{array}{l}\text { Patiềut } \\
(n=24-25)\end{array}$ & $\begin{array}{l}\text { Naaste } \\
(n=24)\end{array}$ & $\begin{array}{l}\text { TMV } \\
(n=24-27)\end{array}$ & $\begin{array}{l}\text { Huisarts } \\
(\mathrm{n}=24)\end{array}$ \\
\hline Emst ziekte $(1-5)^{*}$ & $3,2 / 1,4 / 1-5^{*}$ & $3,0 / 1,0 / 1-5$ & $2,9 / 0,7 / 2-4$ & $3,6 / 0,9 / 1-5$ \\
\hline Pijn $(0-10)^{2}$ & $5,5 / 2,6 / 0,0-9,9$ & $5,7 / 2,5 / 0,6-9,5$ & $4,7 / 1,9 / 1,5-7,9$ & $3,6 / 2,5 / 0,0-7,5$ \\
\hline Functioneren SIP-68 (0-68) ${ }^{3}$ & $17 / 11 / 3-53$ & nvi & nvt & nvt \\
\hline Gezondheidsbeleving (1-5) ${ }^{4}$ & $2,9 / 1,0 / 1-5$ & $2,7 / 0,9 / 1-4$ & $2,4 / 0,6 / 1-3$ & $2,2 / 0,8 / 1-4$ \\
\hline Kwaliteit van leven $(0-10)^{3}$ & $4,9 / 2,6 / 0,4-10,0$ & $4,9 / 2,3 / 0,3-9,9$ & $6,7 / 2,4 / 1,5-9,9$ & $6,1 / 1,8 / 2,2-9,3$ \\
\hline
\end{tabular}

Kenmerken en belasting van naasten volgens patienten, henzelf en zorgverleners

\begin{tabular}{|c|c|c|c|c|}
\hline Item & $\begin{array}{l}\text { Patiênt } \\
(\mathrm{n}=24-25)\end{array}$ & $\begin{array}{l}\text { Naaste } \\
(n=24-25)\end{array}$ & $\begin{array}{l}\text { TMV } \\
(n=27)\end{array}$ & $\begin{array}{l}\text { Huisarts } \\
(\mathrm{n}=23-24)\end{array}$ \\
\hline Praktische steun (1-5) ${ }^{6}$ & $4,8 / 0,5 / 3-5$ & $4,6 / 0,7 / 3-5$ & nvt & nvt \\
\hline Emotionele steun $(1-5)^{6}$ & $4,5 / 0,9 / 1-5$ & $4,5 / 0,7 / 3-5$ & nvt & nvt \\
\hline Belasting CSI (0-13)? & nvt & $2,4 / 2,5 / 0-10$ & $3,0 / 2,5 / 0-8$ & $\begin{array}{l}1,0 / 1,3 / 0-4 \\
(n=9)\end{array}$ \\
\hline Infuuszorg belastend $(1-5)^{x}$ & $3,6 / 1,2 / 1.5$ & $3,5 / 1,4 / 1-5$ & $2,6 / 1,2 / 1-5$ & $2,7 / 0,9 / 2-5$ \\
\hline Naaste ziek & nvt & $25 \%$ & nvt & nvt \\
\hline Ernst ziekte (1-5)' & nvt & $\begin{array}{l}3,5 / 1,2 / 2-5 \\
(n=6)\end{array}$ & nvt & nvt \\
\hline Gezondheidsbeleving (1-5) ${ }^{*}$ & nvt & $2,3 / 0,8 / 1-4$ & nvt & nvt \\
\hline Kwaliteit van leven $(0-10)^{5}$ & nvt & $5,4 / 2,6 / 0,2-9,8$ & $7,1 / 2,0 / 2,0-9,9$ & $7,2 / 1,6 / 1,0-5,0$ \\
\hline \multicolumn{5}{|c|}{ Kwaliteit van zorg volgens patièten, hun naasten en zorgverleners } \\
\hline Item & $\begin{array}{l}\text { Patiēnt }(n=23 \text {, } \\
18,11,25,25)\end{array}$ & $\begin{array}{l}\text { Naaste }(n=24, \\
14,5,25,25)\end{array}$ & $\begin{array}{l}\text { TMV }(\mathrm{n}=23, \\
19,10,27,27)\end{array}$ & $\begin{array}{l}\text { Huisarts ( } n=22 \text {, } \\
7,2,24,27)\end{array}$ \\
\hline Rapportcijfer TMV & $9,3 / 0,8 / 8-10$ & $8,9 / 1,1 / 6-10$ & $7,8 / 0,9 / 6-10$ & $8,1 / 0,8 / 6-10$ \\
\hline Rapportcijfer huisarts & $8,4 / 1,8 / 4-10$ & $7,1 / 3,2 / 0-10$ & $7,0 / 1,7 / 2-9$ & $8,1 / 0,9 / 7-10$ \\
\hline Rapportcijfer specialist & $8,4 / 1,5 / 6-10$ & $9,4 / 0,9 / 8-10$ & $7,5 / 0,9 / 6-9$ & $6,0 / 2,8 / 4-8$ \\
\hline RGO/NWO (32-160)" & $141 / 13 / 117-160$ & $141 / 18 / 96-160$ & $131 / 13 / 112-160$ & $129 / 9 / 116-149$ \\
\hline $\operatorname{CSQ}(4-32)$ & $27 / 4 / 17-32$ & $27 / 5 / 16-32$ & $25 / 4 / 17-31$ & $24 / 4 / 18-31$ \\
\hline
\end{tabular}

Legenda: *-scoremogelijkheden, $" *$ "memiddelde / standaard deviatie / bereik, nvt"niet gevraagd,'=1:zeer ernstig 2:vrij emstig 3:emstig 4 :nauwelijks emstig 5:niet ernstig, ${ }^{2}=0$ :geen pijn 10 :ondraaglijke pijn, ${ }^{2}=$ hoe hoger hoe beperkter, ${ }^{2}=1$ zeer goed 5 : zeer slecht, ${ }^{\prime}=0$-slechts denkbare kwaliteit 10:hoogst denkbare kwaliteit, $=1$ : geen 2 weinig 3 :niet veel en niet weinig 4 : veel 5 zeer veel, =hoe hoger hoe belastender, '=1 zeer mee oneens 5 :zeer mee eens, "=vierpuntsschaal. 
Tabel B12.3.4 Verpleegkundig zorgproces bij intraveneuze infusie van mannitol thuis.

\begin{tabular}{|c|c|c|c|c|c|}
\hline Activiteit & $\%$ totaal & $\bar{x}^{\prime}$ & SD $^{2}$ & Bereik $^{3}$ & Aantal ${ }^{4}$ \\
\hline \multicolumn{6}{|l|}{ Primair proces } \\
\hline Intakegesprekken & 5,4 & 39,69 & 18,83 & $5-65$ & 48 \\
\hline Zorgdragen voor verpleeghulpmiddelen & 0,4 & 17,22 & 10,03 & $5-40$ & 9 \\
\hline $\begin{array}{l}\text { Zorgdragen voor infuusbenodigdheden } \\
\text { (medicatic en infuusmaterialen) }\end{array}$ & 1,4 & 14,71 & 10,44 & $5-45$ & 34 \\
\hline Installeren infusiepomp & 0,9 & 7,79 & 3,33 & $5-20$ & 43 \\
\hline $\begin{array}{l}\text { Voorbereiden van en assisteren bij } \\
\text { inbrengen infuus }\end{array}$ & 1,4 & 20,62 & 11,55 & $10-55$ & 24 \\
\hline Verzorgen insteekopening & 2,6 & 7,56 & 3,70 & $5-25$ & 123 \\
\hline $\begin{array}{l}\text { Aansluiten/verwisselen kant en klare } \\
\text { infuuszak }\end{array}$ & 6,7 & 8,81 & 4,38 & $5-30$ & 268 \\
\hline Verwisselen infuussysteem & 3,8 & 8,71 & 4,33 & $5-30$ & 155 \\
\hline Tijdelijk aan-en afkoppelen & 6,8 & 8,92 & 4,96 & $5-30$ & 269 \\
\hline Verwijderen infuus & 2,1 & 12,18 & 5,77 & $5-30$ & 62 \\
\hline Instructic patienU/naaste verzorgers & 4,1 & 15,32 & 7,54 & $5-45$ & 94 \\
\hline Realiseren therapie en leefregel & 2,2 & 9,56 & 4,58 & $5-30$ & 80 \\
\hline Begeleiden probleemsituatic & 0,7 & 17,50 & 8,26 & $5-35$ & 14 \\
\hline Lichamelijk hygienische verzorging & 5,5 & 15,48 & 7,50 & $5-50$ & 125 \\
\hline Evaluatiegesprekken & $1,945,9$ & 16,71 & 8,99 & $5-40$ & 41 \\
\hline \multicolumn{6}{|l|}{ Instructie van andere sorgverleners } \\
\hline Wijkverpleegkundige & 0,6 & 36,67 & 20,90 & $15-65$ & 6 \\
\hline Huisarts & $0,2 \quad 0,8$ & 13,75 & 11,81 & $5-30$ & 4 \\
\hline \multicolumn{6}{|l|}{ Overleg met andere zorgverleners } \\
\hline Wijkverpleging & 1,4 & 10,10 & 8,87 & $5-60$ & 49 \\
\hline Medisch behandelaar & 1,0 & 8,21 & 3,46 & $5-20$ & 42 \\
\hline Ziekenhuis & 0,6 & 12,81 & 9,30 & $5-35$ & 16 \\
\hline Eerstelijnsvoorzieningen & 0,0 & 5,00 & $\cdot$ & 5 & 1 \\
\hline Vrijwilligers & 0,2 & 14,17 & 13,57 & $5-40$ & 6 \\
\hline Meerdere disciplines & $0,0 \quad 3,2$ & 7,50 & 3,54 & $5-10$ & 2 \\
\hline \multicolumn{6}{|l|}{ Overige taken } \\
\hline Bevorderen dienstverlening & 2,6 & 10,65 & 10,54 & $5-65$ & 85 \\
\hline Reistijd & 41,9 & 20,43 & 9,29 & $5-60$ & 727 \\
\hline Administratic & 4,9 & 14,45 & 9,85 & $5-60$ & 119 \\
\hline Afvalverwerking & $0,7 \mathbf{5 0 , 1}$ & 9,81 & 2,99 & $5-15$ & 26 \\
\hline
\end{tabular}

322 infusiedagen $/ 44$ behandelingen $/ 28$ patienten $/ 35.420$ minuten $=590$ uur $/ 2.473$ handelingen

Legenda: '=gemiddelde tijd in minuten, ${ }^{2}=$ standaard deviatic in minuten, ${ }^{2-i n}$ minuten, $4=$ aantal maal dat een activiteit geregistreerd is. 


\section{Noot 12.4.1}

In het begin zijn omwille van de eenvoud van de in te zetten technologie de antibiotica bij twee patiēnten ook via een infuussysteem met druppelregelaar toegediend. Vanwege de tijd die het instellen via cen druppelregelaar kost, de gelijkmatigheid van de infusiesnelheid, de nauwkeurigheid van het toegediende infusievolume, de alarmeringsmogelijkheden van de infuuspomp en de kleinere kans op te snelle infusie hebben wij vrij snel gekozen voor toediening per infuuspomp.

\section{Neot 12.4.2}

De antibioticaregimes waren: $52 \%$ enkelvoudige (piperacilline $5 \mathrm{x}$ ) en breedspectrum penicillines met B-lactamaseremmer (ticarcilline-clavulaanzuur $5 \mathrm{x}$, amoxicilline-clavulaanzuur $2 \mathrm{x}$ ), $30 \%$ breed spectrum B-lactarnaseresistente cefalosporines (ceftazidim $3 x$, ceftriaxon $3 x$ ) en andere middelen (imipenem $1 x$ ) en $17 \%$ uit aminoglycosiden (gentamicine $2 x$, tobramycine $2 x$ ).

\section{Noot 12.4.3}

Bij éen CF-patiènt in ons project konden zevenmaal het gewicht en vijfmaal de longwaarden vervolgd worden. De gewichtstoename was gemiddeld 1,7 (sd 1,7 bereik -1,1 tot 4,1) kilo en 4,3 (sd $4,2$ bereik $-2,7$ tot 10,4$)$ percent. De longfuncties versiechterden in de tijd, maar gaven toch gemiddeld een 0,1 (sd 0,4 ) liter en $5,5 \%$ (sd 22,2 bereik $-24,1$ tot 39,2 ) percent verbetering van de vitale capaciteit en een 0,1 (sd 0,2 ) liter en 10,6 (sd 27,8 bereik - 18,8 tot 63,2) percent verbetering van het eén-secondevolume. Bij KITTZ traden bij 21 evalueerbare perioden gemiddeld een 0,32 ( $s$ d 0,25 ) liter verbetering op van de vitale capaciteit, een 0,25 (sd 0,22 ) liter verbetering op van het éensecondevolume en 1,5 (sd 1,2) kilo gewichtstoename. Bij multicenter traden bij 37 evalueerbare perioden gemiddeld ongeveer een 0,3 (sd 0,3 ) liter en 12 a 13 percent verbetering op van de vitale capaciteit, ongeveer een 0,2 (sd 0,2 ) liter en 15 à 16 percent verbetering op van het éénsecondevolume en ongeveer 3,3 (sd 1) percent gewichtstoename. Elders is bij patięnten met frequente exacerbaties ( 2 of meer in 12 maanden) een $30 \%$ verbetering in het éen-secondevolume gerapporteerd. ${ }^{3.2}$ In toename van het lichaamsgewicht was onze behandeling vergelijkbaar met KITTZ en multi-center, door de progressieve longverslechtering was de toename van de longfunctie ook percentueel iets lager (absoluut deels ook vanwege jongere leeftijd).

\section{Noot 12.4.4}

Bij de 8 behandelingen van deze CF-patiènt is 41 maal een nieuwe infuuscanule ingebracht vanwege flebitis (11), trombose (2) en subcutaan lopen (1), verschuiven (1), lekken aan de insteekplaats (3) en onbekend (23). Gemiddeld kon de infuuscanule tenminste 4,1 dagen (203/8+41) gebruikt worden. Redenen hiervoor zijn: de patient ging niet voorzichtig om met de infuuscanule, verwijderde dikwijls het beschermende verband en verwijderde op 'eigen indicatie' de infuuscanule. Tevens heeft de patiēnt eenmaal kortdurend Intralipid® ontvangen. Bij deze patiēnt zijn tevens Insyte-W $\$$ met poly-urethaancoating en Quik-Cath $\otimes$ (beide $\oslash 22 \mathrm{G}=0,8 \mathrm{~mm}$, lengte $25 \mathrm{~mm}$ ) infuuscanules toegepast, doch deze bleven niet langer in situ dan de Venflon® infuuscanules.

Gezien de verder ook complexe situatic (waarvan de antibioticabehandeling thuis slechts één onderdeel vormde) bij deze juveniele patiēnt, is in overleg met de hoofdbehandelaar ervoor gekozen het belang van compliance aan de antibioticatherapie te laten prevaleren boven het belang van een zo zorgvuldig mogelijke uitvoering, ondanks dat de patient op dit punt niet aan de inclusiecriteria voldeed. 
Tabel B12.4.1 Klinische gegevens van 15 patienten met 22 antibioticabehandelingen thuis.

Pt Diagnose (verwekker in kweek of punctaat)

\&51 Abces cerebellum na middenoorontsteking links (Pseudomonas acruginosa. Actinomyces meveri. Corvnebacterium sep)

\$ 85 Diabetische voet rechts (Staphylococcus aureus)

o 65 Luchtweginfectie bij CARA (P. aeruginosa)

$932 \mathrm{z} \quad$ Luchtweginfectic bij cystic fibrosis $(\mathrm{P}$. aeruginosa. Asperrillus fumigatus)

$0.47 \mathrm{z}$ Neuroborelliose (liquor negatief)

of 43 Neuroborelliose (liquor negatief)

o 60 Neuroborelliose (liquor negatief)

of 79 Osteomyelitis os pubis beiderzijds (Streptococcus sanguis, Bacteroides fragilis groep, $P$. aeruginosa, S. aureus)

o 79 Pneumonie bij CARA (P. aeruginosa, Klebsiella exvtoca)

o $15 \mathrm{z}$ Pneumonie bij cystic fibrosis '

$I^{2}$ : $\mathbb{P}$. acruginosa, S. aureus, Hacmophilus influenzac)

$2^{2}$. (P. aenuginosa, Str. pyogenes, H influenzas. S. aureus)

3-8 : (P. aeruginosa)

o 51 Postoperatieve infectic na aortabroekprothese en bypassoperatic (CABG) (S. aureus, Enterococcus facealis)

Q 76 Postoperatieve chronische wondinfectie na plaatsen heupprothese links ( $\mathrm{P}$. acruginosa)

P 51 Postoperatieve osteomyelitis na Homan osteotomic linker hallus ( $\mathbb{P}$ aeruginosa)

$\sigma 60 \mathrm{z}$ Tuberculose gesloten (Mrcobacterium tuberculosis)

* 76

Urineweginfectie bij retentieblaas (Klebsiella pecumoniac)
Antibioticum (specialitenaam) dosering in milligram [inloopsnelheid]

ceftazidim (Fortum) $2 \times 1000$ [15] + doxycycline (Vibramycine) $2 \times 100$ [15]

ceftazidim (Fortum) $3 \times 2000[10]+$ clindamycine (Dalacin) $3 \times 600$ [20]

ciprofloxacine (Ciproxin) 2x300 [20] + tobramycine $1 \times 200$ [20]

piperacilline (Pipcil) $3 \times 4000[15]+$ tobramycine 2 xi20 [15]

ceftriaxon (Rocephin) 2x4000 [30]

ceftriaxon (Rocephin) $1 \times 2000$ [30]

ceftriaxon (Rocephin) $1 \times 2000$ [25]

ciprofloxacine (Ciproxin) $2 \times 300[20]+$ clindamycine (Dalacin) 2x900 [30]

piperacilline (Pipcil) 3 dd 4000 [20]

-piperacilline (Pipcil) 4x1500 [30]

-ticarcilline/clavulaanzuur 5000/200

(Timentin) $3 \times 4000[30]$

-ticarcilline/clavulaanzuur $5000 / 200$

(Timentin) $3 \times 4000$ [30]

-ceftazidim (Fortum) $3 \times 2000$ [25]

-start imipenem/cilastatine $500 / 500$ (Tienam) $4 \times 1000[20]+$ gentamycine $2 \times 280[30]$ later piperacilline (Pipcil) $3 \times 4000[20]$ + gentamycine $1 \times 320[30]^{4}$ amoxicilline/clavulaanzuur $1000 / 200$ (Augmentin) 4x1200 [20]

ciprofloxacine (Ciproxin) $2 \times 300[30]^{5}$

piperacilline (Pipcil) 3 dd 4000 [20]

ethambutol (Myambutol )1dd 1200 [120]

36

amoxicilline/clavulaanzuur $1000 / 200$ (Augmentin) 4x1200 [20]

Legenda: Pt=geslacht ơ:man \&:vrouw en leeftijd patient z:patient of naaste heeft zelf antibiotica toegediend, "=aantal dagen antibiotica in ziekenhuis, ${ }^{4}=$ tijdens de thuisbehandeling, ${ }^{1}=$ etén patient met acht behandelingen, ${ }^{2}=$ volgnummer behandeling, ${ }^{2}=$ opname vanwege screening voor longtransplantatic, $=$ in combinatie met Intralipid I dd $500 \mathrm{ml}$ ter aansterking. "=geen infuuspomp gebruikt, ${ }^{2}$-in combinatie met streptomycine $1 \mathrm{dd}$ 1000 later $500 \mathrm{mg}$ intramusculair en $\mathrm{INH} 1$ dd $300 \mathrm{mg}$ per os. 
Tabel B12.4.1 vervolg Klinische gegevens van 15 patienten met 22 antibioticabehandelingen thuis.

\begin{tabular}{|c|c|c|c|c|c|c|}
\hline $\mathrm{Pt}$ & $\begin{array}{l}\text { Start thuis- } \\
\text { behandeling }\end{array}$ & $\begin{array}{l}\text { Ziekenhuis } \\
\text { dagen }\end{array}$ & $\begin{array}{l}\text { Thuis } \\
\text { dagen }\end{array}$ & $\begin{array}{l}\text { Totaal } \\
\text { dagen }\end{array}$ & $\begin{array}{l}\text { Poli- } \\
\text { bezoeken * }\end{array}$ & $\begin{array}{l}\text { Eind thuis- } \\
\text { behandeling }\end{array}$ \\
\hline 851 & dagcentrum & 5 & 9 & 14 & 2 & thuis \\
\hline
\end{tabular}

\begin{tabular}{|c|c|c|c|c|c|c|}
\hline 885 & ziekenhuis & 17 & 28 & 45 & 5 & thuis \\
\hline 865 & ziekenhuis & 23 & 7 & 30 & 1 & thuis \\
\hline 832 & ziekenhuis & 5 & 18 & 23 & 1 & thuis \\
\hline 847 & ziekenhuis & 7 & 14 & 21 & 1 & thuis \\
\hline 843 & dagcentrum & 3 & 7 & 10 & 0 & thuis \\
\hline 860 & ziekenhuis & 4 & 10 & 14 & 0 & thuis \\
\hline 879 & ziekenhuis & 1 & 29 & 30 & 2 & thuis \\
\hline$\$ 79$ & zickenhuis & 14 & 17 & 31 & 0 & thuis \\
\hline \multirow[t]{9}{*}{815} & & & & & & \\
\hline & zickenhuis & 5 & 13 & 18 & 1 & thuis \\
\hline & ziekenhuis & 5 & 49 & 54 & 3 & thuis \\
\hline & ziekenhuis & 6 & 14 & 20 & 1 & thuis \\
\hline & polikliniek & 0 & 44 & 44 & 3 & transplantatie? \\
\hline & 'transplantatie' & 18 & 5 & 23 & 1 & transplantatic ${ }^{3}$ \\
\hline & polikliniek & 0 & 29 & 29 & 2 & thuis \\
\hline & polikliniek & 0 & 15 & 15 & 1 & thuis \\
\hline & ziekenhuis & 5 & 34 & 39 & 6 & heropname \\
\hline
\end{tabular}

$\begin{array}{llllll}* 51 & \text { ziekenhuis } & 10 & 15 & 25 & 1\end{array}$

\begin{tabular}{|c|c|c|c|c|c|c|}
\hline 876 & ziekenhuis & 2 & 43 & 45 & 4 & thuis \\
\hline 851 & thuis & 0 & 29 & 29 & 5 & thuis \\
\hline 860 & thuis & 0 & 57 & 57 & 6 & thuis \\
\hline 876 & thuis & 0 & 15 & 15 & I & thuis \\
\hline
\end{tabular}

\begin{tabular}{lllll}
\hline Totaal & 130 & 501 & 631 & 47 \\
Gerniddelde & 5,9 & 22,8 & 28,7 & 2,1 \\
Standaard deviatie & 6,4 & 14,5 & 13,2 & 1,9 \\
Bereik & $0-23$ & $5-27$ & $10-57$ & $0-6$ \\
\hline
\end{tabular}


Tabel B12.4.2 Resultaten van diverse Nederlandse studies naar antibiotica-infusie thuis.

\begin{tabular}{|c|c|c|c|c|}
\hline & pIT & TNO & Multicenter & KITTZ \\
\hline $\begin{array}{l}\text { Patiénten } \\
\text {-mannelijk } \\
\text {-leeftijd }\end{array}$ & $\begin{array}{l}15 \\
73 \% \\
58,0 / 19,5 / 15-85^{2}\end{array}$ & $\begin{array}{l}79 \\
70 \% \\
42\end{array}$ & $\begin{array}{l}24 \\
38 \% \\
23,3 / \bullet / 7-52\end{array}$ & $\begin{array}{l}11 \\
* 1 \\
18,9 / 6,0 / 10-28\end{array}$ \\
\hline $\begin{array}{l}\text { Behandelingen } \\
\text {-evalueerbaar }\end{array}$ & $\begin{array}{l}22 \\
15-22\end{array}$ & $\begin{array}{l}93^{3} \\
71-75\end{array}$ & $\begin{array}{l}45 \\
37-39\end{array}$ & $\begin{array}{l}30 \\
24\end{array}$ \\
\hline $\begin{array}{l}\text { Verwekkers } \\
\text {-Pseudomonas acruginosa } \\
\text {-Staphylococcus spe } \\
\text {-Borrelia spe. } \\
\text {-Streptococcus spe. }\end{array}$ & $\begin{array}{l}68 \% \\
23 \% \\
14 \% \\
9 \%\end{array}$ & $\begin{array}{l}19 \% \\
29 \% \\
13 \% \\
7 \%\end{array}$ & $100 \%$ & • \\
\hline $\begin{array}{l}\text { Antibiotica } \\
\text {-penicillines } \\
\text {-cefalosporines } \\
\text {-aminoglycosiden }\end{array}$ & $\begin{array}{l}52 \% \\
30 \% \\
17 \%\end{array}$ & $\begin{array}{l}38 \% \\
39 \% \\
3 \%\end{array}$ & ceftazidim $100 \%$ & $\begin{array}{l}15 \mathrm{x} \text { mono-en } \\
15 \mathrm{x} \text { multi- } \\
\text { therapie }\end{array}$ \\
\hline $\begin{array}{l}\text { Behandelduur } \\
\text {-totaal } \\
\text {-ziekenhuis } \\
\text {-thuis }\end{array}$ & $\begin{array}{l}28,7 / 13,2 / 10-57 \\
5,9 / 6,4 / 0-23 \\
22,8 / 14,5 / 5-57\end{array}$ & $\begin{array}{l}31,5 / 28,4 / \bullet \\
12,2 / \bullet / \bullet \\
19,3 / 19,6 / \bullet\end{array}$ & $\begin{array}{l}21,5 / * / 14-26 \\
=2^{5} \\
=19,5^{5}\end{array}$ & $\begin{array}{l}16,6 / 4,0 / 14-22 \\
=3^{5} \\
=13,6^{5}\end{array}$ \\
\hline $\begin{array}{l}\text { Verbetering } \\
\text {-wel } \\
\text {-gering }\end{array}$ & $\begin{array}{l}91 \% \\
4,5 \%\end{array}$ & $91,5 \%$ & $\begin{array}{l}75,7 \% \\
18,9 \%\end{array}$ & - \\
\hline $\begin{array}{l}\text { Complicaties/dag } \\
\text {-teldagen } \\
\text {-canulewisseling } \\
\quad \text {-flebitis } \\
\text {-dagen per canule } \\
\text {-bereiden medicatie } \\
\text {-infuusysteem } \\
\text {-pomp } \\
\text {-overig }\end{array}$ & $\begin{array}{l}501 \\
5,4 \% \\
3,0 \%^{6} \\
9,9 \\
0,4 \% \\
1,6 \% \\
0,5 \%\end{array}$ & $\begin{array}{l}75 \times 22=1.650 \\
6,4 \% \\
5,4 \% \\
9,1^{7} \\
1,9 \% \\
1,8 \% \\
2,1 \%\end{array}$ & $\begin{array}{l}39 \times 19,5=660,5 \\
5,0 \% \\
3,0 \% \\
9,9^{4} \\
\vdots \\
0,5 \%\end{array}$ & $\begin{array}{l}11 \times 13,6=149,6 \\
\because 9 \\
0,3 \% \\
: \\
0,6 \%\end{array}$ \\
\hline $\begin{array}{l}\text { Kosten } \\
\text {-matericel } \\
\text {-personeel }\end{array}$ & $\begin{array}{l}f 400^{10} \\
f 175^{10} \\
f 225^{10}\end{array}$ & $\begin{array}{l}f 250^{\prime \prime} \\
f 100^{\prime \prime} \\
f 150^{\prime \prime}\end{array}$ & $f 470-f 490^{12}$ & $\dot{-}$ \\
\hline Geschatte besparing & $40 \%$ & $40 \%$ & $50 \%$ & • \\
\hline
\end{tabular}

Legenda: '=komt niet voor of is niet vermeld of te berekenen, ${ }^{2}=$ gemiddelde/standaard eviatie/bereik, ${ }^{3}$-waarvan 75 niet virale infecties, "-soort antibiotica niet genoemd, '-ziekenhuisdagen afgeleid uit beschrijving zorgmodel: bij KITTZ enkele bij elke behandeling: bij multicenter 2 a 3 bij de eerste kuur,"-exclusief de apart besproken patient, '=tenminste $75 \times 22 / 75+106=9,1$ dagen, "-tenminste $39 \times 19,5 / 39+38=9,9$ dagen, "=deels 'midline' catheters en centraalveneuze infusie, ${ }^{10}=1994+1995$ prijzen, ${ }^{11}=1991+1993$ prijzen, ${ }^{12}=1993$ en eerdere prijzen. 
Tabel B12.4.3 Kwaliteit van leven en kwaliteit van zorg bij antibioticabehandeling.

Kenmerken van patilenten volgens hentelf, hun naasten en zorgverleners

\begin{tabular}{lllll} 
Item & $\begin{array}{l}\text { Patiēnt } \\
(\mathbf{n}=14-15)\end{array}$ & $\begin{array}{l}\text { Naaste } \\
(\mathbf{n}=11-12)\end{array}$ & $\begin{array}{l}\text { TMV } \\
(\mathbf{n}=15)\end{array}$ & $\begin{array}{l}\text { Huisarts } \\
(\mathbf{n}=14-15)\end{array}$ \\
Emst ziekte $(1-5)^{*}$ & $3,1 / 0,9 / 2-5^{*}$ & $3,6 / 1,2 / 2-5$ & $3,3 / 1,2 / 1-5$ & $3,2 / 1,2 / 1-5$ \\
Pijn $(0-10)^{2}$ & $1,4 / 2,5 / 0,9-8,0$ & $1,1 / 2,5 / 0,0-8,2$ & $1,4 / 1,3 / 0,0-4,5$ & $1,7 / 1,7 / 0,0-5,3$ \\
Functioneren SIP-68 $(0-68)^{3}$ & $17,9 / 14,9 / 0-42$ & nvt & nvt & nvt \\
Gezondheidsbeleving $(1-5)^{4}$ & $2,8 / 0,7 / 2-4$ & $2,8 / 0,8 / 2-4$ & $2,9 / 0,8 / 2-4$ & $2,9 / 0,9 / 2-5$ \\
Kwaliteit van leven $(0-10)^{5}$ & $6,9 / 2,5 / 2,0-10,0$ & $7,0 / 3,0 / 0,2-10,0$ & $7,4 / 2,2 / 2,5-9,0$ & $5,6 / 2,0 / 2,1-9,0$ \\
\hline
\end{tabular}

Kenmerken en belasting van naasten volgens patiènten, henzelf en zorgverleners

\begin{tabular}{|c|c|c|c|c|}
\hline Item & $\begin{array}{l}\text { Patiênt } \\
(n=12,12,15)\end{array}$ & $\begin{array}{l}\text { Naaste } \\
(n=11-12)\end{array}$ & $\begin{array}{l}\text { TMV } \\
(n=12)\end{array}$ & Huisarts ( $n=12)$ \\
\hline Praktische steun (1-5) ${ }^{6}$ & $4,8 / 0,5 / 4-5$ & $3,3 / 1,4 / 1-5$ & nvt & nvt \\
\hline Emotionele steun $(1-5)^{6}$ & $4,4 / 0,8 / 3-5$ & $3,7 / 1,4 / 1-5$ & nvt & nvt \\
\hline Belasting CSI (0-13) & nvt & $1,5 / 1,6 / 0-4$ & $2,0 / 2,7 / 0-10$ & $0,9 / 1,9 / 0-7$ \\
\hline Infuuszorg belastend (1-5) & $3,9 / 1,2 / 1-5$ & $3,9 / 1,2 / 1-5$ & $4,0 / 1,0 / 2-5$ & $3,5 / 1,0 / 2-5$ \\
\hline Naaste ziek & nvt & $16 \%(n-2)$ & nvt & nvt \\
\hline Emst ziekte (1-5)' & nvt & $4,5 / 0,7 / 4-5$ & nvt & nvt \\
\hline Gezondsbeleving $(1-5)^{4}$ & nvt & $\begin{array}{l}2,1 / 0,7 / 1-3 \\
(n=12)\end{array}$ & nvt & nvt \\
\hline Kwaliteit van leven $(0-10)^{5}$ & nvt & $\begin{array}{l}8,6 / 1,3 / 6,0-10,0 \\
(n=11)\end{array}$ & $8,6 / 1,6 / 4,0-7,0$ & $7,6 / 1,5 / 3,7-9,0$ \\
\hline
\end{tabular}

Kwaliteit van zorg volgens patiënten, hun naasten en zorgverleners

\begin{tabular}{|c|c|c|c|c|}
\hline Item & $\begin{array}{l}\text { Patiént }(n=15, \\
11,6,15,15)\end{array}$ & $\begin{array}{l}\text { Naaste }(\mathrm{n}=12 \\
8,2,12,10)\end{array}$ & $\begin{array}{l}\text { TMV }(n=14, \\
11,1,15,15)\end{array}$ & $\begin{array}{l}\text { Huisarts (n= } \\
13,7,5,13,13 \text { ) }\end{array}$ \\
\hline Rapportcijfer TMV & $9,1 / 1,1 / 7-10$ & $8,9 / 1,2 / 7-10$ & $8,1 / 0,7 / 7-9$ & $8,6 / 0,8 / 8-10$ \\
\hline Rapportcijfer huisarts & $7,2 / 1,9 / 3-10$ & $7,5 / 1,2 / 5-9$ & $7,4 / 1,0 / 5-9$ & $7,3 / 1,4 / 6-10$ \\
\hline Rapportcijfer specialist & $8,5 / 1,2 / 7-10$ & $9,5 / 0,7 / 9-10$ & $8 /-18$ & $7,8 / 1,5 / 6-10$ \\
\hline RGO/NWO (32-160) " & $139 / 18 / 101-160$ & $137 / 17 / 107-158$ & $135 / 12 / 125-160$ & $121 / 15 / 100-155$ \\
\hline $\operatorname{CSQ}(8-32)^{\prime}$ & $29 / 4 / 19.32$ & $27 / 4 / 19-32$ & $29 / 4 / 21-32$ & $28 / 4 / 18-32$ \\
\hline
\end{tabular}

Legenda: " "scoremogelijkheden, ${ }^{*}=$ gemiddelde / standaard deviatic / bereik, nvt-niet gevraagd!'=1 zeer emstig 2:vrij ernstig 3:ernstig 4 :nauwelijks emstig 5:niet emstig, ${ }^{2}=0$ :geen pijn 10:ondraaglijke pijn, ${ }^{2}=$ hoe hoger hoe beperkter, ${ }^{4}=1$ :zeer goed 5; zeer slecht, ${ }^{3}=0$ :slechts denkbare kwaliteit 10:hoogst denkbare kwaliteit, ${ }^{4}=1$ :geen 2:weinig 3:niet veel en niet weinig 4:veel 5:zeer veel, =hoe hoger hoe belastender, ${ }^{2}=1: z e e r$ mee oneens 5:zeer mee eens, "=vierpuntsschaal. 
Tabel B12.4.4 Tijdsbesteding verpleegkundig zorgproces bij intraveneuze infusie van antibiotica thuis.

\begin{tabular}{|c|c|c|c|c|c|}
\hline Activiteit & $\%$ totaal & $\bar{x}$ & SD & Bereik & Aantal \\
\hline \multicolumn{6}{|l|}{ Primair proces } \\
\hline Intakegesprekken & 1,6 & 45,19 & 25,29 & $10-120$ & 27 \\
\hline Zorgdragen voor verpleeghulpmiddelen & 0,1 & 15,00 & 10,80 & $5-30$ & 4 \\
\hline $\begin{array}{l}\text { Zorgdragen voor infuusbenodigdheden } \\
\text { (medicatie en infuusmaterialen) }\end{array}$ & 2,7 & 20,15 & 22,71 & $5-210$ & 103 \\
\hline Installeren infusiepomp & 0,2 & 8,95 & 5,16 & $5-25$ & 19 \\
\hline $\begin{array}{l}\text { Voorbereiden van en assisteren bij } \\
\text { inbrengen infuus }\end{array}$ & 0,3 & 29,44 & 11,30 & $15-55$ & 9 \\
\hline Verzorgen insteekopening & 2,0 & 9,60 & 5,67 & $5-35$ & 161 \\
\hline $\begin{array}{l}\text { Aansluiten/verwisselen infuuszak en } \\
\text { klaarmaken medicatie }\end{array}$ & 11,0 & 12,78 & 7,01 & $5-45$ & 652 \\
\hline Wachttijd tijdens inlopen & 16,4 & 24,47 & 11,74 & $5-75$ & 508 \\
\hline Verwisselen infuussysteem & 4,0 & 9,08 & 4,52 & $5-30$ & 333 \\
\hline Spoelen en hepariniseren & 9,5 & 9,70 & 4,77 & $5-55$ & 741 \\
\hline Verwijderen infuus & 0,4 & 9,68 & 4,46 & $5-20$ & 31 \\
\hline Instructie patient/naaste verzorgers & 2,2 & 24,12 & 17,83 & $5-95$ & 68 \\
\hline Consult patient/naaste verzorgers & 0,0 & 12,50 & 3,54 & $10-15$ & 2 \\
\hline Realiseren therapie en leefregel & 1,5 & 12,58 & 8,38 & $5-65$ & 91 \\
\hline Begeleiden probleemsituatic & 0,4 & 17,37 & 9,48 & $5-45$ & 19 \\
\hline Lichamelijk hygienische verzorging & 0,0 & 10,00 & - & 10 & 1 \\
\hline Evaluatiegesprekken & $0,7 \mathbf{5 3 , 3}$ & 23,91 & 15,07 & $5-60$ & 23 \\
\hline \multicolumn{6}{|l|}{ Instructie van andere zorgverleners } \\
\hline Wijkverpleegkundige & 2,0 & 60,20 & 36,27 & $10-120$ & 25 \\
\hline Huisarts & $0,0 \quad \mathbf{2 , 0}$ & 12,50 & 3,54 & $10-15$ & 2 \\
\hline \multicolumn{6}{|l|}{ Overleg met andere zorgverleners } \\
\hline Wijkverpleging & 1,6 & 15,65 & 14,52 & $5-60$ & 77 \\
\hline Medisch behandelaar & 0,9 & 12,04 & 11,01 & $5-65$ & 54 \\
\hline Ziekenhuis & 0,6 & 15,32 & 13,96 & $5-45$ & 31 \\
\hline Eerstelijnsvoorzieningen & 0,2 & 14,00 & 11,50 & $5-45$ & 10 \\
\hline Vrijwilligers & 0,1 & 11,00 & 2,24 & $10-15$ & 5 \\
\hline Meerdere disciplines & $0,2 \quad 3,6$ & 45,00 & 50,50 & $15-120$ & 4 \\
\hline \multicolumn{6}{|l|}{ Overige taken } \\
\hline Bevorderen dienstverlening & 1,4 & 12,98 & 9,48 & $5-60$ & 84 \\
\hline Reistijd & 35,7 & 20,69 & 7,87 & $5-50$ & 1313 \\
\hline Administratic & 3,2 & 12,57 & 12,94 & $5-90$ & 191 \\
\hline Afvalverwerking & $0,8 \quad 41,1$ & 14.65 & 8,27 & $5-40$ & 43 \\
\hline
\end{tabular}

Legenda: '=gemiddelde tijd in minuten, ${ }^{2}=$ standaard deviatie in minuten, ${ }^{3}=$ in minuten, ${ }^{4}=$ aantal maal dat cen activiteit geregistreerd is. 
Tabel B12.5.1 Kenmerken thuis- en niet-thuisbehandelde patienten.

\begin{tabular}{|c|c|c|c|}
\hline $\begin{array}{l}\text { Sociaal-demografisch } \\
\text { Geslacht: } \operatorname{man} \text { / vrouw } \\
\text { Leeftijd " } \\
\text { Alleenstaand } \\
\text { Thuis / bejaardenhuis / verpleeghuis }\end{array}$ & $\begin{array}{l}\text { Thuis } \\
(N=9) \\
6 / 3 \\
67,4 / 8,1 / 55-79 \\
0 \\
7 / 1 / 1\end{array}$ & 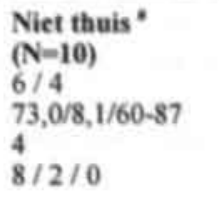 & $\begin{array}{l}\text { Totaal } \\
(\mathrm{N}=19) \\
12 / 7 \\
70,4 / 8,3 / 55-87 \\
4 \\
15 / 3 / 1\end{array}$ \\
\hline $\begin{array}{l}\text { Diagnoses } \\
\text { Aortabroek } \\
\text { CABG } \\
\text { CARAVCOPD } \\
\text { Diabetes } \\
\text { Hartinfarct (aantal personen) } \\
\text { Hartinfaret (aantal hartinfareten) }{ }^{*} \\
\text { Hyperlipoproteinemie } \\
\text { Nierfunctiestoomissen } \\
\text { Perifeer vaatlijden }\end{array}$ & $\begin{array}{l}1 \\
1 \\
0 \\
4 \\
7 \\
1,6 / 1,5 / 1-5 \\
2 \\
7 \\
5\end{array}$ & $\begin{array}{l}2 \\
3 \\
3 \\
4 \\
8 \\
1,8 / 1,0 / 1-4 \\
3 \\
10 \\
9\end{array}$ & $\begin{array}{l}3 \\
4 \\
3 \\
8 \\
15 \\
1,7 / 1,2 / 1-5 \\
5 \\
17 \\
14\end{array}$ \\
\hline $\begin{array}{l}\text { Symptomen } \\
\text { Ascites } \\
\text { Atriumfibrilleren } \\
\text { Cardiomegalic (X-thorax) } \\
\text { Crepiteren longen } \\
\text { Eetstoomissen (belemmering) } \\
\text { Ejectiefractie }{ }^{-0} \\
\text { Gewichtstoename in dagen } \\
\text { Hepatomegalie } \\
\text { Luchtweginfectie } \\
\text { Mitralisinsufficiéntie } \\
\text { Oedeem benen } \\
\text { Plasmacreatininespiegel * } \\
\text { Souffles hart } \\
\text { Tricuspidalisinsufficiéntie }\end{array}$ & $\begin{array}{l}3 \\
2 \\
8 \\
8 \\
4 \\
24 / 7 / 15-33 \\
8 \\
8 \\
1 \\
8 \\
7 \\
194 / 131 / 118-487 \\
7 \\
6\end{array}$ & $\begin{array}{l}2 \\
5 \\
10 \\
10 \\
4 \\
37 / 23 / 15-72 \\
10 \\
7 \\
1 \\
10 \\
8 \\
253 / 147 / 139-600 \\
8 \\
6\end{array}$ & $\begin{array}{l}5 \\
7 \\
18 \\
18 \\
8 \\
31 / 18 / 15-72 \\
18 \\
15 \\
2 \\
18 \\
15 \\
229 / 139 / 118-600 \\
15 \\
12\end{array}$ \\
\hline $\begin{array}{l}\text { Decompensatic } \\
\text { Oorzaak: dilatatic / ischaemic / hypertensic } \\
\text { Plaats: links / rechts / beide }\end{array}$ & $\begin{array}{l}5 / 7 / 4 \\
1 / 0 / 7\end{array}$ & $\begin{array}{l}6 / 7 / 7 \\
1 / 1 / 8\end{array}$ & $\begin{array}{l}11 / 14 / 11 \\
2 / 1 / 15\end{array}$ \\
\hline $\begin{array}{l}\text { Medicatie bij aanmelding } \\
\text { ACE remmers } \\
\text { Alfablockers } \\
\text { Ca-antagonisten } \\
\text { Cordarone } \\
\text { Digitalispreparaten } \\
\text { Diuretica } \\
\text { Ibopamine } \\
\text { Monocedocard } \\
\text { Vasodilatoren }\end{array}$ & $\begin{array}{l}6 \\
2 \\
1 \\
1 \\
6 \\
8(2 \times 2) \\
4 \\
7 \\
0\end{array}$ & $\begin{array}{l}4 \\
4 \\
3 \\
4 \\
6 \\
10(1 \times 2) \\
2 \\
8 \\
0\end{array}$ & $\begin{array}{l}10 \\
6 \\
4(1 \times 2) \\
5 \\
12 \\
18(4 \times 2) \\
6 \\
15 \\
0\end{array}$ \\
\hline $\begin{array}{l}\text { Functioneren } \\
\text { Kortademigheid }(1-4){ }^{*} \\
\text { NYHA }(1-4) \\
\text { Opnames } \leq 2 \text { jaar voor decompensatic }{ }^{. *}\end{array}$ & $\begin{array}{l}3,9 / 0,4 / 3-4 \\
4,0 / 0,0 / 4-4 \\
2,5 / 1,4 / 0-5\end{array}$ & $\begin{array}{l}3,5 / 0,7 / 2-4 \\
3,9 / 0,3 / 3-4 \\
2,7 / 1,5 / 0-5\end{array}$ & $\begin{array}{l}3,7 / 0,6 / 2-4 \\
3,9 / 0,2 / 3-4 \\
2,6 / 1,4 / 0-5\end{array}$ \\
\hline $\begin{array}{l}\text { Reactic op dopamine/lasix behandeling } \\
\text { Reactic: goed / slecht / onbekend } \\
\text { Heropnames voor decompensatie" }\end{array}$ & $\begin{array}{l}8 / 1 / 0 \\
0,3 / 0,5 / 0-1\end{array}$ & $\begin{array}{l}9 / 0 / 1 \\
1,0 / 1,1 / 0-3\end{array}$ & $\begin{array}{l}17 / 1 / 1 \\
0,7 / 0,9 / 0-3\end{array}$ \\
\hline
\end{tabular}

Legenda: "=kwamen niet voor thuisbehandeling in aanmerking en zijn verder in het ziekenhuis behandeld, "-meestal het aantal personen, "=gemiddelde/standaard deviatie/bereik, "'=classificatie New York Heart Association. 
Tabel B12.5.2 Klinische gegevens van patienten met dopamine- en lasixtoediening thuis.

\begin{tabular}{|c|c|c|c|c|c|}
\hline Pt & (co)morbiditeit, oorzaak overlijden & Effect: & Dopamine" & Lasix" & $\mathbf{n}$ \\
\hline P 79 & $\begin{array}{l}\text { ischaemische cardiomyopathie, algemeen vaat- } \\
\text { lijden, preterminale nierinsufficientie, geamputeerd } \\
\text { been rechts en trombose linker been bij NIDDM, } \\
\text { hypertensie en hyperlipoproteinemie IIB }\end{array}$ & + & 160 & 160 & 1 \\
\hline 874 & $\begin{array}{l}\text { gedilateerde, ischaemische en hypertensieve } \\
\text { cardiomyopathic, algemeen vaatlijden en } \\
\text { nierfunctiestoornissen bij NIDDM en hypertensie } \\
\uparrow \text { nierfalen vanwege afnemende hartfunctie }\end{array}$ & + & $\begin{array}{l}120-125 \\
125\end{array}$ & $\begin{array}{l}250 \\
250\end{array}$ & $\begin{array}{l}1 \\
1\end{array}$ \\
\hline 055 & $\begin{array}{l}\text { gedilateerde, ischaemische cardiomyopathie, nier- } \\
\text { functiestoornissen bij NIDDM en myocardinfaret } \\
\uparrow \text { plotseling in slaap overleden, waarschijnlijk } \\
\text { vanwege hartconditie }\end{array}$ & + & $175-180$ & $250-500$ & 1 \\
\hline of 67 & $\begin{array}{l}\text { gedilateerde, ischaemische en hypertensieve } \\
\text { cardiomyopathic, algemeen vaatlijden en } \\
\text { nierfunctie-stoornissen bij myocardinfarct } 5 x \text {, } \\
\text { hypertensie en lawaaidoofheid }\end{array}$ & + & $\begin{array}{l}175-185 \\
175 \\
175\end{array}$ & $\begin{array}{l}250 \\
200-250 \\
250\end{array}$ & $\begin{array}{l}1 \\
1 \\
4\end{array}$ \\
\hline 868 & $\begin{array}{l}\text { gedilateerde, ischaemische en hypertensieve } \\
\text { cardiomyopathic, algemeen vaatlijden en } \\
\text { nierfunctiestoornissen bij myocardinfarct, } \\
\text { aortadilatatie, IDDM en hypertensic }\end{array}$ & + & $\begin{array}{l}200 \\
195 \\
200 \\
200-205 \\
195\end{array}$ & $\begin{array}{l}120-160 \\
120 \\
160 \\
160-250 \\
250\end{array}$ & $\begin{array}{l}2 \\
1 \\
1 \\
1 \\
4\end{array}$ \\
\hline 873 & $\begin{array}{l}\text { ischaemische cardiomyopathie, nierfunctie- } \\
\text { stoornissen bij myocardinfarct, asthmatische } \\
\text { bronchitis en silicose }\end{array}$ & + & 150 & 250 & 3 \\
\hline 071 & 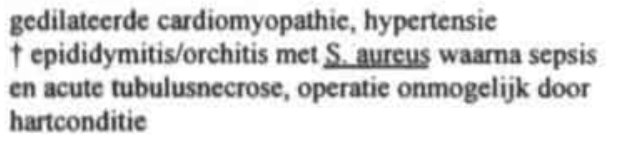 & + & $\begin{array}{l}150-155 \\
150\end{array}$ & $\begin{array}{l}80-200 \\
160\end{array}$ & $\begin{array}{l}1 \\
1\end{array}$ \\
\hline 864 & $\begin{array}{l}\text { ischaemische cardiomyopathic, algemeen vaat- } \\
\text { lijden en nierfunctiestoomissen bij ernstig rheuma } \\
\text { en slechtziend } \\
\dagger \text { longontsteking waarna sepsis }\end{array}$ & 0 & 110 & $225-250$ & 1 \\
\hline *56 & $\begin{array}{l}\text { ischaemische cardiomyopathic, anaemie en } \\
\text { longemfyseem }\end{array}$ & + & $\begin{array}{l}125 \\
125 \\
125\end{array}$ & $\begin{array}{l}120-200 \\
160-250 \\
160\end{array}$ & $\begin{array}{l}1 \\
1 \\
3\end{array}$ \\
\hline
\end{tabular}

Legenda: Pt=geslacht ơ:man 8:vrouw en leeftijd patient, $"=k l i n i s c h$ effect volgens specialist, $"=$ in milligram per 24 uur, $"=$ =verpleeghuispersoneel geinstrueerd, $n=$ aantal behandelingen. 
In het jaarverslag van het dagcentrum worden de volgende cijfers genoemd: 1991:719, 1992:733, 1993:720, 1994:653, 1995:674 en 1996:564 ${ }^{\text {21 }}$ In tabel B12.5.3 zijn de LMR cijfers gehanteerd omdat hierin ook het aantal patiěnten geteld en hun woonplaats achterhaald kon worden. ${ }^{\mathrm{m}}$

Tabel B12.5.3 Dopamine en lasixbehandelingen in het dagcentrum ${ }^{\mathrm{En}} \mathrm{en}$ thuis.

\begin{tabular}{lcccc} 
Plaats behandeling & 1993 & 1994 & 1995 & 1996 \\
Dagcentrum azM & 706 & 596 & 594 & 537 \\
Thuis & - & $101^{1}$ & $311^{2}$ & $6^{3}+?^{4}$ \\
Totaal & 706 & 697 & 905 & onbekend \\
\hline
\end{tabular}

Legenda: ${ }^{1}=1 \mathrm{x}$ door TMV in zickenhuis, ${ }^{2}=2 \mathrm{x}$ door TMV in verpleeghuis, ${ }^{2}=$ nog vanuit project, $"$-vanuit vervolg door SGKH en azM onbekend.

Tabel B12.5.4 Kwaliteit van leven en kwaliteit van zorg bij dopamine- en lasixbehandeling thuis.

\begin{tabular}{lllll}
$\begin{array}{l}\text { Kenmerken van patienten volgens henself. hun naasten en zorgverleners } \\
\text { Item }\end{array}$ & $\begin{array}{l}\text { Patiěnt } \\
(\mathbf{n}=\mathbf{8})\end{array}$ & $\begin{array}{l}\text { Naaste } \\
(\mathbf{n}=7-8)\end{array}$ & $\begin{array}{l}\text { TMV } \\
(\mathbf{n}=7-8)\end{array}$ & $\begin{array}{l}\text { Huisarts } \\
(\mathbf{n}=7)\end{array}$ \\
Emst ziekte $(1-5)^{-1}$ & $2,9 / 1,6 / 1-5 *$ & $2,4 / 1,6 / 1-5$ & $1,8 / 0,7 / 1-3$ & $1,6 / 0,8 / 1-3$ \\
Pijn $(0-10)^{2}$ & $2,5 / 3,6 / 0,0-8,3$ & $4,0 / 4,3 / 0,0-9,5$ & $4,5 / 3,4 / 0,2-9,7$ & $4,0 / 4,3 / 0,0-9,4$ \\
Functioneren SIP-68 $(0-68)^{3}$ & $30 / 14 / 6-45$ & nvt & nvt & nvt \\
Gezondheidsbeleving (1-5) & $3,1 / 1,3 / 2-5$ & $3,4 / 1,2 / 2-5$ & $3,8 / 0,9 / 3-5$ & $3,7 / 0,8 / 3-5$ \\
Kwaliteit van leven $(0-10)^{3}$ & $5,9 / 3,5 / 0,6-10,0$ & $5,1 / 3,5 / 0,6-9,5$ & $3,7 / 2,1 / 0,6-6,0$ & $4,4 / 2,7 / 1,8-8,4$ \\
\hline
\end{tabular}

Kenmerken en belasting van naasten volgens patiënten, henzelf en zorgverleners

\begin{tabular}{|c|c|c|c|c|}
\hline Item & $\begin{array}{l}\text { Patiěnt } \\
(n=7)\end{array}$ & $\begin{array}{l}\text { Naaste } \\
(n=7-8)\end{array}$ & $\begin{array}{l}\text { TMV } \\
(n=7-8)\end{array}$ & $\begin{array}{l}\text { Huisarts } \\
(n=7-8)\end{array}$ \\
\hline Praktische steun (1-5) ${ }^{6}$ & $4,6 / 0,5 / 4-5$ & $4,3 / 1,0 / 2-5$ & nvt & nvt \\
\hline Emotionele steun $(1-5)^{6}$ & $4,1 / 0,9 / 3-5$ & $4,1 / 1,4 / 1.5$ & nvt & nvt \\
\hline Belasting CSI $(0-13)^{7}$ & nvt & $4,6 / 3,5 / 1-10$ & $3,6 / 3,7 / 0-11$ & $4,1 / 2,8 / 0-8$ \\
\hline Infuuszorg belastend (1-5)" & $2,9 / 1,6 / 1-5$ & $4,3 / 0,7 / 3-5$ & $2,9 / 1,0 / 1-4$ & $2,4 / 1,0 / 1-4$ \\
\hline Naaste ziek & nvt & 3 van de 7 & nvt & nvt \\
\hline Ernst ziekte $(1-5)^{4}$ & nvt & $4,7 / 0,6 / 4-5$ & nvt & nvt \\
\hline Gezondheidsbeleving $(1-5)^{4}$ & nvt & $2,7 / 0,5 / 2-3$ & nvt & nvt \\
\hline Kwaliteit van leven $(0-10)^{5}$ & nvt & $5,9 / 3,3 / 0,6-9,7$ & $7,1 / 2,4 / 2,0-9,8$ & $5,0 / 2,6 / 1,0-8,4$ \\
\hline \multicolumn{5}{|c|}{ Kwaliteit van zorg volgens patiënten, hun naasten en zorgverleners } \\
\hline Item & $\begin{array}{l}\text { Patiēnt } \\
(n=5-7)\end{array}$ & $\begin{array}{l}\text { Naaste } \\
(n=6-8)\end{array}$ & $\begin{array}{l}\text { TMV } \\
(n=5-8)\end{array}$ & $\begin{array}{l}\text { Huisarts } \\
(\mathrm{n}=3-7)\end{array}$ \\
\hline Rapportcijfer TMV & $8,6 / 1,1 / 7-10$ & $9,1 / 0,8 / 8-10$ & $7,9 / 0,6 / 7-9$ & $8,1 / 0,9 / 7-10$ \\
\hline Rapportcijfer huisarts & $8,1 / 1,1 / 7-10$ & $8,1 / 1,3 / 6-10$ & $7,0 / 1,2 / 5-8$ & $8,3 / 1,5 / 7-10$ \\
\hline Rapportcijfer specialist & $8,8 / 1,3 / 7-10$ & $9,2 / 1,0 / 8-10$ & $7,3 / 1,4 / 5-8$ & $8,3 / 1,3 / 7.10$ \\
\hline RGO/NWO (32-160) & $140 / 17 / 115-160$ & $144 / 15 / 127-160$ & $127 / 8 / 114-144$ & $126 / 14 / 103-147$ \\
\hline $\operatorname{CSQ}(8-32)^{\prime}$ & $28 / 4 / 23-32$ & $28 / 4 / 20-32$ & $26 / 5 / 18-31$ & $25 / 4 / 19-32$ \\
\hline
\end{tabular}

Legenda: "-scoremogelijkheden, $" *=$ gemiddelde / standaard deviatic / bereik, nvt=niet gevraagd, '=1 zeer ernstig 2:vrij emstig 3 :ernstig 4 :nauwelijks emstig 5 :niet emstig, ${ }^{2}=0$ :geen pijn 10:ondraaglijke pijn, ${ }^{3}=$ hoe hoger hoe beperkter, ${ }^{4}=1$ zeer goed 5 ; zeer slecht, ${ }^{2}=0$ : slechts denkbare kwaliteit 10 :hoogst denkbare kwaliteit,

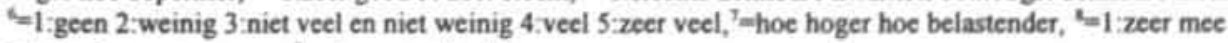
oneens 5 zeer mee eens, "-vierpuntsschaal. 
Tabel B12.5.5 Tijdsbesteding verpleegkundig zorgproces bij infusie van dopamine en lasix thuis.

\begin{tabular}{|c|c|c|c|c|c|}
\hline Activiteit & $\%$ totaal & $\bar{x}$ & $\mathbf{S D}^{2}$ & Bereik $^{3}$ & Aantal * \\
\hline \multicolumn{6}{|l|}{ Primair proces } \\
\hline Intakegesprekken & 1,3 & 57,06 & 27,45 & $10-105$ & 17 \\
\hline Zorgdragen voor verpleeghulpmiddelen & 0,0 & 15,00 & $\cdot$ & 15 & 1 \\
\hline $\begin{array}{l}\text { Zorgdragen voor infuusbenodigdheden } \\
\text { (medicatic en infuusmaterialen) }\end{array}$ & 2,2 & 14,73 & 10,49 & $5-80$ & 110 \\
\hline Aansluiten infuuscassette & 4,0 & 7,44 & 4,29 & $5-30$ & 405 \\
\hline Instellen infuuspomp & 6,6 & 12,15 & 6,50 & $5-60$ & 407 \\
\hline Voorbereiden en inbrengen infuus & 11,4 & 21,23 & 6,84 & $5-45$ & 404 \\
\hline Tussentijds verzorgen insteekopening & 0,1 & 8,89 & 5,46 & $5-20$ & 9 \\
\hline Verwijderen infuus & 11,7 & 22,48 & 6,67 & $5-45$ & 393 \\
\hline Instructie patient/naaste verzorgers & 1,5 & 24,78 & 14,94 & $5-60$ & 46 \\
\hline Realiseren therapie en leefregel & 6,0 & 11,51 & 7,08 & $5-80$ & 394 \\
\hline Begeleiden probleemsituatic & 1,5 & 16,82 & 9,31 & $5 \cdot 70$ & 66 \\
\hline Evaluatiegesprekken & $0,3 \quad 46,9$ & 34,17 & 14,29 & $20-60$ & 6 \\
\hline \multicolumn{6}{|l|}{ Instructie van andere zorgverleners } \\
\hline Wijkverpleegkundige & 0,4 & 37,22 & 35,72 & $10-120$ & 9 \\
\hline Huisarts & $\begin{array}{ll}0,0 & \mathbf{0 , 4}\end{array}$ & 15,00 & 7,07 & $10-20$ & 2 \\
\hline \multicolumn{6}{|l|}{ Overleg met andere zorgverleners } \\
\hline Wijkverpleging & 0,4 & 10,15 & 5,08 & $5-30$ & 33 \\
\hline Medisch behandelaar & 0,6 & 11,05 & 5,73 & $5-30$ & 43 \\
\hline Ziekenhuis & 0,3 & 15,71 & 15,67 & $5-60$ & 14 \\
\hline Eerstelijnsvoorzieningen & 0,1 & 10,00 & 4,08 & $5-15$ & 4 \\
\hline Vrijwilligers & 0,2 & 11,79 & 6,96 & $5-30$ & 14 \\
\hline Meerdere disciplines & $0,1 \quad 1,7$ & 16,25 & 6,29 & $10-25$ & 4 \\
\hline \multicolumn{6}{|l|}{ Overige taken } \\
\hline Bevorderen dienstverlening & 10,0 & 13,41 & 7,29 & $5-90$ & 559 \\
\hline Reistijd & 32,1 & 17,05 & 7,72 & $5-45$ & 1416 \\
\hline Administratic & 8,0 & 11,37 & 5,47 & $5-80$ & 532 \\
\hline Afvalverwerking & $1,0 \quad 51,0$ & 14,80 & 7,43 & $5-40$ & 49 \\
\hline
\end{tabular}

836 infusiedagen / 30 behandelingen / 9 patienten / 75.211 minuten $=1.254$ uur $/ 4.961$ handelingen

Legenda: ${ }^{2}=$ gemiddelde tijd in minuten, ${ }^{2}=$ standaard deviatie in minuten, ${ }^{3}=$ in minuten, ${ }^{4}=$ aantal maal dat een activiteit geregistreerd is. 
Tabel B12.5.6 Complicaties bij thuisbehandeling met dobutamine en dopamine.

\begin{tabular}{|c|c|c|c|c|}
\hline Item & Applefeld $w$ & Miller ${ }^{\text {a }}$ & Collins w & Deze studie \\
\hline Subclavia & 0 & 0 & 1 & 0 \\
\hline Hickman & 14 & 6 & 2 & 0 \\
\hline Centraalveneuze poort & 6 & 5 & 0 & 9 \\
\hline Geimplanteerde pomp & 1 & 0 & 0 & 0 \\
\hline Soort pomp & $\begin{array}{l}\text { Diverse spuit-en } \\
\text { casettepompen }\end{array}$ & $\begin{array}{l}\text { Deltec } \\
\text { cassettepomp }\end{array}$ & $\begin{array}{l}\text { Deltec } 8 \\
\text { cassettepomp }\end{array}$ & $\begin{array}{l}\text { Deltec } 8 \\
\text { cassettepomp }\end{array}$ \\
\hline Infecties & $8-12^{1}(0,3-0,5 \%)^{\circ}$ & $\begin{array}{l}\text { Hickman: } 0 \\
\text { CVP }^{2}=3(1.2 \%)\end{array}$ & 0 & 0 \\
\hline Tromboses & 0 & $\begin{array}{l}\text { Hickman: } 0 \\
\text { CVP }^{2}: 2(0,8 \%)^{*}\end{array}$ & 0 & 0 \\
\hline Extravasatie & $3(0,1 \%)^{*}$ & $\cdot$ & $\cdot$ & 0 \\
\hline Disconnectie/lekken & $\cdot$ & $\cdot$ & $2^{3}(2,8 \%)^{\circ}$ & $5(1,2 \%)^{\circ}$ \\
\hline Pomp defect & $2(0,1 \%)^{\circ}$ & $\cdot$ & - & $3(0,4 \%)^{3}$ \\
\hline Infusiedagen & $\pm 2527^{\circ}$ & $\pm 560^{\circ}$ & 72 & 418 \\
\hline Patienten & 21 & 11 & 3 & 9 \\
\hline NYHA verdeling & III: $24 \%$ IV: $76 \%$ & IV: $100 \%$ & IV: $100 \%$ & IV: $100 \%$ \\
\hline
\end{tabular}

Legenda: " $\%$ per infusiedag, '"verschillende opgaven in tekst, ${ }^{2}=$ alleen bij de centraalveneuze poort daarom wordt gerekend met $5 / 11 \times 560=255$ dagen, ${ }^{1}=$-alleen bij de subclaviacatheter, ${ }^{4}=$ berekend uit artikel, ${ }^{3}=\%$ per pompdag ( 836 omdat elkens twee pompen). 


\section{Zorgsituatie en kwaliteit van leven}

\section{Bijlage 13.1: Dimensiescores Sickness Impact Profile (68 items)}

Tabel B13.1 geeft de dimensiescores van enkele medicatiegroepen op de SIP-68, tabel B13.2 de interne consistentie. De SIP-68 omvat 68 dichotome items in 6 dimensies. Hoe hoger de score hoe meer beperkingen. De dimensies zijn: SA:somatische autonomie (basaal lichamelijk functioneren) 17 items; MC:motorische controle (lichamelijk functioneren) 12 items; PAC:psychische autonomie en communicatie (psychisch functioneren en communicatic) 11 items; SB:sociaal gedrag (sociale activiteiten en hobby's) 12 items; ES:emotionele stabiliteit (emotionele uitingen) 6 items; en de MR:mobiliteitsrange (substantiele beperkingen op huishoudelijk en sociaal gebied) 10 items.

Tabel B13.1 Sickness Impact Profile (68 items) plus dimensies per medicatiegroep.

\begin{tabular}{|c|c|c|c|c|c|c|c|c|}
\hline \multirow{2}{*}{$\begin{array}{l}\text { Dimensies } \\
\text { en totaal }\end{array}$} & \multicolumn{2}{|c|}{ Mannitol } & \multicolumn{2}{|c|}{ Antibiotica } & \multicolumn{2}{|c|}{ Hartmiddelen } & \multicolumn{2}{|c|}{ Totaal * } \\
\hline & S-68 & $\mathbf{I T}$ & S-68 & $\mathbf{I T}$ & S-68 & $\pi$ & S-68 & $\mathbf{r T}$ \\
\hline SA & $\begin{array}{l}3,08 \\
2,98 \\
0-13\end{array}$ & $\begin{array}{l}3,20 \\
3,01 \\
0-13\end{array}$ & $\begin{array}{l}2,73 \\
4,25 \\
0-11\end{array}$ & $\begin{array}{l}2,93 \\
4,68 \\
0-13\end{array}$ & $\begin{array}{r}3,50 \\
2,73 \\
0-7\end{array}$ & $\begin{array}{r}3,63 \\
2,83 \\
0-7\end{array}$ & $\begin{array}{l}3,04 \\
3,31 \\
0-13\end{array}$ & $\begin{array}{l}3,17 \\
3,49 \\
0-13\end{array}$ \\
\hline MC & $\begin{array}{l}3,28 \\
2,59 \\
1-10\end{array}$ & $\begin{array}{l}3,48 \\
2,60 \\
1-10\end{array}$ & $\begin{array}{l}4,20 \\
3,49 \\
0-10\end{array}$ & $\begin{array}{l}4,40 \\
3,58 \\
0-11\end{array}$ & $\begin{array}{r}5,75 \\
2,82 \\
1-9\end{array}$ & $\begin{array}{r}6,00 \\
2,88 \\
1-9\end{array}$ & $\begin{array}{l}4,04 \\
3,00 \\
0-10\end{array}$ & $\begin{array}{l}4,27 \\
3,06 \\
0-11\end{array}$ \\
\hline PAC & $\begin{array}{r}1,24 \\
1,85 \\
0-7\end{array}$ & $\begin{array}{l}1,24 \\
1,85 \\
0-7\end{array}$ & $\begin{array}{r}0,73 \\
1,22 \\
0-4\end{array}$ & $\begin{array}{l}0,73 \\
1,22 \\
0-4\end{array}$ & $\begin{array}{r}4,63 \\
3,89 \\
0-8\end{array}$ & $\begin{array}{r}4,63 \\
3,89 \\
0-8\end{array}$ & $\begin{array}{r}1,65 \\
2,46 \\
0-8\end{array}$ & $\begin{array}{r}1,65 \\
2,46 \\
0-8\end{array}$ \\
\hline SB & $\begin{array}{l}4,08 \\
2,91 \\
0-10\end{array}$ & $\begin{array}{l}4,16 \\
2,94 \\
0-10\end{array}$ & $\begin{array}{l}5,13 \\
2,97 \\
0-10\end{array}$ & $\begin{array}{l}5,27 \\
3,08 \\
0-10\end{array}$ & $\begin{array}{l}8,50 \\
2,93 \\
2-11\end{array}$ & $\begin{array}{l}8,63 \\
2,92 \\
2-11\end{array}$ & $\begin{array}{l}5,08 \\
3,21 \\
0-11\end{array}$ & $\begin{array}{l}5,19 \\
3,24 \\
0-11\end{array}$ \\
\hline ES & $\begin{array}{r}1,40 \\
1,44 \\
0-4\end{array}$ & $\begin{array}{r}1,76 \\
1,74 \\
0-5\end{array}$ & $\begin{array}{r}1,00 \\
1,93 \\
0-6\end{array}$ & $\begin{array}{r}1,07 \\
1,94 \\
0-6\end{array}$ & $\begin{array}{r}2,38 \\
1,06 \\
1-4\end{array}$ & $\begin{array}{r}2,75 \\
1,04 \\
1-4\end{array}$ & $\begin{array}{r}1,38 \\
1,59 \\
0-6\end{array}$ & $\begin{array}{r}1,65 \\
1,78 \\
0-6\end{array}$ \\
\hline MR & $\begin{array}{l}3,28 \\
3,54 \\
0-10\end{array}$ & $\begin{array}{l}3,28 \\
3,54 \\
0-10\end{array}$ & $\begin{array}{l}3,53 \\
4,07 \\
0-10\end{array}$ & $\begin{array}{l}3,53 \\
4,07 \\
0-10\end{array}$ & $\begin{array}{l}5,00 \\
3,55 \\
0-10\end{array}$ & $\begin{array}{l}5,00 \\
3,55 \\
0-10\end{array}$ & $\begin{array}{l}3,63 \\
3,70 \\
0-10\end{array}$ & $\begin{array}{l}3,63 \\
3,70 \\
0-10\end{array}$ \\
\hline Totaal & $\begin{array}{r}16,36 \\
11,04 \\
3-51\end{array}$ & $\begin{array}{r}17,12 \\
11,30 \\
3-53\end{array}$ & $\begin{array}{r}17,33 \\
14,08 \\
0-38\end{array}$ & $\begin{array}{r}17,93 \\
14,89 \\
0-42\end{array}$ & $\begin{array}{r}29,75 \\
13,83 \\
6-45\end{array}$ & $\begin{array}{r}30,62 \\
14,01 \\
6-45\end{array}$ & $\begin{array}{r}18,83 \\
12,84 \\
0-51\end{array}$ & $\begin{array}{r}19,58 \\
13,26 \\
0-53\end{array}$ \\
\hline
\end{tabular}

Legenda: "zie tekst, "=inclusief de medicatiegroepen vocht, anti-epileptica, virostatica en overigen, exclusief terminale patienten, S-68=uitkomsten originele SIP-68, IT=uitkomsten bij hercodering, ${ }^{\circ}=$ gemiddelde en standaard deviatic en bereik. Respondenten: patient:25/15/8/52.

Tabel B13.2 Interne consistentie per medicatiegroep (Cronbach's $\alpha$ ).

\begin{tabular}{llll}
\hline Groep & Totaal & Dimensies & n \\
Mannitol & $\alpha=0,93$ & $\alpha=0,63-0,92$ & 25 \\
Antibiotica & $\alpha=0,95$ & $\alpha=0,63-0,96$ & 15 \\
Hartmiddelen & $\alpha=0,94$ & $\alpha=0,23-0,90$ & 8 \\
Totaal & $\alpha=0,94$ & $\alpha=0,72-0,93$ & 52 \\
\hline
\end{tabular}




\section{Bijlage 13.2: Itemscores Caregiver Strain Index}

Tabel B13.3 geeft de itemscores op de Caregiver Strain Index van de naaste, de verpleegkundige en de arts. Tabel B13.4 geeft de interne consistentie per medicatiegroep en respondent.

Tabel B13.3 Belasting van de naaste verzorgers volgens henzelf, verpleegkundigen en artsen (\%). *

Morfine * Mannitol Antibiotica Hartmiddelen Totaal *

De naaste verzorger werd uit slaap gehaald door de patiént

$52,8 / 40,0 / 56,9 \quad 32,0 / 25,9 / 16,7 \quad 0,0 / 13,3 / 13,3 \quad 87,5 / 37,5 / 57,1 \quad 44,9 / 31,9 / 41,9$

De naaste verzorger vond het lastig om de patient te helpen
$13,2 / 23,6 / 9,8$
$4,0 / 7,4 / 7,4$
$0,0 / 20,0 / 0,0$
$25,0 / 37,5 / 42,9$
$10,3 / 19,8 / 8,6$

Het was lichamelijk zwaar voor de naaste verzorger om de patient the helpen
$41,5 / 36,4 / 33,3$
$12,0 / 7,4 / 0,0$
$16,7 / 0,0 / 6,7$
$37,5 / 25,0 / 14,3$
$31,8 / 23,3 / 21,0$

Door de patiënt te helpen was de naaste verzorger beperit in mogeliftheden
$43,4 / 58,2 / 52,9$
$20,0 / 48,1 / 12,5$
$8,3 / 13,3 / 13,3$
$50,0 / 37,5 / 71,4$
$32,7 / 48,3 / 41,0$

Om de patient te helpen zijn aampassingen bimnen het gezin van de naaste verzorger nodig geweest
$43,4 / 65,5 / 51,0$
$36,0 / 48,1 / 20,8$
$25,0 / 33,3 / 20,0$
$37,5 / 62,5 / 42,9$
$38,3 / 55,2 / 39,0$

De naaste verzorger heeft persoonlijke plannen moeten veranderen
$37,7 / 56,4 / 47,1$
$32,0 / 66,7 / 16,7$
$33,3 / 26,7 / 6,7$
$50,0 / 25,0 / 42,9$
$35,4 / 51,7 / 35,2$

Er werd (behalve door de patiént) ook door anderen cen beroep op de naaste versorger gedaan
$34,0 / 23,6 / 33,3$
$16,0 / 18,5 / 4,2$
$8,3 / 26,7 / 0,0$
$25,0 / 12,5 / 0,0$
$26,2 / 21,6 / 20,0$

Psychisch was het helpen voor de naaste verzorger een belasting
$35,8 / 56,4 / 43,1$
$4,0 / 11,1 / 8,3$
$8,3 / 13,3 / 6,7$
$25,0 / 37,5 / 42,9$
$24,3 / 36,2 / 26,7$

Soms was de naaste verzorger door het gedrag van de patient van streek
$37,7 / 43,6 / 35,3$
$12,0 / 11,1 / 4,2$
$16,7 / 13,3 / 6,7$
$50,0 / 37,5 / 28,6$
$29,9 / 30,2 / 23,8$

De naaste verzorger vond het naar te merken dat de patiënt zoveel veranderd was ten opzichte van vroeger
$43,4 / 45,5 / 31,4$
$20 / 3,7 / 0,0$
$8,3 / 0,0 / 6,7$
$25,0 / 25,0 / 28,6$
$32,7 / 27,6 / 20$

De naaste verzorger heeft werk ernaar moeten regelen
$37,7 / 40,0 / 39,2$
$28,0 / 40,7 / 8,3$
$16,7 / 26,7 / 6,7$
$12,5 / 0,0 / 14,3$
$29,0 / 35,3 / 25,7$

Het helpen bracht ook financiele lasten met zich mee
$11,3 / 12,7 / 7,8$
$12 / 7,4 / 0,0$
$8,3 / 6,7 / 6,7$
$12,5 / 12,5 / 14,3$
$11,2 / 10,3 / 7,6$

De naaste verzorger had het gevoel dat het allemaal teveel voor hem/haar was

$15,1 / 16,4 / 19,6 \quad 12 / 3,7 / 0,0 \quad 0,0 / 6,7 / 0,0 \quad 25,0 / 12,5 / 14,3 \quad 13,1 / 12,1 / 10,5$

Legenda: "=arts is na de indicatiestelling niet altijd bij de uitvoering van infuusbehandeling thuis betrokken geweest, morfine ${ }^{*}=$ morfine met eventuele parenterale comedicatic, "=inclusief de medicatiegroepen vocht, antiepileptica, virostatica en overigen, "=naaste/verpleegkundige/arts. Respondenten: naaste 1:53/25/12/8/107 verpleegkundige:55/27/12/8/116 arts:51/24/15/8/105.

Tabel B13.4 Interne consistentie per medicatiegroep en respondent (Cronbach's $\alpha$ ).

\begin{tabular}{llll}
\hline Groep & Naaste & Verpleegkundige & Arts \\
Morfine & $\alpha=0,79 n=53$ & $\alpha=0,77 n=55$ & $\alpha=0,78 n=53$ \\
Mannitol & $\alpha=0,75 n=25$ & $\alpha=0,77 n=27$ & $\alpha=0,55 n=24$ (9 items) \\
Antibiotica & $\alpha=0,55 n=12$ & $\alpha=0,85 n=15$ (11 items) & $\alpha=0,83 n=15$ (10 items) \\
Hartmiddelen & $\alpha=0,83 n=8$ & $\alpha=0,89 n=9$ (12 items) & $\alpha=0,71 n=7$ (12 items) \\
Totaal & $\alpha=0,79 n=107$ & $\alpha=0,82 n=116$ & $\alpha=0,83 n=108$ \\
\hline
\end{tabular}


Bijlage 13.3: SIP-68 items ter vervanging van ADL/HDL items in STG methodiek Bij de door de STG vermelde items zijn corresponderende items in de SIP-68 gezocht (schema B13.1). ${ }^{2 \nu}$ Bij de ADL schaal konden de SIP-68 items direct gekoppeld worden. Indien één van deze corresponderende SIP items aangekruist was, dan werd het item als een beperking gezien. Bij de HDL schaal was een 1 op 1 koppeling niet mogelijk en is naar een groep van 7 meest overeenkomstige SIP-68 items gezocht. De uitkomsten van de SIP-68 ADL schaal konden variëren van 0 tot en met 11: de score laag (2) is gegeven bij 0-5, de score hoog (6) bij 6-11. De uitkomsten van de SIP-68 HDL schaal konden variêren van 0 tot 7: de score laag (2) is gegeven bij 0-3, de score hoog (6) bij 4-7.

Schema B13.1 Corresponderende items op ADL- en HDL schalen van Stuurgroep Toekomstscenario's Gezondheidszorg en Sickness Impact Profile.

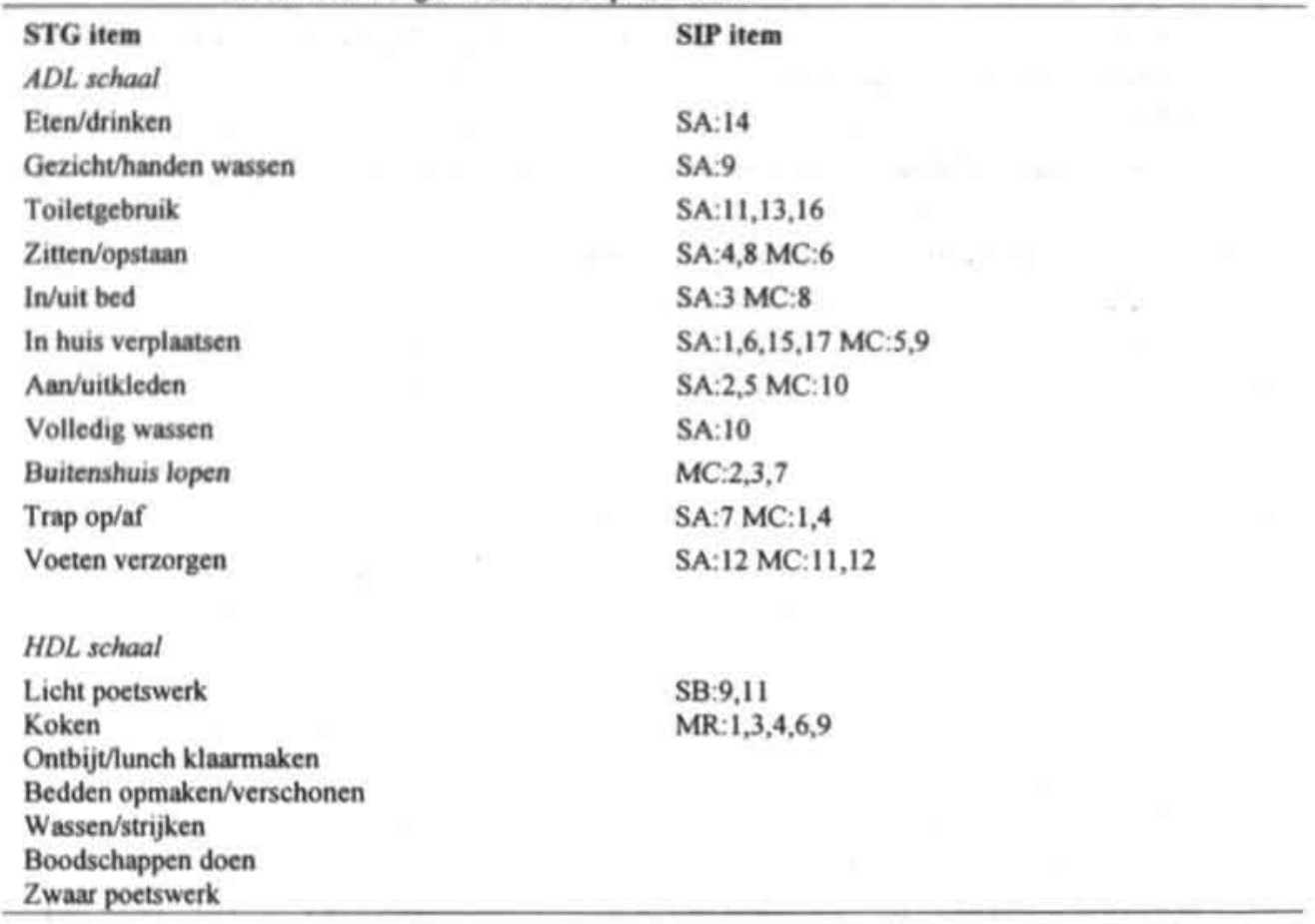

Legenda: "=schaal met 79 dichotome items bestaande uit diverse dimensies die tezamen de functionele status vormen (hoe hoger de score hoe meer beperkingen), SA:somatische autonomie, MC:motorische controle, PAC:psychologische autonomie en communicatic, SB:sociaal gedrag, ES:emotioneel gedrag. MR:mobiliteitsrange. 
Tabel B13.5 geeft een overzicht van de beroepen van patiēnten en hun naaste verzorgers.

Tabel B13.5 Beroepen patienten en naaste verzorgers.

\section{Patient (N-49)}

Administrateur

Administratief medewerker (2)

Arbeider

Ambtenaar

Automonteur

Bejaardenhelpster

Chauffeur

Collectrice staatsloterij

Coordinator vliegveld

Croupier

Horecamedewerker

Huisvrouw (17)

Inpakster

Kraanmachinist

Laborant

Maatschappelijk werker

Metselaar

Mijnwerker

Ondernemer (2)

Opzichter

Portier

Priester

Schoonmaker

Secretaresse

Scholier/student (4)

Timmerman

Verkoopster

Ziekenverzorgster
Naaste verzorger $(\mathrm{N}-54)$

Administratief medewerker (4)

Afdelingschef

Ambtenaar (2)

Arbeider

Arts

Bejaardenhelpster

Beveiligingsbeambte

Bouwvakker

Decorateur

Directeur

Docent (2)

Doktersassistente

Horecamedewerker

Huisvrouw (22)

Lithograaf

Machinist

Medewerker casino

Medewerker spoorwegen

Mijnwerker

Militair

Ondernemer

Procesleider

Student

Tuinier

Verkeersleider

Verkoper

Verpleegkundige

Ziekenverzorgster

Legenda: 0 =aantal indien meer dan eénmaal voorkomend.

\section{Bijlage 13.5: Verklarende variantie in oordelen over de kwaliteit van leven}

Tabel B13.6 Overeenstemming tussen oordelen van respondenten in paren.

\begin{tabular}{|c|c|c|c|c|c|c|}
\hline \multirow[b]{2}{*}{ Item } & \multicolumn{3}{|c|}{ Exclusief terminale patienten } & \multicolumn{3}{|c|}{ Inclusief terminale patienten } \\
\hline & Pat-Naa & Pat-Verp & Pat-Arts & Naa-Verp & Naa-Arts & Verp-Arts \\
\hline Emst ziekte patient & $+H^{\circ}$ & H & 0 & HH+ & $+1++4$ & H+H \\
\hline Pijn patient & H11+ & $H+$ & + & + & $H$ & + \\
\hline Gezondheid patient & + & 0 & + & H+H & H+H & $H+H$ \\
\hline Praktische steun & $H$ & - & - & - & - & - \\
\hline Emotionele steun & + & - & - & - & - & - \\
\hline KvL patiēnt & + & 0 & $+H$ & $H$ & + & + \\
\hline Belasting naaste I & - & - & - & 0 & + & + \\
\hline KvL naaste 1 & - & - & . & 0 & + & 0 \\
\hline
\end{tabular}

Legenda: pat-patient, naa-naaste 1, verp=-verpleegkundige, "-verklarende variantie $+: 5 \%++10 \%+++20 \%$ $+++30 \%++++40 \%++++1+50 \%, 0=$ niet significant en/of geen verband, - -niet gemeten. 


\title{
Bijlagen bij hoofdstuk 14
}

\section{Zorg: kwaliteit, tevredenheid en doelmatigheid}

\author{
Bijlage 14.1: Antwoordmogelijkheden Client Satisfaction Questionnaire \\ De antwoordmogelijkheden van de CSQ zijn binnen dit onderzoek als volgt: \\ (1): uitstekend / goed / voldoende / slecht \\ (2): nee, beslist niet / nee, niet echt / ja, in het algemeen wel / ja, zeker; \\ (3): in bijna alle behoeften is voorzien / in de meeste van de behoeften is voorzien / in slechts \\ enkele van de behoeften is voorzien / in geen van de behoeften is voorzien; \\ (4): nee, beslist niet / nee, ik denk van niet / ja, ik denk van wel / ja, zeker; \\ (5): zeer ontevreden / gemiddeld tevreden of een beetje ontevreden / grotendeels tevreden / zeer \\ tevreden; \\ (6): ja, het heeft veel geholpen / ja, het heeft wel wat geholpen / nee, het heeft echt niet geholpen / \\ nee, het leek de dingen alleen maar te verergeren; \\ (7): zeer tevreden / grotendeels tevreden / gemiddeld tevreden of een beetje ontevreden / zeer \\ ontevreden; \\ (8): nee, zeker niet / nee, ik denk van niet / ja, ik denk van wel / ja, zeker.
}

\section{Bijlage 14.2: Berekening kosten verblijfsdag academisch ziekenhuis Maastricht}

Ook de personele, materiēle en hotelkosten van een ziekenhuisverblijf in het academisch ziekenhuis Maastricht (azM) zijn berekend (tabel B14.1). ${ }^{119}$ Hierbij is eenzelfde soort kostprijsberekening voor de kosten van de gezondheidszorg als die bij de thuiszorg is toegepast. In tegenstelling tot bij thuiszorg komen bij ziekenhuiszorg ook voedings- en verblijfkosten, de zogenaamde 'hotelkosten', voor rekening van de gezondheidszorg. Vanwege de vele aannamen is ook onderstaande berekening slechts een benadering van de werkelijkheid. Vanwege de patiëntenpopulatie in onze studie is uitgegaan van de kosten van 4 algemene verpleegafdelingen ( 2 chirurgische en 2 interne; tezamen zo'n 50.000 verpleegdagen). Als basis is uitgegaan van (gewogen) gemiddelde bedragen per verpleegdag. Als peiljaar is gekozen voor 1996, omdat in deze periode veel interne kostenberekeningen gemaakt zijn. Gerekend zijn de gerealiseerde kosten van het verpleegkundig personeel plus de fictieve kosten van 4 zaalartsen (toenmalige schaal Z27 trap 4). Vanwege de academische functie zijn in werkelijkheid vaak meerdere zaalartsen op een afdeling werkzaam. Kosten voor specialistische zorg en diagnostiek zijn evenals bij de thuiszorg niet toegerekend. De materiēle kosten bestaan uit de gerealiseerde materiěle (afkomstig van magazijnen en externe leveranciers) en medicijnkosten (exclusief experimentele en/of dure medicijnen als EPO). De hotelkosten betreffen de facilitaire kosten en kapitale lasten. De maaltijdkosten zijn $f 36,60$ per dag, de overige kosten betreffen gas, water, licht, gebouwen, rente en afschrijving toegerekend per vierkante meter. De overhead is afgeleid uit de verhouding van niet en wel direct toe te rekenen kosten: 16:84=19\%. Tot de overhead zijn gerekend: behandelzorgeenheid algemeen, directoraat Middelen (zoals personeelszaken) en Patiěntenzorg, Medezeggenschapsraad en Raad van Toezicht. De rente en afschrijving zijn hierin niet meegenomen daar deze al in hotelkosten zijn doorberekend. Het eindresultaat van $f 446$ (1996 prijzen) komt na correctie op $f 432$ (1994 prijzen; CBS prijsindex consumenten 1994-1996=110,4/114,1 $=96,8) .{ }^{\mathrm{s} 24}$ Dit is het middelste jaar van de projectperiode en maakt een kostenvergelijking met de 1993-1995 prijzen mogelijk. 


\section{Kostensoort}

Verpleging

Zaalartsen

Geneesmiddelen

Materiele kosten afdeling

Hotelkosten salaris sociale lasten salaris sociale lasten

\section{Bedrag per verblijfdag}

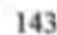

Subtotaal

Overhead 19\% 71

Totaal 446

Bijlage 14.3: Verklarende variantie in oordelen over de kwaliteit van zorg

Tabel B14.2 Overeenstemming tussen oordelen van respondenten in paren.

\begin{tabular}{|c|c|c|c|c|c|c|}
\hline \multirow[b]{2}{*}{ Items } & \multicolumn{3}{|c|}{ Exclusief terminale patiënten } & \multicolumn{3}{|c|}{ Inclusief terminale patiènten } \\
\hline & Pat-Naa & Pat-Verp & Pat-Arts & Naa-Verp & Naa-Arts & Verp-Arts \\
\hline ZKM (lang versie) & $+^{\circ}$ & H & 0 & 0 & 0 & 0 \\
\hline ZKM (korte versie) & $+H$ & + & 0 & 0 & 0 & 0 \\
\hline Belasting infuuszorg ' & + & 0 & 0 & 0 & $\|$ & $\#$ \\
\hline CSQ (lange versie) & H+H & $+H$ & + & + & 0 & 0 \\
\hline CSQ (korte versie) & H+1H & $H$ & + & $\#$ & 0 & $\|$ \\
\hline Rapportcijfer huisarts & $H+1+$ & 0 & 0 & $\#$ & 0 & + \\
\hline Rapportcijfer TMV & +++ & + & 0 & 0 & 0 & 0 \\
\hline Rapportcijfer WV & $+11+$ & 0 & 0 & 0 & 0 & 0 \\
\hline Gem. rapportcijfer & ++ & 0 & + & 0 & 0 & 0 \\
\hline
\end{tabular}

Legenda: pat=patiênt, naa-naaste 1, verp=verpleegkundige, ${ }^{\prime}=$ ter vergelijking hogere score is minder belasting. -7 verklarende variantic $0: n$ geatief of geen verband of nict significant $(p>0,05) \|: 5 \%+10 \%+1+20 \%+1+30 \%$ $+++: 40 \%++++: 50 \%$ of meer. 
Bijlage 14.4: Gevoeligheidsanalyse besparingen

Om de effecten van variaties in de kosten van IT en de ziekenhuisprijzen waarmee vergeleken wordt te inventariseren, zijn drie scenario's doorgerekend (tabel B14.2).

Scenario la: De kosten van IT (tabel 14.16) worden bij morfine (SI morf) en overige intraveneuze infusies (IV ov) vergeleken met het verpleegdagtarief, bij mannitol (IV man), dopamine/lasix (CV dola) en overige centraalveneuze infusies ( $\mathrm{CV}$ ov) met het dagbehandelingstarief en bij antibiotica (IV ab) met een gemiddelde (\$14.5.6).

De totale besparing bedraagt $f 1.439 .277-f 740.198=f 669.079$.

Scenario $\mathrm{Ib}$ : Bij IT waarvoor in het ziekenhuis opname op de verpleegafdeling nodig zou zijn, wordt bij de kosten nogmaals het maximum ITZ tarief van $f 200$ per dag opgeteld vanuit het idee dat naast IT ook verpleegkundige en/of verzorgende zorg nodig is.

De totale besparing bedraagt $f 1.439 .277-f 890.598=f 548.679$.

Scenario 2: Alle IT wordt afgezet tegen de prijs van een verblijfsdag in het azM (bijlage 14.2).

De totale besparing bedraagt $f 1.119 .312-f 740.198=f 379.114$.

Scenario 3: Alle IT wordt afgezet tegen het tarief voor dagbehandeling.

De totale besparing bedraagt $f 971.625-f 740.198=f 231.427$.

Tabel B14.3 Gemiddelde kosten per dag van infuusbehandelingen thuis (guldens).

\begin{tabular}{|c|c|c|c|c|c|c|c|c|}
\hline Kostensoort & & SI morf & $r V$ man & IV $a b$ & IV ov & CV dola & $\mathrm{CV}$ ov & Totaal \\
\hline \multicolumn{9}{|l|}{ Scenario la } \\
\hline Ziekenhuis & & 807 & 375 & 663 & 807 & 375 & 375 & 555 \\
\hline IT & & 239 & 254 & 400 & 420 & 261 & 218 & 286 \\
\hline \multirow[t]{2}{*}{ Besparing } & absoluut & 568 & 121 & 263 & 387 & 114 & 157 & 270 \\
\hline & percent & $70 \%$ & $32 \%$ & $40 \%$ & $48 \%$ & $30 \%$ & $42 \%$ & $44 \%$ \\
\hline \multicolumn{9}{|l|}{ Scenario $\mathrm{Ib}$} \\
\hline Ziekenhuis & & 807 & zie la & zie la & 807 & zie la & zie la & 555 \\
\hline IT & & 439 & & & 620 & & & 344 \\
\hline \multirow[t]{2}{*}{ Besparing } & absoluut & 368 & & & 187 & & & 212 \\
\hline & percent & $46 \%$ & & & $23 \%$ & & & $37 \%$ \\
\hline \multicolumn{9}{|l|}{ Scenario 2} \\
\hline Ziekenhuis & & 432 & 432 & 432 & 432 & 432 & 432 & 432 \\
\hline IT & & 239. & 254 & 400 & 420 & 261 & 218 & 286 \\
\hline \multirow[t]{2}{*}{ Besparing } & absoluut & 193 & 178 & 32 & 12 & 171 & 214 & 146 \\
\hline & percent & $45 \%$ & $41 \%$ & $7 \%$ & $3 \%$ & $40 \%$ & $50 \%$ & $34 \%$ \\
\hline \multicolumn{9}{|l|}{ Scenario 3} \\
\hline Ziekenhuis & & 375 & 375 & 375 & 375 & 375 & 375 & 375 \\
\hline IT & & 239 & 254 & 400 & 420 & 261 & 218 & 286 \\
\hline \multirow[t]{2}{*}{ Besparing } & absoluut & 136 & 121 & -25 & -45 & 114 & 157 & 89 \\
\hline & percent & $36 \%$ & $32 \%$ & $-7 \%$ & $-12 \%$ & $30 \%$ & $42 \%$ & $24 \%$ \\
\hline Totaal infusie & agen & 634 & 322 & 501 & 118 & 836 & 166 & 2591 \\
\hline
\end{tabular}




\section{Bijlagen bij hoofdstuk 15}

\section{Kosten voor de gezondheidszorg, patiënt en maatschappij}

\section{Bijlage 15.1: Salarisberekening Transmuraal infuusverpleegkundigen (TMVs)}

De salariskosten bestaan uit een basisaanstelling en een uurloon bij zorgverlening (tabel B15.1). ${ }^{\text {23 }} \mathrm{Er}$ zijn vier TMVs aangesteld die in paren 7 opeenvolgende dagen 12 uur bereikbaarheidsdienst hadden $(7 \times 12 \times 2,5$ minuut $=3,5$ uur per 2 weken $=0,05 \mathrm{fte}$ ). Deze $0,05 \mathrm{fte}$ is verhoogd met ATV-en vakantiedagen, vakantiegeld en feestdagentoeslag $( \pm 30 \%)$ en ziektevervanging $( \pm 10 \%)$. De resulterende $0,07 \mathrm{fte}$ is inclusief overdrachten, scholing en administratie afgerond op $0,1 \mathrm{fte}$ per functionaris. Het totaal van $f 37.500$ per jaar is afgerond op $f 40.000$ omdat uitgegaan is van een gemiddeld salaris. Verpleegkundigen met ervaring worden doorgaans hoger ingeschaald.

Tabel B15,1 Salarisberekening transmuraal infuusverpleegkundigen (guldens).

$\begin{array}{lrr}\text { Omschrijving } & \text { Per uur } & \mathbf{0 . 4} \text { fe per jaar } \\ \text { Maandloon } / 3.856 \text { voor } 173 \text { uur } & 22,30 & 20.046 \\ \text { Onregelmatigheidstoeslag: } \pm 30 \% & 6,70 & 6.014 \\ \text { ATV-en vakantiedagen, vakantiegeld en } & 8,70 & 0^{*} \\ \text { feestdagentoeslag: } \pm 30 \% & & 7.340 \\ \text { Werkgeverslasten, pensioenafdracht: } \pm 30 \% & 11,30 & 33.400 \\ \text { Subtotaal } & 49,00 & 0 \\ \text { Doorbetaling ziekengeld: } \pm 10 \% & 6,00 & 2.600 \\ \text { Administratie/telefoon/portokosten } & & 1.500 \\ \text { Opleidingskosten } & & 37.500 \\ \text { Totaal } & 55,00 & \end{array}$

Legenda: *-reeds opgenomen in de 0,4 fte.

Bijlage 15.2: Berekening afvalkosten

Er zijn twee soorten afval onderscheiden. ${ }^{26,27}$ Type 1 komt voort uit de infuusbehandeling thuis: gebruikte infuuszakken, infuusnaalden, koppelstukken, ampullen, etc. Tevens sterk met bloed of medicijn doordrenkte of besmeurde verbandmiddelen, afdekdoeken, etc. Type 2 komt voort uit de verpleging thuis en omvatte alle overige afval zoals gazen, desinfectiedoekjes, afdekdoeken, verpakkingsmaterialen, etc. De kosten van type 1 afval betreffen de aanschaf en verwerking van de afvalvaten en de loonkosten van de TMVs om de vaten naar een afvalinzamelingspunt in het azM te brengen (tabel B15.2). De afvalkosten voor type 2 afval komen voor rekening van de patient ( $\$ 15.4)$.

Tabel B15.2 Berekening afvalkosten (guldens).

\begin{tabular}{lrr} 
Omschrijving & $\mathbf{6 0}$ liter & $\mathbf{3 0}$ liter \\
Afvalverzamelvat azM stuksprijs & 13,51 & 11,16 \\
Plus $20 \%$ handlingstoeslag & 2,70 & 2,23 \\
Gemiddeld $18 / 9$ kilo per afvalvat, kiloprijs $f 0,95$ & 17,10 & 8,55 \\
Transportkosten $f 390$ per $84 / 168$ afvalvaten & 4,65 & 2,32 \\
Subtotaal & 37,96 & 24,26 \\
Loonkosten TMV afvaltransport, 15 minuten à $f 55^{\circ}$ & 13,75 & 13,75 \\
Totaal per afvalvat & 51,71 & 38,01 \\
Totaal per patient & \pm 25 & \pm 40 \\
\hline
\end{tabular}

Legenda: "=extra inspanning bezorging azM, bij de patient werd het afval tijdens een huisbezoek meegenomen. 


\section{Bijlage 15.3: Gevoeligheidsanalyse kosten van de gezondheidszorg}

De kosten van de 173 infuusbehandelingen op basis van de individuele kostenoverzichten bedragen in totaal $f 623.000, f 240$ per infusiedag (tabel B15.3). De individuele kostenoverzichten geven echter niet alle kosten weer. De 'gecorrigeerde' kosten bedragen ruim $f 740.000$ of $f 286$ per infusiedag.

Tabel B15.3 Gedeciareerdé en gecorrigeerde kosten van infuusbehandeling thuis (guldens).

\begin{tabular}{|c|c|c|c|c|c|c|}
\hline Kostensoort & SI morf & IV man & IV $a b$ & CV dola & Overig & Totaal \\
\hline TMV declaratie & 57.805 & 33.550 & 70.345 & 69.960 & 33.495 & 265.155 \\
\hline TMV correctic & 85.394 & 49.563 & 103.919 & 103.350 & 49.481 & 391.706 \\
\hline $\begin{array}{rr}\text { artsconsult } & \text { totaal } \\
\text { dag } \\
\text { weekend } \\
\text { totaal }\end{array}$ & $\begin{array}{r}10.888 \\
5.909 \\
7.016 \\
23.812\end{array}$ & $\begin{array}{r}1.834 \\
275 \\
483 \\
2.591\end{array}$ & $\begin{array}{r}1.805 \\
315 \\
207 \\
2.327\end{array}$ & $\begin{array}{r}2.206 \\
309 \\
138 \\
2.653\end{array}$ & $\begin{array}{l}2.490 \\
2.527 \\
1.202 \\
6.219\end{array}$ & $\begin{array}{r}19.222 \\
9.334 \\
9.045 \\
37.601\end{array}$ \\
\hline TDC coordinatic & 10.050 & 6.600 & 5.100 & 12.600 & 4.350 & 38.700 \\
\hline Proefgift dagcentrum & • & 10.875 & • & - & 375 & 11.250 \\
\hline EHBO consult & - & 233 & 712 & - & 0 & 944 \\
\hline EHBO iv naald ' & - & 960 & 1.560 & - & 0 & 2.520 \\
\hline Declaratie SGKH & 2.993 & 2.310 & 1.155 & 1.575 & 1.050 & 9.083 \\
\hline Personeel totaal deciaratie & 94.659 & 57.119 & 81.198 & 86.788 & 45.489 & 365.253 \\
\hline Personecl totaal correctie & 119.255 & 70.821 & 113.617 & 118.603 & 60.425 & 482.721 \\
\hline Medicatie & 17.214 & 5.964 & 67.745 & 7.003 & 14.564 & 112.490 \\
\hline Infuusmateriaal ${ }^{2}$ & 12.380 & 1.684 & 15.944 & 71.271 & 11.657 & 113.038 \\
\hline CADD 10 pomp & - & - & - & 19.903 & - & 19.903 \\
\hline IVAC $591 \%$ pomp & 175 & 1.425 & 2.005 & - & 555 & 4.160 \\
\hline Infuusstandaard & 1.008 & 680 & 632 & - & 248 & 2.568 \\
\hline Afval & 1.525 & 1,100 & 675 & 1.375 & 600 & 5.275 \\
\hline Materieel totaal & 32.404 & 10.853 & 87.001 & 99.553 & 27.623 & 257.434 \\
\hline Totaal declaratie & 127.063 & 67.972 & 168.199 & 186.340 & 73.113 & 622.687 \\
\hline Totaal correctic & 151.659 & 81.674 & 200.618 & 218.155 & 88.049 & 740.155 \\
\hline Totaal aantal dagen infusie & 634 & 322 & 501 & 836 & 298 & 2.591 \\
\hline
\end{tabular}

Legenda: $"=o p$ basis van regionale prijsafspraken $(\mathrm{H}: 8,11), \ldots=$ kosten op basis van declaratic en op basis van correctic, '=het inbrengen van een intraveneuze canule, ${ }^{2=i n c l u s i e f ~ d i s p o s a b l e ~ p o m p r e s e r v o i r s . ~}$

De correctie is gebaseerd op de volgende overwegingen:

- De 173 behandelingen binnen het project hebben in $21 \%$ jaar plaatsgevonden. Gezien de beperkte instroom van 7 patiënten in het eerste $1 / 4$ jaar $(\$ 7.6 .1$ en $\$ 8.4 .2)$, is van 2 jaar uitgegaan.

- Bij 4.821 zorguren aan een uurtarief van $f 55$ bedragen de TMV-kosten $f 265.155$. Inclusief basisaanstelling $(0,4$ fte met reis- en telefoonkosten: $2 \times f 40.000=f 80.000)$, scholing $(f 10.000)$, aansturing door een verpleegkundig specialist $(0,1 \mathrm{fte}: 2 \times f 8.000=f 16.000)$, aanmelding bij het centraal meldpunt $(173 \times 1$ uur à $f 55=f 9.515)$ en declaratie $(173 \times f 52,50=f 9.083)$ bedragen de totale kosten voor twee jaar volgens de transactiekostenmethode (toerekening indirecte kosten via causale relaties tussen activiteiten en produkten) $f 389.753$ ( $\$ 11.4$ en kader tabel B11.4 in bijlage 11.2$).{ }^{430}$ In het COTG-richttarief voor wijkverpleegkundigen van $f 81,25$ ( 65 plus $25 \%$ overhead) dienen materiěle en personele investeringskosten, het gebruik van het centraal meldpunt, aansturing door een verpleegkundig specialist en declaratiekosten te zijn opgenomen. ${ }^{12 x} \mathrm{Op}$ basis van 4.821 zorguren en het COTG-richttarief zou het totaalbedrag $f 391.706$ hebben bedragen. Op grond hiervan is het COTG-richttarief als uurprijs aangehouden. Dit is vergelijkbaar met tarieven in de Verenigde Staten van \$75-\$87,50 (1988 prijzen van \$60-\$70 geìndexeerd met de prijsindex consumenten 1994-1988= $137,8 / 110=1,25$; vanwege de interne markt geen wisselkoerscorrectie). ${ }^{14,}, 72$ 
- De vergoedingen voor de huisartsen zijn gebaseerd op de reguliere tarieven. De kosten van hun scholing zijn niet meegeteld, aangezien zij grotendeels binnen de reguliere nascholing vallen (H:10). - De medische en administratief organisatorische coördinatie is op 2 manieren berekend. De coördinatiekosten berekend op basis van de zorgduur bedragen $f 38.700$. Vanuit de projectbijdrage gerekend bedragen de kosten $f 80.800$ (vet in tabel B11.4 in bijlage 11.2). Geschat is dat hiervan ongeveer de helft toe te schrijven is aan financięle taken en de andere helft aan daadwerkelijke zorgeoördinatie. Aangezien beide uitkomsten niet veel verschillen, is uitgegaan van de berekening op basis van zorgduur. De meerkosten van het financieel beheer van het TDC tijdens de projectperiode (omleiding ten behoeve van het onderzoek) zijn niet berekend omdat zij bij rechtstreekse declaratie aan de zorgverzekeraar niet voorkomen.

- Bij de door het azM geleverde diensten zijn voor proefgiften op het dagcentrum en EHBOconsulten de reguliere tarieven gehanteerd omdat de daadwerkelijke kosten moeilijk te achterhalen zijn. Voor het inbrengen van een nieuwe infuusnaald op de EHBO is tijdens het project een bedrag van $f 40$ overeengekomen. Doorgaans bedraagt het reguliere tarief gemiddeld zo'n $f 100(f 6.300$ totaal). Omdat $f 40$ volgens diverse betrokkenen (waaronder de $\mathrm{EHBO}$ ) dichter in de buurt van de werkelijke kosten ligt, is hiermee gerekend.

- De medicatie en infuusmaterialen binnen het project zijn bij de subcutane infusic van morfine geleverd via de perifere apotheken, bij de overige infusies via de ziekenhuisapotheek van het azM. Ter compensatie van bereidingskosten en receptregels zijn bij levering door het ziekenhuis opslagtarieven gehanteerd. Indien perifere apotheken de bij infuusbehandeling benodigde medicatie en materialen individueel leveren, kunnen de kosten hoger zijn dan de hier genoemde. Prijsverschillen kunnen optreden door schaalvoordelen, het opvangen van ompakverliezen (voor de levering van tien driewegkranen moeten er 100 gekocht worden) en de eventuele extra kosten (verzend-, expresse en 'kleine order' kosten) indien een artikel niet via de reguliere groothandel verkrijgbaar is. Bij een regionale alliantic van perifere apotheken onderling (een/enkele collega's worden depothouder), een groothandel (groothandel depothouder), met het ziekenhuis (ziekenhuis depothouder) of via een facilitair bedrijf kunnen de hier gehanteerde kostprijzen benaderd worden. ${ }^{129}$ Los van de hele discussie omtrent de competentie, concurrentie en regelgeving over de levering van apparatuur, medicatie en infuusmaterialen door ziekenhuizen aan niet opgenomen patiēnten, dient opgemerkt te worden dat zij daartoe kwalitatief (deskundigheid van ziekenhuisapotheek en technische dienst) zeer wel in staat zijn en dit tegen aantrekkelijke prijzen kunnen doen. ${ }^{602},{ }^{830}$ De hier gehanteerde kosten voor medicatie en infuusmaterialen zijn dan ook als redelijk marktconform aan te merken omdat zij gelden bij voldoende marktwerking. Ter illustratie zijn de materiële kosten van ganciclovirinfusie via twee perifere apotheken vergeleken met die via de apotheek van het azM (tabel B15.4).

Tabel B15.4 Kosten per dag van materialen bij ganciclovirinfusie via centraal veneuze poort (guldens).

\begin{tabular}{|c|c|c|c|c|}
\hline Kostenpost & $\begin{array}{l}\text { Homepump } 8 \\
\text { via apotheek } 1\end{array}$ & $\begin{array}{l}\text { Sidekick } 8 \text { via } \\
\text { apotheek } 1\end{array}$ & $\begin{array}{l}\text { Sidekick } 8 \text { via } \\
\text { apotheek } 2 \text { ' }\end{array}$ & $\begin{array}{c}\text { Sidekicko via } \\
\text { project }^{2}\end{array}$ \\
\hline Ganciclovir per $500 \mathrm{mg}$ & 98 & 93 & \pm 96 & 100 \\
\hline Ganciclovir & 49 & 108 & \pm 77 & 80 \\
\hline Pomp & $\therefore$ & $1^{4}$ & 36 & 14 \\
\hline Pompsysteem & 93 & 50 & \pm 42 & 38 \\
\hline Vulkosten & 12 & 12 & $\cdot$ & 12 \\
\hline Infuusmateriaal & 36 & 43 & 49 & 27 \\
\hline Totaal zonder medicatic & 141 & 106 & \pm 94 & 78 \\
\hline Totaal met medicatic & 190 & 214 & 171 & 158 \\
\hline Aantal infusies & 70 & 60 & 20 & 100 \\
\hline
\end{tabular}

Legenda: '=gaf een all-in prijs van $f 119$ voor medicatic, pompsysteem en vullen waardoor de kosten met \pm afgeleid moesten worden, ${ }^{2}$-ziekenhuisapotheek, ${ }^{1}$ "pomp en pompsysteem zijn geintegreerd draagtas is gratis (bijlage 11.1), "veerpomp Sidekick\$ van $f 55$ per stuk plus draagtas van $f 22$ per stuk (bijlage 11.1). 
De kosten zijn ongeveer gelijk. Veelal zijn ze afhankelijk van de ganciclovirdosering en het gekozen toedieningssysteem. Wel lijken de kosten van infuusbenodigdheden via de azM apotheek lager.

- De voor de infuuspompen gehanteerde kostprijzen zijn leasetarieven inclusief service (CADD I\&) pompen per patient via facilitair bedrijf: inzet 4 dagen per week; IVAC $591 \otimes$ pomp via ziekenhuis op basis van utilisatie van $70 \%$ ). De kosten van de infuusstandaarden zijn gebaseerd op uitleen (leden) door of huur (niet-leden) van de het Groene Kruis (exclusief transportkosten). Deze prijzen lijken redelijk accuraat.

- De all-in kosten voor afvalverwerking bedragen voor een WIVA\& vat van 30 liter $\pm f 38$ en voor een vat van 60 liter $\pm f 52$ (bijlage 15.2). Er zijn 73 vaten van 60 liter en 11 van 30 liter gebruikt (totaal $f 4.214)$. Er is gerekend met ongeveer 30 liter 'ziekenhuisafval' à $f 25$ per patiēnt per maand (totaal f5.275). Gezien de stijgende kosten voor afvalverwerking verdient het, zeker wanneer de afvalverwerking via de perifere apotheken verloopt, de voorkeur laatstgenoemde prijs te hanteren.

\section{Bijlage 15.4: Inspanningen van naaste verzorgers in tijd}

Tabel B15.5 geeft een overzicht van de gemiddeld per dag gemeten uurbelasting of produktieverlies uitgedrukt in full-time equivalents (fte's).

In de legenda zijn de herkomst en precieze berekening van deze fte's weergegeven.

Voor verwerking in tabel 15.3 zijn de fte's in tabel B15.5 vermenigvuldigd met de bedragen per kalenderdag geldend voor alle werkenden zoals vermeld in $\$ 15.3 .3$.

Tabel B15.5 Personele kosten voor patienten en naaste verzorgers per infusiedag (fte's).

\begin{tabular}{|c|c|c|c|c|c|c|c|c|}
\hline \multirow{2}{*}{\multicolumn{2}{|c|}{$\begin{array}{l}\text { Arbeid } \\
\text { Volgens patient (naaste') - }\end{array}$}} & SI morf & IV man & IV ab & IV ov & CV dola & CV ov & Totaal \\
\hline & & & & & & & & \\
\hline Uurbelasting ' & $\begin{array}{r}\text { naaste } 1 \\
\text { naaste } 2 \\
\text { naaste } 3 \\
\text { naaste } 4 \\
\text { totaal (a) }\end{array}$ & $\bullet$ & $\begin{array}{l}1,11 \\
0,38 \\
0,14 \\
0,05 \\
1,68\end{array}$ & $\begin{array}{l}0,74 \\
0,13 \\
0,04 \\
0,05 \\
0,95\end{array}$ & $\cdot$ & $\begin{array}{l}1,13 \\
0,52 \\
0,45 \\
0,46 \\
2,55\end{array}$ & $\bullet$ & $\begin{array}{l}0,99 \\
0,35 \\
0,20 \\
0,13 \\
1,67\end{array}$ \\
\hline \multicolumn{2}{|c|}{$\begin{array}{r}\text { Produktieverlies }{ }^{2} \text { naaste } 1 \\
\text { naaste } 2 \\
\text { naaste } 3 \\
\text { naaste } 4 \\
\text { totaal (b) }\end{array}$} & • & $\begin{array}{l}0,12 \\
0,06 \\
0,02 \\
0,19\end{array}$ & $\begin{array}{c}0,07 \\
0,03 \\
- \\
- \\
0,08\end{array}$ & - & $\begin{array}{l}\cdot \\
\dot{-} \\
\dot{-}\end{array}$ & $\bullet$ & $\begin{array}{l}0,08 \\
0,05 \\
0,03 \\
0,00 \\
0,15\end{array}$ \\
\hline \multicolumn{2}{|c|}{$\begin{array}{l}\text { Verhouding totaal a:b } \\
\text { Volgens naaste I (naaste I) }\end{array}$} & • & 9 & 12 & $\cdot$ & $\bullet$ & • & 11 \\
\hline \multicolumn{2}{|c|}{ Uurbelasting (c)' } & 1,99 & 1,27 & 0,92 & - & 1,66 & $\bullet$ & 1,66 \\
\hline \multicolumn{2}{|c|}{ Produktieverlies (d) ${ }^{4}$} & 0,34 & 0,25 & 0,04 & - & - & • & 0,25 \\
\hline \multicolumn{2}{|c|}{ Verhouding $\mathrm{c}: \mathrm{d}$} & 6 & 5 & 23 & - & • & - & 7 \\
\hline \multicolumn{2}{|c|}{ Behandelingen/patiênten } & $57 / 56$ & $44 / 28$ & $22 / 15$ & $10 / 10$ & $30 / 9$ & $8 / 4$ & $173 / 122$ \\
\hline \multicolumn{2}{|c|}{ Totaal infusiedagen } & 634 & 322 & 501 & 118 & 836 & 166 & 2591 \\
\hline
\end{tabular}

Legenda: fte-full-time equivalent, "-niet berekend, =antwoordmogelijkheid komt niet voor, nota bene: de cijfers in tabellen $13.15 \mathrm{en} 13.16$ zijn afgerond en gegevens over het produktieverlies uitgesplitst naar soort infusie zijn niet in het proefschrift opgenomen, '-voorbeeld uurbelasting van naaste 2 bij mannitolinfusie volgens de patient (tabel 13.15): 4,13 uur komt overeen met 4,13/8 $=0,52 \mathrm{fte}$, correctie voor de verhouding van naasten bij 16 naasten 2 en 22 naasten $I$ is $16 / 22=0,73$ (tabel 13.10), de fte per patient per dag is dus $0,52 \times 0,73=0,38 \mathrm{fte}$, ${ }^{2}$-voorbeeld produktieverlies van naaste 2 bij alle soorten infusie volgens de patient: in fte $0,019+0,077 \times 0,5=0,058$ (tabel 13.16), correctie voor de naastenverhouding is naaste $2 /$ naaste $1=38 / 47=0,81$ (tabel 13.10), de fte per patient per dag is dus $0,058 \times 0,81=0,05$ fte, ${ }^{2}$-voorbeeld uurbelasting van naaste 1 bij morfine-infusie volgens naaste I zelf (tabel 13.15): 15,91 uur $=15,91 / 8=1,99 \mathrm{fte},=$ voorbeeld produktieverlies van naaste 1 bij alle soorten infusie volgens naaste 1 zelf in fte per patient per dag $0,189+(0,113 \times 0,5)=0,25$ (tabel 13.16). 


\section{Bijlage 15.5: Gevoeligheidsanalyse rentabiliteit}

Bij verschillende gradaties van onproduktiviteit zijn de vaste personele kosten berekend (bijlage 15.1 en 15.3). De basisaanstelling en aansturing zijn nodig voor instructic, werkoverleg, enzovoorts. Ondanks dat zij bij onproduktiviteit iets dalen, worden ze telkens volledig doorberekend. Bij de scholing is er is vanuit gegaan dat er steeds nieuwe ontwikkelingen zullen zijn en dat verantwoorde inzet periodieke training vereist. De vaste kosten variēren van $f 58.000$ tot $f 158.000$ (tabel B15.6). Een hele fte lijkt een redelijke bovengrens omdat te verwachten is dat tegen die tijd het management vrijwel zeker ingrijpt.

Tabel B15.6 Vaste kosten per jaar bij verschillende mate van onproduktiviteit (guldens).

\begin{tabular}{lccc}
\hline Kostensoort & Geen & $\mathbf{0 . 5}$ fte onproduktief & $\mathbf{1 , 0}$ fte oaprodukticf \\
Basisaanstelling & 40.000 & 40.000 & 40.000 \\
Scholing & 10.000 & 10.000 & 10.000 \\
Aansturing & 8.000 & 8.000 & 8.000 \\
Onproduktiviteit & - & 50.000 & 100.000 \\
Totaal & 58.000 & 108.000 & 158.000 \\
\hline
\end{tabular}

De vaste personele kosten bij verschillende mate van onproduktiviteit zijn vervolgens afgezet tegen de verschillende door ons veronderstelde besparingen van $f 270, f 212, f 146 \mathrm{en} f 89$ per infusiedag (bijlage 14.4). Tabel B15.7 geeft steeds het minimum aantal infusiedagen dat op jaarbasis nodig is om een bepaalde onproduktiviteit op te vangen. Vanwege de andere vaste kosten is er ook bij geen onproduktiviteit een minimum aantal infusiedagen per jaar nodig. ${ }^{312}$ Slechts bij een combinatie van de hoogste onproduktiviteit en de laagste besparingen stijgt het aantal benodigde infusiedagen per jaar boven het aantal dat binnen het project gerealiseerd is $(2.591 / 2=1296)$.

Tabel B15.7 Break even point in infusiedagen bij verschillende maten van onproduktiviteit.

\begin{tabular}{lccc}
\hline & Niet onproduktief & $\mathbf{0 , 5}$ fte onproduktief & $\mathbf{1 , 0}$ fte onproduktief \\
Scenario 1a & 215 & 400 & 585 \\
Scenario 1b & 274 & 509 & 745 \\
Scenario 2 & 397 & 740 & 1.082 \\
Scenario 3 & 652 & 1.213 & 1.775 \\
\hline
\end{tabular}




\section{Referenties (references)}

1. Philipsen H. Rationaliteit en ons oordeel over de verdwijnende patient. Gezondheid en Samenleving $1985 ; 6(3): 142-151$.

2. Philipsen $\mathrm{H}$, Stevens FCJ. Modernization, rationality and continuity of care: theoretical concepts and empirical values. Sociological Focus 1997;30(2):189-204.

3. Stuurgroep Toekomstscenario's Gezondheidszorg. Tockomstscenario's voor cerstelijnszorg en thuiszorg. Deel 1: Scenariorapport. Houtem/Zaventem: Bohn Stafleu van Loghum; 1992.

4. Van Beekum WT. Thuiszorgtechnologie op de drempel. Techniek in de Gezondheidszorg 1989;6(12):5-7.

5. Van Weel C. Thuiszorg voor terminale patienten met kanker. Ned Tijdschr Geneeskd 1989:133(12):625-7.

6. Wagenaar DJTH, De Mulder PHM. Thuiszorg voor patienten met kanker. Ned Tijdschr Geneeskd 1992;136(3):116-8.

7. Schade E, Gersons-Wolfensberger DCHM, Schornagel JH. Ontwikkelingen in de zorg voor patienten met kanker. Ned Tijdschr Geneeskd 1992;136(3):141-5.

8. Beraadsgroep Geneeskunde van de Gezondheidsraad. Medisch handelen op een tweesprong. Den Haag: Gezondheidsraad, 1991. Publikatienummer: 1991/23.

9. Habermas J. Theorie des Kommunikativen Handelns. Frankfurt: Suhrkamp; 1981

10. Van Beekum WT, Banta HD. Possibilities and problems in the development of home care technology Health Policy 1989;9(12):301-7.

11. Smeets PMJH, Warndorff DK, Beusmans GHMI. 'Infuusbehandeling Thuis': De implementatic van technologie in de thuiszorg. Medisch Contact 1993,48(31/32):944-6.

12. Ministerie van Welzijn Volksgezondheid en Cultuur (WVC). Directie Algemene Gezondheidszorg en Beroepen. Hoofdafdeling Medische en Paramedische Zorg. Stimuleringsprogramma Thuiszorgtechnologie. Rijswijk: WVC; 1991.

13. Barnhoorn $\mathrm{H}$, Walda $\mathrm{R}$. De eerste lijn op spitzen. Zorgvernieuwing in de praktijk. $2 \mathrm{e}$ ed. Assen/Maastricht: Van Gorcum; 1992.

14. Grol RTPM, Van Everdingen JJE, Casparie AF. Invoering van richtlijnen en veranderingen. Een handleiding voor de medische, paramedische en verpleegkundige praktijk. Utrecht: De Tijdstroom; 1994.

15. Division Health of Institute of Medicine. Assessing Medical Technologies. Washington DC: National Academy Press; 1985.

16. Raad voor Gezondheidsonderzoek (RGO). Medical Technology Assessment [advies]. 's-Gravenhage: RGO, november 1988.

17. Willems D, Schade E. Sociale en normatieve aspecten van medische technologie. Ned Tijdschr Geneeskd 1995;139(34):1752-5.

18. Smeets PMJH, Maas VPCM. De thuiszorg onder vuur. Zijn kwaliteit, client- en marktgerichtheid te combineren? [afstudeerscriptie]. Rotterdam: Rotterdam School of Management Erasmus Universiteit Rotterdam; juli 1992.

19. Sacket DL. Bias in Analytic Research. Journal of Chronic Diseases 1979;32:51-63.

20. Schrijvers AJP, Van Londen J. Ontwikkelingen in de thuiszorg. 2: Vraag en aanbod. Medisch Contact 1990;45(23):745-7.

21. Schrijvers AJ, Van Londen J. Ontwikkelingen in de thuiszorg. Slot: De toekomst. Medisch Contact $1990 ; 45(24): 768-72$.

22. Vakgroep Huisartsgeneeskunde van de Rijksuniversiteit Limburg (RL) en het Diagnostisch Coordinerend Centrum (DCC) van het academisch ziekenhuis Maastricht. Implementatic Thuiszorgtechnologic Infuussystemen [projectvoorstel]. Maastricht: RL/DCC; 1991.

23. Jasanoff S, Markje GE, Petersen JC, Pinch T, editors. Handbook of Science and Technology Studies. Thousand Oaks US: Sage Publications Inc:; 1995.

24. Bijker WE, Hughes TP, Pinch T, editors. The Social Construction of Technological Systems. New Directions in the Sociology and History of Technology. Cambridge US: Massachusetts Institute of Technology: 1989.

25. Rip A, Misa TJ, Schot J, editors. Managing Technology in Society. The Approach of Constructive Technology Assessment. Londen/New York: Pinter Publishers; 1995.

26. Habbema JDJ, Casparie AF, Mulder JH, Rutten FFH. Medische Technology Assessment en gezondheidsbeleid. Alphen aan den Rijn: Samson Stafleu; 1989.

27. Fletcher RH, Fletcher SW, Wagner EH. Clinical Epidemiology, the essentials. 2nd rev, ed. Baltimore US: Williams \& Wilkins; 1988. 
28. Haerkens HMJ, Van Beekum WT. Introductie van medische apparatuur in de thuiszorg, eerste fase: verkenning, selectie en voorbereiding. Leiden: Centrum voor Medische Technologie (CMT) van de nederlandse organisatie voor Toegepast Natuurwetenschappelijk Onderzoek; 1991. Publikatienummer: CMT/91.029.

29. Rogers EM. Diffusion of innovations. 4th ed. New York: The Free Press; 1995.

30. Scheirer MA. Program Implementation. The Organizational Context. In: Freeman HE, Berk RA, editors. Contemporary evaluation research. Beverly Hills: Sage Publications Inc.; 1981.

31. Fullan M. The Meaning of Educational Change. New York/London: Teachers College Press; 1982.

32. Kleinbaum DG, Kupper LL, Morgenstern H. Epidemiologic Research. California: Belmont; 1982.

33. Cook TD, Campbell DT. Quasi-Experimentation. Design \& Analysis Issues for Field Settings. Chicago: Rand McNally College Publishing Company; 1979.

34. Pope C, Mays N. Reaching the parts other methods cannot reach: an introduction to qualitative methods in health and health services research. British Medical Journal 1995:311:42-4.

35. Latour B, Woolgar S. Laboratory Life. The Construction of Scientific Facts. 2nd ed. Princeton NJ: Princeton University Press; 1986.

36. Latour B. Wetenschap in actie (Science in Action). Wetenschappers en technici in de maatschappij. 2e ed. Amsterdam: Prometheus en Bert Bakker, 1995.

37. Kwaliteitsinstituut voor Toegepaste ThuisZorgvernieuwing (KITTZ). Thuiszorgprogramma Cystic Fibrosis Intraveneuze antibioticabehandeling en sondevoeding Groningen: KITTZ; 1994.

38. KwaliteitsInstituut voor Toegepaste ThuisZ orgvernieuwing (KITTZ). Thuiszorgprogramma Pijnbestrijding via Epidurale en Intrathecale Infusic. Groningen: KITTZ; 1995.

39. Levine D. The Verdun Hospital-in-the-Home Program. Verdun Quebec: Centre hospitalier de Verdun; 1988.

40. Van Aller HB. De verlengde arm. Grootbrengen door kleinhouden in de gezondheidszorg. Nieuw Juristen Blad 1988;(25):901-4. Reacties in Nieuw Juristen Blad 1988;(38):1381-4.

41. Van Lin PMHM. Samenwerking huisarts-wijkverpleegkundige. Uit de Geneeskundige Hoofdinspectic. Medisch Contact 1988;43(25):782.

42. De Bijl NPYM. Uitsluitend voorbehouden aan bevoegden. Tijdschrift voor Gezondheidsrecht 1989;13(5):346-54.

43. Verpleegkundige dreigt buiten wet Big te vallen [interview met $\mathrm{G}$ Boer, staflid vakorganisatie NU'91 naar aanleiding van symposium 'De wet Big op de Medica']. Krantebericht herkomst onbekend.

44. Medisch-verpleegkundig handelen door wijkverpleegkundigen. De Huisarts 1990;(2):15-6.

45. Van der Grinten TED. Macht, tegenmacht, onmacht. De hardnekkige aanwezigheid van het maatschappelijk middenveld in de gezondheidszorg. In: Dekker $\mathrm{E}$, Elsinga $\mathrm{E}$, redactie. Mensen en Machten. Houten: Bohn Stafleu van Loghum; 1990. p. 115-27.

46. Van Schendelen MPCM. Politieke arena en besluitvorming in de gezondheidszorg. In: Boon L, redactic. Macht, Beleid \& Samenwerking. Amstelveen: Stichting Sympoz, Platform voor Ontwikkelingen in de Gezondheidszorg: 1994. p. $12-6$.

47. Aquina HJ. Politiek-bestuurlijke en maatschappelijke veranderingen in de nederlandse samenleving. In: Dekker E, Elsinga E, redactie. Mensen en Machten. Houten: Bohn Stafleu van Loghum; 1990. p. 31-47.

48. Vierhout WPM. Het gezamenlijk consult van huisarts en specialist in de eerste lijn. Een nieuwe werkwijze bij klachten van het bewegingsapparaat [proefschrift]. Maastricht: Rijksuniversiteit Limburg;:1994.

49. Kocken RJJ. Samenwerking en Academisering Huisartsgeneeskunde; van pragmatisme tot modelvorming [proefschrift]. Mastricht: Rijksuniversiteit Limburg; 1995.

50. Themanummer Transmurale Zorg. azM Select [informatiebulletin academisch ziekenhuis Maastricht]. $1995 ; 4(16)$.

51. Pop P, Spreeuwenberg C. Transmurale zorg in de regio Maastricht. Van Diagnostisch Coordinerend naar Transmuraal \& Diagnostisch Centrum. Medisch Contact 1998;53(3):91-4.

52. Berman P. The study of macro- and micro-implementation. Public Policy 1978;26(2):157-84.

53. Schrijvers AJP, Van Londen J. Enkele theoretische beschouwingen over het vernieuwen van zorg. Ned Tijdschr Geneeskd 1991;135(33):1502-6.

54. Van Loon PCJ. Intensieve thuiszorg als ontwikkelingsgebied. Dialoog met Hoefnagels, Post en Spreeuwenberg. Medisch Contact 1988;43(24):748.

55. Plagge HWM, Dutréc MA. Patientenzorg op het snijvlak van eerste en tweede lijn. Samenwerking tussen een academisch ziekenhuis en het kruiswerk. Medisch Contact 1990;45(50):1509-10.

56. Dutrée MA, Van der Veen A. Intensieve thuiszorg. Van aanboddenken naar vraaggericht werken. Medisch Contact 1991;46(18):571-2.

57. Bergsma J, Engel GL. Quality of life: does measurement help? Health Policy July 1988;(10):267-79. 
58. Van der Maas PJ. Kwaliteit van zorg en wetenschappelijk onderzoek. Ned Tijdschr Geneeskd $1994 ; 138(44): 2180-2$

59. De Haes JCJM. Kwaliteit van leven van kankerpatiènten [proefschrift]. Leiden: Rijksuniversiteit Leiden;1988.

60. De Neeling JND. Quality of Life. Het onderzoek naar welzijnseffecten van medisehe behandelingen. Utrecht: Bunge; 1991.

61. De Bock GH, Rijneveld SA, De Haan M. Geneeskunde en kwaliteit van leven. Het meten van een aan gezondheid gerelateerde kwaliteit van leven. Medisch Contact 1990,45(22):701-4.

62. Casparie AF. Kwaliteit in de gezondheidszorg. Huidige inzichten en toekomstige ontwikkelingen. Medisch Contact 1989;44(14):477-82.

63. Imai M. Kaizen. De sleutel van Japan's succesvolle coneurrentic. Deventer/Antwerpen: Kluwer, 1992.

64. Commissie Structuur en Financiering Gezondheidszorg (Commissie Dekker). Bereidheid tot verandering. 's-Gravenhage: Commissie Dekker, maart 1987.

65. Kooi R, Donker M. Cliênten over de RIAGG. Utrecht: Nederlands centrum voor de Geestelijke volksgezondheid, april 1991. Publikatienummer: 91-5.

66. Wet van 18 januari 1996, Wet op de kwaliteit van Zorginstellingen (Kwaliteitswet Zorginstellingen). Staatsblad 1996;(80).

67. Swanborn PG. Methoden van sociaal-wetenschappelijk onderzoek: Nieuwe editie. Amsterdam/Meppel: Boom; 1993.

68. Guyatt GH, Feeny DH, Patrick DL. Measuring Health-related Quality of Life. Annals of Internal Medicine 1993;118(8):622-9.

69. Essink-Bot ML, De Haes JCM. Kwaliteit van leven in medisch onderzock. Een inleiding. Amsterdam: Amsterdam Universitaire Pers; 1996.

70. Groebnet DF, Shannon PW. Business Statistics. A Decision-Making Approach. 3th rev. ed. Columbus Ohio: Merill Publishing Company; 1989.

71. Johnson RR. Elementary statistics. 6th rev. ed. Boston: PWS-KENT Publishing Company; 1992.

72. Van Leeuwen FL. Technologie en thuiszorg. Op de drempel van ongekende mogelijkheden. Tijdschrift voor Maatschappelijke Gezondheidszorg 1992;20(3):4-7.

73. Steering Committee on Future Health Scenarios. Anticipating and Assessing Health Care Technology. Volume 8: Potentials voor Home Care Technology [report]. Utrecht: Bohn Scheltema en Holkema; 1988: p 2,43.

74. Wennink J, Goudriaan G. De eerste lijn en thuiszorg. Slot: Scenario's voor ambulante zorg. Medisch Contact 1990;45(39):1161-4.

75. Wennink J, Goudriaan G. De eerste lijn en thuiszorg. 1: De verwarring. Medisch Contact 1990;45(37):1081-5.

76. Spreeuwenberg C. Knelpunten in de thuiszorg. Medisch Contact 1988;43(19):579.

77. Schrijvers AJP, Van Londen J. Ontwikkelingen in de thuiszorg. 1: Begripsomschrijvingen. Medisch Contact 1990;45(22):707-12.

78. Nationale Raad voor de Volksgezondheid (NRV). Discussie-nota Thuiszorg. Uitgebracht aan de staatssecretaris van Welzijn, Volksgezondheid en Cultuur. Zoetermeer: NRV; 1989. Publikatienummer: $19 / 89$.

79. Peters P, redactic. Nationaal Instituut Voor EersteLijnsgezondheidszorg. Nationaal centrum Geestelijke volksgezondheid, Nationaal Ziekenhuis Instituut. Innovatie in de zorgsector, Jaarboek 92/93. Den haag: VUGA.

80. Duijn J. Thuiszorg: een inventarisatie. Rijswijk: Uitgeverij voor Gezondheidsbevordering; 1989.

81. Baggerman C. Thuiszorg in Nederland. Geldrop: Baggerman; 1988.

82. Miltenburg T, Ramakers C, Mensink J, Tjadens F. Experimenten Thuisverpieging Eindrapport Intensieve thuiszorg. Nijmegen: Instituut voor Toegepaste Sociale Wetenschappen; 1991.

83. Ramakers C, Miltenburg T, Mensink J, Welling N, Tjadens F, Tunissen C. Eindrapport Experimenten Thuisverpleging. Deel II: Intensieve thuiszorg in praktijk. Nijmegen: Instituut voor Toegepaste Sociale Wetenschappen; 1991.

84. Provinciale Groninger Vereniging 'Het Groene Kruis'. Thuiszorgtechnologie 2000. Een thuiszorg innovatieprogramma Groningen: Provineiale Groninger Vereniging 'Het Groene Kruis'; 1992.

85. Van der Lyke SM, Van Miltenburg EM. Spinale pijnbestrijding in de thuiszorg [doctoraalscriptie]. Tevens interview met SM Van der Lyke op 27 augustus 1992. Maastricht: Rijksuniversiteit Limburg; 1992.

86. DeMoss CJ. Giving chemotherapy at home. American Journal of Nursing december 1980,80-2188-9.

87. Scheurer W. Iemand die pijn heeft moet zo snel mogelijk worden geholpen. Pijnbestrijding thuis is afhankelijk van perfect georganiseerde technische ondersteuning. Tijdschrift voor Maatschappelijke Gezondheidszorg 1992;20(1):22-4. 
88. Van der Lyke SM, Van Miltenburg EM. Verpleegkunde en techniek: een grensverleggende ontwikkeling. Tijdschrift voor Maatschappelijke Gezondheidszorg 1990;18(3):14-7.

89. Van Turnhout JM, Oosten HR, Teunissen SC. Formele structuren in 'Kleinschalige zorg'. Medisch Contact 1992;47(13):409-11.

90. Teunissen SC, Oosten HR, Turnhout van JM. Praktijkervaringen in 'Kleinschalige zorg'. Medisch Contact 1992:47(13):411-3.

91. Crul BJP, Van Diejen D, Van Dongen RTM, Van Oss GEJCM, Ziekinski AM, Roosen JR. Terminale thuiszorg in samenwerking met een commercieel bedrijf. Langdurige spinale toediening van opiaten bij kankerpatienten met ernstige pijn. Medisch Contact 1989;44(49):1615-7.

92. Stichting SAmenwerking eerste en tweede lijn voor REgionale geZOndheidszorg (SAREZO). Ambulante cytostatica behandeling [notitie]. Peridurale pijnbestrijding [notitie]. Brunssum: SAREZO, juli 1991.

93. Telefonische informatie van het Buro Intensieve Thuiszorg. Maastricht: 2 september 1992 en 12 februari 1993.

94. Onderzoeksgroep Zorgvernieuwing. Vakgroep Beleidswetenschap. Rijksuniversiteit Limburg (RL). Over starten en volhouden. Evaluatic 'Programma Zorgvernieuwingsprojecten Thuiszorg van WVC' [voortgangsrapportage]. Maastricht: RL; 1990.

95. Herbschleb G. Thuis-controle bij vrouwen met risicovolle zwangerschap. Tijdschrift voor Maatschappelijke Gezondheidszorg 1992;20(3):24-5.

96. Van der Putten M. Of draagbaar ook draaglijk is. AMC Magazine [informatiebulletin Academisch Medisch Centrum] mei 1992:22-3.

97. Romijn JA, Van der Meer R, Kam SS, Sauerwein HP. Praktische aspecten van parenterale voeding thuis bij patienten met benigne en patienten met maligne aandoeningen. Ned Tijdschr Geneeskd 1988:132(2):74-7.

98. Streekziekenhuis Midden Twente (SMT) en Kruisvereniging Midden- en Noord-Oost Twente (KNMOT). Transmurale Zorg in Midden Twente [nota]. Hengelo: SMT/KNMOT; december 1991.

99. Schmidt J, redactie. Eerste evaluatie Project Intensieve ThuisZorg Heuvelland. Maastricht: Meldpunt Intensieve ThuisZorg Stichting Groene Kruis Heuvelland; 1991.

100. Dullemond G. Ouders leren thuiszorg. Het stappenplan van het Sophia Kinderziekenhuis. Tijdschrift voor Maatschappelijke Gezondheidszorg 1992;20(3):48-9.

101. Provinciale Groninger Vereniging 'Het Groene Kruis'. Magazine van de Provinciale Groninger Vereniging 'Het Groene Kruis' (1,2,3). Groningen: Provinciale Groninger Vereniging 'Het Groene Kruis'; 1991-1992.

102. Van Dijk B, Van Giezen-Biegstraaten LMGJ. Transmurale zorg. Medisch Contact 1992;47(13):407-8.

103. Ravensbergen H. Skillslab wordt een begrip [interview met M Spithoven]. Tijdschrift voor Maatschappelijke Gezondheidszorg 1992;20(3):38-40.

104. Boesten N. 'Van ziekenhuiszorg naar thuiszorg'. Projectvoorstel Stimuleringsprogramma Thuiszorgtechnologie WVC. Stichting Medische Technologie; juli 1991.

105. Huijsman R, Boesten N, Schram H. Protocollen voor thuiszorgtechnologie. Een Gorinchems project. Medisch Contact 1993;48(11):345-6. Voorpublicatie in: Van ziekenhuiszorg naar thuiszorg [symposiumverslag]; 2 maart 1992; Gorinchem. Maastricht: Stichting Medische Technologie, 1993.

106. Innovatieproject Amsterdamse Gezondheidszorg (IP). Voorlopige, herziene versie van het protocol 'Infuus Thuis'. Amsterdam: IP; februari 1992.

107. Bertels M. Evaluatie van het project 'Infuus Thuis'. Amsterdam: Innovatieproject Amsterdamse Gezondheidszorg; juli 1992.

108. Interviews met A Pool en B van Kruuk van de Stichting Amsterdams Kruiswerk. Amsterdam: 20 januari 1993.

109. Meijer A, Crebolder HFJM. Ontwikkelingen in de Thuiszorg in de Verenigde Staten. Een vergelijking met Nederland. Maastricht: Naar nieuwe verhoudingen [symposiumverslag]; 1990.

110. Ministerie van Economische Zaken. Medische Thuiszorg. Technieuws Washington [publikatie van het Ministerie] april 1989:1-14. Publikatienummer: TNW 89-02 april 1989.

111. Hornstra S. De visie van een zorgverzekeraar op de financiering van de pijnbestrijding door middel van infusiepompjes. In: Crul BJP, Maas SAEL, redactic. Thuis zonder pijn [symposiumverslag]; 14 februari 1992; Schiedam. Schiedam: Abbott; februari 1992: 51-4.

112. Gezondheidsraad, Commissie thuiszorg voor patienten met kanker. Thuiszorg voor patienten met kanker. Den Haag: Gezondheidsraad; februari 1991. Publikatienummer: 1991/02.

113. Kraaipoel RJ. Ziekenhuizen kunnen hun klanten er niet zomaar uitgooien [rede]. Tijdschrift voor Maatschappelijke Gezondheidszorg 1992;20(3):9.

114. Van der Linden A. Pijnbestrijding en het Integraal Kankercentrum. In: Crul BJP, Maas SAEL, redactic. Thuis zonder pijn [symposiumverslag]; 14 februari 1992; Schiedam. Schiedam: Abbott; februari 1992: 5-8. 
115. Jayabose S, Escobedo V, Tugal O, Nahaczewski A, Donohue P, Fuentes V, et al. Home Chemotherapy for Children with Cancer. Cancer 1992;69(2):574-9.

116. Wiernikowski JT, Rothney M, Dawson S, Andrew M. Evaluation of a home intravenous antibiotic program in pediatric oncology. The American Journal of Paediatric Hematology/Oncology 1991;13(2):144-7.

117. Derksen-Lubsen G, Kerrebijn KF. Voorwaarden te stellen aan thuisbehandeling toegespitst op kinderen met cystische fibrose. Ned Tijdschr Geneeskd 1989;133(22):1118-21.

118. Kind AC, Williams DN, Gibson J. Outpatient intravenous antibiotic therapy. Ten years' experience. Postgraduate Medicine 1985;77(2):105-11.

119. Poretz DM, Eron L, Goldenberg RI, Gilbert AF, Rising J, Sparks S. Intravenous Antibiotic Therapy in an Outpatient Setting. JAMA 1982;248(3):336-9.

120. Poretz DM. Home management of antibiotic therapy. In: Remington JS, editor. Current Clinical Topies in Infectious Diseases. New York: MeGraw-Hill; 1989. p. 27-42.

121. Poretz DM. Home Intravenous Antibiotic Therapy. Clinics in Geriatric Medicine 1991:7(4):749-63.

122. Sutker WL. Home Intravenous Antibiotic Therapy. Infections in Medicine 1988:350-8. Infections in Medicine.

123. Sorensen RU, Kallick MD, Berger M. Home treatment of antibody-deficiency syndromes with intravenous immune globulin. J Allergy Clin Immunol 1987;80(6):810-5.

124. Ryan A, Thomson BJ, Webster ADB. Home intravenous immunoglobulin therapy for patients with primary hypogammaglobulinaemia [letter]. The Lancet October 1988:793.

125. Kobayashi RH, Kobayashi AD, Lee N, Fischer S, Ochs HD. Home Self-Administration of Intravenous Immunoglobulin Therapy in Children. Paediatrics 1990;85(5):705-9.

126. Miller LW, Merkie EJ, Herrmann V. Outpatient dobutamine for end-stage congestive heart failure. Critical Care Medicine 1990;18(1:Suppl):S30-S33.

127. Applefeld MM, Newman KA, Sutton F, Reed WP, Roffman DS, Talesnick BS, et al. Outpatient dobutamine and dopamine infusions in the management of chronic heart failure: Clinical experience in 21 patients. American Heart Joumal 1987;114(3):589-95.

128. Van Zwieten PA. Dopamine en dopaminerge farmaca als therapeutica bij decompensatio cordis. Ned Tijdschr Geneeskd 1990;134(47):2281-84.

129. Kho T, Menheere P, Cheriex E, Stappers J, Gorgels F, Van Hooff J. Intermittent low dose dopamine infusion improves quality of life and volume-control system of patients with severe congestive heart failure. European Heart Journal 1989;10(suppl):386 .

130. Management of Venous Tromboembolism [editorial]. The Lancet 6 February 1988:275-7.

131. Bakker M, Dekker PJ, Knot EAR, Van Bergen PFMM, Jonker JJC. Home treatment for deep venous thrombosis with low-molecular-weight heparin [letter]. The Lancet November 1988:1142.

132. Mahmud K, Keenan JM, Benett MB. Home Heparin Infusion in the Management of Deep Vein Thrombophlebitis. Minnesota Medicine November 1990;73:31-3.

133. Hirsh J. Heparin. The New England Journal of Medicine 1991;324(22): 1565-74.

134. Hirsh J, Levine MN. Low Molecular Weight Heparin [review article], Blood 1992;79(1):1-17.

135. Prandoni P, Lensing AWA, Baller HR, Carta M, Cogo A, Vigo M. Comparison of subcutaneous lowmolecular-weight heparin with intravenous standard heparin in proximal deep-vein thrombosis. The Lancet 1992:339:441-5.

136. Crebolder HFJM, Vrieze OJ, Fransen G, Kuipers J, Limonard C. Thuiszorg en patientenstromen. Coordinatie van classificatie- en registratiesystemen. Medisch Contact 1990;45(24):763-7.

137. Van de Rijdt TP. Protocol: Landkaart of routebeschrijving? Kwaliteit in de eerstelijns zorg 1992;4(4):13-4

138. Lagro A. Sarezo: verwachtingen, resultaten, aanbevelingen. Beter samen? Samen Beter! Vijf jaar experimenteren met zorgvernieuwing [symposiumverslag]; 1993.

139. Poley AJ, De Ridder VA. Inbrengen en begeleiden van het infuus thuis (1). The Practitioner 1991;8:797-9.

140. Interview met $\mathrm{N}$ Boesten van de Stichting Medische Technologie, Maastricht: 2 september 1992.

141. Districtsvereniging Het Groene Kruis Heuvelland, dienst wijkzorg. Medisch Technisch Handelen door Verpleegkundig Beroepsbeoefenaars in de Thuissituatic: Een kader waarbinnen medische handelingen verricht worden. Maastricht: SGKH; 1992.

142. Schlag P. Continuous cancer chemotherapy. Rationale and prerequisites for treatment at home. International Journal of Technology Assessment in Health Care 1985;1:343-51.

143. Mulder JD. Techniek thuis. Bron onbekend:195-201.

144. Baptista RJ, Mitrano FP. Experience with 211 courses of home intravenous antimicrobial therapy. American Journal of Hospital Pharmacy 1989;46:315-6.

145. Brown RB. Selection and training of patients for outpatient intravenous antibiotic therapy. Reviews of Infectious Diseases 1991;13(Suppl 2):S147-51. 
146. Frissen PHJ, Van der Pijl JW. Low complication rate of a totally implantable venous access device (PortA-Cath()) in Aids patients. Amsterdam: Aids-Unit Academisch Medisch Centrum; 1990.

147. Nonnekes J. Thuiszorg-technologie is veel meer dan alleen 'high-tech' [interview met M Heynen]. Tijdschrift voor Maatschappelijke Gezondheidszorg 1992;20(3):10-2.

148. Smeets PMJH. Multi-Parameter Advanced Monitoring System [report]. Utrecht: 1991.

149. Evers GCM. Theorieen en principes van verpleegkunde. Inleiding voor het wetenschappelijk onderwijs en onderzoek. 2e gewijzigde ed. Assen/Leuven: Van Gorcum/Universitaire Pers; 1994.

150. Fawcett J. Analysis and evaluation of conceptual models of nursing. Philadelphia: FA Davis; 1989.

151. Newman MA. The continuing revolution: the history of nursing science. In: Chaska NL, editor. The nursing profession a time to speak. New York: MeGraw-Hill; 1983.

152. Hattinga Verschure JCM. Het verschijnsel zorg. Lochem: De Tijdstroom; 1977.

153. Durkheim E. De la division travail social. Paris; 1883.

154. Hughes EC. Men and their work. Glencoe: The Free Press; 1958.

155. Freidson E. Profession of medicine. A study of the sociology of applied knowledge. Chicago and London: The University of Chicago Press; 1970,1988.

156. Abbott A. The system of professions. An essay on the division of expert labor. Chicago \& London: The University of Chicago Press; 1988.

157. De Melker RA. Huisartsgeneeskunde: over 25 jaar 'nog groter gegroeid'? Medisch Contact 1993:22(48):691-3.

158. Touw-Otten F. Wetenschapsbeoefening en huisartsgeneeskunde: Een analyse van dissertaties en enkele wegen tot structurering van huisartsgeneeskunde als discipline. Deventer: Van Loghum Slaterus; 1981.

159. Leenen HJJ, Klaassen ABM, redactie. Commissie Geneeskunde, Subcommissie Gezondheids(zorg)wetenschappen. Rapport van de subcommissic gezondheids(zorg)wetenschappen. Amsterdam: Koninklijke Nederlandse Akademie van Wetenschappen; 1991.

160. Morell DC. Huisartsgeneeskunst [Nederlandse bewerking door RA De Melker]. Utrecht: Wetenschappelijke uitgeverij Bunge; 1978.

161. Van Es JC. Patient en huisarts. $3^{*}$ ed. Utrecht/Antwerpen: Bohn, Scheltema \& Holkema; 1984.

162. Landelijke Huisartsen Vereniging. Basistakenpakket van de huisarts. Utrecht: LHV; januari 1985/juni $1987 / \mathrm{mei} 1988$.

163. World Health Organization, Regional Office for Europe. Framework for professional and administrative development of general practice/family medicine in Europe. Copenhagen: Primary Health Care Unit; 13 March 1998.

164. Orem DE. Nursing, Concepts of practice. 4th ed. St Louis: Mosby-Year Book Inc.; 1991.

165. Metzger McQuiston C, Webb AA, editors. Foundations of nursing theory: Contributions of 12 key theorists. California: SAGE Publications; 1995.

166. Kruijswijk Jansen J, Mostert H. Het verpleegproces: de verpleegkundige modellen van Orem en King uitgewerkt binnen het verpleegproces. Utrecht: Lemma; 1994.

167. Philipsen H. De naaste en haar patient. Rede gehouden op de 19e dies natalis van de Rijksuniversiteit Limburg. Maastricht: Rijksuniversiteit Limburg; 13 januari 1995.

168. Martinelli A, Smelser NJ, editors. Economy and Society. Overviews in economic sociology. London: International Sociological Association; 1990.

169. Van der Aalst $P$. Burger of consument. Intermediair 1993;29(6):19.

170. Ankone A. Vijf landen proberen chaos in beleid te beteugelen. Politieke beslissingen zelden wetenschappelijk onderbouwd [interview met M Barer en TR Marmor]. Medisch Contact 1995;50(33/34):1015-7.

171. Shepherd WG. The economies of industrial organization. 3rd ed. New Jersey USA: Prentice-Hall Inc.; 1979.

172. Cillikens C. Verzorgingsstaat: van vangnet naar hangmat? De Limburger [krant] 7 juni 1994: p. 13.

173. Laeyendecker L. Gezondheidsstreven: spiegel der cultuur. Houtem: Bohn Stafleu van Loghum; 1990. p. $13-30$.

174. Herraets J. We hebben niet voorzien dat zich een heel ander menstype zou ontwikkelen. De verwording van de verzorgingsstaat. Observant [universiteitsblad Rijksuniversiteit Limburg] 5 oktober 1995;(6):8-9.

175. Lof E. Lof der consumptic. Intermediair 1993;39(6):20-5.

176. Stuurgroep Toekomstscenario's Gezondheidszorg. Toekomstscenario's voor eerstelijnszorg en thuiszorg. Deel 3: Achtergrondstudies. Achtergronddocument C: Complexe thuiszorg; resultaten van een Delphi studie. Houten/Zaventem: Bohn Stafleu van Loghum; 1992.

177. Van Noordt M, Carsouw E. Thuiszorg in de Verenigde Staten. Ervaringen in een New Yorks ziekenhuis. Medisch Contact 1992;47(1):21-4.

178. Ankone WA. Even 'Brussel' bellen. Grensoverschrijdende gezondheidszorg. Medisch Contact 1992; $47(45): 1311-2$. 
179. Hutten JBF, Kerkstra A, editors. Home Care in Europe. A country-specific guide to its organization and financing. Hants (UK)VVermont (USA): Arena/Ashgate Publishing Company; 1996.

180. De Vries B. Groot-Brittanic op rantsoen. De staat van de verzorging deel 4. De Limburger [krant] 10 juni 1994 : p. 19.

181. Znidarsic I. Eigenlijk kent de VS geen ouderenzorg. Nederlandse zorg voor ouderen voorbeeld voor het buitenland. Ziekenhuis \& Instelling September 1995:8-10.

182. Spreeuwenberg C. Scenario's over ordening Medisch Contact 1995;50(7):201.

183. Olmsted Teisberg E, Porter ME, Brown GB. Making Competition in Health Care Work. Incentives throughout the health care system are so skewed that normal rules of competition do not apply. Harvard Business Review July/August 1994:131-41.

184. Dunne JM, Van Dijk P, Van Flinterman C, Leclereq WEM, Nota JA, Wessels B, redactie. Verzameling Nederlandse Wetgeving. Deel 1: De Grondwet. $6 \mathrm{e}$ gewijzigde ed. Lelystad: Koninklijke Vermande BV; 1990.

185. Ministerie van Volksgezondheid en Milieuhygiene. Structuumota Gezondheidszorg (nota Hendiks). 'sGravenhage: Staatsuitgeverij; 1974.

186. Commissie Modemisering Curatieve Zorg (commissie Biesheuvel). Gedeelde zorg; Betere zorg [samenvatting rapport en toespraken BW Biesheuvel en HJ Simons]. 's-Gravenhage: 20 januari 1994.

187. Nationale Raad voor de Volksgezondheid (NRV) en het College voor Ziekenhuisvoorzieningen (CvZ). Transmurale somatische zorg [advies]. Zoetermeer: NRV/CVZ; april 1995.

188. Post D. Heffen we de eerste lijn op? Huisarts en specialist in een nieuwe 'orde'. Medisch Contact 1988;43(19):591-3.

189. Van der Jagt WA. Beheersing gezondheidszorg: droom of werkelijkheid? (1). Ziekenhuismanagement februari 1991;(2):57-64.

190. Commissie Medische Ethiek van de Koninklijke Nederlandse Maatschappij tot bevordering der Geneeskunst. Professioneel kiezen. Utrecht: KNMG; november 1991.

191. Kraajenveld P. Blok Graniet. Machtsverhoudingen in de Gezondheidszorg. Ziekenhuis \& Instelling juni 1994:19.

192. Commissie Keuzen in de Zorg (commissie Dunning). Kiezen en delen, advies in hoofdzaken. Zoetermeer: CKZ; november 1991.

193. Fikenscher TF, Kosten van de gezondheidszorg. Niet bezuinigen, wel indexeren. Medisch Contact 1996;51(39):1240-1.

194. Johnson G, Scholes K. Exploring corporate strategy. 2nd ed. Hertfordshire (UK): Prentice Hall; 1988.

195. Parsons T. Illness and the role of the physician. A sociological perspective. American Journal of Psychiatry 1951:452-460.

196. Szaz TS, Hollender MH. Title unknown. Archives of Intemal Medicine 1956:97:585-92.

197. Lipkin M, Putnam SM, Lazare A, editors. The Medical Interview. Clinical Care, Education and Research. New York: Springer, 1995.

198. Molenwijk AC, Dillman RJM. Artsen over doelen van de gezondheidszorg. 'Meer, minder of anders'. Medisch Contact 1995;50(36):1132-5.

199. Boeije HR. Verpleging en verzorging. Een kwestie van domeinen. Medisch Contact 1996;51(10):323-5.

200. Stevens FCJ, Philipsen H. Beroepen en professies in de gezondheidszorg. In: Aakster CW, Groothof JW, redactic. Medische Sociologie. Se geheel herziene ed. Groningen: Wolters-Noordhoff, 1998. p. 84-93.

201. De Graaf T. Verpleegkunde-Geneeskunde. Hoe bakenen we de grens af? Tijdschrift voor Ziekenverpleging 1993;(6):187-90.

202. Wet van den Isten Juni 1865, regelende de Uitoefening der Geneeskunst. 's-Gravenhage: Staatsblad, 1865. No $60: 43-4$.

203. Eerste Kamer vergaderjaar 1991-1992. Regeling inzake beroepen op het gebied van de individuele gezondheidszorg (Wet op de beroepen in de individuele gezondheidszorg). 's-Gravenhage: SDU-uitgeverij; 1992: p 1-51. Publikatienummer: 19522, nr. 327.

204. Van Wijmen FCB. Het recht, de professionele autonomie en richtlijnen voor medisch handelen. Kwaliteit en Zorg 1996:3(1):25-33.

205. Spreeuwenberg C. Goed hulpverlenerschap: essentie van de WGBO (405). Leenen HJ. Invoering WGBO. Conceptie, groei en geboorte (413-4). Voorn Th. De WGBO in de praktijk. Enige bespiegelingen van een huisarts bij de start van de WGBO (415-6). Bellemakers C. Behandelingsovereenkomst of begeleidingsovereenkomst. Een client-deskundige aan het woord (417-8), Wijmen FCB van. Vertrouwen en verantwoorde zorg. Bij de inwerkingtreding van de WGBO (411-2). Medisch Contact 1995;50(13). 
206. Meeuwissen JHM. Vriendschap sluiten met de WGBO. Een kwestie van de juiste strategie (1513-4). Dekkers F. Vriendschap sluiten met de WGBO. De volwassenwording van het medisch bedrijf 1514-5). Legemaate J. Vriendschap sluiten met de WGBO. Ruimte voor ontwikkelingen en initiatieven (1515-6). Medisch Contact 1995;50(24).

207. Keij FJ, Wermenbol-van den Heuvel G. Standaardinformatie of informatiestandaard? Informatieverstrekking onder de WGBO. Medisch Contact 1995;50(13):419-20.

208. Rutten GEHM, Thomas S, redactie. NHG-Standaarden voor de huisarts. Utrecht: Nederlands Huisartsen Genootschap; 1993.

209. Thomas S, Geijer RMM, Van der Laan JR, Wiersma Tj, redactie. NHG-Standaarden voor de huisarts II. Utrecht: Nederlands Huisartsen Genootschap; 1996.

210. Vencken LM. De WGBO in de praktijk: dossierperikelen. Wachten op evaluatie in het jaar 2000 ? Medisch Contact 1996;51(31/32):1018-9.

211. Kastelein WR. Wet klachtrecht clienten zorgsector op 1 augustus van kracht. Medisch Contact 1995;50(29/30):931-3.

212. Van der Wilk J. De 'derde macht' op de vierde plaats. In: Boon L, redacteur. Macht, Beleid \& Samenwerking. Amstelveen: Stichting Sympoz, Platform voor Ontwikkelingen in de Gezondheidszorg: 1994. p. 39-43.

213. Huygen FJA. Paradigma's voor de huisartsgeneeskunde. Huisarts en Wetenschap 1978;21:447-50.

214. Fransen AH. Functiedifferentiatie van huisartsen. Medisch Contact 1998;53(15):483.

215. De Melker RA. Huisartsgeneeskunst. Utrecht: Wetenschappelijke uitgeverij Bunge; 1976. Nederlandse bewerking van: Morell, DC. An introduction of primary medical care. Edinburgh: Chirchill Livingstone.

216. Bakker JH, Le Grand-van den Bogaard MMM. Verpleegkundig Beroepsprofiel. Zoetermeer. Nationale Raad voor de Volksgezondheid; november 1988: p 5-55.

217. Lips JM. Thuiszorg ervaren en bekeken. Zoals de zorg thuis is wordt zij nergens'. Medisch Contact 1988;44(49):1611-4.

218. Stuurgroep Toekomstscenario's Gezondheidszorg. Toekomstscenario's voor eerstelijnszorg en thuiszorg. Deel 1: Scenariorapport. Houten/Zaventem: Bohn Stafleu van Loghum; 1992. p. 135-7.

219. Kunneman H. Van verzorgingsideaal naar zelfstandigheidsideaal. Zorgen \& Wonen [symposiumverslag]; 1994.

220. Verhoeven H, Bosma E. Technologie in de thuiszorg vergroot de zelfredzaamheid. TGP 1992;10(5):12-4.

221. Van Achterberg T. Continuity of care and client satisfaction in the community. A study of professional and non-professional care for the chronically ill [dissertation]. Maastricht: Universiteit Maastricht; 1997.

222. Beijaert RPH, Hiemstra Y, Hoogvliet G, De Lathouder HC, Van de Muijsenbergh METC, Thie J. Thuiszorgtechnologic. Utrecht: Nederlands Huisartsen Genootschap; 1993. Publikatienummer: Praktijkvoering P28.

223. McFarland GK, McFarlane EA. Nursing diagnosis and intervention. St. Louis: The CV Mosby Company; 1989.

224. Van der Jagt WA. Beheersing gezondheidszorg: droom of werkelijkheid? [slot]. Ziekenhuismanagement april 1991;(4):122-34.

225. Borghuis-Lub TL, Lapre RM. Gezondheidszorg geordend. Een kwartet scenario's. Medisch Contact 1995;50(7):207-10.

226. Brief inzake het verschil tussen verpleegtechnisch en medisch-technisch handelen van de Stichting Provinciaal Samenwerkingsverband van het Limburgse Groene Kruis aan de Stichting Groene Kruis Heuvelland d.d. 25 april 1994. Kenmerk: 1512.O\&D.94:CH/HK.

227. Van der Mijn WB. De lange geschiedenis van de wet BIG. Mijlpaal in moderniseringsproces geneeskundige wetgeving. Medisch Contact 1992;47(12):361-3.

228. Kastelein WR, Legemaate J. Wie zet de BIG weer met vier poten op de grond? Als we de patient daadwerkelijk willen beschermen, zal wellicht naar andere wegen moeten worden gezocht. Medisch Contact 1992:47(12):359-60.

229. CFO, de CNV bond Voor Overheid, Zorgsector en Verzelfstandigde Overheidsinstellingen. Wetsvoorstel Beroepen in de individuele gezondheidszorg. Informatie en standpunten over de wet BIG. Den Haag: CFO; januari 1993.

230. Brief van het Staatstoezicht op de Volksgezondheid, de Geneeskundige Inspectie van de Volksgezondheid voor Limburg, d.d. 27 mei 1991 waarin thuiszorginstellingen in het kader van de kwaliteitswet voorgeschreven wordt een geformaliseerde en schriftelijk vastgestelde interne regeling voor medischtechnisch handelen door anderen dan artsen op te stellen.

231. Van den Boomen UHC, Van Wijmen FCB. Papier en Praktijk. De bevoegdheidsregeling voor verpleegkundigen. Verpleegkunde 1995;(3/4):164-72. 
232. Raad Beroepen Individuele Gezondheidszorg. Voorbehouden handelingen, Advies over de toepassing van artikel 39 voor verpleegkundigen, mondhygienisten en radiologisch laboranten. Zoetermeer: Raad BIG; juni 1995. Publikatienummer. B2/\%95.

233. Geneeskundig Adresbock Nederland 93/94. Schiedam: Nijgh periodieken; 1993.

234. Maandstatistiek van de bevolking juli 1993,41:58-60.

235. Centraal Bureau voor de Statistiek/Ministerie van Volksgezondheid WeC. Menskracht en Opleiding. Vademecum gezondheidsstatistiek Nederland 1993. 's-Gravenhage: SDU-uitgeverij; 1993. p. 190.

236. Bartelds JF, Jansen EPWA, Joostens TH. Enquetteren: Het opstellen en gebruiken van vragenlijsten. Groningen: Wolters-Noordhoff, 1989.

237. Schwerzel $P$, Hendrikse $S$. Te weinig kennis over wetgeving medisch-technische handelingen. Enquête onder wijkverpleegkundigen. Het Beterschap 1986;8(2):22-4.

238. Spreeuwenberg C. Arts, verpleegkundige en Wet BIG. Medisch Contact 1996;51(6):179.

239. Van Santen J. Uw rechten als patient. Utrecht: VWS, KNMG, NP/CF, NVZ, PP/CP Utrecht, SOKG en Stichting de Ombudsman; juni 1995.

240. Francissen PWHM. Nieuwe wet stelt patient centraal. WGBO gaat uit van vertrouwensrelatie tussen hulpverlener en patient. Tijdschrift Gezondheidsvoorlichting 1995;12(4):2-5.

241. Nationale Raad voor de Volksgezondheid (NRV). Advies BIG-Raad. Zoetermeer: NRV; december 1988:7 Publikatienummer: 28/88.

242. Tijmstra T, Busch MCM, Scaf-Klomp W. Meningen van beroepsbeoefenaren. 3: Medische technologie en 'gewone' zorgverlening. Medisch Contact 1991;469(49):1483-4.

243. Elie 1, Schuyt K. Medici en media. Huisartsen en medische informatic in de media. Medisch Contact 1995;50(44):1401-5.

244. Dowling S, Martin R, Skidmore P, Doyal L, Cameron A, Lloyd S. Nurses taking on junior doctors' work: a confusion of accountability. Britisch Medical Joumal May 1996;312:1211-4.

245. Ketelaars C, Ten Dam G. Gedifferentieerd en gespecialiseerd werken in de wijkverpleging. Assen/Maastricht: Dekker \& van der Vegt/Van Gorcum; 1993.

246. Van der Lyke SM, Van Miltenburg EM. Spinale pijnbestrijding in de thuiszorg. TGP mei 1992:21-3.

247. Beroepsgroep Verplegenden en Verzorgenden van de BVV/CFO. Beroepsgroep Verplegenden en Verzorgenden van de BVV/CFO. Voorbehouden handelingen BIG-wet voor verpleegkundigen. CFO; april 1992.

248. Van den Boomen IHC. De arts als opdrachtgever in de wet BIG. Het verrichten van voorbehouden handelingen door verpleegkundigen. Medisch Contact 1995;50(4):113-5.

249. Spreeuwenberg C. Bevoegdheid van verpleegkundigen. Medisch Contact 1995;50(4):109.

250. Nationaal Ziekenhuis Instituut (NZI). De intramuraic gezondheidszorg in eijfers per 1 januari 1993. Utrecht: NZI; 1994.

251. Sanders HWA. Voorbehouden handelingen. Is het formeel toekennen van 'functionele zelfstandigheid' ex artikel 39 Wet BIG nodig en/of nuttig. Medisch Contact 1995;50(31/32):977-80.

252. Van der Mijn WB. De positie van de verpleegkundige in de BIG. Van bevoegdheid naar bekwaamheid. Medisch Contact 1995;50(31/32):981-2.

253. Van den Boomen IHC. De meerwaarde van artikel 39 Wet BIG voor de praktijk. Voorwaarden waaronder voorbehouden handelingen mogen worden verricht. Medisch Contact 1996;51(2):49-50.

254. Kooijman JCM, Campman EAM, Derckx EWCC, Mangnus TM, Schlooz EAM, Keybets H. Delegatie van medisch handelen door huisartsen aan wijkverpleegkundigen. Praktijkervaringen in Limburg. [Reacties Medisch Contact 1995:50(38):1180-1]. Medisch Contact 1995;50(31 32):983-5.

255. Steenvoorden MAGA, Goudriaan G. Mantelzorg. Een zorg voor de hulpverlening. Medisch Contact 1994;49(9):301-3.

256. De Maeseneer J. Thuisgezondheidszorg is een vak. Van probleem-georienteerde naar doel-georienteerde zorg. Huisarts Nu februari 1992;1:47-50.

257. De Grande L. Thuiszorg: de stem van het thuismilieu. Huisarts Nu februari 1992; I:6-11.

258. Blankers B. Mensen zijn niet zielig, maar hebben recht op hulp. Oppas/thuishulpcentrale Heerlen zoekt vrijwilligers. Limburgs Dagblad [krant] 23 september 1994: p. 16.

259. Nationaal Instituut voor Zorg en Welzijn en de Vrijwilligers Terminale Zorg. Vrijwilligers in de terminale thuiszorg. Nieuwsbrief juni 1997;7.

260. Schrijvers AJP, Mulder JD, Van den Muijsenbergh METC, Deyns VJ. Vrijwilligershulp bij terminale thuiszorg. Een Utrechts organisatiemodel. Medisch Contact 1995;15(50):492-4.

261. Wennink HJ, Kooiker SE, W BWG, De Bakker DH, Groenewegen PP. Toekomstscenario's voor eerstelijnszorg en thuiszorg. Samenhangende circuits. Medisch Contact 1992;12(47):365-6.

262. De Maeseneer J, Wittevrongel L, Vandederinck E. De andere kant van thuiszorg. Huisarts Nu februari 1992;1:36-8. 
263. Elie 1. Medici en media. Huisartsen en medische informatie in de media. 1: Het onderzoek. Medisch Contact 1995:50(43):1363-4.

264. Van Es JC. Paradigma's van de huisartsgenceskunde. Huisarts en Wetenschap 1978;21:451-8.

265. Hoefnagels KLJ. Een nieuw ziekenhuisconcept. Doelmatigheid in de gezondheidszorg. Medisch Contact $1993 ; 48(25): 779-82$.

266. Schade E. Zorg Thuis/Thuiszorg in Nederland. Huisarts Nu februari 1992;1:41-4.

267. Verdonck P. De zorgbemiddelaar: een taak voor de huisarts? Huisarts Nu februari 1992;1:13-6.

268. Schrijvers AJP, Van Londen J. 'Thuiszorg' opnieuw bekeken. Tijdschrift voor Ziekenverpleging 1988:42(17):541-3.

269. Van Leeuwen G, Willems C. LVT-Indicatiesysteem. Bunnink: Landelijke Vereniging voor Thuiszorg/Compliance Consult; 1995.

270. Wennink HJ, Kooiker SE, Boerma WGW, De Bakker DH, Groenewegen PP, Schade E. Complexe thuiszorg. Welke zorg onder welke voorwaarden. Medisch Contact 1992;47(12):373-6.

271. Plagge HWM, Kuijpers $A$. Indicatiestelling verpleging en verzorging. Het belang van de ziektekostenverzekeraar. Medisch Contact 1992;47(26):819-21.

272. Appelman A, Ligtenberg H, Van Bergen B, Hollands L. Ontwikkeling van kwaliteitsstandaarden voor de wijkverpleging. Lochem: De Tijdstroom; 1989.

273. Eijkelkamp BAM, Schellekens JWG. Mantelzorg in intensieve thuiszorg. The Practitioner 1992;9(2):81-3.

274. Van Hulst L. Het wonder van het modulaire denken. De ultieme combinatie van individualisering en massaproduktie. Intermediair 1995;31(35):21-5.

275. Felix-Schollaart B, Beusmans GHMI, Berden HJM. Een zorgdossier voor de intensieve thuiszorg. Naar een betere informatieoverdracht. Medisch Contact 1995;50(41):1301-2.

276. Bossers J. De huisarts en het zorgenplan. Huisarts Nu februari 1992;1:18-9.

277. Distriksvereniging Het Groene Kruis Heuvelland. Logboek. Maastricht: Groene Kruis Heuvelland; 1991

278. Zorgverzekeraar VGZ. Logboek Thuiszorg.

279. Stichting Amsterdams Kruiswerk (SAK). Logboek Zorgverlening Amsterdam. Amsterdam: SAK.

280. Nederlands Huisartsen Genootschap. Zorgdossier Intensieve Thuiszorg. Utrecht: NHG; 1994.

281. Nationale Kruisvereniging (NK) en Landelijke Huisartsen Vereniging (LHV). Medisch handelen door verpleegkundige beroepsbeoefenaars in de thuissituatic. Bunnink: NK/L.HV; februari 1990.

282. Academisch Ziekenhuis Rotterdam en Sophia Kinderziekenhuis. De saturatiemeter bij uw kind thuis. Rotterdam: AZR; november 1991.

283. Project thuiszorgtechnologie. Technische handelingen thuis. Protocollen voor de patient, mantelzorg. (wijk)verpleegkundigen en (huis)artsen. Utrecht: Academisch Ziekenhuis Utrecht; 1993.

284. K waliteitsInstituut voor Toegepaste ThuisZorgvernieuwing (KITTZ). Serie Thuiszorgprogramma's. Groningen: KITTZ; 1994-1995.

285. Schonk RSM, Beusmans GHMI, Van Dongen JJAM, redactie. Project innovatie thuiszorg voor chronisch zieke ouderen. Logboek Thuiszorg. Maastricht: Rijksuniversiteit Limburg; 1993.

286. Vierhout W. Gezamenlijk consult huisarts-specialist. Medisch Contact 1987;42(4):106-8.

287. Van Hall EV, Gill K, Trimbos JB. Gynaecologische consultaties in de huisartspraktijk. Medisch Contact 1987;42(4): 105-6.

288. Philipsen $\mathrm{H}$. Beweging in de relatie tussen vraag en aanbod in de thuiszorg. In: ATIS werkconferentic; 15 oktober 1977.

289. Tweede Kamer vergaderjaar 1985-1986. Memorie van toelichting op Regeling inzake beroepen op het gebied van de individuele gezondheidszorg (wet op de beroepen in de individuele gezondheidszorg). 'sGravenhage: SDU-uitgeverij/Tweede Kamer, 1986. p. 40-50.

290. Grypdonck M. Van continuiteit van zorg naar zorg voor continurteit. Tijdschrift voor Ziekenverpleging $1989 ; 43(15) ; 487-91$.

291. Derckx EWCC, Smeets PMJH. Het Transmuraal Verpleegkundig Model [discussienota]. Maastricht: Project Infuusbehandeling Thuis; september 1993.

292. Gielis CMP, Heinen MM. Transmurale zorg, een uitkomst in de toekomst.,? [jaarwerkstuk]. Maastricht: Vakgroep Gezondheidswetenschappen doorstroom Verplegingswetenschap Rijksuniversiteit Limburg: 1993.

293. Joosten WBJA. Transmurale zorg: interorganisationele samenwerking tussen ziekenhuis en kruiswerk [jaarwerkstuk]. Maastricht: Rijksuniversiteit Limburg: 1993.

294. Stichting Groene Kruis Heuvelland (SGKH), dienst wijkzorg. Transferverpleegkundige [conceptnotitie] Maastricht: SGKH; 1993.

295. Stichting Amsterdams Kruiswerk (SAK). Transferverpleegkundige. Amsterdam: SAK; 1993.

296. Stichting Amsterdams Kruiswerk (SAK). Het stedelijk instructie-team. Amsterdam: SAK; 1993. 
297. O'Meara R. A contractual relationship between a Visiting Nurse Association and a Hospice. Quality Review Bulletin 1986;(5):172-4.

298. Stichting SAmenwerking eerste en tweede lijn voor REgionale geZOndheidszorg (SAREZO). Integraal zorgmodel dagbehandeling liesbreuk. Beschrijving en evaluatic van een samenwerkingsproject van eerste en tweede lijn. Brunssum: SAREZO; januari 1993. Publikatienummer: 91.313.

299. Bertels M, Schut H. Protocollenproject Nazorg Heupoperatic. [Verslag tussentijdse evaluatie]. Amsterdam: Protocollenproject Amsterdam; januari 1992.

300. Van Dungen L, Dalmeijer JP, Maciean G, Nagelkerke A, F, Luitse G, De Waal FC. Samenwerking na verwijzing -een samenwerkingsprotocol van huisartsen en kinderartsen-. Medisch Contact 1993,48(19): $600-2$.

301. Swemle ME, Hazenberg HJA, Voorhoede A, Vissers JMH. Protocollaire samenwerking huisarts-internist bij diabetespatienten. Medisch Contact 1993;48(27/28):848-9.

302. Steeghs F, Storm T. Het SAREZO project stomazorg. In: Lagro A, Kok JK, Schoolmeesters M, Spreeuwenberg G, redactic. 5 jaar experimenteren met zorgvernieuwing (verzameling voordrachten van het SAREZO symposium 'Beter samen? Samen beterl': 12 maart 1993; Brunssum). Brunssum: SAREZO; 1993.

303. Carsouw E, Van Noordt M, Schrijvers AJP. Thuiszorg in de Verenigde Staten. Tujdschrift voor Maatschappelijke Gezondheidszorg 1991;19(10):26-9.

304. Jowett S, Armitage S. Hospital and community liaison links in nursing: the role of the liaison nurse. Journal of Advanced Nursing 1988;13:579-587.

305. Van Leeuwen FL. Van Rode Kruis Ziekenhuiszorg naar Thuiszorg [projectverslag]. Den Haag: Stichting Aanvullende Thuiszorg Nederland, Rode Kruis Ziekenhuis, Haags Kruiswerk; 1990.

306. Duijn J. Thuiszorg vanuit het ziekenhuis. Kwaliteit in de cerstelijnszorg 1992;4(1):12-13.

307. Thuiszorg, huisartsen en AZU. Centrum voor thuisbeademing. Thuiszorg, huisartsen en AZU. Thuiszorg. huisartsen en AZU: 1992.

308. Wieringa WJ. Transmurale zorgmodellen en projecten. Transmurale zorgmodellen en projecten; 1993

309. Brasker J. Transmuraal verplegen: van wens naar werkelijkheid. Amsterdam: Academisch Ziekenhuis van de Vrije Universiteit (Onderzoekscentrum le-2e lijn); september 1992.

310. Werkgroep 'Implementatie Thuiszorgtechnologie Infuussystemen'. Notulen d.d. 23 maart. Maastricht: Diagnostisch Coordinerend Centrum; 1992.

311. Centraal Bureau Statistiek (CBS). Statistisch Jaarboek 1994. 's-Gravenhage: SDU-uitgeverij/CBSpublikaties; 1995.

312. Van den Akker PAM. Kwaliteit van sterven. De plaats van overlijden. Medisch Contact 1995;50(26): 867-9.

313. Twycross RG, Lack SA. Therapeutics in Terminal Cancer. London: Churchill Livingstone; 1990

314. Hoofdstuk 3: Symptoombehandeling: Meest voorkomende symptomen bij 7.000 terminale kankerpatienten in het St. Christopher's Hospice (1975-1984). In: Out JJ, Klein J, Stouten EM, redactic. Stervensbegeleiding. Weert: Postgrade; 20 oktober 1992.

315. Meyler WJ, Straat JM, Verhagen EH, Van der Lyke SM, Van Miltenburg EM. Parenterale pijnbestrijding thuis bij de patient met kanker. Patient Care april 1992:31-47.

316. Dorrepaal KL. Pijn bij patienten met kanker [proefschrift]. Amsterdam: Vrije Universiteit;1989

317. Incidence of cancer in the Netherlands. Utrecht: SIG Zorginformatie; 1989

318. Vademecum gezondheidsstatistiek Nederland 1992. 's-Gravenhage: SDU-uitgeverij/CBS-publicaties; 1992.

319. Klein Poelhuis EH, Schade E, Stenvers A, redactie. Praktische thuiszorg voor de terminale kankerpatient. UtrechV/Antwerpen: Bohn, Scheltema \& Holkema; 1987.

320. Van der Veen E. Terminale zorg voor alleenwonende ouderen. Behoeften van hulpvragers, kneipunten in de zorg en mogelijkheden voor verbetering. Utrecht: NIZW; december 1995.

321. Van Tits MHL. Terminale zorg in Nederland. Een raming van de toekomstige omvang en kosten. Medisch Contact 1995:50(26):870-3.

322. Munsterman D, Wieringa GJ, Spraaij R. Bruggen bouwen door transmurale zorg. Ontwikkeling van ziekenhuisverplaatste zorg in Nederland II. HZN mei 1993:477-80.

323. Centraal Bureau voor de Statistiek (CBS). Overiedenen naar doodsoorzaak 1991. Voorburg/Heerien: CBS; 1992.

324. Stichting Diagnostisch Coordinerend Centrum (DCC). Jaarverslag 1993. Maastricht: DCC; 1994.

325. Dingemans WA, Groenman NH, Van Kleef M, Krijgsman MJ, Nederlandse Vereniging ter Bestudering van Pijn, redactie. Pijn en pijnbehandeling. Een basaal onderwijscurriculum. Maastricht: Universitaire Pers Maastricht; 1993. 
326. Inventarisatiegesprekken met de specialisten S Bulstra (Orthopaedie), W Dingemans (Pijnbestrijding) en F van den Wildenberg (Algemene Heelkunde) en met de verpleegkundigen A Hameleers (short stay), T van Haastert en H Stevens-Jamaar (dagcentrum).

327. Bohm E. Das Sudecksche Syndrom. Hefte Unfallheilkd 1985;174:245-50.

328. Omer GC, Thomas SM. Treatment of causalgia. Tex Med 1971;67:93-6.

329. De Bruijn HP. Functional Treatment of Colles fractures [dissertation]. Maastricht: Rijksuniversiteit Limburg:1987.

330. Atkins RM, Duckworth T, Kanis JA. Features of algodystrophy after Colles' fracture. J Bone Joint Surg 1990;72:105-10.

331. Goris RJA, Reynen JAM, Veldman PHJM. De klinische verschijnselen bij posttraumatische dystrofie. Ned Tijdschr Geneeskd 1990;134(44):2138-41.

332. Reijnen JAM. Posttraumatische dystrofic. VVAA Themadag traumatologie voor huisartsen; 1992.

333. Goris RJA. Wanneer en in welk stadium zijn vrije radicalen geindiceerd bij posttraumatische dystrofie? Vademecum 1997; 15(45):ongenummerd.

334. Landelijke Medische Registratic van de Stichting Informatievoorziening voor de Gezondheidszorg (SIG). Ontslagen ziekenhuispatienten. Gepoolde gegevens 1991+1993.

335. Stichting Informatievoorziening voor de Gezondheidszorg (SIG). Databestand SIG Zorginformatie; 1995.

336. Centraal Bureau voor de Statistiek(CBS). Statistisch Jaarboek 1995. Heerlen/Voorburg: CBS; 1995.

337. Inventarisatiegesprekken d.d. 30 oktober 1992 en later met W Mulder van de werkgroep algemene interne geneeskunde Vakgroep Interne Geneeskunde azM.

338. Inventarisatiegesprek d.d. 19 november 1992 met R Kuijten (hoogleraar) en G Vos (kinderintensivist) van de Vakgroep Kindergeneeskunde azM.

339. Inventarisatiegesprekken d.d. 10 december 1992 en later met H Hendriks (kinderpulmonoloog) van de Vakgroep Kindergeneeskunde azM.

340. Hendriks JJE. Protocollen Kindergeneeskunde. Hoofdstuk Pulmonologie. Onderwerp Cystic Fibrosis. Maastricht: Academisch Medisch Centrum; 28 februari 1991.

341. Van Aalderen WMC, Mannes GPM, Van Bommel G, Voorthuis I, Bosma E, Heymans HSA. Continue intraveneuze thuisbehandeling met antibiotica van luchtweginfecties bij 11 patienten met cystische fibrose in Noord-Nederland. Ned Tijdschr Geneeskd 1993;137(48):2482-6.

342. Winter RJD, George RDD, Dealock SJ, Shee CD. Self-administered home intravenous antibiotic therapy in bronchiectasis and adult cystic fibrosis. The Lancet June 1984:1138-9.

343. Nederlandse Cystic Fibrosis Stichting, redactie. Thuisbehandeling en psycho-sociale hulpveriening bij CF. Baarn, juni 1991. Verslag van de gelijknamige studiedag; november 1; Bunnik: NCFS; 1990.

344. Bakker W, Vinks AATMM, Mouton JW, De Jonge P, Verzijl JG, Heijerman HGM. Continue intraveneuze thuisbehandeling van luchtweginfecties met ceftazidim via cen draagbare pomp bij patięnten met cystische fibrose; een multicentrisch onderzoek. Ned Tijdschr Geneeskd 1993;137(48):2486-91.

345. Verhoeven L, Box J, Van de Weg L. Thuisbehandeling by cystic fibrosis. Transmurale zorgmodellen en projecten [symposiumverslag]; december 1993.

346. Van de Weg L, Box J, Verhoeven L. Thuiszorg voor cystic fibrosis patienten. De praktijk. Informatie over het thuiszorgproject-CF. Utrecht: Wilhelmina Kinderziekenhuis Utrecht; \pm 1990.

347. Van Thiel E. Vier dagen of drie weken in het ziekenhuis ... dat is wel even een verschil [interview met A. de Vries]. Tijdschrift voor Maatschappelijke Gezondheidszorg 1992;20(3):20-2.

348. Van Thiel $\mathrm{E}$. Thuisbehandeling van cystic fibrosis patienten maakt 'normaler' leven mogelijk. Tijdschrift voor Maatschappelijke Gezondheidszorg 1992;20(3):18-9.

349. American Thoracic Society. Standards for the diagnosis and care of patients with chronic obstructive pulmonary disease (COPD) and astma. American Review Respiratory Disease 1987; 136:225-44.

350. Stuurgroep Toekomstscenario's Gezondheidszorg. Chronische ziekten in het jaar 2005. Deel 2: Scenario's over CARA 1990-2005. Houten/Antwerpen: Bohn Stafleu van Loghum; 1990.

351. Ruwaard D, Gijsen R, Verkley H. Chronisch aspicifieke Respiratoire aandoeningen (CARA). In: Ruwaard D, Kramers PGN, redactic. Volksgezondheid Toekomst verkenning. De gezondheidstoestand van de Nederlandse bevolking in de periode 1950-2010. Den Haag: SDU-Uitgeverij; 1993.

352. Weel C, Schayck CP. Epidemiologie van COPD. Opsporing en vervolgcontroles. Tijdschrift voor Huisartsgeneeskunde 1996;13(5):225-9.

353. Landelijke Medische Registratie van de Stichting Informatievoorziening voor de Gezondheidszorg (SIG). Jaarboek Ziekenhuizen. Utrecht: SIG; 1990.

354. Inventarisatiegesprekken d.d. 9 december 1992 en later met $\mathrm{G}$ Ten Velde van de Vakgroep Longziekten azM.

355. Murata GH, Gorby MS, Chick TW, Halperin AK. Aminophylline in the Outpatient Management of Decompensated Chronic Obstructive pulmonary Disease. Chest 1990;98(6): 1346-50. 
356. Emerman CL, Effron D, Lukens TW. Spirometric Criteria for Hospital Admission of Patients with Acute Exacerbation of COPD. Chest 1991;99(3):595-9.

357. Schols AMWJ. Ondervoeding bij chronische obstructieve longziekten. Deel I. Prevalentie en consequenties. Schols AMWJ en Weling-Scheepers CAPM. Ondervoeding bij chronische obstructieve longziekten. Deel 2. Oorzaken en therapeutische implicaties. Nederlands Tujdschrift voor Dietisten 1992:47(3):50-6.

358. Koopman MMW. Stollingwerende behandeling bij diepe, veneuze trombose. Tijdschrift voor Huisartsgeneeskunde 10(10):689-91.

359. Brandjes DPM, Heijboer H, Baller HR, De Rijk M, Jagt H, Ten Cate JW. Acenocoumarol and heparin compared with acenocoumarol alone in the initial treatment of proximal-vein trombosis. New Engl J Med 1992;327(21):1485-9.

360. Hull RD, Raskob GE, Rosenbloom D, Panju AA, Brill-Edwards P, Ginsberg JS. Heparin for five days as compred with ten days in the intial treatment of proximal venous thrombosis. N Engl J Med 1990:322(18): 1260-4.

361. Merrigan DM, Enriquez NC, Akahoshi MP. Continuous Heparin Infusion in the Home-bound Ambulatory Patient Using the Travenol Infusor. A Descriptive Report. NITA March/April 1987;10:122-6.

362. Homza SA. Continuous Home heparin Infusion Therapy in the Ambulatory Patient. Joumal of Intravenous Nursing 1991;14(1):37-40.

363. Callister CB, Wood SD, White GL, Tucker ED. Home Treatment of Calf Deep Venous Thrombosis. The Western Journal of Medicine 1991;155(3):299-300.

364. Mosterd A. Epidemiologie. Hart Bulletin december 1994;25:267-71

365. Van Ree JW. Concept onderzoeksproject hartfalen. Maastricht: Rijksuniversiteit Limburg: 1994.

366. Slegers LC. Vroege diagnostiek van hartfalen. Tijdschrift voor Huisartsgeneeskunde 1993;10(12:bijlage):8-11.

367. Bar FWHM, Cheriex EC. Differentiele diagnostiek bij decompensatio cordis. Tijdschrift voor Huisartsgeneeskunde 1993;10(12:bijlage): 12-9.

368. Inventarisatiegesprekken d.d. 22 en 26 oktober 1992 en later met $T$ Kho van de werkgroep algemene interne geneeskunde Vakgroep Interne Geneeskunde azM.

369. Vakgroep Interne Geneeskunde. Jaarverslag 1993. Maastricht: academisch ziekenhuis Maastricht; 1994. p. 10,22 .

370. Afdeling Interne Geneeskunde academisch ziekenhuis Maastricht. Protocol thuisbehandeling ganciclovir (DHPG) intraveneus via een poortsysteem met behulp van de Intermate *. Maastricht: azM; juli 1992.

371. Van den Broek PJ, Van Weert NJHW, Haerkens HMJ, redactic. Medische Apparatuur Thuis. Thuisbehandeling met intraveneuze antimicrobiele middelen. Nijmegen: Instituut voor Toegepaste Sociale wetenschappen; 1995.

372. Integraal Kankercentrum Oost. Richtlijn cytostatica. Nijmegen: IKO; 1992.

373. Stichting AIDS fonds. AlDSbestrijding april 1997;(32):12.

374. Nationale Commissie AIDS-Bestrijding. Het AIDS-beleid geactualiseerd. Amsterdam: Eindadvies van de Nationale Commissie Aids-Bestrijding; september 1995. p 13.

375. Meijman F. Eleven years of experience with HIV infections in a general practice in Amsterdam. European J of General Practice 1995;1(2):53-8.

376. Groen J. Aids in Limburg is geen ver-van-mijn-bedshow [interview met J Schippers]. De Limburger [krant] 6 oktober 1995.

377. Knoben S. Nieuwe effectievere medicijnen vormen lichtpuntje voor Aidspatienten. Traject [informatiebulletin azM] 1994;9(11):2-3.

378. Twaalf procent van spuitende junks in Zuid-Limburg heeft hiv. De Limburger [krant] 18 september 1997: p. 7.

379. Payne SA. A study of quality of life in cancer patients receiving palliative chemotherapy. Soc Sci Med 1992:35(12):1505-9.

380. Greidanus J. Continuous infusion of doxorubicin, epirubicin and mitoxantrone in cancer chemotherapy [dissertation]. Groningen: Rijksuniversiteit Groningen;1988.

381. Vries EGE, Greidanus J, Ooosterhuis BE, De Langen ZJ, Willemse PHB. Thuisbehandeling van patienten met cytostatica. Ned Tijdschr Geneeskd 1990,134(8):377-9. Reacties in Ned Tijdschr Geneeskd 1990:134(18):924.

382. Poorter RL. Continuous infusion of chemotherapy [dissertation]. Amsterdam: Universiteit van Amsterdam;1996.

383. Witteveen PO, Van Boxtel AJH, Nieuwland M, Neijt JP, Blijham GJ. Haalbaarheid van overbrenging van medisch-technische hulp naar de thuissituatie voor patienten met kanker of een emstige infectic. Ned Tijdschr Geneeskd 1995;139(15):788-91 . 
384. Bijeenkomst d.d. 21 januari 1993 te Amsterdam en d.d 28 oktober 1993 te Utrecht in het kader van het WVC Stimuleringsprogramma Thuiszorgtechnologie.

385. Vakgroep Interne Geneeskunde. Jaarverslag 1991. Maastricht: academisch ziekenhuis Maastricht; 1992.

386. Inventarisatiegesprek d.d. 16 november 1992 met $\mathrm{R}$ Jansen van de werkgroep haematologie/oncologie Vakgroep Interne Geneeskunde azM.

387. Werkhorst J. Organisatie van voeding per sonde thuis. Nederlands Tijschrift voor Dietisten $1990 ; 45(10): 218-23$.

388. Wipkink-Bakker A. Sondevoeding thuis. The Practitioner 1992;9(2):90-2.

389. Baart S. Ondervoeding bedreigt patient in het ziekenhuis. Volkskrant 13 september 1997.

390. Sauerwein HP. Indicaties voor parenterale voeding in de inwendige geneeskunde. In: Parenterale en enterale voeding in de praktijk [symposiumverslag]; 21 februari 1981; Rotterdam. Rotterdam: TGO juli 1981;6(speciale uitgave); 1981:9-11.

391. Naber AHJ. Indicaties voor parenterale voeding in de thuissituatie. In: Parenterale voeding in het ziekenhuis en thuis: terugkijken en vooruitzien [symposiumverslag]; 31 maart 1995; Nijmegen. Nijmegen: Katholieke Universiteit Nijmegen; 1995: 11-8.

392. Klasen $\mathrm{H}$. Indicaties voor parenterale voeding in de algemene heelkunde. In: Parenterale en enterale voeding in de praktijk [symposiumverslag]; 21 februari 1981; Rotterdam. Rotterdam: TGO juli 1981;6(speciale uitgave); 1981: 13-5.

393. Krause R. Parenterale voeding in de oncologie. In: Parenterale en enterale voeding in de praktijk [symposiumverslag]; 21 februari 1981; Rotterdam. Rotterdam: TGO juli 1981;6(speciale uitgave); 1981: 21-7.

394. Von Meijenfeldt MF. TPV in de oncologie. Parenterale voeding in de praktijk [symposiumverslag]; 1987.

395. Bijleveld CMA. Indicaties voor parenterale voeding in de pediatrische praktijk. In: Parenterale en enterale voeding in de praktijk [symposiumverslag]: 21 februari 1981; Rotterdam. Rotterdam: TGO juli 1981;6(speciale uitgave); 1981: 17-20.

396. Sinaasappel M. TPV berekening in de kindergeneeskunde. Parenterale voeding in de praktijk [symposiumverslag]; 1987.

397. Verbroekken P. Procesbewaking bij kunstmatige voeding door middel van een voedingsteam. In: Parenterale voeding in het ziekenhuis en thuis: terugkijken en vooruitzien [symposiumverslag]; 31 maart 1995; Nijmegen. Nijmegen: Katholieke Universiteit Nijmegen; 1995: 53-8.

398. Bergmeijer JHLJ. Eerste ervaring met parenteraal thuisvoeden van een kind. Parenterale voeding in de praktijk [symposiumverslag]; 1987.

399. Naber AHJ. Resultaten van centraalveneuze catheters en shunts bij patienten met parenterale voeding in de thuissituatie. In: Parenterale voeding in het ziekenhuis en thuis: terugkijken en vooruitzien [symposiumverslag]; 31 maart 1995; Nijmegen. Nijmegen: Katholieke Universiteit Nijmegen; 1995: 38-42.

400. Steenvoorden-Schouten L, Naber AHJ. Wat moet een huisarts weten over parenterale voeding in de thuissituatic? Vademecum permanente nascholing voor huisartsen mei 1995;13(18a):ongenummerd.

401. Sauerwein HP. Persoonlijke mededeling tijdens het congres Parenterale voeding in het ziekenhuis en thuis: terugkijken en vooruitzien; 31 maart 1995; Nijmegen.

402. Smith CE, Giefer CK, Bieker L. Technological Dependency: A Preliminary Model and Pilot of Home Total Parenteral Nutrition. Journal of Community Health Nursing 1991;8(4):245-54.

403. Medische administratie academisch ziekenhuis Maastricht . Databestand 1993.

404. Medische administratic academisch ziekenhuis Maastricht. Databestanden 1994+1995.

405. Wesseling GJ. Behandeling van COPD in historisch perspectief. Tijdschrift voor Huisartsgeneeskunde 1996;13(3):100-7.

406. Wisman T. Vochtinhalatie en het vernevelen van medicamenten. Techniek in de Gezondheidszorg maart $1993 ;(3): 25-7$.

407. Lammers JJ. Inhalatietherapie bij astma en COPD. Tijdschrift voor Huisartsgeneeskunde 1993;10(6): 437-40.

408. Meulepas M. Thuiszorg voor mensen met ernstig longemfyseem. Tijdschrift voor Huisartsgeneeskunde 1995;12(5):441-4.

409. Leizorovicz A, Simonneau G, Decousus H, Poissel JP. Comparison of efficacy and safety of low molecular weight heparins and unfractionated heparin in the initial treatment of deep venous thrombosis: a metaanalysis. British Medical Journal 1994;309:299-304.

410. Lensing AWA, Prins MH, Davidson BL, Hirsh J. Treatment of Deep Venous Thrombosis With LowMolecular-Weight Heparins. A Meta-analysis. Arch Intern Med 1995;(155):601-7.

411. Siragusa S, Cosmi B, Piovella F, Hirsh J, Ginsberg JS. Low-Molecular-Weight Heparins and Unfractionated Heparin in the Treatment of Patients With Acute Venous Thromboembolism: Results of a Meta-Analysis. The American Journal of Medicine 1996;(100):269-77. 
412. Girolami A. Home Treatment Versus Early Discharge From the Hospital: A Dilemma in the Management of Proximal Vein Thrombosis With Low Molecular Weight Heparins [invited editorial]. Clin Appl Thrombosis/Hemostasis 1997;3(1):66-8.

413. Levine M, Gent M, Hirsh J, Leclereq J, Anderson D, Weitz J. A comparison of low-molecular-weight heparin administered primarily at home with unfractionated heparin administered in the hospital for proximal deep-vein thrombosis. N Engl J Med 1996;334(11):677-81.

414. Koopman MMW, Prandoni P, Piovella F, Ockelford PA, Brandjes DPM, Van der Meer J, et al. Treatment of venous thrombosis with intravenous unfractionated heparin administered in the hospital as compared with subcutaneous low-molecular-weight heparin administered at home. N Engl J Med 1996;334(11): 682-7.

415. Vakgroep Interne Geneeskunde. Jaarverslag 1996. Maastricht: academisch ziekenhuis Maastricht; 1997. p. 41.

416. AJ Beysens, eindredactic. Inpharmatie [bulletin van apotheek en Geneesmiddelencommissie azM] 1997:(2):6-7.

417. Centrale Medische Pharmaceutische Commissie Ziekenfondsraad. Farmacotherapeutisch Kompas 1997. Amstelveen: Ziekenfondsraad; november 1996.

418. Engelsman C, Suurmeijer TPBM, Riewald M. Poliklinische chemotherapie en continuiteit in de zorg. Huisarts en Wetenschap 1989;32(4):103-3.

419. Inventarisatiegesprek d.d. 31 januari 1995 met T. van Haaster, 1. van Lingen, A. Meertens (oncologieverpleegkundigen dagcentrum azM).

420. Cawiey MM. Recent Advances in Chemotherapy. Administration and Nursing Implications. Nursing Clinics of North America 1990:25(2):377-91.

421. Mor V, Allen SM, Siegel K, Houts P. Determinants of Need and Unmet Need among Cancer Patients Residing at Home. Health Services Research 1992;27(3):337-60.

422. Ketelaars C, Ten Dam G. Basiszorg, Differentiaties en Verpleegkundig specialisten [nota], Maastricht: Stichting Groene Kruis Heuvelland; 1992.

423. KwaliteitsInstituut voor Toegepaste ThuisZorgvernieuwing (KITTZ). Eindrapportage Project 'Chemotherapie Thuis'. Groningen: KITTZ; november 1995.

424. Boesten NCMG, Huijsman R, Schram HCF. Evaluatie van het project in Gorinchem 'Van ziekenhuiszorg naar thuiszorg'. Gorinchem: Beatrixziekenhuis; januari 1994.

425. Meijer C. Helft 85-plussers woont nog zelfstandig. Zorgbehoefte in vier jaar nauwelijks veranderd. Ziekenhuis \& Instelling 1996;(maart):25-7.

426. Smeets PMJH, Warndorff DK, Beusmans GHMI. 'Infuusbehandeling Thuis': Ervaringen met de toepassing van medische technologie. Medisch Contact 1993;48(29/30):905-7.

427. Stichting Diagnostisch Coordinerend Centrum (DCC). Jaarverslag 1994. Maastricht: DCC; 1995.

428. Beusmans GHMI. Huisarts en Diagnostisch Centrum. Toepassing van werkafspraken door huisartsen [proefschrift]. Maastricht: Rijksuniversiteit Limburg; 1986.

429. Crebolder HFJM, Stevens FCJ. De eerste lijn in Limburg. Nu en straks [lustrumboek]. Maastricht: Rijksuniversiteit Limburg: 1992.

430. Winkens RAG. Improving test ordening in general practice [dissertation]. Maastricht: Rijksuniversiteit Limburg; 1994.

431. Thijssen-van den Thillart WMFM, Crebolder HFJM. Epidurale en spinale pijnbestrijding. Samenwerking tussen eerste en tweede lijn. Medisch Contact 1992;47(44):1288-90.

432. Stichting Groene Kruis Heuvelland (SGKH), dienst wijkzorg. Basiszorg, differentiatie, specialisatie. Maastricht: SGKH; 1992.

433. Stichting Groene Kruis Heuvelland (SGKH), dienst wijkzorg. Medisch technisch handelen voor verpleegkundig beroepsoefenaars in de thuissituatie. Maastricht: SGKH; 1992.

434. Kobus MH, Carlier JM. Over het ontwikkelen en invoeren van multi-disciplinaire protocollen. Utrecht: NZR-consult; 1990.

435. Berg M. Problemen en potenties van het protocol. De voorwaarden om protocollen positief in te zetten. Medisch Contact 1996;51(11):366-70.

436. Marijnen E. Zorgmodel voor mensen met een heupfractuur. Een nieuwe benadering van protocolvorlming. Medisch Contact 1992;47(24):762-4.

437. Godfroij AJA. Netwerken van organisaties: strategieen, spelen, structuren. 's-Gravenhage: VUGA uitgeverij; 1981.

438. Breedveld $T$. Interpedentic als factor bij samenwerking tussen organisaties. in: De Greve WB, Vrakking WJ, redactic. Strategie van samenwerking tussen organisaties in welzijns- en gezondheidswerk. Lochem: De Tijdstroom; 1980. 
439. Van Zutphen H, Smeets PMJH. Infuusbehandeling Thuis; Van Project naar Reguliere Zorg. In: Handboek Thuiszorg. Utrecht: Elsevier/De Tijdstroom; 1996. p. B9.2-1 t/m B9.2-8.

440. Nationale Raad voor de Volksgezondheid (NRV). Discussienota Begrippenkader Kwaliteit van de beroepsuitoefening. Rijswijk: NRV; 1986.

441. Raad voor Gezondheidsonderzoek (RGO). Advies Kwaliteit van zorg. Terreinverkenning en prioriteiten voor wetenschappelijk onderzoek. 's-Gravenhage: RGO; 1990. Publikatienummer: 6.

442. Nederlandse organisatie voor Wetenschappelijk Onderzoek (NWO), gebied medische wetenschappen. Onderzoeksprogramma Kwaliteit van Zorg 1992-1996. Den Haag: NWO; 1992.

443. Brief van de gebruikersraad Medisch Administratie van het academisch medisch ziekenhuis Maastricht aan de artsen en arts-assistenten betreffende het nalaten van of onvolledig berichtgeven bij ontslag d.d. 13 februari 1995. Kenmerk: PP/SP95.016.

444. Van Weerden AB. Protocollen voor ouderenzorg in de eerste lijn. Medisch Contact 1991;46(29/30):883-6.

445. Van Harten WH, Peters B, Reker HAJ. 'Managed care' en zorgyernieuwing. Total hip'-project Hengelo. Medisch Contact 1993;48(5):140-2.

446. Verheggen FWSM. Myth and reality of informed consent and the patient's choice to participate in clinical trails [dissertation]. Maastricht: Universitaire Pers Maastricht;1996.

447. Project innovatie thuiszorg voor chronisch zieke ouderen. Logboek Thuiszorg. Maastricht: Vakgroep Huisartsgeneeskunde Rijksuniversiteit Limburg; 1993.

448. Paramedische Dienst academisch ziekenhuis Maastricht. Protocol injecteren. Maastricht: azM; 1991 .

449. Nationale Kruisvereniging (NK) en Landelijke Huisartsen Vereniging (LHV). Geprotocolleerde werkinstructies medisch handelen door verplecgkundig beroepsbeoefenaars in de thuissituatie (deel II). Bunnik: NK/LHV; 1990.

450. Swanborn PG. Methoden van sociaal-wetenschappelijk onderzoek, inleiding in ontwerpstrategieên. $3 \mathrm{e}$ ed. Amsterdam/Meppel: Boom; 1984.

451. Samenwerkingsverband Transmurale Zorg. Notulen d.d. 14 december. Maastricht: academisch ziekenhuis Maastricht; 1993.

452. Rogers N. Pharmacist consult. Preparing your patient for home infusion. Nursing October 1995:28.

453. Reenders K. Wat beklijft en waarom ... Tijdschrift voor Huisartsgeneeskunde 1994;11(1):45-6.

454. Fizaan MHHM. Nascholing maken moet leuk zijn. Tijdschrift voor Huisartsgeneeskunde 1994;11(1):23-4.

455. Bureau Ondersteuning Huisartsen Heuvelland. Inventarisatie behoefte aan nascholing met betrekking tot medisch technisch handelen in de thuissituatic. Maastricht: BOHH; 1992. Kenmerk: BOHH/JB/iv 92.072.

456. Van Leer JVM. Hoe vindt de huisarts de weg in de wirwar van nascholing? Tijdschrift voor Huisartsgeneeskunde 1994;11(1):33-4.

457. Bloemer J, Poiesz TBC. Nascholingsbehoeften en -wensen bij de Nederlandse huisarts. Verslag van een consumentenonderzoek. Tilburg: Katholieke Universiteit Brabant; september 1987.

458. Jansen JJM, Metz JCM, Coumans RHM, Grol RPTM, redactie. Vaardigheidscursus voor Huisartsen: Infuustoepassingen voor de huisarts; 28 april 1993; Nijmegen: Werkgroep Onderzoek Kwaliteit Huisartsgeneeskunde; 1993.

459. Jansen $K$. Toetsing van technische vaardigheden van huisartsen [proefschrift]. Maastricht: Universiteit Maastricht;1998. p. 122.

460. Van de Esker FMB. Medisch handelen vraagt om gespecialiseerde bijscholing. Opzet en werkwijze van de Stichting Skillslab. Tijdschrift voor Maatschappelijke Gezondheidszorg 1990;18(10):46-8.

461. Bos W. De hogeschool wacht bij de achterdeur. De moeizame kruisbestuiving tussen het HBO en de universiteit. Observant [universiteitsblad Universiteit Maastricht] 1 april 1993: p. 8-9.

462. Delnoy DMJ. Evaluatie structuur voor deskundigheidsbevordering en ondersteuning van huisartsen [eindrapport]. Utrecht: NIVEL; januari 1990: p 160.

463. Derckx EWCC, Smeets PMJH (project Infuusbehandeling Thuis), Balg EJHP, Dautzenberg GHCJ, Florack DPM, Van de Eynden RCM (Dienst opleidingen azM). Cursusboek Project Infusie Thuis: De Transmuraal Verpleegkundige. Maastricht: Do-azM/TT; september 1993.

464. Van Dongen AWM, Zuidweg J (Werkgroep Deskundigheidsbevordering Huisartsen), Dautzenberg GHCJ (Dienst Opleidingen azM), Smeets PMJH (project Infuusbehandeling Thuis), redactie. Klinische agora: Thuiszorg I, Infuusbehandeling en Pijnbestrijding Thuis [nascholing]; 5 oktober 1993 en 9 februari 1994; Maastricht: WDH/azM/TT; 1993.

465. Ooms FEM. Nascholing wordt scholing. Tijdschrift voor Huisartsgeneeskunde 1994;11(1):37.

466. Hollander JM. Jacobsladder. Tijdschrift voor Huisartsgeneeskunde 1994;11(1):28-30.

467. Vaessen J. Meten is weten. De observatiescoringslijst als hulpmiddel bij intercollegiale toetsing. Nursing juli 1995:53-5.

468. Beraadsgroep Geneeskunde van de Gezondheidsraad. Medisch handelen op een tweesprong. Den Haag: Gezondheidsraad; december 1991: p 41. Publikatienummer: 1991/23. 
469. Stoelinga GBA. Postacademisch onderwijs geneeskunde. Ned Tijdschr Geneeskd 1993;137(33):1675-8.

470. Jansen JJM, Grol RPTM, Rethans JJ. Toetsing van Technische Vaardigheden van Huisartsen [eindrapportage]. Nijmegen/Maastricht: Katholieke Universteit Nijmegen/Rijksuniversteit Limburg: 1995.

471. Van Leeuwen R, De Bock GH, Wensveen CAH. Huisarts en thuiszorg. Effectanalyse nascholingscursus. Medisch Contact 1994;49(40):1251-2.

472. Visser J. Techniek helpt als ook de patient ermee kan werken. Tijdschrift voor Maatschappelijke Gezondheidszorg 1995;23(6):17.9.

473. Van Beeien A. Steeds meer technische zorg thuis. Verpleegkundig instructieteam bij Kruiswerk Amsterdam. Verpleegkunde Nieuws november 1995:36-7.

474. Ziekenfondsraad. Regeling subsidiering Ziekenfondsraad intensieve thuiszorg 1994 e.v. Amstelveen: Ziekenfondsraad; 1994 e.v.

475. Visch $P$. Thuiszorg: geintegreerde zorg en techniek aan huis. Technologie versterkt kwaliteit en substitutic. Medisch Contact 1983;48(20):613-4.

476. Project Infuusbehandeling Thuis (IT). Notulen d.d. 24 juli en 5 augustus. Maastricht: IT: 1992.

477. Lanning RM, Hrushesky WJM. Outpatient time-specified infusion of fluorpyrimidines by implanted pump is less costly than flat delivery by external pump. Progress in clinical and biological research 1990;(341 part B):397-409.

478. Stuurgroepvergadering Diagnostisch Coordinerend Centrum (DCC). Notulen d.d. 7 juli. Maastricht: DCC 1992.

479. Project Infuusbehandeling Thuis (IT). Notulen d.d. 14 en 30 september. Maastricht: IT; 1992.

480. Boudewijn JWT. Thuiszorg in (bedrijfs)economisch perspectief. Flexibele budgetfinanciering als beheersinstrument in de collectieve sector, de thuiszorg als testcase [proefschrift] Amsterdam: Universiteit van Amsterdam;1993, p. 19-25.

481. Roex AJM, Sindram JW. Outputpricing en producttypering. Een nieuwe externe bekostigingsstructuur voor ziekenhuizen en specialisten plus betere patientenzorg. Medisch Contact 1996;25(51):847-50.

482. Schade E, Dokter HACh. Thuiszorg: tussen idee en werkelijkheid. Ned Tijdschr Geneeskd 1995:139(47):2444-8.

483. Poulussen VAC. Zorgprotocollen als onderdelen van een kwaliteitssysteem. Kwaliteit \& Zorg 1997;(2): 94-6.

484. Felix-Schollaart B, Berden HJM, Beusmans GHMI, Beijaert RPH. Bijblijven 1993:12(2):47-52.

485. Stichting Groene Kruis Heuvelland (SGKH). Rapportageformulier WAS"92 [instructicbockje], Maastricht: SGKH; februari 1994.

486. Van Aarnhem AMS, Slee PHTJ. Huisarts en kankerpatient. Utrecht: Wetenschappelijke uitgeverij Bunge; 1992.

487. Drexel H, Dzien A, Spiegel RW, Lang AH, Breier C, Abbrederis K. Treatment of severe cancer pain by low-dose continuous subcutaneous morphine. Pain 1989;(36):169-76.

488. World Health Organisation. Cancer Pain Relief. Geneva: WHO; 1986.

489. Hogan Q. Epidural opiates and local anaesthetics for the management of cancer pain. Pain 1991:271-9.

490. Dorrepaal KL, Aaronson NK, Van Dam FSAM. Pain Experience and Pain Management Among Hospitalized Cancer Patients. A Clinical Study. Cancer 1989;63(3):593-8.

491. Ventafridda V, Tamburini M, Caraceni A, De Conno F, Naldi F. A Validation Study of the WHO Method for Cancer Pain Relief. Cancer 1987;59(4):850-6.

492. Takeda F. Results of field-testing in Japan of the WHO Draft Interim Guidelines on Relief of Cancer Pain The Pain Clinic 1986;1(2):83-9.

493. Wagemans MFM, Spoelder EM, Zuurmond WWA, De Lange JJ. Continue intrathecale pijnbestrijding bij terminale kankerpatienten in de transmurale zorg. Ned Tijdschr Geneeskd 1993;137(31):1553-7.

494. Ventafridda V. Spoldi E, Caraceni A, Tamburini M, De Conno F. The importance of continuous subcutaneous morphine administration for cancer pain control. The Pain Clinic 1986;1(1) 47-55.

495. Moulin DE, Johnson NG, Murray-parsons N, Geoghegan MF, Goodwin VA, Chester MA Subcutaneous narcotic infusions for cancer pain: treatment outcome and guidelines for use. Can Med Assoc J 1992; 146(6):891-7.

496. Drummond MF, Brien BO, Stoddart GL. Torrance GW. Methods for the Economic Evaluation of Health Care Programmes. 2nd ed. New York/Toronto: Oxford University Press; 1997.

497. Melzack R. The tragedy of Needless Pain. Medicine February 1990:45-51.

498. Zylicz Z, Twycross RG. Oral opioids in the treatment of cancer pain [review]. Neth J Med 1991;(38): 10814.

499. Coyle N, Mauskop A, Maggard J, Foley KM. Continuous Subcutaneous Infusions of Opiates in Cancer Patients with Pain. Oncology Nursing Forum 1986;13(4):53-7. 
500. Moulin DE, Kreeft JH, Murray-Parsons N, Bouquillon AL. Comparison of continuous subcutaneous and intravenous hydromorphone infusions for the management of cancer pain. The Lancet 1991;337:465-8.

501. Bruera E, Brenneis.C, Michaud M, MacMillan K, Hanson J, MacDonald RN. Patient-controlled Subcutaneous Hydromorphine Versus Continuous Subcutaneous Infusion for the Treatment of Cancer Pain. J Natl Cancer Inst 1988;80(14):1152-4.

502. Catherine $\mathrm{F}$, Musgrave $\mathrm{RN}$. Terminal dehydration. To give or not to give intravenous fluids? Cancer Nursing 1990;13(1):62-6.

503. Bruera E, Brenneis C, Michaud M, Bacovsky R, Chadwick S, Emeno A. Use of the Subcutaneous Route for the Administration of Narcotics in Patients With Cancer Pain. Cancer 1988;(62):407-11.

504. Swanson G, Smith J, Bulich R, New P, Shiffman R. Patient-Controlled Analgesia for Chronic Cancer Pain in the Ambulatory Setting: A Report of 117 Patients. J Clin Oncol 1989;7(12):1903-8.

505. Ventafridda V, Ripamonti C, Caraceni A, Spoldi E, Messina L, De Conno F. The managament of inoperable gastrointestinal obstruction in terminal cancer patients. Tumori 1990;(76):389-93.

506. Hutchinson HT, Leedham GD, Knight AM. Continuous subcutaneous analgesics and antiemetics in domiciliary terminal care. The Lancet December 1981:1279.

507. Poniatowski BC. Continuous Subcutaneous Infusions for Pain Control. Journal of Intravenous Nursing 1991:14(1):30-5 .

508. Pearson ML, The Hospital Infection Control Practices Advisory Committe. Guideline for Prevention of Intravascular-Device-Related Infections. Infect Control Hosp Epidemiol 1996;17(7):438-73.

509. Shaw HL. Treatment of the Patient with Cancer Using Parenteral Electronic Drug Administration. Cancer August 1992;70(4 Suppl):993-7.

510. Kerr IG, Sone M, DeAngelis C, Iscoe N, MacKenzie R, Schueller T. Continuous Narcotic Infusion with Patient-Controlled analgesia for Chronic Cancer Pain in Outpatients. Annals of Internal Medicine 1988:108(4):554-7.

511. Courtens AM. Kenmerken van zorg en kwaliteit van leven bij patienten met kanker [proefschrift]. Maastricht: Rijksuniversiteit Limburg:1993.

512. Ferris FD, Wodinski HB, Kerr IG, Sone M, Hume S, Coons C. A cost-minimization study of cancer patients requiring a narcotic infusion in hospital and at home. Journal of Clinical Epidemiology 1991;44(3):313-27.

513. Meyler WJ. Richtlijnen voor pijnbestrijding bij kanker. In: Crul BJP, Maas SAEL, redactie. Thuis zonder pijn [symposiumverslag]; 14 februari 1992; Schiedam. Schiedam: Abbott; februari 1992: 9-11.

514. Straat JM. De huisarts heeft een coordinerende taak in de pijnbestrijding thuis. In: Crul BJP, Maas SAEL, redactic. Thuis zonder pijn [symposiumverslag]; 14 februari 1992; Schiedam. Schiedam: Abbott; februari 1992: 29-30.

515. Schulkes-van de Pol J. Pijnbestrijding bij de patient met kanker. Groningen: Nederlandse Vereniging ter Bestudering van Pijn; 1990.

516. Zylicz. Artikel over fentanylpleister in NTVG 1998.

517. Schramejier F, Brunneberg W. Psychosociale zorg bij kanker. Patienten en hulpverleners over problemen en hulpaanbod. Utrecht: Nederlands Centrum Geestelijke Volksgezondheid; 1992.

518. Emancipatieraad. Advies vrouwenmantel en mannetrouw in de thuiszorg. Den Haag: Emancipatieraad; april 1993. Adviesnummer: III/42/93.

519. Wensing M, Grol R, Smits A. Patientenoordelen over kwaliteit van huisartsenzorg. Nijmegen: Wetenschapswinkel Nijmegen in samenwerking met de Werkgroep Onderzoek Kwaliteit Huisartsgeneeskunde. Katholieke Universiteit Nijmegen en Rijksuniversiteit Limburg; september 1991.

520. Harteloh PPM, Casparie AF, Kwaliteit van zorg. Van een zorginhoudelijke benadering naar een bedrijfskundige aanpak. 3e herziene ed. Utrecht: De Tijdstroom; 1994.

521. Den Boer DJ, Bouwman $\mathrm{H}$, redactic. Methodologie en statistiek voor communicatie onderzoek. Houten/Zaventem: Bohn Stafleu van Loghum; 1994.

522. Wensing MUP. Patients evaluate general practice [dissertation]. Maastricht: Maasticht University;1997.

523. Emanuel Es, Emanuel LL. The Economics of Dying. The Illusion of Cost Savings at the End of Life. N Eng J Med 1994;330(8):540-4.

524. Van Bilsen PMA. Spinale pijnbestrijding thuis. De rol van de wijkverpleging in Amsterdam. Tijdschrift voor Maatschappelijke Gezondheidszorg 1994;22(9):24-6.

525. Stichting Groene Kruis Heuvelland (SGKH). Beleidsplan 2000. Informatief [Personeelsmagazine SGKH] $1997 ; 9(4): 1-4$.

526. Franke AL, Persoon A, Temmink D, Kerkstra A. Palliatieve zorg in Nederland. Een inventarisatiestudie naar palliatieve zorg, deskundigheidsbevordering en zorg voor zorgenden. Utrecht: NIVEL; juli 1997.

527. Merskey H, Bogduk N. Classification of chronic pain: descriptions of chronic pain syndromes and definitions of pain terms. Seattle: IASP Press; 1994. p. 40-42. 
528. Bonica JJ. Sympathic Nerve Blocks for Pain Diagnosis and Therapy: Fundamental Considerations and Clinical Applications. New York: Breon Laboratories Inc:; 1980.

529. Bonica J. Causalgia and other Reflex Sympathic Dystrofies. In: Bonica JJ, editor. The Management of Pain. Philadelphia/London: Lea \& Febriger, 1990, p. 220-43.

530. Goris RJA, Kolkman WFA, Leenen LPH, Van Bebber IPT, Corstens FHM, Heerschap A. Symptomatologie van posttraumatische dystrofie. In: Van Es J, Joossens JV, Mandema E, Olthuis G, redactic. Het Medisch Jaar. Utrecht: Bohn Scheitema \& Holkema, 1988, p. 165-77.

531. Van der Rhede-van Kloot EJH. Thoracodorsal Sympathectomy in Patients with Ischaemic hand phenomena [dissertation]. Maastricht Rijksuniversiteit Limburg; 1988.

532. Blumberg H, Griesser HJ, Hornyak M. Neurologische Aspekte der Klinik, Pathophysiologie und Therapie der sympathischen Reflexdystrophie (Kausalgie, Morbus Sudeck). Nervenarzt 1991,(62), 205-11.

533. Blumberg H, Griesser HJ, Hornyak MW. Das distale posttraumatische Odem - Symptom einer sympathischen Reflexdystrophic (M. Sudeck)? Z Orthop 1992;(130):9-15.

534. Blumberg H, Grieser HJ, Homyak M. Neue gesichtspunkte zur Klinik, Diagnostik und Pathophysiologie der sympathischen Reflexdystrofie (morbus Sudeck). Unfallchirurgie 1990;16(2):95-106.

535. Von Schimmert S, Schurawitzki H, Imhof H, Canigiani G, Kramer J, Fialka V. Morbus Sudeck. MRT als neues diagnostisches Verfahren. Fortschr Rontgenstr 1991;154(6):601-4.

536. Van Laere $M$, Claessens $M$. The treatment of reflex sympathetic dystrophy syndrome: current concepts. Acta Orthopaedica Belgica 1992;(58(Suppl I)):259-61.

537. Van den Wildenberg FAJM, Kurvers HAJM, Jacobs MJHM, Eggink GJ, Bulstra S, Sluyter M. Neue Aspekte beim posttraumatischen Dystrophiesyndrom? Unfallehirurg 1994;(97):485-90.

538. Veldman PHJM, Reynen HM, Arntz IE, Goris RJA. Signs and symptoms of reflex sympathetic dystrophy: a prospective study of 829 patients. The Lancet 1993;342(23):1012-6.

539. Blumberg H, Janig W. Clinical manifestations of reflex sympathetic dystrophy and sympathetically maintained pain. In: Wall PD, Melzack R, editors. Textbook of Pain. London: Churchill Livingstone; 1994 p. $685-98$.

540. Goris RJA. Treatment of Reflex Sympathetic Dystrophy with Hydroxyl Radical Scavengers. Unfallchinurg $1985 ;(88): 330-2$.

541. Goris RJA, Van Dongen LMV, Winters MAM. Are toxic oxygen radicals involved in the pathogenesis of reflex sympathetic dystrophy? Free Rad Res Comms 1987;(3):13-8.

542. Telefonische mededeling van RJA Goris. Nijmegen: 24 juni 1993.

543. Gilbert DN, Dworkin RJ, Raber SR, Legett JE. Drug Therapy. Outpatient Parenteral Antimicrobial-drug Therapy. N Eng J Med 1997;337(12):829-38.

544. Koninklijke Nederlandse Maatschappij ter bevordering van de Pharmacie. Informatorium Medicamentorum. Den Haag: KNMP; 1997, p. 410.

545. Brief van RJA Goris in antwoord op het schrijven van PMJH Smeets d.d. 3 februari 1995. Nijmegen: 7 februari 1995 (referentie JG/MT/0229).

546. Inventarisatiegesprekken met de specialisten S. Bulstra (Orthopaedie), W. Dingemans (Pijnbestrijding) en F. v.d. Wildenberg (Algemene Heelkunde) en met de verpleegkundigen A. Hameleers (short stay), T. van Haastert en H. Stevens-Jamaar (dagcentrum).

547. Medische administratic academisch ziekenhuis Maastricht. Databestanden 1993-1995.

548. Egle UT, Hoffiman SO. Ist die sympathische Reflexdystrophie wirklich 'ingesamt als neurologische Storung zu definieren"? [Diskussion und Leserbriefe]. Nervenarzt 1992;(63):120-2.

549. Egle UT, Hoffmann SO. Psychosomatische Zusammenhange bei sympathischer Reflexdystrophie (Morbus Sudeck). Literaturabersicht und erste klinische Ergebnisse. PPmP Psychother med Psychol 1990;(40): 123-35.

550. De Vilder J. Personality of patients with Sudeck's atrophy following tibial fracture. Acta Ortopaedica Belgica 1992;58(Suppl I):252-7.

551. De Bruin AF, Diederiks JPM, De Witte LP, Stevens FCJ, Philipsen H. De SIP-68. De verkorte versie van de Sickness Impact Profile. Maastricht: Rijksuniversiteit Limburg, Vakgroep Medische Sociologie; 1994.

552. Stichting Groene Kruis Heuvelland (SGKH). Produktievoorstellen 1997. Maastricht: SGKH; 1996.

553. Antoniski A, Anderson BC, Van Volkinburg EJ, Jackson JM, Gilbert DN. Feasibility of outpatient selfadministration of parenteral antibiotics. West J Med 1987;(128):203-6.

554. Stiver HG, Telford GO, Mossey JM, Cote DD, Van Middlesworth EJ, Trosky SK. Intravenous Antibiotic Therapy at Home. Ann Intern Med 1978;(89):690-3.

555. Kind AC, Williams DN, Persons G, Gibson JA. Intravenous Antibiotic Therapy at Home. Arch Intern Med April 1979:139:413-5.

556. Rucker RW, Harrison GM. Outpatient Intraveneous Medication in the Management of Cystic Fibrosis [short communications]. Pediatrics 1974;54(2):358-60. 
557. Tice AD. Experience with a Physician-Directed, Clinic-Based Program for Outpatient Parenteral Antibiotic Therapy in the USA. Eur J Clin Microbiol Dis 1995;(14):655-61.

558. Rehm SJ, Weinstein AJ. Home Intravenous Antiobitic Therapy: A Team Approach. Ann Int Med 1983;(99):388-92.

559. Stiver HG, Trosky SK, Cote DD, Oruck JL. Self-adminstration of intravenous antibiotics: an efficient, cost-effective home care program. Canadian Medical Association Journal August 1982;(127):207-11.

560. Williams DN, Gibson JA, Bosch D. Home Intravenous Antiobiotic Therapy Using a Programmable Infusion Pump. Arch Intern Med May 1989;149:1157-60.

561. Williams DN. Home Intravenous Antibiotic Therapy: New Technologies. Recent Results in Cancer Research 1991:(121):215-22.

562. New PB, Swanson GF, Bulich RG, Taplin GC. Ambulatory Antibiotic Infusion Devices: Extending the Spectrum of Outpatient Therapies. American Journal of Medicine November 1991;(91):455-61.

563. Talcott JA, Whalen A, Clark J, Rieker PP, Finberg R. Home Antibiotic Therapy for Low-risk Cancer Patients With Fever and Neutropenia: A Pilot Study of 30 Patients Based on a Validated Prediction Rule. J Clin Oncol 1994;12(1):107-14.

564. Morales JO, Von Behren L. Secondary Bacterial Infections in HIV-Infected Patients: An Alternative Ambulatory Outpatient Treatment Utilizing Intravenous Cefotaxime. American Journal of Medicine 1994;(97(Suppl 2A)):9-13.

565. Meis JFGM, Nohlmans MKE. Lyme-borreliose: ook in Nederland. Tijdschrift voor Huisartsgeneeskunde 1995:12(7/8):369-72.

566. Orton P, Resistant organisms: a dilemma for primary care? [editorial]. British Journal of General Practice July 1997:415-6.

567. Tice AD. Handbook of Outpatient Parenteral Therapy for Infectious Diseases. New York: Scientific American Inc; 1997.

568. Graham DR. Nosohusial Infections: Complications of Home Intravenous Therapy. Infectious Diseases in Clinical Practice 1993;2(2):158-61.

569. Dagan R, Einborn M. A Program of Outpatient Parenteral Antibiotic Therapy for Serious Pediatric Bacterial Infections. Reviews of Infectious diseases January/February 1991;(13(Suppl. 2)):S152-55.

570. Haerkens HMJ, Van Weert NJHW, Van den Broek PJ. Intraveneuze toediening van antimicrobiele geneesmiddelen thuis. Een vergelijking met ziekenhuisbehandeling. Leiden: TNO Preventie en Gezondheid, Divisie Technologie in de Gezondheidszorg; 1997.

571. Van Putten PL. Huisarts en nieuwe antibiotica. Tijdschrift voor Huisartsgeneeskunde 1996;12(3):113-7.

572. Van den Broek PJ, Haerkens HMJ, Van Weert NJHW, Vermeij P. Gunstige ervaringen met intraveneuze antimicrobiele therapie buiten het ziekenhuis. Ned Tijdschr Geneeskd 1997;141(47):2297-2301.

573. MeNulty TJ. Initiation of antimicrobial therapy in the home. American Journal of Hospital Pharmocology 1993:(50):773-4.

574. Scully BE. Home Intravenous Antibiotic Therapy. New Jersey Medicine 1992;89(1):48-51.

575. Grayson ML, Silvers J, Turnidge J. Home intravenous antibiotic therapy. A safe and effective alternative to inpatient care. Med J Aust March 1995;(162):249-53.

576. Craig WA. Selecting the Antibiotic. Hospital Practice 1993;(28(Suppl)):16-20.

577. Poretz DM. High Tech Comes Home [editorial]. American Journal of Medicine November 1991;91:453-4.

578. Sengers IJM, Van Ouwekerk YM, Terpstra S, redactic. Hygiene en infectiepreventie. 2e ed. Utrecht: LEMMA BV; 1995.

579. Werkgroep Infectie Preventie (WIP). Preventie van infecties ten gevolge van intravasale therapie [richtlijn]. Leiden: WIP; februari 1994. Publikatienummer: 11A.

580. Maki DG. Infections due to infusion therapy. In: Bennet JV, Brachman PS, editors. Hospital infections. 3rd. ed. Boston, MA: Little, Brown and Co; 1992.

581. Smeets PMJH, Derckx EWCC, Wolters CAM, Pop P, Beusmans GHMI, Crebolder HFJM. Taken en verantwoordelijkheden bij infuusbehandeling thuis. Artsen en verplecgkundigen: de wet en de praktijk. Medisch Contact 1997;52(10):324-6.

582. Smulders CMF, Schneeberger PM, Bolhuis R. Bacteriemie en sepsis door intravasale catheters. Een prospectief onderzoek op een algemene intensive care afdeling. Tijdschrift voor Hygiene en Infektiepreventie 1996;(4):115-7.

583. Maki DG, Ringer M, Alvarado CJ. Prospective randomised trial of povidone-iodine, alcohol, and chlorhexidine for prevention of infection associated with central venous and arterial catheters. The Lancet August 1991:339-43.

584. Nolet B. Patient Care Issues in Outpatient Intravenous Antibiotic Therapy. Infectious Diseases in Clinical Practice 1993;3(3):225-6. 
585. Poretz DM. The Infusion Center: A Model for Outpatient Parenteral Antibiotic Therapy. Reviews of Infectious Diseases 1991;(13(Suppl 2)):S142-6.

586. Tice AD. An Office Model of Outpatient Parenteral Antibiotic Therapy. Reviews of Infectious Diseases 1991;(13(Suppl 2)):S184-8.

587. Green SL. Practical Guidelines for Developing an Office-Based Program for Outpatient Intravenous Therapy. Reviews of Infectious Diseases 1991;(13(Suppl 2)):S189-92.

588. Rich D. Physicians, Pharmacists, and Home Infusion Antibiotic Therapy. American Journal of Medicine 1994;97(Suppl 2A):3-8.

589. Smeets PMJH, Kho TL, Wolters CAM, Pop P. Infuusbehandeling thuis bij chronisch hartfalen. Hartbulletin 1997;28(3):88-94.

590. Ackerman BH, Wolfe J. Monitoring chronic outpatient infections: providing comprehensive home healtheare pharmacy services. DICP Ann Pharmacother July/August 1991:(25):840-8.

591. Freeman FL. Home Infusion for the 1990s: A Patient's Perspective. New Jersey Medicine 1992;89(1):60-2.

592. Mouton JW, Vinks AATMM. Antimicrobiele behandeling met B-lactam-antibiotica: continue infusie lijkt zinvol. Ned Tijdschr Geneeskd 1993;137(48):2476-9.

593. Kravitz GR. Advances in IV Delivery. Hospital Practice 1993:(28(Suppl)):21-7.

594. Poretz DM, Woolard D, Eron LJ, Goldenberg RI, Rising J, Sparks S. Outpatient Use of Ceftriaxone: A Cost Benefit-Analysis. American Journal of Medicine 1994:77((Suppl 4C)):77-83.

595. Poretz DM, The HIAT Study Group. American Journal of Medicine 1994:97((Suppl 2A)):34-42

596. Brown RB. Selecting the Patient. Hospital Practice 1993:(28(Suppl)):11-5.

597. Balinsky W, Nesbitt S. Cost-effectiveness of outpatient Parenteral Antibiotics: A Review of the Literature. American Journal of Medicine September 1989;87:301-5.

598. Chamberlain TM, Lehman ME, Groh MJ, Munroe WP, Reinders TP. Cost analysis of a home intravenous antibiotic program. American Journal Hospital Pharmocology November 1988:45:2341-5.

599. Halls GA. Antimicrobial practice. The management of infections and antibiotic therapy: an European survey. J Antimicrob Chemother 1993:(31):985-1000.

600. Nathwani D, Davey P. Intravenous antimicrobial therapy in the community: underused, inadequately resourced, or irrelevant to health care in Britain? BMJ December 1996;(31):1541-3.

601. Mouton JW. Pharmacokinetic and Pharmacodynamic Studies of Beta-lactam Antibiotics in Voluntecrs and Patients with Cystic Fibrosis [dissertation]. Rotterdam: Erasmus University Rotterdam;1993.

602. Wijlhuizen TJ, Van Haaren CPLC, Vermeij P, Van den Broek PJ. Indications for home intravenous antibiotic therapy in The Netherlands. International Journal of Antimicrobial Agents 1995;(5):55-8.

603. Crump BJ, Panton R, Drummond MF, Marchment M, Hawkes RA. Transferring the costs of expensive treatments from secondary to primary care. BMJ 1995;310:509-12.

604. Milkovich G. Costs and Benefits. Hosp Prac Off Ed 1993;(28(Suppl 1)):39-43.

605. Kho TL. Dopamine and the circulation in man [dissertation]. Maastricht: Rijksuniversiteit Limburg; 1987.

606. Ziekenfondsraad, Centrale Medisch Pharmaceutische Commissie. Farmacotherapeutisch Kompas 1994. Amstelveen: Ziekenfondsraad; 1994.

607. Collins JA, Skidmore MA, Melvin DB, Engel PJ. Home Intravenous Dobutamine Therapy in Patients Awaiting Heart Transplantation. Journal of Heart Transplant 1990;9(3):205-8.

608. Hattersley AT, Langley S, Thompson JR, Blackwood RA. Home intravenous diuretic therapy for patient with refractory heart failure. The Lancet 1989;1(8):446.

609. Van Stam A, Robles de Medina. Validiteitsclassificatic in de cardiologie. Ned Tijdschr Geneeskd 1986;137(37):1661-3.

610. Dunselman PHJM, Kuntze CEE, Van Bruggen A, Beekhuis H, Piers B, Scaf AHJ. Value of New York Heart Association classification, radionuclide ventriculography, and cardiopulmonary exercise tests for selection of patients for congestive heart failure studies. American Heart Journal 1988;116(6).

611. Landelijke Medische Registratie van de Stichting Informatievoorziening voor de Gezondheidszorg (SIG). Ziekenhuisopnamen 1993 gepoolde gegevens. Utrecht: SIG/Landelijke Medisch Registratie; 1995.

612. Tandon PK, Stander H, Schwarz RP. Analysis of quality of life data from a randomized, placebo-controlled heart-failure trail. Journal of Clinical Epidemiology 1989;42(10):955-62.

613. Hovius I, Bouma L. Home care patients with chronic heart failure on a dobutrex infusion (abstract 065). Empowerment of the chronically ill: a challenge for nursing. Amsterdam: Proceedings of the 2nd European Nursing Congress; 1997.

614. Schrijvers G, Van der Linden B. Quality, costs and cultural beliefs in outpatient treatment with parenteral antibiotics: a comment. International Journal of Antimicrobial Agents 1995;(5):45-6.

615. Van Adrichem JAM. Insurance companies' view on outpatient treatment. International Journal of Antimicrobial Agents 1995;(5):35-8.

616. Dhauteaux. Bron onbekend. 
617. Testa MA, Simonson DC. Assessment of quality-of-life outcomes. N Engl J Med 1996;334(12):835-40.

618. Meyboom-de Jong B, De Maeseneer J. Geen genezen zonder meten. Over de uitkomst van geneeskundig handelen. Huisarts en Wetenschap 1995;38(3):101-4.

619. Hunt SM. The assessment of quality of life in clinical care. Medicographia 1988;10(2):34-7.

620. De Haes JCJM. Indicatoren voor kwaliteit van leven en prioriteiten in onderzoek. Tijdschrift voor Sociaal Gezondheidsonderzoek 1991;69(7):229-31.

621. Fitzpatrick R, Fletcher AE, Gore SM, Jones DR, Spiegelhalter D, Cox DR. Quality of life measures in health care. I: Applications and issues in assessment. BMJ 1992;305:1074-7.

622. Fletcher AE, Gore SM, Jones DR, Fitzpatrick R, Spiegelhalter DJ, Cox DR. Quality of life measures in health care. II: Design, analysis, and interpretation. BMJ 1992;305:1145-8.

623. Spiegelhalter DJ, Gore SM, Fitzpatrick R, Fletcher AE, Jones DR, Cox DR. Quality of life measures in health care. III: Resource allocation. BMJ 1992;305:1205-9.

624. Van Knippenberg FCE, De Haes JCJM. Measuring the quality of life of cancer patients: psychometric properties of instruments. Journal of Clinical Epidemiology 1988;41(11):1043-53.

625. Gill TM, Feinstein AR. A critical appraisal of the quality of quality-of-life measurements. JAMA 1994;272(8):619-26.

626. De Groot $\mathrm{AD}$. Bevordering van welzijn; bijdrage tot een probleemanalyse. In: Baerends GP, Groen JJ, De Groot AD, redactic. Over welzijn. Criterium, onderzoeksobject, beleidsdoel. Deventer: Van Loghum Slaterus; 1978.

627. Campbell A, Converse PE, Rogers WL. The quality of American life, New York: Russell Sage Foundation; 1976.

628. Van Elderen T, et al, Overzichtsstudie kwaliteit van leven onderzoek bij somatische chronisch zieken. Zoetermeer: Nationale Commissie Chronisch Zieken; 1994.

629. De Witte L, Jacobs H, Van der Horst F, Luttik A, Joosten J, Philipsen H. De waarde van de Sickness Impact Profile als maat voor het functioneren van patienten. Gezondheid \& Samenleving 1987;8(2):120-7.

630. World Health Organization. Constitution. New York: WHO; 1946.

631. Konig-Zahn, Furer JW, Tax B. Het meten van gezondheidstoestand. Algemene gezondheid. Assen: Van Gorcum; 1993.

632. Mossey JM, Shapiro E. Self-rated health: a predictor of mortality among the elderly. American Journal of Public Health 1982;(72):800-8.

633. Adriaanse H, Drop M, Halfens R, Philipsen H. Leeft Nederland Oké? Verslag van een onderzoek naar opvattingen, belevingen en gedragingen inzake gezondheid. Maastricht: Rijksuniversiteit Limburg; 1981.

634. Van Haastregt JCM. De relatie tussen de gezondheidsstatus, de ervaren gezondheid en gezondheidsopvattingen [afstudeeronderzoek gezondheidswetenschappen]. Maastricht: Rijksuniversiteit Limburg:1991.

635. Kooiker SE. 'Je gezondheid is je kostbaarste bezit'. De veranderende waarde van gezondheid in de periode 1996-1993. In: Kooiker SE, Mootz M, redactie. Patient en professie. Culturele determinanten van medisch consumptic. Rijswijk: Sociaal Cultureel Planbureau; 1996. p. 63-96.

636. Joosten J. De invloed van klasse, status en burgerschap op subjectieve gezondheid [proefschrift]. Maastricht: Rijksuniversiteit Limburg:1995.

637. Meyler WJ. Pijnbestrijding bij kanker. The practitioner 1992;9(2):85-7.

638. Twycross RG, Lack SA, editors. Symptom control in far advanced cancer; pain relief. England: Pittman; 1983.

639. Penninx BWJH. Social support in elderly people with chronic diseases. Does it really help? [dissertation]. Amsterdam: Vrije Universiteit Amsterdam;1996.

640. Mootz M. Sociale netwerken, kwaliteit van leven en het gebruik van zorgvoorzieningen. Tijdschrift Sociale Gezondheidszorg 1991:69(7):232-6.

641. Maslow AH. Motivation and personality. New York: Harper and Row; 1954.

642. Janssen M. Personal networks of chronic patients [dissertation]. Maastricht: Rijksuniversiteit Limburg: 1992.

643. Sanderman $\mathrm{R}$, Hosman $\mathrm{CMH}$, Mulder $\mathrm{D}$, redactie. Het meten van determinanten van gezondheid: een overzicht van beschikbare meetinstrumenten. Assen: Van Gorcum; 1995.

644. Janssen T. Zorg om mantelzorg. Verzorg(st)er van de invaliderende oudere mens. TVZ 1988;42(6):169-74.

645. Thoits PA. Conceptual, methodological and theoretical problems in studying social support as a buffer against life stress. Journal of health and social behavior 1982;(23):145-9.

646. Ministerie van Welzijn, Volksgezondheid en Cultuur. Thuiszorg in de jaren 190. Rijswijk: WVC; 1991.

647. De Witte L. After the rehabilitation centre. A study into the course of functioning after discharge from rehabilitation [dissertation]. Maastricht: Rijksuniversiteit Limburg; 1991. 
648. De Neeling JND. Kwaliteit van leven: een meetbaar begrip? Een aanwinst die geen aanwinst was. Medisch Contact 1992:47(5):143-5.

649. Van Steenkiste BC, Jaarsma T. Het meten van kwaliteit van leven bij patienten met chronisch hartfalen Hartbulletin 1996:27(10):175-179.

650. Jacobs HM, Luttik A, Touw-Otten FWMM, De Melker RA. De 'Sickness Impact Profile'; resultaten van een valideringsonderzoek van de Nederlandse versie. Ned Tijdschr Geneeskd 1990;134(40):1950-4.

651. De Bruin AF, Diederiks JPM, De Witte LP, Stevens FCJ, Philipsen H. Sip-68. Een verkorte versie van de Sickness Impact Profile. Maastricht: Vakgroep Medische Sociologie Rijksuniversiteit Limburg: 1994.

652. De Bruin AF, Diederiks JPM, De Witte L.P, Stevens FCJ, Philipsen H. The development of a short generic version of the sickness impact profile. Journal of Clinical Epidemiology 1994:47(4):407-18.

653. De Bruin AF, De Witte LP, Stevens FCJ, Diederiks JPM. De bruikbaarheid van de Sickness Impact Profile als generiek maat voor functionele toestand. Tijdschrift voor Sociale Gezondheidszorg 1992;70(3):160-70.

654. Jacobs HM, Touw-Otten FWMM. De Nederlandse versie van de Sickness Impact Profile in huisartsgeneeskundig onderzoek. Huisarts en Wetenschap 1995;38(3):122-27.

655. Bergner M, Bobitt RA, Carter WB, Gilson BS. The Sickness Impact Profile: Development and Final Revision of a Health Status Measure. Medical Care 1981:19(8):787-805.

656. De Bruin AF. The measurement of sickness impact. The construction of the SIP-68 [dissertation]. Maastricht: Rijksuniversiteit Limburg; 1996.

657. Swanborn PG. Schaaltechnieken. Theorie en praktijk van acht eenvoudige procedures. Meppel: Boom; 1982.

658. Robinson BC. Validation of a caregiver strain index. Journal of Gerontology 1983;38(3):344-8.

659. De Witte LP, Tilli DP, Ticheler AJG, Winants BAC, Van der Horst FG, Van der Linden SJ. Leven met een reumatische aandoening. Een onderzoek naar de ervaren kwaliteit van het leven bij 372 mensen met een reumatische aandoening. Hoensbroek: Instituut voor Revalidatie Vraagstukken; 1989.

660. Lemmens F, Donker M. Kwaliteitsbeoordeling door clienten. Een metastudie naar tevredenheidsonderzoek in de geestelijke gezondheidszorg. Utrecht: Nationaal centrum Geestelijke volksgezondheid; april 1990. Publikatienummer 90-6.

661. Wiklund I, Herlitz J, Hjalmarson A. Quality of life five years after myocardial infarction. European Heart Joumal $1989 ; 10: 464-72$.

662. Tsevat J, Cook EF, Green ML, Matchar DB, Dalson NV, Broste SK. Health values of the seriously ill. Annals of Internal Medicine 1995;122(7):514-20.

663. De Boer AH, Hessing-Wagner JC, Mootz M, Schoenmakers-Salkinoja IS. Informele zorg: Een verkenning van huidige en toekomstige ontwikkelingen. Rijswijk: Sociaal en Cultureel Planbureau; 1994.

664. Vernooij-Dassen MJF, Persoon JMG, redactic. Het thuismilieu van dementerende ouderen. Nijmegen: Instituut voor Sociale Geneeskunde; 1990.

665. Te Wierik MJM. Verpleeghuisopname. Een onderzoek naar factoren die van invloed zijn op verpleeghuisopname en het verloop daarvan [proefschrift]. Maastricht: Rijksuniversiteit Limburg; 1991.

666. Coulter A. Shifting the balance from secondary to primary care. Needs investement and cultural change. BMJ 1995;(311):1447-8.

667. Leplège A, Hunt S. The Problem of Quality of Life in Medicine. JAMA 1997;278(1):47-50.

668. Essink-Bot ML. De werkgroep Onderzoek Gezondheidsmeting; standaardisatie van onderzoek naar met gezondheid samenhangende kwaliteit van leven. Ned Tijdschr Geneeskd 1994;138(29).

669. Greenfield S, Nelson EC. Recent developments and future issues in the use of health status assessment measures in clinical settings. Medical Care 1992;30(Suppl):MS23-41.

670. Leeuwen AD. Beknopt Latijns-Nederlands woordenboek. $12 \mathrm{e}$ ed. Groningen: Wolters-Noordhoff; 1970.

671. Van Wijmen FCB. Recht op kwaliteit [inaugurale rede]. Maastricht: Rijksuniversiteit Limburg, 1983.

672. Donabedian A. The Quality of Care. How can it be assessed? JAMA 1988:(260):1743-8.

673. Lohr KN. Outcome measurement: concepts and questions. Inquiry 1988;(25):37-50.

674. Kistemaker JWG, Visser AP. Betekenis van tevredenheid van patienten voor kwaliteit van zorg. Tijdschrift voor Sociale Gezondheidszorg 1995;73(4):214-23.

675. Mintzberg H. The Structuring of Organizations. Englewood Cliffs: Prentice Hall; 1979.

676. Nederlands Centrum voor Democratische Burgerschapsvorming (NCDB). Kwaliteit vanuit patientenperspectief [verslag]. Amsterdam: NCDB; 1990.

677. De Quartel HJC. Het kwaliteitsoordeel van bewoners in een verzorgingshuis ingeschat door hulpverleners: een pilot-study [afstudeerscriptie]. Maastricht: Vakgroep Gezondheidswetenschappen doorstroom Beleid en Beheer van de Gezondheidszorg Rijksuniversiteit Limburg. 1991.

678. Donabedian A. Medical care apraisal. A guide to medical care administration (volume 2). Washington: American Public Health Association; 1969. 
679. Donabedian A. The definition of Quality and Approaches to its Monitoring: Explorations in Quality Assessment and Monitoring (volume 1). Michigan: Ann Arbor, 1980.

680. Williamson JW, et al. Principles of quality assurance and cost containment in health care. San Francisco: Jossey-Bass Publishers; 1982.

681. Berwick DM, Blanton Godfrey A, Roessner J. Curing Health Care. New strategies for quality improvement. San Francisco: Jossey-Bass Publishers; 1991.

682. Relman AS. Assessment and accountability. The third revolution in Medical Care. N Engl J Med $1988 ;(319): 1220-3$.

683. Van Duijn NP. Waarom zouden we vragen of patienten tevreden zijn? Huisarts en Wetenschap 1995: 38(2):46-8.

684. Visser AP. De beleving van het verblijf in het ziekenhuis [proefschrift]. Amsterdam: Vrije Universiteit; 1984. p. 30-31.

685. Calnan M. Towards a conceptual framework of lay evaluation of health care. Social Science \& Medicine 1988:(8):927-33.

686. Weiss GL. Patient Satisfaction with Primary Medical Care. Medical Care 1988;26(4):383-92.

687. Geerts G, Heestermans H, Den Boon CA, Vos ECM, Van Veen PAF, Van der Sijs N, redactie. Van Dale, Groot Woordenboek der Nederlandse Taal. 12e ed. UtrechtAntwerpen: Van Dale Lexicografie; 1992.

688. Van Campen C, Friele RD, Kerssens J. Methods for assessing patient satisfaction with primary care. Review and annotated bibliografy (nr. 35). Utrecht: Nivel; 1992.

689. Pascoe CG. Patient satisfaction in primary health care: a literature review and analysis. Evaluation and Program Planning 1983;(6):185-210.

690. Ley P. Satisfaction, compliance and communication. British Journal of Clinical Psychology 1982;(21):241-54.

691. Linder-Pelz S. Towards a theory of patient satisfaction. Social Science \& Medicine 1982;(16):577-82.

692. Fishbein M, Ajzen L. Belief, attitude, intention and behavior: an introduction to theory and research. Reading MA (US): Addison-Wesley; 1975.

693. Philipsen H. Tevredenheidsonderzoek in de Ambulante Geestelijke Gezondheidszorg [symposiumverslag]. Klientenonderzoek in de GGZ; een boterham met tevredenheid? 1987.

694. Abramowitz S, Coté AA, Berry E. Analyzing patient satisfaction: A multi-analytic approach. Quality Review Bulletin April 1987:123-30.

695. Fitzpatrick R, Hopkins A. Problems in the conceptional framework of patient satisfaction: An empirical exploration. Sociology of Health and Illness 1983;5(3):297-311.

696. Williams B. Patient satisfaction: A valid concept? Social Science \& Medicine 1994:38(4):509-16.

697. Festinger L. A theory of cognitive dissonance. California: Stanford University Press; 1957.

698. De Groot A. Methodologie. Den Haag: Mouton; 1961.

699. LeVois M, Nguyen TD, Attkisson CC. Artifacts in client satisfaction assessment: experiences in community mental health settings. Evaluation and Program Planning 1981;(4):139-50.

700. Counte MA. An examination of the convergent validity of three measures of patient satisfaction in an outpatient treatment center. J Chron Dis 1979;(32):583-8.

701. Cleary PD, McNeil B. Patient Satisfaction as an Indicator of Quality Care. Inquiry 1988;(25):25-36.

702. Lebow JL. Research assessing consumer satisfaction with mental health treatment: a review of findings. Evaluation and Program Planning 1983;(3-4):211-36.

703. Hall JA, Milburn MA, Epstien AM. A Causal Model of Health Status and Satisfaction with Medical Care. Medical Care 1993;31(1):84-94.

704. Visser AP. De satisfactie van ziekenhuispatienten. Ontwikkeling en betekenis van een meetinstrument. Tijdschrift voor Sociale Gezondheidszorg 1983;61(20):720-31.

705. Hays RD, Ware JR. My medical care is better than yours: social desirability and patient satisfaction ratings. Medical Care 1986;(6):519-24.

706. Visser APh, Breemhaar B, Kleijnen JGVM. De rol van sociale wenselijkheid in evaluatieonderzoek onder ziekenhuispatienten. First Conference of the European Association for Impact Assessment; 1988.

707. Caris-Verhallen WMCM, Friele RD. Kwaliteit van thuisbehandeling bij Cystic Fibrosis. Ontwikkeling en toepassing van een meetinstrument. Kwaliteit van Zorg 1996;3(1):14-24.

708. Ware JE, Hays RD. Methods for measuring patient satisfaction with specific medical encounters. Medical Care 1988;26(4):393-402.

709. Larsen DL, Attkisson CC, Hargreaves WA, Nguyen TD. Assessment of client/patient satisfaction: development of a general scale. Evaluation and Program Planning November 1979;(2):197-207.

710. De Brey JHC, Peereboom S. Onderzoek naar tevredenheid bij Riagg-cliènten. Tijdschrift Sociale Gezondheidszorg 1986;64(2):39-43. 
711. Van Wijk AS, Visser AP. Oordelen van patienten over deeltijdbehandeling op een psychiatrische afdeling van een algemeen ziekenhuis (PAAZ). Tijdschritt Sociale Gezondheidszorg 1992;(70):463-8.

712. Schoutrop MJA, Visser AP, Hamers AFM. Kwaliteit van zorg in een psychiatrisch ziekenhuis. Een onderzoek onder de contactpersonen van oudere patienten. Medisch Contact 1993,48(20).627-9.

713. Roberts RE, Pascoe GC, Attkisson CC. Relationship of service satisfaction to life satisfaction and perceived well-being. Evaluation and Program Planning 1983;6(3):373-83.

714. De Lissovoy G, Feustle JA. Advanced home health care. Health Policy 1991:227-42.

715. De Vries $P$. Finaneiering van de gezondheidszorg. Leerboek voor het hogere en universitair onderwijs. Deventer. Kluwer, 1991.

716. Rutten FH, Van Ineveld BM, Van Ommen R, Van Hout BA, Huijsman R. Kostenberekening bij Gezondheidszorgonderzoek. Richtlijnen voor de praktijk. Rapport opgesteld in opdracht van de Stuurgroep Toekomstscenario's Gezondheidszorg. Utrecht: Uitgeverij Jan van Arkel; 1993.

717. Huijsman R. De kosten van transmurale zorg. Een illustratic. Medisch Contact 1995;50(24):777-80.

718. Financiele Patięnten Administratie academisch ziekenhuis Maastricht.

719. Habets JLG. Verblijfskostenberekening infuusbehandeling academisch ziekenhuis Maastricht. Maastricht: Afdeling Financial Control academisch ziekenhuis Maastricht; november 1998.

720. Meijer W, Nieman F. Rapport van de resultaten van de enquete: 'Tevredenheid van Klinische Patienten, azM 1993: Maastricht: Onderzoeksgroep azM; december 1993.

721. Stichting Groene Kruis Heuvelland (SGKH). De tevredenheid van de klant over de patientenzorg in het Heuvelland (met bijlagen). Maastricht: SGKH; 1995.

722. Landelijke Vereniging Thuiszorg (LVT). Handboek gebruikersraadpleging thuiszorg. Bunnik: LVT; maart 1994.

723. Consumentenbond. Knelpunten bij thuiszorg: snelheid en soepelheid. Consumentengids oktober 1993 : 670-3.

724. Knapen M. Experimenten Thuisverpleging. 1988:117-125.

725. Centraal Bureau voor de Statistiek (CBS). Statistisch Jaarboek 1992 en 1996. Voorburg/Heerlen: CBS; 1992 en 1996. p. 327 (1992) en 347 (1996).

726. Culbertson VL, Rhodes RS, Hill EP, Rhodes PJ. Impact of home infusion therapy on the Colorado Medicaid program budget. American Journal of Hospital Pharmacy June 1988;45:1346-9.

727. Hart JS. A physician's perspective on the advantages og home medical care: the other side of case management. Texas Medicine 1994;90(2):50-4.

728. Rutten $\mathrm{M}$, Vondeling $\mathrm{H}$. Economische evaluatie in het kader van ontwikkelingsgeneeskunde: Een algemene inleiding voor artsen. Maastricht: Rijksuniversiteit Limburg, Department of Health Economics; 1992. Publikatienummer: 92.02.

729. Warren CS, Fess PE. Principals of Financial and Managerial Accounting. 2nd ed. Cincinnati: SouthWestern Publishing Co; 1989.

730. Brealey RA, Myers SC. Principles of corporate finance. New York: McGraw-Hill; 1988.

731. Ministerie van Welzijn Volksgezondheid en Cultuur. Lidmaatschap Stichting Groene Kruis Heuvelland 1995. Op basis van: Regeling tot wijziging van het Besluit kraamzorg ziekenfondsverzekering en het Besluit ziekenvervoer ziekenfondsverzekering 1980 alsmede de Regeling nadere regels zorgaanspraken AWBZ, in verband met de jaarlijkse indexering van de verschuldigde bijdragen van de zorg. Rijswijk: 21 november 1994. Kenmerk: VMP/VA-943443.

732. Fiscaal memo 1. Deventer: Kluwer; 1997. p. 44.

733. Telefoontarieven PTT Telecom 1995.

734. Variabel afvaltarief per afvalzak in de gemeente Valkenburg. Valkenburg: 1995.

735. Bruyn-Hundt M. The economics of unpaid work [dissertation]. Maastricht: Rijksuniversiteit Limburg: 1996.

736. Smith $\mathrm{K}$, Wright $\mathrm{K}$. Informal care and economic appraisal: a discussion of possible methodological approaches. Health Economics 1994;(3):137-48.

737. Posnett J, Stephen J. Indirect cost in economic evaluation: the opportunity cost of unpaid inputs. Health Economics 1996;(5):13-23.

738. Rutten-van Molken MPM. Costs \& Effects of pharmacotherapy in asthma and COPD [dissertation]. Maastricht: Rijksuniversiteit Limburg,1994. p. 61.

739. Centraal Bureau voor de Statistiek (CBS). Statistisch Jaarboek 1996. Voorburg/Heerien: CBS; 1996. p. $117-8,122-3$.

740. Boudewijn JWT. Thuiszorg in (bedrijfs)economisch perspectief. Flexibele budgetfinanciering als beheersinstrument in de collectieve sector, de thuiszorg als testcase [proefschrift]. Amsterdam: Universiteit van Amsterdam;1993, p. 65, 134.

741. Tarief 1995 in academisch ziekenhuis Maastricht [brochures]. Den Haag: Tele-hire. 
742. Sorochan M, Beattie BL. Does home care save money? World Health 1994;47(4):18-9.

743. Ministerie van Volksgezondheid, Welzijn en Sport. Stimuleringsprogramma Thuiszorgtechnologie, projectresultaten 1991-1994. Groningen: KITTZ; 1995.

744. Cox M, Van der Winden H. Operational research in de gezondheidszorg. Eerstelijn 1995;1(5):18-21.

745. Parsons T. The social system. Glencoe: The Free Press; 1954.

746. Sales I, Crasborn L. Transmurale zorg als onderneming [afstudeerscriptie]. Tilburg: Tilburg Institute for Advanced Studies Katholieke Universiteit Brabant; 1998.

747. Thie J. Intraveneuze toediening van geneesmiddelen thuis. In: Handboek Thuiszorg. Utrecht: Elsevier/De Tijdstroom; 1993. p. C.4.5.1-38.

748. Dukkers van Emden DM. Eerste ervaringen met thuiszorg voor peritoneale dialyse door de wijkverpleging. Medisch Contact 1995;139(13):664-9.

749. Van Bilsen PMA, Dukkers van Emden DM, Zuurmond WWA, Wagemans MFM. Protocollering van een vorm van thuiszorg in Amsterdam en omstreken: spinale pijnbestrijding. Kwaliteit \& Zorg 1993;3(1):4-13

750. Smeenk FWJM. Transmural care of terminal cancer patients. An evaluation study in the Eindhoven region [dissertation]. Maastricht: Universiteit Maastricht;1998, p. 169.

751. Landelijk Transferpunt Thuiszorg (LTT). Handboek Thuiszorgtechnologie, Medisch Technische Handelingen, Thuisverpleging. Bunnik: LTT; november 1996.

752. Van der Heyden JTM, Van der Hoeve JCL. Professionele autonomie, positionering en beleidsparticipatie. Een delicate trias medica. Medisch Contact 1997;52(11):355-7.

753. Leblanc A. Werkdruk treft huisarts in het hart. De Limburget [krant] 27 december 1997.

754. KwaliteitsInstituut voor Toegepaste ThuisZorgvernieuwing (KITTZ). Chemotherapie Thuis. In: Stimuleringsprogramma Thuiszorgtechnologie. Projectresultaten 1991-1994. Groningen: KITTZ; 1995. p. 11.

755. Mistiaen $P, D e$ Wit L, Wipkink A, Wijkel D. Sondevoeding thuis. Toepassing en regionale verschillen Medisch Contact 1998;53(26):896-8.

756. Duijnstee MSH. Thuiszorg door en voor familieleden. In: Handboek Thuiszorg. Utrecht: Elsevier/De Tijdstroom; 1993. p. B.2.1.1-30.

757. KwaliteitsInstituut voor Toegepaste ThuisZorgvernieuwing (KITTZ). Checklist implementatie-orientie. Groningen: KITTZ; maart 1996.

758. Postema CA, Plagge HWM. Integrale en objectieve indicatiestelling. Medisch Contact 1998;53(16):543-5.

759. Wehnert AK. Prospectief interventic-onderzoek naar de microbiele groei in en op watermatrassen met en zonder toegevoegd desinfectans [afstudeerscriptie opleiding ziekenhuishygiene]. Breda/Maastricht: Opleiding ziekenhuishygiene/academisch ziekenhuis Maastricht;1998. p. 29.

760. Francke A, Persoon A, Temmink D, Kerkstra A. Transmurale zorg in de algemene gezondheidszorg: de stand van zaken. Kwaliteit \& Zorg 1997;5(2):70-80.

761. Van Dijk B, Giezen-Biegstraaten LMGJ. Technologietransfer in de praktijk. Pijnbestrijding bij kanker met behulp van infusietechnieken in de thuissituatic. Medisch Contact 1996;51(19):642-3.

762. Kalsbeek $G$. Het model transmurale zorg. Het project dagverpleging in Zoetermeer. p. 58-62. Van den Hoeven H. Het netwerkmodel. p. 53-7. LVG-congres Huisarts en Thuiszorg. Ontwikkelingen en Perspectieven [symposiumverslag]: 1995.

763. Groeneweg BJ, Heijenbrock WJ, Vissers JMH. Werken volgens protocol. Effecten van implementatie NHG-standaarden. Implementatic van NHG-standaarden in Zaanstreek en Waterland. Medisch Contact 1997:52(18):567-71.

764. Campion EW. New hope for home care? [editorial]. 1995;333(18):1213-4.

765. Van Boxtel R. Euthanasie. Samen tot het einde. Tijdschrift voor verpeegkundigen 1995;(11):343-6.

766. Spieker P. Arts moet euthanasie alleen uitvoeren. Uitvoeren voor verpleegkundigen strafbaar. Verplecgkunde Nieuws september 1995:36-7.

767. Themanummer 'Euthanasie en hulp bij zelfdoding'. Medisch Contact 1997;52(8).

768. Van Boxtel RHL.M, Kamp MMH, Swildens-Rozendaal WJC. Wetsvoorstel euthanasie. Medisch Contact 1998:53(17):570-579.

769. Ostergaard I. Cancer education of general practitioners can be improved. European Journal of General Practice June 1995:(1):75-7.

770. Van Zutphen $\mathrm{H}$, Smeets PMJH. Infuusbehandeling thuis, van project naar reguliere zorg. In: Handboek Thuiszorg. In: Utrecht: Elsevier/De tijdstroom; 1993. p. B.9.2.1-8.

771. Lako CJ, Smelik J. Nederlanders over de kosten van de gezondheidszorg. De resultaten van een enquête. Medisch Contact 1996;51(26):883-5.

772. Wildevuur SE. Care boven cure. Jaaroverzicht Zorg 1998. Medisch Contact 1997;52(38):1171-3.

773. Tijmstra T, Heinsbroek N. Meningen over de zorgverlening in Nederland. Medisch Contact $1998: 53(24): 811-3$. 
774. Zaat J, Schellevis F. Aan je eigen haren omhoog? Over betrouwbaarheid en validiteit van instrumenten voor het meten van 'kwaliteit van leven'. Huisarts en Wetenschap 1995;38(3):105-9.

775. Driesen S, Casparie AF, Van den Bos GAM. Uitkomstindicatoren voor kwaliteitsbewaking en bevordering in de zorg voor chronisch zieken: overzichtsstudie. Den Haag: Gebied Medische Wetenschappen Nederlandse organisatie voor Wetenschappelijk Onderzoek; 1994.

776. Vinkenburg HHM. Twee manieren om kwaliteit van dienstveriening te meten. In: Handboek Kwaliteit van Zorg. Utrecht Elsevier/De Tijdstroom; 1993, p. C7.3.1-24.

777. Friele RD, Kerssens J. Techniek in de Thuiszorg, een evaluatie van het stimuleringsprogramma thuiszorgtechnologie. Utrecht: NIVEL; augustus 1995.

778. Huijsman R, Boesten N. Zorgt technologie thuis voor minder zorg? Tussenbalans van het project 'Van ziekenhuiszorg naar thuiszorg'. MGZ maart 1993;21:42-6.

779. Huijsman $R$, Boesten $N$. Ervaringen van patienten en hulpverleners met zes verschillende vormen van thuiszorgtechnologie vanuit ziekenhuis: Invoering op grotere schaal lijkt aantrekkelijke optic. MGZ december 1993;21:10-3.

780. Interne correspondentic tussen de Vakgroepen Huisartsgeneeskunde en Economie van de Gezondheidszorg van de Rijksuniversiteit Limburg.

781. Bos W. 'Maatschappijstroom' op de helling bij Gezondheidswetenschappen. Nieuwe richtingen moeten oude vervangen. Observant [universiteitsblad Rijksuniversiteit Limburg] 15 februari 1995

782. Fullan N, Park P. Curriculum implementation: A foundation booklet. Ontario: 1980.

783. Parkinson RS, Chairperson MSPH, Beck R, Collins GH, Eriksen ME, MeGill AM, et al. Managing health promotion in the work place. Guidelines for implementation and evaluation. Palo Alto: Mayfield Publishing Company; 1982.

784. Windsor RA. Evaluation of health promotion and educational programs. Palo Alto: Mayfield Publishing Company; 1984

785. Crul BJP. Mens en pijn. Dilemma's van de hedendaagse pijnbestrijding [inaugurale rede]. Medisch Contact 1997:52(36):1082-3.

786. Van der Grinten TED. Kansen voor een transmurale gezondheidszorg. Medisch Contact 1997:10(6): 477-80.

787. Van Schaik F. Ziekenhuisverplaatste zorg. Tijdschrift voor Huisartsgeneeskunde 1993;10(6):477-80.

788. Buma JT. De huisarts en zijn patient. Grondslagen van het medisch denken en handelen [proefschrift] Amsterdam: Gemeente Universiteit Amsterdam;1949.

789. Meininger. Proefschrift in 1958. In: Touw-Otten F, redactie. Wetenschapsbeoefening en huisartsgeneeskunde: Een analyse van dissertaties en enkele wegen tot structurering van huisartsgeneeskunde als discipline. Deventer: Van Loghum Slaterus; 1991.

790. De Geus CA. Huisarts en kankerpatient [proefschrift]. Utrecht: Rijksuniversiteit Utrecht; 1970.

791. Vlamings HLA. Samenwerking van huisarts en maatschappelijk werkster [proefschrif]. Nijmegen: Katholieke Universiteit Nijmegen; 1967.

792. De Vries AEN. Gezin en hulpverlening in DorpbijStad. Een epidemiologische studie over het werk van de huisarts, de wijkverpleegster en de maatschappelijk werker in een Brabants dorp [proefschrift]. Nijmegen. Katholieke Universiteit Nijmegen; 1973.

793. De groep van Lissabon onder voorzitterschap van Ricardo Petrella. Grenzen aan de concurrentic. 2 e ed. Brussel: VUB Press; 1994.

794. Beniger JR. The Control Revolution. Technological and Economic Origins of the Information Society. Cambridge US/London: Harvard University Press; 1986.

795. A survey of the world economy. The hitchhiker's guide to cybernetics. The Economist 28 September 1996: p. 3-50.

796. Cortenraad J. De spiraal moet doorbroken worden. De staat van de verzorging deel 3. De Limburger [krant] 9 juni 1994: p. 12

797. Hingstman L, Harmsen J. Beroepen in de extramurale gezondheidszorg. Utrecht: De Tijdstroom/NIVEL; 1994.

798. Secretariaat van de Specialisten Registratie Commissic. Rapport betreffende opleidingen en assistentenbestand van de door de S.R.C. erkende opleidingsinrichtingen per 1 januari 1993

799. Nationaal Ziekenhuis Instituut (NZI). Statistiek personeelssterkte 1993: algemene ziekenhuizen, academische ziekenhuizen en categorale ziekenhuizen. Utrecht: NZI; 1994.

800. Stichting Organisatie voor Strategisch Arbeidsmarktonderzoek. Onderzoeksprogramma arbeidsmarkt Zorgsector 1994-1997. Den Haag: OSA; december 1993: p 10-1. Publikatienummer: ZI.

801. Bertels K, Nauta D. Hoofdstuk 6+7. In: Inleiding tot het modelbegrip. Bussum: De Haan; 1969. 
802. Aggleton $\mathrm{P}, \mathrm{Chalmers} \mathrm{H}$. Theorieen en modellen in de verpleegkunde. Zeven buitenlandse theorieen in perspectief. [Nederlandse vertaling van: Nursing models and the nursing process. MacMillan, 1986]. Utrecht/Antwerpen: Bohn, Scheltema \& Holkema; 1986.

803. Derekx EWCC. Complexiteitsscore. Een onderzoek naar de validiteit, betrouwbaarheid en hanteerbaarheid van een complexiteitsscorelijst voor verpleegsituaties binnen de wijkverpleging [doctoraalscriptie].

Maastricht: Vakgroep Gezondheidswetenschappen doorstroom Verplegingswetenschap Rijksuniversiteit Limburg; 1992.

804. Servais J. Prijs voor beste wetenschappelijk onderzoek. Traject [informatiebulletin azM] 1995;10(1):10.

805. Vrouw zegt te zijn genezen na bezoek aan wenende madonna. De Limburger [krant] 7 augustus 1994.

806. Aan de Brugh M, Enserink M. De bacterien slaan terug. Het naderende einde van het antibiotica-tijdperk. Intermediair 1994;30(14):29-33.

807. Consumed with fear. The Economist 24 April 1993: p. 89-90.

808. Tuberculose weer bezig aan opmars in Europa. Tuberculose breidt zich ook uit in Nederland. Limburgs Dagblad [krant] 21 juni 1994.

809. Ekkelboom J. Radicalenvangers voorkomen degeneratic van ledematen [katern wetenschap]. De Volkskrant 20 november 1993.

810. Bos W. Resistentic tegen antibiotica wordt drama. Industrie verzuimt nieuwe middelen te ontwikkelen. Observant [universiteitsblad Universiteit Maastricht] december 1996: p. 5.

811. Parenterale voeding in het ziekenhuis en thuis: terugkijken en vooruitzien [symposiumverslag]; 31 maart 1995; Nijmegen. Nijmegen: Katholieke Universteit Nijmegen; 1995.

812. Hartfalen: een nieuwe epidemic. Limburgs Dagblad [krant] 24 maart 1997.

813. Stommels $F$. Leven met een rugzak. Moeder van drie kinderen zit aan infuusslang en kan tòch de straat op. De Limburger [krant] 5 augustus 1995: p. 35.

814. Probleem van het hartfalen grootste uitdaging van cardiologie van vandaag [interview met A Dunning]. Topic 1993:4(4):2-4.

815. Brown KK. Hartversterkend. De behandeling van decompensatio cordis met inotrope middelen [bewerkt door D de Jonghe en T Schrijver]. Nursing december 1996:18-22.

816. Produktiedata 1994 dagcentrum academisch ziekenhuis Maastricht.

817. Ministerie van Welzijn, Volksgezondheid en Cultuur (WVC). Brief tockenning subsidie voor projectvoorstel 'Implementatie Thuiszorgtechnologie'. Rijswijk: WVC; 29 april 1992.

818. Ministerie van Welzijn, Volksgezondheid en Cultuur (WVC). Brief over goedkeuring verlenging 'Project Implementatie Thuiszorgtechnologie', Rijswijk: WVC; 19 augustus 1994.

819. academisch ziekenhuis Maastricht (azM). Jaarverslag 1993-1995. Maastricht: azM; 1993-1995.

820. Stichting Groene Kruis Heuvelland (SGKH). Jaarverslag 1993-1995. Maastricht: SGKH; 1993-1995.

821. Vakgroep Interne Geneeskunde Maastricht. Jaarverslagen 1992-1996. Maastricht: academisch ziekenhuis Maastricht; 1993-1997.

822. Landelijke Medische Registratie. Databestanden 1993-1996 van het academisch ziekenhuis Maastricht (azM). Maastricht: azM; 1994-1997.

823. Stuurgroep Toekomstscenario's Gezondheidszorg. Toekomstscenario's voor eerstelijnszorg en thuiszorg. Deel 3: Achtergrondstudies. Achtergronddocument C: Complexe thuiszorg; resultaten van een Delphi studie. Houten/Zaventem: Bohn Stafleu van Loghum; 1992. p. 18.

824. Centraal Bureau Statistiek (CBS). Statistisch Jaarboek 98. Voorburg/Heerlen: CBS; 1998.

825. Stichting Groene Kruis Heuvelland (SGKH). Salarisberekening transmuraal infuusverpleegkundige. Maastricht: SGKH; 1993.

826. Besluit van 21 mei 1991, houdende aanwijzing van chemische afvalstoffen (Besluit aanwijzing chemische afvalstoffen). Staatsblad; 1991. No:247:1-9.

827. Project Infuusbehandeling Thuis (IT). Afvalprocedure infuuszorg thuis. Maastricht: IT; 1993.

828. Centraal Orgaan Tarieven Gezondheidszorg (COTG). Brief inzake de budgetsystematiek en produktieafspraken 1996 aan de (erkende) kruisorganisaties en ziektekostenverzekeraars. COTG; 21 december 1995.

829. Molitor RE. Competition in the home infusion therapy [letter]. American Journal of Hospital Pharmacy July 1991:(48):1441-2.

830. Peeters-Udding LM. Transmurale farmacie. Pharmaceutisch Weekblad 1996;131(6):170-2. 



\section{Inleiding}

In Nederland vindt complexe medisch-technische zorg (CMTZ), zoals infuusbehandeling thuis (II), nog vooral klinisch plaats. In de kliniek dient de technologie voomamelijk voor toepassing van diagnostick en therapie, in de thuissituatie zjin ook de aelfstandigheid en zelfredzaamheid van de patiënt en naste verzorger(s) van belang Aanbod, inhoud en structuur van de zong dienen daarom geinnoveerd te worden. De innovatie en het onderzock daarnaar vallen uiteen in drie delen: ontwikkeling (inventarisatie en modelontwikkeling), implementatie (invoering en proceseraluatie) en evaluatie van de effecten.

\section{Inventarisatie en modelontwikkeling}

Getracht is continuteit in zorghehocte en aanbod te bewerkstelligen door vanuit zowel substanticle (-zinvolheid) als functionele (-doelmatigheid) rationaliteit een zongconcept te ontwikkelen. Vanuit het perspectief van de patiètent en diens naaste wordt op basis van het gezondheidskundig uitgangspunt inhoud gegeven an het concept zelforg in relatie tot de -uit kennistoename en technologisering voorndoeicnde-specialisatie, arbeidsverdeling en functie-en structuurdifferentiatie binnen de professionele zongerlening. Analyses daarbi] betreffen: een literatuurinventarisatie van envaringen met CMTZ thuis; kaders bij deze zorg, waaronder de zorgverleningstheorie van Orem; een landelifke enquête onder verpleegkundigen en artsen over de taken en verantwoordelijkheden bij infuusbehandeling. Op grond van bovenstaande is een zorgmodel voor CMTZ ontwikkeld.

\section{Procesbeschrijving en procesevaluatie innovatie}

Dit deel heeft vooral betrekking op coördinatie van zorg met accent op de toename in onderlinge afhankelijkheid, informatie, schaalgrootte en bureaucratisering. Centrale processen zijn de: keuze van doelgroepen en omschrijving van individuele selectiecriteria; vormgeving van de zorgverlening in de praktijk op basis van het ontwikkelde transmurale zorgmodel; informatievoorziening, scholing en combinatie van technologie en financiering. Ten slotte volgen de toegepaste behandelingen met aandacht voor de thuiszorgtechnologie.

\section{Effect-evaluatie}

Hierin wordt stilgestaan op de interactie tussen de substanticle rationaliteit die tot uiting komt in bijvoorbeeld sociale steun, tevredenheid en welzijn (kwaliteit van leven) en de functionele rationaliteit (organisatic en kosten). Beide rationaliteiten kruisen zich bij kwaliteit van, tevredenheid over en doelmatigheid van zorg. Tot slot worden de kosten soor de gezondheidszorg en het patièntsysteem beschreven.

\section{Afsluiting}

Er wordt afgesloten met een beschoirwing en samenvatting, Bij imoering van thuiszorglechnologie blijken op macro-, middenkader-en individued niveau respectievelijk finandiering, protocollering en attitude de belangrijkste factoren. 